UNIVERSIDADE DE SÃO PAULO

Pedro Evaristo Conceição Santos

Os Entes Silenciosos da Sociedade Israelita Segundo o Deuteronômio

Cópia Corrigida

São Paulo

2016 


$$
\text { UNIVERSIDADE DE SÃO PAULO }
$$

\author{
FACULDADE DE FILOSOFIA, LETRAS E CIÊNCIAS HUMANAS \\ DEPARTAMENTO DE LETRAS ORIENTAIS \\ PROGRAMA: ESTUDOS JUDAICOS E ÁRABES \\ ÁREA DE CONCENTRAÇÃO: ESTUDOS JUDAICOS
}

Pedro Evaristo Conceição Santos

\title{
Os Entes Silenciosos da Sociedade Israelita Segundo o Deuteronômio
}

\author{
Cópia Corrigida
}

Tese apresentada ao Programa de Pósgraduação em Estudos Judaicos e Árabes do Departamento de Letras Orientais da Faculdade de Filosofia, Letras e Ciências Humanas da Universidade de São Paulo para obtenção do título de Doutor.

Orientador: Professor Doutor Reginaldo Gomes de Araújo 
Autorizo a reprodução e divulgação total ou parcial desse trabalho, por qualquer meio convencional ou eletrônico, para fins de estudo e pesquisa, desde que citada a fonte.

Catalogação da Publicação Serviço de Biblioteca e Documentação

Faculdade de Filosofia, Letras e Ciências Humandas da Universidade de São Paulo

S237p

Santos, Pedro Evaristo Conceição

Os entes silenciosos da sociedade israelita segundo o Deuteronômio / Pedro Evaristo Conceição Santos - 2016.

$236 \mathrm{f}$.

Orientador: Prof. Dr. Reginaldo Gomes de Araújo

Tese (Doutorado) - Universidade de São Paulo, USP, Faculdade de Filosofia, Letras e Ciências Humanas, Departamento de Letras Orientais, Programa: Estudos Judaicos e Árabes, Área de Concentração: Estudos Judaicos. $236 \mathrm{f}$.

1. Estudo Judaicos. 2. Bíblia Hebraica. 3. Literatura - Deuteronômio. 4. Sociedade Israelita.

I. Araújo, Reginaldo Gomes de (orient.). II. Título. III. USP. 


\section{Banca Examinadora}

Presidente: Prof. Dr. Reginaldo Gomes de Araújo (USP)

Titular: Prof. Dr. Moacir Aparecido Amâncio (USP)

Titular: Prof. Dr. Grabriel Steinberg Schvartzman (USP)

Titular: Prof. Dr. Rodrigo Franklin de Sousa (MACKENZIE - Externo)

Titular: Prof. Dr. Tércio Machado Siqueira (METODISTA - Externo) 


\section{Agradecimentos}

À minha esposa, Digna Santos, e a meu filho, Nathan Santos, pela sua paciência e apoio, dando os incentivos nos momentos em que precisei. São os amores de minha vida.

Ao Professor Doutor Reginaldo Gomes de Araújo, um agradecimento muito especial pelo seu trabalho minucioso e paciente de leitura, correções e indicação de literatura necessária à pesquisa.

À CAPES, pela bolsa de estudos que propiciou o necessário aporte financeiro para os congressos, compra de livros e manutenção no trabalho de pesquisa.

Aos professores que estiveram envolvidos na qualificação, pelas sugestões proveitosas, as quais ficarão marcadas como contribuição ao meu trabalho de pesquisa.

Aos professores que ministraram as disciplinas em sala de aula, em especial à Professora Suzana Chwarts que, além das aulas, foi minha tutora no estágio.

À equipe de funcionários que me ajudaram na parte burocrática da Instituição.

E ao Deus de Israel por sua bondade, expressa através de cada agradecimento acima. 


\section{Abreviações}

AEC Antes da Era Comum

ANE The Ancient Near East - an anthology of texts and pictures

ARA Bíblia Almeida Revista e Atualizada

ATP Antigo Testamento Poliglota-Hebraico, Grego, Português, Inglês

BDB The New Brown - Driver-Briggs - Gesenius Hebrew and English Lexicon.

BEG Bíblia de Estudo de Genebra

BH Bíblia Hebraica

BHQ Bíblia Hebraica Quinta: Deuteronômio

BJ Bíblia de Jerusalém, nova edição - revista e ampliada

BP Bíblia do Peregrino

BW7 Bible Works 7

CBI Comentario Biblico Iberoamericano.

DCH The Dictionary of Classic Hebrew

DTMAT Diccionario Teologico Manual del Antiguo Testamento

EBC The Expositor's Bible Commentary.

GGL-BW7 Gingrich Greek Lexicon no BW7

HALOT The Hebrew and Aramaic Lexicon of the Old Testament

HHL-BW7 Holladay Hebrew Lexicon no BW7

ITC International Theological Commentary

JPSTC The JPS Torah Commentary

NAC The New American Commentary

NCBC The New Century Bible Commentary

OTC Old Testament Commentaries

TDNT Theological Dictionary of the New Testament

TDOT Theological Dictionary of the Old Testament

TWOT Theological Wordbook of the Old Testament

WBC Word Biblical Commentary 


\section{Resumo}

Esta pesquisa tem como objeto "Os Entes Silenciosos da Sociedade Israelita segundo o Deuteronômio". E com quê esse objeto tem a ver? A pesquisa será desenvolvida a partir do livro de Deuteronômio e mirará àqueles que estão em silêncio dentro do livro. São eles: o pobre, a viúva, o órfão, o estrangeiro, o levita, o escravo e a escrava.

No desenvolvimento da pesquisa, notou-se que todos eles poderiam ser colocados sob a nomenclatura de "pobre". E, de fato, todos eles são pobres. Mas o redator emprega as palavras para "pobre" para designar um "homem" que, mesmo que estando em situação econômica degradada, ele ainda é livre, e, em determinado momento de sua vida, pode até optar por se tornar um escravo de um irmão. Também, percebeu-se que há quatro personagens que, quase sempre, aparecem juntos. Esses são aqueles que são chamados pelas palavras: viúva, órfão, estrangeiro e levita.

Diante disso, a pesquisa foi desenvolvida da seguinte forma: o capítulo inicial, onde se faz o levantamento das palavras que ocorrem dentro do Deuteronômio, e no qual se faz algumas observações iniciais.

O segundo capítulo buscará entender as palavras para pobre que ocorrem dentro do Deuteronômio. Notar-se-á aqui que elas apontam para um irmão israelita e que legislação será feita para que o "tu/vós", a quem se dirige o redator do livro, aja em obediência a fala de seu Deus e seja benigno com o seu irmão empobrecido. O capítulo termina com um tratamento de Moisés como um personagem que foi identificado com os Entes Silenciosos do Israel antigo.

O terceiro capítulo será desenvolvido com os Entes Silenciosos que aparecem, comumente, juntos. Eles são considerados "estrangeiros" por sua condição de desarraigamento. Eles não possuem propriedade. Mas existem dentro da propriedade do "tu/vós". A pesquisa também desenvolverá um entendimento do dízimo do terceiro ano.

O quarto capítulo trata dos escravos e escravas. A legislação deuteronômica fará uma distinção entre os escravos e escravas que são de Israel e os que não o são. $O$ ano da libertação dos empobrecidos e dos escravizados será tratado, em sua segunda parte, pois, a primeira fora tratada no capítulo 2 .

Palavras-chave: Pobre, Viúva, Órfão, Levita, Estrangeiro, Escravo, Escrava. 


\begin{abstract}
This research has the object "The Silent Beings of Israeli society according to Deuteronomy." And what this object has to do? The research will be developed from the book of Deuteronomy and will target those who are silent inside the book. They are: the poor, the widow, the orphan, the stranger, the Levite, the male and female slaves.

In developing the survey, it was noted that all of them could be placed under the nomenclature of "poor." And indeed, they are all poor. But the writer uses the words to "poor" to mean a "man" that even being in degraded economic situation, he is still free, and at one point in your life, he can even chooses to become a slave of a brother. Also, it was noted that there are four personages that almost always appear together. These are those who are called by the words: widow, orphan, the stranger, and Levite.
\end{abstract}

Therefore, the research was carried out as follows: the first chapter, where it is the lifting of words that occur within the Deuteronomy, and which makes some opening remarks.

The second chapter will seek to understand the words to poor occurring within the Deuteronomy. It will be noted here that they point to an Israeli brother and that legislation will be made so that the "thou / you", to whom is the book's editor, act in obedience to the speech of their God and be charitable with your impoverished brother. The chapter concludes with a treatment of Moses as a man who was identified with the Silent Beings of ancient Israel.

The third chapter will be developed with the Silent Beings that appear commonly together. They are considered "foreign" by their uprooting condition. They have no property. But they are within the grounds of "thou / you." The research also develop an understanding of the tithe of the third year.

The fourth chapter deals with the male and female slaves. The Deuteronomic legislation will make a distinction between male and female slaves who are of Israel and those who are not. The year of the liberation of impoverished and enslaved will be treated in its second part, because the first had been treated in Chapter 2 .

Keywords: Poor, Widow, Orphan, Levite, Foreign, Male Slave, Female Slave. 


\section{SUMÁRIO}

INTRODUÇÃO 16

1. OS ENTES SILENCIOSOS NO LIVRO DE DEUTERONÔMIO: A DISTRIBUIÇÃO DOS VOCÁBULOS 25

1.1. A distribuição das palavras 28

1.1.1. Deuteronômio 1 a $11 \quad 29$

1.1.2. Deuteronômio 12 a $26 \quad 29$

1.1.3. Deuteronômio 27 a $34 \quad 29$

1.1.4. Observações da distribuição das palavras 30

1.2. Entes Silenciosos falantes? 33

1.2.1. O לירו, le

1.2.1.1. O lēwî fala para abençoar 33

1.2.1.2. O lēwî fala para amaldiçoar $\quad 35$

1.2.1.3. Os sacerdotes levitas "falam" 36

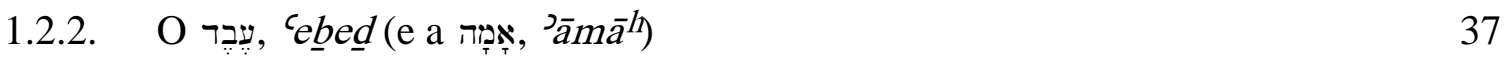

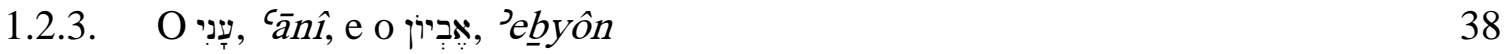

1.2.3.1. O clamor do ‘̄ânî e do ’ebyôn 38

1.2.3.2. A bênção do ‘̄̄nî $\quad 39$

1.2.4. Algumas observações 39

2. OS ENTES SILENCIOSOS CARACTERIZADOS POR SUA "POBREZA" 43

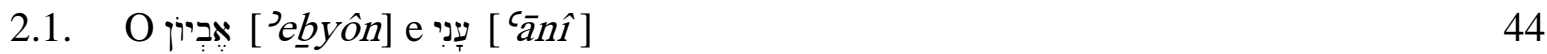

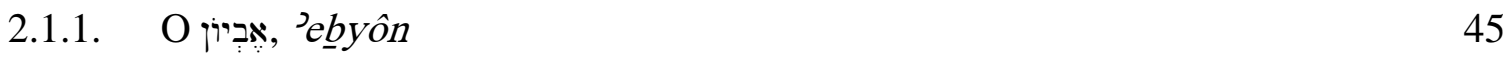

2.1.1.1. Um termo geral para referir-se a uma pessoa dentro de determinada condição econômica, a condição de pobreza. 45

2.1.1.2. Elementos filológicos 49

2.1.1.2.1. A etimologia de (’abyôn) 49

2.1.1.2.2. Comparação com o Targum 50

2.1.1.2.3. Comparação com a Septuaginta (LXX) 51

2.1.1.3. Algumas notas 51

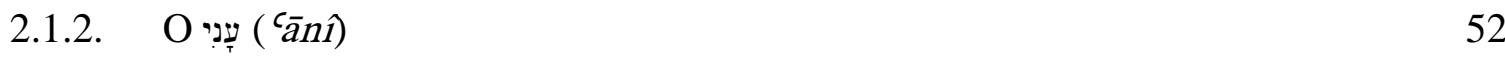

2.1.2.1. Elementos filológicos 52 
2.1.2.1.1. A etimologia de עָנִ (

2.1.2.1.2. Comparação com o Targum 54

2.1.2.1.3. Comparação com a Septuaginta (LXX) 54

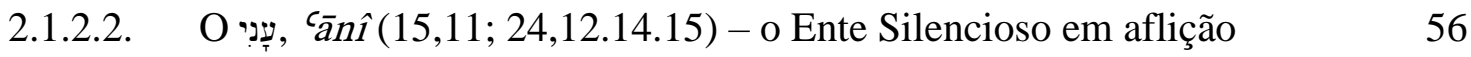

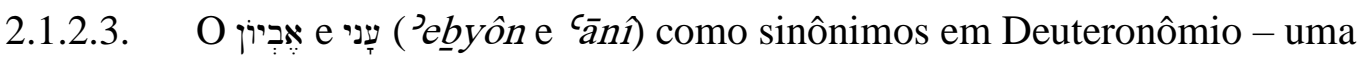
exegese de Deuteronômio 24

2.1.2.3.1. Tradução sugerida para Deuteronômio 24,10-15 57

2.1.2.3.2. O Sitz im leben de Deuteronômio $24 \quad 60$

2.1.2.3.3. Análise de Deuteronômio 24,10-15 61

2.1.2.3.3.1. Primeiro caso: a situação de um homem que penhora sua capa pessoal por um empréstimo (Deuteronômio 24,10-13) 62

2.1.2.3.3.2. A situação de um homem que trabalha por sua sobrevivência (Deuteronômio 24,14-15) 65

2.2. O O $\mathrm{O}:$ o Ente Silencioso pobre na porta da justiça $(1,17)$

2.2.1. Observações iniciais 70

2.2.2. Elementos filológicos 72

2.2.2.1.

2.2.2.1.1. A etimologia da palavra

2.2.2.1.2. Comparação com o Targum 73

2.2.2.1.3. Comparação com a Septuaginta 73

2.2.2.2. דָרָ, $d \bar{a} l$ ("pobre") 74

2.2.2.2.1. A etimologia da palavra לד,,$d \bar{a} l \quad 74$

2.2.2.2.2. Comparação com o Targum 75

2.2.2.2.3. Comparação com a Septuaginta 75

2.2.3. Análise do texto de Deuteronômio 1,17 76

2.2.3.1. Tradução de Deuteronômio 1,16.17 e dos textos paralelos em Êxodo 23,2.3 e Levítico 19,15 76

2.2.3.2. Análise dos textos 79

$\begin{array}{ll}\text { 2.2.3.2.1. O contexto de Deuteronômio 1,16.17 } & 79\end{array}$

2.2.3.2.2. O texto próprio: os juízes instruídos 81

2.2.3.2.2.1. Uma observação inicial 81

2.2.3.2.2.2. Elementos na análise do texto 81

2.2.3.2.3. Os textos paralelos em Êxodo e Levítico 86 
2.2.3.2.3.1. Êxodo 23,3: a testemunha deve ser verdadeira

2.2.3.2.3.2. Levítico 19,15: outro desafio aos juízes

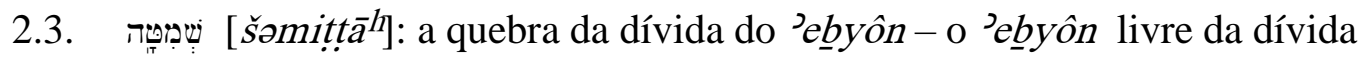
(Deuteronômio 15)

2.3.1. A importância de Deuteronômio 15

2.3.2. A base redacional sobre o "tu/vós" 95

2.3.3. A estrutura literária de Deuteronômio 15: Os blocos literários de Deuteronômio 1596

2.3.4. O sitz im leben de Deuteronômio 15

2.3.5. O benefício da šomițta $\bar{a}^{h}$ para o pobre em Deuteronômio 15 - tradução e análise do capítulo

2.3.5.1. A introdução (Deuteronômio 15.1) 101

$\begin{array}{ll}\text { 2.3.5.1.1. Tradução } & 101\end{array}$

2.3.5.1.2. O ano do cancelamento - o centro do capítulo 102

2.3.5.2. O 'ebyyôn: o ba' $\quad$ al e seu empréstimo ao ’ebyôn - seu irmão e seu próximo

(Deuteronômio 15,2-6) 104

2.3.5.2.1. Tradução (Deuteronômio 15,2-6) 105

2.3.5.2.2. O que caracteriza o evento da šomițtăh ? 107

2.3.5.2.2.1. É um evento oficialmente proclamado (Deuteronômio 15,2) 107

2.3.5.2.2.1.1. Uma explicação necessária: O que um Ba al (“credor”) deve fazer com as dívidas de um emprestador? 107

$\begin{array}{ll}\text { 2.3.5.2.2.1.2. A mão do } b a{ }^{\varsigma} a l & 108\end{array}$

2.3.5.2.2.2. Inclusão e exclusão na šomitțăh ${ }^{h}$ (Deuteronômio 15,3.4) 108

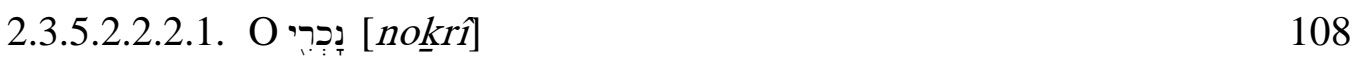

2.3.5.2.2.2.2. Uma comunidade ideal - sem ’ebyôn 109

2.3.5.2.2.2.3. Deuteronômio e seu sistema de recompensas 111

2.3.5.2.2.2.3.1. "O Deus de Israel te abençoará em tudo o que fizeres"

(Deuteronômio 7,13; 15,4.6.10.18; 28,8; 30,16).

2.3.5.2.2.2.3.2. “... prolongareis os vossos dias” (Deuteronômio 4,40; 5,16.33; 6,2;

$11,9.21 ; 17,20 ; 22,7 ; 25,15 ; 30,20 ; 32,47)$.

2.3.5.2.2.2.3.3. "para que te vá bem" ou "para que bem vos suceda" (Deuteronômio 4,40; 5,16.29.33; 6,3.18.24; 12,25.28; 19,13; 22,7; 305.9 ). 115

2.3.5.2.2.2.3.4. "para que vivais" (Deuteronômio 4,1; 5,33; 8,11).

2.3.5.2.2.2.3.5. " "para que entreis e possuais a terra" (Deuteronômio 4,1; 8,1; $11,8)$. 115 
2.3.5.2.3. O imperativo da obediência para não ter 'ebyôn (Deuteronômio 15,5.6) 116

2.3.5.3. O clã e seu cuidado com o irmão empobrecido (Deuteronômio 15,7-11) 117

2.3.5.3.1. Tradução

2.3.5.3.2. Solidariedade com o irmão empobrecido

2.3.5.3.2.1. Uma hipótese possível $(15,7)$

2.3.5.3.2.2. Coração generoso em lugar do duro $(15,8.9)$

2.3.5.3.2.3. Uma contradição em Deuteronômio 15 ?

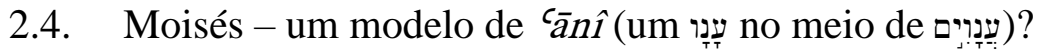

2.4.1. O texto - Números 12,1-3

2.4.1.1. Tradução

2.4.1.2. O contexto

2.4.2. O evento envolvia incialmente uma crítica contra a mulher de Moisés.

2.4.3. A caracterização de Moisés como ‘̄anî

2.4.3.1. Moisés é chamado de hāâî̌.

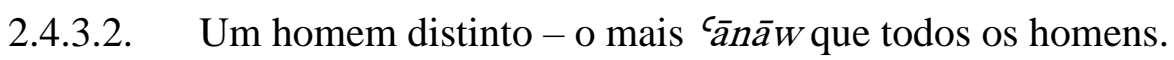

3. OS ENTES SILENCIOSOS EM BLOCO

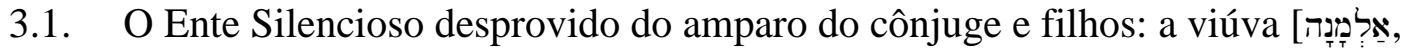
’almānāh

3.1.1. Algumas observações iniciais

3.1.2. Elementos filológicos

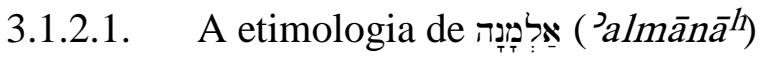

3.1.2.2. Comparação com o Targum

3.1.2.3. Comparação com a Septuaginta

3.1.3. Uma 'iššă ${ }^{h}{ }^{2}$ almānā $\bar{a}^{h}$, em meio aos Entes Silenciosos

3.1.3.1. Em todas as ocorrências de 'almānă $\bar{a}^{h}$, em suas versões em Aramaico e

Grego, as palavras empregadas são também substantivos: a 'almāna $\bar{a}^{h}$ nomeia a mulher. 150

3.1.3.2. Em Deuteronômio, a ’almāna $\bar{a}^{h}$ aparece sempre sozinha - sem filhos, sem família e sem marido.

3.1.3.3. A 'almāna $\bar{a}^{h}$ é produto de tempos de dificuldades econômicas.

3.1.3.4. Era proibido tomar a roupa da 'almānāh em um processo judicial $(24,17)$. 153 
3.1.3.5. Ela se encontrava nos "teus portões".

3.2. O Ente Silencioso desprovido da proteção do pai: o órfão [יתז [י] 156

3.2.1. Observações iniciais 156

3.2.2. Elementos filológicos 158

3.2.2.1. A etimologia 158

3.2.2.2. Traduções para o Aramaico e o Grego 159

3.2.3. O yātôm dentro do Deuteronômio 159

3.3. O Ente Silencioso desprovido da proteção de sua terra ou pátria: o estrangeiro [ר] lgēr] 162

3.3.1. Observações 162

3.3.2. Elementos filológicos 163

3.3.2.1. A etimologia 163

3.3.2.2. Tradução para o Aramaico 165

$\begin{array}{lll}\text { 3.3.2.3. Tradução para a LXX } & 167\end{array}$

3.3.3. O gēr dentro de Deuteronômio 168

3.3.4. Outros termos para indicar o estrangeiro 169

3.3.4.1. נדִרִ (Deuteronômio 17,15 [nokrrî] 169

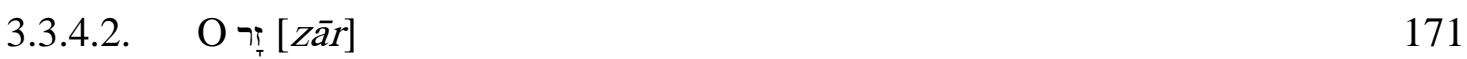

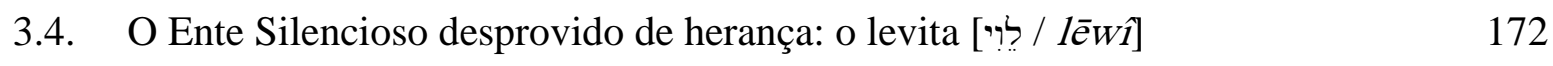

3.4.1. Observações 173

3.4.2. Etimologia 173

3.4.3. Traduções para o Aramaico e Septuaginta 174

$\begin{array}{lll}\text { 3.4.3.1. Targum } & 174\end{array}$

$\begin{array}{lll}\text { 3.4.3.2. Septuaginta } & 175\end{array}$

$\begin{array}{ll}\text { 3.4.4. Análise textual } & 175\end{array}$

3.4.4.1. O lēwî como Ente Silencioso específico 175

3.4.4.2. O lēwî como membro da classe sacerdotal 179

3.4.4.2.1. O motivo dessa especificação 179

3.4.4.2.2. A caracterização dos "sacerdotes levitas" 180

3.4.4.3. O lēwî como uma tribo em Israel 182

3.4.4.4. O lēwî como um cuidador da arca da aliança 184

3.5. O Dízimo do terceiro ano (Deuteronômio 26,12-15) 185 
3.5.1. Tradução 185

$\begin{array}{lll}\text { 3.5.2. O contexto } & 187\end{array}$

3.5.3. Estrutura e análise de Deuteronômio 26,12-15 189

3.5.3.1. Estrutura da perícope de Deuteronômio 26,12-16 189

3.5.3.2. Análise: O que é o dízimo do terceiro ano? 189

$\begin{array}{ll}\text { 3.5.3.2.1. A voz do redator } & 189\end{array}$

3.5.3.2.2. A confissão de obediência do "tu" 190

3.5.3.2.2.1. O sagrado não pertence ao dono $(26,13) \quad 190$

3.5.3.2.2.2. Os elementos de exclusão $(26,14) \quad 191$

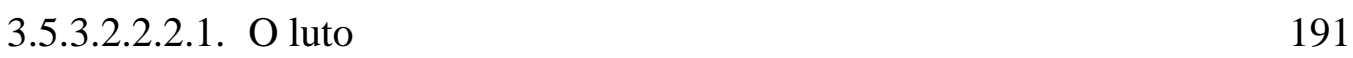

3.5.3.2.2.2.2. A impureza 192

3.5.3.2.2.2.3. O morto 193

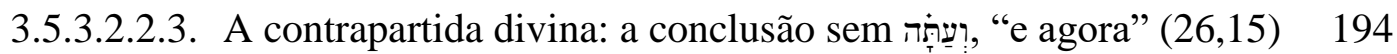

3.5.4. O Dízimo do terceiro ano - uma antecipação a Deuteronômio 26,12-15: $14,28.29195$

3.5.4.1. Tradução 195

3.5.4.2. O contexto 196

$\begin{array}{lll}\text { 3.5.4.3. } & \text { Análise de Deuteronômio 14,28.29 }\end{array}$

3.5.4.3.1. Como identificar o dízimo para a doação aos Entes Silenciosos 197

3.5.4.3.2. Os destinatários do dízimo postado "nos portões" 198

3.5.4.4. O dízimo em Deuteronômio tem meta básica socorrer os Entes Silenciosos? 199

4. OS ENTES SILENCIOSOS COMO PROPRIEDADE 204

4.1. Algumas notas iniciais 204

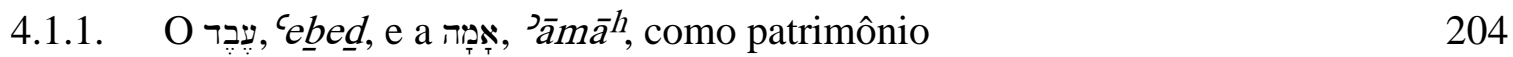

4.1.2. As aparições do 'e $\underline{\text { be }} \underline{\text { d }}$ e da ${ }^{\supset} \bar{a} m \bar{a}^{h}$ em Deuteronômio 205

4.1.3. Outros Entes Silenciosos associados com o 'e $e \underline{b} \underline{\underline{d}}$ e a ' $\bar{a} m \bar{a}^{h} \quad 205$

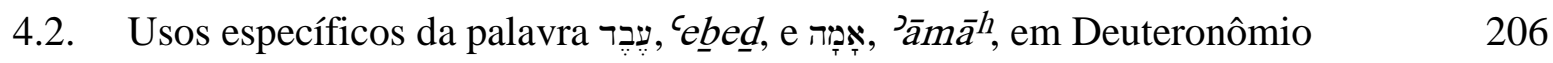

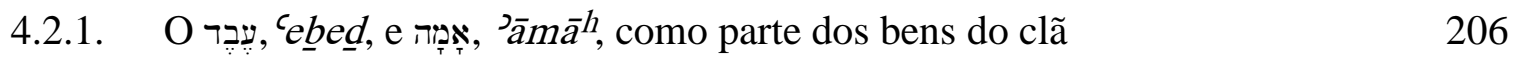

4.2.2. O ce $\underline{b} \underline{\underline{d}} \mathbf{d}$ como um representante oficial 208

4.2.3. Israel como 'e $\underline{b} \underline{\underline{d}} \quad 209$

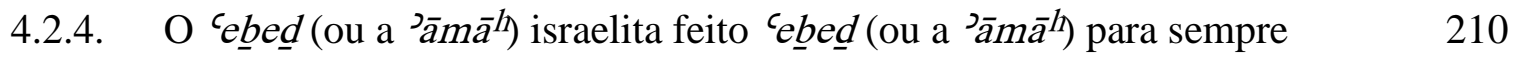


4.3. O ${ }^{\complement} e \underline{b} e \underline{d}$ e a ${ }^{~} \bar{a} m \bar{a}^{h}$ na šomitt $\bar{a}^{h}$ : Liberdade ou escravidão permanente? O dilema do 'e $\underline{b}$ ed e da 'āma $\bar{a}^{h}$ em Deuteronômio 15,12-18 211

4.3.1. Tradução 211

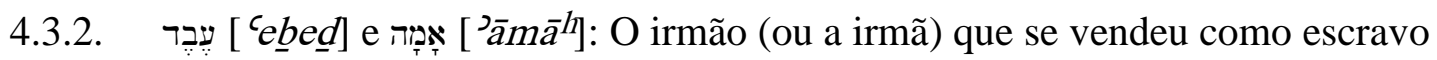
(Deuteronômio 15,12-18)

$\begin{array}{lll}\text { 4.3.2.1. Venda voluntária }(15,12) & 214\end{array}$

4.3.2.2. Liberalidade na saída 215

4.3.2.2.1. Saída com suporte $(15,13) \quad 215$

4.3.2.2.2. Bênção para abençoar $(15,14) \quad 216$

4.3.2.2.3. Liberdade baseada na memória $(15,15) \quad 216$

$\begin{array}{lll}\text { 4.3.2.3. A recusa em sair } & 217\end{array}$

4.3.2.3.1. A recusa em sair tem que ser voluntária $(15,16) \quad 217$

4.3.2.3.2. A recusa tem que ser oficializada $(15,17) \quad 217$

4.3.2.4. Obediência para a prosperidade $(15,18) \quad 218$

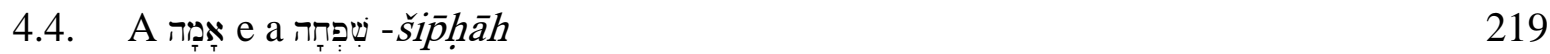

CONSIDERAÇÕES FINAIS 222

$\begin{array}{ll}\text { REFERÊNCIAS } & 228\end{array}$ 


\section{INTRODUÇÃO}

A primeira ocorrência de um dos vocábulos se referindo a um pobre, seguindo a ordem ${ }^{1}$ dos livros na BH, aparece dentro do livro de Êxodo 22,25 (Hebraico v. 24), עִ עִ [ ‘̄añi]. A última referência a ele está dentro do livro de Eclesiastes 9,16. ${ }^{2}$ Aqui a tradução da palavra "pobre" é de uma palavra aramaica normalmente usada para traduzir o texto Hebraico para o

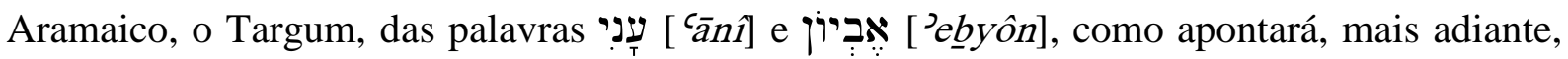

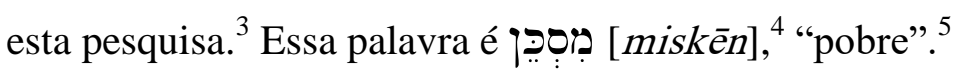

O quadro na página seguinte apresenta apenas as primeiras e as últimas ocorrências das palavras que serão à base da pesquisa nesta tese sobre os Entes Silenciosos dentro do Deuteronômio. O quadro tem o objetivo de mostrar que a BH tem ocorrências em quase todos os livros presentes em sua coleção.

\footnotetext{
${ }^{1}$ A ordem dos livros dentro da BH é diferente daquela presente nas Bíblias usadas por evangélicos e católicos. A BH começa com Gênesis e termina com Crônicas. A BH segue a tríplice divisão: Torah, Profetas e Escritos.

${ }^{2}$ Segundo a divisão da $\mathrm{BH}$, os Escritos são a última divisão, não os livros proféticos, como nas Bíblias cristãs. $\mathrm{Na}$ divisão da $\mathrm{BH}$, segundo as versões cristãs, o último livro onde aparece uma palavra para designar um pobre é

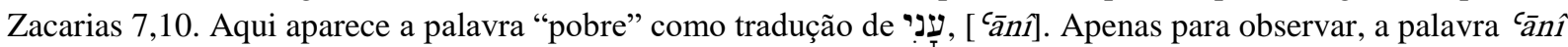
abre e fecha as aparições de vocábulos para "pobre" nas Bíblias cristãs. Na BH, a palavra que fecha é uma palavra aramaica [miskēn] usada para traduzir ‘̄annî em diversos textos do Targum.

${ }^{3}$ Essa constatação estará presente dentro da análise das palavras ‘̄an̂̀ e ’ebyôn dentro do segundo capítulo desta pesquisa.

${ }^{4}$ Essa palavra aparece antes, em Eclesiastes 4,13, onde qualifica a palavra "jovem” [ילְרי. / yéled]. Todavia, no versículo seguinte (4,14), a palavra usada para qualificar a condição de nascimento do yéled é ש̛̣ [rās̄], "pobre":

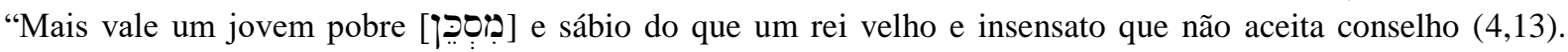
Mesmo que ele tenha saído da prisão para reinar e mesmo que tenha nascido mendigo [שָ ] para exercer sua realeza $(4,14) "(\mathrm{BJ})$.

${ }^{5}$ O sistema de transliteração seguido por esta pesquisa segue a transliteração "BHT - Transliterated Hebrew OT" do BW7.
} 


\begin{tabular}{|c|c|c|}
\hline Palavras hebraicas & Primeira ocorrência & Última ocorrência \\
\hline 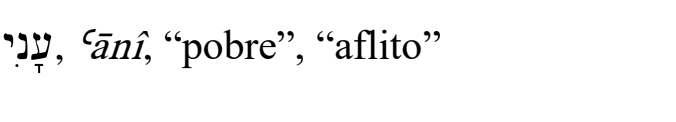 & $\begin{array}{l}\text { Exodo } 22,24 \\
\text { (Hebraico) }\end{array}$ & Eclesiastes 6,8 \\
\hline אֶבְיוֹן & Êxodo 23,6 & Ester 9,22 \\
\hline גִ gēr, "estrangeiro residente" & Gênesis 15,13 & 2 Crônicas 30,25 \\
\hline יתוֹ, yātôm, "órfão" & Êxodo 22,21 & Lamentações 5,3 \\
\hline 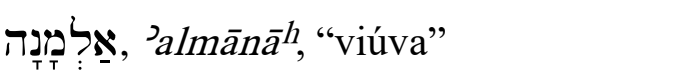 & Gênesis 38,11 & Lamentações 5,3 \\
\hline "לִי?, lēwî, "levita" & Gênesis 29,34 & 2 Crônicas 35,11 \\
\hline 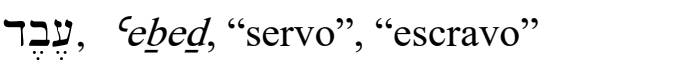 & Gênesis 9,25 & 2 Crônicas 36,20 \\
\hline 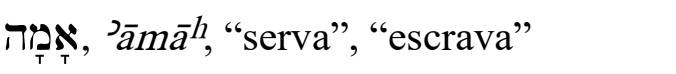 & Gênesis 21,10 & Rute 3,9 \\
\hline ${ }^{\dagger} p_{T}, q \bar{a} t \bar{o} n$, "pequeno", "insignificante" & Gênesis $1,16^{6}$ & 2 Crônicas 34,30 \\
\hline
\end{tabular}

Depois do alistamento dessas palavras, deve-se fazer uma pergunta: Por que as pessoas nomeadas por essas palavras são denominadas de "Entes Silenciosos" nesta tese? Na

\footnotetext{
${ }^{6}$ Deve-se destacar que a palavra ${ }^{6}$ nem sempre é usada para qualificar uma pessoa em contraste com outra

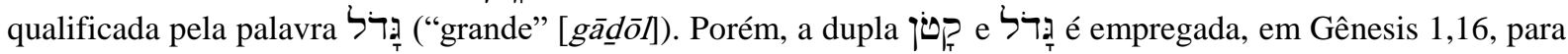
fazer contrastes entre luminares criados pelo Criador - o "grande" aparece em primeiro lugar e foi criado para o domínio do dia; o "menor" aparece em segundo lugar e fora criado para o domínio da noite. Além disso, há o contraste no tamanho de cada um, mesmo que antes os dois tenham sido chamados de "os grande luminares"

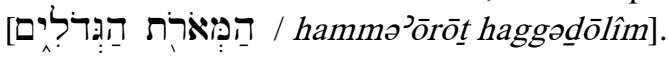


dissertação de Mestrado, desenvolvida a partir de Deuteronômio 26,1-11, percebeu-se, na confissão encontrada nesse texto, a declaração que o confessor deveria ser generoso com o "estrangeiro" [ㄱ: g: gēr] e o "levita". Na unidade seguinte, iniciada em 26,12, são apresentados

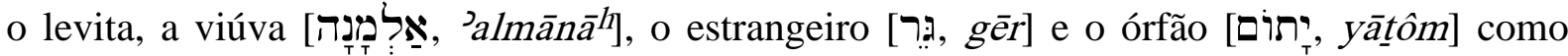
beneficiários de um tipo de dízimo, o dízimo do terceiro ano. Assim, surgiu o interesse em pesquisar esse grupo de pessoas, membros da comunidade israelita, com o acréscimo das

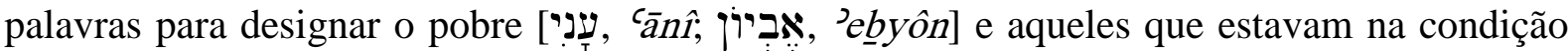

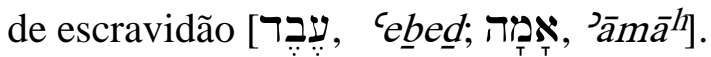

Nessas duas unidades do Deuteronômio (26,1-11 e 26,12-19), notou-se que esses Entes Silenciosos vivem à margem da comunidade, por um lado, quando são vistos da perspectiva econômica, por sua condição de dependência de pessoas dentro da comunidade em que vivem. Por outro lado, eles não estão à margem da comunidade porque a sua presença é notada, forçando seus vizinhos a agirem para que eles não pratiquem um ato desumano contra um membro em seu contexto, e, principalmente, impedindo que eles se esqueçam da bondade do Deus de Israel que, ao longo de sua história, tem-lhes tratado com expressiva bondade. Dessa perspectiva, tratar os Entes Silenciosos com favor é uma espécie de retribuição à sua Divindade.

A denominação de "Ente Silencioso" ou "Entes Silenciosos" pode ser justificada da seguinte maneira. O livro não fala diretamente a eles, mas se dirige àqueles que podem ser incluídos no "tu" ou "vós" a quem o orador fala. O livro inteiro é constituído de discursos que formam o diálogo entre o orador e o "tu" e o "vós". Quem são estes que são tratados pelos pronomes pessoais "tu" e "vós"? Pelo emprego dos pronomes pessoais "tu/vós", ele é do sexo masculino com idade suficiente para ser considerado de maior idade para agir com liberdade em favor dos Entes Silenciosos e também tem capacidade de levar outros a fazerem o mesmo. Assim, ele não somente é um homem livre, como também tem capacidade de influência. Dessa forma, pode-se dizer que o "tu/vós" é líder de sua casa e também lidera o seu clã. Está dentro de sua responsabilidade e capacidade agir para benefício de seu clã e daquele que é um Ente Silencioso. $^{7}$

\footnotetext{
${ }^{7}$ Segundo Crüsemann, o "tu/vós" de Deuteronômio pode ser identificado com o "povo da terra" de Judá (1 Reis

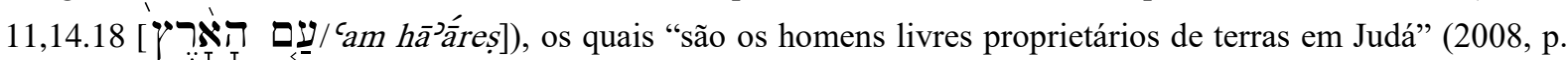
299). Para ele, o Código Deuteronômico "tomou forma nas circunstâncias em que o cam hāăáreș judaíta tinha tomado o poder diretamente. A lei dá forma e legitimidade de fato a esta soberania popular" (p. 301). Weinfeld,
} 
A estruturação do livro de Deuteronômio em cima de discursos dirigidos ao "tu/vós" demonstra que o livro não foi direcionado a nenhum governante, como alguém que deva atender o Ente Silencioso. Ele mirava o povo, "tu/vós, colocando seu foco no homem livre e com condições de suprir as necessidades do Ente Silencioso. Ele fala ao "tu" ou ao "vós" porque são estes que podem fazer a diferença. Ele fala ao indivíduo e, ao mesmo tempo, à comunidade.

O livro fala da situação do Ente Silencioso ao "tu/vós" para que estes demonstrem empatia ao sofrimento dele. O orador não fala diretamente ao Ente Silencioso, mas fala sobre ele a outros. O sujeito de quem se fala, o Ente Silencioso, passa a ser o conteúdo do discurso do orador ao "tu/vós", mas ele mesmo não é o receptor da fala do orador. A razão para isso é que esta pesquisa entenderá que, a partir do momento em que pessoa entra na classe de um Ente Silencioso, ela passa a ser alguém dependente das ações beneficentes de outros. Portanto, entrar na condição de um Ente Silencioso implica em cair na dependência de outros e, nesse momento, ele passa a ser silente porque outro passa a falar por ele. Por isso, os outros, "tu/vós", estão em condições de ajudar àquele que chegam a ser compreendido como um Ente Silencioso porque estão em situação muito melhor.

O terceiro motivo para esta pesquisa denominá-los de Entes Silenciosos é porque eles não falam de sua condição de Entes Silenciosos, pois tal condição não precisa ser explicada nem demonstrada. As pessoas que estão nesse estado falam através de sua própria situação, pois é autoevidente. Já que os Entes Silenciosos não tem poder de ação, o orador fala a quem tem tal poder para falar e agir pelos Entes Silenciosos.

O quarto motivo é que os Entes Silenciosos tratados em Deuteronômio não são elevados à posição de perseguidos por causa de sua fé, sua opção política, ou mesmo por mera maldade do perseguidor, como alguns salmos apresentam a condição do 'ānî e o ’ebyyôn (apenas para exemplo: Salmo 9,17-20; $\left.{ }^{8} 10,1-18^{9} ; 12,5 ; 22,26 ; 35,10-17\right)$. Em Deuteronômio, eles são pessoas comuns, vivem no meio de sua comunidade, e ela não pode negar o direito deles à vida.

por sua vez, afirma que "embora em alguns casos o intercâmbio de tratamento singular e plural possa indicar a existência de diferentes camadas, em geral, a alternância reflete variações estilísticas introduzidas pelo mesmo autor" (1991, p. 16). Mitchell defende a tese que a presença do singular e plural dentro do livro de Deuteronômio representa a diversidade de autoria dentro do livro (1899, p. 66, 73, 82, 83).

${ }^{8}$ Aqui se deve atentar para o paralelo entre o ’ebyôn / ‘ănāwîm $(9,18)$ e dak [\rceil$\left.\rceil\right], 9,9.12$; “oprimido, miserável”" (HHL-BW7).

${ }^{9}$ Nesse salmo se vê o paralelo entre dak , yātôm e ${ }^{c} \bar{a} n \hat{i}(10,2.12 .14 .17 .18)$. 
Em suma, eles são Entes Silenciosos porque eles não têm voz. Daí o orador, cujo conteúdo foi registrado pelo redator em Deuteronômio, assumiu a posição de "voz dos Entes Silenciosos". Mas ao fazer isso, ele o faz com o intuito de que cada um dos que constituem o "tu/vós" a quem ele se dirige seja também uma voz em favor dos Entes Silenciosos. Nos textos relacionados a eles, há o orador que fala ao "tu/vós" sobre o "ele", o Ente Silencioso. Essa terceira pessoa passa a ser o conteúdo do discurso.

O quadro anterior mostrou que esta pesquisa não tratará apenas daqueles que são chamados por algumas das palavras traduzidas por "pobre" nas versões em Português da BH, e que, nessas linhas, as duas palavras que aparecem em Deuteronômio foram as palavras

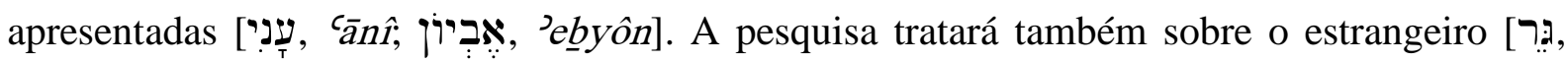

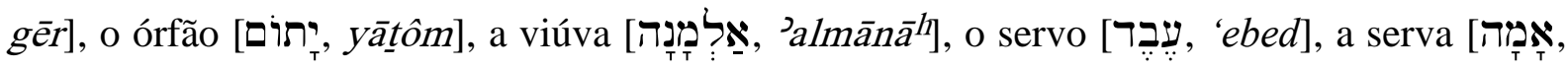
'amah], e até o levita ['! לִ, lēwî]. Todos esses estão sob a temática dos Entes Silenciosos. Entretanto, os Entes Silenciosos tratados nesta pesquisa são aqueles que estão dentro do livro de Deuteronômio e em textos paralelos em outros livros da $\mathrm{BH}$, particularmente do Pentateuco.

A perspectiva da pobreza dentro do Deuteronômio é fundamental para o conceito de generosidade. Pois, ao dar ao "pobre", o "tu/vós" estava sendo generoso com o Deus de quem ele já tinha recebido generosidade. Isso faz indissociável que a fé de Israel era fundamentada na relação humana e divina sem precedentes nos outros lugares do mundo bíblico. Noutra forma de dizer, a fé no Deus de Israel era demonstrada no profundo relacionamento do homem com seu Deus.

Por se tratar do livro de Deuteronômio, menciona-se aqui que ele experimentou, através de sua história, vários períodos redacionais. ${ }^{10}$ Aqueles, normalmente aceitos, variam, de modo geral, em três ou quatro períodos, dependendo do autor a que se consulta. ${ }^{11}$ Ao longo deste período que pode ir desde o século oitavo AEC até o tempo do sacerdote Esdras, no período do pós-exílio, o escrito lida com assuntos relacionados com os Entes Silenciosos e também com seus relacionamentos com seu próximo. E aqui, a palavra "próximo" é uma referência

\footnotetext{
${ }^{10}$ Para mais detalhe sobre a questão redacional do livro de Deuteronômio, notar: NASCIMENTO \& SANTOS, 2014, p. 23-38.

${ }^{11}$ Para citar alguns, ver KRAMER, Pedro. Origem e legislação do Deuteronômio - programa de uma sociedade sem empobrecidos. São Paulo: Paulinas, 2006, p. 16-39. VON RAD, Gerhard. Deuteronomy, a commentary. Philadelphia: The Westminster Press, 1966, p. 23-30. SANCHEZ, Edesio. Deuteronomio. Buenos aires: Kairos Ediciones, 2002, p. 19-29.
} 
àquele a quem o livro aponta - uma pessoa de seu relacionamento, alguém com quem se convive dentro da comunidade, o qual pode ser um irmão, no sentido de um membro do clã, ou irmão no sentido geral, um membro do povo de Israel.

No livro de Deuteronômio, encontra-se uma declaração que pode ser tida como relevante para designar a questão dos Entes Silenciosos, ${ }^{12}$ ao menos de um grupo específico dentro desse grupo. Essa se encontra em Deuteronômio 15,11: "Nunca deixará de haver pobres ${ }^{13}$ na terra; é por isso que eu te ordeno: abre a mão em favor do teu irmão, do teu humilde e do teu pobre em tua terra" (BJ). Tal afirmação demonstra a importância dos Entes Silenciosos para a legislação do livro de Deuteronômio, e, também se pode dizer, da importância da legislação deuteronômica para eles. Assim, há interação de interdependência ${ }^{14}$ de um para com outro. A legislação a ser estabelecida coloca em relevo a condição pessoal de um grupo de pessoas que, por sua condição socioeconômica vinha sendo desconsiderada pela comunidade ao seu redor.

Por que trabalhar sobre os Entes Silenciosos em Deuteronômio? O tema não tem sido abordado pela pesquisa bíblica na forma em que ele será tratado nesta pesquisa. Existe a tese de doutorado de Schwantes sobre o pobre, ${ }^{15}$ onde ele trabalha as quatro palavras para "pobre"

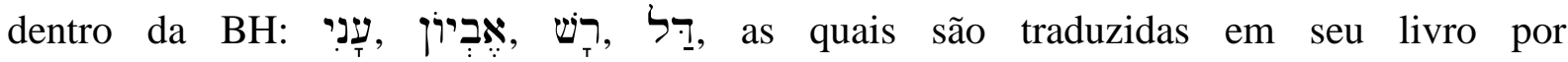
"encurvado/oprimido", "pobre", "pobre" e "fraco/pequeno/pouco". Entretanto, sua pesquisa se fixou nessas quatro palavras e como as pessoas por elas denominadas são tratadas na Torah, nos Escritos e nos Profetas. O livro lançado em 2013 chama-se $O$ direito dos pobres.

O livro é formado por quatro capítulos. O primeiro trata dos conceitos por trás das quatro palavras alistadas no parágrafo acima (p. 19-58); o segundo busca entender os pobres dentro dos escritos legais (p. 59-94); o terceiro, ao que parece, é o centro do trabalho do Prof. Milton por duas razões: a primeira é que o capítulo ocupa a maior parte do livro (p. 95-250), e, a segunda, é que ele trata dos pobres dentro da literatura profética, onde há maior número de

\footnotetext{
${ }^{12}$ Esta pesquisa estudará vários vocábulos para designar diferentes pessoas ou grupos de pessoas como "Entes Silenciosos", entre os quais está o אבֵבִיון ['ebyôn], cuja tradução usual é a palavra "pobre". Porém, esta pesquisa expressa o entendimento que a palavra hebraica tem sentido mais abrangente que sua forma comum de tradução com o vocábulo "pobre".

${ }^{13}$ Um grupo específico dentro do que esta pesquisa denomina de "Entes Silenciosos". Mas a esse conjunto, esta pesquisa mostrará que ela tem pelo menos mais dois outros grupos de Entes Silenciosos.

${ }^{14} \mathrm{O}$ livro trata das questões relacionadas aos Entes Silenciosos porque eles eram presentes naquele momento no meio do povo de Israel, segundo o Deuteronômio. Por outro lado, ao ser escrito, o Deuteronômio buscou beneficiar os Entes Silenciosos, não se esquecendo deles no meio do povo. Isso quer dizer que era uma presença significativa para ser notada.

${ }^{15}$ SCHWANTES, Milton. O direito dos pobres. São Leopoldo: Oikos; São Bernardo do Campo: Editeo, 2013.
} 
livros e mais conteúdo para ser tratado; o quarto busca entender os pobres dentro da perspectiva dos livros de sabedoria (p. 251-328).

A pesquisa desenvolvida nesta tese trabalha com o Deuteronômio e com àqueles que pertencem às camadas frágeis da sociedade deuteronômica, e não somente com os que são chamados de "pobre". Cuidar do Ente Silencioso, dentro do Deuteronômio, é valorizar o próprio Deus de Israel e também a si mesmo por obedecer às leis propostas para o seu bem. Dessa perspectiva, busca-se demonstrar que Deuteronômio fora escrito, não somente com a finalidade de estabelecer um pacto com o povo que estava diante da possibilidade ${ }^{16}$ de entrar na Terra da Promessa, como de estabelecer leis que regulamentariam vários relacionamentos a serem vivenciados dentro da terra. Entre os quais está o relacionamento com os Entes Silenciosos. ${ }^{17}$

Pode-se, então, dizer que o Deuteronômio tem uma vertente que olha para os Entes Silenciosos no meio do povo, e, para protegê-los, leis foram desenvolvidas com o fim de estabelecer a convivência salutar entre os que tinham posses e os que não as tinham. A legislação formada por essas leis mostra que eles, mesmo em condição financeira desfavorável, eram participantes importantes na aliança de Israel com seu Deus e, como tal, precisavam ser protegidos.

O livro de Deuteronômio fora escrito sobre diferentes eixos redacionais. Um deles é a colocação de um bloco histórico para registrar a saída do povo do Egito até sua entrada na Terra da Promessa. O outro eixo é a escrita da šoma ${ }^{\complement}$ como motivação para a vida dentro da comunidade. Outro eixo é a escrita de elementos relacionados a Moisés, nos capítulos finais do Deuteronômio.

É possível notar também que há um eixo maior, relacionado a leis que serviriam para reger a vida do povo em sua comunidade. Estas leis estão escritas dentro do bloco denominado de "Código Deuteronômico" (Deuteronômio 12-16). Dentro desse bloco, há leis destinadas à proteção dos Entes Silenciosos na terra. A vida em comunidade implicava em novos

\footnotetext{
${ }^{16}$ Não se busca com esta afirmação estabelecer uma proposta de data para o livro. Isso é apenas uma afirmação baseada no que está dito em Deuteronômio 1,1-4, o qual pressupõe o povo nas planícies de Moabe, antes de sua entrada na Terra da Promessa.

${ }^{17}$ Crüsemann declara que as partes mais importantes do Código Deuteronômico têm origem antes o Exílio, “especialmente da sua postura linguística predominante, incluindo suas implicações teológicas: O Deuteronômio pressupõe a posse tranquila da terra por Israel, bem como de sua liberdade, e isso de forma uniforme" (2008, p. 296).
} 
relacionamentos. Então as leis não somente os protegeriam, mas estabeleceriam princípios de relacionamento para vivência dentro da comunidade.

Haja vista que o Deuteronômio foi escrito incluindo a perspectiva dos Entes Silenciosos, esta pesquisa buscará responder três perguntas a serem feitas ao livro. A primeira é aquela que pergunta sobre a natureza dos Entes Silenciosos dentro da comunidade abordada pelo Deuteronômio: Quem são os Entes Silenciosos dentro do livro? Aqui se buscará o entendimento por meio das diferentes palavras empregadas para identificar os diferentes Entes Silenciosos dentro do Israel Antigo. Nas análises textuais, em cada capítulo, serão consideradas as circunstâncias que geraram seus desenvolvimentos e em que ambiente elas vieram a nascer.

A segunda pergunta busca conhecer a legislação criada para estabelecer a proteção dos menos favorecidos dentro da sociedade israelita coberta pelo livro. Por que o Deuteronômio tem preocupação especial com tais Entes Silenciosos? Aqui se buscará descrever tais leis e mostrar a necessidade e natureza delas, bem como o fim a que elas foram destinadas. Neste ponto, a exegese seguirá a seguinte metodologia: tradução do texto hebraico para o português, com análises sintáticas das frases constituintes do texto; a busca de estabelecimento do contexto social que gerou aquele texto onde está a lei; e, por último, a análise do texto por meio de exegese. Em cada capítulo destinado ao grupo específico de Entes Silenciosos serão analisados os textos do Deuteronômio pertinentes à legislação que beneficie os respectivos grupos. A literatura do Deuteronômio vai mostrar que os Entes Silenciosos não devem ser uma preocupação apenas da liderança, mas de toda a sociedade. Eles passam a ser apresentados como um problema de todos, não de alguns.

A estruturação desta tese em seus capítulos demonstrará que os Entes Silenciosos, em Deuteronômio, estão divididos em três grupos. O primeiro é aquele que trata das pessoas chamadas pelas palavras para "pobre" [אָּביון / עָנִי]; o segundo grupo consiste daqueles que

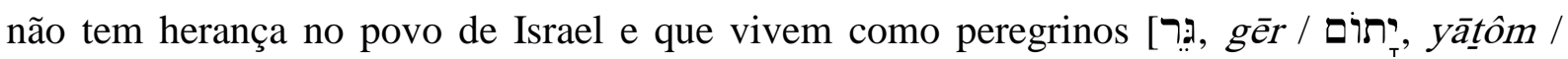

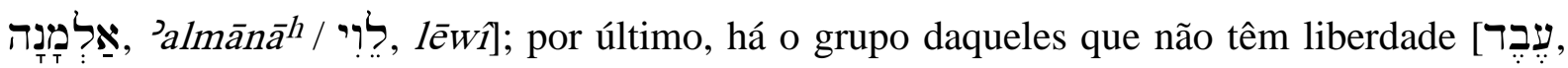

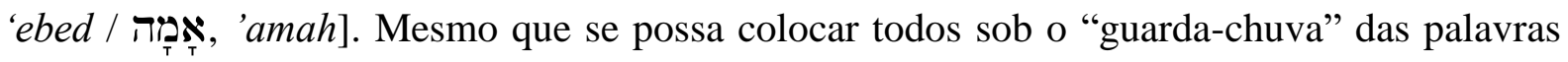
para "pobre", não é isso que o Deuteronômio faz. Dentro daqueles que pertencem às camadas inferiores da comunidade, aqui denominados de "Entes Silenciosos", o Deuteronômio 
distingue entre os que são chamados de "pobre" (normalmente um homem e com alguma propriedade), dos que são sem herança, e dos que são sem liberdade.

Sempre que necessário, em cada capítulo, a pesquisa fará comparação com o texto da Septuaginta e com o Targum, como parte das respostas às questões levantadas, tendo como propósito notar como tais palavras foram traduzidas para essas versões, e, a partir disso, entender melhor o vocábulo hebraico. A comparação com estas versões tem como finalidade mostrar como os tradutores entenderam o texto Hebraico, e se as traduções feitas por eles cooperam com o entendimento do texto. Esta pesquisa reconhece que essas versões vieram em tempos posteriores ao que é tratado pelo texto da BH. Entretanto, seus tradutores estiveram mais bem posicionados na aproximação com a produção do texto da $\mathrm{BH}$.

Deve-se considerar que Deuteronômio foi estruturado com discursos atribuídos a Moisés nas planícies de Moabe, às vésperas da entrada do povo de Israel na Terra de Canaã. Esses discursos são dirigidos ao "tu/vós" com quem o orador dialoga. Discursos são constituídos de palavras. O titulo hebraico atribuído ao livro vem da primeira frase do Deuteronômio: "Estas são as palavras”. Com isso, “o título judaico dá importante dica quanto ao caráter literário do Deuteronômio" (CONSTABLE, 2015, p. 1).

Em Deuteronômio, o discurso é uma forma de diálogo em que o orador mantém proximidade com os seus ouvintes. Dentro desses discursos narrativos é que o Deuteronômio vai tomando sua forma, mostrando que a legislação deuteronômica se estabeleceu num contexto dialogal, onde as leis, principalmente as casuísticas, foram dadas numa estrutura narrativa. ${ }^{18}$ Essas histórias casuísticas ganhavam a memória da audiência pela forma como elas eram apresentadas, pois tinham as condições necessárias para fazer parte da memória do povo e, assim, poderem ser repetidas no contexto de vida de cada pessoa. Isso demonstrava a sensibilidade do orador que, ao colocar a legislação dentro de uma estrutura narrativa, buscava que o "tu/vós" guardasse e repartisse com outros que haviam ouvido. A legislação não era apenas para os que sabiam ler. A legislação era para todo o povo de Israel.

\footnotetext{
${ }^{18}$ Bartor, em seu artigo "Reading Biblical Law as Narrative", mostra que a Lei como Narrativa deve ser vista como uma história, pois para ele, "Lei é uma arena em que histórias humanas são apresentadas. Ela descreve situações e eventos concretos e faz uso de pessoas reais em estabelecer normas obrigatórias e a formação de políticas desejáveis" (2012, p. 292, 293). Bartor diz ainda que "A narrativa é um modo de pensamento, uma ferramenta cognitiva que nos permite atribuir significado às ações e eventos, e, portanto, serve como um meio mais importante para o reconhecimento do mundo, da humanidade, e da realidade humana" (2012, p. 299). Sendo assim, ela fazia parte da cosmovisão do orador e do ouvinte, fazendo com que seu uso fosse um instrumento de valor para o ensino e a aprendizagem, pois tanto o orador quanto seus ouvintes estavam dentro de uma área comum de diálogo.
} 


\section{OS ENTES SILENCIOSOS NO LIVRO DE DEUTERONÔMIO: A DISTRIBUIÇÃO DOS VOCÁBULOS}

A literatura bíblica está construída a partir dos elementos que são disponíveis em seu tempo de escrita com o fim de ser parte de seu tecido literário: o homem e Deus, homem e mulher, rico e pobre, homem e natureza, paz e guerra, filho e filha, mãe e pai, amigo e inimigo, e outros. Com o livro de Deuteronômio não é diferente. Seu eixo principal é Deus e o homem. Porém, pode-se afirmar que a ênfase do livro é colocada sobre os relacionamentos humanos. O livro inteiro foi escrito considerando este tripé: o orador, tu/vós e ele (ou eles, ela, elas). Mas quando o foco é o homem, vários relacionamentos são percebidos. O tu/vós se relaciona com ele (a) / eles (as): Deus, o próximo/irmão, bens, terra. Entre os relacionamentos homemhomem está aquele que existe da comunidade do tu/vós com os que são envolvidos pela ideia básica desta tese, os Entes Silenciosos.

O livro de Deuteronômio apresenta um grupo significativo de palavras para se referir a diferentes pessoas dentro da condição de Ente Silencioso. Entretanto, isso não quer dizer que o livro apresente todas as palavras usadas na BH para apontar uma pessoa nessa condição. A razão para isso é que as palavras não empregadas no livro são palavras já contempladas, em seus significados básicos, pelos vocábulos que o livro emprega. Por essa razão, deve-se considerar a riqueza vocabular que fora empregada dentro desse livro para revelar o interesse do orador/legislador ${ }^{19}$ com essa classe de pessoas dentro da sociedade israelita de então.

Dentro dos escritos legais, o Código da Aliança determina que o órfão e a viúva não sejam sujeitos a opressão (Êxodo 22,21 [22]). Mas é o livro de Deuteronômio que concentra atenção particular sobre aqueles que se encontram dentro de um limite social, de tal forma que podem ser considerados fracos quando vistos da perspectiva econômica (RINGGREN, 1990, p. 480). E, por isso, também são sem voz dentro da sociedade em que vivem, necessitando que outro ou outros fale ou falem por eles.

Deuteronômio está interessado no homem israelita e nos seus múltiplos relacionamentos, e, nalguns textos, o livro mostra interesse naqueles que são denominados Entes Silenciosos. São eles: a viúva, o órfão, o estrangeiro, o escravo, a escrava, e, em certos casos, também o

\footnotetext{
${ }^{19}$ No corpo da pesquisa se empregará os termos "legislador", "redator" ou "orador" intercambiavelmente, por entender que o livro é produto de várias atividades de redação.
} 
levita. ${ }^{20}$ O livro tem "preocupação com a justiça social” (SCHNIEDEWIND, 2011, p. 134-3135). Essa justiça é feita, na perspectiva do Deuteronômio, pelo homem a seu "irmão/próximo". 21

Além desses termos, o orador empregou outros vocábulos para referir-se a eles como sendo "fracos". Ele trata o Ente Silencioso com o sentido de necessitado, e também como Ente Silencioso no sentido de oprimido ou humilhado. Essa riqueza de vocábulos mostrará a criatividade da redação do próprio livro. Apesar de ele ser sem voz, daí a ideia de ele ser silencioso, o mesmo Ente Silencioso, por sua vez, fala por meio da voz do orador, o qual sai em seu interesse para lhe prover meios de proteção dentro do contexto em que vive, enriquecendo, com isso, a legislação contida no livro de Deuteronômio em sua redação canônica. $^{22}$

Ao notar que as palavras relacionadas aos Entes Silenciosos aparecem nos três conjuntos literários que compõem o livro (Deuteronômio 1-11, 12-26, 27-34), ${ }^{23}$ percebe-se, com isso, que a preocupação com as pessoas desse grupo era uma constante ao longo do desenvolvimento do livro. ${ }^{24}$ Esta pesquisa, porém, não está afirmando que todas as palavras aparecem em cada bloco, mas que as palavras relacionadas aos Entes Silenciosos, no todo, ou em parte delas, aparecem em cada um dos três conjuntos literários que formam o livro de Deuteronômio.

Portanto, afirma-se que o propósito deste capítulo é o estudo dos vocábulos que compõem o conjunto denominado de "Entes Silenciosos", e que aparecem dentro do livro de Deuteronômio. Aqui a pesquisa buscará suas ocorrências e significação dentro do livro, de

\footnotetext{
${ }^{20}$ O livro de Deuteronômio desenvolve ou trata de assuntos que não foram abordados em códigos anteriores, particularmente como aquele encontrado no código existente em Êxodo 19-23.

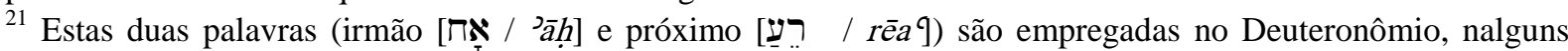
textos, para indicar o beneficiário das ações do tu/vós, e se referem a algum Ente Silencioso (Deuteronômio $1,16 ; 15,2.7)$.

${ }^{22}$ Entende-se por redação canônica a forma em que o livro se encontra hoje na BH, a redação final do livro na forma como ele chegou até hoje.

${ }^{23}$ Essa divisão é baseada na própria constituição do livro que parece abordar conteúdos diferentes, mas bem relacionados e estreitamente entrelaçados de forma a dar sentido único ao livro.

${ }^{24}$ Há diferentes modos de dividir o livro de Deuteronômio de acordo com seu período redacional. Nesta pesquisa é pressuposto que o livro seja dividido em três etapas redacionais, segundo o esboço por capítulos apresentado neste parágrafo. Esta é apenas uma forma simples de dividir o livro. Mas esta pesquisa reconhece a complexidade do assunto para se trabalhar aqui, cuja competência foge de seu alcance. Craig, em seu comentário sobre o livro de Deuteronômio (1976, p. 67-69), divide o livro em seis partes: Introdução ao Deuteronômio (1,15); O discurso de Moisés: Prólogo histórico (1,6-4,43); O discurso de Moisés: A Lei (4,44-26,19), subdividido nos capítulos 5-11, denominados de "Os Mandamentos Básicos", e nos capítulos 12-26 que trazem o que ele chama de "Legislação Específica"; O discurso de Moisés: bênçãos e maldições (27,1-28,69); O discurso de Moisés: ordens de conclusão (29,1-30,20); A continuidade da Aliança de Moisés a Josué (31,1-34,12).
} 
modo a se perceber que este viés literário vem a tornar-se um eixo para o livro, sem o qual ele apresentaria notória pobreza. Como centro deste capítulo está a questão: Quem são os Entes Silenciosos segundo o livro de Deuteronômio?

O que essa pergunta busca responder tem a ver com os vocabulários empregados no livro para falar dos Entes Silenciosos. Essa questão será respondida, em primeiro lugar, por apresentar onde se encontram os diferentes vocábulos que ocorrem dentro do livro. Depois este capítulo buscará entender a condição de cada Ente Silencioso ao qual cada palavra se refere. As pessoas que são indicadas por aquelas palavras e em quais partes do livro elas aparecem, seguindo a tríplice divisão de Deuteronômio, bem como quais são as palavras para designar cada elemento que constitui aquela classe de pessoas.

O grupo dos Entes Silenciosos tem, em seus variados vocábulos, distribuição desigual dentro do livro de Deuteronômio. Isso será apresentado por situar as palavras nos lugares em que elas aparecem dentro do livro. Esta pesquisa apresentará as que se referem aos Entes Silenciosos, seguindo a divisão geral do Deuteronômio em suas três partes constituintes, mostrando nos subpontos seguintes onde estão tais palavras que foram empregadas para designar cada um daqueles que são denominados nesta pesquisa pela nomenclatura de Entes Silenciosos. $^{25}$

\footnotetext{
${ }^{25}$ As aparições dos vocábulos serão apresentadas de acordo com a ordem de menção deles em cada uma das divisões literárias de Deuteronômio. Por isso, esta pesquisa não seguirá uma ordem padrão para cada bloco literário do livro. É pretensão colocar aqui todas as ocorrências de cada um dos vocábulos com o fim de trazer, ao final do capítulo, as conclusões parciais relativas a essas palavras de acordo com suas aparições dentro do livro.
} 
1.1. A distribuição das palavras

\begin{tabular}{|c|c|c|c|}
\hline Vocábulos & Deuteronômio 1-11 & Deuteronômio 12-26 & Deuteronômio 27-34 \\
\hline אבריוֹן & & $15,4 \cdot 7 \cdot 9.11 ; 24,14$ & \\
\hline 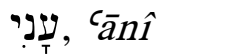 & & 15,$11 ; 24,12.14 .15$ & \\
\hline רוִּ $g \bar{g} r$ & $\begin{array}{ll}1,16 ; & 5,14 ; \\
10,18.19 & \end{array}$ & $\begin{array}{l}14,21.29 ; \quad 16,11.14 ; \\
23,8 ; \quad 24,14.19 .20 .21 ; \\
26,11.12 .13\end{array}$ & 27,$19 ; 28,43 ; 31,12$ \\
\hline 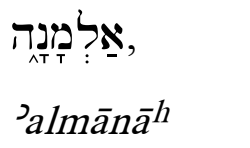 & 10,18 & $\begin{array}{l}14.29 ; \quad 16,11.14 \\
24,19.20 .21 ; 26,12.13\end{array}$ & 27,19 \\
\hline & 10,18 & $\begin{array}{l}14.29 ; \quad 16,11.14 ; \\
24,19.20 .21 ; 26,12.13\end{array}$ & 27,19 \\
\hline לִי! , lēwî & & $\begin{array}{l}\text { 12,12.18.19; } \\
\text { 14,27.28.29; 16,11.14; } \\
\text { 18,1.6.7; } \\
26,11.12 .13\end{array}$ & $27,9.14 ; 31,9.24$ \\
\hline 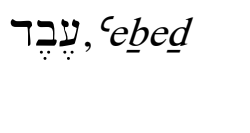 & & $\begin{array}{l}12,12.18 ; \quad 15,15.17 \\
16,11.14 ; 23,16 ; 24,22\end{array}$ & \\
\hline אִָָ אָה & & $\begin{array}{l}12,12.18 ; \\
16,11.14\end{array}$ & \\
\hline$\dot{u}_{\langle\tau}, q \bar{T}, t \bar{o} n$ & 1,17 & & \\
\hline
\end{tabular}




\subsubsection{Deuteronômio 1 a 11}

Dentro desse bloco literário do livro de Deuteronômio há a aparição de "estrangeiro" $(1,16$;

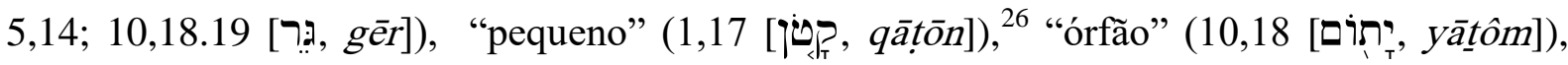

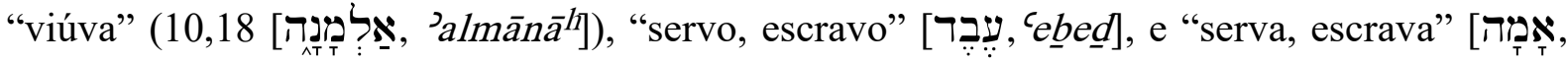

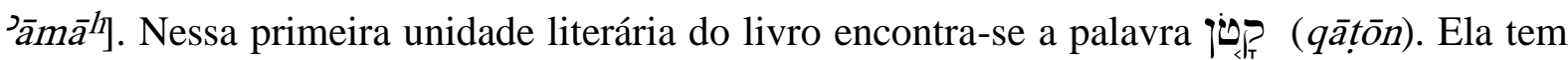
apenas essa ocorrência em todo o livro de Deuteronômio para designar um Ente Silencioso. ${ }^{27}$

\subsubsection{Deuteronômio 12 a 26}

Na segunda parte do livro, a qual é formada por aquele bloco de literatura que é chamado de

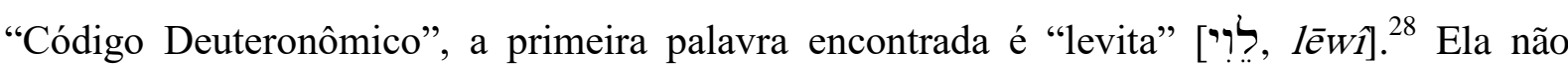
apareceu na primeira divisão do livro como também as palavras traduzidas por "pobre".

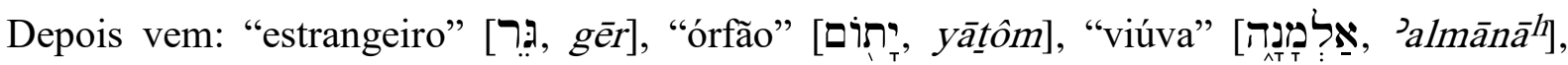

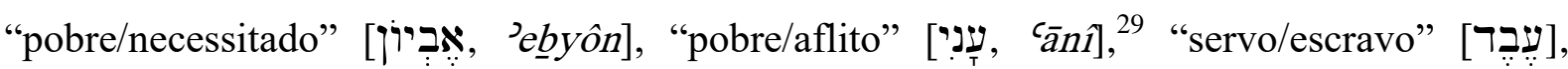

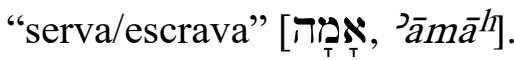

\subsubsection{Deuteronômio 27 a 34}

O terceiro bloco literário do livro de Deuteronômio é aquele que apresenta poucas palavras para se referir aos Entes Silenciosos. A razão para isso está na própria natureza do conteúdo dessa seção. Ela se constitui das palavras de despedida de Moisés e, nessas, duas grandes declamações poéticas - um cântico de Moisés e a bênção mosaica final (Deuteronômio 32 e 33), bem como da narrativa de sua morte (34). Assim, as palavras e suas aparições são:

\footnotetext{
${ }^{26}$ Nesse versículo, a palavra "pequeno" faz contraste com a palavra "grande". É notório que o assunto abordado aqui está relacionando ao problema do poder econômico e a força que o "grande" poderia exercer para interferir em um julgamento justo para os dois lados da questão, principalmente porque o que está sendo proibido é a parcialidade do julgamento na justiça para beneficiar o "grande" ou o "poderoso" em detrimento dos direitos daquele que é considerado "pequeno".

${ }^{27}$ Uma análise de textos paralelos para identificar o "pequeno" está presente no capítulo 2. Nesse capítulo, será mostrado o relacionamento de $q \bar{a} t \bar{o} n$ com o conjunto de palavras relacionado ao "pobre", 'ébyôn/ 'ānî.

${ }^{28}$ A forma hebraica do substantivo traduzido por "Levi" e "levita" é a mesma [לרי]. O contexto é quem vai determinar a diferença para a tradução. Assim, em determinado contexto a palavra pode designar o filho de Jacó que deu origem à tribo de Levi, noutro contexto ela apontará para um membro daquela tribo. Isso é apenas para destacar dois exemplos.

${ }^{29}$ Tanto a palavra אִבְי concentram suas ocorrências em dois capítulos do livro de Deuteronômio, capítulos 15 e 24.
} 


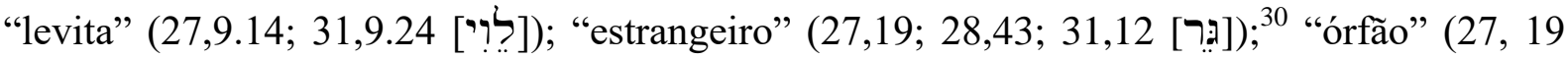

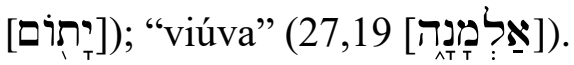

\subsubsection{Observações da distribuição das palavras}

Dessa distribuição das palavras pelo livro de Deuteronômio, algumas observações são apresentadas. A primeira é que não somente as referências estão concentradas em sua maior parte no bloco denominado de Código Deuteronômico (Deuteronômio 12-26), como também nesse bloco há o aparecimento de novas palavras para se dirigir aos Entes Silenciosos, tais

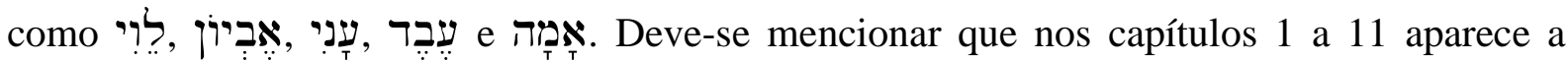
palavra para apontar um Ente Silencioso, sendo aquela uma forma de demonstrar que o

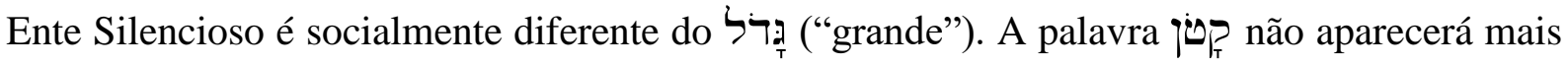
dentro do livro para se referir a um Ente Silencioso.

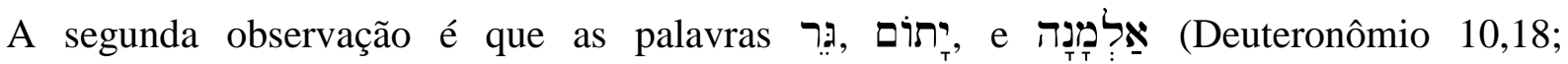
$24,19.20 .21$; 27,19) aparecem dentro do livro em conjunto como beneficiários da mesma ordenança. Neste sentido, o que se pode notar é que os três pertencem ao mesmo grupo de peregrinos dentro do povo de Israel.

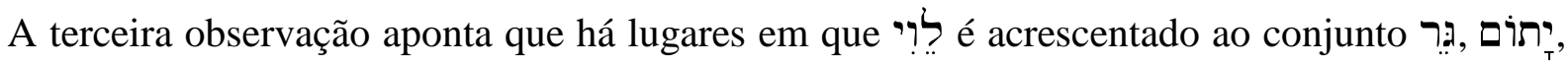

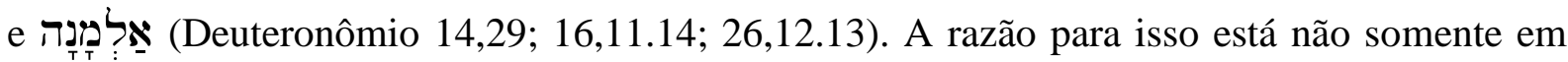
que eles sofriam das mesmas necessidades, mas também porque apresentavam as mesmas fragilidades. Eles eram os mais susceptíveis à opressão e não apresentavam um defensor capaz de servir de obstáculo entre um possível opressor e eles. Pode ser possível que parte das viúvas e órfãos era estrangeira e que o levita, por não possuir herança entre o povo, e assim não ter residência fixa, poderia ser considerado como um tipo especial de estrangeiro devido à sua condição de levita.

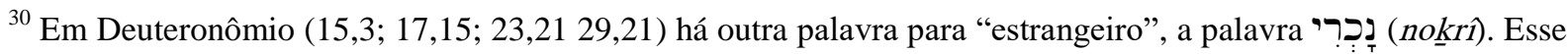
é o estrangeiro que não vive entre o povo, e, portanto, não depende daquele povo, ou nação, para sua sobrevivência. Em Deuteronômio 31,16 é encontrada a construção "deus de terra estrangeira" (de onde vem este

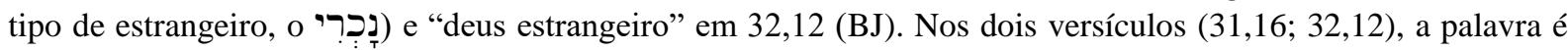

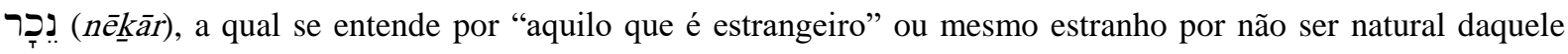
lugar (WILSON, 1980, p. 579).
} 


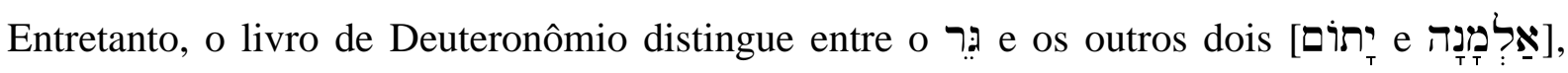
deixando esses na condição de nativos. Como o רạ era um estrangeiro que decidiu viver no meio de Israel, ele havia se adaptado ao povo e, exceto por sua origem, era também considerado um do povo, podendo até ir à justiça contra um "grande" (Deuteronômio 1,16.17). Tal favor da legislação deuteronômica não era concedida a um נְְִָ (noknrî).

A quarta observação é que a palavra que mais ocorre nos três blocos literários constituintes do livro de Deuteronômio é (estrangeiro). A primeira razão para isso é que desde a chamada de Abraão (Gênesis 12) até a entrada de Israel na Terra da Promessa, o povo havia sido estrangeiro em peregrinação por terras alheias, e, por isso, conhecia bem o que era ser estrangeiro em terra alheia. Assim, ele deveria tratar bem o estrangeiro que andasse por suas terras (Deuteronômio 10,19; ver também Êxodo 22,21). A outra razão é que a terra pertence ao Deus de Israel (Êxodo 19,5) e o sentimento que o povo deveria possuir era aquele de ser estrangeiro, numa terra que não lhe pertencia (Levítico 25,23), e que lhe havia sido dada em concessão. Ele deveria ser tomado por um sentimento contínuo de alguém que, mesmo possuindo uma propriedade na Terra da Promessa, ainda devia se sentir como estrangeiro, pois a Terra pertencia, em última análise, ao Deus de Israel (Levítico 25,23). ${ }^{31}$

Além disso, deve-se recordar que o povo de Israel havia por muito tempo sido estrangeiro entre outros povos. Os estrangeiros em seu meio seriam um teste para ver se o povo agiria com bondade, como aquela com que o Deus de Israel o havia tratado todo o tempo durante sua peregrinação por terras estrangeiras. O detalhe aqui está em que o padrão de tratamento não é aquele dado pelos povos a Israel no meio de quem ele viveu, mas o tratamento do Deus de Israel para seu povo, enquanto peregrino em outras terras.

Entretanto, mesmo que não seja declarado pelo texto de Deuteronômio, é possível apontar mais uma razão para maior incidência da palavra רạ. O deslocamento de pessoas entre as nações que gerava o גạ era motivado basicamente pela guerra, fome e praga. ${ }^{32}$ Essas pessoas

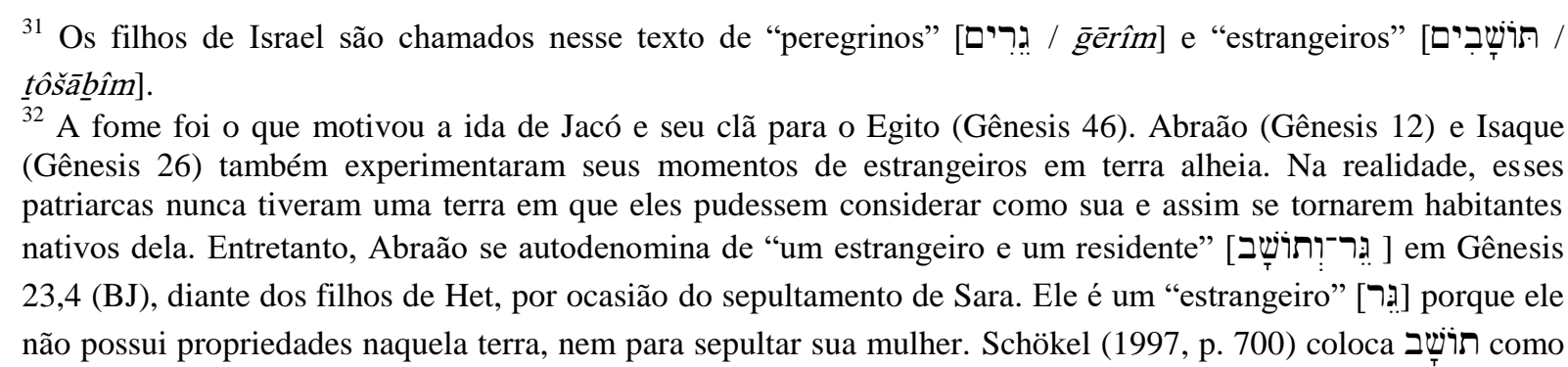


estavam empobrecidas pelas perdas de tudo que possuíam, necessitando de serem sustentadas por aqueles que as acolhiam, e que tinham com que ajudá-las.

A quinta observação sobre as ocorrências das palavras nos quadros comparativos é que as que foram empregadas para designar os Entes Silenciosos serão divididas em três grupos gerais. O primeiro é aquele que se compõe dos Entes Silenciosos que são denominados de "pobres". Dentro do livro de Deuteronômio, duas palavras estão relacionadas a esse grupo: עָנִִי e אֶבריון Mas está incluído aquele que é chamado de jưs, em Deuteronômio 1,17. Mais adiante serão

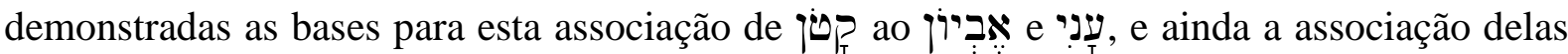
com a palavra בַּל, outra palavra para "pobre".

O segundo grupo é aquele constituído por aqueles que podem ser considerados "peregrinos"

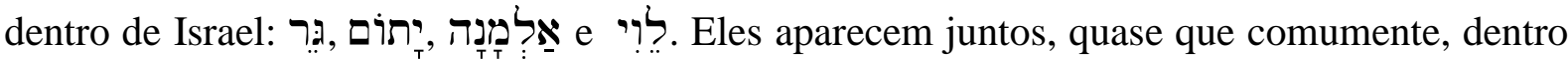
do livro de Deuteronômio, mesmo que às vezes o conjunto das referências ou tenha o grupo inteiro ou uma parte dele. Por causa disso, são colocados juntos no seu desenvolvimento, e serão tratados num capítulo separado dos Entes Silenciosos envolvidos pelas palavras para "pobre" e as que designam o "escravo" e a "escrava". Mas isso quer dizer que eles não eram considerados "pobres"? Mais adiante, será respondida essa questão. Deve-se apontar ainda que esses Entes Silenciosos poderiam ou não desfrutar da proteção de um clã.

O último grupo tem aquelas palavras que apontavam para os que gozavam da proteção de um clã. Essa proteção se dava, principalmente, porque protegê-los era também uma proteção ao patrimônio do clã. Esse grupo se constituía daqueles abraçados pelas palavras עָמָה e "escravo" e a "escrava". Mesmo que esses não tivessem aquela liberdade que os outros Entes Silenciosos possuíam de forma relativa, eles tinham outras vantagens por pertencerem ao patrimônio do clã, tais como: proteção, alimentação ou mesmo o trabalho compulsório. Se houvessem de servir a um senhor generoso, no dia de sua saída teriam presentes para o recomeço da vida, no caso do israelita que havia se vendido como escravo para um clã.

Por último, tem-se que notar que os capítulos seguintes terão esta ordem: primeiro, o capítulo que tratará dos Entes Silenciosos que estão envolvidos pelas palavras para "pobre"; depois seguirá aqueles que aparecem agrupados e formam um conjunto - a viúva, o órfão, o

sinônimo de aㅗ. Já o verbo "peregrinar” [ㄱำ é atribuído tanto a Abraão (Gênesis 12,7; 21,1.23.34) como aos irmãos de José em sua ida para o Egito (Gênesis 47,4). 
estrangeiro e o levita; por fim, o capítulo que tratará dos Entes Silenciosos que estão sujeitos à servidão.

\subsection{Entes Silenciosos falantes?}

Numa leitura simples do Deuteronômio se notará que há palavras que são colocadas nos lábios dos Entes Silenciosos. Deve-se levantar a questão se os Entes Silenciosos, em algum momento do texto do Deuteronômio, quebram o seu silêncio e expressam alguma palavra e em que situação isso ocorre. Será que eles não são tão silenciosos quanto se espera que sejam, segundo a temática desta tese?

O procedimento para o desenvolvimento neste ponto é seguir a ordem de aparição dos Entes

Silenciosos que "falam" dentro do livro de Deuteronômio. É certo que eles "falam". Porém, nem todos o fazem. Além do mais, nota-se que as falas dizem respeito àquilo que o redator do livro apontou como fala que eles teriam ou que deveriam falar em momentos específicos. Dessa maneira, tem-se aqui um estrato daquilo que, eventualmente, teria sido dito por eles em determinadas circunstâncias. Isso não quer dizer que eles fossem permanentemente silenciosos em todas as circunstâncias de suas vidas. Quer dizer apenas que suas falas apresentadas no texto são escritas em forma resumida do que eles deveriam dizer nos contextos que exigissem suas palavras. Na realidade, pode-se dizer que as falas eram fórmulas que deviam ser decoradas para serem ditas nos devidos contextos estabelecidos pelo redator do livro.

\subsubsection{O ל ל $\mathrm{O}$, lēwî, e a fala do redator para ele}

\subsubsection{O lēwî fala para abençoar}

Os levitas são os Entes Silenciosos que mais "falam" em Deuteronômio. O motivo básico para essa posição de "mais falante" está na função que eles desempenhavam dentro de Israel. Eles eram membros da tribo sacerdotal e, como tal, eram os que detinham conhecimento para instrução do povo. 
A primeira ocorrência de uma fala do $l \bar{e} w i ̂$ aparece em Deuteronômio 10,8. O texto citado diz: ${ }^{33}$ "Neste tempo, o Deus de Israel separou a tribo de Levi para carregar a arca da aliança do Deus de Israel, para permanecer diante do Deus de Israel para servi-lo e para abençoar em seu nome até este dia". ${ }^{34}$ Essa segunda subdivisão do propósito de a tribo de Levi permanecer diante do Deus de Israel, mostra uma fala pública, quando os peregrinos eram abençoados nos fins das festas anuais, ou depois de uma visita particular para o cumprimento de algum voto feito pelo peregrino. ${ }^{35}$

A bênção apresentada em Números 6,22-27 é a que devia ser invocada sobre os peregrinos como forma de perpetuar o nome do Deus de Israel sobre seu povo como meio de bênção $(6,27)$. Mas também funcionava pedagogicamente para ensinar ao povo quem era o Deus a quem ele deveria servir. Assim, a repetição dessa bênção nas festas imprimia sobre a mente do povo o senso de devoção, ensinando ao povo quem era o Deus de Israel. Para os peregrinos e seus filhos, a bênção era o momento de recepção da esperança, enquanto aguardavam o período que se seguia viria com o sucesso desejado para seus empreendimentos.

Deuteronômio 10,8 não é o único lugar, no livro, onde lēwî é chamado para abençoar como parte de sua ministração ao povo de Israel. Deuteronômio 21,5 coloca a bênção como parte do ministério dos "sacerdotes, filhos de Levi" dentro de um contexto judicial, onde se especula

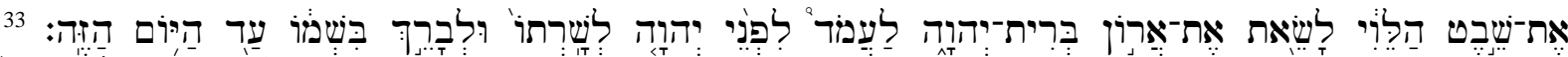

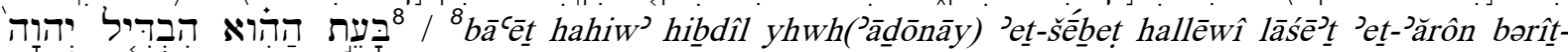

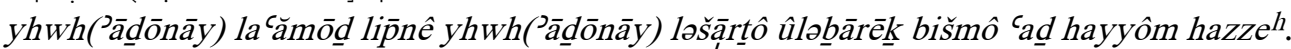

${ }^{34}$ Esse versículo faz parte das memórias do Monte Sinai, por ocasião da entrega dos Dez Mandamentos, na segunda vez, depois de Moisés ter quebrado as primeiras tábuas. O versículo é construído com um verbo que mostra que o Deus de Israel separou a tribo de Levi com dois propósitos, sendo que o segundo propósito pode ser dividido em dois outros. Assim, o Deus de Israel "separou a tribo de Levi" com o fim de conduzir a arca da aliança e permanecer diante de Deus no santuário central. Como carregar a arca relembra as peregrinações no deserto, então o santuário central aqui relembra o tabernáculo móvel no deserto. Essa permanência no serviço a Deus no tabernáculo tinha dois objetivos - ministrar e abençoar. Todos os verbos que apontam para esses propósitos e suas subdivisões são infinitivos construtos nascidos do ideal divino de separação da tribo de Levi. O

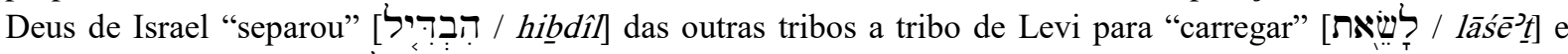

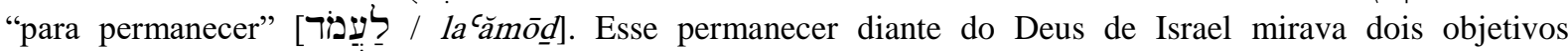

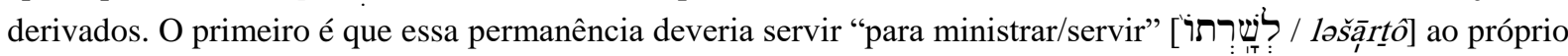
Deus de Israel, numa referencia aos ritos diários. O segundo tem haver com a questão da fala. A tribo de Levi

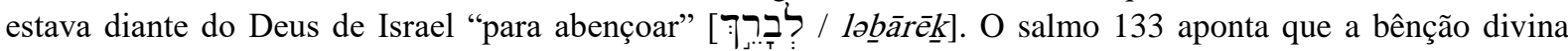
estava sobre o Monte Sião, onde estava o Templo com a arca da aliança. O salmo 128 diz que é de Sião que Deus abençoa (ver Salmo 134, onde a mesma ideia é repetida). Mas como ele abençoa? Ele abençoe por meio das palavras de bênção vindas dos lábios de Levi - sejam sacerdotes, sejam levitas. As bênçãos miravam a colocação do Nome do Deus de Israel sobre seu povo e, com isso, alcançar proteção e prosperidade. Balaão entendeu isso ao dizer para Balaque, rei de Moabe, que Israel era povo abençoado e, como ele não podia revogar a bênção divina, ele também não poderia amaldiçoar Israel (Números 23,20).

${ }^{35}$ A confissão presente em Deuteronômio 26,1-11 pressupõe que o confessor, ao iniciar seu retorno para casa, recebesse a bênção. Corrobora com isso a bênção de Eli sobre Ana em 1 Samuel 1,17 e 2,20. 
sobre quem matou uma pessoa encontrada morta, mas sem saber quem a matou, com a ideia de que o criminoso procedeu da cidade mais próxima. Entretanto, os anciãos daquela cidade, alegando inocência, convocam os sacerdotes para dar seu parecer e livrar aquela cidade das penalidades impostas sobre quem matasse alguém. Ao pronunciar a bênção, os "sacerdotes, filhos de Levi” imprimiam sobre aquela cidade a libertação da culpa (ou possibilidade dela), causando a sensação de paz vinda do Deus de Israel.

Dentro desse contexto é afirmado que os "sacerdotes, filhos de Levi”, foram escolhidos "para ministrar e para abençoar no nome do Deus de Israel". ${ }^{36}$ Como parte da bênção e de seu serviço ao Deus de Israel, e como seus representantes que abençoam em seu Nome, está a decisão sobre a demanda na questão do morto de quem não se conhece seu assassino nem a sua procedência. A declaração de inocência é bênção declarada no Nome do Deus de Israel, pois traz alívio sobre as cidades inocentes.

Finalmente, Deuteronômio 27,12 afirma que a tribo de Levi deve abençoar. Mas aqui, o texto é aquele que trata da bênção a ser pronunciada sobre o Monte Gerizim, depois de o povo haver entrado na Terra da Promessa. Entretanto, nesse texto, a tribo de Levi está junto com outras cinco tribos que pronunciariam a bênção enquanto outras seis pronunciariam a maldição.

\subsubsection{O lēwî fala para amaldiçoar}

Paradoxalmente, cabia a lēwî também amaldiçoar. Depois de dizer que um grupo de tribos iria abençoar sobre o Monte Gerizim, o redator afirma que lēwî deveria amaldiçoar. Deuteronômio 27,14-26 coloca uma fala que deveria ser dita em voz alta. Do versículo 15 -26 se encontra essa fala de maldição, com todas as frases começando com o verbo no infinitivo absoluto, "amaldiçoar" [אָּרוּ / ’ārûr].

A palavra de maldição era proferida pelo resultado do comportamento do povo ou de um membro daquele grupo de pessoas. Amaldiçoar era colocar fora da proteção do Deus de Israel aquele sobre quem a maldição era colocada. Portanto, era uma palavra de exclusão da

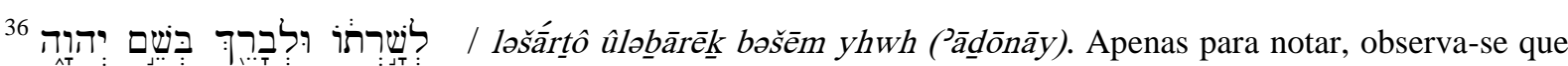
os verbos infinitivos construtos encontram-se também em 10,8. Eles demonstram os objetivos a serem alcançados por meio da ação do verbo finito. 
comunidade da bênção, o povo de Israel. ${ }^{37}$ Enquanto que a bênção trazia a indicação de sucesso e união na família, a maldição era desagregadora e implicava em fracasso. Era o extremo oposto da bênção.

Para a cidade que, eventualmente, fosse acusada de acobertamento do assassino, a maldição, pela cumplicidade no assassinato, a maldição lhe era imposta por cumplicidade. Segundo Motyer (1983, p. 987-988), há três colocações quando a maldição procede de Deus. A primeira é que a palavra de maldição é também uma palavra "de denúncia contra o pecado" (Deuteronômio 29,19.20; Números 5,21.23). A segunda mostra que, com a maldição, Deus está julgando o pecado (Números 5,22.24.27; Josué 24,6). Finalmente, quando a pessoa está sofrendo as consequências de seu pecado é considerada uma maldição porque Deus a julgou, (Números 5,21.27).

Ao deixar com o lêwî o dever de amaldiçoar, o orador deixava com aqueles que teriam, dentro de Israel, a capacidade para decidir quando pronunciar a maldição sobre o culpado somente quando houvesse convicção da culpa da cidade ou de alguém. Essa palavra viria como resposta à investigação realizada.

\subsubsection{Os sacerdotes levitas "falam"}

Mesmo que os sacerdotes levitas não pertençam ao grupo próprio de levitas chamados de Entes Silenciosos, porque eles não se apresentam como aqueles que estão entre aqueles que têm necessidades econômicas. Mesmo assim, deve-se acrescentar aqui que, em Deuteronômio 27,9 os sacerdotes levitas falam. Essa fala, porém, é prioritariamente de Moisés. O texto ${ }^{38}$ diz: "E falou Moisés e os sacerdotes para todo o povo de Israel com o fim de dizer". ${ }^{39}$ O verbo "falar", no singular "e falou", coloca ênfase na fala sobre Moisés. Assim, o texto quer comunicar que a fala é de Moisés, mas com a repetição desta mesma fala para o povo por meio dos sacerdotes.

\footnotetext{
${ }^{37}$ Para consulta a maiores detalhes sobre a questão da palavra de maldição, notar a pesquisa de Pedro E. C. Santos, A Presença de Deus em Gênesis e Êxodo, 19-20.

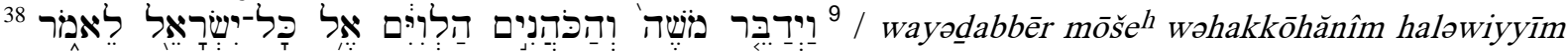
'el kol-yiśrāèèl lèèmōr.

${ }^{39}$ O infinitivo construto é traduzido aqui como infinitivo de propósito. Assim, a tradução comum "dizendo" oculta a ideia que a construção quer comunicar o propósito da fala que é apresentar um conteúdo. A preposição prefixa $I$ aponta para uma direção ou um fim. Entretanto, esta construção hebraica [לאמר]] pode ser simplesmente colocada na tradução como dois pontos (:).
} 
Então Moisés fala aos sacerdotes levitas o que eles deveriam falar para o povo em obediência à ordenança de Moisés. O conteúdo dessa fala está em Deuteronômio 27,9.10 - ao entrar em aliança com seu Deus, Israel passaria ser o povo desse Deus e, assim, deveria obedecer atentamente as palavras da Lei divina.

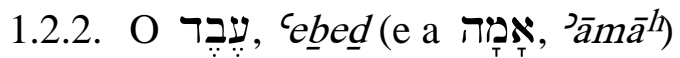

O segundo Ente Silencioso a ter uma "fala" em Deuteronômio é o ‘e $\underline{b} e \underline{d}$. Qual 'e $\underline{b} e \underline{d}$ "fala"? O 'ebe $\underline{b}$ que "fala" é aquele que é israelita e que se vendeu como escravo e está perto de ser liberto no Ano do Cancelamento de Dívidas (Deuteronômio 15,16.17). É o 'e ébed que, voluntariamente, tomou a decisão de se vender à escravidão na casa de outro israelita com condições de comprá-lo por um tempo e, provavelmente, com recursos para assumir e pagar as dívidas adquiridas pelo escravo (ou escrava) temporário. É um 'e $\underline{b} e \underline{d}$ especial por se tratar de um membro do povo de Israel, não de um 'e $\underline{b} e \underline{d}$ comprado de outros povos.

As suas palavras são uma declaração que ele não quer deixar o clã daquele senhor: ${ }^{40}$ " $\mathrm{E}$ acontecerá que ele te dirá: "Não sairei de contigo"". ${ }^{41}$ Essas palavras, colocadas na boca do 'ebe $\underline{\text { d }}$, deveriam ser declaradas também diante de um tribunal, para que fosse oficializada a possessão perpetua do 'e $\underline{b} e \underline{d}$ pelo clã a quem ele servia.

A marca dessa perpetuidade era colocada na orelha do 'e $\underline{b} e \underline{d}$, por meio de um furo. No Código da Aliança (Êxodo 20,22-23,19) nada é dito sobre a 'āmmăh que também quer ficar para sempre com seu senhor (ou com a sua senhora). Mas Deuteronômio acrescenta essa possibilidade $(15,12.17 \mathrm{c})$, não dada a ' $\bar{a}^{m} \bar{a}^{h}$ naquele Código, mas colocada em Deuteronômio, indicando um desenvolvimento posterior ao Código da Aliança, com o fim de atender ao desejo dela. De qualquer forma, preferir à escravidão perpétua em lugar da liberdade aponta para uma de duas direções - ou o ambiente com aquele clã apresentava as

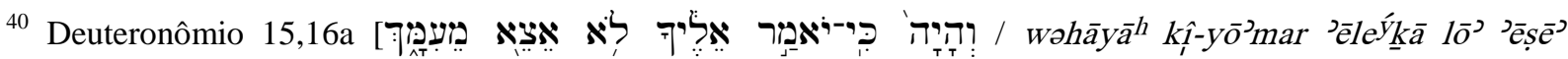
$m \bar{e}^{-}$immāan $]$. A declaração do teu irmão 'e $\underline{b} e \underline{d}$ pode ser assim colocada: "Não saio de tua companhia", com o fim de demonstrar uma ideia presente, no momento em que o senhor do 'e $\underline{b} e \underline{d}$ iria colocá-lo em liberdade. Nesse momento, ele declararia sua preferência e decisão definitiva. Por isso, tal decisão deveria ser bem pensada porque ela não teria volta.

${ }^{41}$ No Código da Aliança (Êxodo 20,22-23,19), a declaração do escravo hebreu que quer ficar para sempre com seu senhor é mais completa em 21,5: "Eu amo meu senhor, minha mulher e meus filhos, não quero ficar livre" (BJ).
} 
condições superiores as da liberdade, ou o contexto de liberdade seria assaz difícil para o recomeço, levando o ${ }^{\complement} e \underline{b} e \underline{d} /{ }^{\supset} \bar{a} m \bar{a}^{h}$ a preferir a vida de escravo.

Há um detalhe significativo que deve ser visto na decisão do "teu irmão hebreu ou hebreia" 42 em ficar permanentemente com seu senhor ou sua senhora - a liberdade de escolha. A possibilidade de liberdade, e com ganho, está diante deles, pois eles não deveriam ser despedidos de mãos vazias (Deuteronômio 15,13.14). Mas escolhem ficar, mesmo sabendo que, depois dos procedimentos legais e da marca de orelha estabelecida, eles não têm mais a escolha de retornar à condição anterior.

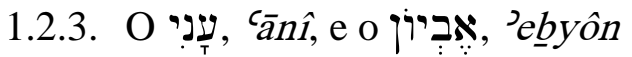

\subsubsection{O clamor do 'ānîe do ’ebyôn}

Deuteronômio 24,15 fala do clamor do "pobre". Nesse capítulo, as duas palavras são empregadas para "pobre" [ ‘̄anî̀ e ’ebyyôn]. No versículo anterior há um problema entre um trabalhador "pobre e necessitado" [ ‘ānî e ’ebyôn] e seu empregador - esse não o pagou por seus serviços. O texto sugere que, mesmo diante dos apelos do trabalhador, o empregador não efetua o pagamento daquela diária. $\mathrm{O}$ que lhe resta é clamar. O texto diz que o pagamento

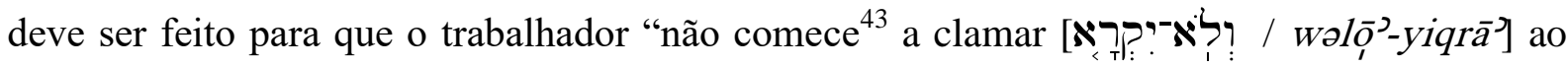
Deus de Israel”.

O verbo "clamar" sugere um grito de invocação de Deus para que ele aja em seu favor, julgando a sua causa. O Deus de Israel é invocado como juiz. Neste julgamento se verá que o empregador está fazendo injustiça. E, por isso, o texto diz que se achará pecado (injustiça) naquele empregador $(24,15)$. O clamor a Deus é resultante de situação extrema, onde o diálogo homem-homem não existe, ou se tornou impossível. Nesse momento extremo, o homem 'ānî e ’ebyôn tem apenas o "ouvido" divino com quem dialogar - o do Deus de Israel. Assim, esse trabalhador, vendo que não tinha atenção por parte de seu empregador, e estando

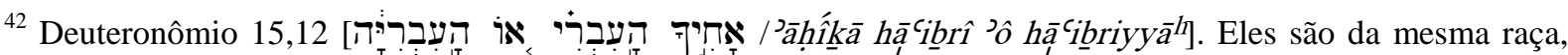
mas o que os diferencia aqui é a condição social. É uma palavra que aponta para a origem comum. Eles

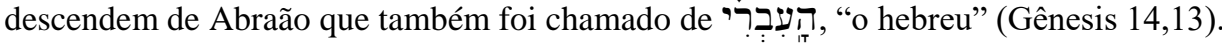

${ }^{43}$ Pressupõe-se que, depois de as tentativas de apelo do 'ānî /'ebyôn serem recusadas pelo seu interlocutor, ele passa a entender que ele precisa começar a falar com um interlocutor que vai the ouvir. Assim, ele começa a clamar ao Deus de Israel.
} 
sob o domínio do opressor, exerce sua fé e fala com Deus, pois estabelece a confiança que ele o ouvirá e resolverá seu problema.

\subsubsection{A bênção do '`ānî}

A outra "fala" do "pobre" é a fala para abençoar. Aqui a palavra para "pobre" é ‘ānî (Deuteronômio 24,12). O empréstimo que o ‘̄anî fizera tinha como garantia um penhor que lhe servia de proteção durante a noite. Esse penhor deveria ser devolvido no fim da tarde para que o ‘̄anî tivesse proteção durante a noite. Se aquele que fizera o empréstimo procedesse assim, Deuteronômio 24,13 diz que ele seria abençoado pelo ‘ānî. Provavelmente, a bênção será a invocação do Deus de Israel para que abençoasse aquele que está devolvendo o penhor. Dessa forma, o "pobre" invoca Deus tanto para clamar por justiça, quanto para pedir bênção sobre aquele que age em bondade com o necessitado. ${ }^{44}$ A boca que grita também invoca a bênção divina.

\subsubsection{Algumas observações}

O que se pode notar por meio dessas "falas"? Primeiro, o inter-relacionamento não é completo porque eles não falam entre si (os Entes Silenciosos). Não há diálogos entre eles, principalmente entre aqueles pertencentes ao mesmo grupo de Entes Silenciosos. Em todas as falas, eles se expressam por meio da declaração do orador quanto ao conteúdo que eles deviam proferir. De certa forma, eles continuam silentes porque suas falas não são espontâneas, tais como a daquelas que vêm como conteúdo de uma declaração como "e disse", ou "e disseram".

Segundo, notadamente a maior parte das falas dos Entes Silenciosos está com Ente Silencioso lêwî. Ele fala para abençoar, amaldiçoar e para ordenar ao povo de Israel que obedeça às palavras do Deus de Israel. Isso era de esperar. A tribo de lêwî era uma tribo culta. Ela era responsável pela manutenção dos ritos no Tabernáculo, e, posteriormente, no Templo, e também pela instrução do povo nos mandamentos do Deus de Israel. Mesmo assim, ainda havia levitas que dependiam de outros para sua sobrevivência, e parece que esses formavam o grupo maior de levitas.

\footnotetext{
${ }^{44}$ A questão do sistema de recompensas desenvolvido dentro de Deuteronômio será abordada dentro da análise de Deuteronômio, capítulo 15, no segundo capítulo.
} 
Terceiro, as falas são palavras colocadas nos lábios dos Entes Silenciosos pelo redator (ou redatores) do livro de Deuteronômio, como notado acima, fazendo com que as falas deles não sejam tão espontâneas quanto se deveria esperar. O redator deuteronômico está esperando precisão nas declarações bem como afirmações que favoreçam a memória. Esses tempos eram tempos de grande necessidade da memória, e o redator, sabendo disso, coloca afirmações que favoreçam a lembrança, principalmente, daqueles, como o escravo que queria ficar para sempre com seu senhor. Assim, o texto vem na forma de um diálogo entre o redator e a comunidade que o ouve e guarda na memória o que está sendo dito.

Quarto, mesmo que o inter-relacionamento não seja entre os próprios Entes Silenciosos, estes "falam" com outras pessoas - com a comunidade, e com Deus. Eles estão interagindo com seus pensamentos e desejos. Eles podem comunicar algo e, como tal, estão expressando o que eles são - pessoas criadas à imagem do Deus de Israel, como qualquer membro do povo israelita. Porém, deve-se notar que, a fala do servo, da serva e do pobre é expressa "de baixo para cima”. Aqueles falam com seu senhor e sua senhora, e este dirige sua fala ao seu Deus.

Quinto, os Entes Silenciosos podem abençoar o próximo, numa demonstração de poder da sua palavra. Clamar ao Deus de Israel contra alguém por seu desprezo a algum Ente Silencioso não era o que alguém dentro de Israel desejaria. O Deus de Israel é um Deus justo. Com ele não há barganha que favoreça um ou outro. Assim, a palavra do Ente Silencioso oprimido carregava um poder inesperado para alguém, aparentemente, fragilizado.

Porém, diante disso, o que faz a pesquisa manter que os grupos de pessoas designadas pelas palavras continuam sendo "Entes Silenciosos"? O motivo básico é que o que eles dizem é dito para eles dizerem, ou o que deveria ser dito por meio deles nas circunstâncias designadas pelo orador. Assim, o orador continua sendo a sua voz, fazendo com que as palavras dos Entes Silenciosos sejam palavras que estão dentro de um ambiente controlado pelo redator que é quem diz o que o Ente Silencioso deve dizer. Elas são orientações do orador para sua audiência - ele fala o que eles deveriam falar em determinadas circunstâncias. Dentro da fala dos Entes Silenciosos, onde eles são silentes, porém, falam por meio da boca do redator, o qual diz o que eles devem falar.

Portanto, pode-se afirmar, como resultado da análise anterior, que os Entes Silenciosos de Deuteronômio podem ser divididos em três grupos. O primeiro é aquele que se compõe por aqueles que são denominados pelas duas palavras "pobre" empregadas no livro [עָנגי e אִביון e 
Mais adiante se demonstrará que há outras palavras para "pobre" dentro da BH. Mas em Deuteronômio somente aquelas duas são usadas. Por meio de análises comparativas com textos dentro do Pentateuco se estabelecerá a relação delas com outra palavra. Esse capítulo terminará como uma análise de Moisés em Números 12, onde ele aparece qualificado como um homem humilde diante de um conflito intra familiar. $\mathrm{O}$ readator o identifica com os membros desse capítulo.

O segundo grupo é composto por aqueles que quase sempre aparecem juntos dentro do livro.

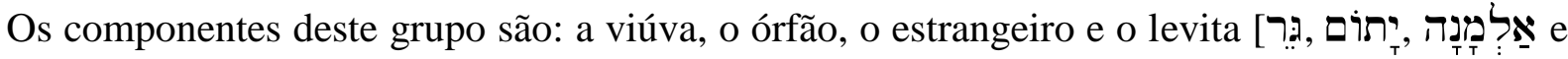

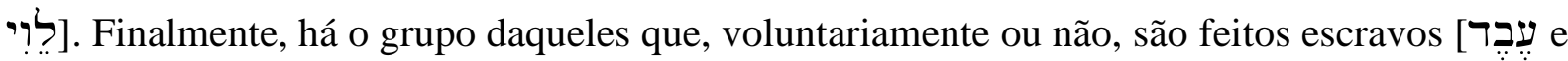
אָז

Os capítulos seguintes tratarão de cada um desses grupos existentes dentro do Deuteronômio, numa tentativa de demonstrar que os Entes Silenciosos estão dividos em estratos sociais e que, mesmo que todos eles pudessem ser chamados de עִ עִנִי e, eles são denominados por palavras diferentes com fim de demonstrar sua especificação. A legislação do Deuteronômio ousou por não generalizar, ao especificar cada um em seu devido estrato social.

Nos dados anteriores se notou que alguns deles falam. Mas falam dentro de linhas mestras dadas pelo redator. No seu discurso sobre eles, ele coloca palavras que poderiam ser pronunciadas dentro de determinados contextos. Assim se percebe a completa dependência dos Entes Silenciosos - eles precisavam de que alguém lhes dissesse o que dizer para que pudessem falar. De alguma forma, a voz do redator vinha em benefícios daqueles que não podiam falar para expressar o seu sofrimento pessoal como Ente Silencioso. Como Moisés num momento de crise aguda com seus irmãos, os Entes Silenciosos precisavam que alguém falasse por eles. Mesmo que eles queiram falar, eles se negam a falar até que outro fale por eles.

A voz do redator vinha como alívio para cada um deles. $\mathrm{O}$ redator funcionava como um parente muito próximo que agia para resgatar os Entes Silenciosos de seu silêncio sofredor. O redator no Deuteronômio mostra que a comunidade pode ser agente da solução de seus problemas, um agente participativo que, sob a bênção de seu Deus, trabalhava para que uma comunidade "sem pobres" viesse a existir. Essa comunidade ideal viria com a benção divina sobre o "tu/vós" obediente ao seu Deus. É assim que é a legislação deuteronômica. Ela é a voz 
de Deus por meio da voz de homens, conhecidos dos Entes Silenciosos, e, como os Entes

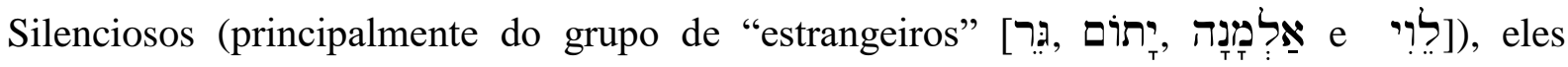
também são "estrangeiros" (Levítico 25,23; Deuteronômio 10,19 [גר?רים]) porque a terra pertence ao Deus de Israel, e eles estão na terra como concessionários, enquanto atenderem a voz de seu concessor.

No caso de Moisés, a voz do orador é a voz de Deus, em Números $12 .{ }^{45}$ Como Ente Silencioso ideal, Deus fala em seu favor. Mas isso é representativo daquilo que Deus faz, em Deuteronômio, em favor de todos os Entes Silenciosos. Ele fala em seu favor por meio do legislador. E assim, numa ação da dupla divina e humana, Deus vem em benefício daquela porção de seu povo que está empobrecida.

Enfim, como Deus, através do orador/redator deuteronômico, falou em favor de cada grupo dos Entes Silenciosos? Como ele os tratou e os distinguiu com ações beneficentes? Os capítulos seguintes apresentarão as respostas.

\footnotetext{
${ }^{45}$ O capítulo seguinte será concluído com uma análise detalhada de Números 12 para demonstrar seu elo com os Entes Silenciosos qualificados por sua pobreza.
} 


\section{OS ENTES SILENCIOSOS CARACTERIZADOS POR SUA "POBREZA"}

O capítulo um mostrou um panorama das palavras relacionadas aos Entes Silenciosos e como eles podem ser reunidos em grupos diferentes, com base nas ocorrências textuais onde eles aparecem em conjunto e, dentro de suas comunidades, onde eles eram conhecidos e mantinham relacionamentos com outros membros. Nesse capítulo, também foi analisado o texto onde Moisés é chamado de $\varsigma_{a} n \bar{a} w$, identificando-o, dessa forma, com aqueles que

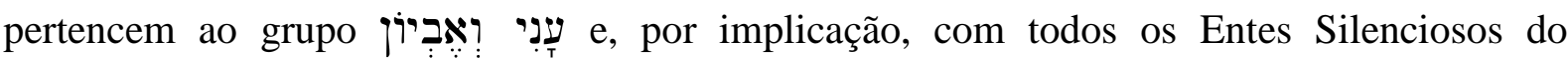
Deuteronômio. Pode-se afirmar que, seguramente, o tópico relacionado a Moisés estaria bem incorporado no capítulo a seguir. Entretanto, pensando em Moisés como um padrão de עִָָ para o povo de Israel, optou-se por colocá-lo no capítulo anterior.

Pensar em comunidade dentro do Deuteronômio, seja aquela que está no campo seja a que está na cidade, é entender que o livro não foi escrito num vácuo histórico. Os Entes Silenciosos eram membros de suas vilas, aldeias e cidades, e eram conhecidos de todos a quem o livro se destina (tu/vós). A vida em comunidade era fundamento de vivência dentro de Israel, a começar por sua constituição em tribos, e, dentro das tribos, os clãs que as constituíam e a elas davam sentido e organização.

Os Entes Silenciosos eram membros dessas comunidades espalhadas por todo o Israel e que, por sua vez, mantinham relacionamentos com as famílias que formavam as tribos. Portanto, eles não podiam ser esquecidos porque eles estavam ali, convivendo como membros dessas comunidades estabelecidas em suas terras, as quais eram consideradas como herança da parte do Deus de Israel. Eles mantinham relacionamento diário com as pessoas ao seu redor.

Os Entes Silenciosos a serem estudados neste capítulo são aqueles que estão envolvidos pelas

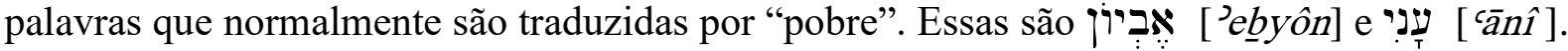
Elas são as palavras para "pobre" que ocorrem dentro do livro de Deuteronômio. Há também uma ocorrência da palavra $u p_{T}$ ("pequeno"), e que se perceberá que ela faz referência ao "pobre" por meio da análise de textos paralelos dentro do Pentateuco, onde, em lugar de pט 
aparece ("po- ("pobre"). Essa, em determinados textos, aparece em paralelo com as palavras que estão presentes no Deuteronômio. ${ }^{46}$

Neste capítulo também estará presente uma pesquisa sobre a identificação de Moisés - e de outros personagens bíblicos importantes - com o grupo de Entes Silenciosos, particularmente com aqueles que pertencem ao bloco constituído pelos עָנִי e אבריון e A autoria do livro é atribuída a Moisés pela tradição. Nesse aspecto, torna-se significativo que ele seja apresentado como alguém que seja relacionado a eles.

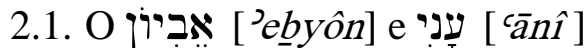

\begin{tabular}{|c|c|c|c|}
\hline Vocábulos & Deuteronômio 1-11 & Deuteronômio 12-26 & Deuteronômio 27-34 \\
\hline אבְביוןן & & $15,4.7 .9 .11 ; 24,14$ & \\
\hline עִ עִ עִ & & 15,$11 ; 24,12.14 .15$ & \\
\hline
\end{tabular}

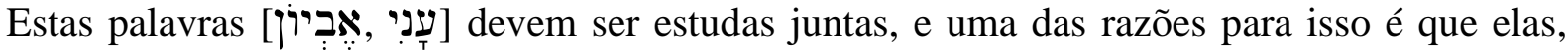
normalmente, são traduzidas por "pobre" dentro do livro de Deuteronômio, exceto quando elas ocorrem no mesmo versículo. ${ }^{47}$ Quando isso acontece, os tradutores da BJ, por exemplo, traduziram o ’ebyôn ou o ‘ānî de forma diferente uma da outra. Assim, quando uma foi

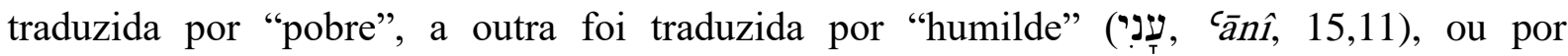
"necessitado" (אבריון, 'ebyyôn, 24,14). Essa diferença na tradução pode ser encontrada em outros textos quando elas aparecem juntas.

O outro motivo, e o mais significativo, é que as duas palavras surgem dentro dos mesmos capítulos da mesma divisão do livro de Deuteronômio, o chamado Código da Aliança

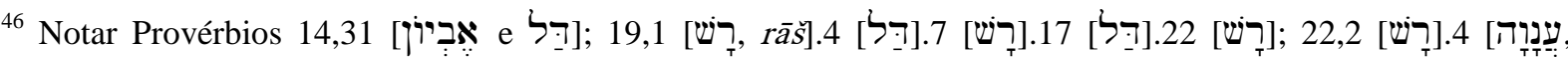

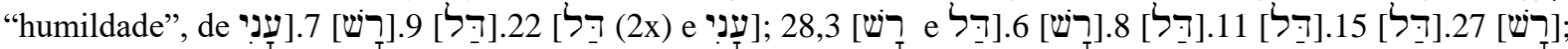

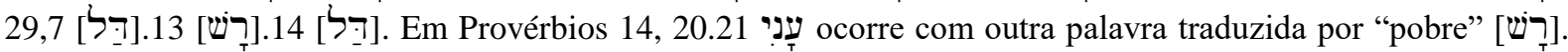
Essa é, em realidade, um qal particípio de רוֹשוֹ, "ser pobre".

${ }^{47}$ O que pode ser notado pela tradução da BJ (רֵביון -15,4 ["pobre"].7 ["pobre" nas 2 ocorrências da palavra].9 ["pobre"].11 ["pobre" nas duas ocorrências]; 24,14 ["necessitado"]; עָָנִ - 15,11 ["humilde"]; 24,12 ["pobre"].14 ["pobre"].15 ["pobre"]).
} 
(Deuteronômio 12-26, notadamente capítulos 15 e 24). Elas têm o mesmo campo semântico, mesmo que também apresentem diferenças de ênfase, ainda que relacionadas à mesma pessoa dentro da comunidade, e, com isso, a possibilidade de que, a ocorrência delas juntas, seja para enfatizar a condição de pobreza da pessoa a quem elas se referem.

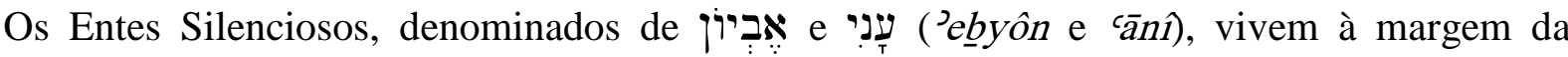
comunidade, por um lado, quando eles são vistos da perspectiva econômica - eles não produzem, mas necessitam do resultado da produção de outros. Por outro lado, eles não estão à margem da comunidade (como que num gueto) porque a presença deles pode ser notada e, por atenção a eles, a comunidade é levada a agir para que ela não pratique uma maldade contra si mesma, esquecendo-se da bondade divina com a qual tem sido tratada ao longo de sua história, por não tratar com generosidade um Ente Silencioso em seu meio.

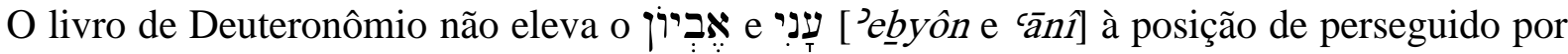
ser um justo, e que, por isso, está em sofrimento, como alguns salmos ${ }^{48}$ parecem apresentar. Os Entes Silenciosos são seres humanos comuns, aos quais não se pode negar o direito à

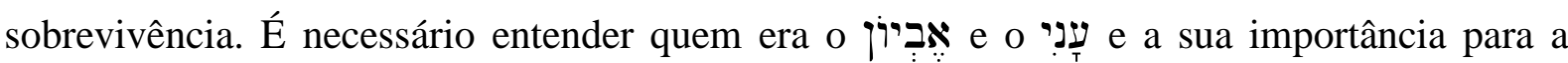
comunidade no meio da qual vivia.

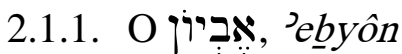

2.1.1.1. Um termo geral para referir-se a uma pessoa dentro de determinada condição econômica, a condição de pobreza.

Entretanto, como termo masculino, ele aponta para um homem nessa condição, não para uma mulher. ${ }^{49}$ Isso quer dizer que dentro do Deuteronômio $(15,4.7 .9 .11 ; 24,14)$, o termo nunca

\footnotetext{
${ }^{48}$ Notar Salmos 9,18; 10,2.9.17; 12,$5 ; 14,6$. No Salmo 10,18 outra palavra é apresenta para "oprimido" [习习习],

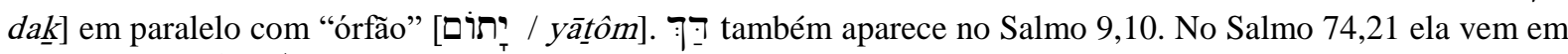

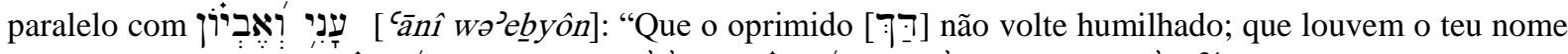

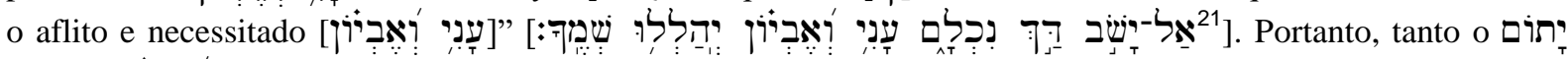
como o estão sujeitos a viver sob opressão por sua condição de fragilidade.

${ }^{49}$ A palavra אבריון ('ebyôn) é um adjetivo masculino (DAVIDSON, 1970, p. 3, 4). Como adjetivo que qualifica pessoas na condição de pobreza é que ela ocorre dentro do livro de Deuteronômio. A condição de pobreza pode ser temporária. A palavra "viúva", por sua vez, é um substantivo, fazendo com que a mulher nomeada por essa palavra, sempre esteja relacionada ao marido que perdeu. Em Amós 4,1, אֶבְיון, em paralelo com דַּ, carrega o

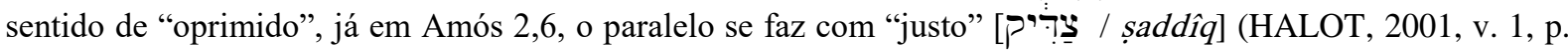
$5)$.
} 
chega a designar uma mulher como uma pessoa pobre. ${ }^{50}$ Ele sempre aponta para um homem, e isso se pode inferir dos dois textos onde ela aparece, juntamente com $\varsigma_{\bar{a}} n \hat{i}$ (Deuteronômio 15 e 24). Então o אִבְירון ('ebyôn) é um termo que se refere a um homem que, por qualquer motivo, chegou à condição de pobreza, e em tal condição depende da generosidade de seu clã ou de outros clãs sob os quais ele vive.

Aqui se deve acrescentar a seguinte observação: a pesquisa não quer dizer que a palavra

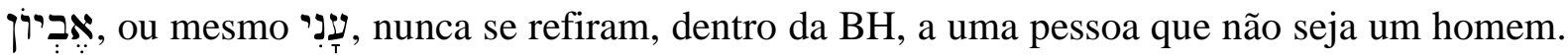

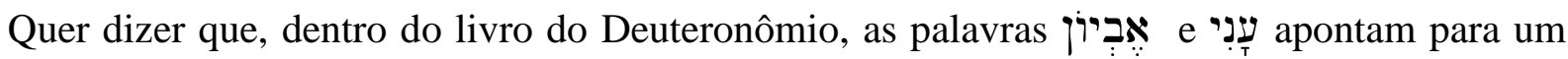
homem dentro da comunidade.

É entendido dessa forma pelos seguintes motivos. Primeiro, as palavras que aparecem em

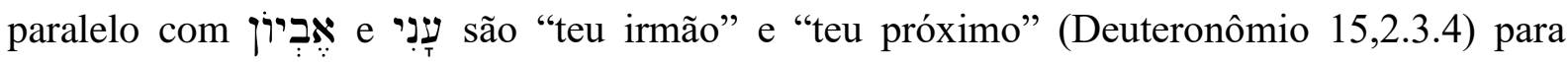
apontar que o אֶבְבְִ pertencem ao grupo da proximidade do clã do "tu/vós", ou mesmo que, não sendo do mesmo clã, ele é um membro da comunidade de Israel. Em Deuteronômio 15,7 o texto aponta para "teu irmão" como um membro dessa comunidade estendida, Israel, não para alguém que pertença ao mesmo clã do "tu/vós".

Em segundo lugar, a legislação se dirige a àlguém específico dentro da comunidade de Israel. A legislação presente em Deuteronômio 15 e 24 é diferente daquela que trata dos outros membros do grupo de Entes Silenciosos. Uma leitura desses textos mostrará que as palavras para órfão, viúva, estrangeiro e levita não aparecem nesses capítulos como que deveria usufruir dos benefícios da legislação ali presente. A palavra para escravo aparece no capítulo

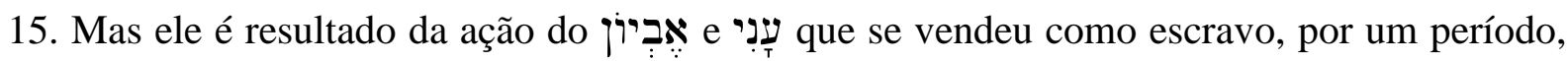
para quitar dívidas e sobreviver ao caos que sobreveio a ele.

Em terceiro lugar vem a sua identificação com o "irmão hebreu" - ele não somente é irmão como ele é um hebreu. A palavra traduzia por "hebreu" [עִבְרִיר, ‘ibrî] aparece várias vezes dentro da BH. Dentro de Deuteronômio a palavra aparece como um substantivo definido

\footnotetext{
${ }^{50}$ A mulher, quando apresentada na condição de um Ente Silencioso, em Deuteronômio, e, com isso, sendo colocada como necessitada de atenção especial pela comunidade, é chamada de "viúva". Isso quer dizer que a mulher sob a proteção do clã não é classificada como "pobre", mesmo que ela não tenha direito a nada do clã. Se ela está sob a proteção do clã, ela tem um meio de sobrevivência. Parece que a mulher "viúva", em Deuteronômio, é alguém que vive à parte dos clãs da comunidade. Ela é apresentada como um ser solitário dentro do Deuteronômio.
} 
[דוֹ a se vender como escravo a outro israelita. Das ocorrências de بִבְרִירי dentro da BH, pode-se afirmar os seguintes pontos: primeiro, ela, em geral, é usada para designar um homem quando empregada como substantivo ou adjetivo masculino, tendo como exceções suas aparições no livro de Êxodo $(3,18 ; 9,1.13 ; 10,3)$, na construção “o Deus dos hebreus”, em que a palavra designa o povo de Israel inteiro, constituído, naturalmente, de homem e mulher.

Segundo, nas ocorrências da palavra feminina de עִבְרִ no livro de Êxodo (1,15.16.19; ["hebreia", עִבְריָה, Cibriyyāh]), ${ }^{52}$ não há um emprego genérico para designar um homem e uma mulher, mas especifica a mulher na sua função de procriação. Já em Deuteronômio $(15,12)$ e Jeremias $(34,9)$, ela aparece para distinguir a mulher do homem dentro da condição de escravidão. Deuteronômio é o único lugar no Pentateuco onde a mulher se vende para se tornar escrava de um clã israelita. O texto paralelo de Êxodo 21,2 coloca apenas o homem sendo comprado como "servo hebreu".

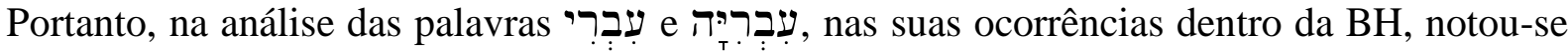
que עִבְברִ não é empregado como termo genérico, exceto em alguns textos pontuais, para designar todo o Israel. Ele de modo geral quer falar do homem, e, quando quer se referir a mulher, o texto emprega o feminino, עִבְרָיהת. Isso favorece a interpretação da pesquisa que

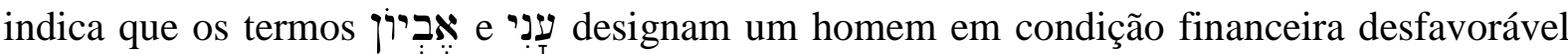
em distinção dos outros Entes Silenciosos.

Por fim, em Deuteronômio 24,12, especificamente, a palavra עִָָ funciona como um adjetivo

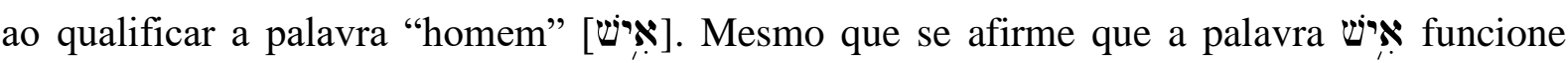
como um artigo indefinido, "um", a frase na qual a palavra está inserida não aponta nessa direção: "E se ele (for) homem pobre, tu não deitarás no seu penhor", impedindo-o de se

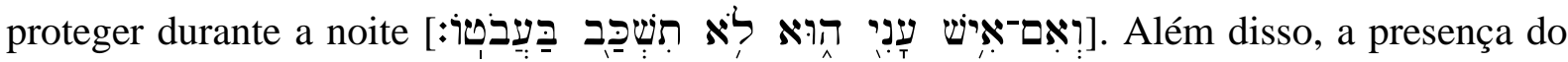
pronome הוּא, no texto confirma que o orador está se dirigindo ao "tu/vós" para falar de um

\footnotetext{
51 עִבְר aparece com o artigo também em Gênesis 14,13; 39,17; Jeremias 34,9.14 e, sem ele, ela está presente em

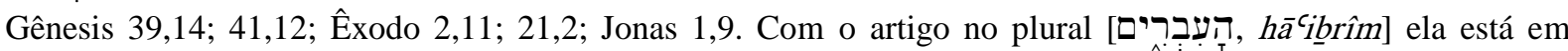
Gênesis 40,15; 43,32; Exxodo 2,6; 3,18; 5,3; 7,16; 9.1.13; 10,3; 1 Samuel 4,6.9; 13,3.19; 14,21; 29,3. A palavra

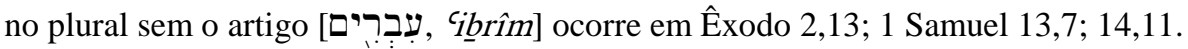

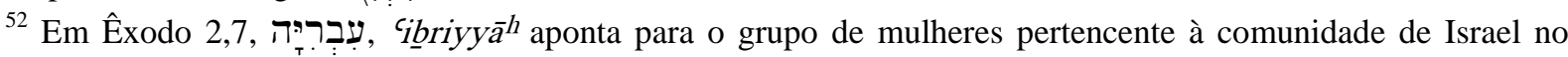
Egito.
} 
homem. Entretanto, o pronome הוּא pode também ser visto como um pronome demonstrativo,

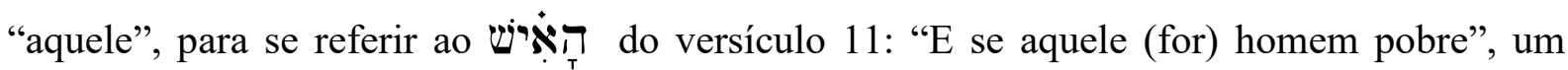
agravante apresentado à situação, ordenando ao que fez o empréstimo não reter o penhor consigo.

Assim, nesta pesquisa, se pode dizer que as palavras אֶָנִִי e dentro do Deuteronômio, não são um termo genérico para se referir a todos os Entes Silenciosos, seja ele macho ou fêmea. Elas apontam para um homem livre ${ }^{53}$ mesmo que sua condição financeira leve-o a ser "necessitado e aflito".

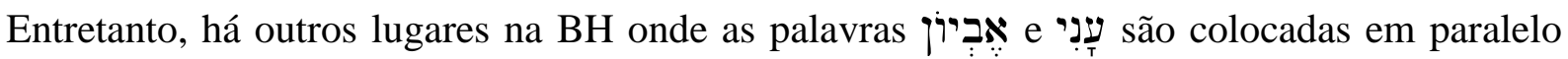

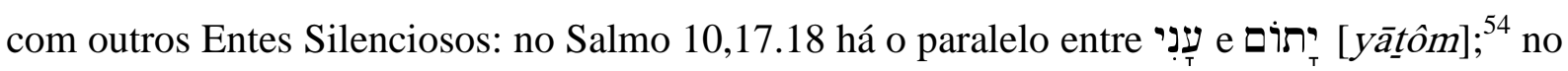

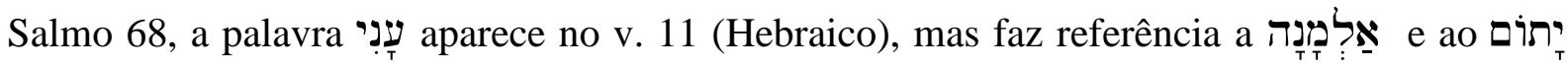
presentes no v. 6 (Hebraico); o Salmo 109,1-15 (BJ) fala de alguém, de quem a mulher ficará

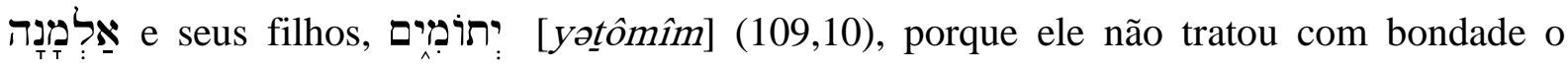

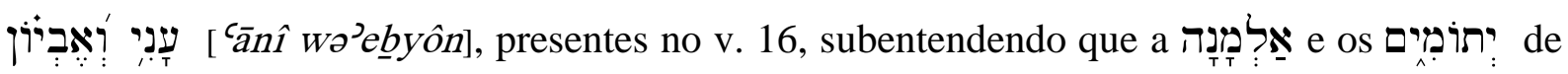

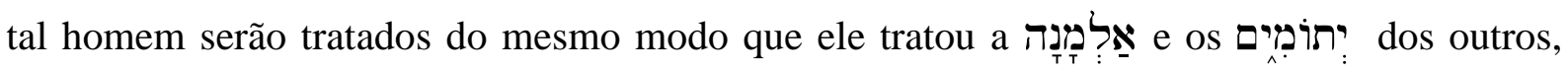

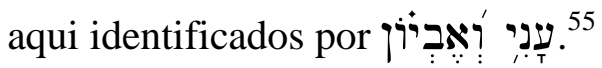

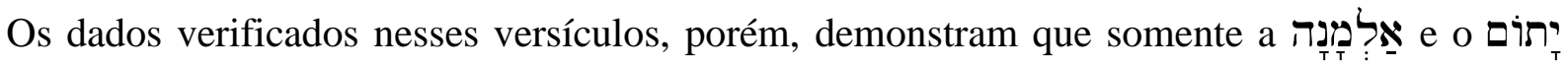

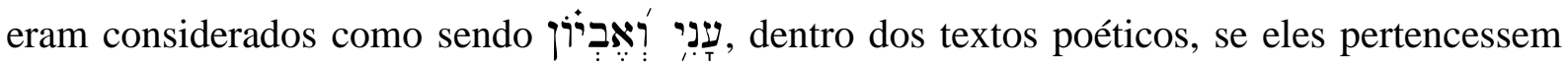
ao povo de Israel. Esse detalhe coloca em relevo que a perspectiva dos escritores da $\mathrm{BH}$

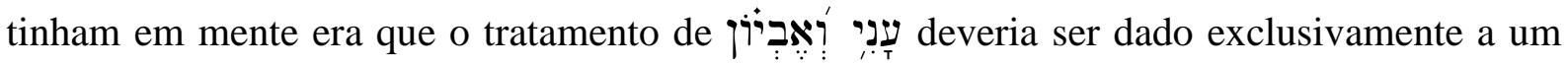

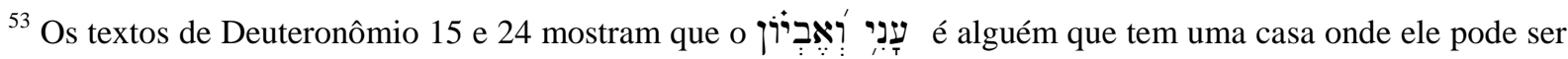
encontrado $(24,10.11)$. Mas isso não implica que ela seja dele. O mais provável é que ele seja morador em uma casa do dono da terra. Se for assim, a atitude do fiador é, principalmente, de muita reverência e obediência a Deus, não invadindo uma casa que é sua e está dentro de suas terras.

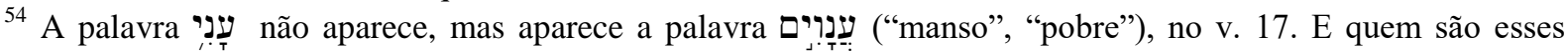

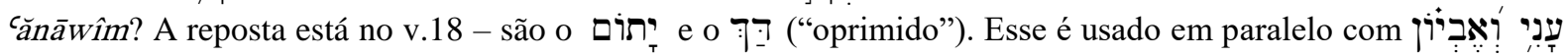
no Salmo 74,21.

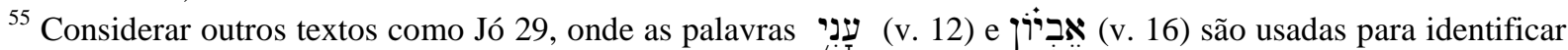

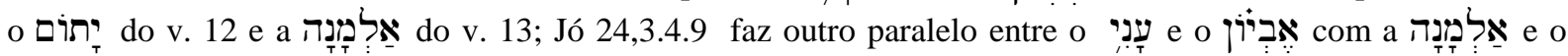
י. יתוזם Atentar que esses paralelos acontecem, nos escritos de poesia, onde o poeta demonstrava sua arte de

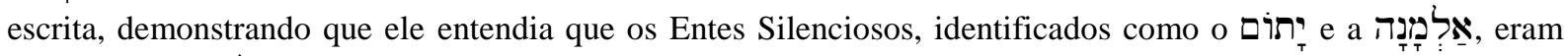

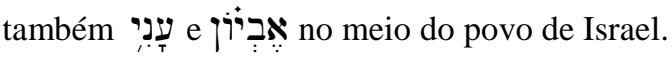


membro povo de Israel, seja ele um homem, viúva ou um órfão. ${ }^{56}$ Mas isso vem a ser um desenvolvimento posterior e dentro de um contexto artístico de composição poética da $\mathrm{BH}$.

Ao procurar os dados dentro dos outros livros do Pentateuco, o que se constatou é que o era uma pessoa distinta dos outros Entes Silenciosos e se aplicava a um homem. Ressalta-se que essas comunidades não eram grandes, e as pessoas envolvidas na condição de eram facilmente notadas. Mesmo porque tais pessoas dependiam das ações do clã, ou dos clãs, ao qual estavam apegadas por motivo de trabalho ou dependência de qualquer forma, levando o orador/legislador do Deuteronômio a ter em mente uma pessoa específica, que não era nenhum dos outros Entes Silenciosos, mas um homem qualificado pela condição

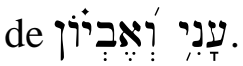

\subsubsection{Elementos filológicos}

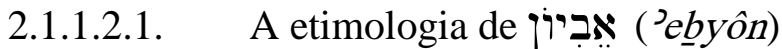

A אבירין ('ebyôn) é indefinida (BOTTERWECK, 1974, p. 27; COPPES, 1980, p. 4). A primeira sugestão é que ('ebyôn) tenha origem a partir de uma raiz semítica, sendo derivada de אבה [( $\left.{ }^{\mathrm{P}} \underline{b}^{h}\right]$, cujo significado original é "perder, estar em necessidade".

Tendo essa etimologia, o אִבְירון ( 'ebyôn) seria alguém carente, uma pessoa "que quer alguma coisa que ele não tem, e consequentemente... um necessitado e pobre" (BOTTERWECK, 1974, p. 28). A ideia de querer algo que não possui e, dentro disso, o sentimento de não poder obter, traz o peso do sofrimento por um desejo não alcançado. Quando o Deuteronômio diz que o israelita deva ser benigno com o אֶבְיוֹן ele aponta para o "tu/vós" atender uma necessidade que o אִבְביון deseja que seja suprida. Quando ele não alcança o favor, ele apela para o Deus de Israel. Essa ideia se harmoniza com a tradução que coloca, de modo geral, que o אִָּ seja um "necessitado".

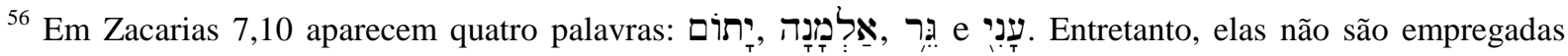

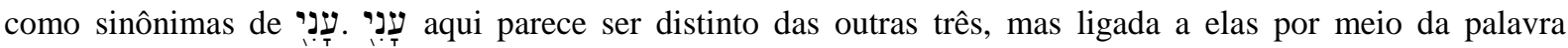

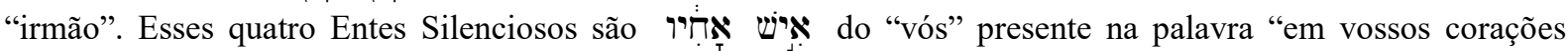

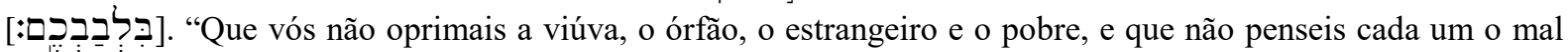

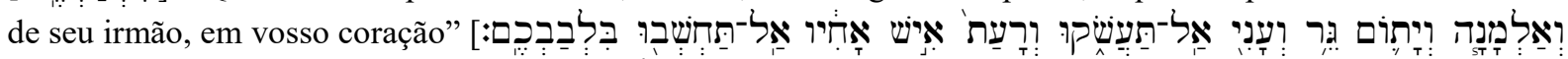

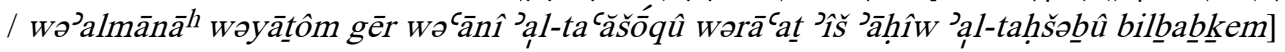


A outra sugestão é que o vocábulo אְִִּ tenha relação com o Ugarítico 'bynt ("miséria") e 'bynm,"pessoa da cidade de ill" (BOTTERWECK, 1974, p. 28). Finalmente, há também a sugestão de que a palavra אֶבְיוֹן seja derivada do Egípcio, byn - "sem valor, preguiçoso, estar em condição desprezível/miserável, maligno" (BOTTERWECK, 1974, p. 29). Todas essas raízes demonstram que a visão daquele contexto sobre o אִבְיוֹ não era uma visão favorável à pessoa qualificada por ela.

Diante do que foi apresentado no parágrafo acima, a melhor opção quanto à etimologia seria colocar a palavra אֶבְיון ('ebyôn) dentro de um relacionamento com uma palavra semítica, אבה , cujo significado vem ao encontro do sentido que a palavra pode apresentar dentro do livro de Deuteronômio.

Assim, o אִבְיוֹן ('ebyôn) é uma pessoa que chegou à essa condição porque ela perdeu outra condição anterior àquela em que se encontrava na de אִבְיון ('ebyôn) atual, e, por isso, naquele momento, ela era uma pessoa que estava em necessidade, usualmente a necessidade de alimento, mas também necessidade de um lugar de proteção - um lar. Acrescenta-se a isso também a necessidade de amparo por parte da comunidade, essa representada pela pessoa (ou pessoas) que poderia (poderiam) ajudá-lo. ${ }^{57}$

\subsection{Comparação com o Targum}

Nos textos onde ocorre a palavra אֶבְיוֹ ('ebyôn), o Targum apresenta o Aramaico que traz a palavra ("מסבָינָאי ("homem pobre", ${ }^{58}$ Deuteronômio 15,4.7.9.11; 24,14). Com isso, o Targum segue a ideia do Hebraico de que o אִבְיון ('ebyôn) se refere a um homem, não a uma mulher, que chegou à condição de pobreza, em sua tradução do Deuteronômio. Schökel propõe que essa palavra tenha o significado de "pobre, indigente", além de que ela seja sinônima tanto de בָּל (1997, p. 385). ${ }^{59}$

\footnotetext{
${ }^{57}$ Para Schwantes, “penso... poder afirmar o seguinte...: 'byn(t) (e os documentos de Mari) fazem alusão ao lamento (ou designam a pessoa que lamenta) e, com isso, não se referem à pobreza legítima; enquanto que 'bymn caracteriza pessoas realmente pobres' (2013, p. 37).

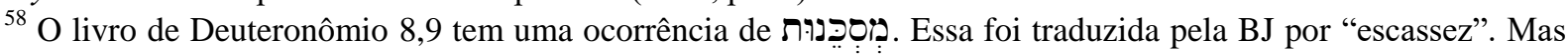
também pode ser entendida como "pobreza" (segundo a opção de tradução dada pelo HHL-BW7).

${ }^{59}$ Berezin (2003, p. 380) traduz 2 por "coitado, desgraçado, infeliz, pobre”. Vale salientar aqui que o livro de Deuteronômio não parece admitir que o אִבְירוּ seja alguém "indigente” ou "desgraçado, infeliz" por causa do povo que está ao seu redor. Seguindo nessa mesma direção, deve-se notar o texto em Êxodo 22,25-28; 23,3 e 23,26 onde as três palavras são empregadas em um contexto de proteção ao pobre. Em 22,25 aparece a palavra
} 


\subsection{Comparação com a Septuaginta (LXX)}

Nos textos no livro de Deuteronômio, onde ocorre a palavra (ִ אִבְיון ('ebyôn), a LXX traduz

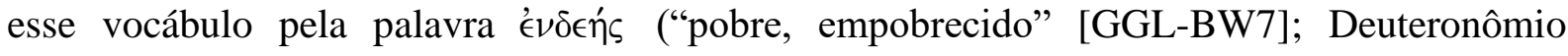

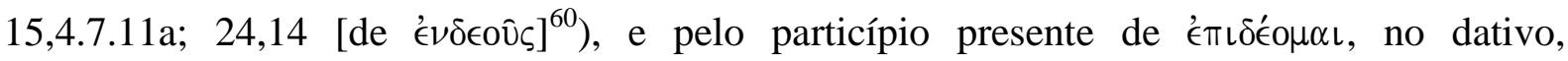
$\epsilon \pi\left\llcorner\delta \in \mu^{\prime} \in \omega\right.$ ("um que está necessitando, quem [aquele que] está em necessidade"; 61 Deuteronômio 15,9.11c). Em Deuteronômio 15,11, a palavra אֶבְיוּן aparece duas vezes, sendo

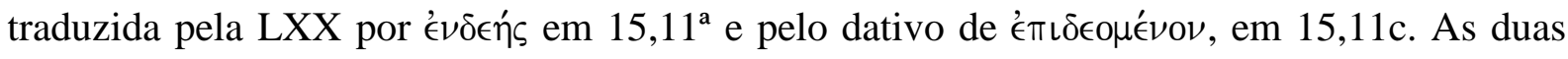
são usadas como adjetivos para qualificar um homem, da mesma forma como é empregada a palavra (ְבְיון ('ebyôn) em Deuteronômio na BH. Da mesma forma que a palavra hebraica

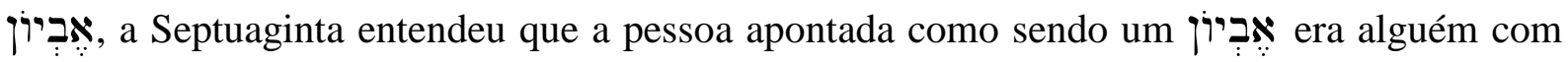
necessidade de algo que precisava ser suprida.

A forma diferente de traduzir a mesma palavra hebraica dentro do mesmo texto indica que os tradutores da Septuaginta entenderam que a palavra hebraica tinha abrangência de significado maior que as palavras gregas individualmente, podendo dizer que o אִבְביון ('ebyôn) é não somente alguém que está empobrecido, mas que, por esse empobrecimento, ele está em necessidade, normalmente entendido como necessidade de comida e vestimenta, mas também de amparo.

\subsubsection{Algumas notas}

Primeiro, todas as ocorrências do אִבְיוֹן ( 2 byôn) mostram que a palavra era empregada para qualificar um homem em condição de precariedade por causa da ausência de patrimônio que pudesse lhe dar o sustento. As traduções, em segundo lugar, para a Septuaginta e o Targum entenderam o mesmo que as ocorrências de ’ebyôn no texto Hebraico. Entretanto, elas lançaram luz por mostrar que אִבְיון ( Jebyôn) traz em seu corpo elementos elucidativos da

\footnotetext{
‘̄an̂i, em 23,3 a palavra usada é $d \bar{a} l$ e em 23,6 acha-se a palavra ’ebyôn. Mesmo que os conteúdos desses mandamentos de proteção sejam diferentes, o objetivo é o mesmo - proteger o pobre. Entretanto, Coppes (1980,

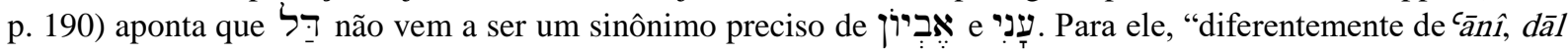
não enfatiza sofrimento ou opressão; diferentemente de 'ebyôn, ela não enfatiza primariamente necessidade, e diferentemente de rāsh, ele representa aqueles que sentem falta de algo mais do que alguém destituído (de algo)... Em $d \bar{a} l$, a ideia de privação física (material) é predominante".

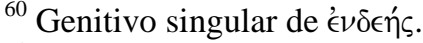

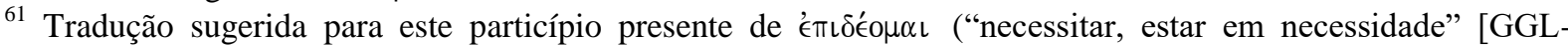
BW7]).
} 
condição daquele homem na comunidade israelita do Deuteronômio - ele era uma pessoa "pobre" e que, por isso, ela "estava passando necessidade".

Portanto, pode-se dizer que o אִבְירון ( 'ebyôn) é aquela pessoa que se encontra na condição de necessitado. Mas necessitado de que? Pelo conteúdo de Deuteronômio, o אביִיוֹן ('ebyôn) tem necessidade da generosidade de seu irmão israelita, tendo em vista sua carência de comida e vestimenta. Quando ele for assalariado, que seja feito o pagamento em dia para que ele tenha como manter sua vida. Então a questão relaciona-se à sobrevivência daquele que está na pobreza $(24,15)$.

Entretanto, o vocabulário existente na $\mathrm{BH}$ é rico ao tratar da pessoa pobre. Dentro do livro de Deuteronômio há ainda outra palavra para qualificar o homem na condição de pobreza.

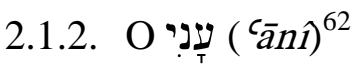

Inicialmente, o que se pode dizer é que este Ente Silencioso, qualificado pela palavra עָד é é considerado como alguém que está em aflição e humilhação pela condição em que ele se encontra $(24,12-15)$ naquele momento. ${ }^{63}$ Porém, para se chegar a uma definição melhor, considerar-se-á a análise seguinte.

\subsubsection{Elementos filológicos}

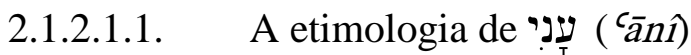

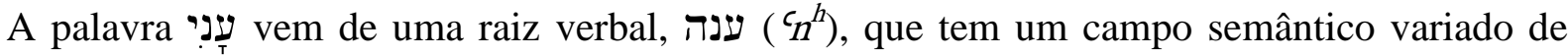
significações dentro da BH. É o que Stendebach chama de "raízes homônimas", cuja forma de escrita é a mesma, mas o significado pretendido pelo contexto é diferente (2001, p. 215). São estas: ענה ( ענה ( $\left.{ }^{c} n^{h}\right)$ I ("responder") II ("ser afligido"), ענה ( ${ }^{c^{h}} n^{h}$ ) III ("mostrar-se,

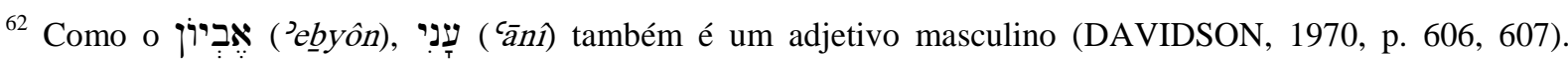
Entretanto, ao que se pode acrescentar nesta pesquisa, os dois adjetivos nunca são usados dentro da BH no

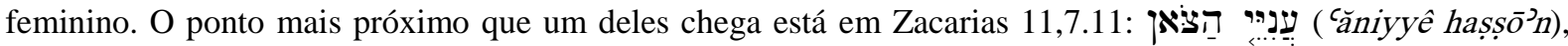
"pobres do rebanho". "Rebanho" é feminino no Hebraico, mas "pobres" é um adjetivo masculino no plural no

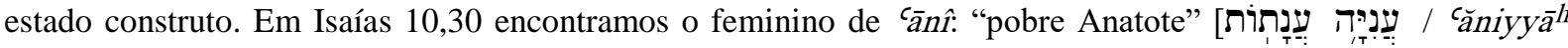

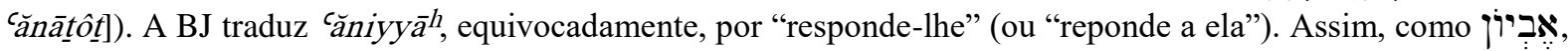
עָ também é empregada em sua maioria para qualificar um homem.

${ }^{63}$ "Num sentido sociológico: sem (suficiente) propriedade e, portanto, dependente de outros, Deuteronômio 15,11 e 24,12 " (HALOT, 2001, v. 1, p. 856). 
manifestar-se"), ענה ( ענה ( $\left.n^{h}\right)$ IV (“cantar") (STENDEBACH, 2001, p. 215, 216). ${ }^{64}$ Seguindo a visão de Stendebach, o adjetivo עָנִי ( ענה IInn̂̀) vem da raiz verbal ("ser afligido"). Assim, o עִ עִנִ ( 'ānî) é alguém que está em desespero por causa de alguma aflição, ou opressão, a que ele está sujeito naquele momento.

Para Martin-Achard, a raiz verbal ענה II, tem o sentido provável de "estar pressionado, deprimido". Segundo ele, essa raiz se encontra no Fenício com o sentido de "oprimir, submeter”, em Moabita, "perseguir”, em Aramaico bíblico, “mísero”, e Árabe, "ser humilde, submisso". ${ }^{65}$ Por esses usos da raiz verbal pode-se considerar que o ‘̄̄nî era alguém que se destacava por seu desespero e fragilidade diante de sua situação pessoal e, por isso necessitava de atenção. ${ }^{66}$ Mas desespero de quê? Desespero da vida - dívida, fome, ameaça de escravidão e perda da família.

A situação de pobreza de um homem poderia chegar ao ponto de desespero em que ele seria obrigado a vender sua filha como escrava. Chegar a esse ponto seria o ponto alto da aflição de um homem. A legislação de Êxodo 21,7-11 proibe a revenda da filha daquele homem para um

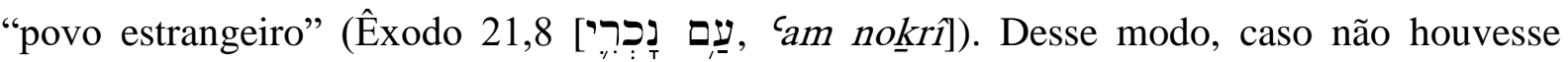
socorro, ele corria o risco de perder a vida ou a liberdade, sua ou de sua família. A legislação, tanto de Êxodo como de Deuteronômio, entendida que esse ponto de aflição não deveria ser cumulativo sobre aquele homem, e impede que sua filha fosse vendida ao נִכְְ, de onde ela não teria retorno. A legislação é uma legislação pela vida. ${ }^{67}$ Ajudar o עָ é contribuir para aliviá-lo das fontes de opressão que causam o seu encurvamento.

\footnotetext{
${ }^{64}$ Coppes (1980, p. 679-684) coloca uma posição diferente de significação das raízes. As significações são: ענה ענה I ("responder"), ענה II ("ser ocupado"), ענה III ("ser afligido, humilhar"), e ענה IV ("cantar"). Aqui são apresentados alguns dados diferentes da ordem apresentada por Stendebach. O primeiro é que ענדה ענה "ענה II é que tem o sentido de "ser afligido", não a raiz ענה III, como em Coppes. Segundo, o sentido de "manifestar-se" de ענה III, de Stendebach, não ocorre em nenhuma das raízes apresentadas por Coppes. Por outro lado, o sentido de ענה ענר II, "ser ocupado", de Coppes, não é encontrado em nenhuma das quatro raízes apresentadas pelo Stendebach. Isso é representativo da dificuldade que os estudiosos têm para definir a etimologia das palavras. Mesmo assim, podese dizer que as raízes ענה II do Coppes e ענה III do Stendebach têm algum relacionamento. Provavelmente, aquele que se manifesta por meio de alguma ocupação.

${ }^{65}$ Martin-Achard, ענה "nh II "ser mísero" (1985, p. 435).

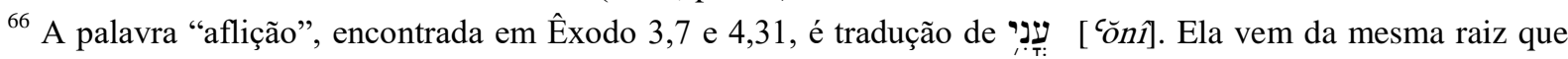

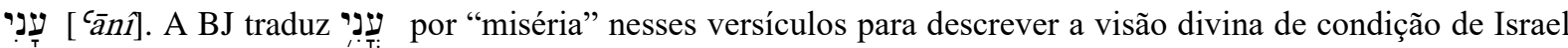
no Egito.

${ }^{67}$ Schwantes traduz עָנִ por "encurvado", "oprimido" (2003, p. 38). Pode-se dizer que o resultado da opressão torna o pobre encurvado, dobrado ante o opressor.
} 


\subsection{Comparação com o Targum}

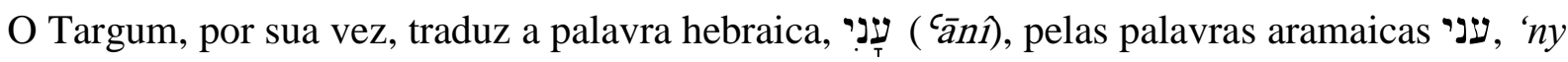
("humilde, pessoa pobre", Deuteronômio 15,11; 24,14.15), e מִִּ miskeyn ("homem pobre" [HHL-BW7], Deuteronômio 24,12). Considera-se que em Deuteronômio 15,4.7.9.11 e 24,14, o Targum traduz a palavra hebraica אִּבִין pelo vocábulo aramaico implicação

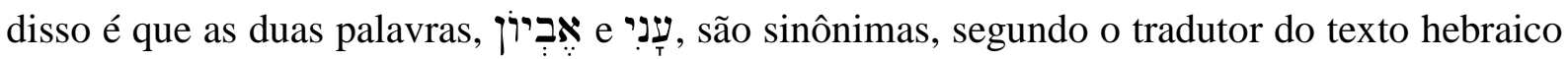
para o aramaico, mesmo que uma enfatize a necessidade e a outra a aflição, mas designam a mesma pessoa vista de diferentes ângulos.

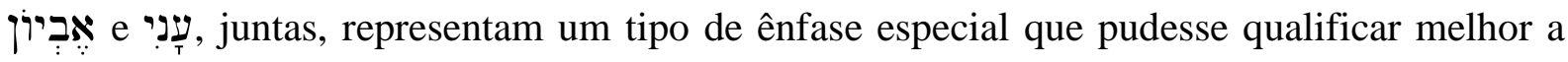
pessoa assinalada pelas duas palavras. ${ }^{68}$ Esse tipo de ênfase será apresentado na exegese de Deuteronômio 24. Incialmente, o que se pode afirmar é que o uso das duas palavras, nesta

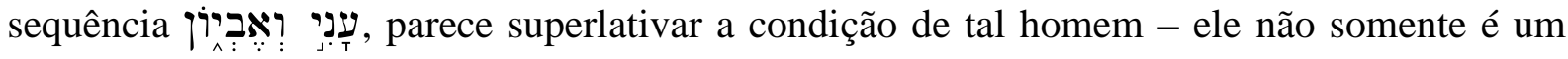
homem necessitado e, portanto, pobre, ele também está sob opressão.

O que se tem a pontuar do Targum é que o uso de מִסֵין, tanto para traduzir אִבְירין quanto עִ ְָנִ para o Aramaico, demonstrou que as duas pertencem ao mesmo campo semântico e que a condição de pobreza, da pessoa apontada por elas, era algo a qual se devia receber atenção por parte daqueles a quem o orador/legislador se dirige.

\subsection{Comparação com a Septuaginta (LXX)}

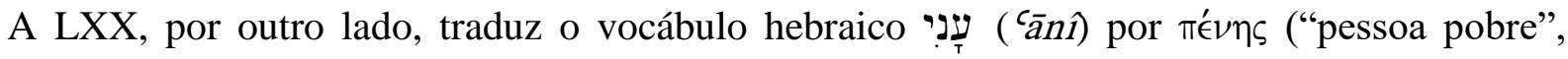
Deuteronômio 15,$11 ; 24,14.15),{ }^{69}$ e por $\pi^{\prime} \epsilon \eta \eta \tau \iota$ ("ser pobre ou necessitado", 70 Deuteronômio 24,12). Aqui se pode notar que os que traduziram o texto Hebraico para o Grego, a LXX, entenderam que seria melhor traduzir עָנִ, em Deuteronômio 24,12, com uma forma verbal e

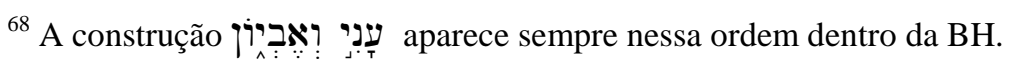

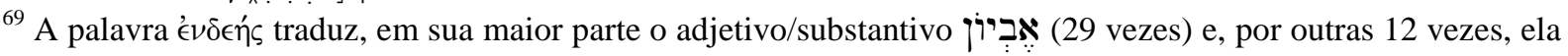

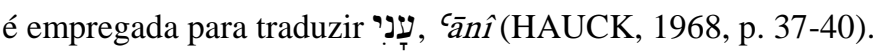

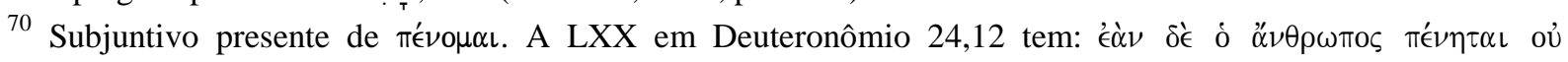

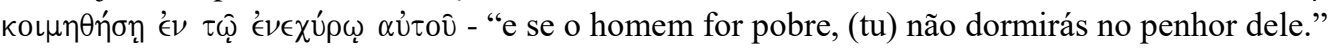


não com um adjetivo. Mas isso não tira o sentido de que eles ainda assim queriam que o subjuntivo implicasse numa qualificação do homem em vista. ${ }^{71}$

O homem em foco continua sendo descrito por sua condição social e econômica. Como pobre, socialmente ele é distinto daquele que tem recursos financeiros para gerir sua vida, e, portanto, está em posição inferior. Como necessitado, ele não pode suprir suas próprias necessidades por causa de sua falta de recursos.

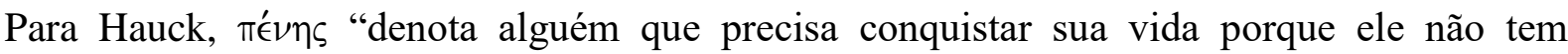
propriedade", ${ }^{72}$ um campo para trabalhar e que ele chame de seu. Ele é alguém dependente da oferta de trabalho no campo alheio. Isso, porém, não quer dizer que ele nunca teve propriedade, mas que por alguma circunstância anterior à sua condição presente, ele a perdeu, e passou a depender dos outros para obter seu sustento e, talvez, o sustento de sua família.

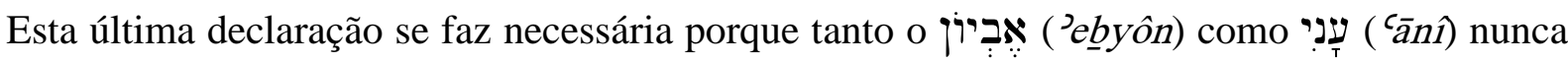
trazem junto uma declaração de que eles possuam dependentes, seja mulher ou filhos/filhas, em Deuteronômio.

A ausência de uma família que acompanha este Ente Silencioso pode apontar em uma de quatro direções ou para uma e outra em conjunto. Primeiro, pode ser que ele nunca teve família e em resposta a isso ele acabou caindo em pobreza por desprezar sua herança. ${ }^{73}$ Segundo, pode ser que ele tenha perdido sua família ao vendê-la como escrava para sua própria sobrevivência por já haver vendido toda a sua herança. ${ }^{74}$

Terceiro, pode ser também que ele fora expulso do clã, por qualquer razão, incluindo a impossibilidade de sustentar sua família, sendo que o clã reteve a mulher e os filhos como forma de pagamento de dívidas assumidas. ${ }^{75}$ Por último, pode ser que o empobrecimento se

\footnotetext{
${ }^{71}$ O subjuntivo do verbo $\pi \dot{\epsilon} \nu \eta \tau \alpha \iota$ e a conjunção pertencem a terceira classe de condição, cuja construção deixa em aberto a possibilidade quanto à condição a ser encontrada. Desse modo, o que a construção em grego quer dizer é que, caso o homem seja mesmo pobre, o penhor deve ser devolvido para que ele se cubra durante a noite. ${ }^{72}$ Este significado vem do uso da palavra no mundo grego (HAUCK, 1968, p. 886).

${ }^{73} \mathrm{O}$ caso de Esaú que vendeu o seu direito de primogenitura por um prato de comida, sem qualquer acusação de consciência, é um representante modelo desse tipo de atitude (Gênesis 25,29-34). O descuido com a herança da terra foi abordado no livro de Provérbios $(6,6-11 ; 13,18 ; 21,17 ; 23,20.21 ; 24,30-34 ; 28,19)$. Os exemplos da vida apresentados em Provérbios podem ser alguns dos motivos por trás do empobrecimento em Deuteronômio. Se for assim, o valor da vida é tido em alta consideração no Deuteronômio, ao ponto de levar aqueles, chamados de "tu/vós", a contribuírem para preservar um homem como ser humano, mesmo que sua pobreza pudesse ter sido evitada.

${ }^{74}$ Êxodo 21,7; Levítico 25,14-31; Neemias 5.

${ }^{75}$ Aqui não há um exemplo específico da BH para apresentar. Porém, as expulsões de Adão do Jardim e a de Caim posteriormente podem ser representativas da possibilidade de os clãs expulsarem seus membros por motivos variados (Gênesis 3, 4).
} 
deu devido à mudança de cidade ou país e subsequente retorno em condição de pobreza. ${ }^{76}$ Somente pelo texto de Deuteronômio, porém, é impossível deliberar qual é a motivação por trás do redator ao apontar para a necessidade de atenção a esse tipo de Ente Silencioso. O que se pode dizer é que o redator está olhando para uma condição pessoal do homem denominado pela palavra עיָנִ

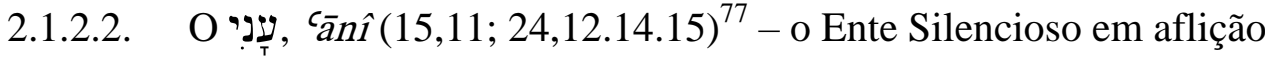

É possível dizer que o ‘ānî é uma palavra que designa o Ente Silencioso como alguém que está enfrentando uma condição aflitiva, passando por situação humilhante, sendo que essa também é uma humilhação pública, a qual precisa ser suprimida por meio daquele que tem recursos para isso, o homem livre e chefe do clã. Hauck diz que, citando Levítico 19,9s, 23,22 e Deuteronômio 24,14.15, עִָָ aponta para alguém "que não possui patrimônio e que precisa ganhar seu sustento trabalhando para outros, especialmente como diarista" (1968, p. 39).

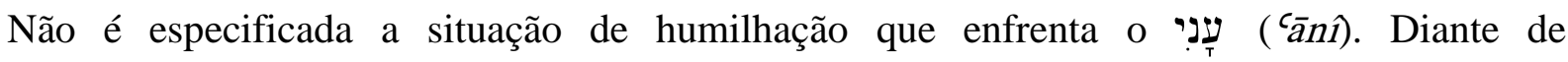
Deuteronômio 24, pode-se sugerir que a situação envolvente tem a ver com a questão financeira. Ele está necessitando de que seu penhor seja devolvido para que ele tenha com que se cobrir durante a noite (24,10-12). Seria uma demonstração de bondade para com aquele que tinha apenas o penhor para se cobrir durante a noite que se seguia, e único "patrimônio" que ainda lhe restava. Assim, se esse "patrimônio" beneficiaria o עָנִ em sua sobrevivência, é certo que não deveria ser tomado.

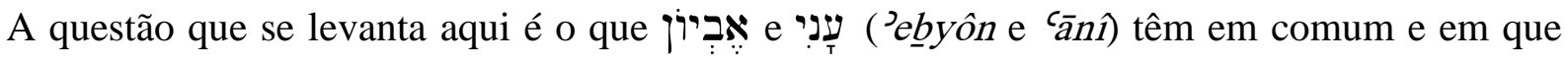
ponto elas se tocam. A razão para a pergunta é que elas aparecem juntas nos mesmos textos

\footnotetext{
${ }^{76} \mathrm{O}$ caso de Elimeleque e sua família deve ter se repetido muitas vezes e com muitas famílias ao longo da história de Israel, principalmente em tempos de guerra (Rute 1-2), fome ou praga.

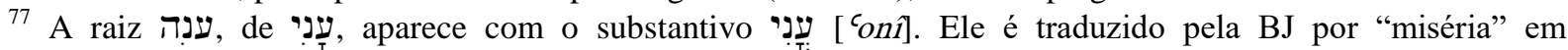
Deuteronômio 16,3 para qualificar o pão ázimo ("pão de miséria") que deveria ser comido na festa dos Pães Ázimos. A outra ocorrência desta palavra está na confissão encontrada em Deuteronômio 26,1-11. No versículo 7 ela é traduzida por "miséria" para qualificar a condição do povo de Israel no Egito. Há ainda outra palavra relacionada ao assunto dos Entes Silenciosos e que aparece em Deuteronômio 28,48.57 - רִ̣ . A BJ traduz a palavra em 28,48 por "privação" e em 28,57 por "faltando". Nesses dois casos a palavra vem acompanhada de ל
} 
dentro do livro (capítulos 15 e 24). O passo seguinte desta pesquisa é desenvolver esse assunto, mas apenas em Deuteronômio $24 .^{78}$

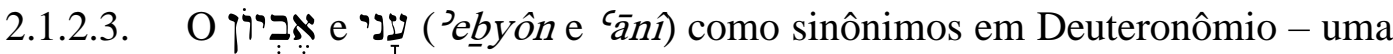
exegese de Deuteronômio 24

O livro de Deuteronômio foi escrito para lidar com o homem ambientado em um país que tem sua economia baseada em produtos extraídos do campo, seja pelo cultivo de alguma lavoura seja pela criação de animais. Assim é de se esperar que, principalmente o Código Deuteronômico, trate dos relacionamentos dentro desse tipo de ambiente. Esse ambiente é o que está por trás do texto traduzido a seguir. ${ }^{79}$

\subsection{Tradução sugerida para Deuteronômio 24,10-15}

10 - "Quando tu fizeres ${ }^{80}$ um empréstimo ao teu próximo de alguma coisa, ${ }^{81}$ não virás à sua casa para tomar ${ }^{82}$ o seu penhor (garantia)." ${ }^{, 83}$

11 - "No lugar de fora ${ }^{84}$ (tu) ficarás, ${ }^{85}$ e o homem, a quem tu estás emprestando, ${ }^{86}$ trará para ti o penhor., $\$ 7$

\footnotetext{
${ }^{78}$ Deuteronômio 15 será dividido para ser analisado neste capítulo e também no capítulo 4 desta tese. Ele tem conteúdo mais abrangente que foge escopo deste capítulo.

${ }^{79}$ Isso não quer dizer que Deuteronômio não toque em elementos citadinos. A presença de um rei a ser escolhido $(17,14.15 ; 28,36 ; 33,5)$, o lugar central para o santuário (12), as cidades-refúgio $(4,41.42)$ e as cidades conquistadas $(3,4)$ pressupõem um ambiente que também contempla a cidade. Além do mais, a presença de "portões" em vários lugares no livro pressupõe um ambiente citadino misturado com ambiente do campo. Assim, para esta pesquisa, há um ambiente misto - campo e cidade como pano de fundo para o livro de Deuteronômio.

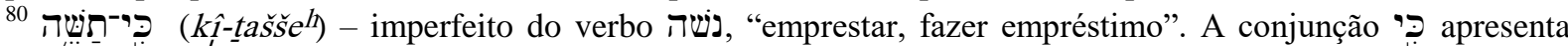
uma hipótese podendo ser traduzida por "quando". Mas também pode ser traduzida por "se", próprio para tradução da construção prótase, introduzida por 'ִ e e apódose com a determinação seguinte que o caso requer.

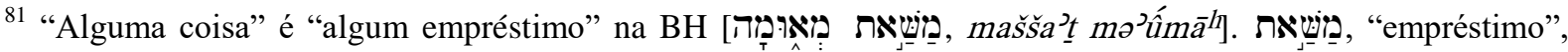
vem de נשיה. Do que é constituído o empréstimo não é especificado aqui, deixando sua aplicação aberta para qualquer tipo de empréstimo.

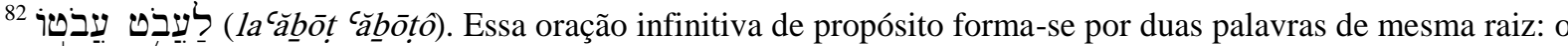
verbo עבט, "tomar ou dar um penhor por um débito" (HARRIS, 1980, p. 641), e o substantivo עַבוֹט ,penhor, artigo empenhado como garantia de um débito" (HARRIS, 1980, p. 641). Essa oração infinitiva faz parte do

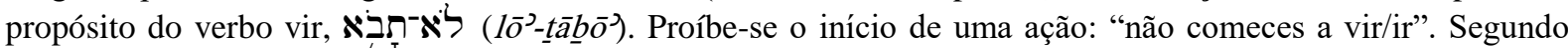

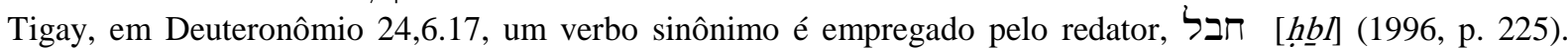

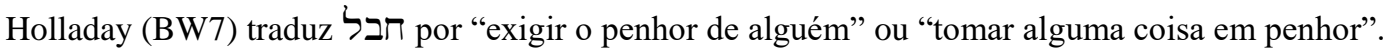

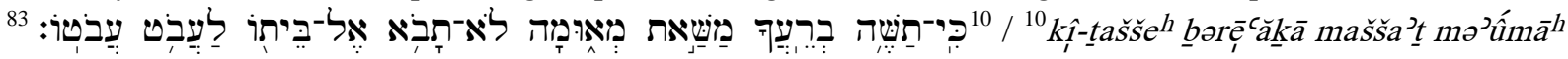

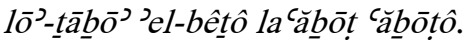

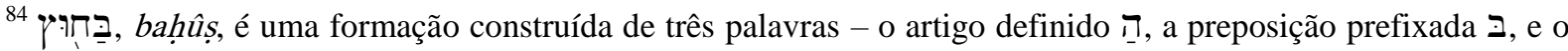
substantivo חוּ. Todo este conjunto visa especificar claramente onde deve ficar aquele que viria receber o penhor - "no (lugar de) fora". Fora de sua casa ou mesmo propriedade. Ultrapassar esse limite seria considerado invasão e humilhação pública de outro homem.
} 
12 - " "E se o homem for pobre $\left(c_{\bar{a}}^{c} n \hat{\imath}\right)^{88}$, não te deitarás ${ }^{89}$ no penhor ${ }^{90}$ dele.."91

13 - "Deverás fazer retornar, ${ }^{92}$ para ele, o penhor, quando o sol se pôr. ${ }^{93}$ E (ele) deitará com seu manto (o penhor). ${ }^{94} \mathrm{E}$ (ele) te abençoará. ${ }^{95} \mathrm{E}$, para ti, será justiça ${ }^{96}$ diante de $y h w h$ ('ā $\underline{\text { dōnāy), }}{ }^{97}$ teu Deus." 98

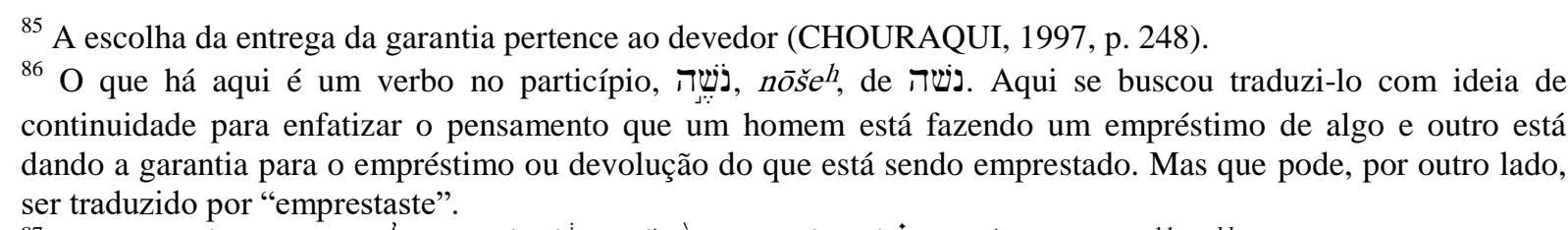

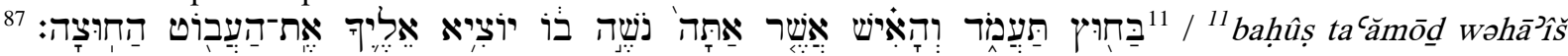

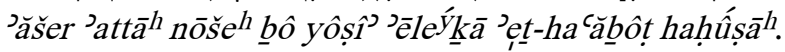

${ }^{88} \mathrm{O} c_{a}$ âî também é empregado em uma legislação similar encontrada em Êxodo 22,25 (no texto Hebraico é $22,24)$. Somente que o problema a ser evitado ali não está relacionado com o penhor, mas com juros a serem cobrados, no caso de empréstimo em dinheiro.

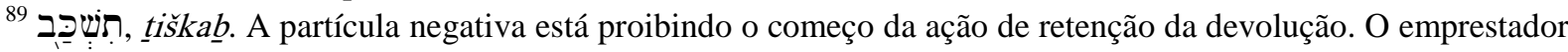
jamais deveria dormir sobre o penhor do homem que fez o empréstimo. Tigay, porém, afirma que "credores, provavelmente, não dormiriam nas roupas penhoradas do pobre" (1996, p. 226).

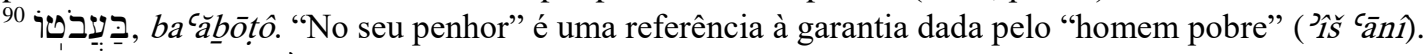

${ }^{91}$

${ }_{92}$ Aqui temos uma construção comum para dar ênfase dentro da BH - um infinitivo absoluto e um verbo finito

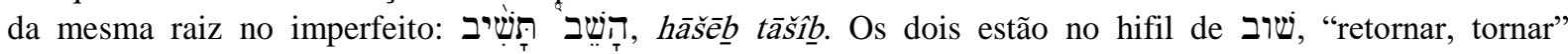
(HAMILTON, 1980, p. 909). Por isso, preferiu-se apresentar uma tradução indicando que o homem a quem foi dado o penhor será quem vai fazer retornar o penhor para seu dono, "o homem pobre": "Causar o retorno (ou fazer retornar)", "causarás retornar (ou farás retornar)". A ênfase vem para dar a força do dever a ser levado pelo "tu". Daí porque às vezes se traduz por "certamente farás retornar" para pôr a ordem dentro do contexto de uma determinação a ser seguida pela pessoa a quem ela foi dirigida, cuja obediência a ela não pode ser recusada. É um dever.

${ }^{93}$ Oração infinitiva temporal para indicar o momento que o penhor deve ser devolvido para o homem que o deu

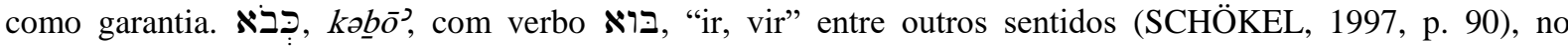
infinitivo construto, sendo que a preposição prefixa $\supseteq$ traz um sentido temporal aqui. Daí a tradução "quando ir/vir", dependendo do contexto.

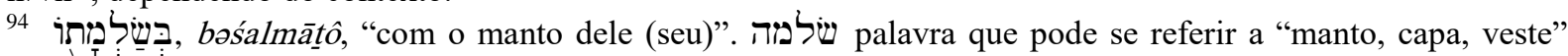
(SCHÖKEL, 1997, p. 644). Pelo contexto, sugere-se que o penhor serviria para cobrir ou envolver o seu dono durante a noite. Em dias frios, ela serviria de proteção. Assim, o ato de devolver o penhor para que sirva de cobertor durante a noite era um ato de bondade com o devedor, apesar da dívida que o penhor dava garantias de pagamento.

95 "Quando é dito que um humano abençoa, usualmente significa 'proferir uma oração começando com a palavra

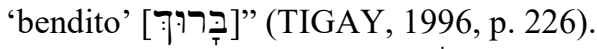

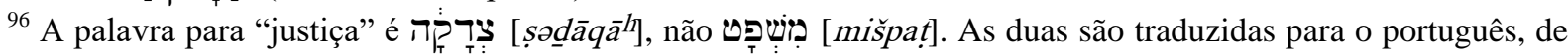
modo geral, pela palavra "justiça". Enquanto que a segunda aponta para um tribunal onde se faz justiça, a primeira mira um ato justo. Assinale-se que o ponto de vista para avaliar o ato como justo ou não é o divino. Para o credor, devolver o penhor que lhe dava garantia do pagamento da dívida poderia não ser justo, mas para Deus isso seria como justiça (notar Deuteronômio 6,25). Para Tigay, a implicação disso é que a pessoa que devolve a vestimenta para o pobre "acumula crédito por feito meritório" $(1996$, p. 83). Para ele, o conceito que está por trás do texto é a de "aquisição de capital" na ideia talmúdica, onde "um bom feito produz capital e nutre juros" (1996, p. 83). Por sua vez, Abraham ibn Ezra entende "justiça" como aquilo que "é certo para você lhe permitir dormir com sua garantia" (2003, p. 114).

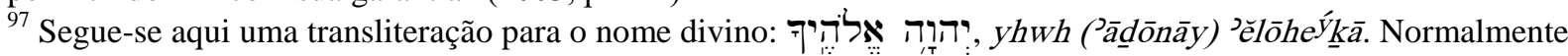
esta pesquisa, quando fala de Deus, não o cita por seu nome pessoal, mas por chamá-lo de "Deus de Israel" ou "o Deus de Israel". 
14 - "Não extorquirás ${ }^{99}$ salário (pagamento) ${ }^{100}$ de teu irmão excessivamente pobre ${ }^{101}$ ( ${ }^{\complement} \bar{n} n \hat{\imath}$ Wə’ebyôn), ${ }^{102}$ ou do teu estrangeiro que vive na tua terra, ${ }^{103}$ nos teus portões." 104

15 - "No seu (mesmo) dia darás o seu salário, e (antes que) o sol vá de sobre ele. Porque pobre $^{105}$ (é) ele. E para ele mesmo levanta ${ }^{106}$ sua vida. ${ }^{107} \mathrm{E}$ assim ele não clamará sobre ti a $y h w h$ ('ā $\bar{d} \bar{o} n \bar{a} y)$, e haverá em ti pecado ${ }^{108}$."109

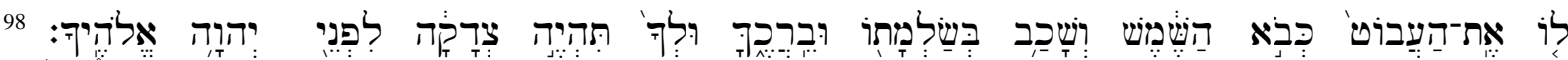

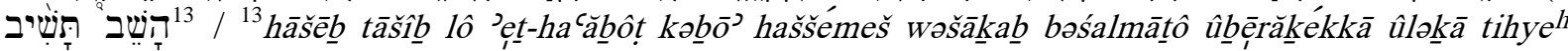

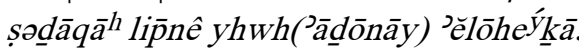

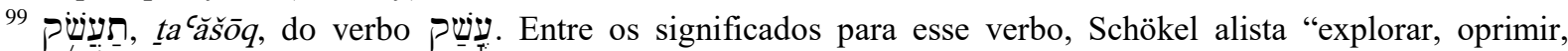
defraudar, surrupiar" (1997, p. 524). Diante disso, optou-se aqui por traduzi-lo por "extorquir" pela violência que isso representa sobre uma pessoa que tem somente aquilo como meio de sua sobrevivência, e também porque a violência está na força que representa deixar de pagar alguém, mesmo que se tenha condição para isso. Assim, deixar de pagar, por si só, expressa violência contra quem necessita do pagamento. O verbo p עִ também "está associado com roubo e fraude (Levítico 19,13; 1 Samuel 12,4.5). Ele aparece nas maldições de Deuteronômio 28,29.33" (NELSON, 2002, nota p, p. 285). O verbo é "um termo geral para maltrato e trapaça sobre aquilo que pertence a outro... é um termo que estigmatiza o atraso no pagamento de salário como um roubo" (TIGAY, 1996, p. 226, 227).

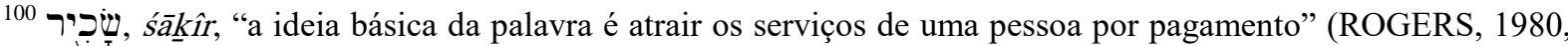
p. 878). McCarthy diz que "oprimir o salário implica em traição a respeito do salário que fora combinado" (2007, p. 118).

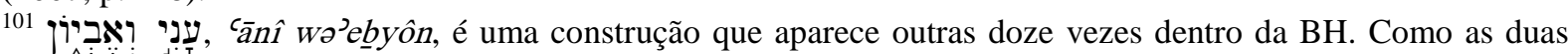
palavras são traduzidas por "pobre" em contextos diferentes, nos quais elas não aparecem juntas, optou-se por manter esta tradução para salientar que são palavras com mesmo campo semântico ("teu irmão pobre e pobre"). Porém, em discussão posterior, esta pesquisa destacará que a ocorrência delas juntas é por motivo de ênfase, em que uma enfatiza a condição que a outra apresenta.

${ }^{102} \mathrm{Em}$ outros livros da BH, essa construção aparece distribuída com outras palavras: ‘ānî e dāl (Isaías 11,4; 26,6) e dāl e 'ebbyôn (Salmo 113,7; Provérbios 14,31; Isaías 24,4). Apenas para salientar - em Isaías 11,4, a

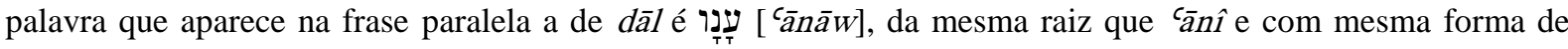

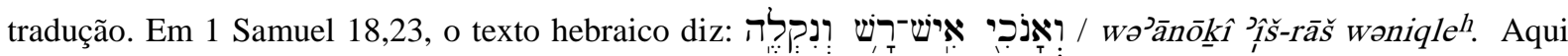

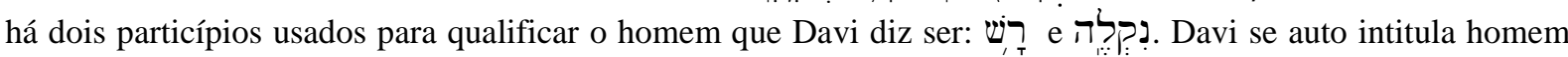
"que é pobre" e "que é de pouca estima (alguém de quem pouco se leva em conta)".

${ }^{103}$ Em Levítico 19,13 aparece a mesma lei que a de Deuteronômio 24,14. A diferença está em que, em Levítico, a lei é aplicada a todos os trabalhadores, mas, em Deuteronômio 24,14, o foco é o trabalhador pobre, seja ele um israelita, seja um estrangeiro residente (TIGAY, 1996, p. 226).

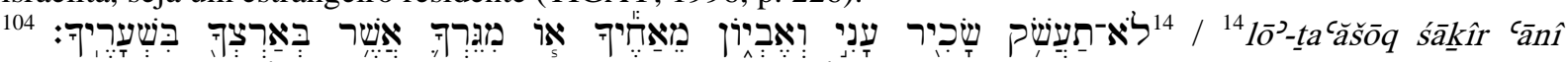

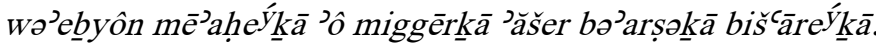

105 cănî.

${ }^{106}$ נפשיא é particípio, podendo ser traduzido perifrasticamente por "está levantando", ou, simplesmente, por "levanta, ergue". Ezra entende que o verbo nesse texto tem a ideia de "suportar", no sentido de "sustentar a si mesmo dali" (2003, p. 114).

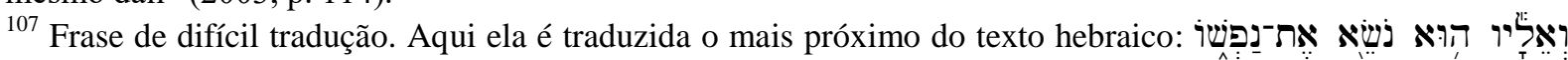

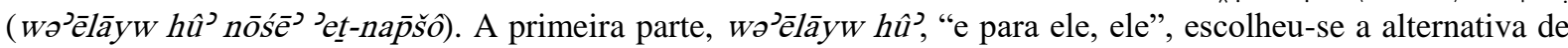
traduzir h $\hat{u}^{\supset}$ por "mesmo, si mesmo", haja vista que a preposição ’ēl já vinha acompanhada do sufixo pronominal da 3 a pessoa do singular masculino. Mas que também seja possível a alternativa seguinte: "e para ele, ele levanta sua vida".

${ }^{108}$ Quando o fiador entrega o penhor, para proteção do homem pobre, antes do pôr do sol é "justiça", a não entrega é "injustiça". No texto é "pecado" ( (Hebraico), onde é referido o pagamento de um voto. O redator olha para o atraso no pagamento como um ato de crueldade por parte daquele que contratou o trabalhador (TIGAY, 1996, p. 227). 


\subsection{O Sitz im leben ${ }^{110}$ de Deuteronômio 24}

O contexto de vida no qual o capítulo está ambientado é dentro da perspectiva do relacionamento entre um homem que faz um empréstimo e o outro que o recebe. Há de se destacar também que os dois parecem possuir ao menos uma propriedade, pois o que fez o empréstimo precisa ficar fora da porta da casa ${ }^{111}$ daquele que tomou o empréstimo. ${ }^{112}$ Assim, o ambiente ${ }^{113}$ específico no qual o texto se ambienta não é claro, pois o homem credor tem acesso à porta daquele que fez a dívida, e isso poderia acontecer tanto na cidade quanto no campo. Pode-se pressupor aquela vida rural que se desenvolve a partir da vida no entorno (ou em função) da cidade. Mas isso é que se pode apenas pressupor. ${ }^{114}$

Dentro desse ambiente, duas situações são apresentadas. A primeira é aquela de um homem pobre que fez um empréstimo e, como garantia de pagamento, entregou sua capa com a qual ele se cobre durante a noite. A capa era a única "boa" garantia que ele tinha para quitar o empréstimo. A outra é a de um trabalhador carente, pobre, que trabalha em função de sua sobrevivência. A subtração de seu salário poderá levá-lo a uma situação de crise. O ambiente do oitavo século no Reino do Norte e a subsequente situação encontrada por Josias como herança de seu antecessor, Amon, ${ }^{115}$ bem como no exílio e pós-exílio favoreceriam o surgimento de situações que o Deuteronômio pretendia corrigir.

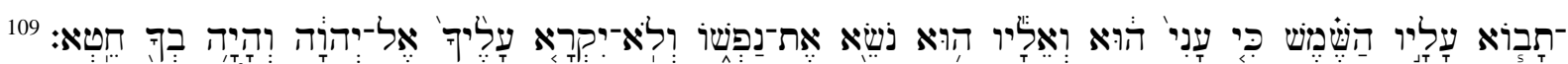

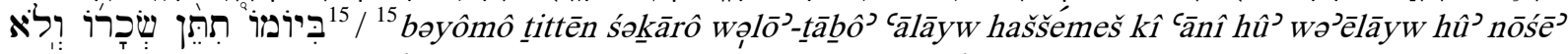

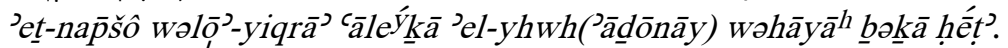

${ }^{110}$ Crüsemann traduz essa construção por "lugar vivencial" (2008, p. 25).

${ }^{111}$ A casa em vista, porém, pode fazer parte da propriedade do credor, fazendo do homem endividado um morador na propriedade daquele a quem ele prestava serviço, ao mesmo tempo faz da casa do devedor seu território, o qual deve ser respeitado pelo credor. O credor, nesse caso, poderia pensar que, por ceder a casa a um morador devedor, ele teria o direito de invadir aquela casa para receber o que the era devido. A legislação quebra esse paradigma e estabelece a ordem do respeito pelo ser humano como tal.

${ }^{112} \mathrm{O}$ livro de Deuteronômio busca resolver aqui um problema comum e que corresponde às necessidades de homem endividado em risco de ser violentado pelo credor.

${ }^{113}$ Com a apropriação do material de Deuteronômio nos reinados de Ezequias e Josias (principalmente), o seu conteúdo foi adaptado para a nova realidade, sugerindo constantes atualizações de seu material para novos contextos, principalmente o ambiente citadino.

${ }^{114}$ É recorrente dentro do livro de Deuteronômio o contexto de "cidade". Mesmo que o livro tenha nascido dentro da perspectiva do homem que lida com a terra em um ambiente rural (Deuteronômio 26,1-11 aponta nessa direção - o campo), a aplicação da legislação do Deuteronômio ganhou aplicação para a vida de quem mora em

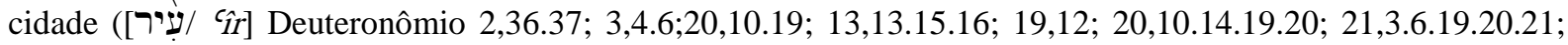
$22,15.17 .18 .21 .23 .24 ; 25,8 ; 28,3.16 ; 34,3)$. Essas inúmeras ocorrências da palavra "cidade" demonstram que a vida em Deuteronômio tinha aspectos citadinos muito presentes.

${ }^{115}$ Notar o que diz 2 Crônicas 33,21-25. Amon foi filho de Manassés, e do qual é dito que ele corrompeu o povo, a tal ponto de fazerem pior que qualquer povo que havia sido expulso diante de Israel (2 Reis 21,9; 2 Crônicas $33,9)$. 
Assim, o redator do Deuteronômio levanta uma possibilidade casuística e um mandamento direto, e, com isso, procura estabelecer um padrão mínimo que trouxesse solidariedade no relacionamento entre aqueles que estivessem na condição de poder manter o trato correto entre o fiador e aquele que havia tomado um empréstimo, bem como entre quem trabalhava no campo e quem contratava seu serviço.

A situação deve ter sido desesperadora para aquele que não possuía defesa diante de um "grande", e, por isso, a intervenção do redator se mostraria apropriada, criando (ou tornando abrangente) uma legislação a partir de uma situação rotineira do cotidiano da vida no campo, e na cidade, e, com isso, procurava solucionar um problema recorrente dentro das comunidades do Israel do século VIII AEC, e em períodos subsequentes da história de Israel, já estabilizado na Terra da Promessa.

Porém, o que essa legislação casuísta destaca? Qual era a situação problemática que ela tenta corrigir? A análise que segue responderá a esses questionamentos.

\subsection{Análise de Deuteronômio 24,10-15}

O capítulo 24,10-15 começa com uma construção comum, dentro do livro de Deuteronômio, empregando uma estrutura que é formada de uma prótase, onde está a oração condicional, e de uma apódose, na qual se declara o dever. Essa construção é chamada de "Direito Casuístico"116 (2000, p. 195). ${ }^{117}$ Tal construção, encontrada no versículo 10, poderia ser invertida - "Não virás à sua casa para tomar o seu penhor (garantia), quando tu fizeres um empréstimo ao teu próximo de alguma coisa", com o intuito de reforçar a proibição. Essa é a finalidade do texto ao começar com uma hipótese casuística, e, com isso, a ideia básica do texto não seria afetada.

\footnotetext{
${ }^{116}$ Deve-se levar em consideração que o Direito Casuístico não é uma criação dos legisladores israelitas, mas uma construção encontrada nas legislações de outros povos. De Vaux menciona que "os códigos mesopotâmicos são redigidos em forma 'casuística' e uma parte da legislação israelita encontra neles um bom paralelo estilístico" (2003, p. 180). Ele também diz que se pode fazer comparação com "os tratados impostos pelos reis hititas a seus vassalos" (2003, p. 180). Crüsemann, por sua vez, afirma que o Direito Casuístico "está relacionado de forma bem estreita com o direito do Antigo Oriente e, no fundo, dele se origina" (2008, p. 25). Crüsemann fala também do "Direito Apodítico", no qual estão "diferentes formas de sentenças como mandamentos e proibições, maldições e sentenças jurídicas participiais" (2008, p. 25). Esse direito é "o direito antigo e original de Israel" (2008, 25).

117 Silva diz que prótase é a oração condicional que abre o texto. A apódose é a oração que traz a ordem, ou declaração de impunidade ou pena (2000, p. 195). O usual, nesse tipo de construção, é a oração condicional apresentar uma hipótese ("Se algo acontecer"), seguida de uma ordenança a ser cumprida (a apódose), caso a condição apresentada na prótase se torne uma realidade.
} 
2.1.2.3.3.1. Primeiro caso: a situação de um homem que penhora capa pessoal por um empréstimo (Deuteronômio 24,10-13)

O primeiro caso é aquele de um homem que toma um empréstimo. A garantia que o empréstimo seria devolvido deveria ser dada. Essa garantia não poderia ser retirada à força da casa do homem que tomou o empréstimo. Porém, aquele que receberia a garantida proposta deveria ficar fora. Este "fora" sugere "fora da casa", ou da propriedade, onde o devedor guarda a garantia. ${ }^{118}$

O que o redator está proibindo é uma espécie de uso da força vista na violência ao entrar na casa de alguém, para retirar uma garantia de pagamento sem o devido convite para isso. ${ }^{119}$ Como o empréstimo dava ao credor grande poder sobre aquele que tomou o empréstimo (NELSON, 2002, p. 290), o redator busca impedir a violência que essa ação representava, não deixando que ela aconteça. O fiador torna-se solidário com o devedor, ficando fora para esperar a entrega voluntária da garantia. Essa era uma forma de mostrar respeito pelo homem que devia entregar o penhor, não o desonrando em sua própria casa. ${ }^{120}$

Partindo da ideia de que o imperfectivo ${ }^{121}$ indica que a ação está "no processo de realização" (ARNOLD \& CHOI, 2003, p. 56-57), a ação proibida pela construção $1 \bar{o}^{3}-\underline{t} a \underline{b} \underline{\underline{o}}$ ', "não virás", coloca ênfase no início da ação, ao mesmo tempo em que proíbe sua frequência ou repetição, caso esse tipo de comportamento tenha acontecido repetidamente dentro das diferentes comunidades lideradas por diferentes clãs dentro do Israel do século oitavo e daí por diante (século VI AEC, período do exílio e pós-exílio). ${ }^{122}$

\footnotetext{
${ }^{118}$ Os dispositivos para a efetivação das transações comerciais entre o que empresta e o que toma emprestado são relativamente simples (DRIVER, 1895, p. 276).

${ }^{119}$ Para Craigie, "este requerimento protege a privacidade da casa do recipiente, e deixa-o escolher o artigo que deve ser dado" como garantia do empréstimo (1976, p. 308).

${ }^{120}$ Para a halakhah, Deuteronômio 24,10.11 significa "que o credor não pode tomar a possessão do devedor por qualquer tipo de força. Para prevenir isso, ela permite somente com o aval da corte” (TIGAY, 1996, p. 225).

${ }^{121}$ Nomenclatura proposta pelo orientador para a ação incompleta do verbo Hebraico.

122 A queixa do "Israel pobre" contra o "Israel rico" em Neemias é ilustrativa desse tipo de violência, quando o primeiro acusa o segundo de escravizar seus filhos e filhas por causa de dívidas não pagas. O texto deixa subentendido que alguns estavam escravizando os próprios "irmãos”. Há uma acusação de Neemias contra alguns de seu tempo que estariam vendendo seus próprios irmãos a estrangeiros (Neemias 5,8), tornando a escravidão quase insolúvel.
} 
O penhor seria entregue ao fiador, fora da casa, e à noite deveria retornar para o que tomara o empréstimo: $24,12.13$ - "E se o homem for pobre $\left(\complement_{\bar{a}} n \hat{1}\right),{ }^{123}$ não te deitarás no penhor dele. Deverás fazer retornar o penhor para ele, quando o sol ir. E (ele) deitará com seu manto. E (ele) te abençoará. E, para ti, será justiça ${ }^{124}$ diante de yhwh (’ādōnāy), teu Deus.” A ação inversa desta ordem seria considerada uma injustiça diante do Deus de Israel.

Salientem-se os seguintes dados. Primeiro, o penhor dado era algo que serviria de garantia e

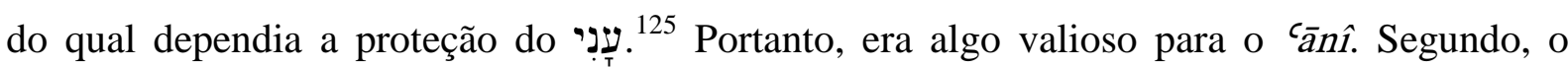
fiador não deveria fazer qualquer outro uso do penhor para benefício pessoal. O princípio proíbe o usufruto do penhor durante a noite por parte do fiador. Ele deveria retornar ao seu dono para seu benefício durante a noite e esta ação é levada a cabo pelo próprio fiador. Assim, o penhor tem aqui a função específica de garantir que a dívida será paga, não que ele deva entrar como parte do patrimônio do fiador e assim este usufruir dele. A ordem para devolução é colocada na forma de um dever a ser cumprido. A BJ entendeu assim e traduziu esta construção no infinitivo absoluto + imperfeito por "deverás devolver". O "tu", ou o homem livre e com capacidade de ajudar o עִ עִ que vem a seguir serviria para estímulo e para ver a vantagem que ele teria caso ele partisse para a obediência.

Portanto, diante da possibilidade da proibição ser atendida pelo fiador, haveria um benefício adicional para ele, se ele obedecesse ao mandamento, especificamente, no caso do homem endividado ser "pobre", era este: "E (ele) te abençoará. E, para ti, será justiça diante de yhwh ('āôōnāy), teu Deus". Primeiro, a retorno do עָ̣ seria em que, da parte dele, haveria invocação de sucesso para o empreendimento do fiador. $\mathrm{O}$ jé já deu o que tinha que dar e o que ele tem de mais para dar está dentro da fé. $\mathrm{O}$ עִ buscaria, diante do Deus de Israel, o favor para aquele que estivesse usando de benevolência para com ele. Invocar a bênção de

\footnotetext{
${ }^{123}$ Para Tigay, o homem pobre é não somente um necessitado, mas que ele é mais que isso, ele é “absolutamente destituído, ao ponto que ele não possui nada que possa ser penhorado, exceto o envoltório com que ele dorme à noite" (1996, p. 225).

${ }^{124}$ Para Chouraqui, “a justificação não é nem esmola nem caridade puramente livre. Devemos compará-la antes à equidade, que realiza a justiça interpretando leis e contratos da maneira mais favorável à parte em dificuldade... A justificação decorre dos atos que provam a justiça do homem" (1997, p. 248).

${ }^{125}$ Algo tão importante assim daria ao fiador a certeza de que a dívida seria paga. O fiador estava evitando um calote, com isso, protegendo seu patrimônio. Como o patrimônio era também uma herança que seria deixada para os filhos, o credor está também protegendo a próxima geração de seus filhos.
} 
Deus sobre o credor coloca o עִָָ em posição de poder. Isso só ocorreria se nesse quadro estivesse presente o seu Deus (NELSON, 2002, p. 291).

Assim, o redator coloca um segundo elemento - o próprio Deus de Israel entenderia isso como um ato de justiça feito pelo fiador em sua obediência ao mandamento de devolver, ao pôr do sol, o penhor do עִ עָנִי ${ }^{126}$ Essa justiça seria creditada pelo próprio Deus em favor do credor benevolente. O que o redator está dizendo é que o credor também tem uma dívida essa é com Deus. Se ele for beneficente com o seu devedor, Deus também será com ele. Mas a obediência do credor faz com que Deus passe a dever a ele. O pagamento da parte divina será a bênção.

Uma observação adicional deve ser feita. A justiça é dita que seria diante de Deus. À semelhança do patriarca Abraão, em Gênesis 15,6, a justiça ${ }^{127}$ viria como resposta a um ato de fé. Somente se o credor cresse que seria abençoado pelo Deus de Israel por devolver o penhor ao pôr do sol, e que aquele ato seria agradável ao seu Deus, é que ele iria até a casa do עִִָי para devolver-lhe aquela garantia que serviria de proteção ao עְִִָ. "Justiça" aqui tem a ver com o correto relacionamento com o seu próximo necessitado, mas que isso seja em obediência a uma ordem divina.

Como a "justiça" é diante de Deus, então, o correto relacionamento é primariamente com o Deus de Israel, e o resultado disso se dará no campo dos relacionamentos humanos. O correto relacionamento do homem com homem, vindo em obediência ao seu Deus, resulta no correto relacionamento do homem com Deus. O resultado disso será que aquele que assim procede em fé será abençoado.

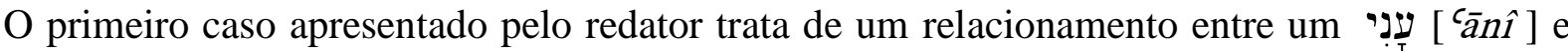
um fiador, envolvendo a questão de um empréstimo e sua garantia. O segundo caso segue pelo caminho do relacionamento de trabalho.

\footnotetext{
${ }^{126}$ Deve-se destacar que a promessa que o עִָ vai vabençoar o fiador e que Deus entenderá isso como um ato de justiça diante dele são afirmações que o redator está dando como fonte de estímulo à generosidade por parte do fiador. O que se percebe aqui é a colocação de uma motivação teologicamente bem estabelecida. Para Nelson, como justiça está em oposição ao pecado $(15,9 ; 24,15)$, aqui "há o reflexo da fórmula cúltica pela qual o sacerdote declararia a pessoa justa" (2002, p. 291).

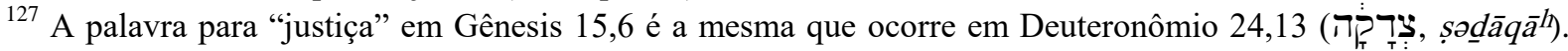
Essa justiça se adquire diante do Deus de Israel por ser obediente a ele. Obediência a Deus é resultado de fé que a parte de "yhwh ( $\bar{a} \underline{a} o \bar{n} n \bar{a} y)$, teu Deus", a bênção, será cumprida. É claro que essa justiça será resultante da obediência ao mandamento divino (ver Ezequiel 18,9).
} 
2.1.2.3.3.2. A situação de um homem que trabalha por sua sobrevivência (Deuteronômio 24,14-15)

Tanto o caso de um homem que toma um empréstimo e entrega um bem essencial como garantia de pagamento ao fiador quanto ao que trabalha pela sua sobrevivência diária têm em

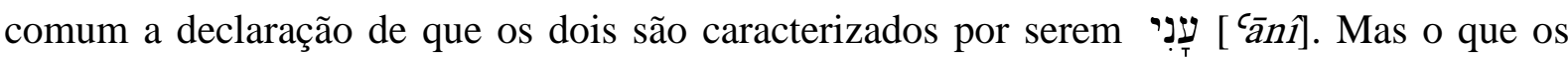
envolve são assuntos diferentes e a estrutura da escrita também difere uma da outra. $\mathrm{O}$ segundo caso não é colocado na forma de uma hipótese, mas na forma de um mandamento constituído de uma negativa seguida de um imperfectivo. ${ }^{128}$

\section{Observe o texto:}

14 - "Não extorquirás salário (pagamento) de teu irmão excessivamente pobre, ${ }^{129}$ ou do teu estrangeiro ${ }^{130}$ que vive na tua terra, nos teus portões."

15 - "No seu dia darás o seu salário, e (antes que) o sol vá de sobre ele. ${ }^{131}$ Porque ele (é) pobre. E para ele mesmo levanta sua vida. ${ }^{132} \mathrm{E}$ (assim) ele não clamará sobre ti a yhwh ('ā $\underline{a} \bar{o} n \bar{a} y)$, e (se ele clamar) haverá em ti pecado.",133

A proibição lida com a sonegação do direito ao pagamento de um empregado contratado por um dia de trabalho. Ele era um diarista que trabalhou para receber ao final do dia um

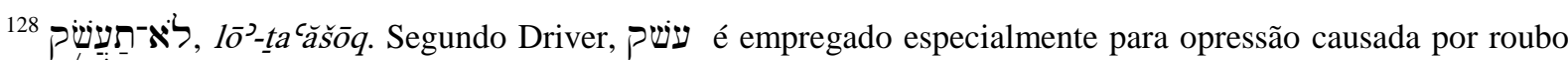
ou fraude. Ele cita como outros exemplos Deuteronômio 28,29.33; 1 Samuel 12,3.4; Ezequiel 18,18; 22,20; Amós 4,1; Malaquias 3,5 (1895, p. 276).

${ }^{129}$ O Salmo 72,13 traz a seguinte construção: :

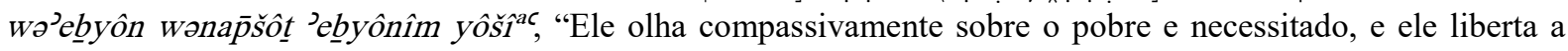
vida (alma) dos necessitados"). A construção dal wə’ebyôn aproxima o campo semântico de dal do de cānî. Outra ocorrência desta mesma construção está no Salmo 82,4. Nessa mesma ordem, mas separadas por um particípio no plural, elas aparecem em Amós 4,1. A construção dal wə ‘̄nnî não aparece na BH. Mas o inverso está presente: ‘̄anî wadal (Sofonias 3,12: "E deixarei no meio de ti um povo pobre e insignificante, e buscarão

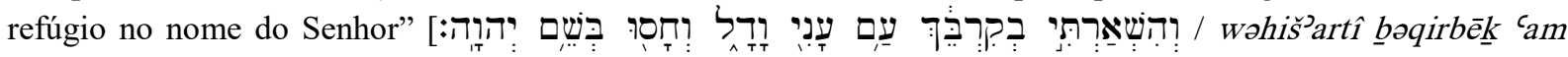

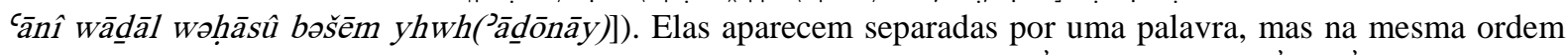

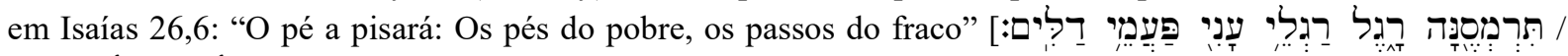
tirmosénnāhh ráăgel raḡlê ‘ānî pa ămê dallî̀m].

${ }^{130}$ A mesma legislação para o irmão pobre vale para todo estrangeiro [ר g / / gēr] na mesma condição de trabalhador assalariado.

${ }^{131}$ Esta é uma indicação de que o salário não deve ficar para o dia seguinte. O sol não deve se pôr sobre o salário do trabalhador, ou seja, ter seu pagamento adiado.

${ }^{132}$ Notar esse duplo apelo à solidariedade humana ("Porque ele (é) pobre. E para ele mesmo levanta sua vida"), sobre que o "teu irmão" deveria demonstrar sua compaixão.

${ }^{133} \mathrm{O}$ grito do oprimido viria na forma de um lamento diante de Deus, onde imprecações seriam invocadas sobre o empregador, como se ele fosse um inimigo do assalariado (NELSON, 2002, p. 291-292). O grito de socorro do pobre seria ouvido por Deus que viria em seu auxílio. 
pagamento relativo às horas trabalhadas. Portanto, um pagamento devido a ele pela trabalho prestado, mas sem a especificação do tipo de trabalho feito.

O primeiro elemento caracterizador do ‘̄anî aqui é que ele também é um 'ebyôn. É possível

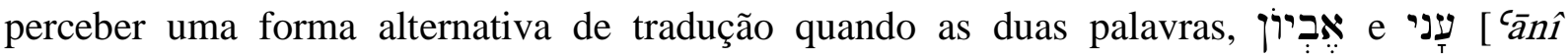
Wə̉ebyôn], ${ }^{134}$ ocorrem no mesmo versículo, na sequência uma da outra, como acontece aqui (Deuteronômio 24,14). Para esta pesquisa, seria melhor entender e traduzir a segunda palavra, ’ebyôn, como uma forma de ênfase sobre a primeira que aparece no texto. Daí a ideia de "pobre e necessitado".

A sugestão seria que, em lugar de traduzir por "pobre" e "necessitado", como faz a BJ, seria melhor traduzir por "muito/muitíssimo pobre", "paupérrimo". Entende-se com isso, pelas análises anteriores, que as duas palavras já trazem em si a ideia de necessitado, fazendo desnecessária sua tradução por uma palavra diferente, apenas porque há necessidade de traduzi-la. Portanto, o redator quis enfatizar a penúria do homem denominado por $\varsigma_{\bar{a} n \hat{\imath}}$ wə’ebyôn.

Nessa direção, deve-se observar o que acontece no Salmo 35,10: "Todos os meus ossos

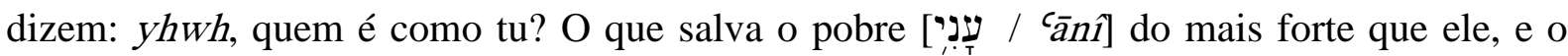

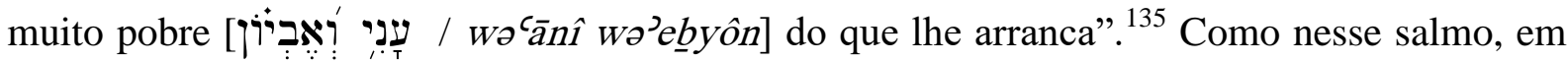
Deuteronômio 24,10-15, o ‘ānî aparece só $(24,12.15)$ e acompanhado do ’ebyôn $(24,14)$. Isso reforça a ideia de que, se o salmista quisesse falar apenas de um homem pobre, o ‘ānî seria suficiente. Mas, tal qual em Deuteronômio, o salmista também quer enfatizar que o cānî é também 'ebyyôn - alguém muito pobre, e, por isso, também muito indefeso, exceto pela presença do Deus de Israel em seu socorro. No caso de Deuteronômio, Deus atenderá uma

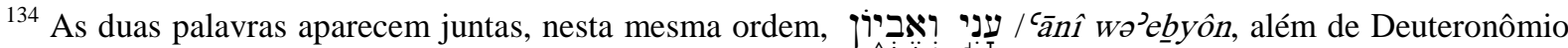
24,14, em Jó 24,14 ("o pobre e o indigente"); Salmos 35,10 ("o pobre e o indigente"); 37,14 ("o pobre e o indigente"); 40,18 ("pobre e indigente"); 70,6 ("pobre e indigente"); 74,21 ("o pobre e o indigente"); 86,1 ("pobre e indigente"); 109,16 ("o pobre e o indigente").22 ("pobre e indigente"); Jeremias 22,16 ("do pobre e do indigente"); Ezequiel 16,49 ("ao pobre e ao indigente"); 18,12 ("o pobre e o necessitado"). A tradução colocada em parêntesis é a que é encontrada na BJ. Uma observação pode ser colocada aqui - a ideia de "pobre e necessitado" é enfática sobre a condição do homem tratado no texto, pois pode ser que houvesse um pobre que não fosse necessitado.

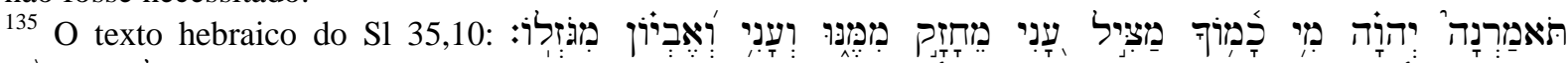
I wə’ebyôn miggōzlô - "Todos os meus ossos dizem ao Senhor: Quem é como tu? Aquele que livra (está livrando) um pobre do mais forte que ele, e um pobre e necessitado daquele que o rouba".
} 
queixa contra quem sonegar o salário do trabalhador. A queixa será apresentada pelo ‘̄annî wə’ebyôn.

O segundo elemento que caracteriza o ‘ānî é que ele também é "irmão" do empregador. A provável situação é a de um clã que possui terras, e um dos membros desse clã caiu na condição de um 'ānî Wə’ebyôn. Essa possibilidade se torna mais forte porque este "teu irmão" também á alguém “que (está/vive) na tua terra, nos teus portões”. É possível que essa declaração seja uma oração que esteja qualificando o "teu estrangeiro" que vem em seguida a "teu irmão". Mas também pode ser entendida como um qualificativo para os dois. Tanto um como o outro estariam vivendo sob a proteção da liderança do clã e dentro. Por isso a afirmação - "na tua terra, nos teus portões", ou seja, dentro da propriedade do "teu irmão".

Vivendo assim, "na tua terra, nos teus portões", o ‘̄an̂i se tornaria alguém fragilizado pela condição de dependência, e o "irmão" empregador poderia entender que, por viver o "ānî dentro de suas terras, ele não veria problema em deixar de pagá-lo porque já lhe dava um lugar de morada e proteção. A legislação é taxativa: "Não extorquirás o salário (pagamento) de teu irmão muitíssimo pobre". E ainda enfatiza: "No seu dia darás o seu salário, e (antes que) o sol vá de sobre ele", seguido de uma reafirmação da condição de sua vida: "Porque pobre (é) ele". Note-se que essa explicação vem como reforço da motivação para o salário do trabalhador não ser retido.

O terceiro elemento caracterizador é o motivo de o ‘̄anît trabalhar - "E para ele mesmo levanta

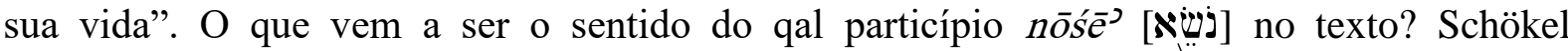
apresenta uma lista significativa de sentidos que tem a raiz $n s^{\prime}$ - "levantar, erguer, pôr, carregar, levar, trazer, transportar" (1997, p. 450). Entre os sentidos figurados, ele aponta os sentidos de "suportar, aguentar, tolerar, poder com, manter, sustentar" (1997, p. 452). A

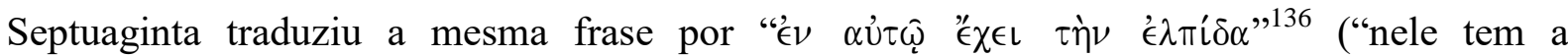
esperança").

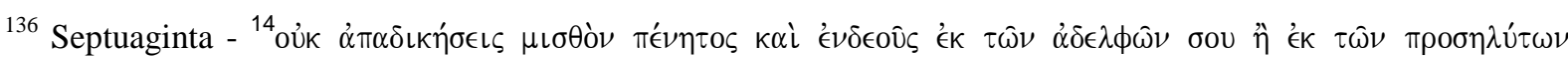

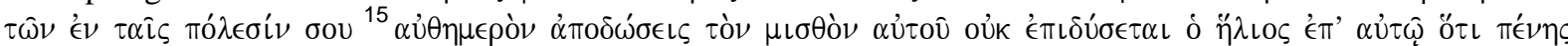

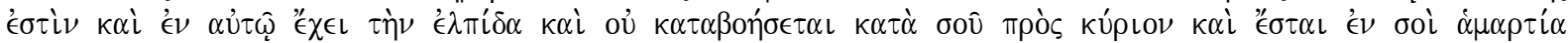
(tradução sugerida: (14) "Não reterás salário de uma pessoa pobre e pobre de teus irmãos, ou dos prosélitos nas tuas cidades, (15) pagarás no mesmo dia o salário dele. Não descerá o sol sobre ele, porque pobre é e nele tem esperança, e (assim) não gritará contra ti ao Senhor e será (encontrado) em ti pecado").
} 
Com isso, algumas observações conclusivas podem ser colocadas. Primeiro, como apontou Schökel, em sentido figurado, a raiz $n s^{\prime}$ pode ser traduzida por "manter, sustentar". Isso se aproximaria do entendimento que a Septuaginta trouxe para a tradução para o grego - "nele tem a esperança". "Nele" numa referência ao "salário" ou pagamento que aquele trabalhador pobre esperava para o fim do dia. Mas "esperança" de quê? A esperança de sustentar sua "vida" por meio do recebimento do pagamento devido. Aquele pagamento era a única esperança que o ‘̄ân tinha para continuar vivo. Era nele que ele tinha esperança de manter sua vida.

Assim, "E para ele mesmo levanta sua vida" tem a ver com o trabalho que traz esperança de sustento para aquele dia. O çan̂în não tem quem trabalhe por ele ou outro meio de sobrevivência. Cortar o salário dele seria frustrar as esperanças que ele, como trabalhador, tinha para o fim do dia. Porque aquilo era a forma dele "carregar a sua vida" ou levantar o sustento a si mesmo. Cortar ou adiar o pagamento diário do trabalhador era uma ameaça à sobrevivência dele.

Para finalizar sua colocação sobre o pagamento da diária do trabalhador, o redator coloca um incentivo da mesma maneira em que o fez para motivar o fiador a devolver o penhor no final do dia. A falta do pagamento levaria o '̌ñî a apelar para o Deus de Israel, e isso levaria Deus a agir em favor dele. O pagamento em dia impediria o ‘̄annî de querer justiça, e se ele assim procedesse não seria encontrada falta grave no empregador: "ele não clamará ${ }^{137}$ sobre ti a yhwh ( $\mathcal{a} \underline{d} \bar{o} n \bar{a} y)$, e (se ele clamar) haverá em ti pecado".

O "pecado" aqui tem a ver com a atitude de descumprimento da ordenança divina, sendo um desvio daquilo que o Deus de Israel queria naquela situação para o seu povo. Portanto, trata-se de um ato de desobediência - ele falhou em cumprir uma ordem divina. Enquanto que a "justiça diante de Deus" é a harmonia do homem com a vontade divina, o pecado, por outro lado, é o oposto dessa conformidade. Fazer o que o Deus de Israel ordena é harmonizar-se com uma vida justa - ou uma vida em conformidade com as ordenanças divinas. Essa é uma

\footnotetext{
${ }^{137}$ Dá para se estabelecer uma questão: Por que o $\varsigma_{a} n \hat{i}$ clamaria ao Deus de Israel, não ao rei, para que lhe fosse feita justiça? Entendendo-se que o Código Deuteronômico vem do século oitavo do Reino do Norte, onde não houveram reis "como Davi", então é possível entender por que esse Ente Silencioso clamaria a Deus, pois da parte do rei não haveria resposta. Entretanto, pode-se ainda se afirmar que o Código Deuteronômico vem de longo prazo se desenvolvendo para estabelecer as relações entre as partes constituintes da sociedade por ele regida, sendo possível seu desenvolvimento desde tempos em que não havia reis para governar o povo, e onde o povo considerava Deus como seu rei e a quem ele deveria apelar nas situações em que ele se sentisse injustiçado.
} 
vida de retidão. Não fazer o que Deus manda é uma ofensa legal, portanto, um crime (NELSON, 2002, p. 292).

O que o redator salienta aqui é que o Deus de Israel é o defensor daqueles que não têm a quem recorrer quando uma injustiça é praticada contra ele. Mas, ao mesmo tempo, age contra aqueles por meio de quem a injustiça está sendo canalizada contra o cānî. Assim, o redator coloca a infração daquele apontado pelo pronome "tu" sob o prisma do relacionamento do homem com seu Deus. Agir contra um trabalhador pobre é agir em desobediência à vontade do Deus. Dessa forma, o Deus de Israel se interpõe como um defensor do pobre, o qual, em última instância, agiria quando os meios humanos de defesa do ‘̄anîn não fossem suficientes para impedir a injustiça. Ele age para fazer justiça, condenando o culpado de desobediência.

Ainda há um detalhe a ser observado. O fim do dia é um marco importante na visão do redator - é quando o penhor deve ser devolvido ao homem que tomou um empréstimo, e também é quando o trabalhador deve receber o pagamento pelo dia de trabalho. A primeira é "quando o sol ir", a outra é o paralelo da primeira, "antes que o sol vá". O sol marca não somente a chegada do dia e da noite, como o momento chave para determinadas ações humanas. No caso em pauta, a chegada do sol permite que o penhor seja entregue ao fiador e que o contratado comece seu trabalho. O pôr do sol, por outro lado, marca a devolução do penhor ao endividado bem como o momento quando o contratado encerra seu trabalho e deve receber seu pagamento.

O fim do dia, portanto, é um ponto limítrofe no relacionamento do fiador/empregador com o ‘̄anî wə’ebyôn. Ele põe um ponto final até onde se toleraria ficar com a capa ou com o salário de uma diária de um trabalhador. Falhar em obedecer a esse limite é incorrer em desobediência ao Deus de Israel. ${ }^{138}$ Nesse texto, a desobediência é chamada de transgressão de uma ordem divina. É rebeldia que vem em resultado da falta de fé no Deus que dá essas ordenanças. Em Deuteronômio $9,18,{ }^{139}$ pode-se dizer que se encontra uma definição da

\footnotetext{
${ }^{138} \mathrm{O}$ pôr do sol é o limite que marca o fim de um dia e o começo de outro. Para o redator, o que se acordou para ser realizado naquele dia deve ser feito no dia acordado. Não deve ser deixado para o outro.

139 "Eu me atirei diante do Deus de Israel, como anteriormente, quarenta dias e quarenta noites. Não comi pão nem bebi água. Por causa de todo o vosso pecado que pecastes ao fazer mal ao olhos de 'ādōnāy, para o insultar"

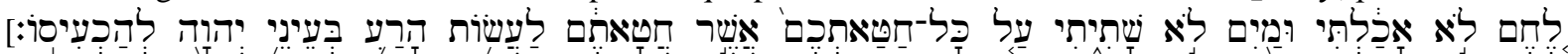

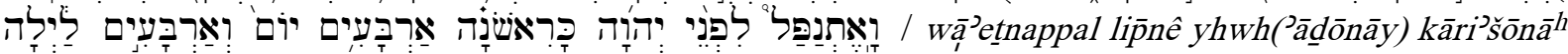

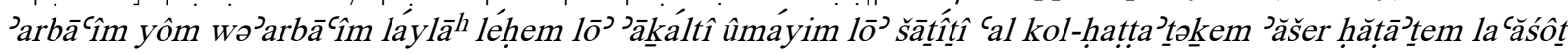

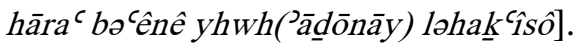


transgressão da ordem divina. Nesse texto, a transgressão é fazer mal aos olhos de Deus, ${ }^{140} \mathrm{o}$ qual dá a medida do padrão do que é certo ou errado.

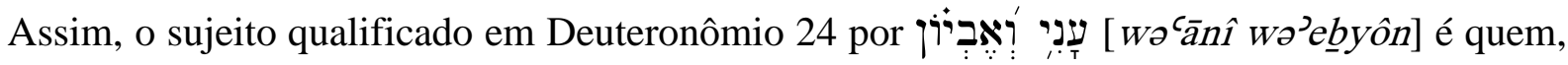
aparentemente, tem residência fixa, um lugar onde se pode esperar na porta para receber permissão de entrada ou não; é também alguém que presta serviço diário em troca de um pagamento que lhe trará suprimento de necessidades do dia; ele também é alguém que, pela

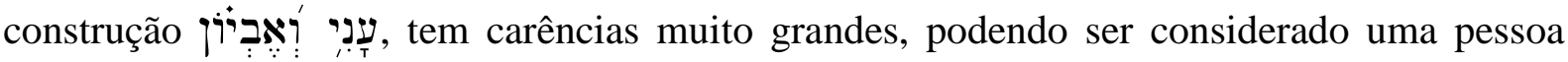
muito pobre, ou, simplesmente, paupérrima.

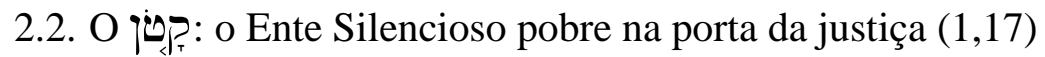

\begin{tabular}{|l|l|l|l|}
\hline Vocábulo & Deuteronômio 1-11 & Deuteronômio 12-26 & Deuteronômio 27-34 \\
\hline iט P $_{T}, q \bar{a} t \bar{o} n$ & 1,17 & & \\
\hline
\end{tabular}

2.2.1. Observações iniciais

Deuteronômio 1,17 tem uma palavra indefinida para se referir a um Ente Silencioso. Diz-se indefinida porque esta pesquisa entende que não se sabe precisamente a quem ela, inicialmente, refere-se (se ao pobre, estrangeiro, órfão, escravo, ou a outra pessoa que se enquadre dentro da definição de "pequeno"), olhando somente da perspectiva de Deuteronômio 1,17.

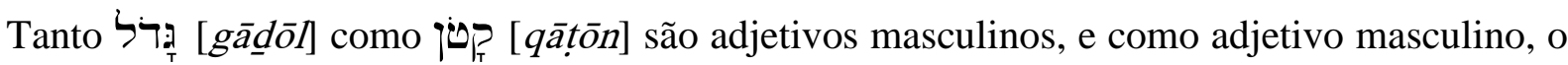
termo ${ }^{0}$ aponta para um ser humano do gênero masculino, mas isso não implica na exclusão daqueles Entes Silenciosos do gênero feminino apontados pelas palavras "viúva" e "serva/escrava". ${ }^{141}$ Portanto, o embate judicial ao qual o texto se refere acontece,

\footnotetext{
${ }^{140}$ Essa construção será recorrente dentro do livro de Reis para avaliar negativamente os reis que não foram obedientes a Deus, cumprindo as ordens divinas, mesmo que tenham sido bem sucedidos como estadistas.

${ }^{141} \mathrm{O}$ qătōon designa um membro da comunidade de Israel e, de modo específico, como será analisado nos termos empregados nos textos paralelos mais adiante, ele vem a designar um homem pobre e que está num processo judicial com um "grande".
} 
hipoteticamente, ${ }^{142}$ entre dois seres humanos, sendo um chamado de ${ }^{0} \varphi_{T}[q \bar{a} t \bar{t} \bar{n}]$, do ponto de vista da justiça (ou do juiz) encarregada de julgar um caso entre os dois requerentes no processo judicial.

A questão, como apontada acima, envolvida pelo texto, é judicial, envolvendo um ${ }^{0} \boldsymbol{p}_{\mathrm{T}}$

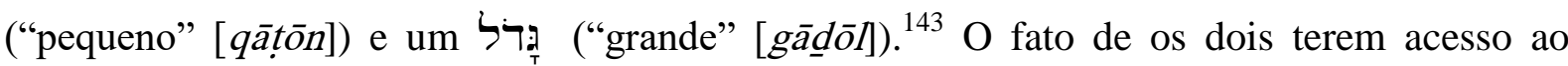
serviço de um juiz, para julgar uma causa entre eles, sugere que tanto um como o outro sejam pessoas com acesso ao tribunal para o julgamento de sua causa. Como o $\left.{ }^{\dagger}\right\rangle_{T}[q a \bar{a} t \bar{n} n]$ está em

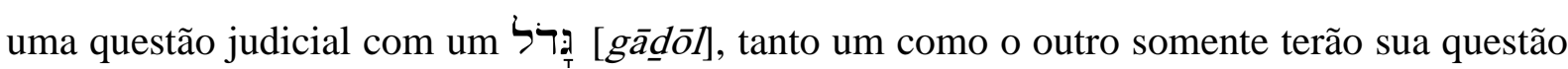
julgada com o devido direito, se os juízes forem imparciais em seu julgamento.

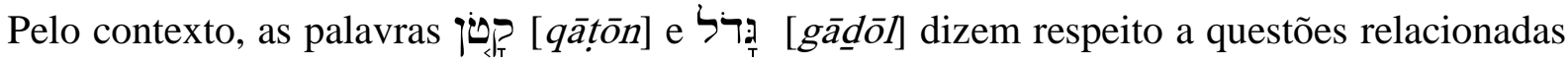
a influência, ou poder de influência, a presença ou a falta dela, e também a questão do poder econômico que poderia influenciar na decisão final do juiz. ${ }^{144}$ As razões para isso podem ser

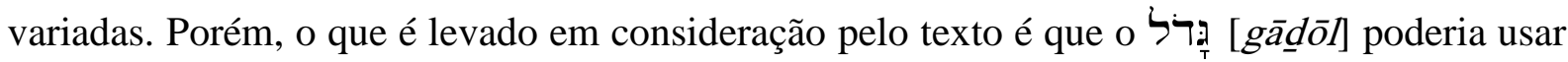
de sua capacidade de influenciar a justiça para ganhar uma causa sobre aquele que é

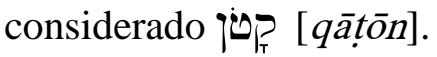

O peso da influência do gād $\bar{o} 1$ poderia afetar na decisão de quem estivesse julgando a questão entre os dois. Por outro lado, o qātōn, por ser qāṭōn, também poderia acionar uma espécie de solidariedade parcial daquele que tivesse a tarefa de julgar a questão entre os dois personagens. $^{145}$

\footnotetext{
${ }^{142} \mathrm{O}$ texto não está se referindo a um caso concreto, mas a um evento que pode acontecer - e já deveria ter acontecido - e, quando viesse a ocorrer, os que estavam na condição de julgar a questão deveriam saber como agir.

${ }^{143}$ Essa perícope, envolvendo o "grande" e o "pequeno", mostra um problema sério da perspectiva da ação imparcial na justiça. Essa ordem aponta na direção da forte pressão a que um juiz poderia sofrer para não ser imparcial. Portanto, mesmo que o mandamento de Deuteronômio 1,17 pudesse ser hipotético, a realidade de vida dentro das comunidades poderia apontar na direção de uma justiça que privilegiaria o "grande" em detrimento do "pequeno".

${ }^{144}$ Segundo HALOT, em Deuteronômio 1,16.17, encontra-se uma expressão de polarização (2001, v. 2, p. 1092, 1093), onde um ${ }^{0}$ está na justiça contra um construção que inclui tudo ("tanto grande como pequeno"), mas que a polarização existente busca mostrar que a justiça em Israel deveria agir sem levar em consideração a posição social de qualquer um dos lados do processo.

${ }^{145} \mathrm{Em}$ seu anseio por declarar sua inocência e afirmar que o que ele estava sofrendo não se motivou por algum delito cometido por ele, Jó se defende, entre outras formas, afirmando que ele jamais negou justiça aos seus próprios servos e servas: "Se recusei julgamento (justo) ao meu servo e a minha serva, na disputa deles comigo"

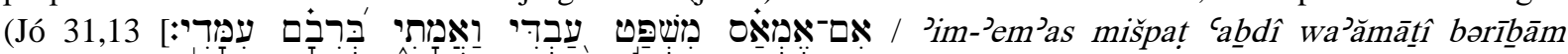

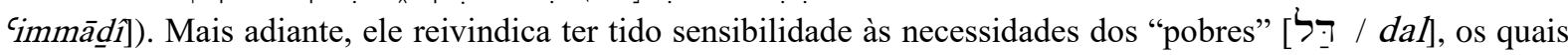


Qual o conceito de "justiça" em Deuteronômio 1,17? Basicamente, justiça tem a ver com julgamento de acordo com a Lei deuteronômica estabelecida para aquele tipo de litígio. Assim, o juiz que agisse com justiça estaria julgando o caso de acordo com a lei que ele conhecia. No caso em pauta, fazer justiça implica em julgar sem qualquer parcialidade. O juiz deveria evitar a tendência para o lado do "grande" por ser "influente" ou a inclinação para o lado do "pequeno" por ser "menos favorecido", e deveria ser feita levando-se em consideração o direito de cada um.

\subsubsection{Elementos filológicos}

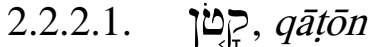

\subsection{A etimologia da palavra $\quad$ A}

A raiz v. 2, p. 795). Assim, o adjetivo qāțōn tem a ver com a ideia de "pequeno" e também com o sentido de "jovem", mas em determinados contextos, com o sentido de "insignificante" (TWOT, 1980, v. 2, p. 795) no aspecto socioeconômico. É nesse sentido que qātōnn é empregado em Deuteronômio 1,17.

Conrad afirma que as palavras que pertencem ao grupo qāțōn procedem "de uma raiz semítica comum [qtn] com o significado de ser estreito/apertado, ser fino/fraco" (CONRAD, 2004, p. 3). Esse sentido está em harmonia com a ideia de pequenez, pois a conotação negativa de "ser insignificante, ser fraco" é um uso "inerente ao grupo de palavras" qātōon (CONRAD, 2004, p. 4).

Partindo da perspectiva acima, o qātōon de Deuteronômio 1,17 é uma pessoa com dificuldades particulares para enfrentar alguém considerado gād $\bar{o} l$ pela justiça, a qual é convocada para dar uma decisão acerca de um conflito entre os dois. Assim, o termo qātōon é colocado como

são identificados por ele como sendo a viúva e o órfão (Jó 31,16.17.18). Além de chamar o órfão e a viúva de

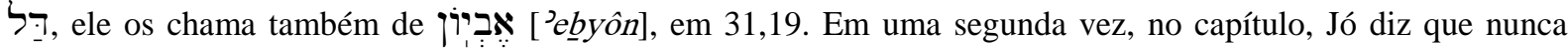
levou vantagem na justiça, mesmo que pudesse fazer por sua posição na comunidade $(31,21)$ : "Se eu empunhei minha mão contra o órfão, porque vi meu suporte no portão". "Portão" da cidade era o lugar onde se reunia o tribunal para fazer justiça [im-hănîpốtî cal-yātôm yādn $k \hat{\imath}$-'er'eh bašša'car 'ezrātin]. Mesmo Jó sendo um "grande", ele tomou a decisão de nunca abusar de sua posição contra um "pequeno". 
sinônimo da desvantagem que alguém poderia sofrer no tribunal, em conflito com um gād $\bar{d} 1$. A palavra carrega o conceito de um parecer frágil diante do outro.

A justiça imparcial seria a forma de contribuir para o equilíbrio entre os dois lados, fazendo com que o verdadeiro devedor assumisse a responsabilidade pelo que viesse a dever ao outro. A aplicação da justiça serve a estes dois propósitos: libertar aquele que deve ser liberto por causa de sua inocência; causar dano a quem deve ser penalizado.

\subsection{Comparação com o Targum}

A palavra encontrada no Targum NeofMagnalia para tradução de qātōon é זיעיר. O dicionário da BW7 dá como palavras para sua tradução "pequeno", “jovem”, "pouco em número". 146 O Aramaico favorece à idéia que o que está por trás da palavra זעיר o conceito relacionado a importância social dentro da comunidade. Isso é salientado quando se nota a palavra que traduz o Hebraico gādōl, "grande", para o Aramaico é רבר, segundo o dicionário da BW7, pode ser traduzido por "largo", "grande", "importante”, "chefe", "ancião". Com isso concorda o Glossário Aramaico-Português que a traduz por "grande", "chefe" (ARAÚJO, 2005, 313). A tradução para o Aramaico favorece a idéia de que a peleja judicial, apontada em Deuteronômio 1,17, ocorre entre alguém que é sem importância dentro da comunidade, um qātōon, e um líder, um chefe, alguém que goze de importância e respeito por sua posição, um gāâōl.

\subsection{Comparação com a Septuaginta}

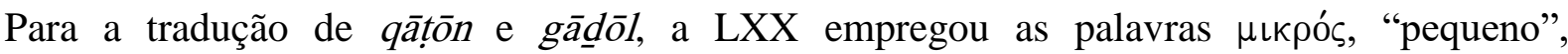

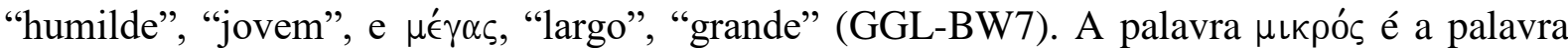
usual para traduzir qātōon, e como essa, ela também traz, entre outros conceitos, o de ser insignificante (MICHEL, 1967, p. 649). ${ }^{147}$ A palavra $\mu$ '́ $\gamma \alpha \varsigma$, por sua vez, apresenta seu sentido

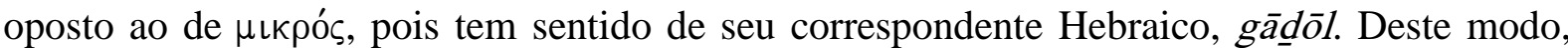

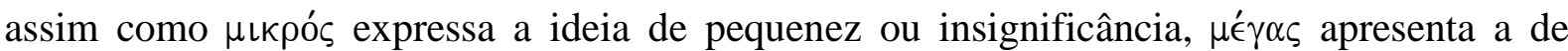
grandeza e significante (GRUNDMANN, 1967, p. 530).

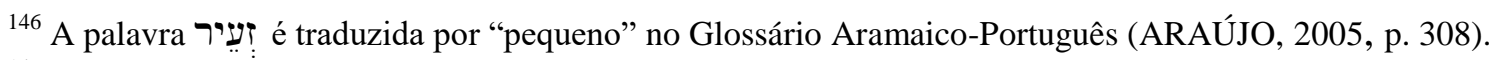

${ }^{147}$ Para alguns exemplos, Isaías 22,24; Zacarias 4,10.
} 
Tendo essa comparação em vista, deve-se concluir que o redator de Deuteronômio está fazendo um tipo de análise da importância das duas pessoas que estão trazendo uma questão

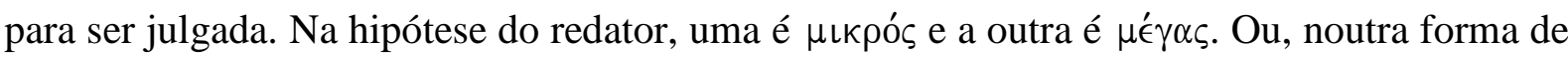

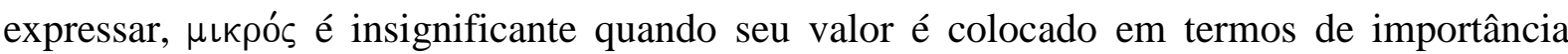
econômica dentro de sua comunidade, $\mu$ '́ $\gamma \alpha \varsigma$ é grande quando seu valor é posto pelo que ele representa economicamente para a mesma comunidade.

Assim, as traduções para o Aramaico e para o Grego, a Septuaginta, entenderam que as palavras qātōn e gād $\bar{c} l$ tratam, no texto de Deuteronômio $1,16.17$, das pessoas que são vistas pela sua importância econômica para as comunidades em que elas vivem. Numa linguagem comum, poderia se dizer que tinha posses e o outro não as tinha, e que dependia de uma justiça justa para dar a palavra final sobre a questão levada a juízo.

Agora, que palavra foi empregada para se referir a uma pessoa pobre dentro dos textos paralelos que tratam da mesma questão judicial, mas que estão nos livros de Levítico e Êxodo? A sequência desta pesquisa procurará responder a essa pergunta.

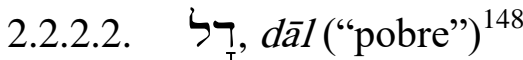

A palavra דָרל $(d \bar{a} I)$ aparece aqui porque ela surge em textos paralelos, os quais tratam da mesma legislação de Deuteronômio 1,17, no lugar de qātōn. Tais textos serão adiante analisados no capítulo. Porém, apenas para mencioná-los inicialmente, eles são Êxodo 23,2.3 e Levítico 19,15.

\subsection{A etimologia da palavra $\quad$ ר}

A raiz $d l(l)$, Hebraico $d l l \mathrm{I},{ }^{149}$ tem ocorrências em línguas semíticas orientais, tais como o Assírio Antigo com o substantivo dullu ("tribulação, miséria"), o Babilônio tardio dullulu (“opressão, oprimido"). No Cananita há o Ugarítico $d l$ e $d l l$, e o Hebraico $d l$, "pobre, necessitado" (FABRY, 1978, p. 208-209), para citar alguns exemplos a fim de notar que a raiz

\footnotetext{
${ }^{148}$ É uma palavra que designa alguém que seja considerado "inferior", "pobre", Gênesis 41,19; "desamparado", Êxodo 30,15; "impotente", Êxodo 23,3; e "insignificante", Jeremias 5,4 (HALOT, 2001, v. 1, p. 221, 222). Esses significados, os quais levaram a diferentes modos de tradução da palavra דָ , mostram que a importância de seu tratamento está em que ela apresenta sentidos que cobrem os mesmos significados das palavras para pobre encontradas em Deuteronômio.

${ }^{149}$ Fabry (1978, p. 208-209) aponta que deve ser feita a distinção entre a raiz dll I e as raízes $d l l$ II ("oscilar", em Jó 28,4), dll III (“louvar"), dlh I (“tirar"), e dlh II (“oscilar”).
} 
$d l$ ou $d l l$ tem a ver com limitações econômicas que alguém experimenta em um momento de sua vida. Provavelmente por isso a palavra $d \bar{a} l$ tenha sido empregada nos textos paralelos a Deuteronômio 1,17, em Êxodo 23,2.3 e Levítico 19,15, como forma de reafirmar que a parcialidade é proibida, mesmo que ela venha a favorecer alguém que enfrente dificuldades em sua vida.

Das quarenta e oito vezes que ela ocorre na BH (EVEN-SHOSHAN, 1989, p. 265), ela está presente no Pentateuco em Gênesis, Êxodo e Levítico, mas não em Deuteronômio e Números. Assim, aquilo que é dito em Deuteronômio de forma geral com qātōon é definido em Êxodo e Levítico com a palavra $d \bar{a} l$.

\subsection{Comparação com o Targum}

O Targum Neofiti traduz a palavra dāl por מסכן, "homem pobre" (HHL-BW7), em Exxodo 23,2.3 e Levítico 19,15, fazendo com que dāl tenha o mesmo significado que o ’ebyôn e o $\varsigma_{\bar{a} n} \hat{n}$, na sua tradução para Aramaico, pois essa palavra também é empregada para traduzir o ’ebyyôn e o 'ānî. Desse modo, o redator do Deuteronômio preferiu usar palavras que tenham o mesmo significado que $d \bar{a} l$ para designar um "homem pobre" dentro da comunidade dirigida pela legislação de Deuteronômio. Isso faz com que 'ebyôn, 'ānî e dāl tenham o mesmo campo semântico.

\subsection{Comparação com a Septuaginta}

$\mathrm{Na}$ pesquisa comparativa com o grego da Septuaginta, constata-se que seus tradutores empregaram os termos $\pi \epsilon ́ \nu \eta \zeta$, "pessoa pobre", para traduzir o termo Hebraico dāl para o

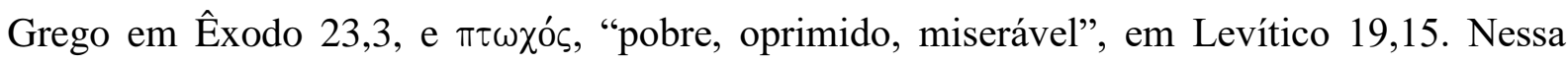
comparação, a palavra $\pi \tau \omega \chi o ́ \varsigma$ não aparece como uma forma de tradução para os vocábulos ’ebyyôn e cānî em Deuteronômio, acrescentando uma nova coloração ao conceito dos Entes

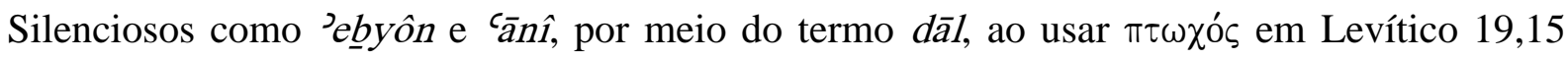
para a tradução da Septuaginta, deixando o dāl com o sentido de alguém sob opressão, como o ‘̄annî.

Entretanto, deve-se destacar que, enquanto מסכן traduz tanto ’ebyôn como ‘ānî para o

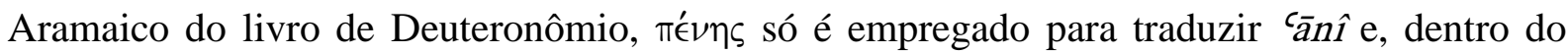




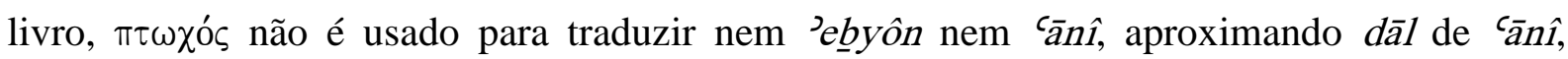
principalmente por enfatizar o aspecto do sofrimento que tanto o dāl quanto o ‘̄anî salientam, fazendo com que a desvantagem do qātōn diante do gād̄ōl exigisse dos juízes a estrita obediência à ordem de serem imparciais no julgamento entre os dois, pois um erro da justiça traria mais sofrimento a quem já desfrutava dele. ${ }^{150}$

\subsubsection{Análise do texto de Deuteronômio $1,17^{151}$}

\subsubsection{Tradução de Deuteronômio $1,16.17$ e dos textos paralelos em Êxodo} 23,2.3 e Levítico 19,15

Deuteronômio 1,16 - "E eu ordenei os vossos juízes, ${ }^{152}$ naquele tempo, dizendo: ${ }^{153}$ Ouvi ${ }^{154}$ entre vossos irmãos e, então, fareis justiça entre um homem e entre seu irmão ${ }^{155}$ e entre $^{156}$ seu $^{157}$ estrangeiro ${ }^{158}$.,159

\footnotetext{
${ }^{150}$ Schwantes destaca o sentido de fragilidade para $d \bar{l} l$ ao colocar os sentidos de "fraco", "pequeno", "pouco" (2013, p. 24). É uma palavra que aparece em paralelo com dois outros Entes Silenciosos - o órfão (Isaías 10,2) e a viúva (Isaías 10,2).

${ }^{151}$ Num texto paralelo a Deuteronômio 1,17, Levítico 19,15, aparece $d \bar{a} l$, "pobre", no lugar de jự, "pequeno", sugerindo, com isso, que a palavra ${ }_{i \in f}$ representa alguém que seja um dāl, na perspectiva do redator de Deuteronômio. Mostrando que a legislação do livro de Deuteronômio tem por base uma legislação mais antiga, como aquela encontrada no livro de Levítico. Ou, por outro lado, a legislação em Levítico, resolveu pôr de forma específica àquilo que o redator do Deuteronômio entendia por qătōn. Para o redator de Levítico, o qățōn de Deuteronômio era, na realidade, um homem dāl, um homem "pobre".

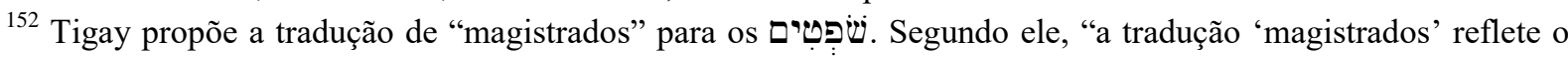
ponto de vista que a raiz שפט se refere a todo tipo de autoridade governamental, executivo, legislativo bem como judicial" (1996, p. 12). Ele acentua, porém, que na BH, o substantivo em seu sentido amplo "parece ser limitado a reis e líderes militares nacionais", como no livro de juízes $(1996$, p. 12). Nos textos claros, onde outros tipos de oficiais são referidos, o significado de "juiz" é melhor, como em Deuteronômio 1,16 (1996, p.
} 12).

${ }^{153}$ A construção gramatical é muito comum em narrativa, principalmente no Pentateuco: $ל$ - a preposição

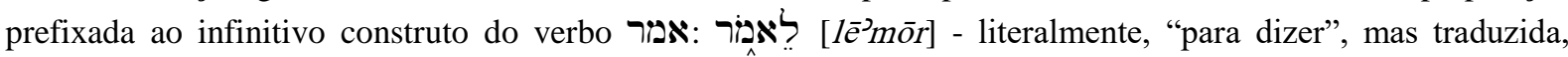
comumente, por "dizendo". "Dizendo", mesmo que adequada para a tradução de $1 \bar{e}$ 'mōr , encobre a ideia de propósito que lēemōr carrega: "Eu ordenei (...) com o fim de dizer".

${ }^{154}$ Aqui se encontra outro infinitivo, só que desta vez é o absoluto do verbo שמע, "ouvir". Aqui ele é usado

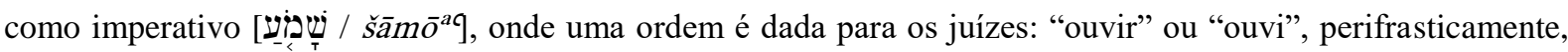
"deveis ouvir". Para Ezra, šămōac é "um substantivo verbal, como 'relembrar" [זְָ / zākar] (2003, p. 4). Assim, a ordem é para os juízes relembrarem o que eles já tinham ouvido e colocarem em prática no eventual julgamento.

${ }^{155}$ Dentro de Deuteronômio, אָ é empregado "para enfatizar a igualdade e fraternidade de todos os israelitas, seja rei ou servo, profeta ou sacerdote" (TIGAY, 1996, p. 12). Notar Deuteronômio 15,2; 17,15.20; 18,2.15.18; $22,1-4$.

${ }^{156}$ Deve ser notada a repetição da preposição (construto) / בּבין (absoluto), "entre", antes de cada uma das

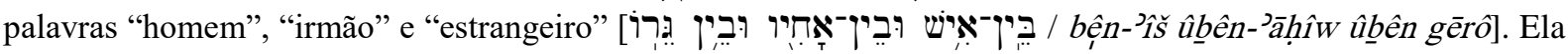

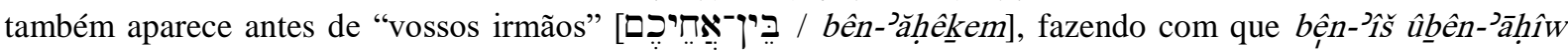
ûbên gêrô seja uma especificação do que o redator quer dizer por "vossos irmãos", colocando este tipo de 


\section{Deuteronômio 1,17 - "Não reconhecereis ${ }^{160}$ uma face no julgamento. Ouvireis tanto do pequeno ${ }^{161}$ quanto do grande. ${ }^{162}$ Não tereis medo ${ }^{163}$ da face de um

\author{
homem, ${ }^{164}$ porque o julgamento é para ${ }^{165}$ o próprio Deus. E a palavra ${ }^{166}$ \\ que é pesada ${ }^{167}$ para vós trareis perto, para mim, e eu a ouvirei."168
}

estrangeiro, o gēr, como parte do "vossos irmãos", como um estrangeiro residente e adaptado aos costumes do povo no meio do qual ele vive.

157 "Implica que o gēr foi, ao menos em alguns casos, dependente de um indivíduo específico" (TIGAY, 1996, p. 13).

${ }^{158}$ Primeira referência ao 7 : $[g \bar{e} \bar{r}]$ dentro de Deuteronômio.

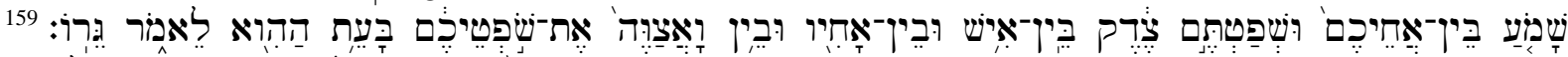

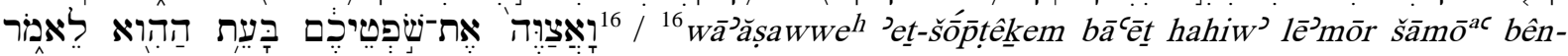

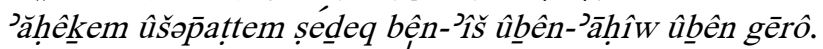

${ }^{160}$ Aqui há um verbo hifil com uma negativa proibindo qualquer começo na direção de uma decisão judicial

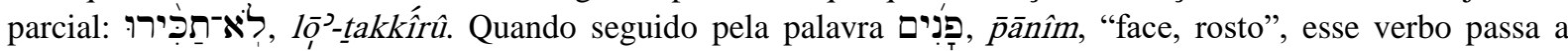
comunicar a ideia de "mostrar consideração, no sentido de parcialidade por alguém" (HHL-BW7), e como exemplo é citado Deuteronômio 1,17. Para Ezra, o verbo "aponta para o julgamento em relação à pessoa a quem ele (o juiz) reconhece" (2003, p. 4), com a ideia de favorecer o conhecido.

${ }^{161}$ É provável que Deuteronômio não empregasse a palavra dāl, como fizera Levítico e Êxodo, em lugar de $q \bar{a} t \bar{t} \bar{n}$ para que outros Entes Silenciosos pudessem ser incluídos no qāt tōn.

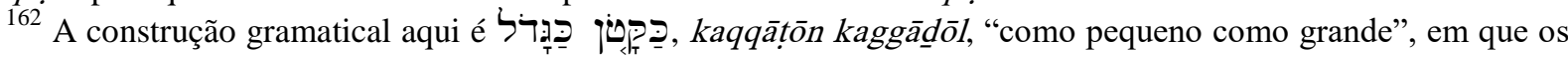

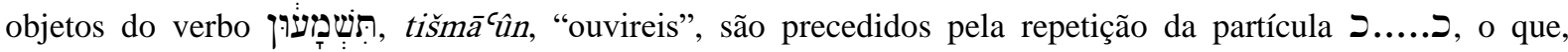
segundo o BDB, é peculiar ao hebraico "para significar inteireza de correspondência entre dois objetos" (1979, p. 454). A implicação disso é que os juízes de Israel, segundo essa legislação, deveriam dar completa atenção tanto a um quanto a outro, independentemente de sua posição social dentro da comunidade. Notar que os objetos vêm em posição de ênfase no texto. Para Chouraqui, "a ideia é que os atos devem ser julgados de maneira objetiva" (1997, p. 35).

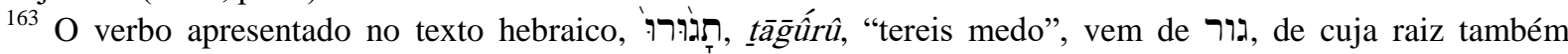
procede a palavra רִִּ "estrangeiro". Entretanto, Kirst et al. (1987, p. 39-40) apresenta três raízes verbais com a mesma forma de escrita, mas com significado diferente uma da outra. São elas: I, "morar ou viver como estrangeiro/forasteiro/cliente, demorar-se como forasteiro"; גור II, "hostilizar/atacar"; גור III, "ter medo". Como no caso da raiz ענה, notada antes, aqui também temos o que é chamado de raízes homônimas.

${ }^{164} \mathrm{~A}$ frase

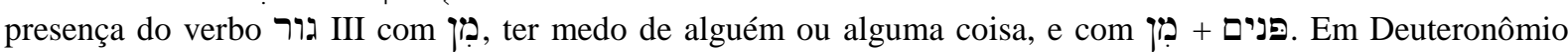

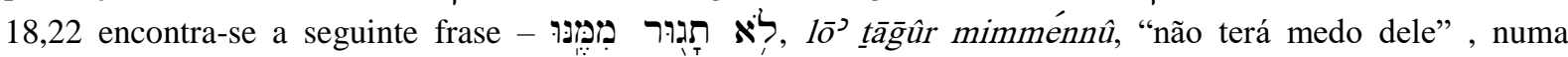
referência a um tipo de profeta que não devia ser temido pelo povo. Em Números 22,3 é dito que Moabe tinha

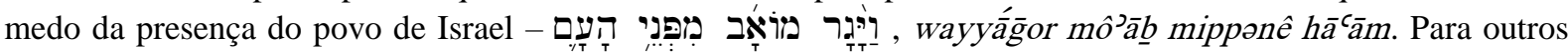
exemplos notar: STIGERS, 1980, p. 156-157.

165 A preposição $ל$ pode ser entendida tanto como "para" como "de". Pela tradução desta pesquisa, foi-se entendido que ela aponta numa direção - "para Deus". Porém, ela também pode ser entendida como de procedência, "de". Assim, o julgamento corretamente realizado chegaria a uma decisão que seria entendida como sendo do próprio Deus. Tanto um como outro são possíveis. A primeira coloca Deus como o alvo maior para um julgamento bem feito - no final, os juízes julgam para (ou em lugar de) Deus. A segunda coloca a decisão dos juízes em um julgamento bem feito como sendo uma resposta divina ao caso. Assim, porque fazer um julgamento justo? Porque ele é feito para Deus, ou, porque ele vem de Deus.

${ }_{166}$ Weinfeld faz citação a um rei hitita que deu ordens a seus oficiais semelhantes às de Moises dadas em Deuteronômio 1,17. Tal rei disse: "Se alguém traz ação judicial... o comandante a julgará adequadamente... se o caso for tão grande [= difícil], ele deverá encaminhá-lo para o rei. Ele não deve decidi-lo em favor de um superior... ninguém deve tomar suborno... faça tudo àquilo que é reto" (von Schuler, 1957, p. 36s Apud 1991, 140-141). 
Êxodo $23,2^{169}$

"Não estarás ${ }^{170}$ atrás de muitos para (fazer) males. ${ }^{171}$ E não responderás sobre uma disputa ${ }^{172}$ para (te) inclinar atrás de muitos para distorcer (perverter) (uma decisão da corte) ${ }^{173}$."174

Êxodo 23,3

"E o pobre ${ }^{175}$ não tratarás com distinção na sua disputa."176

Levítico 19,15

\author{
"Não farás injustiça ${ }^{177}$ no julgamento. Não levantarás a face do pobre ${ }^{178}$ \\ e não honrarás a face do grande. ${ }^{179}$ Julgarás com justiça teu \\ companheiro." 180
}

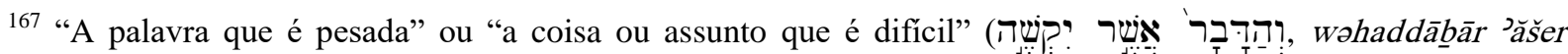
yiqš ${ }^{h}$ ). Provavelmente seja uma referência a um problema de difícil solução para os juízes e que precisavam da interferência de um com maior capacidade de decisão. Ou, por outro lado, a lei não era conhecida e precisava da consulta de Moisés a Deus para que fosse conhecida (TIGAY, 1996, p. 13). Há exemplos desse tipo de consulta em Levítico 24,10-23; Números 9,1-14; 15,32-36; 27,1-11; 36,1-10. A brevidade do texto, o fato que a narrativa é um resumo da existente em Êxodo, e que o povo está sendo preparado para ingressar na Terra da Promessa tenham feito com que Moisés omita a necessidade de consultar Deus. Além disso, Deuteronômio não prevê a vinda de um profeta com novas leis (TIGAY, 1996, 13). Cairns propõe que "a palavra que é pesada" significa o que ainda não tem decisão anterior para ajudar o juiz na condução do julgamento (1992, p. 34, 35).

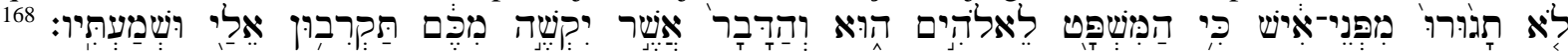

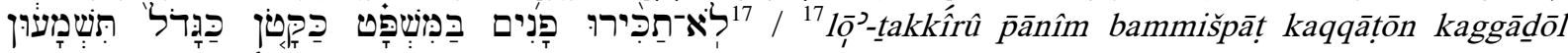

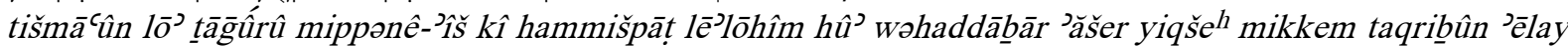
ûšomactîw.

${ }^{169}$ Êxodo 23,1-3 estabelece cinco proibições para o comportamento no tribunal com o fim de impedir o perigo para a imparcialidade e a integridade do processo judicial (SARNA, 1991, p. 142).

${ }^{170}$ A BJ traduz essa frase inicial assim: "Não tomarás o partido da maioria para fazeres mal". Essa parece ser mais uma interpretação que uma tradução. O ATP, usando da versão da SBB, traduziu-a por: "Não seguirás a multidão para fazeres mal". O verbo inicial do versículo é o verbo היה, "ser ou estar". É um verbo estativo que aponta um estado ou uma condição. A negativa לאל, "não", proíbe de forma veemente a participação em um estado ou condição de violência coletiva contra alguém.

${ }^{171}$ Essa declaração inicial é uma afirmação geral. O "mal" (ou "males" [רעית é plural de) será especificado a seguir, quando a figura de um tribunal é evocada e uma multidão (ou "muitos") já tomou uma direção na tentativa de influenciar os juízes e as testemunhas. Os "males" têm três aspectos. O primeiro é que os que compõem o "muitos" [רברבים], pela força numérica que representam, tentam influenciar a decisão do juiz. $\mathrm{O}$ segundo é que a decisão do "muitos" foi tomada sem ouvir os dois lados da questão. O terceiro e, talvez o mais importante, é que a decisão que o "muitos" tenta influenciar não é uma decisão divina porque ela carece de fundamento das evidências adquiridas na investigação dos juízes.

${ }^{172}$ A palavra traduzida nesses dois versículos por "disputa” é ריב. Ela aponta para uma contenda legal diante de um tribunal constituído para decidir uma questão entre partes (KIRST et al., 1987, p. 227).

${ }^{173}$ Os verbos "inclinar" e "distorcer" são traduções da mesma raiz, נטה, sendo que o primeiro é um infinitivo construto qal e o segundo é um infinitivo construto hifil (KIRST et al., 1987, p. 155).

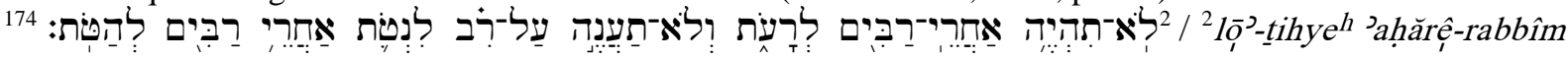

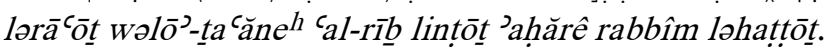

175 "Pobre" aqui é tradução da palavra hebraica dāl.

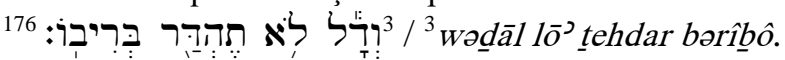

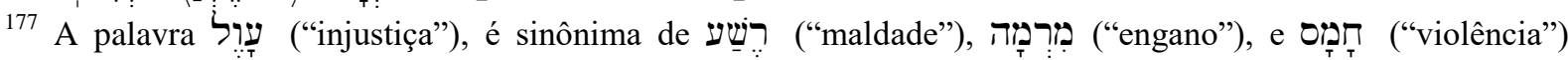
(LEVINE, 1989, p. 128).

${ }^{178}$ A parcialidade no julgamento foi expressamente proibida. O juiz não poderia beneficiar o pobre [ $[\bar{d} \bar{a}]$, nem o gādōol (Êxodo 23,3). A justiça não deveria pender nem para um lado nem para o outro. 


\subsubsection{Análise dos textos}

\subsection{O contexto de Deuteronômio $1,16.17^{181}$}

Deuteronômio $1,16.17$ pertence a uma unidade literária maior que começa no versículo 9 e termina no versículo 18. Deuteronômio 1,9-18 é chamado por Weinfeld de "perícope de natureza intrusiva" $(1991,139)$, usada aqui para quebrar a sequência da narrativa da jornada

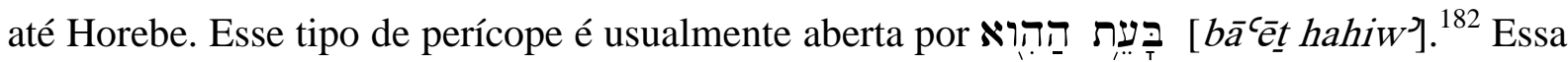
fórmula de abertura, comum em Deuteronômio 1 a 11, ocorre três vezes nessa perícope intrusiva. Na primeira vez (1,9-15), está a indicação dos juízes, na segunda $(1,16.17)$, há as instruções sobre como deve se tratar um processo judicial entre um "grande " e um “pequeno”, e, por fim, uma palavra de instrução ao povo (WEINFELD, 1991, p. 139).

Esse bloco de literatura está inserido dentro daquilo que é considerado o primeiro discurso atribuído, pelos redatores, a Moisés. Esta unidade literária maior do Deuteronômio vai do capítulo 1,5 ao capítulo 4. Há a recapitulação de muitos eventos dentro da história de Israel, apresentada em forma de discurso, como um sermão exortativo, tem como propósito estabelecer uma espécie de introdução a todo o livro.

É dentro desse bloco literário que se encontra uma palavra do redator para aqueles que haveriam de exercer um julgamento entre pessoas da comunidade. $\mathrm{O}$ contexto imediato do texto (Deuteronômio 1,12-16, 18) aborda a questão de escolha daqueles que seriam os líderes da comunidade e que teriam, como parte das suas funções, o dever de exercer a posição de juízes. ${ }^{183}$

\footnotetext{
${ }^{179}$ Para Levine, o contexto favorece a tradução de גָדוֹל por por "rico", pois a palavra está em contraste com דָָל cujo sentido é "alguém com falta de recursos, pobre" (1989, p. 129).

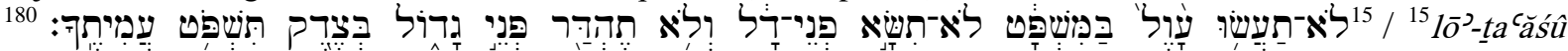

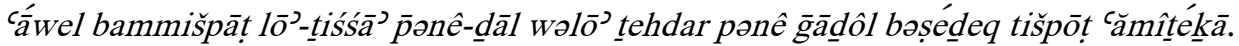

${ }^{181}$ Deuteronômio 16,19 apresenta um mandamento similar aos encontrados nos textos de Deuteronômio 1, Êxodo 23 e Levítico 19, mas sem especificar uma pessoa pobre. Parece ser de aplicação geral a qualquer pessoa, pobre ou não, que procure os juízes para resolver uma questão com próximo: "Não torcerás um julgamento, não considerarás uma face e não tomarás um suborno. Porque o suborno cega (apaga) os olhos dos sábios e perverte

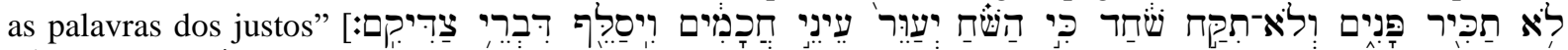

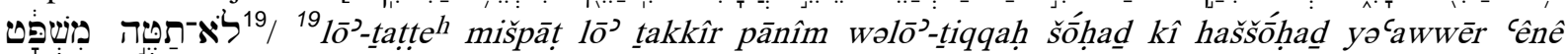
hăăkāmîm wî̀sallēp̄ dibrê ṣaddîqīm].

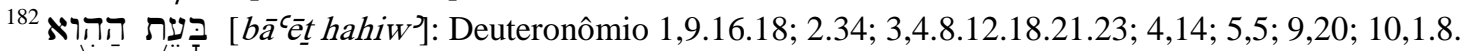

${ }^{183}$ A estela de Horemheb (XIV AEC), um documento egípcio que apresenta instruções para a constituição de juízes: "Eu excursionei pelo país... eu procurei pessoas de integridade, boas de caráter, que saibam como julgar... $\mathrm{Eu}$ as tenho instruído, dizendo: Não se associem intimamente com outro povo, não recebem suborno" (WEINFELD, 1991, p. 141, Apud HELCK 1955, p. 107s.).
} 
Esse contexto mostra que eles foram instruídos a fazer julgamentos sem parcialidade. Provavelmente isso era parte da cerimônia de posse quando o orador colocava, de forma pública, como os juízes deveriam agir no julgamento, e, com isso, destacavam que, mesmo em situações muito difíceis, eles deveriam manter a atitude de juízes divinamente encarregados daquela posição diante do povo.

Deuteronômio 1,16 coloca de forma específica que a situação colocada diante do tribunal da comunidade poderia ser "entre um homem e seu irmão ou o estrangeiro [gēr] que mora com ele” (BJ). O gēr já se identifica com alguém que não é da própria comunidade. Mas, quem é o "homem" e o teu "irmão"? Para esta pesquisa, "homem" aponta para alguém que está na posição de alguém que desfruta de liberdade e que pode ser identificado com o gādōl. A

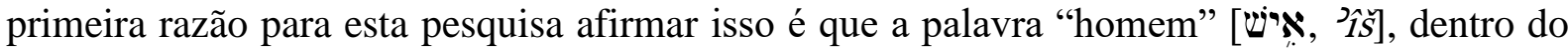
livro de Deuteronômio, comumente aponta para uma pessoa que é livre e está no usufruto desta liberdade. ${ }^{184}$

A segunda razão é a própria construção da frase no versículo 16. Numa tradução mais literal, a última colocação diz: "entre um homem e entre seu irmão e entre seu estrangeiro". Isso quer dizer que o problema seria de um 'îš com seu "irmão" e (ou) com o seu gēr. Mas o gēr de quem? Do 'ר̂š ou do seu irmão? Para o texto é o gēr do ’ȟs̆, de quem são dependentes o "seu irmão" e o gēr, acolhido sob a proteção do 'ר̂̆

Assim, tanto "irmão" quanto o gēr estão para aqueles que desfrutam de desvantagem social. Eles são os dependentes do '̂ि̌̆, o homem livre e proprietário de terras. ${ }^{185}$ Nesse caso, eles, “seu irmão e o gēr", são identificados pela palavra qātōnn no versículo seguinte.

${ }^{184}$ Notar Deuteronômio 1,16.23.31; 4,3; 8,5; 17,2.5.12; 20,5.6.7.8; 21.15.22; 22,13.16.18.22 23.24.25.26.28.29; 23,$1 ; 24,1.2 .3 .5 .11 ; 25,7.9 ; 27,15 ; 28,30.54 .56 ; 29,19 ; 32,25 ; 33,1.8$. Em dois lugares, onde a palavra "estrangeiro" faz a qualificação da palavra 'î̌s, merece destaque: em 17,15, quando da escolha do rei, é dito que ele não pode ser um homem estrangeiro [ ' $1 \hat{s}$ noknrî]; em 25,5 a mulher de um falecido, tendo ele irmão, é proibida de se casar com alguém fora do clã; aqui esse homem fora do clã, ou de outro clã, é chamado de "homem estranho" [ [ 'î̌s $z \bar{a} r$ ]. O "homem $z \bar{a} r$ " [רזָ] é usado para um homem fora da família de Arão (Êxodo 29,32.33; 30,33; Levítico 22,10), para um não levita (Números 1,52) e para o "fogo estranho" [ '’ēš zārāh] que Nadabe e Abiú ofereceram em Levítico 10,1, culminando em suas mortes prematuras. No Salmo 81,9 (BH 81,10) zār está em paralelo com nēkār. As duas são traduzidas por "estranho" ou "estrangeiro": "Não haja em ti deus estranho e

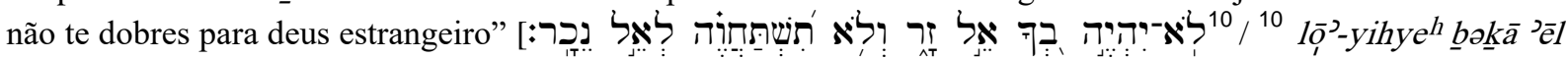

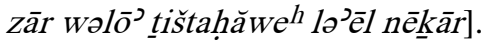

${ }^{185} \mathrm{O}$ que se pode dizer é que a "sociedade deuteronômica" apresentava os seguintes estratos sociais: o homem livre ( 'î̌s - e com condições de manter essa liberdade, a mulher livre, mas dependente e sob a proteção do $3 \hat{i} \check{S}$, os 


\subsubsection{2. $\quad$ O texto próprio: os juízes instruídos}

\subsection{Uma observação inicial}

O problema levantado dentro de Deuteronômio 1,16.17 não representa um caso real, mas uma situação que poderia acontecer e, provavelmente, deve ter acontecido muitas vezes no decorrer da história do povo de Israel. Desse modo, o redator se antecipa apresentando uma situação e dando a solução para ela. Leibowitz chama atenção para o emprego do infinitivo

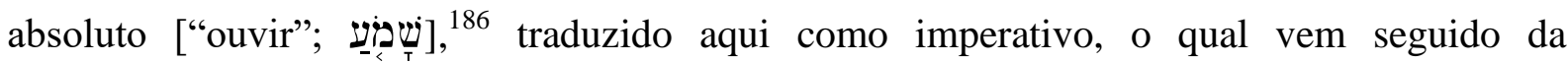

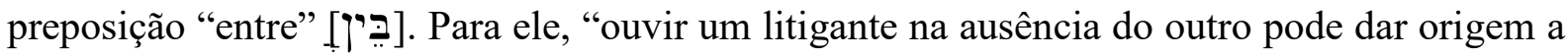
parcialidade, pois um não pode corrigir a impressão deixada por outro. Mas se os dois estão presentes ainda há o perigo a ser evitado no interesse da justiça" $\left(1995\right.$, p. 10). ${ }^{187}$

\subsection{Elementos na análise do texto}

O primeiro elemento a considerar nesse versículo é que ele começa com um advérbio de negação seguido de um imperfectivo. Nesse caso, o orador estaria proibindo uma ação antes que ela começasse: "Não reconhecereis uma face".

Face é representativo daquilo que a pessoa é externamente do ponto de vista do que vê. Por isso, a proibição impede o juiz de ser tendencioso numa decisão apenas pela questão da aparência de um em detrimento de outro. Face parece ser representativo daquilo que a pessoa era ou do que ela representava. E qual a aparência dos envolvidos que o juiz do caso estaria vendo? Que um era qāțōn e o outro gād̄ol. Essa visão limitada poderia ser a base de decisão de um juiz. Ele poderia preferir um ao outro e fazer uma decisão judicial equivocada.

Um segundo elemento é o contexto do qual o juiz faria parte e onde não deveria haver consideração do que uma pessoa era ou representasse. O contexto é “no julgamento", onde o artigo e a preposição fazem com que mišpāt pareça ser o lugar onde as decisões judiciais

\footnotetext{
Entes Silenciosos livres, mas com liberdade relativa por causa de sua condição de dependência do $\hat{1} s ̌$ ( 'ebyyôn e

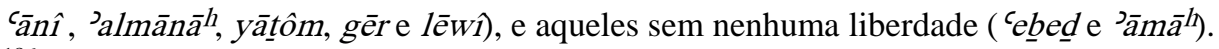

${ }^{186} \mathrm{O}$ uso do infinitivo absoluto aqui é chamado de uso independente. "Esse uso parece ter o propósito de atrair a atenção ao significado básico do verbo", deixando para o contexto a definição de como ele deve ser traduzido (ROSS, 2001, p. 175). Lambdin diz que "o infinitivo absoluto é usado no lugar de um verbo finito, sem ser claramente dependente de outro verbo na oração" (2003, p. 199).

187 "Certamente que, sem ouvi-los, não pode haver um caso. Por que foi usada a forma infinitiva incomum šămo $\bar{o}^{a c}$ em lugar do imperativo šimu ${ }^{\complement}$ ? A implicação a ser tirada é que os juízes devem ser pacientes e ouvi-los" (ha-Hayyim apud LEIBOWITZ, 1995, p. 10).
} 


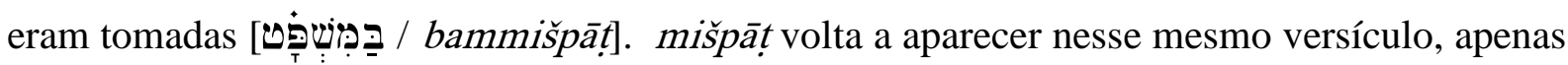
com o artigo definido, hammišpạt. Antes, no versículo 16, aparece outra palavra ligada ao assunto de um tratamento judicial, "justiça” [ק sֶ / ṣédeq].

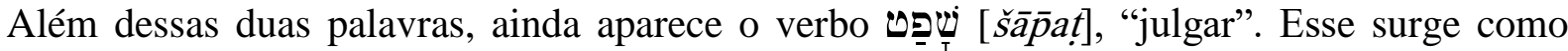
particípio no versículo 16 para se referir aos juízes. Os juízes são denominados como "aqueles

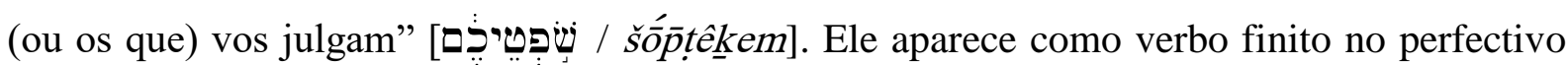

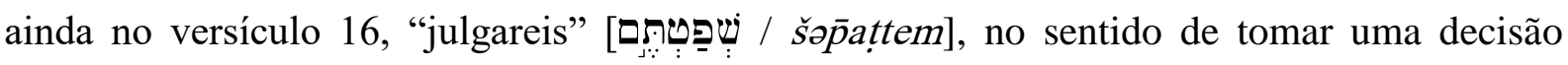
justa, haja vista que vem seguido da palavra șédeq.

A pergunta que se faz é: o que essas palavras têm a ver com um tribunal e as decisões judiciais que ali seriam tomadas? Qual a importância delas aqui e para o livro inteiro de Deuteronômio?

Em primeiro lugar, a construção gramatical apresenta cada palavra como sendo uma caracterização do processo judicial que está em curso entre o qāțōn e o gād $\bar{o} l$. O primeiro elemento deste processo judicial é os šóptînm - esses são aqueles que julgam ou agem como juízes. Eles já foram apontados pelo povo para essa posição, sendo que eles deveriam apresentar determinadas características apropriadas para que pudessem ocupar posição de um juiz.

Deuteronômio 1,13 diz que os šô̄tînm deveriam ser, segundo a tradução da BJ, "sábios"

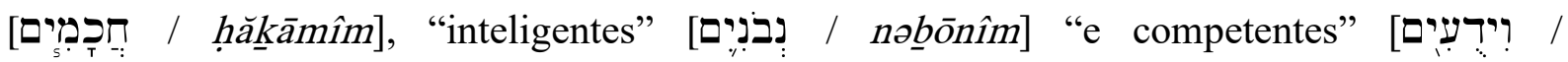

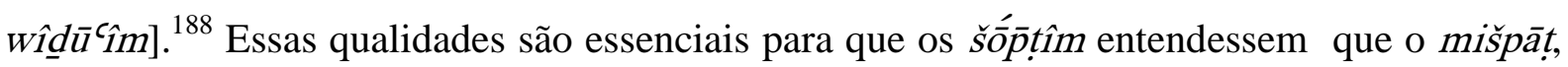
sentença ou julgamento, era de (ou para) Deus. Qualidades que deveriam demonstrar sua

\footnotetext{
${ }^{188}$ Das três palavras que deveriam caracterizar os $\check{s} \overline{\bar{o}} \bar{p} t \hat{m} m$, duas são particípios usados como adjetivos e uma é

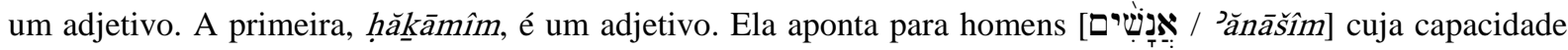
de julgamento, ou a sabedoria para tal juízo, foi adquirida pela experiência. A segunda, nobōnnîm, é um nifal particípio do verbo בין, "entender", o qual põe em destaque a capacidade de discernimento dos šố̄tînm. Poderse-ia dizer que essa característica completa a primeira. Aqueles que são ḥăkāmî̀m aprenderam pela experiência

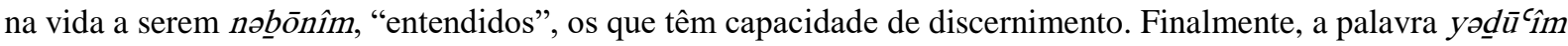
é um qal particípio passivo de ידע, "saber, conhecer". Como perífrase, este particípio passivo poderia ser traduzido assim: "aqueles que têm tido saber (sabedoria)/conhecer (conhecimento)". Entretanto, essa última palavra é traduzida pela Torá por "conhecidos", tanto no v. 13 quanto no 15. A Torá entendeu que as pessoas escolhidas eram do conhecimento daqueles que as escolheriam. Isso não está em discordância com o modo como a palavra foi entendida nesta pesquisa. Ao contrário, eles escolheriam os "conhecidos" porque sabiam de sua competência para participar no tribunal da comunidade. Os escolhidos eram pessoas que tinham saber para julgar, e a comunidade os conhecia como pessoas que detinham tal saber.
} 
primária devoção ao Deus de Israel. Assim, os š́̄̄ṭ̂tm deveriam ser vistos como representantes divinos na decisão que tomavam. A decisão deles seria considerada como se fosse a decisão que o próprio Deus de Israel tomaria.

Em segundo lugar, como segundo elemento do processo de julgamento está o verbo

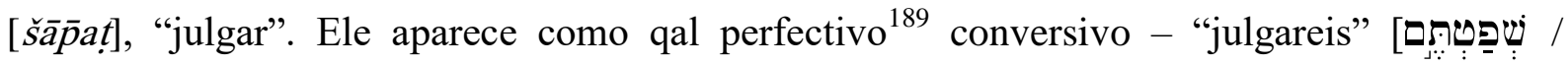
šəpattem], no versículo 16. O verbo aponta não somente para o processo todo, mas, principalmente, para a decisão a ser tomada. Por isso ele aponta não somente para aquele que está agindo como juiz, mas também para aquele que, como juiz, está tomando uma decisão.

Daí se entende, em terceiro lugar, porque ele vem sucedido do terceiro elemento de todo esse processo judicial, o ${ }^{190}$ sédeq, “a justiça”. Como substantivo masculino, ele fala daquilo que é certo. Assim, tomar a decisão correta é decidir șédeq - é fazer justiça. Com o ṣédeq feito, aquele a quem o sédeq foi feito obteve sucesso, ou justiça [ṣédeq], ${ }^{191}$ no julgamento [מִ mišspāt].

Em quarto lugar, o último elemento desse processo judicial é mišpāt. Essa palavra aparece

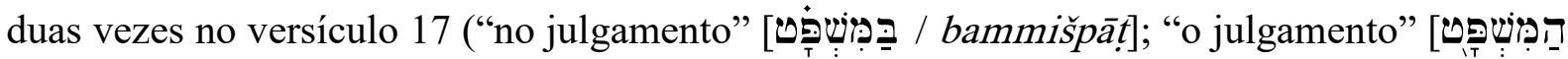
/ hammišspăt]). Ela tem formas de tradução diferentes, dependendo da versão: A ARA traduz as duas ocorrências assim - "no juízo" e "o juízo"; a BJ - "no julgamento" e "o julgamento"; a BP - "na sentença" e "a sentença".

Olhando os modos de tradução apresentados acima, "Não reconhecereis uma face no julgamento. Ouvireis tanto do pequeno quanto do grande. Não tereis medo da face de um homem, porque o julgamento é para o próprio Deus...", nota-se que a primeira ocorrência de mišpāt pode corretamente ser traduzida por "julgamento", entendendo que a palavra acentua o processo judicial em desenvolvimento naquele tribunal, principalmente que a palavra aparece seguida de uma proibição para que a pessoa não tenha o reconhecimento como base para se dar uma sentença no processo judicial [bammišpāt]

\footnotetext{
${ }^{189}$ Nomenclatura sugerida pelo orientador para a ação completa do verbo hebraico.

${ }^{190}$ O emprego do artigo masculino "o" aqui é porque sédeq é substantivo masculino, "o que é correto, normal;

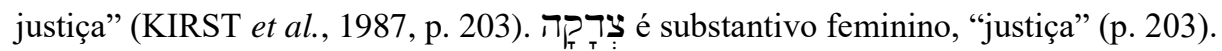

${ }^{191}$ Outro significado para ṣédeq (KIRST et al., 1987, p. 203).
} 
Aqui ela se aproxima mais do sentido pretendido pela BJ, "julgamento" e pela tradução seguida pela ARA, “juízo”. Nesse contexto de um processo judicial em desenvolvimento pode também ser entendido pela preposição $\beth$ e o artigo $\boldsymbol{n}$ prefixados à palavra mišpa ạt. A preposição ב pode ser traduzida por "em, dentro de" e também por "em meio de, entre" (KIRST et al., 1987, p. 21).

Essa forma de traduzir a preposição aponta para o contexto em que o processo está sendo desenvolvido. Além da preposição, o verbo "ouvir" na frase seguinte, "Ouvireis tanto do pequeno quanto do grande", aponta para um procedimento que deve ser desenvolvido para que a decisão final no processo judicial, bammišpāt, seja acertada, no sentido de decisão correta por respeitar os direitos de cada uma das partes.

Na segunda ocorrência da palavra em Deuteronômio 1,17, ela tem mais o sentido de "sentença". ${ }^{192}$ Assim, hammišpāt mira, não o processo judicial em desenvolvimento, mas o resultado daquele processo - a sentença que vai condenar um e libertar o outro. Esse sentido é favorecido pelo próprio texto. ${ }^{193}$

Há também o motivo teológico para que a sentença, ou hammišpāt, não fosse imparcial: “porque o julgamento é para o próprio Deus", onde o Deus de Israel é colocado como o juiz final e que o mišpăt seria considerado como um mišpăt divino. Se os juízes decidissem por uma sentença equivocada, eles estariam expondo, a um entendimento errôneo, o próprio Deus. Por isso, decidir por uma sentença como se fosse a sentença do próprio Deus atraía uma grande responsabilidade sobre os juízes.

Weinfeld (1995, p. 30) estabelece que as palavras mišpāt e șédeq estão relacionadas ao contexto de justiça social dentro de Israel. Desse modo, quando o texto começa ordenando aos juízes "fazer justiça", o redator estava ordenando aos šóptîm um julgamento justo, o qual somente seria feito se eles se dessem ao trabalho de ouvir - ponto fundamental no processo de julgamento - cada parte envolvida, para que pudessem estabelecer o julgamento correto. E por que ouvir antes de fazer justiça? Porque, depois de os ouvirem, os šóptînm teriam como

\footnotetext{
${ }^{192}$ Entre as opções de tradução para mišpāt, dadas por Kirst et al., está a opção de traduzi-la por "sentença arbitral, decisão legal" (1987, p. 146).

${ }^{193} \mathrm{Se}$ a pessoa fosse um $g \bar{a} \underline{\underline{d}} \bar{o} l$, é porque pertencia a esse grupo que era considerado pela comunidade como gāâōl. O mesmo se pode dizer daqueles que eram chamados de qățōnn.
} 
fazer a justiça - o que significa que, diante do que foi dito, eles decidiriam quem é certo e quem é errado e apontar qual a pena ou não de cada um.

A implicação disso é que quando a "face", ${ }^{194}$ ou o que cada um representava, era o critério de justiça, de fato não haveria justiça. Haveria uma perversão porque o direito de um seria pervertido em detrimento do direito de outro. A justiça feita deve ser vista como uma decisão que seja livre de pressão de quem quer que seja e que seja tomada de acordo com a veracidade do que aconteceu. Ha-Hayyim disse que o ato de "levantar a face" num julgamento "implica em negligenciar alguma transgressão ou assunto desagradável" (Apud LEIBOWITZ, 1995, p. 13), fazendo com que o devedor viesse a ser beneficiado com esse desvio do juiz (ou dos juízes).

Assim, a justiça social, a qual tornava a sociedade mais justa em seus relacionamentos, era o

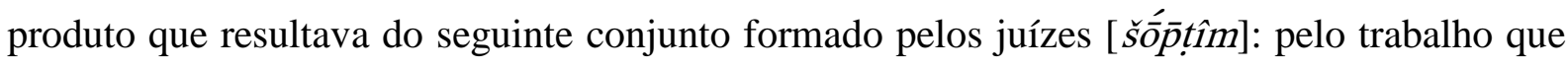
tais juízes tinham, "fazer justiça" [šop̄attem ṣédeq], e a decisão judicial que viria a ser tomada

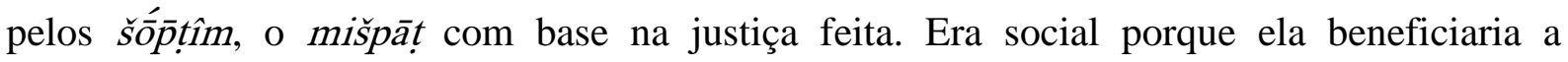
sociedade formada pelo qāțōn e pelo gād̂lōl, além de beneficiar os próprios envolvidos.

Além disso, deve-se levar em consideração que toda essa “organização judicial" era formada por pessoas do povo, escolhidas por ele, e a quem cabia a função de julgar. Eles eram membros do "tu" e do "vós". Para o Deuteronômio, esse julgamento não era o papel do rei. Em Deuteronômio 17,14-20 não é dada ao rei a função de juiz, mas é dada àqueles que seriam escolhidos para essa função (Deuteronômio 1,12-16). Essa escolha era de pessoas da comunidade para julgar pessoas de sua própria comunidade. Tal proximidade trazia sobre os juízes uma grande pressão, exigindo a necessidade de firmeza de caráter, um absoluto necessário.

Agora, mesmo que os textos paralelos tratem de situação semelhante à envolvida em Deuteronômio 1,16.7, qual é o aspecto específico que elas tratam? Em que aspectos estas passagem contribuem para o entendimento de Deuteronômio 1,16.17?

\footnotetext{
${ }^{194}$ Thutmose III falou ao seu vizir Rekhmire sobre quem devia ser escolhido para juiz: "Ele é um que não se fez amigo de alguém... é abominação de Deus mostrar face [= parcialidade]. Esta é uma instrução... considere-o como alguém que você sabe que não o conhece, alguém que é próximo de você como alguém que é muito distante" (Faukner Apud WEINFELD, 1991, p. 141).
} 


\subsection{Os textos paralelos em Êxodo e Levítico}

\subsection{1. $\quad$ Exxodo 23,3: a testemunha deve ser verdadeira}

Os livros de Êxodo e Levítico apresentam textos correlatos que, enquanto Deuteronômio 1,16.17 trata como qātōon, esses dois livros colocam especificamente um dāl no lugar do $q \bar{a}$ țōn de Deuteronômio. Em Levítico 19,15 parece haver um refinamento de uma legislação mais antiga e que precisou ser adaptada ao seu tempo, e em Êxodo 23,3 onde a proibição é dada para aquela ação judicial que buscasse beneficiar o pobre por ser pobre ou rico por ser rico. Esse elemento aponta para uma legislação que mostra que a justiça social não pode ser pendente para um lado. Se ela é justiça social, então ele deve ser feita para qualquer membro da sociedade - seja ele qāttōn, seja ele gādōol.

Os textos citados de Êxodo e Levítico não apresentam as mesmas figuras que Deuteronômio 1,17 apresenta - qāțōn e gād $\underline{d} \bar{o} l$. Mas outros elementos correlatos se apresentam na escrita dos redatores desses livros. O primeiro texto, em sua ordem de aparição dentro da BH, é Êxodo 23,2-3. Esses versículos pertencem ao bloco de literatura do livro de Êxodo denominado de Código da Aliança $(20,22-23,19)$. O ambiente a que se relaciona esse texto mostra o povo em seu estabelecimento no campo, ou na sua propriedade, e tendo um processo judicial em andamento. O versículo 2 destaca uma proibição sobre alguém que está na condição de julgar para que ele não distorça uma sentença por causa da pressão dos "muitos", mesmo que isso seja para favorecer um homem pobre $[d \bar{a} l]$.

A palavra para este processo judicial é ריב] [rîb] Ela pode ser traduzida por "contenda", "controvérsia", "disputa", "causa" (SCHÖKEL, 1997, p. 617). O verbo, do qual rị̂ deriva [ריב], em sentido primário, parece ter sido aquele relacionado ao combate físico ("lutar"; “combater"; Êxodo 21,18), daí ele passou a ter o sentido de debate verbal (Gênesis 31,16), depois veio a designar aquele debate jurídico, tendo o Deus de Israel como sujeito (CULVER, 1980, p. 845-846). ${ }^{195}$ Mas, daí em diante, houve derivação para a disputa verbal e também para a questão judicial (CULVER, 1980, p. 845). O substantivo rî́b traz esse aspecto de um embate judicial e é deste modo que ela deve ser entendida pelo contexto em que a palavra está

\footnotetext{
${ }^{195}$ Culver ainda acrescenta outros dois sentidos para o verbo ריב [rîb $\left.\underline{b}\right]$ : o primeiro é "ficar à espreita" (1 Samuel 15.5); o segundo é "reclamar" a alguém (Juízes 21,22; Jeremias 2,29). Os três significados apontados no corpo desta pesquisa são os mais comuns, e podem ser mais bem relacionados com o significado da palavra ריב nos textos em análise.
} 
colocada dentro de Êxodo 23. ${ }^{196}$ As partes estão presentes para apresentarem suas posições no conflito, e os juízes estão lá para decidirem a partir do que eles ouvirão durante o debate entre as partes.

Portanto, há um rị̂b. Porém, ao que o texto deixa entender é que, quando a comunidade está reunida para um rîb $\underline{b}$, ela pode já ter tomado uma decisão em favor de um lado da disputa. Diante disso, distorções poderiam ser feitas. A proibição escrita pelo redator do Código da Aliança tem os seguintes elementos: primeiro, mesmo que muitos tivessem tomado partido de um lado do $r \hat{i} \underline{b}$, a testemunha não deveria ser levada a torcer seu testemunho em favor do lado da maioria; ${ }^{197}$ segundo, mesmo que um lado do $r \hat{r} \underline{b}$ fosse um $d \bar{a} l$, a pessoa que testemunhava deveria manter-se firme em suas convicções diante do que ela ouviria no debate judicial. Sem, contudo, alterar seu testemunho para se aliar a maioria.

Juntamente com o que se tem escrito sobre Êxodo 23,2.3, deve-se colocar uma diferenciação entre a forma como esta pesquisa traduziu o versículo e a tradução para português de algumas versões. A BJ traduziu esse versículo da seguinte forma: "nem serás parcial com o desvalido no seu processo". A BP fez a tradução assim: "Não favorecerás o poderoso em sua causa". ${ }^{198}$ A ARA colocou a tradução desta maneira: "nem com o pobre serás parcial na sua demanda".

O problema encontrado nessas três versões para o português está na forma como elas traduziram o verbo ou como foi traduzida a palavra $d \bar{a} l$. A BP entendeu que palavra $d \bar{a} l$ deveria ser substituída por gādōl, na sua tradução, enquanto que a BJ e a versão do ARA entenderam que o verbo deveria ser traduzido por "ser parcial". O aparato crítico da BH apresenta como hipótese duvidosa a possibilidade de o gāâdol ser entendido no lugar de $d \bar{a} l$, e cita como exemplo Levítico 19,15, o qual será tratado mais adiante. Mesmo assim, esta

\footnotetext{
${ }^{196}$ A BJ usou a palavra "contenda" para traduzir rị̂b, em Jó 31.13, pressupondo um debate verbal entre Jó e um

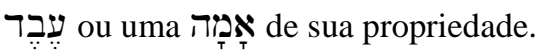

197 No livro de Provérbios 24,28 há um provérbio que é introduzido por verbo no jussivo, o que demonstra que isso não era preocupação somente de um legislador ou redator de uma legislação, mas também dos sábios dentro de Israel. Isso indica que o risco de alguém ser falsa testemunha era grande ("Que tu não sejas testemunha sem causa contra teu próximo, e enganes com teus lábios" [ירוֹ

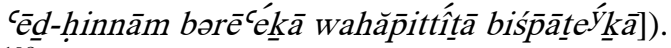

198 "Poderoso" é pontuado por * que remete a uma observação onde o tradutor salienta que a palavra é na realidade $d \bar{a} l$. Numa nota sobre esse versículo, o tradutor coloca o seguinte comentário: “... no v. 3, o texto hebraico lê $d \bar{a} l$, desvalido, que muitos corrigem para găd $\bar{o} l$, pessoa importante, como o sentido parece pedir" (BP, p. 150).
} 
pesquisa entende que o aparato crítico não decide por essa possibilidade de entender o gāâdōl, em lugar do dāl, mantendo o texto como está no Hebraico.

O problema com a BJ e ARA está em que o verbo traduzido por "ser parcial", nessas versões, é o verbo הדר. SCHÖKEL (1997, p. 167) aponta que esse verbo tem o sentido de "honrar, respeitar, autorizar". Além desses sentidos, o verbo também pode ter o sentido de "glorificar" (HAMILTON, 1980, p. 207) ${ }^{199}$ e "tratar com distinção". ${ }^{200}$ Essa é a opção que a tradução feita por esta pesquisa sugere que seja seguida.

Por sua vez, a Septuaginta traduziu o texto hebraico assim: "e a pessoa pobre não mostrarás

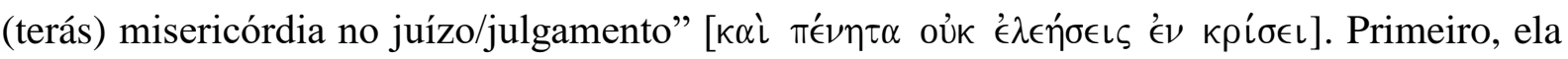

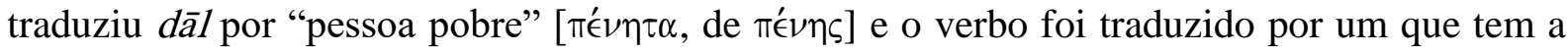

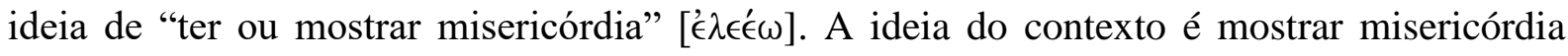
para quem não tem o devido merecimento. Mas também tem a ideia de mostrar a misericórdia em detrimento do outro. Para não incorrer no erro de exercer parcialidade no julgamento.

Diante do que foi assinalado acima, o texto de Êxodo 23,2-3 está declarando uma proibição de parcialidade na justiça. A ordem colocada no versículo 2 destaca que ninguém deveria dar um testemunho falso por pressão de um grupo maior. O que o versículo 3 apresenta é que isso não deveria ser feito, nem que isso viesse a beneficiar um Ente Silencioso como um dāl. Pois alguém poderia entender que por um $d \bar{a} l$ até poderia valer uma exceção à regra. Mas como o Deus de Israel não é parcial, então, seu povo, como seu represente na terra, deveria agir da mesma maneira.

O que isso tem a dizer é que a condição social de alguém não poderia servir de motivo para uma distorção proposital diante da justiça para favorecer um lado. ${ }^{201} \mathrm{O}$ livro de Provérbios 28,3 mostra que "um homem pobre" [géber rāss], mas com poder, pode ser um instrumento de opressão contra outros “pobres” [dallîm]: "Um guerreiro pobre e que oprime pobres (é) chuva

\footnotetext{
${ }^{199}$ Esse dicionário de palavras teológicas da BH afirma que uma idéia relacionada é "mostrar parcialidade", e dá, como exemplo, Êxodo 23,3, onde é apresentado um caso de parcialidade "para o pobre, o qual é apanhado numa crise legal, simplesmente por causa de sua pobreza, não por causa de sua inocência".

${ }^{200}$ Uma das ideias sugeridas por HHL-BW7.

201 Para esta pesquisa, a opção das versões apresentadas, em não seguir o texto Hebraico nas suas traduções, pode ser justificada ou pela ideologia da "opção pelos pobres", ou por falta de entender que o Deus de Israel leva ao extremo sua opção de agir imparcialmente, mesmo que isso viesse a beneficiar um pobre. Para ele, o pobre é um membro de seu povo, e, como tal, deve apresentar as qualidades exigidas de qualquer um dos membros de sua comunidade.
} 
que prostra e não há pão". ${ }^{202}$ Para os sábios de Israel, a pobreza de um homem não era uma condição de inocência, ou mesmo um meio de produzir violência contra outros na mesma condição. ${ }^{203}$ Um homem pobre que oprime outros pobres era considerado como a chuva torrencial que, em lugar de regar o campo para aumentar sua produção, destruía o solo e não deixava mantimento para ser colhido.

Diante desses textos (Êxodo 23,2-3; Levítico 19,15), o que se pode afirmar é que, para os seus redatores, a condição social nunca deveria ser colocada como motivo para um juiz julgar uma causa, de modo parcial, contra seu próximo, alterando uma decisão da justiça para beneficiar uma pessoa da preferência de um juiz (ou dos demais juízes). E, como notado acima, essa também foi parte da preocupação da sabedoria em Israel (Provérbios 28,3) partilhando, numa outra forma de dizer, dos mesmos ideais dos redatores de Êxodo, Levítico e Deuteronômio, pois poderia ser que a condição econômica de alguém atrairia complacência do povo e de algum dos juízes, e até a complacência da comunidade diante da violência de alguém contra seu próximo por ser um pobre. Entretanto, a legislação que regia a vida de um, regia a vida de outro, fosse pobre, fosse rico, pois fazer justiça tem que olhar o ser humano com tal, não mirar sua condição social.

Deve-se destacar que há uma diferença entre o Deuteronômio 1,16-17 e Êxodo 23,2-3: enquanto que em Deuteronômio a palavra é dirigida aos šópṭ̂tim, em Êxodo ela é dirigida àquele que vai responder ou testemunhar ${ }^{204} \mathrm{em}$ um rîb. Também mais adiante, em Êxodo 23,6, aparece uma repetição do versículo três, quase que palavra por palavra. ${ }^{205}$ Porém, em lugar de dāl aparece 'ebayôn (Êxodo 23,6), fazendo com que as duas palavras pertençam ao mesmo campo semântico.

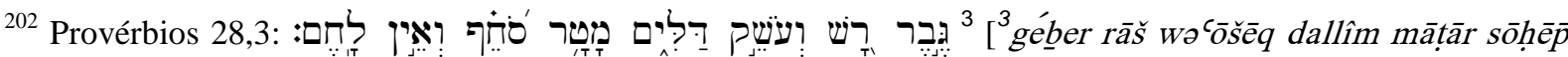
wəวên lăhnem]. Para esta pesquisa, o emprego de rāšs e dallîm mostra o efeito estilístico do autor deste provérbio, com o fim de não repetir as palavras.

${ }^{203}$ SCHÖKEL aponta que mātătr sōḥēp aponta para uma "chuva torrencial", e cita este versículo como prova (1997, p. 465).

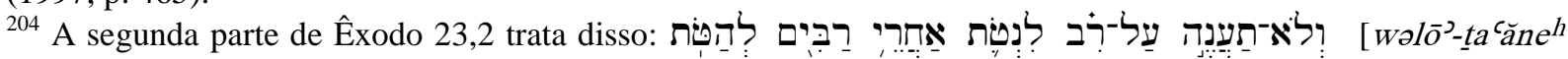

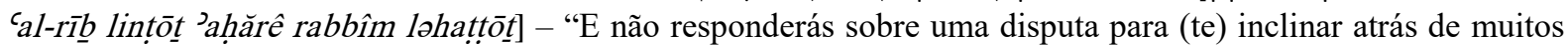
para distorcer/perverter (uma decisão da corte)". O verbo עָ עָ pode ser traduzido por "testemunhar" que também é "responder" só que em contexto judicial, como aqui (SCHÖKEL, 1997, p. 507).

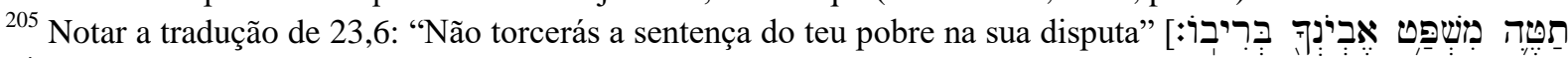

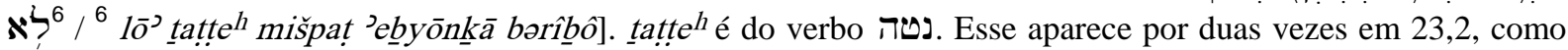
anotado antes, e uma vez em 23,6. A proibição de "não torcer" mostra que o ideal da justiça deveria ser mantido - fazer justiça a todos, e de igual modo.
} 
2.2.3.2.3.2. Levítico 19,15: outro desafio aos juízes

Mas e Levítico 19,15? Ele afirma algo diferente ou complementar a Deuteronômio 1,16-81 e Êxodo 23,2-3? A tradução proposta por esta pesquisa para Levítico 19,15, "Não farás injustiça no julgamento. Não levantarás a face do pobre e não honrarás a face do grande. Julgarás com justiça teu companheiro", apresenta um paralelo entre os verbos "levantar" [נשטא] e "honrar" [הדר]. Esse paralelo pode ser notado por alguns detalhes a serem desenvolvidos nos parágrafos seguintes.

Em primeiro lugar, o verbo נשָא tem um conjunto de significados abrangentes que procede de seu emprego em diferentes estruturas verbais (binyanim) do Hebraico. A estrutura empregada em Levítico 19,15 é a do qal. Entre os sentidos dados na tradução dessa estrutura verbal estão o de "levantar" e "erguer" (SCHÖKEL, 1997, p. 451). Entretanto, Schökel acrescenta que

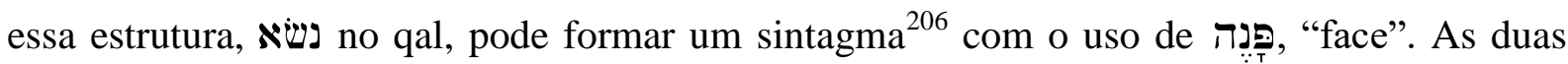
palavras juntas podem ter o sentido de "conceder favor ou favoritismo, ser parcial", o que, segundo ele, é um uso comum dentro da $\mathrm{BH}^{207}$

O verbo הדר, "honrar", por sua vez, além desse sentido inicial, também pode ser traduzido com o sentido de "respeitar" ou "autorizar" no qal. ${ }^{208}$ O texto de Levítico 19,15 não está proibindo o respeito ou honra que é devida ao ser humano que procura a justiça para dar uma resposta justa à sua questão. O texto está falando de uma honra que acarretará prejuízo a um dos lados da disputa judicial naquele tribunal.

O emprego desses verbos favorece o entendimento de que as duas palavras (הדר ;שאו), de raízes diferentes, apresentam o mesmo significado. Portanto, para o redator, a condição social de uma pessoa não pode ser o motivo para que ela seja favorecida pela justiça. Tal pessoa deve ter os mesmo direitos de defesa, ou de acusação, que seu oponente.

Em segundo lugar, as duas frases começam com proibições. Além disso, a frase concluinte do versículo mostra que a justiça deve ser feita tanto para o dāl como para o gād $\bar{o} l$, pois os dois

\footnotetext{
206 "Uma unidade sintática, composta por um ou mais vocábulos que forma orações" (Wikipédia, vocábulo "Sintagma", consultada dia 19 de fevereiro de 2013, às 11 horas).

${ }^{207}$ Schökel dá exemplos de Gênesis 19,21 e Deuteronômio 10,17, estando os dois usos de נשטא no qal (1997, p. 451).

208 Schökel cita, entre os exemplos de uso do verbo com os significados apontados aqui, Levítico 19,5 (1997, p. 167).
} 
são qualificados pela palavra "próximo", um "concidadão" ou mesmo um "parente"

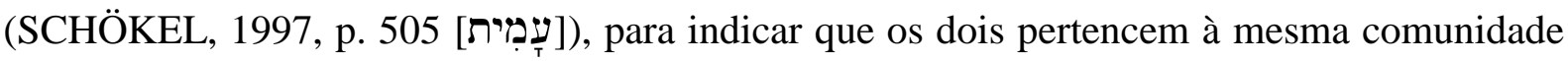
e são conhecidos um do outro. Aliás, eles podem pertencer ao mesmo clã.

Diante disso, esta pesquisa indica que Levítico 19,15 ilumina o entendimento de Êxodo

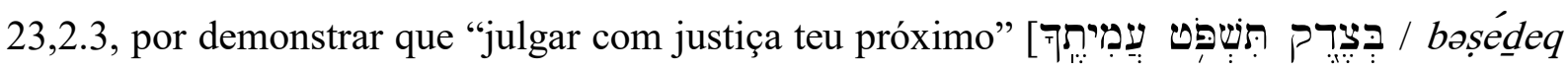
tišpōt ‘ămîtékāa é julgar imparcialmente qualquer pessoa que chegue com uma questão ao tribunal e ela tem de ser julgada, e condenada ou inocentada, não por sua condição social, mas por seu comportamento, sendo declarado culpado ou inocente.

Com isso, a pesquisa conclui que os três textos - Deuteronômio 1,16.17, Êxodo 23,2.3 e Levítico 19,15 lidam com o mesmo ponto - a imparcialidade deve ser a meta dos juízes ao julgar, e os que procuram tais juízes devem esperar que seu julgamento seja imparcial, e que esse independe de sua condição social, porque é assim que o Deus de Israel julga o povo que a ele pertence, Israel.

Há também uma unidade do propósito dos textos que é estabelecer uma justiça imparcial por parte dos juízes, das testemunhas e dos que estarão ali para assistir o julgamento, porém o foco dos três tem uma pequena diferença - enquanto que os textos de Deuteronômio 1,16-17 e Levítico 19,15 colocam como alvo de suas palavras os juízes, o texto de Êxodo 23,2-3 mira aquele que vai testemunhar bem como a audiência do julgamento em andamento. Todos juízes, julgados, testemunhas e audiência - devem esperar que uma justiça fosse tão justa quanto seu Deus.

Finalmente, há uma questão que precisa ser respondida: qual a relação entre qățōn, dāl, ’ebyôn e 'ānînos textos em que foram analisados nessa unidade da pesquisa?

A relação existente ocorre por meio da palavra dāl presente nos textos de Levítico e Êxodo, os quais tratam da mesma questão. Essa identificação mostra que o qāțōn era alguém que pertencia às camadas dos desfavorecidos contempladas pela legislação do Deuteronômio. Nessa comparação, entre os textos de Deuteronômio, Êxodo e Levítico, pontua que o qātōnn é um $d \bar{a} l$.

Esta palavra, dāl, por sua vez, com sua tradução para o Targum com palavra מסכ, a mesma usada para traduzir as palavras ’ebyôn e cānî do texto Hebraico do livro de Deuteronômio 
para o Aramaico, mostra que ela pertence ao campo semântico do ’ebyyôn e ‘̄annî, colocando dāl dentro dos grupo do Entes Silenciosos do livro de Deuteronômio por meio do qāțōn, haja vista que os três textos analisados antes tratam do mesmo assunto - a imparcialidade que um julgamento deve ter, tanto para o qātōonl dāl quanto para o gād̄ôl.

Assim, o qāṭōn é um dāl, ou um 'ebyôn, ou um ‘ānî-essas palavras tem o mesmo campo semântico para indicar alguém pobre. Ele também pode ser um $g \bar{e} r$ (Deuteronômio 1,16), ou mesmo um אָָ [ $3 \bar{a} h]$, "irmão", do gād̆ōl. Por essa aproximação, o qāțōn é um membro do grupo de Entes Silenciosos do livro de Deuteronômio. Assim, com esses relacionamentos, pode-se justificar o motivo de se colocar qățōn sob a divisão que trata dos Entes Silenciosos envolvidos pelas palavras 'ebyôn e $\varsigma^{\top} \bar{n} n \hat{r}^{209}$

No livro do profeta Jeremias, há um texto onde se pode verificar a identificação, por implicação, do qāṭōn com dāl, e seu contraste com o gādolol. O texto (Jeremias 5,4.5) está inserido dentro de uma procura por pessoas, em Jerusalém, que andem em obediência aos mandamentos do Deus de Israel. Em meio às suas avaliações pessoais, Jeremias pensa que os “pobres" [dallîm] não obedecem ao seu Deus porque são pobres e não têm conhecimento do que Deus quer deles. Então Jeremias procura os "grandes" [god̄ōlîm] por imaginar que encontrará entre eles gente capaz de fazer o que o Deus de Israel pede que façam porque eles têm conhecimento.

Para Jeremias, os gộlolîm são os que detêm o conhecimento por causa de sua posição de liderança. Aqui ele mira os profetas, sacerdotes e príncipes (ver Jeremias 1,18; 4,9; 5,31; 13,13). Mesmo que Deuteronômio não seja tão específico na identificação do gād $\bar{o} l$ como em Jeremias, dá, porém, para reconhecer que o problema existente em Deuteronômio é entre um chefe, um líder importante da comunidade, e um homem pobre, um homem sem a importância do $g \bar{a} \underline{d} \bar{o} l$.

\footnotetext{
${ }^{209}$ No livro atribuído ao profeta Isaías, dentro de uma mesma unidade literária, aparecem as três palavras para "pobre" [dāl, 'ebbyôn e 'ānî], com diferentes sentidos de tradução, cuja motivação é apresentar a ênfase particular de cada delas: "fracos" [dāh], "indigentes" [ 'ebyyôn], "pobres" [ ‘ $\bar{a} n \hat{n}]$ (14,30.32; BJ). Outras ocorrências paralelas

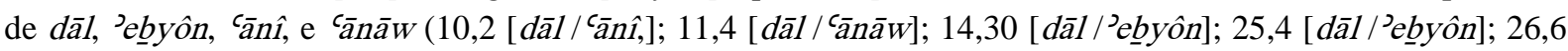

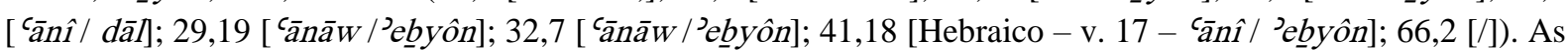
quatro palavras não aparecem juntas em Isaías. Em Isaías 66,2, ‘ānî está em paralelo com "abatido de espírito"

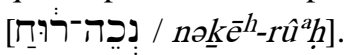


Há algo mais a dizer. O relacionamento entre esses textos pode não somente ser obtido por meio da ideia central da imparcialidade no julgamento e por meio da identificação do qāttōn com o dāl, mas também por meio de outro lado na disputa judicial de Deuteronômio 1,17, o gādōl. Em Êxodo 23,2-3 é apenas subentendido que há uma disputa judicial entre duas pessoas, sendo que uma é claramente identificada como sendo um dāl. Como essa pessoa é um dāl, e ela não deve ser tratada de forma diferente apenas por ser dāl, o que fica subentendido é que o outro lado do processo judicial é um gādōl. Enquanto em Êxodo 23,2-3 esse elemento pessoal é subentendido, em Levítico 19,15 ele é declarado: "Não levantarás a face do pobre [ $d \bar{a} l]$ e não honrarás a face do grande [ $g \bar{a} \underline{d} d \bar{o} l] ”$. O gād $\bar{d} \bar{o} l$ é o outro lado do rîb, tanto em Deuteronômio quanto em Levítico.

Deuteronômio 1,16.17 mostra um lado do relacionamento dos Entes Silenciosos denominados pela palavra "pobre" e outro membro da comunidade, chamado de gād $\bar{o} l$. O rîb era apenas uma parte dos relacionamentos dentro da comunidade, quando um dos lados do rî́b apelava para resolver uma questão para a qual não se encontrou solução entre os dois lados dela.

Mas o rîb não era o único relacionamento tenso para o qual a justiça era convocada para mediar à paz e trazer solução. A que deve ter sido tenso em determinados momentos. $\mathrm{O}$ estabelecimento da שְִׁ̣ viria a trazer paz nas relações trabalhistas entre um Ente Silecioso e um gād $\underline{d} \mathbf{o}$. Ela tembém viria a estabelecer um tempo preciso para a quebra de qualquer dependência que uma dívida causasse

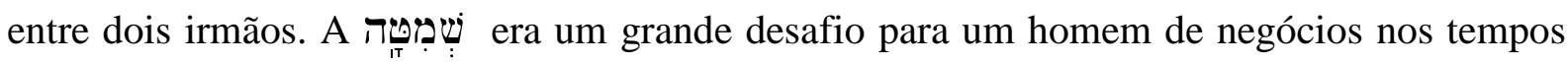

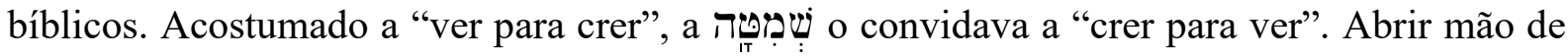
seu recebimento do valor de uma dívida a qual tinha o direito de receber era um passo de grande fé no seu Deus. Para obedecer, ele precisava crer que viria o lucro depois de nada receber da dívida na 


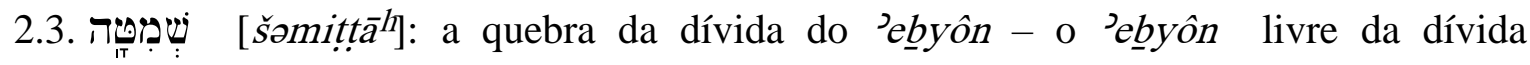
(Deuteronômio 15)

\subsubsection{A importância de Deuteronômio 15}

O primeiro elemento que mostra a importância desse capítulo é que a presença do interrelacionamento entre pobreza e escravidão fica acentuada dentro dele no Deuteronômio. $\mathrm{O}$ texto indica a possibilidade de um homem livre se tornar escravo por causa de sua condição econômica, e também apresenta o seu oposto, onde um escravo pode se tornar livre devido a uma legislação beneficente.

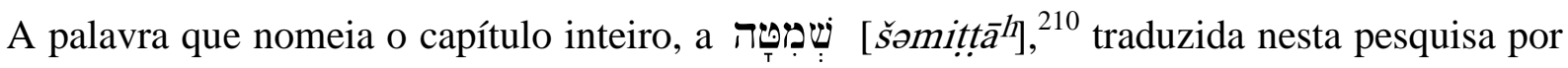
"quitação (ou cancelamento) de débitos", tem apenas cinco aparições dentro da BH. Todas elas ocorrem dentro de Deuteronômio (15 e 31), ${ }^{211}$ indicando que ela é uma legislação inovadora que quebraria os paradigmas de uma escravidão permanente. ${ }^{212}$

Esse capítulo é o único lugar dentro do Deuteronômio onde o ciclo liberdade-pobrezaescravidão-liberdade (ou até escravidão voluntária permanente) é colocado para mostrar eventuais mudanças para uma mesma pessoa. Deve-se pontuar que esse ciclo poderia ser o ciclo na vida de uma pessoa, seja homem ou mulher. O homem em pauta é uma pessoa livre que, em sua liberdade, chega ao nível mais baixo da pobreza, mas, ainda como homem livre, opta por uma escravidão voluntária. No tempo em que sua libertação é chegada, ele escolhe sair livre, ou, em sua liberdade de escolha, faz a opção de ser um escravo por toda a vida dali em diante.

\footnotetext{
${ }^{210} \mathrm{O}$ verbo do qual o substantivo procede é שמפ, cujos sentidos são: "liberar, deixar cair, deixar soltar, deixar descansar" (AUSTEL, 1980, p. 936). Thompson diz que a šmitță ${ }^{h}$ tem o sentido literal de "deixar ir" (1982, p. 178). Assim, o cancelamento da dívida é uma soltura - tanto do direito de receber quanto do dever do devedor de pagar. Pode-se afirmar que fazer uma šsmițta $\bar{a}^{h}$ é fazer uma proclamação pública de um evento de libertação.

${ }^{211}$ Suas aparições estão sempre relacionadas á quitação de dívidas (AUSTEL, 1980, p. 936). Elas ocorrem em

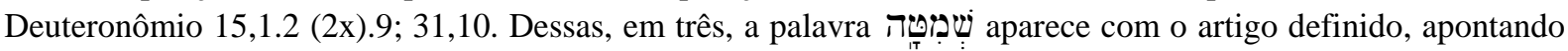
para um evento específico que ocorre no ano sétimo $(15,2.9 ; 31,10)$. As duas que aparecem sem um artigo apontam para uma realização - aquilo que deve ser feito: "Ao fim de cada sete anos farás (uma) šomițțāth, $(15,1)$; "E esta palavra é o (modo de fazer o) cancelamento de dívidas" (15,2a). A ocorrência exclusiva aqui reforça a ideia da originalidade da šomitță $\bar{a}^{h}$ para Israel e exclusividade do Deuteronômio.

212 "Somente em Deuteronômio o ano sabático é apresentado como o ano em que os débitos deveriam ser cancelados" (THOMPSON, 1982, p. 178). Isso demonstra um desenvolvimento da legislação original estabelecida em Levítico 27,1-7. A legislação da šomițță ${ }^{h}$ era a demonstração que algo se fazia necessário para completar a legislação original.
} 
Outra importância do capítulo é que ele aponta para a interrupção de uma prática disseminada, dentro das comunidades rurais e citadinas, onde o ${ }^{2} e \underline{b y o ̂ n}{ }^{213}$ perdia a possibilidade de restauração à condição anterior ao seu empobrecimento. Assim, o ’ebyôn era mantido na continua condição de subserviência ao $b a^{c} a l^{214}{ }^{14}$ impedindo-o de acessar novo começo, e, portanto, a liberdade.

No desenvolvimento de Deuteronômio 15 há duas situações que ilustram o interrelacionamento entre o $b a^{c} a l$ e seu 'ebyyôn. A primeira é a do empréstimo feito ao ’ebyôn quando estava se aproximando o ano de concessão do perdão às dívidas. A segunda é do ’ebyôn que se vende para ser escravo quando ele percebe que essa condição passa a ser melhor que a de um 'ebyôn, na qual ele se encontrava. ${ }^{215}$

O capítulo 15 é como uma janela por meio da qual o sol entra para iluminar o interrelacionamento entre um $b a^{\complement} a l$ e um 'ebyôn, e como a misericórdia poderia ser exercida, mesmo em meio às situações sociais de pobreza e riqueza. Aliás, o capítulo demonstra um grande valor da riqueza onde ela dá a capacidade de quem a possui para ser generoso com quem precisa e, ao mesmo tempo, de depender, em sua confiança, que as palavras do Deus de Israel serão cumpridas para ele.

\subsubsection{A base redacional sobre o "tu/vós"}

A questão relacionada às pessoas a quem se dirige o redator de Deuteronômio é recorrente em todo o livro. Neste ponto da pesquisa, destaca-se que a aparição da construção sobre o “tu/vós" apresenta peculiaridades dentro do livro de Deuteronômio. Mas aqui, a forma como redator fala é diretamente posta sobre o personagem apontado pelo pronome "tu". A motivação para isso existe, em primeiro lugar, porque o redator está falando com seu ouvinte,

\footnotetext{
213 ’ebyôn é a palavra empregada no capítulo para designar o pobre, exceto em Deuteronômio 15,11, onde o cānî aparece na construção humilde, do teu pobre"). Como a palavra ’ebyôn é a que é empregada para designar o "pobre" dentro de Deuteronômio 15, para esta pesquisa, a palavra 'ānî aparece como parte do esforço literário do redator para destacar a condição de pobreza a que chegou o 'ebyôn.

${ }^{214}$ Palavra empregada para designar o "credor" que fazia um empréstimo ao ’ebyôn. Esta pesquisa entende que o bacal era um proprietário de terra, ou um comerciante na cidade, e é com esse que o capítulo continuará falando até o seu final. Ele proclama a liberdade do irmão escravizado e também dá liberdade das dívidas. De qualquer modo, o $b a^{c} a l$ era alguém com condições de ter e manter um escravo.

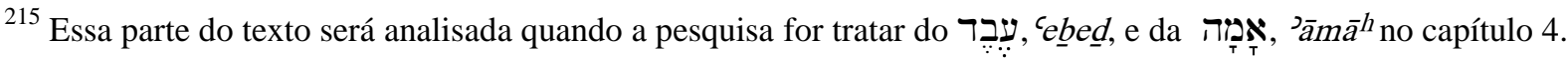


o bacal, aquele que se tornara credor, ${ }^{216}$ com quem ele trata sobre as condições de débitos, generosidade e escravidão de um irmão israelita. Portanto, a forma pessoal de tratar é direta e tem o alvo bem definido - o bacal, um senhor de terras, ou apenas alguém com posses, e que possui as condições econômicas para emprestar e para comprar um escravo irmão.

Na análise de Deuteronômio 15 se buscará desenvolver a questão básica do interrelacionamento entre os Entes Silenciosos e outros membros de suas comunidades dentro do Deuteronômio. A análise de Deuteronômio 1,17 já mostrou que os "pobres", denominados de "pequenos" podiam ter acesso à justiça. No tribunal eles se relacionavam com um "grande" e também com os juízes e a comunidade presente. Nos textos paralelos, em Êxodo e Levítico, a comunidade se mostrou muito ativa na questão que envolvia um "pobre".

Neste ponto do capítulo, a pesquisa trabalhará, principalmente, com uma análise do capítulo 15 de Deuteronômio. Esse capítulo fora escolhido porque uma parte das palavras relacionadas

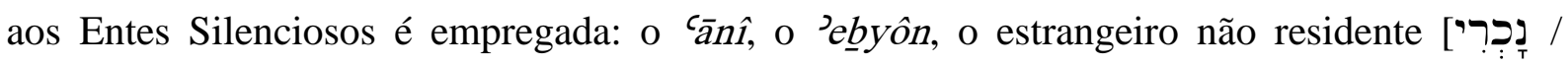
nok rî̀], o 'e $\underline{b} e \underline{d}$ e a ${ }^{\supset} \bar{a} m \bar{a}^{h}$.

Deuteronômio 15 vem a ser o único capítulo dentro do livro onde se pode fazer algum tipo de relação entre essas palavras e as pessoas que elas representam. Mas há associações entre elas dentro de outros capítulos do Deuteronômio, as quais serão apresentadas nos capítulos seguintes. Entretanto, essas associações existem entre os membros do mesmo grupo de Entes Silenciosos. Esses, porém, mantêm distinção entre si.

\subsubsection{A estrutura literária de Deuteronômio 15: Os blocos literários de Deuteronômio} 15

Deuteronômio 15 tem quatro unidades literárias que se completam. É possível que essas unidades fossem independentes inicialmente, ${ }^{217}$ mas que, num processo redacional constante da literatura do Deuteronômio, elas foram unidas para formar esse capítulo e, ao mesmo

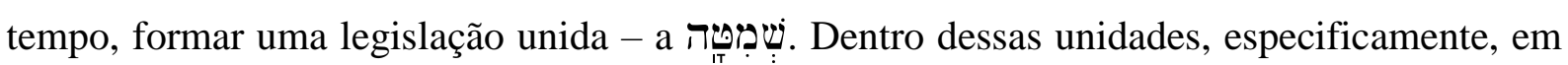
Deuteronômio 15,2-18, há a provisão para que o sofrimento do pobre fosse aliviado quando

\footnotetext{
${ }^{216} \mathrm{O}$ texto não especifica qual é o tipo de propriedade que possui o $b a{ }^{c} a l$ nem o seu padrão econômico. Ele

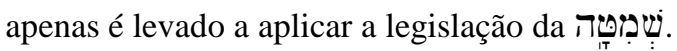

${ }^{217}$ Esta pesquisa trabalha com o texto na forma em que ele aparece aqui. Assim, apenas se pode conjecturar que esta legislação apareceu, inicialmente, em separado para tratar de diferentes situações que um homem podia se envolver.
} 
ele viesse a enfrentar dificuldades extremas: incapacidade de pagar suas dívidas, dificuldades para a obtenção de empréstimos e o contrato de venda para a servidão (TIGAY, 1996, p. 144).

A primeira unidade é aquela que trata daquilo que vem a ser o centro do capítulo - o Ano do Cancelamento de Dívidas $(15,1),{ }^{218}$ e essa lida diretamente com Israel, o povo que experimentou sua "šomitțăalt" no Êxodo. Além disso, ele é um capítulo que trata com o homem israelita que está passando por privação e, por isso, ele toma certas iniciativas para manter sua sobrevivência e liberdade. Ao tomar um empréstimo, deve receber ajuda humanitária, ou se escravizar para sobreviver à sua crise financeira. Essa unidade funciona como uma introdução ao capítulo. Ela serve como uma chamada. Quando perguntado sobre o

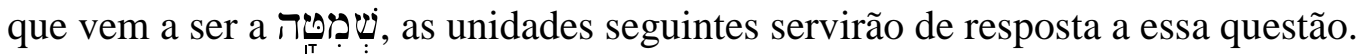

A segunda unidade é a que aborda o perdão concedido ao tomador de um empréstimo no ano sétimo (15,2-6). Em sua dificuldade por sobrevivência, esse homem encontra no outro a possibilidade de ajuda por meio de um empréstimo, garantindo o pagamento com a entrega do penhor.

A terceira unidade literária está intimamente ligada com a segunda, porém, ela aborda a questão do empréstimo quando o ano sétimo está próximo (15,7-11). A proximidade com o Ano do Cancelamento de Dívidas poderia não ser vantajoso fazer qualquer empréstimo, dificultando a vida do ’ebyôn. Essa unidade lida com o eventual prejuízo que o bacal poderia pensar que teria, em lugar do benefício que a שִ ש: representava para um ’ebyôn que estivesse no meio de seu povo.

A quarta unidade está ligada a questão do cancelamento de dívidas do ano sétimo, e trata do assunto do irmão que, em uma atitude extrema, se vendeu como escravo para outro israelita como meio de sobrevivência $(15,12-18)$. Ela demonstra o extremo ao qual alguém pode apelar em sua luta para sobreviver em uma crise financeira.

A quinta unidade não está ligada diretamente ao Ano do Cancelamento de Débitos, nem com soltura de escravos hebreus, mas com a consagração do primogênito ao Deus de Israel $(15,19$ 23). Essa unidade, aparentemente, está separada dos outros quatro blocos literários. Mas, se

\footnotetext{
${ }^{218}$ Tigay indica que o ano da šmițta $\bar{a}^{h}$ viria ser o mesmo do ano sabático, pois em Êxodo 23.10-11 o verbo שמט ("dispensar, deixar sair, deixar cair"), de onde vem a palavra šomitță ${ }^{h}$, é empregado em relação à dispensa da colheita dos campos, e que em Neemias 10,32 a mesma associação foi feita (1996, p. 145).
} 
for olhada do ponto de vista da consagração ao seu Deus, Israel deve sua obediência a ele, como povo consagrado, no cumprimento daquela legislação que trata do cuidado que ele deve ter com os Entes Silenciosos. O filho primogênito deveria ser aquele que assumiria as responsabilidades do clã em lugar do pai, e isso incluía responsabilidade de cumprir os mandamentos divinos.

Há lugares no Pentateuco onde Israel é chamado de filho primogênito do Deus de Israel. ${ }^{219}$ Até Efraim ${ }^{220}$ é chamado de primogênito. ${ }^{221}$ Assim, Israel deve sua lealdade ao seu Deus como um primogênito que é leal ao seu pai como filho mais velho, e a ele deve sua obediência e honra em acatar suas palavras. Seguir os mandamentos de Deus é a forma mais elevada de honrá-lo, como seu "pai”, e um meio prático de dar continuidade a uma tradição familiar.

O primogênito daria continuidade à tradição do pai. Como primogênito de Deus, Israel deve ser àquele que levará adiante o que ele foi instruído pelo seu pai - o Deus de Israel. Mas aqui, Israel não é o filho mais velho, mas é o herdeiro de tudo que pertence a Deus como seu pai. Daí a necessidade de Israel ser um primogênito que corresponda àquilo que se espera dele como seu herdeiro.

Assim, Deuteronômio 15,19-23 está intimamente relacionado com as unidades anteriores pela lealdade que o primogênito de Deus deve manter na manutenção das tradições familiares, no

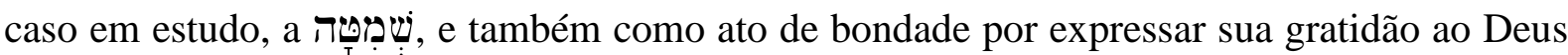
que o socorreu quando o libertou da escravidão no Egito. ${ }^{222}$

\footnotetext{
219 Israel é chamado de primogênito do Deus de Israel em Êxodo 4,22, e de "meu filho" (4,23). Todos os primogênitos de Israel deveriam ser consagrados ao Deus de Israel, tanto de homens como de animais (Êxodo 13,2.12). Os primogênitos dos filhos de Israel podiam ser resgatados. Animais seriam mortos em seu lugar, representando sua consagração total. Eles foram consagrados a Deus no dia que saíram do Egito com a morte dos primogênitos dos egípcios (Números 8,17). Ao que parece, os primogênitos dos egípcios perderam a vida em lugar dos primogênitos de Israel. Esses eram passíveis de resgate por um substituto, aqueles não.

${ }^{220}$ Como representante maior de todas as tribos que formavam o Reino do Norte, Efraim é elevado à posição de líder. Uma parte, Efraim, é colocada no lugar de todo o Reino do Norte, constituído pelas dez tribos que se separaram de Judá e Benjamim.

${ }^{221}$ Jeremias 31,9 está inserido dentro de um contexto de arrependimento futuro do Reino do Norte. A afirmação que Efraim é primogênito do Deus de Israel nunca é feito a respeito de Judá nos escritos da BH. Essa declaração em si é inédita pela condição de rebeldia que fundamentava o Reino do Norte, desde seu nascimento, com o culto aos bezerros de ouro presentes no norte e sul daquele reino. Ela também chama atenção pela sua ausência em relação à Judá porque esse se manteve leal ao seu Deus sob o domínio de alguns reis piedosos.

${ }^{222}$ Mesmo que a unidade que trata dos primogênitos, em Deuteronômio 15, esteja relacionada com as unidades precedentes, ela não participará da análise do capítulo.
} 


\subsubsection{O sitz im leben de Deuteronômio 15}

A experiência de um Ente Silencioso, o qual, ao mesmo tempo, é um Ente Excluído, não é favorável em nenhuma cultura. O livro de Deuteronômio, cuja vivência abraça períodos tão diferentes quanto distantes uns dos outros, como o século VIII AEC, no Reino do Norte, e o período do Exílio e pós-Exílio, ou mesmo em tempos de avivamentos religiosos, como aqueles ocorridos nos dias de Ezequias e Josias. Tudo isso é demonstração que diferentes redatores estão no trabalho árduo de aplicar a mesma legislação às suas realidades.

Eles também estão vivenciando um contexto onde há necessidade de dar voz à solução de uma circunstância desfavorável aos Entes Silenciosos, cuja presença era comum em seus dias. Agora, se o livro teve diferentes períodos redacionais e aplicações a diferentes períodos históricos de Israel e Judá, significa que sempre houve necessidade de retorno ao Deuteronômio para recordar e aplicar a mesma legislação.

O ambiente de Deuteronômio 15, como do bloco inteiro de 12 a 26, é tanto do campo como da cidade. A situação por trás da deliberação do ano de cancelamento de dívidas é a dificuldade que um senhor, com bens, enfrentava no trato com aquele que havia se vendido como escravo, seu compatriota em Israel, e com aquele que havia tomado um empréstimo.

Essa dificuldade estava no coração do cancelamento das dívidas de forma simples: sem o retorno daquilo que havia sido dado para aquele que havia se vendido como escravo ou do empréstimo dado a um devedor. O contexto por trás do texto também revela a luta pela sobrevivência aonde, na condição extrema de alguém, se vende como escravo.

O contexto temporal favorece ao período do ano sabático proclamado para o descanso da terra. Nesse ano, todo proprietário deveria deixar de plantar para que a terra produzisse por si só o alimento (Êxodo 23,10-11; Levítico 25,1-7). Aquele descanso dado aos homens e animais uma vez por semana passava a ser ampliado para todos por um ano, incluindo o campo de semeadura.

Entretanto, a aplicação da šomitța $\bar{a}^{h}$ envolve pequena diferença para o irmão devedor e para o escravo hebreu (esse também era um devedor). O escravo hebreu trabalharia seis e seria liberto na proclamação do ano sabático para a terra. Porém, os devedores do bacal só experimentariam a completa libertação de suas dividas "ao fim de sete anos" [miqqēș šę bac- 
šānîm], quando um novo período de sete anos seria iniciado, e o devedor experimentaria a liberdade. $^{223}$

Qual a motivação para isso? Primeiro, no sábado de descanso da terra todos passavam a ser iguais em sua dependência do Deus de Israel, pois todos esperavam que ele cumprisse sua parte de abençoar o solo em sua produtividade. Todos viveriam daquilo que a terra produzisse, e essa produção era para todos. De certo modo, não haveria pobre ou rico, pois todos estariam na mesma condição, dependendo do que o solo viesse a produzir (Levítico 25,2-6). Segundo, no ano de descanso também haveria a possibilidade de soerguimento do devedor. Haja vista que a sua dívida fora perdoada, durante o ano de descanso da terra, um novo projeto de vida poderia ser planejado. Assim, a šomitțăh não deve ser vista só pela sua generosidade em dar liberdade a um devedor ou escravo, mas também pela sua generosidade em dar outra oportunidade a quem perdeu, por qualquer motivo, algo no passado.

Entretanto, não se deve idealizar a sociedade pensada pelo redator como sendo uma sociedade sem conflito. A própria ordem para que os débitos dos devedores fossem cancelados no fim de sete anos e a liberdade compulsória dos escravos comprados de entre seus irmãos, no fim de seis anos, pode não ter sido bem aceita pelo $b a^{c} a l$. As ordens para que o $b a^{c} a l$ desse presentes ao escravo que está sendo liberto $(15,14)$, não considerar um peso (ou prejuízo) a libertação no sétimo ano $(15,18)$, não explorar o próximo a quem se havia feito um empréstimo $(15,2)$, e não ficando com a garantia mais tempo que o prazo no fim dos sete anos indicam que o ambiente de conflito pode ter sido instalado por causa das novas ordens.

Além do mais, o ano sétimo era o ano de descanso da terra, e que tudo o que espontaneamente nascesse era para o $b a^{c} a l$, para o estrangeiro, viúva, animais e o órfão. O $b a^{c} a l$ poderia considerar que tudo isso lhe causaria prejuízo e poderia não querer atender a legislação da

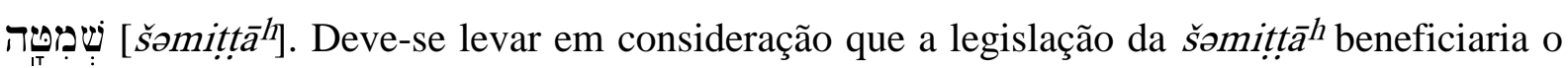
irmão pobre e o irmão escravo. O benefício do $b a^{c} a l$ viria de seu compromisso em obedecer ao que o Deus de Israel estava ordenando.

\footnotetext{
${ }^{223}$ Pode-se apontar aqui que há uma escravidão que não impõe a limitação física - a escravidão que a dívida impõe sobre o devedor. Mas há outra escravidão que se impõe pela venda da própria pessoa. As duas são ocasionadas pela dívida. Notar o exemplo presente em 2 Reis 4, onde uma mulher pede socorro ao profeta Eliseu, para que seus filhos não fossem levados como escravos para quitar dívidas.
} 
Ao pensar em Deuteronômio 15, não se deve se esquecer de pontuar que os conflitos entre o $b a^{c} a l$ e o que ele atendia com seus bens necessitavam ser resolvidos. A quebra de velhos hábitos não foi uma decisão simples para $b a^{\complement} a l$, acostumado a sempre levar vantagens. Essa forma de escrever demonstra que o redator (ou o redator de cada período) conhecia bem seu ambiente e com quem ele estava se relacionando e tinha conhecimento do assunto que estava tratando. Nem todos iriam aceitar, ou estavam aceitando, sem algum tipo de resistência, a šomitțāh.

Esse era o ambiente por trás de Deuteronômio 15 - um ambiente de ano de descanso do povo, dos animais e da terra. Mas não era um descanso sem suas dificuldades. Havia seus conflitos com a aplicação de uma nova legislação que viria mudar o relacionamento entre o $b a^{c} a l$ e seu irmão pobre ou escravizado. É nesse território, seja o campo, seja a cidade, que os relacionamentos existentes em Deuteronômio 15 estão ocorrendo. É um território físico campo, cidade - mas também é um território social, onde os relacionamentos humanos acontecem e os conflitos existentes necessitam ser resolvidos.

2.3.5. O benefício da šomitța ${ }^{h}$ para o pobre em Deuteronômio 15 - tradução e análise do capítulo

\subsubsection{A introdução (Deuteronômio 15.1)}

\subsection{Tradução 224}

1 - “Ao fim de sete ${ }^{225}$ anos farás ${ }^{226}$ (um) cancelamento ${ }^{227}$ (de débitos)."228

\footnotetext{
${ }^{224}$ O primeiro objetivo desta tradução é demonstrar a estrutura literária de Deuteronômio 15, e sua inter-relação entre esses cinco blocos literários. A tradução será apresentada na forma de uma diagramação da estrutura literária do texto. O segundo objetivo é notar o fluir do texto de tal forma que se perceba aquela frase, ou palavra, que precise de análise mais acurada para seu melhor entendimento. A tradução de cada bloco literário será encontrada na análise do capítulo.

225 A pergunta que é respondida por essa construção adverbial temporal é quando seria o tempo para ser realizado o cancelamento do pagamento de dívidas. O texto estabelece que fosse ao fim de (cada) sete anos. O estabelecimento desse tempo ficaria fixado na mente dos ouvintes. Portanto, a cada sete anos um novo ciclo de liberdade das dívidas seria iniciado.

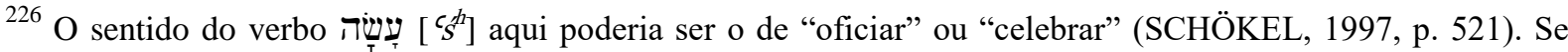
assim for, o texto dá uma declaração oficial diante do Deus de Israel, colocando a šomitțāh dentro de um contexto religioso. E nesta direção que aponta Deuteronômio 15,2. A šomitță ${ }^{h}$ é um tempo de celebração. Podese imaginar que cada endividado escravizado aguardava com ansiedade esse ano. Então, era um tempo de celebração nacional, ao menos para esse grupo seleto de israelitas. Havia uma proclamação oficial da $\breve{s}$ omițt $\bar{a}^{h}$ em Israel.

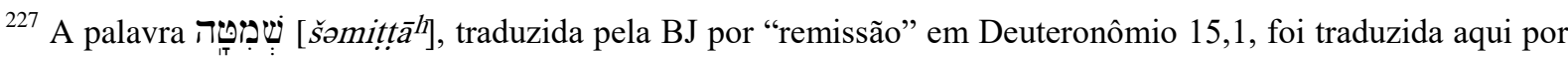
"cancelamento (de débitos ou dívidas)" porque é esse sentido que melhor se harmoniza com o conteúdo do
} 


\subsubsection{2. $\quad \mathrm{O}$ ano do cancelamento - o centro do capítulo}

O tema do capítulo é colocado numa frase simples em forma de ordem dirigida a alguém, na segunda pessoa do singular, o que, colocado na ordem invertida da frase em hebraico, faria com que a tradução ficasse assim - "Tu farás (um) cancelamento ${ }^{229}$ ao fim de sete anos". A frase é a fórmula introdutória do capítulo e funciona como uma propaganda panfletária daquilo que será dito em seguida. Para uma cultura acostumada à transmissão oral, essa declaração marcava as mentes dos ouvintes e também seria fonte de atração sobre o que isso viria a ser para aquela audiência, constituída de homens denominados pela palavra ' $b a a^{c} a$ P', bem como para aqueles que, durante os anos anteriores, haviam se endividado. ${ }^{230}$

Entretanto, essa fórmula introdutória aponta para um evento proclamado pelo "tu”, o qual será identificado no versículo seguinte como sendo o $b a^{c} a l$, o dono do empréstimo feito a um homem devedor, ${ }^{231}$ e que ele também é aquele que comprou a liberdade de seu irmão para ele

capítulo inteiro. Esta pesquisa entende que a BJ tenha sido influenciada em sua tradução para o Português pela

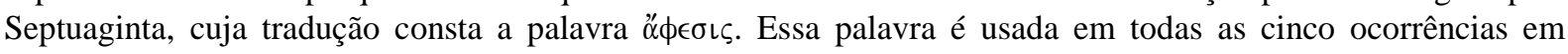

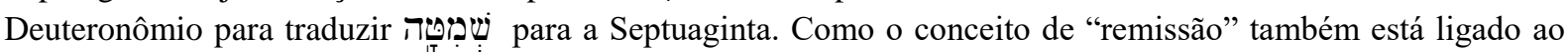
de "perdão", então se pode notar aqui a influencia dos escritos do Novo Testamento Grego. A palavra é usada

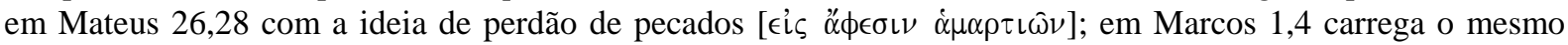

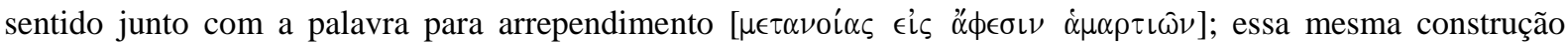
aparece em Lucas 3,3. O perdão envolve o cancelamento de dívidas, mas ele é muito mais que isso, pois

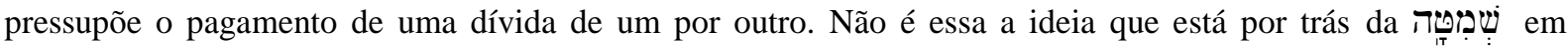
Deuteronômio, mesmo que indiretamente o conceito de um substituto esteja embutido nas promessas divinas feitas ao $b a^{c} a l$ que obedecer ao mandamento divino de cancelar a dívida ou de libertar um escravo irmão. Deus assume a dívida do devedor diante do credor e promete pagá-lo por meio de bênção. O grande desafio do credor seria confiar em seu Deus. O verbo correspondente, שמפט, é incomum dentro da BH, "é um termo técnico, o qual, em tempo antigos, era aplicado no contexto da agricultura, e, em tempos mais recentes, foi adaptado para a economia urbana e comercial" (CAIRNS, 1990, p. 146). Ezra afirma que שמפט significa "deixá-la cair", o que, ilustrativamente, é o que acontece em 2 Reis 9,33 (2003, p. 69).

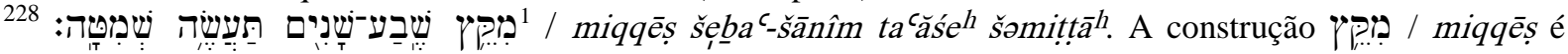

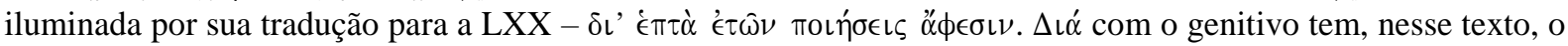
sentido de "depois" (RUSCONI, 2003, p. 121). A preposição jִ̣ também é usada em sentido temporal no texto hebraico. A tradução dessa pode ser também por "depois de" (KIRST et al., 1987, p. 130). Assim, a tradução poderia ser de qualquer modo que apontasse que, terminando o período de sete anos (como alternativas de tradução: "no término de"; "quando terminar"; "no fim de"; etc.), as dívidas do "teu irmão" deveriam ser perdoadas, ou canceladas, e ele experimentaria um novo tempo de liberdade em sua vida, possibilitando novo começo, sem dívidas e com a ajuda de seu irmão, o ba ${ }^{\complement} a l$.

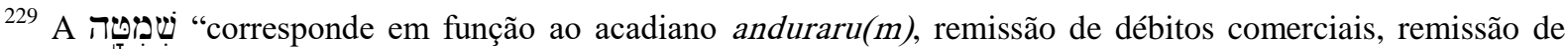
escravos privados, entrega dos depósitos de segurança" (HALOT, 2001, v. 2, p. 1558).

${ }^{230}$ Tigay menciona que, como a šmitt $\bar{a}^{h}$ visava beneficiar o pobre, nem todas as dívidas eram cobertas pelo evento da šomitt $\bar{a}^{h}$ no sétimo ano. Ele diz que, segundo a halakhah, os salários atrasados, dívidas de mercadorias dos comerciantes, e alguns empréstimos segurados não estavam cobertos pelo cancelamento de dívidas na

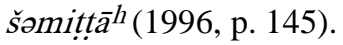

${ }^{231}$ No progresso do texto, percebe-se que o trato da dívida com bacal é feito com outro homem. Esse é identificado como alguém que é "teu irmão" e "teu próximo". 
lhe servisse como um 'ébed. Como evento proclamado oficialmente, havia uma solenidade ao redor disso, e tudo era público na comunidade onde credor e devedor viviam juntos. Essa solenidade envolvia juramentos solenes ${ }^{232}$ que o $b a^{\complement}{ }^{\complement}$ l não viria a cobrar a dívida que havia sido cancelada.

A primeira pergunta é: o que o texto quer dizer com "ao fim de sete anos" [miqqēs šę šānîm] ${ }^{233} \mathrm{O}$ que o redator está dizendo é que dentro de cada período de sete anos, no fim desse período, as dívidas deveriam ser canceladas para o devedor israelita. Assim, qualquer empréstimo deveria ser avaliado tendo em vista a proximidade do fim do período de sete anos em curso. Dessa maneira, no fim de sete anos - no término desse período de sete anos e antes do começo de um novo período de sete - haveria a liberdade de dívidas que seria proclamada em todo o Israel, mas, individualmente, por cada $b a^{c} a l$ sobre o devedor que estava sob seu domínio. ${ }^{234}$ Tigay aponta que "segundo a halakhah, os débitos eram cancelados ao pôr do sol do último dia do sétimo ano" (1996, p. 145).

Qual a importância do ano sétimo? O ano sétimo era um ano de cancelamento de dívidas, porém, no fim. ${ }^{235}$ Entretanto, dentro do contexto da šomițțăh , mas relacionado ao irmão que se vendeu como escravo, há a seguinte declaração: “Quando o teu irmão hebreu, ou (tua irmã) hebreia, se vender a ti, seis anos servirá a ti. E no ano sétimo, tu o mandarás fora livre de junto de ti (de contigo)" (Deuteronômio 15,12). Assim, "o fim de sete anos" não implica que a

\footnotetext{
${ }^{232}$ No livro de Neemias (5,1-19), um evento de protesto é levantado por aqueles que estavam endividados, haviam perdido seus campos nos empréstimos, e alguns já haviam perdido a liberdade para que dívidas fossem pagas. Para resolver o problema, Neemias pede que as dívidas sejam canceladas e que um juramento, não apenas uma palavra fosse dada, fosse prestado diante dos sacerdotes $(5,12)$. Houve uma cerimônia solene diante do representante divino, o sacerdote. Em Deuteronômio 15, a figura do sacerdote está ausente. O solenidade inteira era realizada pelo $b a c^{c} a l-o$ texto diz "tu farás šomitțătr".

${ }^{233}$ Coloca-se aqui uma teoria. É possível apresentar um forte motivo para pôr o fim de sete anos como a data máxima para o pagamento ou o encerramento de dívidas feitas nos sete anos anteriores. $\mathrm{O}$ ano sétimo era o ano de descanso da terra. Esse ano poderia ser o ano de recuperação do devedor, tendo condições de pagar a sua dívida, pois, afinal, ainda nesse ano ele estaria na dependência do dono do campo para sua alimentação. Caso não houvesse condições para sua recuperação, a dívida não seria transportada para o novo período de sete anos. Ela seria extinta na proclamação do cancelamento das dívidas pelo próprio credor, o $b a{ }^{c} a l$.

${ }^{234} \mathrm{~A}$ šmittt $\bar{a}^{h}$ era o cancelamento das dívidas fazendo com que o credor abrisse mão do recebimento de qualquer pagamento por elas. Em certo sentido, Deuteronômio 24,10-13 também fala de uma suspensão de pagamento temporário, quando o credor devolveria, no pôr do sol, o penhor que o devedor lhe houvesse dado para que servisse de cobertura durante a noite. Era uma suspensão parcial porque o credor reaveria o penhor na manhã seguinte.

${ }^{235}$ Para Driver, a palavra "fim" não deve ser pressionada a dizer exatamente o fim do ano sétimo. Para ele deve ser considerado o fim do período de sete anos e, assim, "fim" é usado para indicar que o sétimo ano tem chegado. Como demonstração disso, ele sugere que "no fim de sete anos" de Jeremias 34,14 seja o equivalente de "no sétimo ano" de Deuteronômio 15,12, "onde o período assim denotado é claramente concebido como ter sido começado tão logo o período de seis anos tenha terminado" (1895, p. 174). Assim, ao fim de sete anos não indica o fim exato do sétimo ano, mas o fim do período de seis anos e o começo do sétimo.
} 
šmitța $\bar{a}^{h}$ do irmão empobrecido endividado só chegue no final dos sete anos, mas no ano sétimo.

Qual o resultado prático disso? O recomeço para o ’ebyôn era uma forma muito bem planejada de igualar as possibilidades para todos dentro de Israel a partir do ano do descanso da terra. De um lado estava o $b a^{c} a l$ - o credor que tinha condições de sobrevivência garantida e que precisava deixar a terra descansar e viver do que ela produziria naturalmente naquele ano, de outro estava o 'ebyôn - o endividado que também esperaria viver do que a terra produziria, mas livre de qualquer débito.

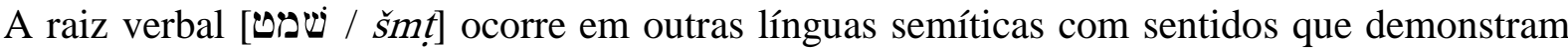
diferentes variações do mesmo conceito: Acádio - "retirar"; Árabe - "escaldar, despejar a água quente sobre, suspender" (MULDER, 2006, p. 198-199). A ideia de um cancelamento pode ser vista nos sentidos de "retirar" e "suspender". Assim, o $b a^{`} a l$ retira ou suspende seus direitos ao recebimento de uma dívida, demonstrando que o cancelamento dela é uma decisão unilateral do $b a^{c} a l$ ao suspender seus direitos de recebimento. ${ }^{236}$

\subsubsection{O ’ebyôn: o bacal e seu empréstimo ao ’ebyôn - seu irmão e seu próximo (Deuteronômio 15,2-6)}

Depois de declarar o "título" do que o redator pretende falar, ele passa a definir o que ele tem em mente com a šmitt $\bar{a}^{h}$. Ao definir a šomitt $\bar{a}^{h}$, o redator apresenta os principais personagens envolvidos com ela. O primeiro é o $b a^{c} a l$, aquele que tinha condições de se tornar um credor de um ’ebyôn. O segundo é o ’ebyôn, identificado como sendo "seu

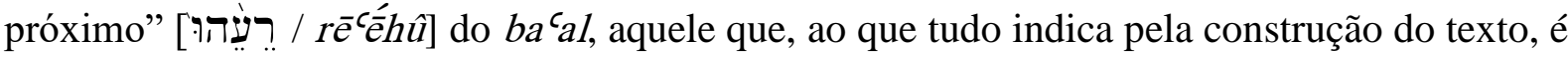

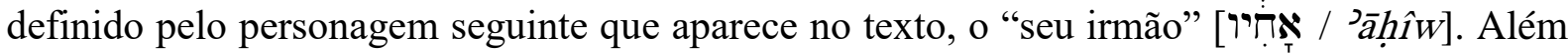
desses personagens, outros aparecem. Um deles é a comunidade que, mesmo que ela não seja destacada, ela está presente na proclamação que o $b a^{c} a l$ faz da šomitțăh , porque ela é um evento público e formalizado pela sua declaração.

\footnotetext{
${ }^{236}$ Thompson diz que "uma das características da expressão deuteronômica da lei israelita... é a profunda preocupação com o bem estar do membro individual da sociedade, fosse ele rico ou pobre" (1982, p. 177). O bem estar que a šomitța $a^{h}$ levaria a alguém que não pôde pagar uma dívida dentro de um período de sete anos é de difícil descrição. Porém, sem exageros, havia expressão de muita alegria, mesmo quando alguém viesse a ficar como escravo permanente de seu ba ${ }^{\complement} a l$.
} 
Os outros Entes Silenciosos que aparecem no capítulo são o 'e $e \underline{b} \underline{e} \underline{d}$ e a ${ }^{\top} \bar{a} m \bar{a} h$, e, juntamente com esses, a comunidade e os juízes, pois quando o ${ }^{\complement} e \underline{b} e \underline{d}$ e a ${ }^{~} \bar{a} m \bar{a}^{h}$ queriam ficar para sempre na casa de seus senhores, os juízes eram chamados para atestar a fala deles, pois a decisão não podia ser reconsiderada no futuro depois de tomada. Estes (juízes, comunidade) não estão declaradamente presentes nesse texto, mas isso não quer dizer que suas presenças não estivessem subentendidas.

Finalmente, o Deus de Israel é apresentado como aquele que está ordenando a šomitță $\bar{a}^{h}$ por meio da fala do redator, e, ao mesmo tempo, é a Deus que este evento é proclamado. Isso quer dizer que ela vem como expressão de obediência do $b a^{\complement} a l$ ao seu Deus e como demonstração de sua honra a ele.

\subsection{Tradução (Deuteronômio 15,2-6)}

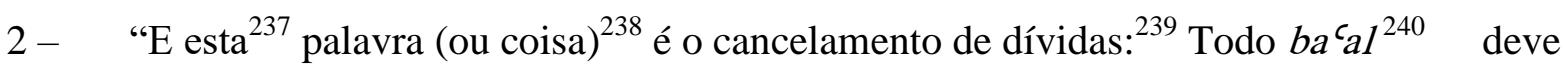
abrir sua mão de empréstimo que fez (emprestou) ao seu próximo. ${ }^{241}$ Ele (o bacal) não oprimirá seu próximo e seu irmão porque proclamou ${ }^{242}$ o cancelamento de dívidas para o Deus ${ }^{243}$ de Israel." ${ }^{244}$

\footnotetext{
${ }^{237}$ Aqui há uma possível resposta à audiência. A audiência está curiosa por querer saber o que vem a ser a šsmițta $\bar{a}^{h}$. Israel ouviu do ano sétimo de descanso para terra e do ano cinquenta de devolução de terras e do duplo sábado de descanso da terra (Levítico 25), mas, o que vem a ser a šomitță $\bar{l}$ ? Deuteronômio 15,2 se propõe a responder essa pergunta. Como o orador está falando a um grupo de $b a{ }^{c} a l$, o questionamento sobre o significado šmitțăth vem desse grupo.

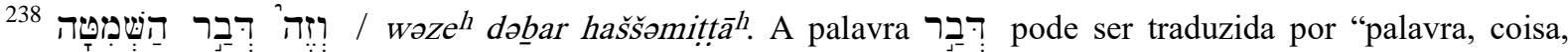
assunto". Aqui se optou por manter a ideia de palavra, tendo em vista que o texto é considerado uma comunicação de uma mensagem divina.

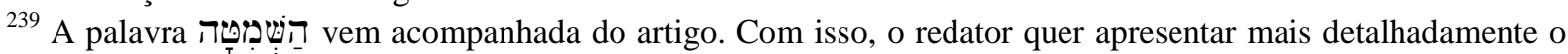

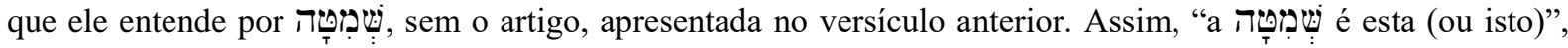
segundo o redator.

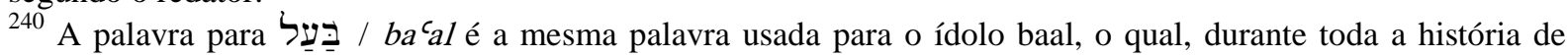
Israel fez dura competição com o culto ao Deus de Israel. Mas aqui ela carrega o sentido de proprietário ou dono de terras ou, simplesmente, o senhor de posses que fez o empréstimo. Pode ser aqui uma referencia ao chefe do clã do "teu irmão".

${ }^{241}$ No ato de justiça (misharum) do rei babilônico Ammitsaduka, os empréstimos feitos para negócios não eram cancelados (TIGAY, 1996, p. 145).

${ }^{242} \mathrm{O}$ verbo está na terceira pessoal masculina singular [Nר $\left.\boldsymbol{N}_{T} / q \bar{a} r \bar{a}\right]$, sugerindo que quem proclama a libertação das dívidas é o próprio $b a^{\complement} a l$. Se assim for, como sugere o texto, então a proclamação era um evento solene que ocorria dentro da propriedade do bacal. Aqui o sentido de "proclamar" é mais evidente, pois um anúncio público é feito.

${ }^{243}$ O propósito do cancelamento de dívidas ser para Deus é que ele, no final, deve servir de honra ao Deus de Israel, pois ele tem dado ao credor a riqueza para ter condições de deixar cair de sua mão o direito de recebimento do pagamento da dívida (EZRA, 2003, p. 69). Ainda, segundo Ezra, "a associação aqui com Deus é devida a declaração anterior que 'é o sábado de Deus (Levítico 25,2)”' (2003, p. 69).
} 
3 - $\quad$ "O estrangeiro ${ }^{245}$ tu pressionarás (para pagar). ${ }^{246} \mathrm{E}$, aquilo que é para ti (que te é devido), tu abrirás tua mão ao teu irmão.,247

4 - "Porque ninguém ${ }^{248}$ não será pobre ${ }^{249}$ [ 'ebyôn $]$ em ti. ${ }^{250}$ Porque deveras ${ }^{251}$ o Deus de Israel te abençoará na terra que '’ạdōnāy ${ }^{252}$ teu Deus está dando para ti (em) herança, para a possuir." 253

5 - $\quad$ "Somente se deveras ${ }^{254}$ ouvires a voz de 'ādōnāy teu Deus para guardar, para fazer todo este mandamento que eu estou te ordenando hoje."255

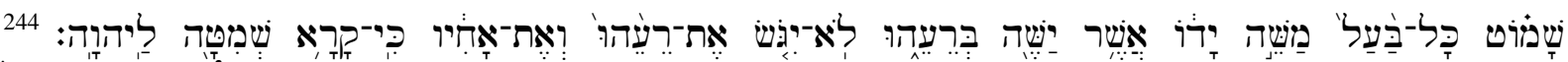

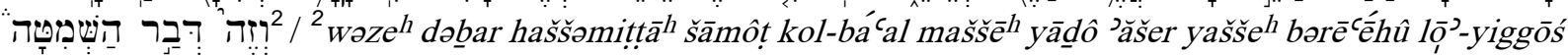

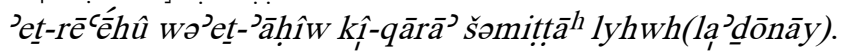

${ }^{245}$ Como o gēr era protegido pela legislação deuteronômica para o estrangeiro residente, o "estrangeiro" ao qual

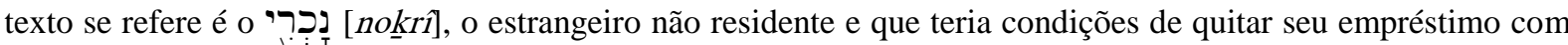

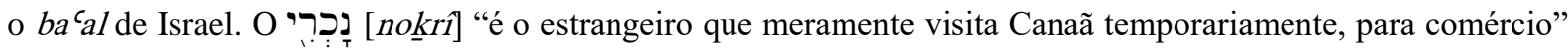
(DRIVER, 1895, p. 175).

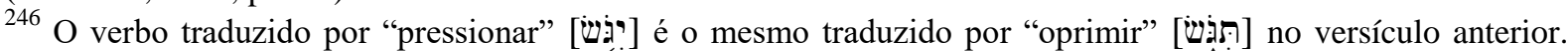
Nos dois casos, o que está sendo permitido e proibido é o uso da força ou opressão sobre um devedor para receber o pagamento. A BJ traduz o verbo נָּג no v. 2 e 3 pelo verbo "explorar". Para esta pesquisa, no entanto, a ideia do texto é a de pressionar para receber o pagamento de uma dívida, não a ideia de explorar com intuito de tomar além daquilo que não lhe pertence.

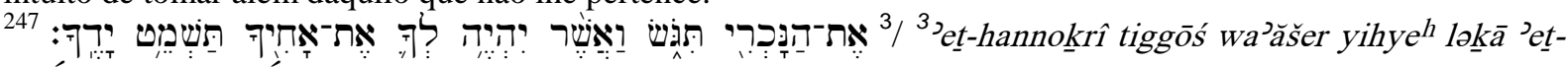

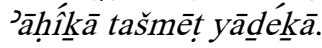

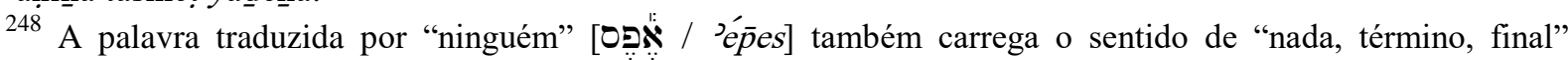
(DHPAP, 1987, p. 16). De qualquer forma, o que segue afirma que com a benção divina Israel deixaria de ter pobres entre seus irmãos. Assim, a cessação de pobres seria decorrente da benção divina. Aparentemente, esse tempo ideal nunca chegou à sua realização.

249 "Cuida para que não haja pobre em tua casa que espere uma ajuda e não a encontre absolutamente" (CHOURAQUI, 1997, p. 176). Ele pressupõe que o texto esteja se dirigindo ao líder do clã e a pobreza que pudesse chegar a ela.

250 “... o ideal teológico: obediência consciente à Torah de Yahweh com suas provisões humanitárias sábias efetivamente eliminaria pobreza, ou a repararia antes que ela se tornasse crônica" (CAIRNS, 1990, p. 148).

${ }^{251}$ Aqui há a presença daquela construção hebraica típica para reforço, quando um verbo finito é acompanhado de mesma raiz no infinitivo absoluto: “... porque certamente o Deus de Israel te abençoará”

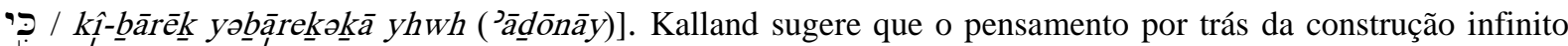
absoluto + imperfectivo de mesma raiz seja refletido na tradução proposta por ele: "ele ricamente te abençoará". No seu entender, a plena obediência será honrada com ricas bênçãos garantidas (1992, p. 105).

${ }^{252}$ Uma opção adotada nesta pesquisa para traduzir no Nome do Deus de Israel.

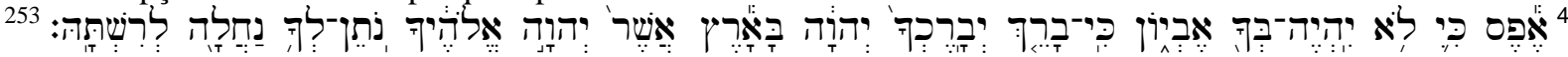

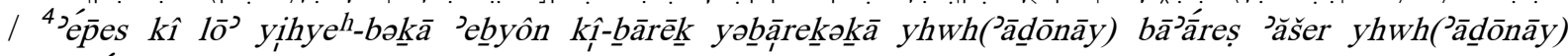

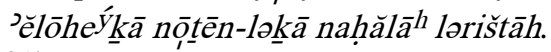

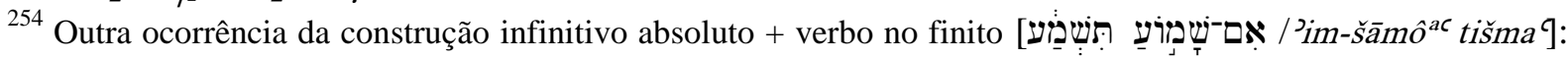
"se guardar tu guardares".

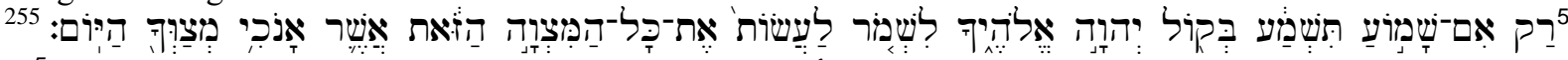

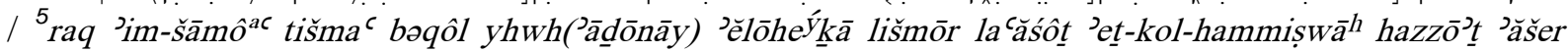
’̄nōknî moșawwok̄ā hayyôm. 
6 - "Porque ${ }^{2} \bar{a} \underline{d} \bar{o} n a \bar{y} y$ teu Deus te abençoará, ${ }^{256}$ conforme falou para ti. E tu emprestarás ${ }^{257}$ a muitos povos, mas tu não tomarás emprestado. Tu governarás sobre muitos povos, porém sobre ti (os muitos povos) não governarão." 258

\subsection{O que caracteriza o evento da šmitțăt}

2.3.5.2.2.1. É um evento oficialmente proclamado (Deuteronômio $15,2)$

2 - "E esta palavra (ou coisa) é o cancelamento de dívidas: Todo bacal (senhor) deve abrir sua mão de empréstimo que fez ao seu próximo. Ele (o $\left.b a^{c} a l\right)$ não oprimirá seu próximo e seu irmão porque proclamou o cancelamento de dívidas para o

Deus de Israel."

2.3.5.2.1.1. Uma explicação necessária: O que um Ba`al (“credor”) deve fazer com as dívidas de um emprestador?

O diálogo entre o orador e sua audiência exige uma explicação sobre o que vem a ser a šmitțăh . Deuteronômio 15,2 (e também 15,3-6) se propõe dar uma explicação do que viria ser o evento do Cancelamento de Dívidas, pois, era a primeira vez que os ouvintes ouviam sobre a šomitța $\bar{a}^{h}$. Ela consistiria em que todo $b a^{c} a l$ abriria mão das dívidas feitas com ele pelo seu irmão ou pelo seu próximo.

Deuteronômio 15,2 apresenta clara especificação que em Deuteronômio o ’ebyôn qualifica

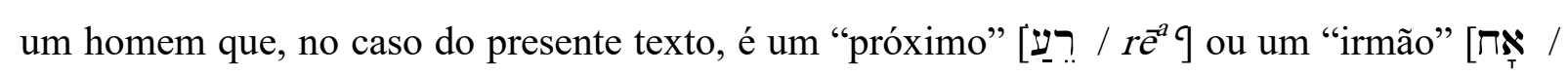
गāḥ] (“o teu próximo, o qual é teu irmão") do ba`al. De qualquer forma, ele não é

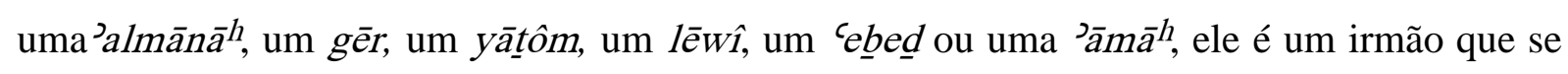

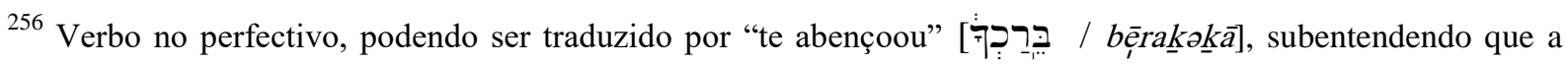
proclamação da šomitța ${ }^{h}$ deveria tomar por base aquilo que ele já tinha recebido até ali da parte de ’ādōnnāy teu Deus. Entretanto, como esse parágrafo parece ser uma resposta ao questionamento do $b a^{c} a l$ sobre o que vem a ser a šmițtāa , então optou-se por manter a tradução do verbo no futuro.

${ }^{257}$ Verbo [עבט / $\left.b \underline{b} t\right]$ que carrega o sentido de "emprestar mediante penhor", no hifil, tanto aqui como no versículo 8 (KIRST et al., 1987, p. 172). Ele foi traduzido aqui por "emprestarás" e "tomarás emprestado" neste versículo.

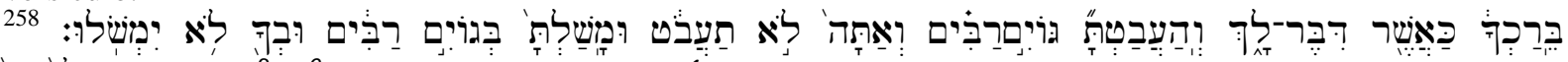

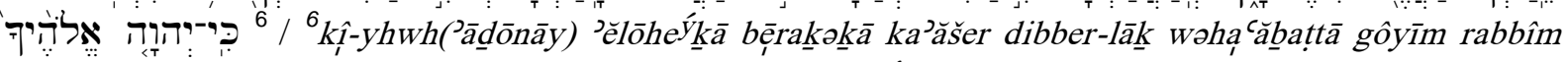

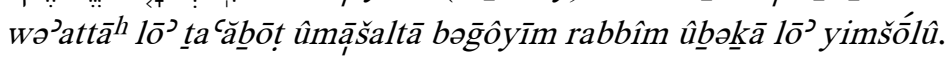


tornou um ’ebyôn do bacal. É para benefício dele que a šomițtāa é solenemente proclamada pelo $b a^{c} a l$.

Mas o que vem a ser o abrir de mão do bacal?

\subsection{2. A mão do $b a^{\varsigma} a l$}

A “mão" [דיT $/$ yāg $]$ é empregada nesse capitulo como representação do bacal. Aqui ela é capaz de representar o próprio ba ${ }^{c} a l$, onde uma parte dele é usada para o representar. Porém, o ato de abrir a mão implica em soltar aquilo que ele segura. E o que é que o ba`al segura? Ele segura o direito de receber representado naquilo que lhe fora concedido como garantia do recebimento - penhor (Deuteronômio 24,10). Havia a obrigação moral urgente sobre o $b a^{c} a l$ para que ele emprestasse ao próximo que caiu em dificuldades (CHOURAQUI, 1997, p. 177).

Abrir mão da garantia de recebimento do pagamento era a demonstração que o devedor não tinha mais dívida com o bacal. E sem dívidas, o ’ebyôn tinha a oportunidade de reconstruir sua vida.

2.3.5.2.2.2. Inclusão e exclusão na šmitțāa

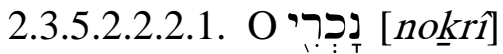

3 - "O estrangeiro tu pressionarás. E aquilo que é para ti, tu abrirás tua mão ao teu irmão."

Aqui a šomitțăh apresenta uma cláusula de exclusão - o nokrrînão estava incluído no ano do cancelamento de dívidas. Ao contrário, o nokxrî deveria ser forçado a pagar aquilo que ele devia ao bacal. O nokkrî não estava sujeito à obrigação de abrir mão do produto de sua propriedade a cada sete anos como um israelita e, assim, o bacal também não tem motivo para

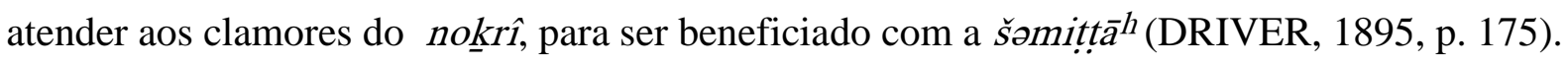




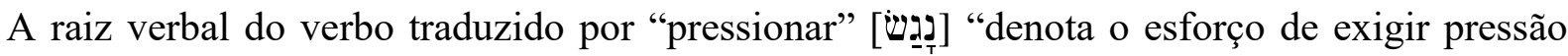
opressiva para pagamento ou trabalho" (COPPES, 1980, p. 553). ${ }^{259}$ É algo como a permissão, divinamente permitida e legalmente declarada, para algum tipo de violência com o fim de receber do nokrî o que ele devia. Entretanto, essa "violência" teria que ser concedida pela justiça, dando ao $b a^{c} a l$ o direito de ter de volta do nok $r i ̂$ o empréstimo feito, com a implicação da venda do nokrrî, como escravo, para a quitação da dívida.

Talvez a melhor ilustração desse verbo esteja no particípio que se encontra em Êxodo 3,7: “E disse 'ādōnāy: De fato vi a aflição do meu povo (que está) no Egito, e ouvi o seu grito de diante dos que lhe oprimem. Porque eu conheço o seu sofrimento (angústia)". ${ }^{260}$ A BJ traduz

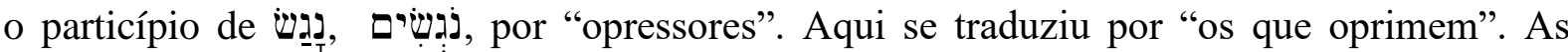
palavras "grito" e "sofrimento", presentes no versículo, demonstram que os opressores do rei do Egito agiam, não somente com palavras, mas com violência física.

Desse modo, o que o redator está autorizando é a exclusão do nokxrî da šomitțāh , ao mesmo tempo em que permite que o $b a^{c} a l$ faça uso da força, se possível, para receber aquilo que o nok rrî lhe deve. Opostamente, porém, o bacal deveria agir de modo diferente com o "teu irmão" dando-lhe liberdade das dívidas - abrindo-lhe a mão do que ele lhe devia, deixando de lado a garantia de pagamento.

Qual a finalidade deste "abrir mão" daquilo que é do ba`al em favor de seu irmão ’ebyôn? A resposta se encontra no versículo seguinte: o projeto de uma comunidade ideal onde não há "teu irmão, teu próximo" ’ebyôn.

\subsection{2. Uma comunidade ideal - sem ’ebyôn}

4 - $\quad$ "Porque ninguém será pobre [’ebyôn] em ti. Porque deveras o Deus de Israel te abençoará na terra que Jādōñāy teu Deus está dando para ti herança, para a possuir."

\footnotetext{
${ }^{259}$ Schökel traduz esse verbo por "premer", "exigir" (1997, p. 420). Berezin o traduz por "oprimir", "forçar", "pressionar" (BEREZIN, 2003, p. 427). Esses sentidos para a tradução de נָָגֵ cooperam para ideia de uso de força na cobrança da dívida do nok̂rî, caso ele não quisesse pagar ou quisesse se beneficiar com a šomitță ${ }^{h}$.

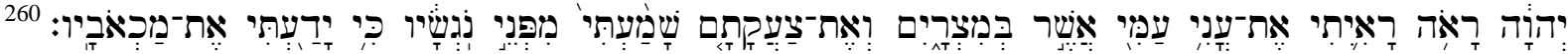

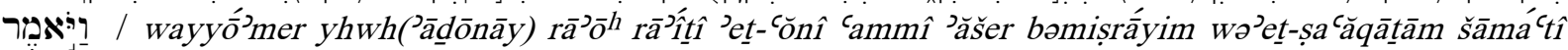

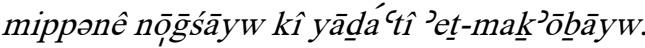


"Ninguém será pobre". O que isso quer dizer? O contexto da šomitța $\bar{a}^{h}$ explica a frase. O que o redator quer dizer é que, não que não haverá mais 'ebyôn, mas que não haverá mais 'ebyôn endividado, dando à šomitt $\operatorname{ta}^{h}$ grande significado de um divisor de águas - ela fazia separação entre o ’ebyôn com dívidas e o ’ebyôn sem dívidas a partir da šomitțāh . Após a šomițțăh o ’ebyôn continuaria 'ebyôn, mas sem a obrigação de pagar uma dívida e com possibilidades “iguais" as do bacal para prosperar. Sem 'ebyôn endividado, a šomitță ${ }^{h}$ perderia o seu sentido.

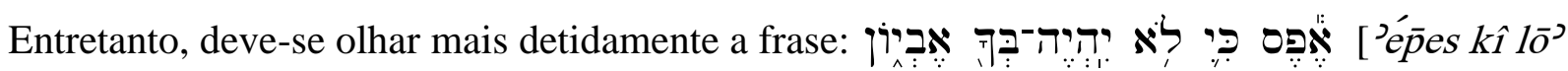

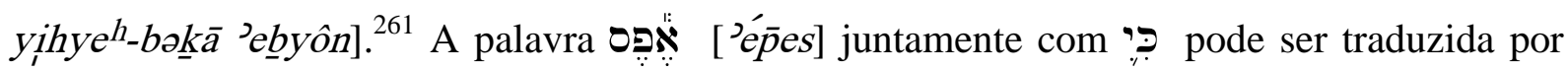
"só que" (KIRST et al., 1987, p. 16) deixando a construção com a seguinte tradução: "Só que não haverá, entre ti, um 'eḅyôn”. Berezin diz mais. Além de sugerir que a construção possa ser traduzida por "só que", ela propõe também que se introduza uma conjunção adversativa, “contudo" (BEREZIN, 2003, p. 9), ${ }^{262}$ fazendo contraste com o que foi dito anteriormente: "O estrangeiro tu pressionarás. E aquilo que é para ti, tu abrirás tua mão ao teu irmão" (15.3b). Primeiro, o ba cal não pressionará o ’ebyyôn como ele deve fazer com o noknrî. E, segundo, ele também agirá para dar chance a liberdade de dívidas ao seu irmão. Há uma clara pressão do $b a^{c} a l$ sobre si mesmo. Com essa ideia em mente, as condições para que não haja ’ebyôn "no meio de ti" só estarão presentes em Israel se as condições seguintes vierem a ser estabelecidas.

Quais são as condições ideais para a cessação de pobreza em Israel? A razão para a cessação de um pobre entre o povo de Israel será a bênção de Deus sobre a terra que será dada por herança aos filhos de Israel. Note como ficaria uma tradução para Deuteronômio 15,3.4: “O estrangeiro tu pressionarás (para receber o empréstimo). E aquilo que é para ti (que te é devido do ’ebyôn nativo) tu abrirás tua mão ao teu irmão. Só que (como resultado disso) não

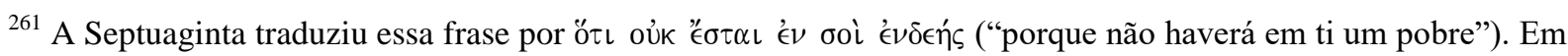

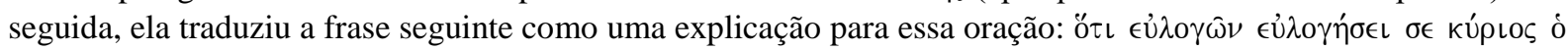

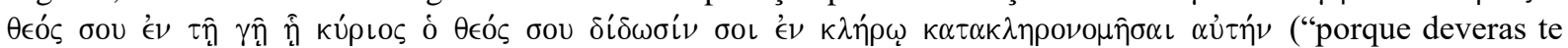
abençoará o Senhor teu Deus na terra, a qual o Senhor teu Deus te dará em porção de herança"). Deus abençoará o $b a^{\varsigma} a l$, e, com isso, ele terá condições de livrar seu irmão de dívidas, possibilitando o recomeço.

${ }^{262}$ Schökel sugere que a tradução para construção verdade que, agora que" (1997, p. 73). Para ele, essa construção também é adversativa. A šomitța $\bar{a}^{h}$ é o motivo para que Israel deixe de ter pobres. Ora, sem pobres para socorrer, Israel teria recursos para emprestar a outros povos, como será salientado em Deuteronômio 15,6.
} 
haverá ’ebyôn em ti. Porque deveras o Deus de Israel te abençoará na terra que ’ād̄ōnāy teu Deus está dando para ti (em) herança, para a possuir". Em resposta a generosidade do ba ${ }^{c} a l$, Deus deixará a terra de sua herança com ele (e seus filhos). Para destacar, as duas condições para que não haja 'ebyôn em Israel - o $b a^{c} a l$ deve abrir mão do que ele esperava receber do ’ebyôn, na šomitță $\bar{a}^{h}$, devolvendo-lhe as garantias dadas para o pagamento; e, por sua vez, Deus, em vista da obediência do $b a^{c} a l$ na šmițt $\bar{a}^{h}$, será favorável com $b a^{c} a l$ fazendo com que sua terra seja próspera no ano de seu descanso (o sétimo ano).

Em Deuteronômio 15,4 a pesquisa é introduzida com o sistema de recompensas muito bem elaborado pelo redator como forma de incentivar a obediência por parte do ba ${ }^{c} a l$. Era uma forma de quebrar a resistência da audiência para a colocação em prática da šomitță $\bar{h}$, caso ela se sentisse ameaçada por eventuais prejuízos com o cancelamento de dívidas a receber. Esse sistema de recompensa não é privativo de Deuteronômio 15,4. Ele está espalhado em todo o livro.

\subsection{3. Deuteronômio e seu sistema de recompensas}

Há um sistema de recompensas elaborado dentro do livro de Deuteronômio, formado por diferentes expressões que ocorrem separadamente e, nalguns casos, vêm juntas, com o fim de enfatizar a recompensa pela obediência àquilo que fora ordenado. Porém, nem todas elas dizem respeito a algum mandamento que se relacione no trato do tu/vós com os Entes Silenciosos. Mas tratam de recompensas pela obediência a algum mandamento apontado pelo redator naquela unidade textual.

Isso quer dizer que a sociedade deuteronômica era baseada na meritocracia? Sim e não. Não porque Deuteronômio 8 assinala que a base da escolha divina de Israel não tinha como fundamento os méritos do escolhido, mas o amor eletivo do Deus de Israel para com seu povo. Deus escolhera Israel porque ele tinha amor por ele.

Por outro lado, a resposta é sim. A partir do momento que Israel aceita um relacionamento pactual com seu Deus, a sua sobrevivência, como povo abençoado, dependeria de sua obediência à Palavra divina (Deuteronômio 8,3: “o homem não vive só de pão, mas de tudo o 
que sai da boca do Senhor, disso vive o homem."). ${ }^{263}$ Além do mais, Israel poderia não corresponder às expectativas divinas apenas por sua saída do Egito sob a direção divina por meio de Moisés. Como, então, manter a fidelidade de Israel depois que ele tomasse posse de sua herança na Terra da Promessa? A fidelidade de Israel resultará em bênçãos divinas sobre a herança do Israelita que se mantiver fiel ao seu Deus. Isso implicava em continuidade ou descontinuidade da herança. Se o israelita fosse fiel a Deus, ele continuaria em sua herança. Caso contrário, ele a perderia.

Portanto, esse sistema de recompensa tinha como finalidade estimular o tu/vós a cumprir o que Deus pedia dele, cujo resultado era demonstrar que a vida a ser usufruída na Terra da Promessa era resultado da obediência do povo de Israel ao seu Deus. Além disso, cada uma das promessas de recompensa tocava na alma do ser humano que a ouvia - o sucesso, tanto em seu relacionamento com seu Deus quanto em seus empreendimentos. No relacionamento com seu Deus porque ele mostrava obediência ao mandamento divino; em seus empreendimentos porque, como resultado de seu cumprimento ao mandamento divino, ele tinha prosperidade na sua herança. Com isso, a vida bem sucedida no campo, ou na cidade, estava no objetivo de cada uma destas recompensas. Isso quer dizer que o Deuteronômio foi dado para a vida no mundo - na terra que viria como herança, ele é um livro que é "um guia do caminho para se viver feliz neste mundo", onde é seu campo de atividade (Torá, 2001, p. 535 , v. 13). O objetivo do redator "não é ensinar fé somente, mas fé com implicações comportamentais" (TIGAY, 1996, p. 57).

Dentro de Deuteronômio há um claro sistema de recompensas desenvolvido. ${ }^{264}$ A questão que este sistema responde é: O que levaria uma pessoa a obedecer aquilo que lhe está sendo ordenado, como na šmițțăh, por exemplo? Qual a recompensa que ela teria se fosse obediente ao seu Deus? A resposta é: a promessa divina que ela teria vantagens nas suas

\footnotetext{
${ }^{263}$ Notar outros exemplos da meritocracia dentro de Deuteronômio 8: a vida, a multiplicação e o usufruto da herança dependiam da obediência aos mandamentos divinos $(8,1.6)$; a memória dos feitos de Deus são essenciais para a permanência na Terra da Promessa $(8,11-20)(B J)$.

${ }^{264} \mathrm{O}$ livro de Lucas $(14,13.14)$, o terceiro evangelho nos escritos do Novo Testamento, diz: “... quando deres uma festa, chama pobres, estropiados, coxos, cegos; feliz serás, então, porque eles não têm com que te retribuir. Serás, porém, recompensado na ressurreição dos justos" (BJ). Essa citação mostra que o texto do Novo Testamento dependeu do texto de Deuteronômio, com a diferença que o texto de Deuteronômio 15 coloca a recompensa dentro da vida do $b a^{\complement} a l$, mesmo que no futuro. A citação de Lucas coloca a recompensa em um período ideal, chamado de "ressurreição dos justos".
} 
realizações como resultado de sua obediência. Esse sistema de recompensa incluía as declarações seguintes. ${ }^{265}$

A seguir serão dadas as recompensas prometidas em Deuteronômio para a obediência de Israel a algum mandamento divino.

2.3.5.2.2.2.3.1. "O Deus de Israel te abençoará em tudo o que fizeres" (Deuteronômio 7,13; 15,4.6.10.18; 28,8; 30,16).266

A resposta que se busca é saber qual o tipo de bênção que o povo deveria esperar por ser obediente ao seu Deus. O texto de Deuteronômio 7,13 detalha a bênção que o povo deveria esperar que lhe viesse como resultado de sua obediência - “... abençoará também o fruto do teu ventre, e o fruto do teu solo, teu trigo, teu vinho novo, teu óleo, ${ }^{267}$ a cria das tuas vacas e a prole das tuas ovelhas" (BJ). ${ }^{268}$ Essa declaração é demonstrativa de que o povo entendia o que o redator queria dizer por bênção divina, mesmo em texto onde ela não fora detalhada para seus ouvintes.

Entretanto, ao proclamar que haverá recompensa para o bacal, em Deuteronômio 15,4.6.10.18, o redator está assumindo que outro pagará a dívida do ’ebyôn com o bacal. Ao proclamar a šomitțāh o bacal estava transferindo a dívida do ’ebyôn para ’āâdōnāy seu Deus.

\footnotetext{
${ }^{265}$ Nalgumas destas citações havia dupla recompensa como estímulo. Por exemplo, em Deuteronômio 22,6-7: "para que te vá bem e prolongues teus dias". O que há aqui é que a frase seguinte explica o que o redator quer dizer com a primeira. O que significa ir bem? Significa ter longevidade. A mesma coisa parece estar presente no texto de Deuteronômio 5,33 onde está presente uma recompensa tripla: "para que vivais e bem vos suceda, e prolongueis os vossos dias na terra que haveis de possuir". O que significa viver? Significa ser bem sucedido e ter longevidade. A ideia não é viver por viver, mas o desfrutar da vida no mundo (especificamente na herança) sob a benção do Deus de Israel. Portanto, obediência a Deus resultará em vida: prosperidade e longevidade.

${ }^{266}$ Há oito ocorrências dessa recompensa em Deuteronômio, mas metade se encontra em Deuteronômio 15, mostrando a relevância da šomitța $\bar{a}^{h}$ e, por outro lado, a dificuldade que o povo encontraria para coloca-la em prática. O redator estava estimulando a obediência do povo com essas promessas de recompensas.

${ }^{267}$ Aqui há três importantes produtos da Terra da Promessa (notar Deuteronômio 11,14; 12,17; 14,23; 18,4; 28,51) - a fertilidade da terra está unida com a fertilidade dos animais, juntamente com a fertilidade da esposa (CAIRNS, 1992, p. 91, 92).

${ }^{268}$ Deuteronômio 7,13 não é uma promessa de recompensa para o povo pôr em prática os mandamentos divinos (v. 12). Mas, o detalhe aqui é aquilo que o texto aponta como sendo o tipo de bênção que o povo deveria esperar - “... abençoará também o fruto do teu ventre, e o fruto do teu solo, teu trigo, teu vinho novo, teu óleo, a cria das tuas vacas e a prole das tuas ovelhas" (BJ). O texto apresenta por duas vezes o verbo abençoar. No primeiro, o

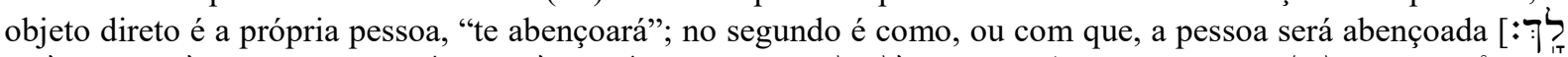

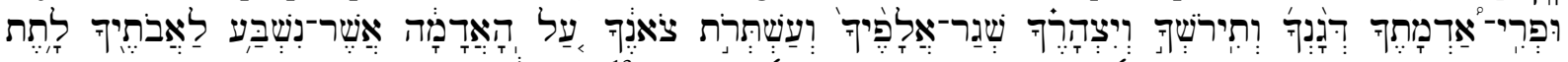

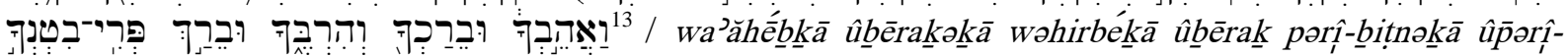

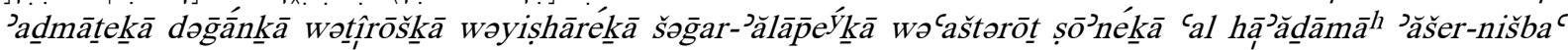

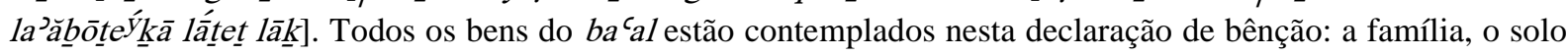
que será fértil, suas plantações e seus animais.
} 
Esse, por sua vez, assumia o compromisso de efetuar o pagamento ao bacal, no futuro, por meio do cumprimento de sua promessa de abençoá-lo.

Mesmo que não haja aqui, de forma expressa, a figura do parente resgatador (Levítico

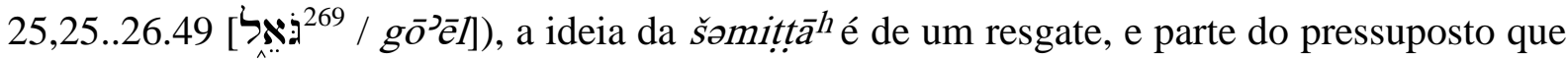
nenhum membro do povo de Israel deve viver escravizado por ninguém, nem por uma dívida, a não ser que ele opte por uma escravidão voluntariamente. ${ }^{270}$ Assim, a bênção é uma troca de garantia de pagamento. $\mathrm{O} b a^{c} a l$ troca (ele deixa a garantia cair de sua mão) a garantia de pagamento dada pelo ’ebyôn pela garantia de pagamento dada por ’’ādōnāy seu Deus, a bênção sobre seus bens na Terra da Promessa.

2.3.5.2.2.2.3.2. “... prolongareis os vossos dias” (Deuteronômio 4,$40 ; 5,16.33 ; 6,2 ; 11,9.21 ; 17,20 ; 22,7 ; 25,15 ; 30,20$; $32,47)^{271}$

O usufruto da herança na Terra da Promessa dependia dos anos de vida de cada um. Morrer cedo representaria uma demonstração do desfavor divino com o falecido precocemente. Assim, o esticamento dos dias de um israelita na sua herança era algo desejado e prometido por Deus como resposta à obediência de Israel a sua Palavra.

Em Deuteronômio 5,16, o quinto mandamento resultará no prolongamento da vida que virá sobre aqueles que honrarem seus pais, numa demonstração que "o direito das futuras gerações de israelitas a herança da terra de Israel de seus pais é contingenciada pela honra a eles" (TIGAY, 1996, p. 70). Pode-se dizer que a bênção divina tem um custo - a obediência do israelita. Entretanto, o esticamento da vida é mais que longevidade. Cairns afirma que é "vida

\footnotetext{
${ }^{269}$ Aqui há um qal particípio do verbo tanto pode resgatar a possessão de seu irmão que foi vendida quanto ao próprio irmão que se vendeu como escravo (Levítico 25,25-55). O gōēel também agia como o "vingador do sangue" (BJ), fazendo justiça ao vingar o sangue inocente derramado de seu parente próximo (Números 35,12-29). O gō’e $l$ aparece sete vezes nessa unidade textual $(35,12 \cdot 19 \cdot 21.24[2 \mathrm{x}] \cdot 27[2 \mathrm{x}])$. A vida se pagava com a vida. E o gōe $\bar{e} l$ era quem tinha a responsabilidade de a cobrar. Mais adiante, Números 35,33 mostra que o $g \bar{o} \bar{e} \bar{l} l$ age como um sacerdote, ao fazer expiação pela terra por meio da morte do homicida.

${ }^{270}$ A base dada por Levítico para que um membro do povo de Israel pudesse ser resgatado é que Israel é um povo de servos de 'ạdōnāy teu Deus, os quais já experimentaram a escravidão compulsória e foram resgatados por 'āâōnāy seu Deus. Portanto, eles são servos de 'āạōnāy (Levítico 25,42.55).

${ }^{271}$ Em Deuteronômio 30,18 se encontra uma recompensa oposta ao prolongamento dos dias. A desobediência levaria ao não prolongamento dos dias. Seria um encurtamento da vida do povo de Israel. Afinal, a vida depende da obediência aos mandamentos divinos.
} 
que possui qualidade porque é vivida sob a constante proteção e condução de Deus bem como em relacionamento com ele" (1992, p. 54).

\subsection{3.3. "para que te vá bem" ou "para que bem vos suceda" (Deuteronômio 4,40; 5,16.29.33; 6,3.18.24; $12,25.28 ; 19,13 ; 22,7 ; 305.9$ ).}

O sucesso é o que está previsto nessa promessa de recompensa. Mas não é qualquer sucesso. É o sucesso que resulta de sua obediência ao seu Deus, e isso inclui a conquista dos povos ocupantes da Terra que será dada a Israel como herança. Para que Israel tivesse a sua herança, ele teria que conquistar. O sucesso nessa conquista viria como resultado de sua obediência.

2.3.5.2.2.2.3.4. "para que vivais" (Deuteronômio 4,1; 5,33; 8,11).

A vida para Israel é muito mais que apenas viver. É desfrutar do prazer de viver com a bênção divina. Assim, o israelita vivia para o trabalho, o culto e sua família. Quando ele participava de uma festa, ele tinha suas razões: desfrutar do que Deus lhe tinha dado e repartir isso com sua família e os pobres (Deuteronômio 26,1-18). Portanto, a promessa da vida está intimamente relacionada com o prolongamento dela, pois o desfrutar de seus relacionamentos sob a bênção divina só aconteceria se o israelita tivesse vida longa para usufruir de todos os bens que sua herança poderia dar.

\subsection{3.5. "para que entreis e possuais a terra" (Deuteronômio 4,1; 8,1;11,8).}

Essa promessa de recompensa mostra o que o israelita estava pensando na conquista da Terra. Ele até poderia entrar na terra, mas ele usufruiria dela como terra conquistada? Essa recompensa promete satisfazer os dois elementos. Ele não somente entrará na Terra como desfrutará dela como sendo dele.

As recompensas têm dupla finalidade. A primeira é levar o ouvinte a pensar no ganho que ele obterá se for obediente ao mandamento que está sendo dado. Ele recebe a garantia pela sua obediência. A segunda finalidade é apenas implicada. Se o ouvinte não "fizer" aquele mandamento, ele não receberá a bênção, mas a disciplina ou juízo como forma de protesto divino contra a deslealdade do israelita à aliança estabelecida com ele por meio de seus "pais". Todas as recompensas tem um garantidor - o Deus de Israel. Ele é aquele que, por 
meio do redator, empenha sua palavra como garantia que o cumprir da ordem divina dará certo para o israelita obediente.

2.3.5.2.3. O imperativo da obediência para não ter ’ebyôn (Deuteronômio $15,5.6)$

5 - $\quad$ "Somente se deveras ouvires a voz de गādōnāy teu Deus para guardar, para fazer todo este mandamento que eu estou te ordenando hoje."

6 - "Porque 'ādōnāy teu Deus te abençoará, conforme falou para ti. E tu emprestarás a muitos povos, mas tu não tomarás emprestado. Tu governarás sobre muitos povos, porém sobre ti não governarão.”

Esses dois versículos são um reforço ao incentivo dado para o cumprimento da promessa de não haver 'ebyyôn no meio do povo de Israel, devido à bênção de Deus sobre o seu povo. רִ [raq], palavra que abre Deuteronômio 15,5 no texto Hebraico, é normalmente traduzida por “somente”. Ela é uma partícula de restrição ou exclusão (SCHÖKEL, 1997, p. 631). É como se o redator estivesse dizendo que a promessa encontrada dentro de 15,5 só se tornará realidade se, de forma exclusiva, Israel obedecer ao seu Deus e cumprir a šomitttă $h$.

Israel só será abençoado com a bênção dada em 15,4 e em 15,6 se o mandamento divino for colocado em prática dentro da sua realidade de vida. A conjunção "se" [א / 'im] estabelece a condição para o cumprimento pleno da promessa de bênção. Então, quando isso aconteceria plenamente? Se Israel verdadeiramente ouvisse o mandamento divino, guardando-o, notadamente, por colocá-lo em funcionamento no ano sétimo de cada período de sete anos.

A bênção prometida pelo Deus de Israel tem alcance maior que a apresentada em 15,4. Aqui ela parece ser uma bênção apenas local - é a herança do israelita que será abençoada. Mas em 15,6 ela chega aos outros povos com quem Israel mantinha relacionamento. Em resposta à obediência do $b a^{\complement} a l$ em abrir mão do empréstimo feito ao seu irmão ’ebyôn, Deus promete fazer dele um credor de outros povos, fazendo com que Israel domine sobre muitos povos, mas ele mesmo não se sujeitará a ninguém, exceto ao seu Deus por meio de sua obediência na Šmițtāah. 
Essas promessas de bênção em seu alcance global mostram a preocupação do redator com a possibilidade de falta de cumprimento por parte de sua audiência ao que está colocado como mandamento divino de cancelamento da dívida. Deuteronômio 15,7-11, como se notará a seguir, desvenda esse problema de forma clara, e apresenta a proposta para que o bacal seja obediente no caso de um empréstimo quando a šomitțăh está próxima.

2.3.5.3. O clã e seu cuidado com o irmão empobrecido (Deuteronômio 15,7$11)^{272}$

Esta unidade textual é continuação daquela que foi colocada nos versículos 2 a 6 . Aqui ela aborda a questão da dificuldade de um $b a^{c} a l$ em fazer um empréstimo a um irmão ’ebyôn por causa da proximidade da šomițtă $\bar{a}^{h}$, pensando no prejuízo que isso poderia lhe causar, ao ter que cancelar a dívida existente de seu irmão ’ebyôn. Provavelmente, essa foi a maior dificuldade que a implantação da šomitț $\bar{a}^{h}$ deve ter experimentado.

Observou-se na unidade anterior a colocação de incentivos para a sua aplicação, sendo todos eles relacionados a ações divinas que beneficiariam quem a colocasse em prática, fazendo da $\check{S}$ omițțāh um instrumento de relacionamento triangular, onde os três elementos contantes seriam: o Deus de Israel, o ba`al e o ’ebyôn.

\subsection{Tradução}

7 - "Quando ${ }^{273}$ em ti houver" ${ }^{274}$ (um) ’ebyôn, de um de teus irmãos, em um de teus portões, na tua terra que 'ādōnāy teu Deus está dando para ti, não farás teu coração duro, ${ }^{275}$ não recolherás ${ }^{276}$ a tua mão de teu irmão ${ }^{277}$ 'ebyôn ${ }^{278}$.

\footnotetext{
${ }^{272}$ Esta seção não é uma determinação legal propriamente dita, mas uma exortação ética. É uma antecipação de um problema que poderia surgir com a legislação dada (TIGAY, 1996, p. 147).

273 A conjunção ’ִ é empregada aqui em seu sentido temporal, "quando", em lugar de seu sentido explicativo, "porque" (KIRST et al., 1987, p. 100).

${ }^{274}$ Não na pessoa, mas em "teu meio", "ao teu redor", "quando em torno de ti estiver".

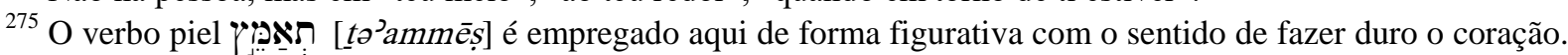
No qal, ele tem o sentido de "ser forte" (KIRST et al., 1987, p. 13). Como o piel é o intensivo do qal, o "ser forte" do qal torna-se "ser duro".

${ }^{276}$ A oração "não recolherás a tua mão de teu irmão 'ebyôn" é uma nota explicativa daquilo que vem a ser o endurecimento do coração diante das necessidades do 'ebyôn. A raiz verbal ץ BH por "fechar". A ideia de "recolher" vem do HHL-BW7. Deve-se atentar que essa é a segunda vez que a "mão" aparece em Deuteronômio 15. Nas duas ocorrências $(15,3.7)$ a ideia é a de liberalidade no tratamento com o irmão empobrecido. "Recolher a mão" está em oposição a "abrir a mão". "Mão" volta a aparecer em 15,8.
} 
8 - “Antes, ${ }^{279}$ deveras abrirás ${ }^{280}$ a tua mão para ele, e deveras lhe emprestarás o suficiente para sua necessidade, ${ }^{281}$ daquilo que ele sente ${ }^{282}$ falta". ${ }^{283}$

9 - $\quad$ "Seja cuidadoso ${ }^{284}$ contigo (mesmo), para que não haja alguma coisa perversa ${ }^{285}$ com teu coração para dizer (pensar consigo mesmo): 'Aproxima-se o ano sete, ano da Šomitțăh ${ }^{, 286}$ e teu olho ${ }^{287}$ seja mal contra teu irmão ’ebyyôn, e nada dês para ele. E ele gritará contra ti ao Deus de Israel, e haverá em ti pecado". 288

${ }^{277}$ Por duas vezes ’ebyôn qualifica "teu irmão" neste versículo. A ênfase deve ser notada tanto por salientar que a generosidade é para um irmão como ela virá sobre um irmão pobre.

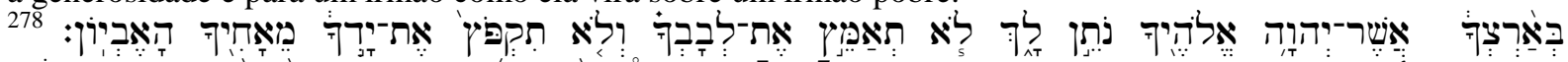

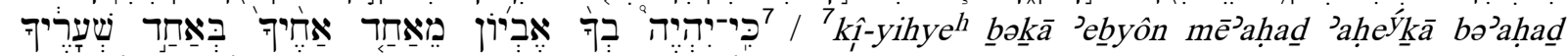

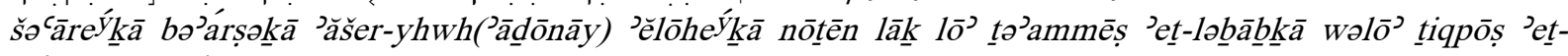

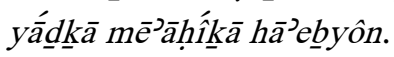

${ }^{279}$ Aqui a conjunção fọnciona como uma partícula que expressa oposição ao que vem sendo proibido na oração anterior (HHL-BW7). A BJ a traduziu por "pelo contrário" para salientar a força do contraste entre as duas colocações.

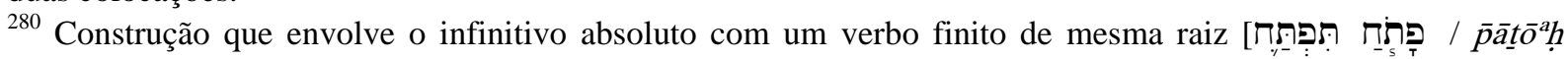
tip̄taḥ]. A BJ traduziu essa construção por um imperativo, "abre".

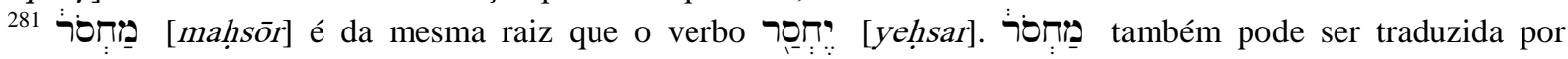
"pobreza" (KIRST et al., 1987, p. 122). Já o verbo רoח pode ser traduzido, no qal, por "diminuir, sentir falta, ter carência" (KIRST et al., 1987, p. 73). A generosidade que está sendo ordenada ao bacal tem a ver com o suprimento de uma necessidade ocasionada pelo empobrecimento do 'ebyyôn.

282 "Tu emprestarás para (suprir) sua falta daquilo que ele sente falta". É uma formação redundante. Ele teria suprido algo que lhe falta e que lhe faz falta em sua vida.

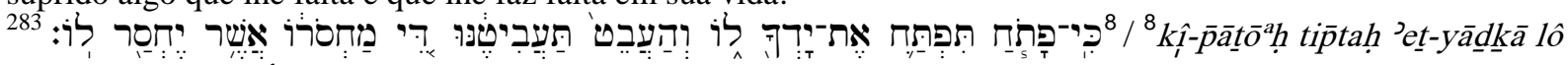

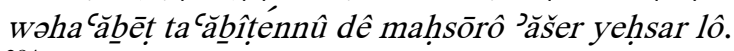

${ }^{284}$ A BJ traduziu esse imperativo por "fica atento". Seguindo a sugestão do dicionário da Bible Works 7 , traduziu-se esse nifal imperativo "ser cuidadoso". Esse dicionário sugere também "ser protegido". No caso em pauta, o $b a^{c} a l$ devia se proteger da desobediência a um mandamento divino.

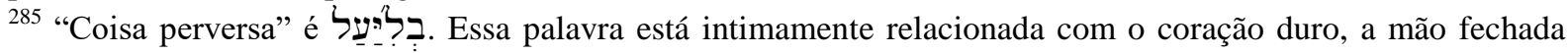
$(15,7)$, o olho mal $(15,9)$ e o coração mal $(15,10)$. "Há, de fato, algo sinistro, para não dizer 'demoníaco', na insensibilidade (deliberada) que aceita a riqueza da bondade de Deus e então se recusa imitar o Doador e repartir a dádiva" (CAIRNS, 1990, p. 148).

${ }^{286}$ A presença da šomitțta ${ }^{h}$ aqui mostra que o redator ainda está falando do empréstimo dos versículos 2 a 7 , quando o $b a{ }^{\top} a l$ teria que abrir mão de receber seu empréstimo e ainda devolver a garantia a "teu irmão 'ebyôn" como demonstração que ele dispensou seu irmão de qualquer pagamento da dívida.

${ }^{287}$ A palavra "olho" é empregada para se referir a atitude de coração do bacal.

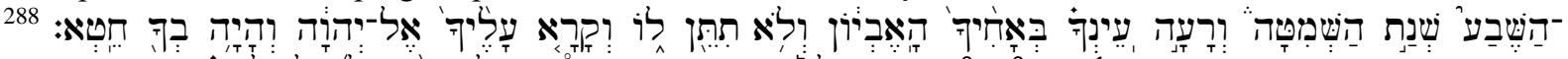

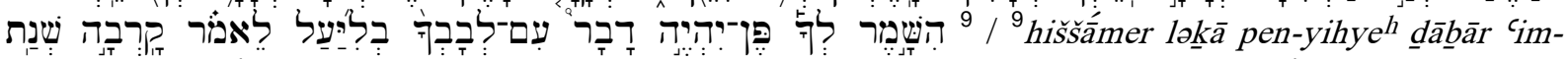

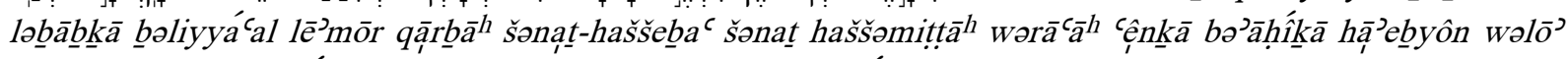

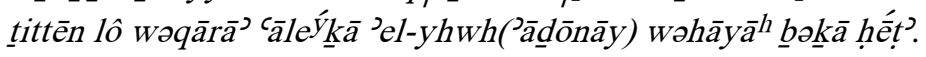


10 - "Deveras darás ${ }^{289}$ para ele. E o teu coração não será mal no teu lhe dar. ${ }^{290}$ Pois, por causa dessa coisa, ${ }^{291}$ ग̄âdōnāy teu Deus te abençoará em toda tua obra e em todo empreendimento ${ }^{292}$ de tua mão". ${ }^{293}$

11 - "Porque o pobre não cessará ${ }^{294}$ do meio da terra. Portanto, eu te ordeno ao dizer: Certamente abrirás ${ }^{295}$ a tua mão para teu irmão muito pobre ${ }^{296}$ na tua terra". ${ }^{297}$

\subsection{Solidariedade com o irmão empobrecido}

\subsection{Uma hipótese possível $(15,7)$}

"Quando em ti houver (um) 'ebyôn" é a declaração que abre essa unidade textual, e demonstra que a pobreza era um elemento recorrente dentro do mundo bíblico e, particularmente, no mundo de Israel. A familiaridade do bacal com ’ebyôn é demonstrada nas declarações seguintes. Ele é alguém do meio de "teus irmãos", está dentro dos "teus portões", sendo esses qualificados pela terra que é dada em herança. Assim, ao mesmo tempo em que a

${ }^{289}$ Construção literária comum neste capítulo: infinitivo absoluto + verbo finito de mesma raiz nātôn tittēn].

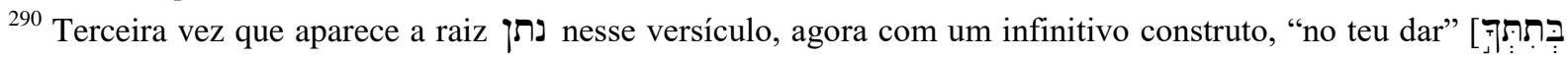
I botitttokāa]. Outra forma de traduzir poderia ser "na tua doação". Está em vista algo que seria dado pelo credor ao seu endividado.

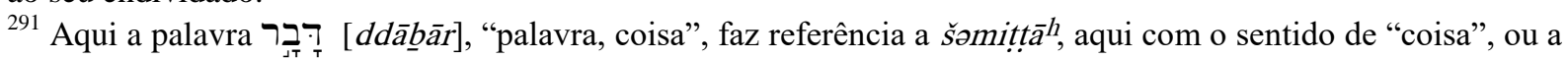
declaração de libertação de dívida feita pelo $b a{ }^{c} a l$, assim "palavra".

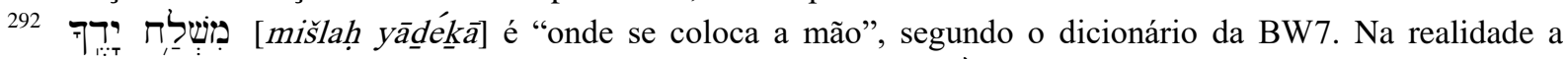

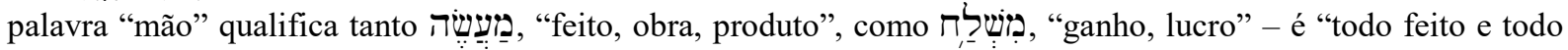
ganho de tua mão". Ou, noutra forma de dizer, está sendo dito ao $b a a^{a} l$ é que ele seria bem-sucedido em tudo que ele viesse a empreender. A mão que deixa cair o direito de receber uma dívida é a mesma que receberá a benção divina em todo o seu trabalho.

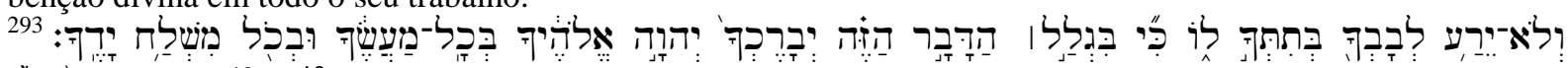

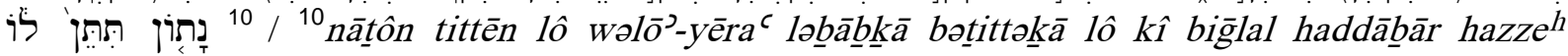

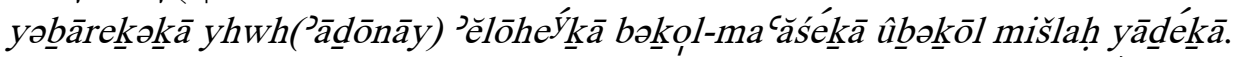

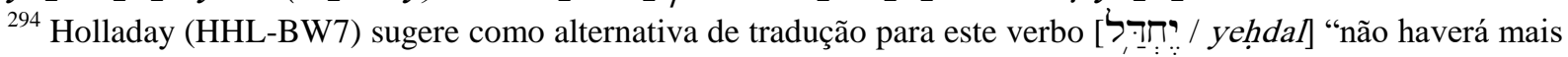
em existência ('no longer be in existence')", sugerindo que, por meio da generosidade do $b a c^{c} a l$, o pobre deixará de ser pobre. A outra possibilidade é que, sem a generosidade do $b a{ }^{\varsigma} a l$, o pobre não terá longa existência e deixará de viver. Por outro lado, o entendimento usual é que sempre haverá pobre na terra e, por isso, o $b a^{\varsigma} a l$ sempre terá alguém com quem deverá ser generoso.

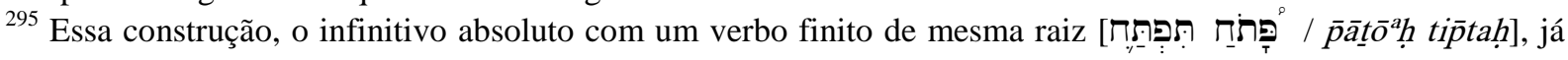
apareceu em Deuteronômio 15,8.

296 Aqui se encontra uma construção onde "teu irmão" é qualificado por duas palavras para pobre [ ‘̄nny e

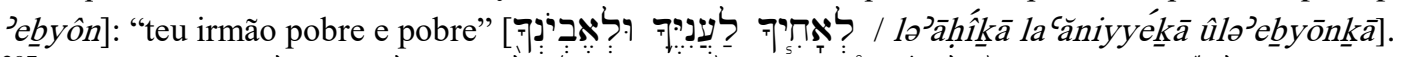

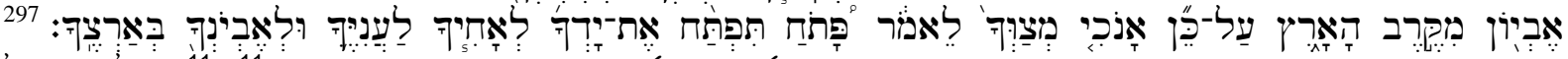

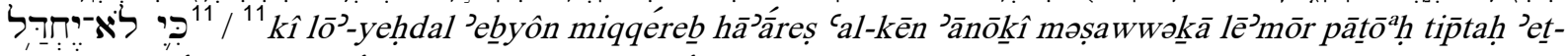

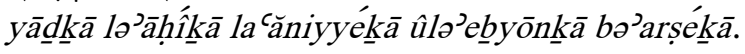


proximidade ajudaria na generosidade do $b a^{c} a l$, ela também poderia prejudicá-la, haja vista que o bacal poderia considerar que aquele ’ebyôn não deveria merecer tal atitude de generosidade de sua parte.

Entretanto, ao afirmar que a terra do $b a^{c} a l$ tinha sido concedida por doação ("tua terra que ’ādōnāy teu Deus está dando para ti”), o redator está dizendo que a mesma coisa deveria ser feita ao 'ebyyôn. O ba'al não possuía uma terra como herança até a doação de “ 'ād̄ōnāy teu Deus". Assim, o ’ebyôn também não tem com que sobreviver, a não ser que o bacal lhe conceda uma doação, por meio de um empréstimo, mesmo que o ano do cancelamento da dívida esteja perto. A generosidade do $b a^{c} a l$ deveria vir de uma generosidade precedente. Ele primeiro recebeu para depois poder dar. Ou, noutra forma de dizer, ele só poderia dar porque ele já tinha recebido.

Mesmo que Deuteronômio 15,7 comece com uma possibilidade hipotética, o que vem a seguir no texto aponta para a dura realidade que um hipotético ’ebyôn poderia encontrar num ba`al. As frases paralelas "não farás teu coração duro" e "não recolherás a tua mão de teu irmão 'ebyôn" indicam que o caminho da liberdade financeira do 'ebyôn na šomitțāa poderia não ser fácil. Ao proibir a dureza de coração e o "encurtamento" da mão, o redator destaca que o fim da pobreza ocorreria mediante a generosidade do $b a^{\varsigma} a l$. É uma ordem que é colocada como vinda de Deus por meio de uma solução humana.

\subsection{Coração generoso em lugar do duro $(15,8.9)^{298}$}

Deuteronômio 15,8.9 é introduzido por um uso adversativo da conjunção ’ִ̣. No lugar da mão fechada de 15,7, o $b a^{c} a l$ deveria ser possuído de um coração generoso, mas com determinados parâmetros. A necessidade a ser suprida deveria ser aquela apresentada pelo ’ebyôn. O empréstimo viria para suprir uma falta que o ’ebyôn está sentindo. Isso implica em algumas ações por parte do bacal. Ele deveria entender a necessidade do ’ebyôn para poder dar aquilo que serviria de suprimento para a carência que ele tinha. Ele também deveria fazer o empréstimo com coração sincero. Isso quer dizer que, além de ter que entender o que o

\footnotetext{
${ }^{298}$ Para Merrill, depois de ser tratada da hipótese de não haver pobres dentro de Israel, o redator passa a tratar da realidade do povo e como a comunidade deve tratar com ela (1984, p. 244).
} 
’ebyôn necessitava para realizar o empréstimo, o bacal deveria estar ciente de suas motivações.

Deuteronômio 15,9 diz: "Seja cuidadoso a ti (mesmo), para que não haja alguma coisa perversa com teu coração ao pensar consigo mesmo: ${ }^{299}$ 'Aproxima-se o ano sete, ano da Šomitță ${ }^{h}$ ', e teu olho seja mal contra teu irmão 'ebyôn, e não (nada) dês para ele. E ele gritará contra ti ao Deus de Israel, e haverá em ti pecado”. Primeiro, o bacal deveria se proteger de si mesmo ("cuida de ti mesmo"). Pensar num eventual "prejuízo" antes que na necessidade do próximo causaria um dano para aquele que precisava da cobertura de uma carência. A vida do ’ebyôn estava acima de seu "prejuízo". Para evitar um dano maior a si mesmo, o bacal teria que tomar cuidado consigo mesmo. Segundo, o seu temor não deveria ser motivado por um possível "prejuízo", mas por uma intervenção divina em favor do ’ebyôn e contra o ba`al. Deus seria o juiz do ’ebyôn.

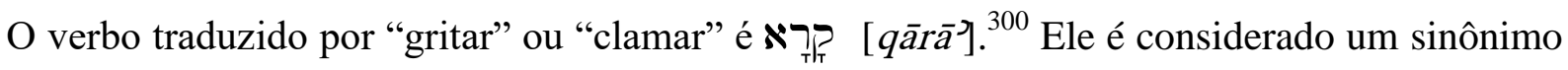

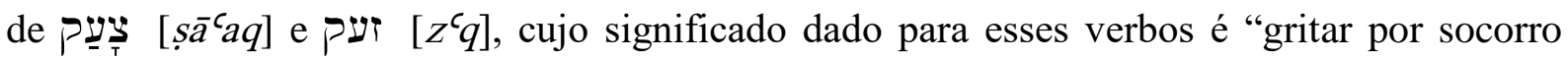
urgente" (COPPES, 1980, p. 810). șā́aq é empregado para o grito dos israelitas sob a escravidão no Egito. Como tal, ele aparece na confissão encontrada em Deuteronômio 26,7

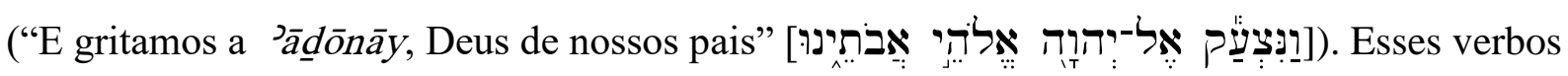
estão presentes em Êxodo 2,23 [ $\left.z^{c} q\right] ; 3.7\left[\right.$ [clamor" / $\left.s^{c} q\right] .9\left[\right.$ [clamor” / $\left.s^{c} q\right]$.

Essa relação sinonímica entre esses verbos torna a ordem divina uma palavra de libertação semelhante aquela presente no livro de Êxodo. Faraó deveria deixar o povo sair do Egito. Mas ele não o fez. Mais tarde ele viria confessar que ele havia pecado, ou, desobedecido ao Deus

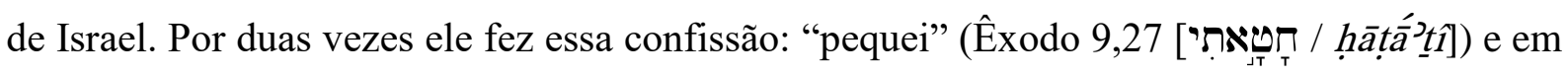

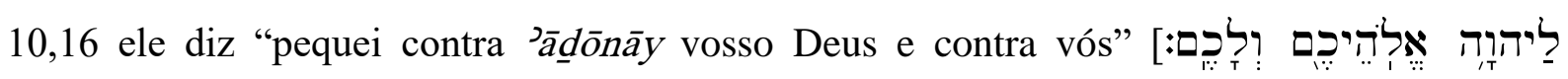

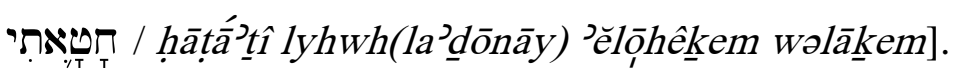

\footnotetext{
299 Bartor afirma que em Deuteronômio 15,9, o redator integra as palavras do $b a^{\varsigma}$ al na sua exortação ao dar expressão a um discurso interior que reflete seus pensamentos e o estado de sua mente. Ele entra na sua mente, responde a sentimentos e pensamentos que o levariam a uma ação, antes que ela seja realizada (2012, p. 302).

300 A ideia de קרז como o grito dado pelos desesperados está presente no livro de Jonas (1,6.14). Em Deuteronômio 15,9, há declarada o conceito de gritar com o intuito de fazer uma acusação de sonegação do empréstimo, tendo em vista que se aproxima o tempo do perdão de dívidas.
} 


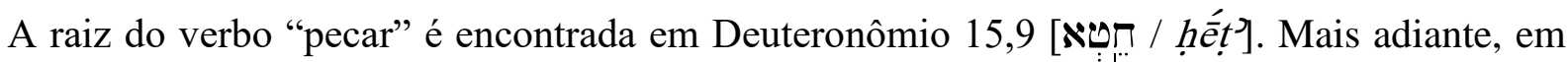
Deuteronômio $15,12-15,{ }^{301}$ quando por ocasião da libertação do irmão que havia se vendido como escravo, o bacal deveria tratá-lo com generosidade, da mesma forma que ele fora resgatado do Egito com generosidade. Então, a saída do Egito e a libertação da šomitță ${ }^{h}$ são colocadas em igualdade, notadas as diferenças entre elas. Cancelar a dívida de seu irmão é agir, como Deus, na libertação de uma escravidão que pesa sobre seu irmão - a escravidão do endividamento.

Nesses dois textos $(15,8.9)$, encontra-se um jogo de ideias. Se o bacal não fizesse o

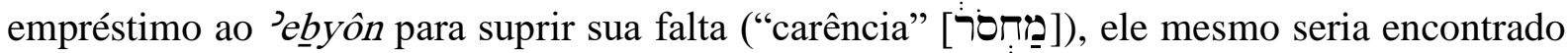
em "falta" ("pecado" [ח] $\left[\begin{array}{l}\text { ] } \\ ]\end{array}\right)$. Assim como o Faraó foi encontrado em falta por desobedecer ao mandamento divino de deixar o povo partir do Egito, o ba ${ }^{c} a l$ seria encontrado em "falta" por não deixar seu próximo livre de sua carência. Manter o ’ebyôn no seu "Egito" de pobreza, descontadas as diferenças, pode ser considerado um instrumento de opressão. O empréstimo seria, por sua vez, um instrumento de libertação. E, com a chegada da šomitța $\bar{a} h$, o $b a^{c}{ }^{c}$ l proclamaria liberdade ao ’ebyôn.

A questão que o texto levanta é a seguinte: Faraó, mesmo com seu coração endurecido, não deixou Israel partir? Sim. Mesmo com sua mão fechada, ele não deixou Israel partir com riqueza dada pelos egípcios? Sim. Então, o endurecimento de coração não é uma alternativa apropriada para o $b a^{c} a l$. Em lugar da bênção, Faraó recebeu juízo. Assim, Deuteronômio enfatiza o valor da obediência para o próprio ba ${ }^{\complement} a l$ : "por causa dessa coisa, ’ād̄ōnāy teu Deus te abençoará em toda tua obra e em todo empreendimento de tua mão". Mão generosa do $b a^{\complement} a l$ resultará em mão generosa do Deus de Israel.

\subsection{Uma contradição em Deuteronômio 15?}

Ao fechar a unidade de Deuteronômio 15,7-11, o redator leva ao ápice o bloco inteiro de 15,111. No final, ele diz porque a šomitt $a^{h}$ deve ser proclamada e porque o bacal deverá se habituar com ela:

\footnotetext{
301 O verbo פָדָ [padah] é usado em Deuteronômio para "resgatar", "redimir", o povo de Israel do Egito. Na análise desse texto no capítulo sobre o servo e a serva esse verbo será tratado com mais detalhe.
} 
11 - "Porque o pobre não cessará do meio da terra. Portanto, eu te ordeno ao dizer: Certamente abrirás a tua mão para teu irmão pobre muito pobre na tua terra”.

O versículo em pauta requer uma explicação, pois ele parece contradizer o que foi dito em Deuteronômio 15,4. Três alternativas podem ser dadas para explicar esse texto: primeiro, o pobre deixará de ser pobre ("não haverá mais a existência de um pobre"); segundo, o pobre não terá existência longa (“o pobre não terá mais existência na terra”); terceiro, sempre haverá pobre na terra (“o pobre não cessará do meio da terra”). Qual delas se harmoniza melhor com o contexto?

Essa unidade textual não é independente daquela que se encontra nos versículos 2 a 7 . A presença da šomitță $\bar{a}^{h}$ destaca que a doação não seria doação por doar. Mas um empréstimo com garantias de recebimento. A proximidade do ano da šomitțăh poderia levar o ba ${ }^{\varsigma} a l$ a perceber um "prejuízo" iminente, ou que o irmão ’ebyôn poderia aproveitar de proximidade do ano da šmițța ${ }^{h}$ para levar vantagem no empréstimo.

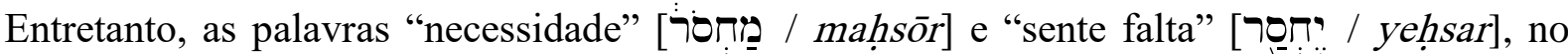
versículo 8, apontam para uma necessidade real do irmão ’ebyôn. Além do mais, a palavra ’ebyôn qualifica um indivíduo que é conhecido da comunidade, bem como do ba`al, como sendo "pobre". Além disso, ele é "teu irmão 'eḅyôn", o que indica que ele faz parte do relacionamento próximo do bacal.

Das três alternativas dadas acima, o que se pode dizer sobre a primeira é que para a šomitță $\bar{a}^{h} \mathrm{o}$ pobre deixará de ser pobre ("não haverá mais a existência de um pobre") por causa da generosidade do $b a^{c} a l$. Entretanto, se o $b a^{c} a l$ não for generoso, o pobre não terá existência longa ("o pobre não terá mais existência na terra").

Entretanto, a terceira alternativa está em harmonia, não somente com Deuteronômio 15,11 como com 15,5: sempre haverá pobre na terra ("o pobre não cessará do meio da terra"). Um olhar mais atento para Deuteronômio 15,4 se notará que a pobreza que a pobreza que não existirá é "em ti” - no $b a^{\complement} a l$. A implicação disso é que, se o $b a^{\varsigma} a l$ proclamar a šomitțăh para o seu irmão empobrecido, ele não terá pobre nele mesmo. Ou noutra forma de olhar, ele não se tornará um pobre, porque Deus o abençoará em tudo o que ele colocar sua mão, dando-lhe recursos, não só para socorrer seu irmão, como para emprestar a outros povos. 
Isso deve fazer um retorno ao exemplo de Faraó e o Egito. A generosidade dos egípcios foi forçada, fazendo com que, para que se livrassem do incômodo dos escravos israelitas, eles dessem tudo o que eles pediram para que saíssem do Egito, tornando-se empobrecidos. Se o ba ${ }^{c} a l$ fosse generoso com seu irmão empobrecido, ele não se tornaria um ’ebyôn à semelhança dos egípcios. Essa generosidade, porém, não deveria ser casual, pois sempre haveria alguém para socorrer em sua pobreza.

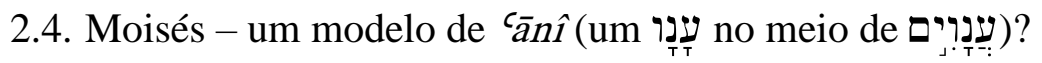

Dentro das narrativas da BH há uma característica que certas grandes personalidades apresentavam. Seja essa uma declaração pessoal sua, seja uma declaração vinda de outros. Há um ponto em comum entre algumas dessas grandes personagens bíblicos - alguns deles se consideraram "pobres" no meio de seu povo. Jefté disse que sua família era uma das mais pobres no meio de Manassés (Juízes 6,15 [דָּ / dal]). Saul considerou sua família a menor de

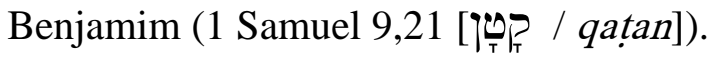

Davi se considerou um "homem pobre e sem dignidade" quando os servos de Saul

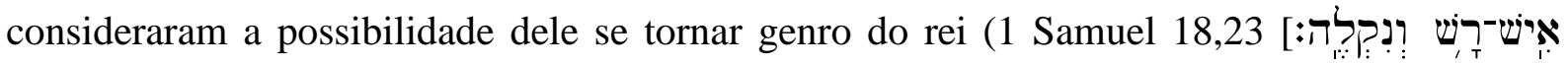

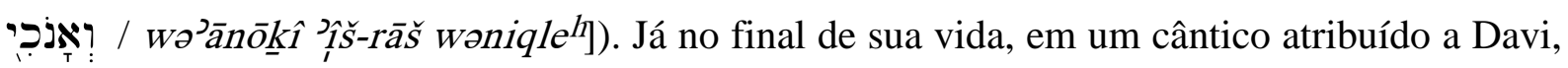
ele se inclui entre aqueles que são chamados de עִִָָ : "E tu livrarás o povo aflito, mas os teus olhos sobre os que se exaltam, tu trarás abaixo". ${ }^{302}$ Esse cântico é um memorial de Davi de seu sofrimento em meio as muitas perseguições e sua libertação causada por Deus de todas elas.

O que diferencia essas declarações daquela que se encontra em Números 12, sobre Moisés, é que a de Números não sai da boca de Moisés, mas do redator do livro e, provavelmente, o redator lançou no livro de Números aquilo que ele recebera de uma tradição oral antiga, ou de algum panfleto com essa tradição.

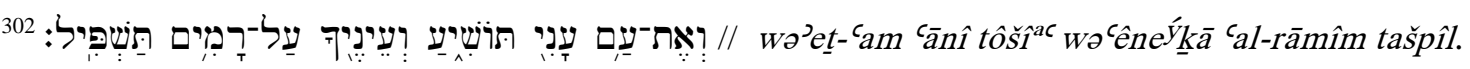




\subsubsection{O texto - Números $12,1-3$}

\subsubsection{Tradução}

1 - "E falou ${ }^{303}$ Miriam, e Arão, ${ }^{304}$ contra Moisés por causa da mulher cuchita que (ele) tomou, porque uma mulher cuchita (ele) tomou.",305

2 - $\quad$ “E disseram: ${ }^{306}$ 'De fato, yhwh (’ādōnāy) falou somente ${ }^{307}$ através de ${ }^{308}$ Moisés? Não falou $^{309} y h w h$ ( ’ādōnāy) também através de ${ }^{310}$ nós?’ E yhwh (’ādōonāy) ouviu., 311

${ }^{303}$ Três versões consultadas traduzem esse verbo na terceira pessoa masculino plural para envolver Arão diretamente na trama ("Maria e Arão murmuraram" [BJ]; "Maria e Arão falaram" [BP]; "Falaram Miriã e Arão" [ARA]). Porém, o verbo está na terceira pessoa feminina singular, רַת [wattodabbēr], o que, no entendimento desta pesquisa, essa rebelião de irmãos contra Moisés teve início e liderança de Miriam, justificando assim a disciplina divina posterior somente contra ela, não contra Arão. Aparentemente, Arão era um coadjuvante em todo o evento - e em toda sua vida - de Moisés e, agora, de sua irmã, Miriam. Preste-se atenção também que a narrativa coloca Miriam à frente de Arão $(13,4-5)$, enquanto que o reverso seria o esperado (MILGROM, 1990, p. 93). Para Rashi, “o termo linguagem severa (Gênesis 42,30)... O אמאר (Germo, porm, é sempre uma expressão que denota súplica (Gênesis 19,7)" (RASHI, Bamidbar, 1934, p. 58).

${ }^{304}$ A separação de Miriam de Arão por uma vírgula nessa tradução se dá por entender que a iniciativa e liderança desta contenda contra Moisés é toda de Miriam, sendo Arão um sujeito passivo, como o verbo salienta na análise acima. Essa tradução é para ênfase. No texto Hebraico, porém, a separação se dá por vav conjuntivo [?] e mostra que os dois estão relacionados no propósito de criticar Moisés, mesmo que a preeminência seja de Miriam sobre Arão. É ela quem abre o debate sobre a liderança de Moisés (RASHI, Bamidbar, 1934, p. 58).

1 1 ${ }^{1}$ wattodabberr

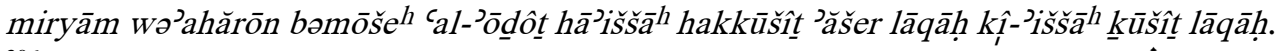

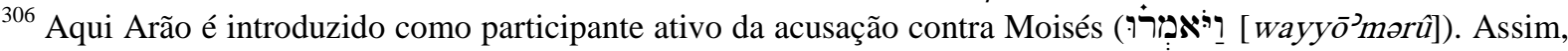
depois da iniciativa de Miriam, ele participa com ela da fala contra Moisés. Por meio desses dois versículos pode-se concluir que Miriam tomou a iniciativa e se tornou porta-voz do grupo, ela e Arão, que reivindicava mais espaço na liderança do povo de Israel. Arão participa com ela e leva a força do sacerdócio junto por essa luta pela liderança com Moisés.

307 Milgrom sugere que, por questão de ênfase, $P$ 그 seja entendido como “apenas e unicamente" (1990, p. 94). Parece ser esse o entendimento subjacente no questionamento de Miriam: "Deus fala apenas e unicamente por Moisés?".

308 A preposição prefixa ao nome Moisés, ב, é traduzida aqui em seu uso instrumental, "através de", principalmente levando em consideração que Moisés também é profeta por meio de quem Deus fala (notar 1

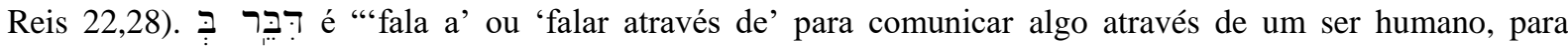
transmitir uma mensagem através dele” (LEVINE, 1993, p. 328). O mesmo verbo é usado com a mesma preposição em 12,5, mas com sentido diferente ("falar contra"). Para um uso semelhante ao de 12,2, notar 2

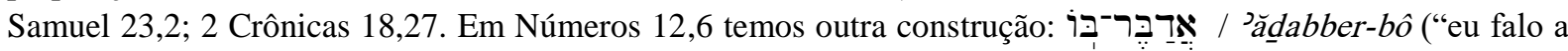
ele" ou "eu falo com ele").

${ }^{309}$ Essa pergunta levantada pelo grupo não é questionada por Deus. Deus fala também através deles. Porém, o que há é a grande diferença qualitativa que existe entre a manifestação divina para Moisés e eles. Para Moisés, Deus desvenda até a forma do ser divino (Números 12,8).

${ }^{310}$ Aqui aparece uma construção com a preposição ב, "de, através de". Miriam é chamada de "profetisa" em Êxodo 15,20. Arão é chamado de profeta de Moisés ("teu profeta"), em Êxodo 4,14-16; 7,1. Notar ainda Miquéias 6,4. Interessantemente que Arão não seja chamado de "profeta de $y h w h$ " no Pentateuco. Ele falaria apenas aquilo que Deus já houvesse falado a Moisés. Como "profeta de Moisés", ele é representante deste, não do Deus de Israel. E, como sacerdote, ele representa o povo diante do Deus de Israel. Entretanto, representar Deus diante do povo passa a ser o papel do profeta, que, aqui, tem Moisés como seu representante maior. Nessa 
3 - "E o homem Moisés (era) manso ${ }^{312}$ (pobre/humilde) ${ }^{313}\left[\underset{T}{\left[{ }_{T}\right.} / \varsigma_{\bar{a}} n \bar{a} W\right]^{314}$ mais do que ${ }^{315}$ todo homem sobre a face do solo., 316

\subsubsection{O contexto}

O conflito intrafamiliar, envolvendo a elite da liderança ${ }^{317}$ do povo de Israel no deserto, ocorre dentro de uma sequência de crises envolvendo todo Israel, bem como suas queixas motivadas pela sua condição de vida no deserto. Mas essas queixas, dentro do capítulo 11 de Números, mesmo que fossem dirigidas a Moisés e Arão como representantes divinos no meio do povo, atingiam diretamente ao Deus de Israel que, no final, era quem havia levado o povo até ali. Por isso, Deus apresentava sua indignação, repetidamente, contra seu povo (Números 11,1.10.33).

O capítulo 12 passa a ser aquele que conclui a questão levantada sobre a liderança do povo e a rebelião contra os líderes instituídos divinamente, mas com o agravante que essa rebelião alcança e parte da família de Moisés. ${ }^{318}$ Até aqui, porém, as crises não eram dirigidas diretamente a Moisés e Arão, mas de modo velado, pois eles eram os representantes divinos no meio do povo. As queixas do povo contra Moisés e Arão eram, no final, dirigidas ao

questão de silêncio, notar o silêncio de Jacó quando soube que seu filho Rubem havia se deitado com uma de suas mulheres (Gênesis 35,22).

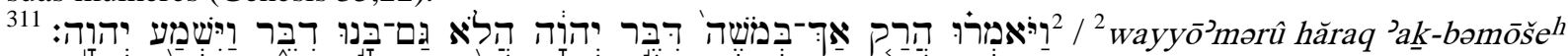

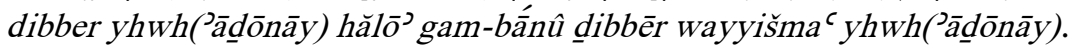

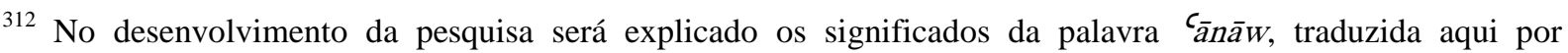
"manso", porém, entre parêntesis foi apresentado alguns significados alternativos que poderiam constar na tradução desse versículo. Esse é o único exemplo de $\varsigma_{\bar{a} n a ̄ W}$ no singular na BH (MILGROM, 1990, p. 94).

$313 \varsigma_{\bar{a}} \bar{a} W$ é um adjetivo masculino. Portanto, ela é usada para qualificar Moisés como um homem que apresenta as qualidades que a palavra $\varsigma_{\bar{a}} n \bar{a} w$ incorpora - mansidão, humildade, simplicidade.

314 Apenas para constar, aqui nós temos o caso de Qerê (lido) e Ketiv (escrito). O texto da BH, encontrado na

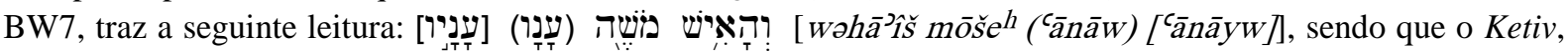

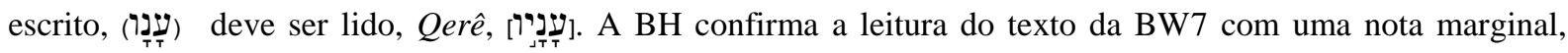

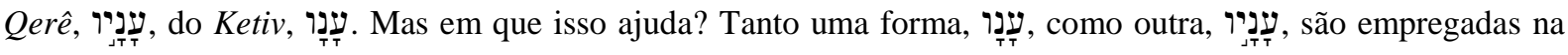

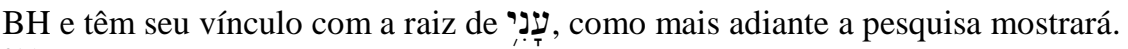

${ }^{315}$ Moisés é o mais manso em oposição clara a Arão e Miriam, cujo posto de Moisés desejam. Isso faz de Moisés um modelo de pessoa submissa. Ele está na posição em que está, não por vontade própria, mas porque outro o quer ali.

[ִדānāy]

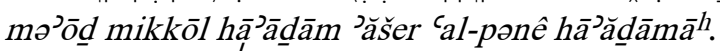

317 Moisés era o líder máximo do povo de Israel, Arão o sumo-sacerdote, e Miriam era reconhecida como profetiza e, aparentemente, uma espécie de líder feminina sobre as mulheres. Tal aspecto transparece em Êxodo 14, quando ela lidera um grupo de mulheres em celebração ao Deus de Israel pela derrota definitiva do exército egípcio sob o Mar Vermelho.

${ }^{318}$ Notar que o espírito que havia em Moisés é repartido com outros para capacitá-los a levar o povo juntamente com Moisés. É significante, porém, que Arão e Miriam não estejam nesse grupo de "ungidos" com o espírito de Moisés (ASHLEY, 1992, p. 222). 
próprio Deus. Keil e Delitzsch assinalam que as rebeliões, até aqui levantadas, foram provenientes da insatisfação do povo com as condições de privação em sua peregrinação pelo deserto e que, em sua direção central, estava Deus, mais que Moisés (p. 809). Portanto, eram rebeliões provenientes da insatisfação do povo contra o seu Deus que, aparentemente, não os estava levando para aquela terra singular que ele havia prometido.

Miriam e Arão inauguram o período de críticas dirigidas para Moisés. O que há aqui é uma espécie de ataque contra Moisés devido a um julgamento errôneo de sua pessoa, e que abre uma sequência de outros ataques contra o líder máximo do povo de Israel naquela ocasião. Como esse evento ocorreu de forma pública, ele estimulou outros líderes a fazerem o mesmo, tais como Corá, Datan e Abiram, em Números $16 .^{319}$

Como notado na tradução acima, o ataque foi orientado por Miriam, colocando-a com a agente principal da instigação aberta contra Moisés. O verbo está no singular feminino ("E ela falou"). Além disso, o nome "Miriam" vem antes do nome de Arão para salientar preeminência dela no evento. $\mathrm{O}$ verbo pode ser traduzido pela perífrase "e ela começou a falar" ${ }^{320}$ para salientar um início de ação, bem como a sua continuidade. Como Arão foi envolvido na questão não está claro. ${ }^{321}$ Ele resistiu à tentação de participar com o povo na festa ao bezerro de ouro (Êxodo 32). Mas aqui, ele vê a possibilidade de assumir a liderança do próprio Israel.

O evento do bezerro de ouro (Êxodo 32), no entanto, sugere que Arão tinha uma personalidade dependente, facilmente influenciável e dependente de duas personalidades fortes - Moisés e Miriam, e fraco quando estava sob pressão, como no caso ocorrido em Êxodo 32, quando o povo pressiona Arão para fazer os substitutos de Moisés, os deuses, e, no

\footnotetext{
${ }^{319}$ Para ilustrar a estranheza do comportamento de Miriam e Arão, recorre-se à história de Davi. Davi demonstrou-se crítico com os filhos de Zeruia (Joabe, Abisai, Asael), irmã de Davi (1 Crônicas 2,5), chegando ao ponto de procurar substituto para o comandante do exército, Joabe (2 Samuel 3,39; 16,10; 19,22). Entretanto, mesmo com a acidez de Davi contra seus primos, principalmente Joabe, eles sempre trabalharam em favor do reinado de Davi sobre Israel. Mesmo quando Joabe teve a oportunidade de ser honrado acima de Davi, ele não o fez (2 Samuel 12,26-28), e até fez o trabalho sujo de Davi, fazendo com que Urias morresse (2 Samuel 11,16.17). Para Joabe, o clã estava acima de tudo. Essa unidade, mesmo em meio aos problemas internos, não parece ter sido a busca de Miriam e Arão.

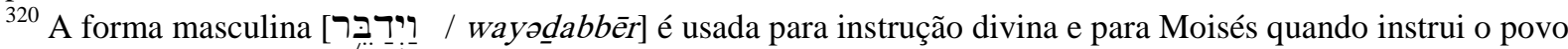
(ver Números 1,$1 ; 2.1 ; 9,4 ; 11,24)$. O uso dessa forma no feminino atrairia naturalmente a atenção dos ouvintes

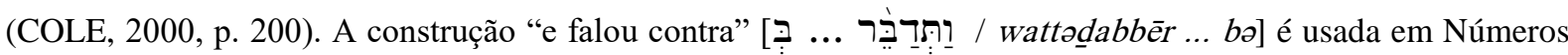
(21,5.7; também Jó 19,18; Salmo 50,20; 78,19) para indicar uma comunicação hostil (BUDD, 1984, p. 136).

${ }^{321}$ Budd sugere que, tendo Miriam como a pessoa que fala, a entrada de Arão tenha sido uma adição aqui e nos outros lugares do evento. Ele também aponta que a punição que veio somente sobre Miriam é outra indicação disso (1984, p. 133).
} 
final, de Deus, para que guiem o povo à Terra da Promessa, em lugar de Moisés - esse era o propósito deles: arranjar não um, mas vários substitutos ${ }^{322}$ para Moisés (RASHI, Shemoth, 1934, p. 180), ${ }^{323}$ eles precisavam de um substituto que determinasse a vontade de Deus para o lugar de Moisés, o meio humano para conhecer a vontade divina (SARNA, 1991, p. 203). Aquele evento apresentou um Arão fraco diante da ausência de Moisés e da pressão do povo, não se impondo como o verdadeiro líder humano substituto (ao invés de um bezerro de metal $)^{324}$ - alguém que dissesse com firmeza o que o povo deveria fazer. Seu comportamento fraco trouxe grande prejuízo para a liderança e para o próprio povo, segundo a narrativa de Números.

Além de Corá, Datan e Abiram, em Números 16, outros descontentes do meio do povo foram estimulados a fazer o mesmo contra Moisés, o que deixou, por sua vez, Arão vulnerável a elas por se achar muito próximo de seu irmão, e ser o porta-voz dele, mais que Miriam, fazendo com que, posteriormente, a própria posição de Arão viesse a ser questionada, e outros desejassem seu posto de Sumo-Sacerdote de Israel (Números 16,2.10).

Portanto, o contexto em que Números 12 está inserido é de conflito entre líderes, ou entre líderes e o povo, fazendo com que a intervenção divina se faça necessária para que o povo no deserto não experimentasse o caos, principalmente para não causar seu próprio retorno para o Egito. O bloco de literatura que vai de Número 11 até 25 apresenta o ciclo de "rebelião e julgamento de um povo medroso" (ALLEN, 1990, p. 695).

\subsubsection{O evento envolvia incialmente uma crítica contra a mulher de Moisés.}

Por mais que pareça esquisito, o problema levantado contra Moisés é também um ataque contra a sua esposa. A essência da crítica pode ser vista em que ele se casara com uma mulher fora do contexto do clã, ou mesmo do povo de Israel. O texto não deixa dúvida: "por causa da

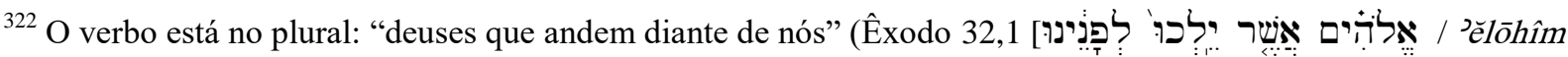
วăšer yệlıkû lop̄ānếnû]) - deuses que nos guiem.

${ }^{323}$ Em Êxodo 15,20.21, Miriam lidera um grupo de mulheres com cânticos após a travessia do mar. Além disso, ela é chamada de profetisa. Esses dois detalhes demonstram a força da personalidade de Miriam. Como profetisa ela exercia autoridade como porta-voz divina. Miriam foi hábil ao agir em benefício de Moisés quando ele foi colocado no rio para escapar da morte, ainda pequeno (Êxodo 2), inclusive tramando para a própria mãe do menino ser a ama de leite. Ela demonstrou coragem, habilidade e liderança. Ela poderia pensar que Moisés devia a vida a ela e, por isso, teria ele um débito com ela. Ai, a imposição sobre Moisés para ele repartir a liderança sobre o povo de Israel. Isso é uma conjectura possível.

${ }^{324}$ Arão era três anos mais velho que Moisés (Números 33,29). Ele não teve o privilégio de viver no palácio do Faraó e aprender tudo sobre a arte da liderança, como Moisés. Arão enfrentou os "anos de chumbo" da escravidão no Egito. Isso pode ter influenciado em sua personalidade dependente. Ele queria e aprendeu a sobreviver. O homem que poderia ser um bravo guerreiro tornou-se dócil para sobreviver.
} 
mulher cuchita que (ele) tomou, porque uma mulher cuchita (ele) tomou."325 "Cuchita" foi o apelido colocado sobre a mulher, para que sua origem não fosse esquecida, mostrando que ela teve pouca aceitação dentro do povo de Israel como mulher do homem que era como a "boca de Deus" para Arão (Êxodo 4,14-16) e, subsequentemente, para todo o povo de Israel, incluindo a própria Miriam.

Porém, há algo a mais a informar sobre a mulher de Moisés e a respeito da origem dela. $\mathrm{O}$ texto por duas vezes diz que ela é "cuchita". Entrementes, segundo a narrativa do livro de Êxodo (2,15.16), quando Moisés fugia da perseguição de Faraó, ele acabou indo morar em Midiã, não em Cuche.

Quatro sugestões são feitas para tentar resolver o problema da origem da mulher de Moisés. Allen (1990, p. 797-798) apresenta as primeiras duas respostas possíveis à questão levantada sobre a origem de Séfora, aqui chamada de "mulher cuchita". A primeira possibilidade é que, para Allen, a pele da Séfora era mais morena que da maioria do povo de Israel, fazendo com que a crítica de Miriam viesse a usar o termo em forma de desprezo ao ancestral dela.

A segunda possibilidade é que, com a morte, talvez, da primeira mulher de Moisés, Séfora, ele se tenha casado com uma mulher originária de Cuche. Allen entende que isso pode ser comprovado pela repetição das palavras "mulher cuchita" e "tomou" nas frases: “... da mulher cuchita que ele tomou, porque ele tomou uma mulher cuchita", pois o verbo "tomar" parece indicar algo recente e a repetição aponta para uma ênfase textual.

A terceira possiblidade é aquela apresentada por Rashi (Bamidbar, 1934, p. 58-59). Para ele, a crítica inicial contra Moisés foi motivada devido à sua separação de Séfora, o que Miriam conhecia e a repartiu com Arão. Assim, Moisés divorciou-se de Séfora e tomou a mulher cuchita como esposa.

Entretanto, a BJ (2002, p. 220-221) traz uma nota em que declara que, pelo sentido básico de Cuche, o texto estaria apontando para Séfora como sendo etíope. A mesma nota, porém,

${ }^{325}$ A primeira vez que aparece a construção "mulher cuchita", tanto a palavra "mulher" quanto "cuchita" estão

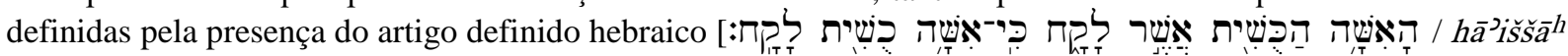

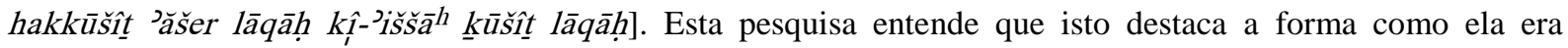
conhecida no meio de Israel - os dois termos da construção são substantivos definidos. Isso provavelmente era uma espécie de apelido que nomeava a mulher de Moisés. Na segunda vez, tanto "mulher" quanto "cuchita" estão sem o artigo. Aqui a ausência do artigo aponta para a qualidade da esposa de Moisés - ela é "cuchita", ou, noutra forma de dizer, ela é de Cuche, para salientar a origem dela. A última frase do texto é uma explicação polida do redator da razão de a mulher de Moisés ser apelidada pelos seus cunhados e, provavelmente, por todo o povo, de "mulher cuchita". 
afirma que em Habacuque 3,7 Cuche é colocado em paralelo com Midiã. ${ }^{326}$ Assim, o casamento de Moisés com uma mulher cuchita seria uma variante do casamento que ele teve com a filha de um sacerdote midianita. O que leva à conclusão de que "mulher cuchita" é um apelido colocado por Miriam e Arão, e usado pelo povo em geral, para se referir à mulher de Moisés. Provavelmente esse tenha sido um apelido pejorativo relacionado à cor de Séfora.

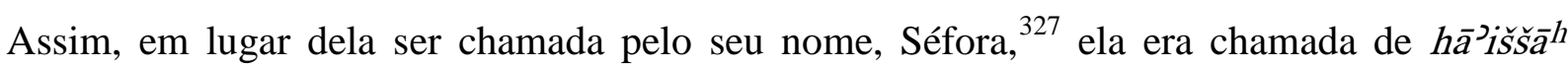
hakkūšît. ${ }^{328}$

Nesta pesquisa acrescenta-se a quarta possibilidade. Nessa afirma-se que a construção

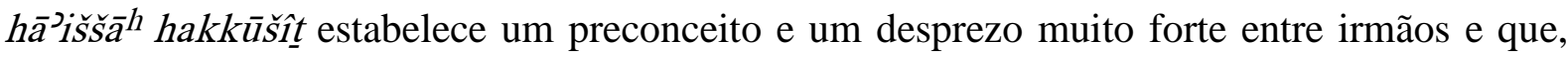
provavelmente, alimentou-se por anos até se consolidar nas declarações de Miriam. Midiã, o ancestral de Séfora, fora filho de Abraão por meio de Quetura (Gênesis 25,1.2.4). Assim, quando Moisés fugiu da perseguição egípcia, ele se refugiou no meio de parentes (Êxodo 2,15-21). Porém, Gênesis $(25,6)$ diz que, ainda em vida, Abraão separou Quetura e seus filhos de Isaque, filho de Abraão por meio de Sara, o herdeiro, divinamente apontado (Gênesis 21,12), de tudo que Abraão possuía, incluindo a bênção divina e a continuação da descendência em nome de Abraão (Gênesis 7,19; 21,12).

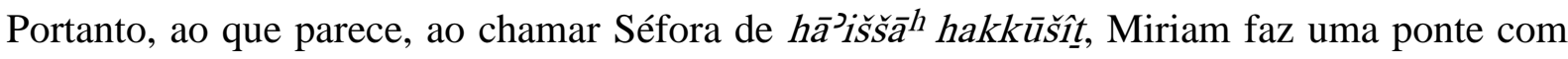
Cuche, um descendente de Noé por meio de Cam, seu filho amaldiçoado (Gênesis 9,21-27) que, na realidade, teve sua maldição lançada sobre o outro filho de Cam, Canaã, irmão de

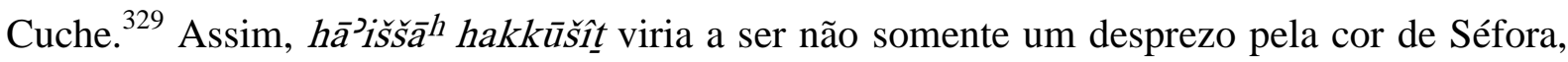

\footnotetext{
${ }^{326}$ Ashley dá três sugestões para identificar Cuche: um etíope (Ezequiel 29,10); um habitante de Cuche (Gênesis 10,8); e um habitante de Cuche em paralelo com Midiã encontrado em Habacuque 3,7 (1992, p. 223). Ele também especula que ela pudesse pertencer ao misto de gente que saiu do Egito (Êxodo 12,38) ou da ralé de Números 11,4 (1992, p. 224).

${ }^{327}$ Ela é chamada de "Séfora, a mulher de Moisés", em Êxodo 18,2.5, mas no contexto da família do seu pai, Jetro.

${ }^{328}$ O desprezo pela mulher de Moisés é grande. Normalmente uma mulher casada é identificada pelo marido. Note-se alguns exemplos: "Sarai, mulher de Abrão", Gênesis 12,17; "Ada, mulher de Esaú... Basemate, mulher de Esaú", Gênesis 36,10; "Raquel, mulher de Jacó", Gênesis 46,19; "Jael, mulher de Héber", Juízes 4,21; "Mical, mulher de Davi”, 1 Samuel 19,11; "Abigail, mulher de Nabal”, 1 Samuel 25,14; "Bate-Seba... mulher de Urias”, 2 Samuel 11,3. Aqui ela é colocada sozinha, sem a identificação com Moisés, numa forma possível de desprezo ao indicar que ela não tinha relacionamentos com o clã ao qual ela estava associada. Não há indícios que Moisés tenha tomado outra mulher como esposa, pertencente ao próprio povo de Israel, tendo uma lealdade matrimonial incomum nos grandes líderes do povo.

${ }^{329}$ A maldição recai sobre uma parte, mas tem a finalidade de atingir o todo. Isso quer dizer que, mesmo que a maldição seja sobre Canaã, o alvo dela é alcançar Cam e, por implicação, todos os seus descendentes. Assim, amaldiçoar a descendência era o mesmo que amaldiçoar o progenitor daquela descendência. Essa ideia que a punição sobre um descendente tem por finalidade punir o pai é vista em outra situação dentro da BH. Quando Davi adulterou com Bate-Seba e depois ordenou a morte de seu marido, Urias, para se casar com ela (2 Samuel
} 
como também um desprezo pelo irmão excluído da herança com Isaque, como fora Cam excluído da família de Noé. ${ }^{330}$

Pelo relato das narrativas, o povo está no início de suas peregrinações pelo deserto, a mulher tinha sido trazida por seu pai, Jetro, para Moisés, depois que Moisés a enviou com os filhos, provavelmente por entender que sua presença com ele no Egito representava algum tipo de perigo para ela e seus filhos (Êxodo 18,1-4). Com isso em mente, é possível sugerir que a mulher cuchita é a mesma com quem ele se casou quando de sua fuga da presença de Faraó para Midiã. ${ }^{331}$

Mas há um elemento a mais que torna a crítica à mulher de Moisés apenas um detalhe. A questão que está por trás de tudo é: Por quem Deus fala ao povo? Quem de fato é o representante legítimo do Deus de Israel no meio do povo? "Porque Moisés é o favorito de Deus" (KALLAND, 1990, p. 797), haja vista que Deus fala também por meio de Miriam e Arão?

Na realidade, a luta travada entre os irmãos tinha a ver com a liderança, ou poder, e sobre quem possuía mais intimidade com o Deus de Israel para que desenvolvesse a liderança sobre o povo. A liderança deixa de ser daquele que é escolhido por Deus para ser, simplesmente, por meio de quem Deus fala. No final, a questão toda gira em torno do poder (ou controle) sobre o povo de Deus.

O problema desenvolvido por meio do ciúme gerado entre irmãos pode também ser colocado assim: Se Deus fala também por meio de Miriam e Arão, então, porque a liderança do povo de

11), Davi recebeu como punição a morte do filho que nasceria daquele relacionamento com Bate-Seba (2 Samuel 12,5-19), punindo o pai da criança, Davi.

${ }^{330}$ Jezabel fez esse tipo de analogia com o fim de desprezar o outro. Depois que Jeú deu golpe de estado no rei de Israel, Jorão, e de matá-lo, ele se dirigiu para Jezreel a fim de colocar seus planos em andamento. Ao chegar ali, Jezabel o recebe com o seguinte sarcasmo: "Tudo vai bem, Zambri, assassino de seu senhor?" (2 Reis 9,30; BJ). Zambri reinou apenas 8 dias sobre o Reino de Norte, Israel. Ele assassinou Elá que era rei de Israel (1 Reis 16). Zambri era um oficial de Elá e chefe da metade de seus carros de guerra. Nessa analogia, Jezabel alude ao assassinato de Elá, comparando Jeú com Zambri que acabara de assassinar seu senhor. Para Jezabel, Jeú é um assassino usurpador, tal como Elá. Esse é o ponto de comparação.

${ }^{331} \mathrm{Na}$ cronologia das narrativas das peregrinações do povo de Israel pelo deserto, essa é a última referência que se faz à mulher de Moisés. Assim, como até aqui não houve nenhuma menção à morte de Séfora, na narrativa seguinte também não. Como o papel básico de uma mulher dentro de uma família israelita é a procriação, ela tem cumprido a sua função, e com isso ela teria concluído de forma plena seu papel dentro da comunidade. Interessantemente, por outro lado, vale salientar que não é dito que Miriam seja casada ou mesmo que tenha tido filhos. Aquela que era criticada por sua cor e por pertencer a família do filho excluído era bem sucedida como mulher, segundo os padrões da época. Não poderia ser este um motivo oculto para Miriam ter tanta aversão à "mulher cuchita" de Moisés? Ao contrário de outras situações na narrativa bíblica (como Penina e Ana em 1 Samuel 1-2), aqui é a "sem filhos" que maltrata uma mulher "com filhos". 
Israel está somente nas mãos de Moisés, o irmão mais novo? Por que a liderança está com ele, e os outros dois têm apenas atividade delegada? Ser considerado como porta-voz divino implicava em maior poder e influência sobre o povo por parte de quem era o arauto divinamente autorizado.

O término do versículo 2 não é mero adendo à narrativa: "E yhwh ('āâōnāy) ouviu”. Ele tem como propósito preparar os ouvintes/leitores para intervenção divina judicial (KEIL \& DELITZSCH, p. 811). Deus dará sua palavra final sobre o questionamento que Miriam e Arão têm levantado.

Como Moisés reage a isso? Qual será seu papel diante de tal acusação? Quem sairá em sua defesa? Por que ele é caracterizado como um ‘̄annt? O que Moisés e um ‘̄annî tem em comum?

\subsubsection{A caracterização de Moisés como ‘̄anî}

\subsubsection{Moisés é chamado de hāôî̌.}

Números 12,3 apresenta uma caracterização muito particular de Moisés por parte do narrador/redator do evento. Primeiro, ele é chamado de "homem" definido pelo artigo, ${ }^{332}$ e coloca essa palavra numa posição de ênfase, abrindo a declaração que a segue. Esse destaque prepara o caminho para o que será dito em seguida. Moisés é apenas um homem. ${ }^{333}$ Mas quem está por trás dele que o faz diferente? Porque ele é tão especial que Deus vem em sua defesa? A humanidade dele fica em relevo para mostrar que a acusação é improcedente e que a função de Moisés é delegada.

Ele é um membro da comunidade de Israel no deserto como qualquer outro homem no meio do povo de Israel. Porém, ele é $h \bar{a} \vec{i} \hat{s}$, “o homem”. Ele não é qualquer homem - ele é o homem por excelência. Ele é alguém que seria como o próprio Deus para o sacerdote de Israel, Arão, segundo a própria palavra do Deus de Israel a Moisés (Êxodo 4,14-16). Assim, ele mais que um homem, ele é "o homem”, o ser humano ideal, cujo nome é Moisés. Esse ideal de humanidade, segundo o Êxodo, só pode ser construído pelo relacionamento divino e

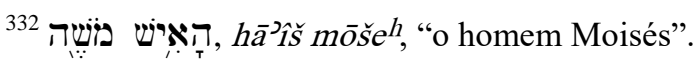

333 "wวhââि demonstrou extraordinário caráter na área da humildade” (COLE, 2000, p. 202).
} 
humano na construção de um povo. Por isso Moisés, como o hăâî̌, é objeto da ira dos que se opõem ao projeto divino para o povo no deserto.

Mas não é somente aqui que Moisés é chamado de $h \bar{a} \widehat{\imath} \hat{i} s$. Em pelo menos outros três lugares aparece a denominação "o homem Moisés" (Êxodo 11,3; 32,1.23) ${ }^{334}$ Nesses três casos, há um contexto de conflito. No primeiro (Êxodo 11,3), a polêmica entre o Deus de Israel e os deuses do Egito é o cenário, tendo Faraó como representante dos deuses egípcios e Moisés e Arão como representantes do Deus de Israel. No segundo (32,1.23), Moisés enfrenta o envolvimento do povo com o bezerro de ouro desenvolvido por Arão. Assim, a identificação de Moisés como hăâî̌ aponta para Moisés como um homem específico, conhecido pela posição que ocupava - o porta-voz e representante direto do Deus de Israel e, como em Números 12, um homem em conflito. Contudo, diferentemente dos outros lugares em Êxodo, ele não está lutando por Deus, mas será Deus quem lutará por ele. O divino e o humano estão entrelaçados nesses conflitos. Em Êxodo 11 e 32, Moisés trava as guerras contra os outros deuses e seus representantes. Em Números 12, Deus trava a batalha de Moisés contra aqueles que querem ocupar o lugar de seu escolhido.

Assim, essas ocorrências textuais deixam transparecer que o conflito não era contra Deus diretamente, mas contra seu representante humano, o seu hăâs.s. ${ }^{335}$ Dessa maneira, mesmo que isso não indique uma vontade humana de atacar o Deus de Israel diretamente, o resultado indesejado, mas alcançado, é que Deus se sente ofendido pelas acusações contra seu representante oficial e age para defendê-lo, e, como implicação direta, defender a si mesmo. Um ataque ao representante de Deus é um ataque ao próprio Deus que o enviou com seu representante autorizado.

\footnotetext{
${ }^{334}$ Em Êxodo 11,3 se encontra a construção igual a Números 12,3 - “o homem Moisés”. Já em Êxodo 32,1.23 a construção é "Moisés, o homem". Mas isso não implica mudança de significado, mas de ênfase. No primeiro, "homem" está na posição de ênfase, no último texto, "Moisés". Milgrom sugere que a construção "o homem Moisés" talvez queira enfatizar que ele era apenas um homem (1989, p. 94). Deve-se mencionar que em Êxodo 11,3, "o homem Moisés" é grande aos olhos dos oficiais de faraó, não aos seus próprios olhos (1989, p. 94). É instrutivo pensar que, mesmo sendo que foi e fazendo o que ele fez, Moisés não se considerou "muito grande"

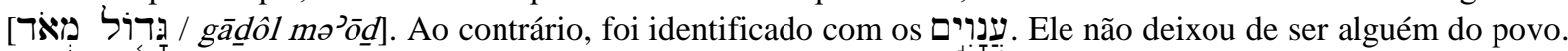
Sua identificação com sua gente foi a tal ponto de ele preferir ser destruído com o povo em lugar de sair dele outro povo de Deus (Êxodo 32,9-15.32; 34,8-9).

${ }^{335}$ Mesmo assim, é o Deus de Israel que está sendo questionado. Em Êxodo 11,3, Deus está sendo questionado sobre a sua capacidade de vencer os deuses do Egito e retirar o seu povo dali. Em Êxodo 32,1.23, está em questão a capacidade de Deus de levar o povo para a terra que ele prometera, bem como a sua capacidade de se fazer presente no meio de seu povo e conduzi-lo para o lugar que ele prometera. Já em Números 12, Deus está se acusado de não fazer escolhas sábias. Afinal, existem outros por meio de quem ele fala e que são tão capazes quanto (ou até mais que) Moisés, o preferido de Deus.
} 
2.4.3.2. Um homem distinto - o mais $\varsigma_{\bar{a}}$ Uāa $w$ que todos os homens.

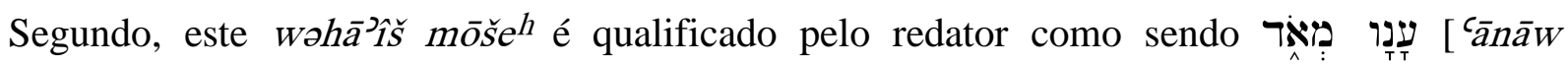

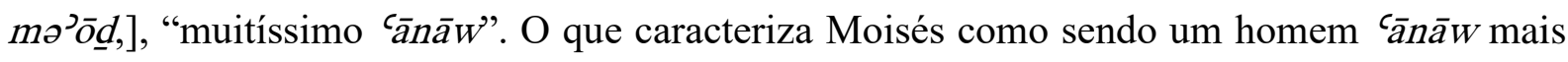
do que todos os outros homens sobre a face do solo? O que uma expressão desse tipo quer dizer sobre o homem a quem ela aponta? É notório que a presença dessa descrição editorial indica um elogio que distingue Moisés de todos os outros homens do Israel no deserto, incluindo o próprio Arão.

Como tratado acima, numa nota sobre a tradução, verificou-se que temos aqui um Qerê Ketiv.

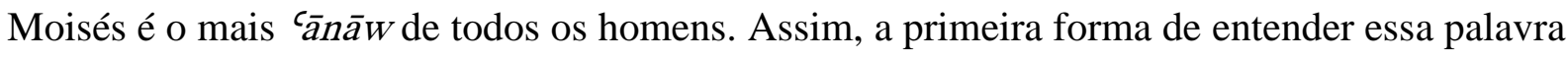
é observar como as traduções para o Português traduziram a palavra ‘̄añāw: "humilde", "sofrido", e "manso". 336 Isso já mostra a variedade de sentidos que essa palavra apresenta. Como homem "humilde", a palavra traz o mesmo sentido de alguém que é manso e, portanto, dócil.

Holladay (HHL-BW7) apresenta como uma possibilidade de tradução para essa palavra a alternativa de alguém "gentil (quando diante de Deus)" e cita como exemplo Números 12,3 Moisés é alguém que é completamente submisso a tudo o que Deus o manda fazer. Nesse sentido, ele é um perfeito Ente Silencioso, pois esse aspecto da submissão era algo característico dos Entes Silenciosos, principalmente daqueles que pertencem ao grupo עִנִִי . Como Ente Silencioso ele cumpre ordens e, quando ele tem que falar alguma queixa, como um Ente Silencioso, ele fala com Deus. ${ }^{337}$

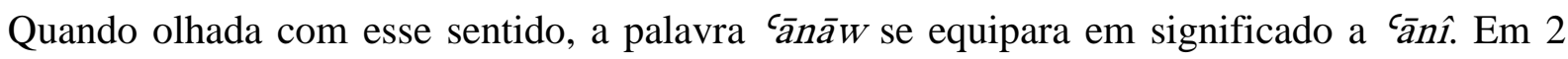

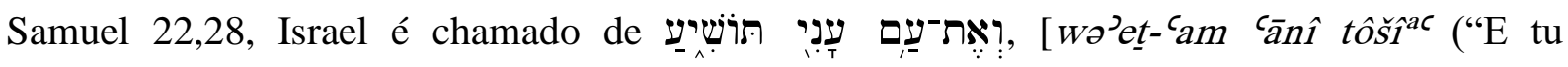
libertarás o povo humilde")]. ${ }^{338}$ Gerstenberger aponta que a palavra cānāw "aparece

\footnotetext{
${ }^{336}$ As citações vêm destas bíblias e nesta ordem de aparição: BJ, BP, BEG.

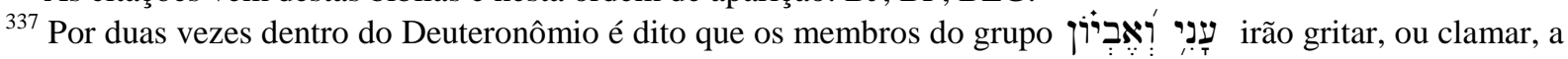
Deus por uma agressão feita a eles (Deuteronômio 15,9; 24,15), mostrando que sua voz, como a de Moisés, em determinados momentos só seria ouvida por Deus.

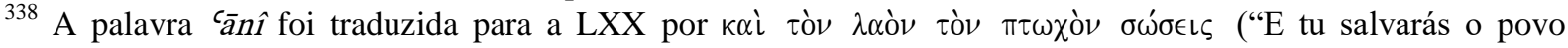
pobre"). As traduções para o português traduziram-na da seguinte forma: "povo afligido" (BP), "povo pobre" (BJ), "povo humilde" (BEG).
} 
representada na versão Samaritana por 'ān̂̂’' (GERSTENBERGER, 2001, p. 242), sugerindo que seus tradutores entenderam que as duas palavras são sinônimas. ${ }^{339}$

Por sua vez a LXX traduziu ‘ānāw por $\pi \rho \alpha u ̈ \varsigma$ (ATP), cujo significado básico é "gentil,

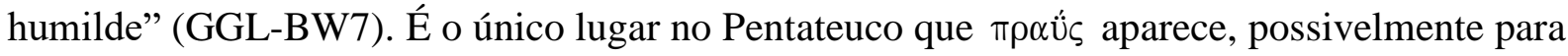
expressar o ideal de piedade ou o modelo de líder ideal, cuja submissão à vontade divina é acima de qualquer dúvida (HAUCK \& SCHULZ, 1968, p. 647). As traduções do texto hebraico para o aramaico trazem as seguintes palavras: Targum Neofiti, ענוון, "humilde"; Targum Pseudo-Jonathan, ענוותן, "pessoa modesta"; Targumim, עִנְוֹתן, "pessoa modesta". Rashi projeta sobre essa palavra o significado de "humilde e paciente" (BAMIDBAR, 1934, p. 59). Com isso, indo na mesma direção dessas traduções, ‘̄ānāW projeta sobre Moisés a figura de um líder completamente dedicado ao seu Deus na realização da missão que lhe foi dada como líder de seu povo, cujo resultado está presente em sua humildade e paciência no trato com seu povo. No Salmo 22,27 (hebraico), עִ ְִנִִיִ está em paralelo com “os que o (Deus) buscam”. É uma palavra que salienta devoção, fidelidade (MILGROM, 1990, p. 94).

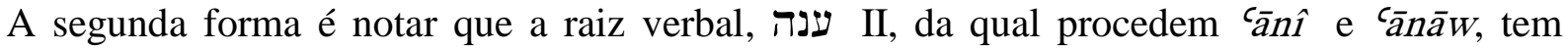
também o sentido de "encontrar-se a si mesmo em situação de impedimento, humildade, posição inferior" (HAUCK \& SCHULZ, 1968, p. 647). ‘ānî aponta para alguém que, na escala social e econômica, é sem propriedades e ganha seu pão por meio de prestar seu serviço a outros e, portanto, está na posição de sujeição (HAUCK \& SCHULZ, 1968, p. 647). Então o ‘ānî é caracterizado por sua dependência de alguém para sua sobrevivência, usualmente daquele dono de terras que o acolhia para trabalhar em seus domínios.

Portanto, resposta para aquelas duas perguntas (p. 54) pode ser dada em duas formas. $\mathrm{Na}$

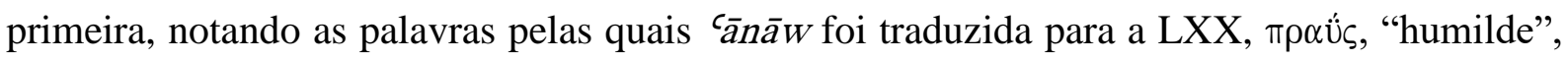

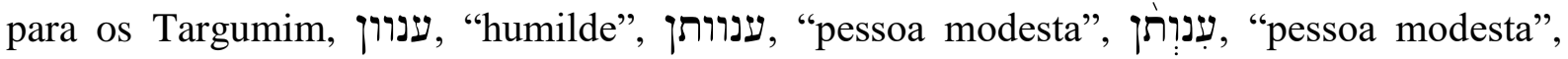
pode-se concluir que Números 12,3 apresenta Moisés como alguém que não está na posição que está por motivo de ambição pessoal, mas por determinação de alguém superior. Em sua vocação, segundo a narrativa de Êxodo 3-4, ele recusa, até ao fim do diálogo com Deus, a posição de homem que levaria o povo de Israel do Egito para uma vida de liberdade da casa

\footnotetext{
${ }^{339}$ Das 19 ocorrências dessa palavra, todas são no plural, e uma no singular, justamente a de Números 12,3 (GERSTENBERGER, 2001, p. 242).
} 
de escravos, como o Egito é chamado em vários lugares da $\mathrm{BH} .{ }^{340}$ Ele só segue para o Egito depois que aquela missão lhe é divinamente imposta.

$\mathrm{Na}$ segunda forma de responder, a intervenção divina se faz notória pela declaração final

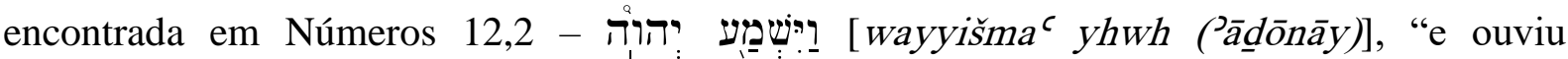
Jādōnāy", não Moisés. ${ }^{341}$ "A consequência do ouvir do Senhor é auto entendido e é mais poderoso pelo silêncio deliberado do texto sobre o assunto que se houvesse sido colocado em palavras" (MILGROM, 1990, p. 94). É o Deus de Israel quem defende Moisés. Como ‘̄̄nāW que é, ele não pode responder. Alias, é surpreendente como o texto deixa Moisés completamente silencioso diante das acusações de Miriam e Arão contra ele, transparecendo que o redator nota que o silêncio de Moisés o faz igual a um ‘̄annil $\varsigma_{\bar{a}} n \bar{a} W$, porque, como tal, outro teria que responder por ele. ${ }^{342} \mathrm{Ou}$, na linguagem do Deuteronômio, outro iria legislar por ele e faria com que a justiça fosse feita em seu favor. Moisés é um Ente Silencioso que precisa que outro fale por ele e o socorra em meio às acusações que comprometem sua liderança.

Moisés aqui é um ānāw. Mas o Deus de Israel, como um líder de um clã e como quem convocou Moisés para um trabalho "nos seus campos", vem em defesa de seu protegido. Em Números 11,10, Moisés ouve o chorar do povo. Mas aqui, o mesmo Moisés se cala, e Deus ouve o que se diz contra ele. O motivo é que o próprio Deus chama Israel de "minha casa" em Números $12,7,{ }^{343}$ apontando para a posição de Moisés como a de um líder delegado do clã denominado de Israel. Ele não pode se defender, mas quem o colocou ali pode fazer a sua defesa. Assim, aquele que está na posição de um ‘̄anāW é alguém que também não pode responder. O $\varsigma^{c} \bar{a} n \bar{a} W$ não responde. Por isso ele precisaria de outro que falasse no seu lugar.

\footnotetext{
${ }^{340}$ Nas duas versões dos Dez Mandamentos (Êxodo 20,1-17 e Deuteronômio 5,6-21), o Egito é chamado de “

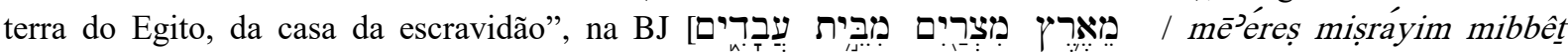
‘ăbāâîm].

${ }^{341}$ Essa construção aparece em Números 11,1 para Deus. Em 11,11 o representante divino, Moisés, é quem ouve as queixas do povo. Nesses dois casos, como em Números 12, a resposta divina ao seu ouvir da queixa do povo é ira contra os queixosos, mesmo quando o ouvir tenha sido de seu representante, sugerindo uma espécie de solidariedade entre o divino e o humano na liderança do povo de Israel. Moisés é o lado humano na liderança de Israel.

${ }^{342}$ Em Deuteronômio, o ‘̄anî tem quem fale por ele - o redator ou o Deus de Israel. Interessantemente, o mesmo acontece no evento de Números 12. Moisés não responde à acusação. O defensor do cannî, o Deus de Israel, reponde à Miriam e Arão e, por implicação, a todo o Israel.

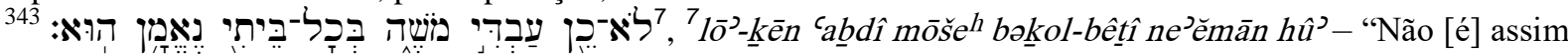

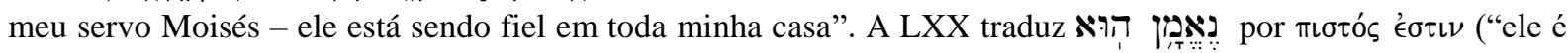

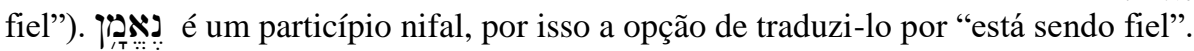


Não é especificado onde esse evento ocorre no arraial de Israel. Mas o convite divino para os três é para que eles compareçam no centro de poder da comunidade de Israel no deserto - a Tenda da Congregação, o tabernáculo onde se encontrava a presença divina em meio a seu povo. É lá onde ele defende Moisés e toma providencias contra seus acusadores, ou, numa outra forma de ver, é ali, no tribunal divino, que ele faz justiça ao ${ }^{\complement} \bar{a} n \hat{\imath} / \complement_{\bar{a}} n \bar{a} W$.

Nas narrativas do Pentateuco, em meio a muitas mulheres de personalidade forte, apenas Miriam resolve questionar a liderança de um homem diante de outros homens e demais pessoas. ${ }^{344}$ Mesmo assim, deve-se apontar que a narrativa começa com Miriam falando, e termina com Miriam em seu período de silêncio, em seu exílio por sete dias (Números 12,115). Se colocada fora do arraial de Israel é ser, temporariamente, excluída da comunidade onde está a presença divina, a comunidade da bênção, então Miriam parte para seu exílio temporário, fora da comunidade de Israel para vivenciar seu exílio e sua maldição temporária. $^{345}$ Aquela que tratou com desprezo um irmão excluído, agora experimentava temporariamente sua própria exclusão. ${ }^{346}$

Uma terceira forma de entender $\bar{c}_{\bar{a}} \bar{a} w$ é aquela que pode ser extraída de Gerstenberger, o qual, fazendo um trabalho comparativo entre $\varsigma_{\bar{a} n \hat{\imath}}$ e ${ }^{\bar{a}} n \bar{a} W$, concluiu que houve um desenvolvimento em que a primeira tem o sentido de "pobre", e a segunda o sentido de "humilde, devoto", principalmente em seu uso plural, mesmo que, para ele, essa distinção não deva ser estabelecida como fixa (GERSTENBERGER, 2001, p. 242). A ideia de uma pessoa devota se aplica a Moisés por Deus nas palavras divinas dadas em sua defesa. Deus diz que Moisés é "fiel em sua casa". Ele é devotado a Deus no exercício de sua vocação. Essa devoção é vista em sua completa fidelidade ao seu senhor, o Deus de Israel, o dono da casa, sobre a qual ele foi colocado como administrador.

\footnotetext{
${ }^{344}$ Parece ter sido um evento público. Assim como a forma divina de solução também foi pública. Obviamente, havia o objetivo pedagógico para toda a comunidade.

${ }^{345} \mathrm{O}$ castigo divino sobre Miriam tem alguns pontos a mencionar. Primeiro, o castigo é uma ironia - aquela que chamava Séfora de cuchita havia de se tornar, forçadamente, muito branca por causa da lepra. Segundo, intimidade com o Deus de Israel não é para qualquer um. Ele só mantém o diálogo "face a face", como com Moisés, com quem ele quer. O castigo divino sobre Miriam era a indicação que, mesmo com quem Deus fala, pode experimentar o juízo divino e ser afastado de seu povo. Ficar fora da comunidade onde está o Santuário divino não é bênção, mas maldição. Séfora não era amaldiçoada por sua cor. Mas Miriam foi ao se tornar, inesperadamente, "branca". Essa "brancura" era excludente, mostrando que a crítica à cor de Séfora tinha algo de tenebroso na sua expressão - o questionamento da autoridade divina de decidir para a liderança de seu povo quem ele quisesse.

${ }^{346}$ Nota-se no profeta Miquéias que a missão de liderar o povo de Israel em seu Êxodo até a Terra da Promessa fora confiada tanto a Moisés como a Arão e Miriam: "Sim, eu te fiz subir da terra do Egito, resgatei-te da casa da escravidão, e enviei diante de ti Moisés, Arão e Maria" (6,4 [BJ]).
} 
Da ideia de devotado vem a de "consagrado". Há uma frase repetida através do Pentateuco, na qual é afirmado que os filhos de Israel fizeram o que lhes foi ordenado, conforme tudo o que Deus tinha ordenado a Moisés e que o próprio Moisés também procedeu assim. ${ }^{347}$ Essa é uma maneira de declarar que Moisés precisava falar a Israel o que Deus lhe tinha comunicado. É uma demonstração de fidelidade extrema ao seu Deus no que ele lhe havia falado.

Uma quarta forma de entender cānāw é pela compreensão da raiz verbal ענה II que também tem o sentido de "estar aflito". Os adjetivos derivados dessa raiz, ‘̄annî e c̄ānāw, trazem também a idéia de aflição de alguma forma. Moisés é um homem humilde porque, mesmo em

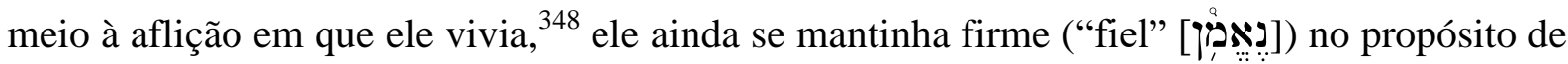
levar o povo à Terra da Promessa. Liderar um grupo de escravos recém-libertos e amargurados não foi uma tarefa fácil para Moisés. ${ }^{349}$ Como Moisés se apresenta em aflição? Ele expressa isso na seguinte forma: "só falta apedrejar-me" (Êxodo 17,4). Além desse exemplo, ao longo da trajetória do povo no deserto, basicamente, os livros de Êxodo e Números carregam, em seu conteúdo, vários conflitos que houveram entre Moisés e o povo que ele liderava. ${ }^{350}$ Moisés foi um homem que vivenciou a aflição na liderança de Israel. Como um Ente Silencioso, Moisés experimentou o sofrimento na liderança de modo calado, exceto nos momentos que ele fala com Deus sobre eles.

Uma quinta forma de entender a palavra ‘̄annāW é vê-la como sinônimo de ‘̄antî. O conceito de "pobre" é muito aplicado à vida profética. Aqui se deve entender "pobre", não necessitado, mas pelo lado da vida simples e também pela disposição do profeta de não explorar o povo em seu benefício próprio. ${ }^{351} \mathrm{Na}$ contenda entre Moisés e o grupo de Corá (Números 16),

\footnotetext{
${ }^{347}$ Aqui estão algumas referências para exemplo: Êxodo 25,9.40; 26,30; 29,35; 36,1; 39,32.42; 40,16.

${ }^{348}$ Números 11 está carregado de exemplos de sofrimento que Moisés está experimentando com o povo, onde recebem como retorno a ira divina e a de Moisés também. Porém, Moisés demonstra muita paciência com o povo sob sua liderança.

349 Notar também as queixas de Moisés a Deus pela dificuldade de liderar o povo no deserto (Números 11,11.14.15). Nessas queixas, Moisés parece demonstrar sua vulnerabilidade e dificuldade para atender as necessidades do povo. Assim, Deus, como o Grande Líder de Israel, precisava conhecer das dificuldades que Moisés tinha para realizar seu papel de representante divino no meio do povo no deserto.

${ }^{350}$ Os que são alistados aqui são aqueles que foram muito marcantes para a liderança de Moisés. Além do evento de conflito entre os irmãos (Números 12,1-3), há também o evento do bezerro de ouro (Êxodo 32) onde Arão mostra toda a fragilidade de sua liderança, o conflito com o grupo de Corá (Números 16), e aquele que culminou na proibição divina de entrada na Terra da Promessa tanto de Moisés como de Arão (Números 20).

351 Ao que parece, alguns dos profetas de Israel buscavam manter uma vida simples, reivindicando para si uma aura de dependência de seu próprio trabalho para poder viver e, por implicação, a ideia que a sua dependência estava aos cuidados do Deus que os convocara para ser seu porta-voz. Em Amós 7,14, o profeta diz que sua "profissão" é ser "boieiro e colhedor de sicômoros". Ele não dependia da ajuda de outros muito menos do rei de Israel, como faziam os profetas da corte. Havia um grupo de profetas que buscava manter todo tipo de independência do Estado para sua sobrevivência (Elias em 1 Reis 18,19). Parece que a atitude de não se
} 
Moisés é acusado de querer se fazer príncipe do povo de Israel no deserto (16,12-14). A resposta de Moises foi: "E disse para yhwh ('āâōnāy): Que tu não favoreças a oferta deles. (porque) Não carreguei um jumento deles, e nem fui mal a um (só) deles". ${ }^{352}$ Moisés mostra que sua liderança sobre o povo não foi coercitiva nem com interesses ocultos. Sua colocação diante de Deus mostra que, se ele possui alguma coisa, ele a possui por seu próprio esforço, e que a acusação feita a ele demonstra ser, por si só, uma acusação falsa. A administração de Moisés é justa e transparente.

Mas há um detalhe a demonstrar sobre Moisés - nunca é dito, em todo o Pentateuco, que ele possuísse alguma propriedade. Parece que sua única propriedade pessoal tenha sido o seu cajado por meio do qual ele realizou muitos dos sinais estampados no Pentateuco. Apenas para destacar outro exemplo de grande profeta, Samuel, quando de sua prestação de contas diante do povo de Israel e do seu primeiro, Saul, pede que qualquer um do povo pudesse falar contra a sua lisura na liderança dos israelitas, ${ }^{353}$ obtendo como resposta que Samuel havia sido íntegro nas suas ações. De Samuel é dito que ele tinha uma casa (1 Samuel 7,17). Mas de Moisés se diz que tinha apenas uma tenda (Números 3,38), além do cajado mencionado acima.

Com isso, pode-se apontar Moisés como um modelo de serviço profético - sem riqueza, e uma vida simples. Além do mais, pode-se dizer, pelas diferentes formas de ver a palavra ‘̄anāw, que Moisés era um líder completo do ponto de vista da piedade. Isso também indicava que ele nunca usou a sua posição em benefício próprio, incluindo aí benefícios para sua

aproveitar de circunstâncias favoráveis para buscar benefício próprio fazia parte de uma decisão pessoal dos grandes líderes do Israel antigo. Mesmo que Abraão seja considerado pela narrativa do Gênesis como um homem muito rico $(13,2)$, ele optou por desprezar os despojos de guerra dos reis de Sodoma e Gomorra e seus aliados para que não fosse dito que ele havia sido enriquecido por aqueles despojos (Gênesis 15). Davi disse que não apresentaria sacrifício que não lhe custasse nada (1 Crônicas 21,24).

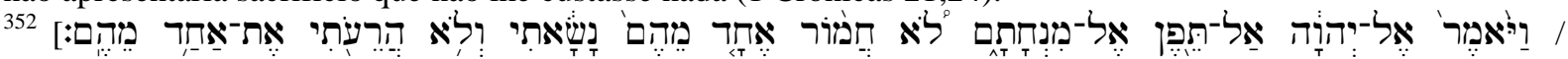

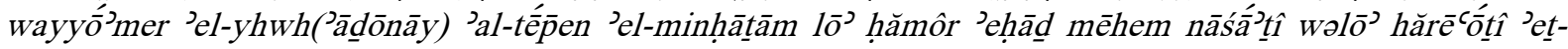
Jahad mēhem]. O restante da narrativa demonstra que Moisés foi atendido nesse pedido a Deus, mostrando a aprovação divina a Moisés.

${ }^{353}$ A defesa de Samuel diante do povo de Israel e do primeiro rei, Saul, é bem completa, e a resposta do povo favorece a integridade de Samuel. Note a citação da BJ: "Aqui estou. Deponde contra mim diante de Iahweh e do seu ungido: de quem tomei o boi e de quem tomei o jumento? A quem explorei e a quem oprimi? Da mão de quem recebi compensação para que fechasse os olhos diante do seu caso? Eu vos restituirei. Eles, porém, disseram: Tu não nos exploraste, nem nos oprimiste e de ninguém tiraste coisa alguma. Ele lhes disse: Iahweh é testemunha contra vós, e o seu ungido é hoje testemunha de que nada achastes em meu poder. E o povo disse: Ele é testemunha" (1 Samuel 12,3-5). Mas há uma diferença crucial entre Moisés e Samuel. Os filhos de Samuel foram acusados de ganho desonesto (1 Samuel 8,1-5). Nesse aspecto, nada é dito dos filhos de Moisés. Os filhos de Moisés parecem ter sido homens íntegros. 


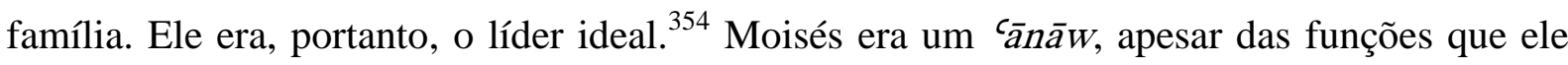
desempenhava no meio de Israel. No exercício de sua liderança, Moisés desempenhava as funções de sacerdote, profeta e rei. Ele, desse modo, era o profeta ideal. Somente um homem $\varsigma_{\bar{a}} n \bar{a} W$, em seu significado pleno, poderia ser o que Moisés era e fazer o que ele fazia sem orgulho e autopromoção sobre o povo. ${ }^{355}$

Em tudo isso um ponto se faz notar - o ’ebyôn e o ${ }^{\complement} \bar{a} n \hat{i}$ ou $\varsigma^{\complement} \bar{a} n \bar{a} W$ são ${ }^{356}$ membros de uma sociedade com a qual eles mantêm algum tipo de relacionamento. Eles não são indivíduos isolados. Para Gerstenberger, "o ‘ānînunca é um indivíduo isolado, mas um representante de um estrato social. Os ${ }^{a}$ nîym e ${ }^{a}$ nāwîm são sinônimos com os privados e vulneráveis econômica e socialmente; eles são idênticos aos dallîm, 'ebyyônîm, e rāšîm" (GERSTENBERGER, 2001, p. 244). ${ }^{357}$ Moisés é colocado entre eles. Ele é o modelo ideal de

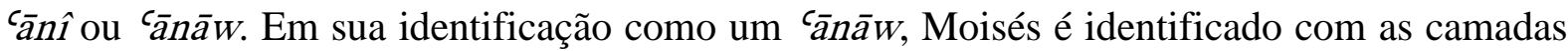
mais carentes da sociedade israelita, onde estão o ’ebyyôn e o ‘ānî. Essa identificação com os que sofrem deveria fazer parte do papel profético, bem como do rei e do sacerdote.

Em sua identificação com o ’ebyyôn e o ‘ānî, Moisés esteve na porta da justiça, diante de Deus, para que sua causa fosse julgada, mas a convite do próprio Deus, não por seu espírito de preservação. Um julgamento de uma questão existente entre Moisés, um jup p e Miriam e

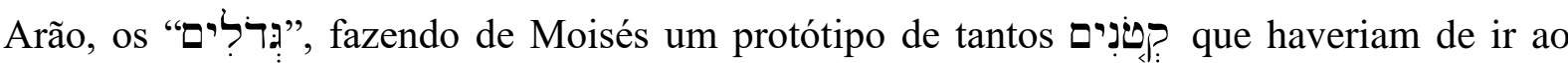
portão de suas comunidades buscarem justiça ao longo da história seguinte do Israel bíblico.

Como síntese do capítulo, deve-se notar que as palavras ‘̄annî e ’ebyôn são palavras usadas, dentro do Deuteronômio, para homens que tem se tornado empobrecidos e que, devido a sua nova condição, precisam de ajuda de seu irmão, o bacal. No Deuteronômio, elas não são

\footnotetext{
${ }^{354}$ Deuteronômio $18,15.18$ torna Moisés o protótipo do profeta ideal, ao anunciar que seria levantado em Israel outro profeta ideal e que esse seria semelhante a Moisés. Assim como Moisés falava as palavras divinas que Deus lhe dava, o profeta ideal vindouro também teria as palavras divinas em sua boca.

${ }^{355}$ Keil e Delitzsch comentam que "esta marca do caráter de Moisés serve para introduzir o ponto de vista da pessoa atacada, e assinala a razão porque Moisés não somente absteve-se de qualquer autodefesa, mas também não clamou a Deus por vingança pela injúria que tinha sido feita a ele" (p. 811). O homem que se calou diante da acusação dos irmãos só podia esperar que quem o chamou pudesse vir em sua defesa e falar por ele. Como Ente Silencioso ele se cala, Deus não. Em Deuteronômio Deus fala pelos Entes Silenciosos ao tu/vós, e para esses estabelece a sua vontade em relação aqueles. Acudir os Entes Silenciosos é obedecer á voz de Deus e imitá-lo.

${ }^{356}$ Martin-Achard diz que o significado ${ }^{\top} \bar{n} n \bar{a} W$ não é tão distinto de $\varsigma_{\bar{a}} n \hat{r}$ : "pobre, inferior, sofrido, pequeno, e humilde" (MARTIN-ACHARD, 1985, p. 441).

${ }^{357}$ Notar alguns lugares onde $\varsigma_{a} \bar{n} \bar{w} W$ aparece em paralelo com outras palavras para designar um "pobre" (Isaías

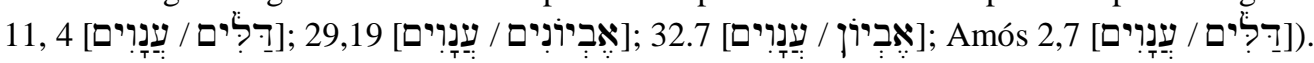


usadas para designar os outros membros dos Entes Silenciosos e nem aparecem relacionados com eles. Dentro de Deuteronômio, o ‘̄anî e ’ebyôn tem alguma propriedade, é livre, mesmo que ele venha a se vender como escravo, e que pode chegar à pobreza extrema, onde ele tem apenas uma capa como objeto de valor e suficiente para servir de garantia de um empréstimo.

Isso demonstra que os Entes Silenciosos chamados de ‘̄ānî e ’ebyyôn são um grupo específico, distinto dos outros grupos de Entes Silenciosos. Até porque essas palavras apontam especificamente para um israelita. Por isso que elas não designam os outros membros dos outros grupos, pois uma 'almāna $\bar{a}^{h}$ poderia ser uma mulher estrangeira que se casou com um israelita. Também não seria um gēr, pois o 'ānî e o ’ebyyôn dentro do Deuteronômio apontam para um israelita nativo. O yātôm seria aquele que perdera o seu pai e todo seu elo com seu clã. Já o lēwî pertencia a uma tribo específica de Israel. O ${ }^{\complement} \underline{e} \underline{b} \underline{d}$ e a ${ }^{\jmath} \bar{a} m \bar{a}^{h}$ apontavam para um israelita e uma israelita ou não, pois essas palavras também designavam um escravo e uma escrava adquiridos de outras terras.

A compararação com a Septuaginta e os Targumim também aponta na direção de o ‘ānî e o ’ebyôn indicarem um homem empobrecido. O texto que, em Deuteronômio, aproximou o ‘̄annî e 'ebyôn dos outros Entes Silenciosos foi 1,6.17. A palavra presente nesse texto é qāțōn que, por meio de análise comparativa, notou-se que ela se refere ao '`ānî e 'ebyyôn, por meio do dāl.

Porém, o qāṭōn não é o único beneficiário da ordenança nesse texto. $\mathrm{O}$ outro beneficiário é o gēr. Essa palavra, no entanto, não está em paralelo com qātōon. qātọ̄n está em paralelo com 'āh, "irmão", assim como gād̄ōl pode ser identificado com o ’ר̌š do versículo anterior. O texto pressupõe que gēr poderia entrar na justiça contra um israelita, caso seus direitos de estrangeiro residente houvessem sido violados.

Seguiu-se com um exemplo de figura importante que se calou quando, por sua posição, ele poderia se defender e até reagir contra. Sua identificação com os Entes Silenciosos do grupo ‘̄an̂ e ’ebyôn se deu por meio de um vocábulo que é traduzido por "manso/humilde".

Assim, o que se viu foi a capacidade que alguns homens, na $\mathrm{BH}$, tinham de se identificar com as camadas mais fragilizadas da comunidade. Mesmo que sejam identificados alguns deles, 
um foi tratado com mais detalhe devido a sua importância para a comunidade de Israel, e para toda a BH. Esse foi Moisés. ${ }^{358}$

Portanto, ‘̄annî e ’ebyyôn apontam para um grupo específico de pessoas dentro de Deuteronômio, notadamente de homens que têm se tornado pobres e precisam de ajuda do próximo/irmão deles.

\footnotetext{
${ }^{358} \mathrm{~A}$ colocação de Moisés como um $\Upsilon_{a} \bar{a} \bar{a} W$ tem a ver com o entendimento que ele se identifica com os fragilizados diante da opressão do mais forte. Entretanto, ānāw é uma palavra que tem relacionamento próximo com ‘̄antî, pois pertence à mesma raiz.
} 


\section{OS ENTES SILENCIOSOS EM BLOCO}

Os quatro membros deste bloco de Entes Silenciosos ['almānāh yātôm, gēr e lēwî] normalmente aparecem juntos dentro do livro de Deuteronômio. ${ }^{359}$ Essa é a razão para eles serem colocados juntos neste capítulo. Na página seguinte está um quadro comparativo para demonstrar as ocorrências deles dentro dos mesmos textos dentro do livro. Dos quatro membros deste grupo, os únicos que aparecem no grupo e isoladamente são gēr e $l \bar{e} w \hat{k}$. Por outro lado, deve-se notar que a dupla 'almāna $\bar{a}^{h}$ e yātôm não aparece sozinha, como costuma acontecer nos profetas. ${ }^{360}$

Como característica dos Entes Silenciosos tratados sob os vocábulos relacionados com a pobreza, os que serão tratados neste bloco também são notados por sua solidão, mesmo que, como visto no quadro seguinte, eles aparecem quase sempre juntos, numa indicação de formação de um grupo social específico dentro da sociedade deuteronômica.

\footnotetext{
${ }^{359}$ O quadro comparativo, na próxima página, visa salientar as ocorrências dos elementos em conjunto, não apresenta a ocorrência desses elementos com outros membros dos outros dois grupos constituintes dos Entes Silenciosos. Apenas para constar, em Deuteronômio 16,11.14 o conjunto Jalmānā ${ }^{h}$, gēr, yātôm, lēwî aparece junto com 'ebed e 'amah; em 24,14, gēr aparece ao lado de 'ebyôn e 'ānî, em 12,12.18, lēwî está ao lado de 'ebed e 'amah.

${ }^{360}$ Notar para o exemplo Isaías $1,17.23$.
} 


\begin{tabular}{|c|c|c|c|}
\hline Vocábulos & Deuteronômio 1-11 & Deuteronômio 12-26 & $\begin{array}{l}\text { Deuteronômio 27- } \\
34\end{array}$ \\
\hline 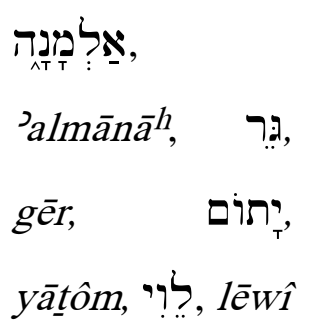 & & $\begin{array}{ll}14,29 ; & 16,11.14 \\
26,12.13 & \end{array}$ & \\
\hline 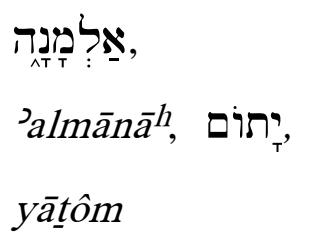 & & & \\
\hline ר: $g \bar{e} \bar{r} r$ & 1,$16 ; 5,14 ; 10,19$ & 14,$21 ; 23,8 ; 24,14$ & 28,$43 ; 31,12$ \\
\hline 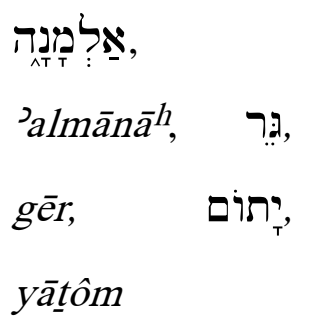 & 10,18 & $24,17.19 .20 .21$ & 27,19 \\
\hline 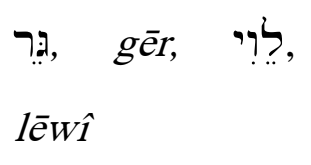 & & 26,11 & \\
\hline 它 & & $\begin{array}{ll}12,12.18 .19 ; & 14,27 \\
18,1.6 .7 ; 21,5 & \end{array}$ & $\begin{array}{l}27,9.14 ; \quad 31,9.25 \\
33,8\end{array}$ \\
\hline
\end{tabular}

Algumas observações podem ser apontadas aqui da perspectiva da ordem de aparição desses Entes Silenciosos. Em primeiro lugar, a אַלְ é é a única mulher que aparece nas listas de aparição dos quatro e, especificamente, dentro do bloco literário chamado de Código Deuteronômico. Segundo, a ordem usual, quando os quatro estão juntos é a seguinte: 


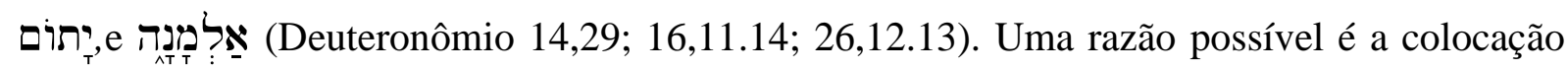
do homem antes da mulher, comum em sociedade patriarcal. Porém, é possível também que essa ordem não esteja estabelecida por questões de gênero, mas porque elas já estavam prontas e dessa forma era que elas eram entendidas pelos seus ouvintes. Era uma ordem já estabelecida e o redator não a quis alterar.

Teceiro, quando o לִ̣ está ausente, a ordem pode ser trocada, mas segue com um homem em

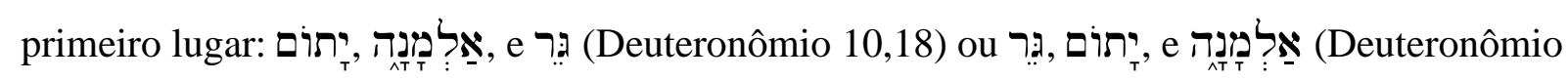
24,17.19.20.21; 27.19). O detalhe a pontuar é a presença de dois textos fora do Código Deuteronômico $(10,18 ; 27,19)$. Em quarto lugar, há um texto onde aparecem apenas o לִ̣ e o רִ

Como última observação, há textos dentro de Deuteronîmio em que o ạ̣ aparece sozinho $(1,16 ; 5,14 ; 10,19 ; 14,21 ; 23,8 ; 24,14 ; 28,43 ; 31,12)$, e isso nas três divisões maiores do livro.

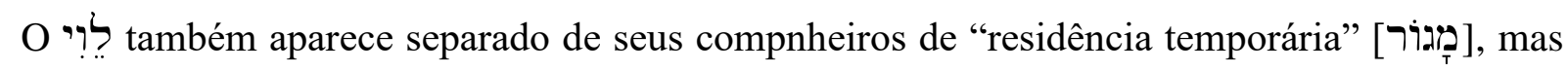
somente no Código Deuteronômico e na última divisão do livro (12,12.18.19; 14,27; 18,1.6.7; $21,5 ; 27,9.14 ; 31,9.25 ; 33,8)$.

O que esses quatro Entes Silenciosos têm em comum é o seu desenraizamento, falta de proteção e consequente facilidade de serem oprimidos sem que haja quem os socorra. Desse ângulo, o livro de Deuteronômio é um avanço com uma legislação que os proteje e também provê meios de sustentá-los.

3.1. O Ente Silencioso desprovido do amparo do cônjuge e filhos: a viúva אַלְלָָָּה, دalmānāh]

\begin{tabular}{|c|c|c|c|}
\hline Vocábulo & Deuteronômio 1-11 & Deuteronômio 12-26 & Deuteronômio 27-34 \\
\hline 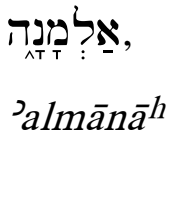 & 10,18 & $\begin{array}{l}14.29 ; \quad 16,11.14 ; \\
24,17.19 .20 .21 ; \\
26,12.13\end{array}$ & 27,19 \\
\hline
\end{tabular}




\subsubsection{Algumas observações iniciais}

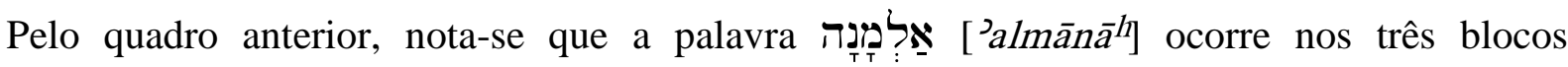
principais de literatura do livro de Deuteronômio. Porém, seu maior índice de ocorrência está em Deuteronômio 12 a 26. Juntamente com a ' ${ }^{\prime} \bar{m} \bar{a}^{h}$, ela integra o gênero feminino dentro do grupo denominado por esta pesquisa de Entes Silenciosos, aparecendo em um mesmo versículo somente em Deuteronômio 16,11 e 14. Comumente, porém, seus companheiros de aparição são o órfão e o estrangeiro em 10,18; 24,19.20.21, sendo que o levita é acrescentado ao grupo em 14,29; 16,11.14 e 26,12.13. Já se pode perceber com isso que ela nunca está só em sua aparição dentro do livro. As companhias da 'almānă $\bar{a}^{h}$, porém, precisam de ajuda tanto quanto ela, e a legislação que alcança um alcança os outros membros desse grupo também.

Significativamente, pode-se afirmar que a palavra 'almānă $\bar{a}^{h}$ é um substantivo feminino e é sempre assim que ela aparece dentro da BH. Com isso, afirma-se que não há uma ocorrência de um substantivo masculino que designe um homem como "viúvo"361 dentro dos livros da BH. A condição de "viuvez" é tipicamente feminina. Como a palavra Jalmānāh é um substantivo, ela designa a própria pessoa e assim a mulher chamada de ’almānăh passa a ser nomeada pela condição em que ela se encontra. Desse modo, ela passaria a ser chamada de วalmāna $\bar{a}^{h}$ dentro de sua comunidade e como tal ela seria reconhecida ali.

Assim, sua condição de viúva também seria seu nome a partir da perda de seu marido. Ela seria apenas designada de $\supset^{\prime} \operatorname{lm} \bar{a} n \bar{a}^{h}$ na sua comunidade. Ao menos, com o marido vivo, ela seria reconhecida por ser a "mulher de". Ao ser reconhecida na comunidade como 'almānāh, ela ainda seria tratada pelo nome de seu marido, só que ele agora é morto e, por isso, ela é "a viúva de".

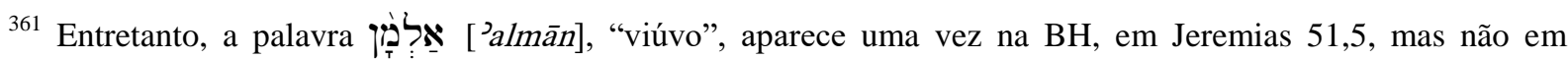
referência a um homem. No livro de Jeremias, porém, a palavra 'almān está apontando para Israel e Judá, como se o Deus de Israel estivesse morrido para seu povo e, Israel e Judá, como uma nação unificada, seu povo, se tornou 'almān. Note a tradução para proposta para Jeremias 51,5: "Porque não (é) viúvo, Israel e Judá, de seu

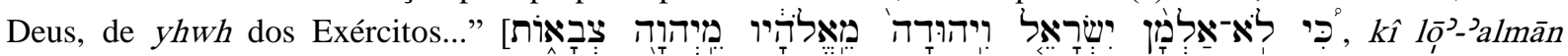

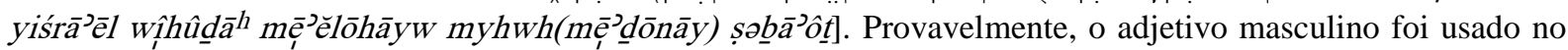
singular por causa de uma referência à nação unificada - daí o sentido de povo. O qual primariamente designa o nome de um dos filhos de Jacó, e a quem Jeremias profetizava diretamente, ou uma referência ao conjunto do povo de Deus na BH, o Israel e Judá unificados em um só povo, o povo de Israel. Deus não morreu e ainda considera Israel e Judá como uma nação unificada. Poderíamos olhar de outra ótica - Israel e Judá tentaram matar seu Deus, mas ele não morreu. A BJ traduz Jeremias 51,5 assim: "porque Israel e Judá não são viúvas....".
} 
Essa forma de apresentação está bem enunciada em Rute 4,5, quando Boaz, ao negociar com outro sobre o resgate da propriedade de Noemi, ele diz para aquele que ele também comprará a propriedade de Rute, "a mulher do morto". ${ }^{362}$ Em 1 Reis 17,10, a mulher que sustentaria em

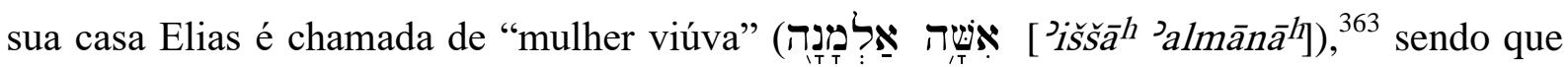
em 17,20 ela é chamada de 'almānăh , apenas. Portanto, "ao que tudo indica, elas eram uma categoria única em Israel de acordo com a legislação de Deus...” (SCOTT, 1980, p. 47).

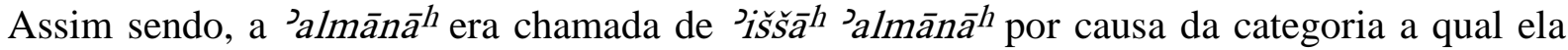
pertencia - viúva.

A condição deste tipo de Ente Silencioso é duplamente desfavorável. Primeiro por haver perdido o marido, sua principal fonte de amparo. Em um ambiente dado a guerras e lutas pela posse da terra, não seria tão incomum uma viúva dentro da comunidade. ${ }^{364}$ Mesmo assim, deveria ser desesperador para a mulher se imaginar viúva em um ambiente tipicamente masculino e hostil a ela.

Segundo, ela também goza de condição desfavorável por ser mulher. A mulher é usualmente anônima. Ela não tem voz. A mulher do grupo de Entes Silenciosos é duplamente sem voz por ser mulher e, além disso, ser 'almānā $\bar{a}^{h}$ uma viúva. Assim, a mulher a ser tratada nesta pesquisa aparece como viúva, mas uma viúva desprovida de recursos que pudessem compor a herança do marido falecido, ${ }^{365}$ ou desprovida de filhos em condição de suprir-lhe as necessidades básicas.

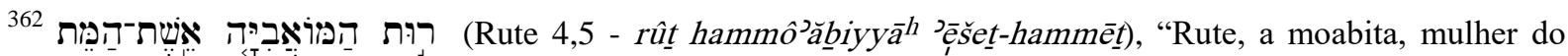
morto". O qal particípio usado para qualificar o marido já falecido de Rute, "aquele que morreu", pode ser uma

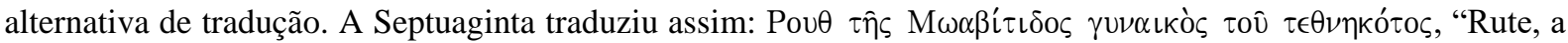

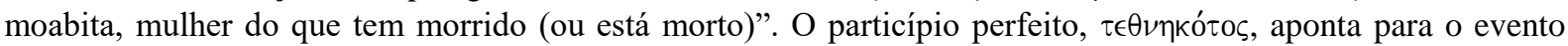
passado e seus efeitos no presente da redação do texto. Malom, esposo falecido de Rute (4.10), é alguém que "tem morrido e permanece morto".

${ }^{363}$ Considerar outros exemplos desta construção, ’iššăh Jalmānăh $\bar{a}^{h}$ em 2 Samuel 14,5; 1 Reis7,14; 11,26. A idéia de pertença ao marido acompanha a mulher mesmo depois dele ser morto. Deve ser notada a construção "mulher de Jeroboão" em 1 Reis 14,6. A mulher que casa é mulher de alguém, seja ele vivo ou morto.

364 Outro motivo para o empobrecimento da mulher era o repúdio. Notar um exemplo de 1 Crônicas 8,8, onde duas mulheres são repudiadas, aparentemente de uma vez. Os motivos não são apresentados para ação tão drástica.

${ }^{365}$ É possível que houvesse viúvas ricas dentro do povo de Israel a quem o livro de Deuteronômio se dirige. Mas esta pesquisa não está preocupada com elas. Pois se estas viúvas possuem recursos e meios para sua manutenção, o legislador não teria preocupação em colocar determinados dispositivos legais que viessem em auxílio de tais mulheres.
} 
Por outro lado, ser chamada de "viúva de" tem o seu valor social. A mulher identificada pelo marido morto trazia à memória ${ }^{366}$ o nome de seu esposo e, por causa dele, ela devia ser respeitada. Esse respeito pode ocorrer pelo levirato, como acontece no livro de Rute, onde Boaz a assume como esposa com o fim de trazer o nome do morto sobre a sua herança por meio do primeiro filho que viria a nascer na relação de Boaz com Rute. Nas palavras do próprio Boaz, “... adquiro por mulher Rute, a moabita, viúva de Maalon, para perpetuar o nome do falecido sobre sua herança e para que o nome do falecido não desapareça do meio de seus irmãos nem da porta da cidade" (BJ).

Mas nem todo parente próximo poderia assumir a viúva de seu irmão. No livro de Rute, o parente mais próximo e a quem cabia o resgate da propriedade de Rute e Noemi, em primeira instância, recusou assumir esse direito porque ele não queria prejudicar a sua família (Rute 4,6). Isso implica que a aplicação da lei do levirato tinha seus limites e que a mulher viúva, e sem filhos, não tinha a garantia que ela seria redimida da condição de viúva.

Entretanto, em Deuteronômio, a viúva aparece sempre denominada pela palavra "viúva" e sem referência a um marido. O marido é subentendido porque ela é chamada de "viúva". Porém, nunca ela aparece como "viúva de". Enquanto que "viúva de" identificava a mulher com alguém conhecido da comunidade, em Deuteronômio a אַ אַלְקָנדה é completamente desenraizada e sem identificação com a comunidade em que vive por meio do morto.

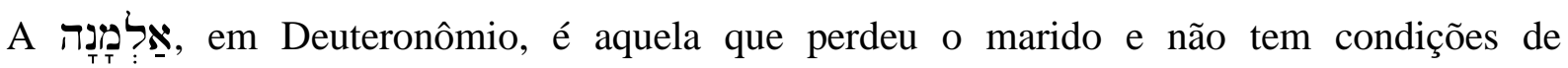
suprimento de suas necessidades diárias. Ela também não tem um clã para servir-lhe de amparo, provavelmente por causa da ausência de filhos - a ausência de filhos pode indicar esterilidade, algo impensável para alguém de quem se esperava descendência para o marido e crescimento do clã. Portanto, se ela já seria desprezada pela condição de viúva, muito mais ainda pela condição de ser sem filhos, fato cruel para qualquer mulher naquela cultura.

Para Chwarts, diante do grande apelo bíblico pela defesa de uma viúva sem filhos, há a indicação que "este ser social não era reabsorvido na casa do pai e na sociedade em geral" (2004, p. 223). Os motivos para isso, apresentados por Chwarts, são dois. Primeiro, "o fator

\footnotetext{
${ }^{366}$ O livro de Deuteronômio tem clara determinação de preservar a memória dos eventos passados. Os capítulos 1 a 4 mostram, não somente os caminhos tomados pelo povo depois de sua saída do Egito, como a recordação de determinados eventos marcantes nalguns desses lugares. Além disso, as Confissões presentes em 6,20-25 e 26,111 mostram o grande interesse que Êxodo fosse mantido na memória como parte da história de Israel e sua importância para o presente das gerações seguintes de israelitas.
} 
distância física era um empecilho para o retorno à casa paterna”, e, em segundo lugar, o valor do indivíduo estava no "seu desempenho sociobiológico - logo, de sua produtividade" (2004, p. 223).

É com esse tipo de pessoa, a viúva sem filhos e sem clã, que a legislação em Deuteronômio irá se preocupar para prover bases legais com o fim de sua proteção, amparo, e para dar alguma dignidade à vida da 'almāna $\bar{a}^{h}$. Mesmo que a viúva estivesse longe de seu amparo familiar, as comunidades, no meio das quais ela vivia, não podiam omitir seu auxílio a ela.

\subsubsection{Elementos filológicos}

\subsubsection{A etimologia de אַלְ ( 'almānāh}

Originalmente, a palavra 'almānă $\bar{a}^{h}$ parece ter sido empregada como um adjetivo, não como um substantivo, tendo em vista a construção comum composta pela palavra mulher e viúva, assim "mulher viúva" ('ishshāh Jalmānāh). ${ }^{367} \mathrm{Na}$ maioria das línguas semíticas antigas apresentam as consoantes 'lmn. Elas estão presentes no Hebraico ( ${ }^{2} \operatorname{llm} \bar{a} n \bar{a} \bar{a}^{h}$ ), no Acádio ('almattum, almattu), no Ugarítico ('almanatu), no Fenício ('almant) e, provavelmente, no Árabe ('armalatun). ${ }^{368}$ Nessas línguas "o termo crucial é um adjetivo, e frequentemente o substantivo 'mulher' aparece com ele” (HOFFNER, 1974, p. 288).

Para Kühlewein, porém, não se pode ter certeza quanto à etimologia de 'almānă $\bar{a}^{h}(1978, \mathrm{p}$. 265). Essa seja a razão provável de não se dar um sentido claro para a raiz 'Imn, (HOFFNER, 1974, p. 287-288) sendo apenas indicado como raiz provável. ${ }^{369}$ Desse modo, pode-se observar que a palavra que era empregada para qualificar uma mulher, após a morte de seu marido. Passou a ser a palavra que veio a nomeá-la, substituindo seu nome dentro de sua comunidade.

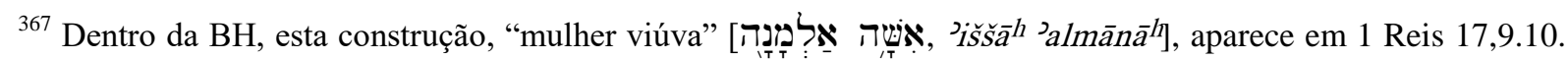
No Salmo 109,9 encontra-se o seguinte: "E serão seus filhos órfãos, e sua mulher, viúva" [yihyû-bānāyw

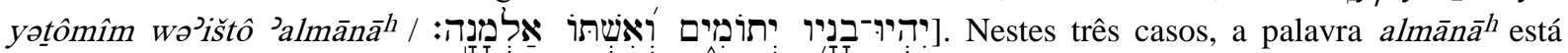
sendo empregada para qualificar o substantivo $\jmath_{i s ̌ s ̌ a ̆}^{h}$. Portanto, seu uso aqui é adjetivo, mesmo que ela ainda seja um substantivo, mas sendo usado como adjetivo.

368 HOFFNER, 1974, p. 287-288. Em Acádio, Imn venha de lemnu, "pobre"” como uma possibilidade (HOFFNER, 1974, p. 288).

${ }^{369}$ No mundo sumério-acádio, a 'almattu não apontava para uma mulher que houvesse perdido o marido, mas para uma mulher que, mesmo casada, não desfrutava de suporte financeiro de um membro masculino do seu clã, seja ele marido, filhos crescidos ou mesmo seu sogro (HOFFNER, 1974, p. 288). Em Deuteronômio, porém, a viúva é aquela mulher que perdeu o marido por meio da morte dele, e, por causa disso, está completamente desamparada. 


\subsubsection{Comparação com o Targum}

A palavra usada para traduzir 'almāna $\bar{a}^{h}$ para o Aramaico é אַרְּ (Deuteronômio 10,18; 27,19), אַרפֵַלתָא (Deuteronômio 14,29; 16,11.14; 24,19.20.21; 26,12.13). O significado básico destas palavras aramaicas é "viúva" e vêm da palavra ארמלה [ $\left.{ }^{2} r m I^{h}\right]$, a qual também é um substantivo (HHL-BW7). Dentro da BH, nenhuma destas palavras aparece nas porções textuais aramaicas.

\subsubsection{Comparação com a Septuaginta}

A palavra usada para traduzir o Hebraico 'almānna $\bar{a}^{h}$ para o Grego da Septuaginta foi $\chi \eta ́ p \alpha$, "viúva", em todas as ocorrências da palavra ’almānăh em Deuteronômio. ${ }^{370}$ Como o vocábulo

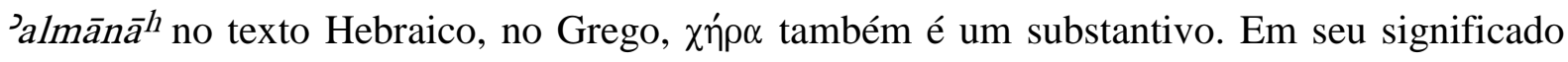

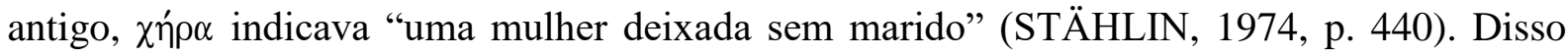
resultou que “ $\chi \eta ́ p \alpha$ pode significar não somente uma 'viúva', mas também 'uma mulher vivendo sem marido"” (STÄHLIN, 1974, p. 440), em seu sentido original.

\subsubsection{Uma 'iššă ${ }^{h}$ 'almānāh em meio aos Entes Silenciosos}

O que caracteriza a 'almāna $\bar{a}^{h}$ dentro do livro de Deuteronômio?

3.1.3.1. Em todas as ocorrências de 'almānăh Grego, as palavras empregadas são também substantivos: a 'almānā ${ }^{h}$ nomeia a mulher.

Isso contribui para reafirmar que mulher que enviuvava perdia a nome dentro da comunidade, e passava a ser reconhecida por sua condição de mulher que perdera o marido. A motivação para isso está no marido morto. Diante daquela comunidade, esta mulher seria reconhecida como alguém que havia sido casada, porém, com a perda do marido, ela poderia ser desposada por outro homem, tendo também o direito de ter filhos por meio do levirato. Entretanto, a 'almāna $\bar{a}^{h}$ que é tratada dentro de Deuteronômio não parece ter esperança de vida melhor, a não ser esperar o apoio da comunidade em meio da qual vivia.

\footnotetext{
${ }^{370}$ Nos demais livros da BH, a palavra $\chi \eta ́ p \alpha$ também é empregada para traduzir ’almānāh .
} 
3.1.3.2. Em Deuteronômio, a ’almānāh aparece sempre sozinha - sem filhos, sem família e sem marido.

Esse é um problema sério para o qual Deuteronômio tenta uma solução. A solidão indica que ela perdeu qualquer tipo de amparo que um clã poderia lhe conferir. Além disso, ela também perdeu a identidade familiar. Ela passa a vagar sem um lugar do qual dependa sua sobrevivência. Esta preocupação com a ’almānă $\bar{a}^{h}$ em estado de solidão é também uma preocupação presente em outros escritos da BH. Mas em Deuteronômio há uma legislação que a proteja e a ajude a receber algum tipo de proteção em meio à sua vulnerabilidade.

A solidão também implica que ela não tem o status de mãe. Ela não procriou. Mesmo que se pense que um filho expulse sua mãe de seu clã, mas isso não seria o usual, e um filho com essa natureza não seria bem aceito dentro da comunidade em que vivesse. Por isso, é melhor pensar que a 'almānā em questão é alguém que "falhou" no cumprimento de seu principal papel dentro de um clã - a procriação.

Assim, a solidão dela se dá também pela ausência de procriação. Nessa circunstância, ela já teria provado que não teria condição de procriar e, por este motivo, também estaria fora dos propósitos do clã de seu marido, e também impossibilitada de obter atenção de outro homem para um casamento. Se ela não pode gerar, ela também pode não ter boa opção para outro casamento.

Por um lado, como dito acima, a ’almānā $\bar{a}^{h}$ apresentava-se sempre solitariamente, por outro, ele está habitualmente na companhia de outros Entes Silenciosos - o órfão e o estrangeiro. Um motivo para isso era a condição que o órfão e a viúva tinham em comum, a ausência de família, ou clã, com quem se relacionar. O outro é o pacto de sofrimento que os unia. Juntamente com o estrangeiro e o levita, eles faziam parte do grupo de pessoas que não eram escravos e tinham alguma liberdade para ir e vir, mas sofriam pela falta de um clã que lhes desse a proteção.

\subsubsection{A ' 'almānā $\bar{a}^{h}$ é produto de tempos de dificuldades econômicas.}

Normalmente, a presença de órfão e viúva dentro de uma comunidade salientava dificuldades criadas pela guerra. Esta era um dos principais fatores que levava à desestruturação da família. A morte do marido e filhos numa guerra trazia grandes dificuldades para a mulher 
recém-enviuvada. Ela poderia ser morta pelos conquistadores, ser vendida como escrava, ou largada à própria sorte. A mulher solteira e virgem levava grande vantagem nessa situação em que ela poderia servir a um senhor e até se casar com um de seus conquistadores. ${ }^{371}$

Partindo do pressuposto que Deuteronômio teve suas origens dentro do Reino do Norte, ${ }^{372}$ então há todo sentido de notar a preocupação com a viúva. O Reino do Norte sempre esteve envolvido, em toda a sua existência, com alguma guerra. Certamente que o prolongamento desses combates levou clãs inteiros à desestruturação familiar e a perda de qualquer tipo de organização. As constantes necessidades de defesa do Reino levavam também a constantes necessidades de mão-de-obra para a manutenção das guerras. Tal situação gerava pobreza e muitas viúvas.

Em Deuteronômio não há uma legislação que proíba a expulsão de viúva do clã. Entretanto, o Código de Hamurabi ${ }^{373}$ legislou contra essa possibilidade. Esse Código, ${ }^{374}$ no parágrafo 172 , diz assim:

Se seu marido não lhe deu presentes de casamento, eles (os filhos) devem fazer um bom dote a ela e ela deve receber dos bens de seu marido uma porção correspondente a um herdeiro individual. Se seus filhos a atormentarem com o fim de a fazerem deixar a casa, os juízes devem investigar seu caso e colocar a culpa sobre os filhos, de modo que a mulher nunca precise deixar a casa de seu marido. Se essa mulher tem em mente a ideia de sair, ela deve deixar para seus filhos o presente de casamento que seu marido lhe deu, mas tomará o dote da casa de seu pai a fim de que o homem de sua escolha pudesse casar com ela (MEEK, 1973, p. 157-158).

\footnotetext{
${ }^{371}$ Notar as ordenanças atribuídas a Moisés em Números 31 e Deuteronômio 21,10-14.

${ }^{372}$ Notar Sanchez em seu comentário ao Deuteronômio, p. 19-20.

373 "Hamurabi foi o sexto de onze reis da Dinastia da Antiga Babilônia. Ele governou por 43 anos, de 1728 a 1686, conforme aos mais recentes cálculos” (MEEK, 1973, p. 138). A promulgação do Código de Hamurabi se deu em seu segundo ano de reinado. Segundo Meek, "a data-fórmula para seu segundo ano, 'O ano que ele promulgou a lei da terra', indica que ele promulgou seu famoso código legal bem no começo de seu reinado" (1973, p. 138). Entretanto, o próprio Meek destaca que o prólogo da cópia disponível para a tradução aponta para eventos mais tardios em seu reinado.

374 "Muitas das provisões do código referem-se às três classes sociais: a do awelum ("filho do homem"), ou seja, a classe mais alta, dos homens livres, que era merecedora de maiores compensações por injúrias - retaliações mas que por outro lado arcava com as multas mais pesadas por ofensas; no estágio imediatamente inferior, a classe do mushkenum, cidadão livre mas de menor status e obrigações mais leves; por último, a classe do wardum, escravo marcado que, no entanto, podia ter propriedade. $\mathrm{O}$ código referia-se também ao comércio (no qual o caixeiro viajante ocupava lugar importante), à família (inclusive o divórcio, o pátrio poder, a adoção, o adultério, o incesto), ao trabalho (precursor do salário mínimo, das categorias profissionais, das leis trabalhistas), à propriedade" ("O Código de Hamurabi” IN: http://www.dhnet.org.br/direitos/anthist/hamurabi.htm). Meek (1973), em uma nota na p. 139, diz que o termo awelum "parece ser usado ao menos em três sentidos: (1) algumas vezes indica um homem da classe mais alta, um nobre; (2) algumas vezes um homem livre de qualquer classe, alta ou baixa; e (3) ocasionalmente um homem de qualquer classe, do rei ao escravo", salientando a ambiguidade do termo original.
} 
Se caso fosse consumado, com a expulsão da viúva, ela se tornaria uma peregrina sem o apoio de uma família. O Código de Hamurabi se interpôs para encerrar costumes desumanos contra a mulher viúva. No caso do Código Deuteronômico isso não foi previsto. Uma possibilidade para essa ausência é que, em Israel, esse nível de desumanidade nunca fora visto e, portanto, não havia a necessidade de uma legislação específica para pôr fim a esse tipo de perversidade contra a viúva.

Outra possibilidade é que a viúva apoiada pela legislação do Deuteronômio era como o próprio texto destaca - uma viúva solitária, sem marido, filhos ou parentes próximos. O único bem que ela possuía era sua roupa e, por isso, esse bem não podia ser tomado dela em juízo (Deuteronômo 24,17). Com a longa distância para percorrer até a casa de seus parentes, a viúva protegida pelo Código Deuteronômico era alguém sem teto e sem terra.

3.1.3.4. Era proibido tomar a roupa da Зalmāna $\bar{a}^{h}$ em um processo judicial $(24,17)$.

No texto de Deuteronômio 24,17b, há bem estabelecido que a roupa de uma viúva não deveria ser tomada como forma de garantia de um pagamento. Não é especificado o motivo para esta ordem absoluta. Como visto, porém, em Deuteronômio 15, a roupa poderia servir de penhor de um homem cānî (Deuteronômio 24,12), mas não da ’almānă $\bar{a}^{h}$. A condição da 'almānāh impediria a justiça de obrigá-la a entregar sua roupa.

A motivação por trás da proibição é que roupa era tudo o que ela possuía. Retirar sua roupa seria como retirar sua própria vida, ou, num sentido menos dramático, seria como retirar a sua proteção, principalmente durante as noites mais frias. Assim, aquele que havia dado algo por empréstimo a ela, deveria fazer isso por generosidade, sabendo que ele não teria qualquer garantia que haveria de receber de volta o que lhe deu emprestado.

\subsubsection{Ela se encontrava nos "teus portões".}

As construções gramaticais, "vivem nas tuas cidades" (Deuteronômio 14,29; 16,11.14; BJ) 375 e "vivem no meio de ti" (Deuteronômio 16,11; BJ), ${ }^{376}$ aparecem para qualificar o estrangeiro,

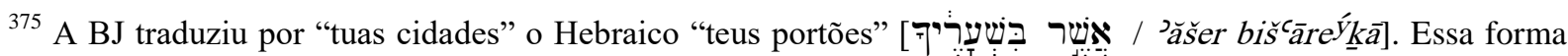
de tradução é uma forma de contextualizar o texto. Entretanto, ele distorce a ideia que o ouvinte ou leitor primeiro tinha de "teus portões".

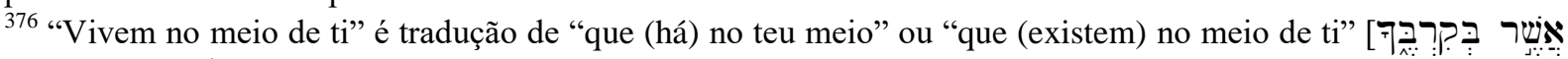
/ ’ăšer bəqirbék̄ā].
} 
o órfão e a viúva que deviam ser atendidos pela comunidade na qual eles viviam. Entretanto, partindo do pressuposto que Deuteronômio foi escrito para comunidades que viviam no campo, ou nas cidades, a tradução "nos teus portões" favorece o entendimento que a ’almānāh era alguém que estava dentro da propriedade daquele clã, e que esta condição de dependência deveria ser vista, não como momento de exploração, mas como oportunidade de ajuda.

Assim, a proibição que uma decisão judicial não poderia obrigar a ’almāna $\bar{a}^{h}$ entregar sua capa sugere que ela era alguém muito mais necessitada de ajuda que o 'ānî de Deuteronômio 24, pois este tinha uma moradia, pois esta não podia ser violada para que um penhor fosse entregue. ${ }^{377}$ Viver "dentro dos teus portões” aponta para a busca de proteção. Ela está ali, não somente para ser beneficiada com a ajuda, mas também como alguém que busca proteção.

Do que foi dito até aqui sobre a 'almānăh, algumas observações podem ser destacadas. Primeiro, com o passar do tempo a palavra ’almāna $\bar{a}^{h}$ deixou de ser apenas um qualificativo para a mulher para ser um nome, um substantivo que designava a mulher como pessoa. Assim, em segundo lugar, isso leva a conclusão que a 'almānă $\bar{a}^{h}$ pertencia a uma classe distinta dentro da comunidade. Não se pode avaliar se esta classe possuía muitos membros, mas é possível dizer que elas eram reconhecidas como tal nas suas comunidades. Em terceiro lugar, a sua vulnerabilidade era notória por ser mulher e viúva, fazendo-a fragilizada por não ter um marido, ou mesmo filhos, e, juntamente com gēr e yātôm, um grupo de peregrinos e desprotegidos entre os clãs constituintes das comunidades do campo, e das cidades também.

Enquanto que órfão, estrangeiro e levita são palavras para designar pessoas do sexo

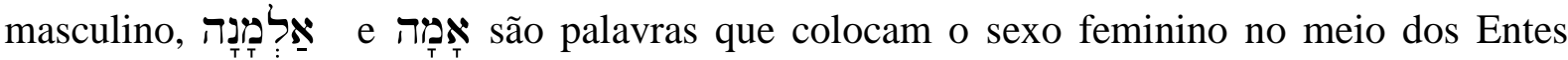
Silenciosos. A razão para isso é que a mulher que perdia o marido podia ter alternativas. $\mathrm{O}$ levirato era uma, já mencionado. A outra era que a mulher também tinha a possibilidade de retornar para a casa paterna. Mas essa possibilidade implicaria em custos financeiros para a família de seu pai, o que poderia gerar dificuldade, pois ela podia ser um peso financeiro para

\footnotetext{
${ }^{377}$ Por outro, com o crescimento das comunidades e as populações se concentrando em torno das cidades, os portões das cidades eram os lugares de reunião. O portão da cidade era o lugar de julgamento e onde se fazia justiça. A questão que deve ser levantada é: Qual o motivo da presença da 'almānā $\bar{a}^{h}$ ali? A resposta é que a دalmānāh estava ali para pedir por justiça por algum motivo. Esquecer-se dela seria o mesmo que não fazer justiça. Com isto em mente, o redator está falando com aqueles que detinham o poder de julgamento. Ela recorria a eles em caso de necessidade. Portanto, a ’almāna $\bar{a}^{h}$ estava no portão da cidade em uma situação de fragilidade e dependência.
} 
uma família em apertos econômicos. Além do mais, as distâncias poderiam não favorecer o retorno.

Ela também tinha a alternativa de permanecer na casa dos pais do marido morto. Mas esta alternativa podia não ser vantajosa para aquela que caía no estado de viuvez. Ela não seria produtiva porque a força de sua produção familiar havia sido perdida. Além disso, ela seria também um peso econômico para o clã constituído de famílias que precisavam sobreviver.

De qualquer forma, cair na condição de mulher viúva era a coisa mais indesejada que uma mulher poderia imaginar acontecer com ela, mas que era um risco a correr com o casamento, principalmente em tempos de guerras, e nos períodos que Israel e Judá mantiveram-se "rebelados" contra as leis do Deus de Israel. O legislador de Deuteronômio entende perfeitamente isso. E por isso legislou em favor desta desfavorecida.

A Lei do Levirato era o modo de manifestar misericórdia com o morto por parte do irmão próximo em termos de idade. O primeiro filho desta união seria o herdeiro da propriedade do falecido. Ao que tudo indica, quando o falecido tivesse uma filha, mas não um filho, aquela assumiria o direito a herança (Números 27,1-11), com a limitação que ela somente poderia casar com alguém de dentro de sua própria tribo. Entretanto, não há muitos exemplos da prática dessa legislação dentro da história do Israel bíblico. Além do mais, a reação dos filhos de Judá a ordem do pai de tomarem a esposa do irmão falecido para gerarem descendência para ele não era algo muito bem aceito pelos irmãos.

Outro modo de prover cuidados para a mulher viúva vinha de seus filhos já crescidos e com condições para sustento seu e dela. Essa vem a ser uma das razões para o quinto mandamento (Deuteronômio 5,16). A honra ao pai e mãe é dada para o homem que tinha independência dos pais e apresentava as condições de cumprir aquele mandamento. A honra ao pai e mãe incluía não somente a reverência de filho aos pais, como o apoio nas horas de necessidade deles. A viuvez era certamente um dos momentos mais difíceis para a mulher, e a presença de um filho capaz de ampará-la diminuiria em muito o sofrimento motivado pela perda do marido.

Por último, uma viúva podia ser herdeira de um marido com propriedades, um marido rico. Nesse caso, a viúva, se tivesse filhos, estes bens seriam distribuídos entre os filhos, ficando 
parte considerável da herança com o filho mais velho, e dele seria a responsabilidade de suprir as necessidades da mãe.

Diante disso, pode-se dizer que a viúva dentro de Deuteronômio, amparada pelas leis deuteronômicas, é uma viúva que não tem seus meio próprios de sustento, e que não possui meios de suprimento de suas necessidades básicas tais como os três exemplos apresentados acima. Ela é uma viúva que depende da sociedade para sua sobrevivência. Daí o legislador deuteronômico deixar uma legislação que pudesse lhe dar amparo. O redator de Deuteronômio está corrigindo algum erro ocasionado pela prática da lei presente no livro de Êxodo. A viúva podia não herdar a propriedade por ocasião do falecimento do marido, mas ela não podia perder o direito à vida. ${ }^{378}$

HALOT aponta que as "viúvas eram frequentemente obrigadas ao silêncio" (2001, v. 1, p. 58). Elas sofriam em silêncio diante das agressões sofridas da parte da comunidade, e da família do marido falecido. A condição desfavorável da mulher e ainda de sua condição de

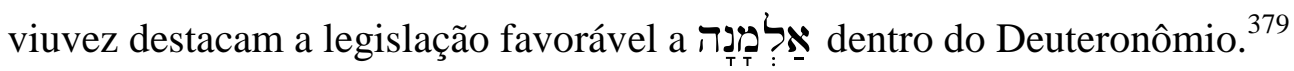

3.2. O Ente Silencioso desprovido da proteção do pai: o órfão [יתרז ]

\begin{tabular}{|l|l|l|l|}
\hline Vocábulo & Deuteronômio 1-11 & Deuteronômio 12-26 & Deuteronômio 27-34 \\
\hline aiș, yātôm & 10,18 & $\begin{array}{l}14.29 ; \quad 16,11.14 ; \\
24,17.19 .20 .21 ; \\
26,12.13\end{array}$ & 27,19 \\
\hline
\end{tabular}

3.2.1. Observações iniciais

O órfão, na condição de Ente Silencioso, era aquele que havia perdido o pai, por qualquer motivo, e que não tinha propriedade - ou porque o pai que havia morrido também não tinha

\footnotetext{
${ }^{378}$ Gênesis 38,11.14.19 mostra o caso de uma viúva por nome de Tamar. Depois de enviuvar, ela tira e coloca as roupas de viuvez indicando que a viúva trajava um tipo de vestimenta que a qualificava como viúva. Esse traje específico a levava a ser reconhecida pela comunidade como viúva, e atraía o respeito da comunidade masculina pelo homem falecido. O traje de viúva funcionava como meio de proteção.

379 A condição de tristeza da אַ אַלְמָנָד é ilustrada em Lamentações de Jeremias 1,1 na queda de Jerusalém: "Quão solitária está a Cidade populosa! Tornou-se viúva a primeira entre as nações; a princesa das províncias em trabalhos forçados". Como viúva, Jerusalém está em lamentação $(1,2)$, servidão $(1,3)$, luto $(1,4)$, sem filhos $(1,5)$ e sem beleza $(1,6)$.
} 
propriedade por ser também um Ente Silencioso, ou porque o yātôm perdera a propriedade para pagar dívidas deixadas pelo falecido. Também pode ser possível que sua condição de sem propriedade seja motivada por expulsão do clã para que a propriedade ficasse com os filhos mais velhos ou outro motivo. Deve-se recordar que às vezes os filhos eram colocados para pagar a dívida deixada pelo pai falecido (2 Reis 4,1$)$.

A concentração na ideia que o yātôm é o que é por causa de sua relação com o pai, ${ }^{380}$ e a perda deste, pode ser mais bem entendida a partir da declaração presente no livro de Lamentações 5,3: "Órfãos somos sem pai, e nossas mães (são) viúvas". ${ }^{381}$ O texto poderia

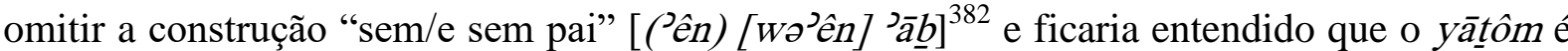
sem pai. Mas o que o texto faz é enfatizar a relação do yātôm com a ausência do '’āb-ele é 'ên 'āa.$^{383}$

A palavra yātôm é um substantivo masculino (BDB, 1979, p. 450). Isso quer dizer que, como a 'almānāh , ele também perdia o nome por causa da morte do pai, passando a ser identificado dentro de sua comunidade pelo que ele havia perdido, e não pelo que ele representava pelo seu nome. Deve-se destacar que esta palavra não apresenta seu oposto feminino, a "órfã", ao menos dentro da BH. A filha poderia ser absorvida por um clã para dar continuidade por meio da geração de filhos. Mas o menino era quem levaria o nome do pai sobre a herança. Sem herança, o menino sem o pai é apenas yātôm.

Como demonstra o quadro abaixo, o yātôm sempre aparece dentro do Deuteronômio acompanhado de outros Entes Silenciosos. Os seus companheiros são usualmente a ’almāna $\bar{a}$, o gēr e o lēwî.

\footnotetext{
${ }^{380}$ Notar o papel central do homem para o estabelecimento de dois tipos de Entes Silenciosos: o órfão pela perda do pai e a viúva pela perda do marido.

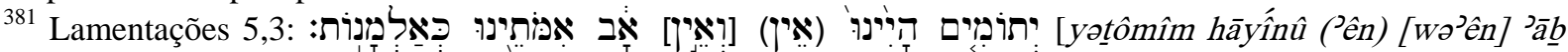

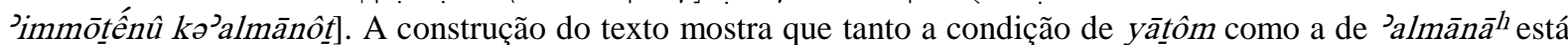
em relação ao homem. Os filhos são órfãos porque não tem pais e, por implicação, as mães são viúvas porque não tem maridos, os quais estão mortos, deixando filhos órfãos e as mães, desses filhos, viúvas.

${ }^{382} \mathrm{O}$ texto apresenta uma variante textual [wว’ên / ויאין] que faria a tradução ser: "Órfãos somos e sem pai". De qualquer forma, o "e" acrescentaria uma ênfase a própria situação daquele que havia perdido o pai.

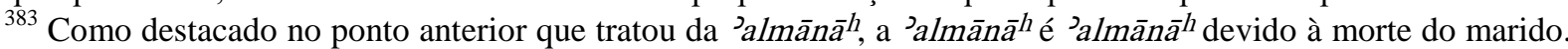
Porém, o texto demonstra que o yāt tôm pode ter mãe e ainda assim ser um yātôtom dentro da comunidade a qual pertence.
} 


\begin{tabular}{|c|c|c|c|}
\hline Vocábulos & Deuteronômio 1-11 & Deuteronômio 12-26 & $\begin{array}{l}\text { Deuteronômio 27- } \\
34\end{array}$ \\
\hline 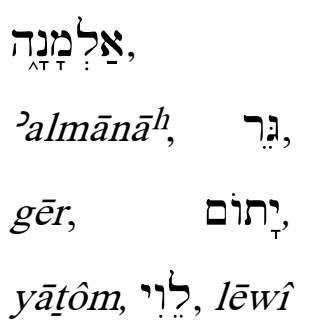 & & $\begin{array}{l}\text { 14,29; } \\
26,12.13\end{array}$ & \\
\hline 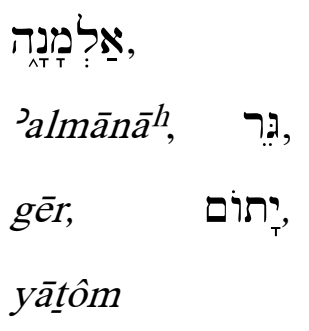 & 10,18 & $24,17.19 .20 .21$ & 27,19 \\
\hline
\end{tabular}

3.2.2. Elementos filológicos

\subsubsection{A etimologia}

A etimologia da palavra yātôm pouco pode iluminar a palavra e seus usos dentro do livro de Deuteronômio. Um destaque pode ser feito com o correspondente árabe [yatim] que, além de “órfão", pode significar "único" (RINGGREN, 1990, p. 478). Entretanto, as palavras da mesma raiz e que trazem o mesmo sentido de yātôm em outras línguas trazem paralelos significativos para o vocábulo hebraico. O egípcio nmḥ.W, além de "órfão" também pode significar "pobre e humilde", e aponta para o órfão como uma pessoa "sem ajuda e necessitado" (RINGGREN, 1990, p. 478).

O egípcio também lança luz sobre o texto hebraico por colocar juntos o yātôm e a ’almānăh numa mesma declaração, bem como por atribuir ao rei o papel de protetor do yātôm e da ’almānăh $\bar{a}^{h}$ RINGGREN, 1990, p. 478). Este último detalhe, porém, difere do Deuteronômio 
porque o redator (ou redatores) deste entende que o papel de socorrer os Entes Silenciosos pertence à comunidade, não ao rei. ${ }^{384}$

Este detalhe - o rei como protetor do yātôtom e da 'almānă $\bar{a}^{h}$ - também aparece como papel do rei no Acádio. Seguindo uma tradição que procedia desde 2400 AEC, a conclusão do código de Hamurabi estabelece que os órfãos e as viúvas devem desfrutar de seus direitos e que não poderão ser oprimidos pelo mais forte (RINGGREN, 1990, p. 478).

Haja vista que o Deuteronômio tenha nascido nas comunidades do Norte no século oitavo, onde os reis não tinham interesse em ajudar os pobres do reino e estavam sob a crítica profética, o redator coloca o dever de ajudar os Entes Silenciosos da comunidade nas mãos dos que podiam fazer algo por eles, a comunidade.

\subsubsection{Traduções para o Aramaico e o Grego}

A palavra empregada para traduzir o Hebraico yātôm para o Aramaico é יתים [ytym], e a tradução para a LXX vem com a palavra ỏ $\rho \phi \alpha \nu$ ć. As duas têm o mesmo sentido e forma de

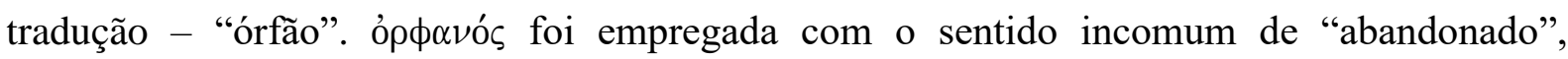
“destituído" e "privado" (SEESEMANN, 1967, p. 487). Tais sentidos podem servir de iluminação sobre o yātôm dentro do Deuteronômio, principalmente pelos sentidos de

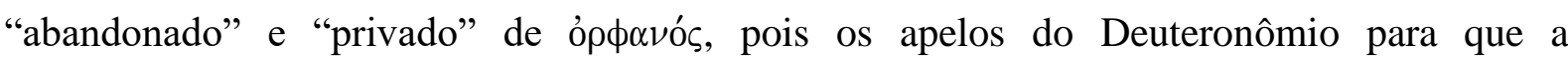
comunidade tivesse olhares beneficentes pelos Entes Silenciosos, e não somente o yātôm, porque há um elemento que os caracteriza é o conceito de estarem privados dos benefícios que, provavelmente, os outros membros da comunidade desfrutavam - terra, clã, recursos. No caso do yātôm, da 'almānāh, do gēr e do lēwî, os conceitos relacionados a "privado" e

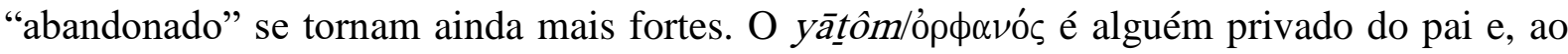
que indica dentro do Deuteronômio, separado do clã de quem poderia usufruir proteção.

\subsubsection{O yātôm dentro do Deuteronômio}

A palavra aparece dentro dos três blocos literários maiores do Deuteronômio $(10,18 ; 14,29$; $16,11.14 ; 24,17.19 .20 .21 ; 26,12.13 ; 27,19)$, aparecendo por quarenta vezes dentro da $\mathrm{BH}$

\footnotetext{
${ }^{384}$ Para que não se passe ao largo, o papel do rei em Deuteronômio é bastante diluído. É dito mais o que ele não deve fazer que o que ele deve fazer (Deuteronômio 17,14-20). Talvez num olhar positivo sobre o papel do rei, o Deuteronômio estabelece que ele deve fazer uma "cópia desta lei" para lê-la em todos os dias de seu reinado para aprender a "temer a Iahweh teu Deus" (Deuteronômio 17,19 - BJ).
} 
(HARTLEY, 1980, p. 419), ${ }^{385}$ e, como já pontuado, sempre acompanhado por outros Entes Silenciosos numa clara indicação da formação de uma classe social específica dentro da comunidade do Deuteronômio. Nestas ocorrências tornam difícil salientar um detalhe específico do yātôm que também não seja aplicado aos outros do grupo.

Entretanto, mesmo sabendo que o que se diz do yātôm se diz do outro que está no mesmo grupo social, cabe fazer algumas afirmações acerca yātôm do dentro do Deuteronômio. Primeiro, o yātôtom é colocado ao lado da ’almānā $\bar{a}^{h}$ como beneficiários da justiça do Deus de Israel, caso a justiça dos representantes divinos, os juízes, não os beneficiassem (Deuteronômio 10,18). Depois de apresentar as qualificações do Deus de Israel - "Deus dos deuses e Senhor dos senhores, Deus grande, guerreiro/valente, o temível (o que é temido) que não levanta a face, e não recebe suborno" ${ }^{386}$ - o redator mostra o que este Deus faz.

E o que este Deus, descrito de forma tão elevada e temerosa, faz em favor do yātôm e da

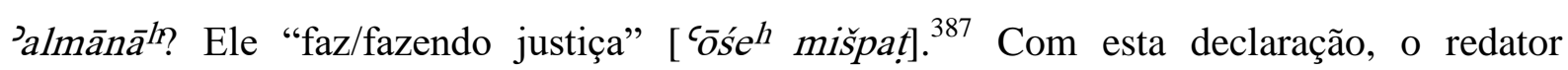
aproxima o yātôm e a 'almānă $\bar{a}^{h}$ do "pobre" [dāl, ’ebyôn, ‘̄añî], porque ele também faz justiça para eles. A frase paralela, mesmo que com construção gramatical diferente, mas com mesmo significado, é presente em Deuteronômio 1,16 [“julgareis justiça” / ûšōattem șédeq]. Mas há outro paralelo dentro deste texto com os Entes Silenciosos pertencentes ao grupo social denominado por "pobres", como o atributo de imparcialidade divina, "não levantará faces", o mesmo que é exigido dos juízes em Levítico 19,15. Assim, o yātôtom é beneficiário das

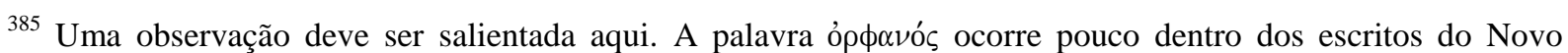
Testamento, apenas duas vezes - uma no livro de Tiago 1,27 e outra no Evangelho de João 14,18 (SEESEMANN, 1967, p. 488). No primeiro texto há a afirmação daquilo que consiste a verdadeira religião "pura e sem mácula". Para Tiago é visitar as viúvas e órfãos em suas aflições e manter-se separado do mundo (BJ). O segundo texto consiste de uma promessa de Jesus para seus discípulos, onde ele afirma de forma enigmática que "não vos deixarei órfãos, eu virei a vós" (BJ). Essas afirmações são uma pontuação do quão pouco o NT se refere à questão desses Entes Silenciosos.

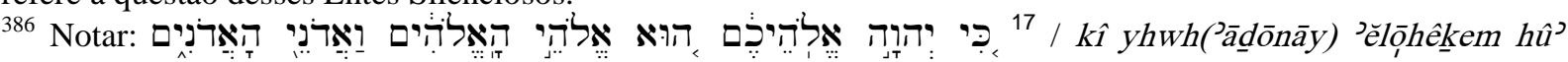

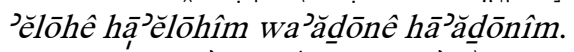

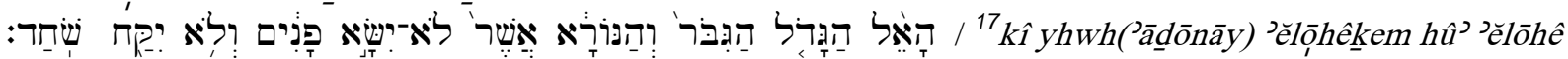

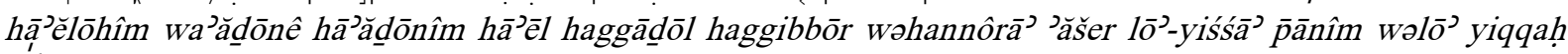
šóhad.

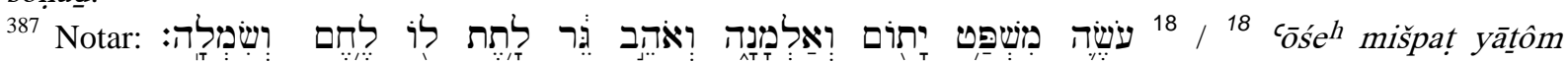

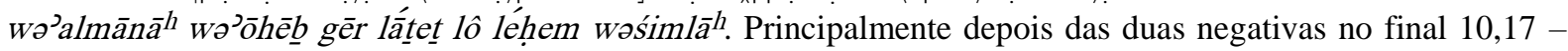
"não levantará faces e não tomará suborno" - o redator responde o que este Deus faz ou "está fazendo", haja vista que a construção ${ }^{c} \bar{o} s^{h}{ }^{h}$ mišspat pode ser traduzida pela perífrase "mas está fazendo justiça". Lembrando que mišpat tem haver com decisão judicial, demonstrando que o Deus de Israel será favorável ao yātôtm Wəålmāna $\bar{a}^{h}$, se houver injustiça contra eles.
} 
decisões justas do Deus de Israel. Se porventura ele não encontrasse justiça da parte dos juízes, ele encontraria da parte de Deus.

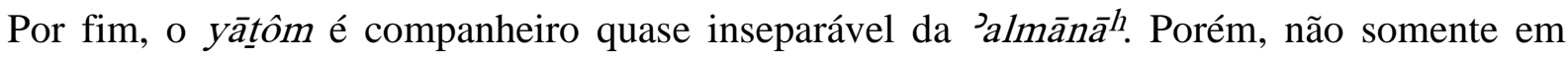
Deuteronômio, mas também em outros livros da BH. O personagem central do livro de Jó é acusado por um de seus amigos, Elifaz, de não atender as necessidades das viúvas e, no caso dos órfãos, que Jó os fez perecer $(22,9)$. Porém, para Jó, quem faz isso são aqueles que ele chama de ímpios que se apropriam do patrimônio remanescente dos órfãos e das viúvas $(24,3)$. Ao contrário das acusações, Jó saía em socorro do órfão e levava alegria para a viúva $(29,12.13 ; 31,17.18 .21)$.

Os salmos também trazem os dois juntos. No Salmo 68,6, Deus se apresenta como aquele que é o pai dos órfãos e que faz justiça aos direitos da viúva, principalmente contra aqueles que vivem para destruir tanto um como o outro $(94,1.6)$, pois é a este Deus que o salmista clama para que ele execute vingança contra os perversos, inclusive fazendo com que os filhos destes se tornem órfãos e, suas mulheres, viúvas $(109,9.12)$. É claro que nos salmos Deus é convidado a tomar o lado do yātôm e da 'almānăh . O motivo para isso é duplo - os salmos em sua maioria vieram de tempos de exílio e pós-exílio, fazendo com que a ausência do rei e a falta de perspectiva de vida pelo caos da remoção do povo para outras terras fizesse com que a única alternativa de socorro viesse do Deus de Israel.

Por outro lado, o profeta Isaías critica a ausência de atenção dos reis para com o yātôm e a Jalmānăh , mostrando que, mesmo durante o reinado de determinados reis - provavelmente a maioria deles, a justiça em favor dos dois não foi exercitada por eles (Isaías 1,17.23; Jeremias 7,6; 22,3). Esta luta do homem de Deus contra a liderança política e religiosa do povo - reis, sacerdotes e profetas - irá consumir boa parte das mensagens do profeta Jeremias, com o seu apelo para que eles praticassem a justiça.

Ao olhar esses textos em que os dois vêm juntos, algumas possibilidades podem ser estabelecidas. A primeira é que o yātôm e a 'almānāh são parentes - mãe e filho. ${ }^{388} \mathrm{~A}$ identificação dos dois com a mesma situação, pois ela é 'almānă $\bar{a}^{h}$ porque perdeu o marido, e, o marido que ela perdeu deixou um filho que agora passa a ser um yātôm. Assim, os dois vêm

\footnotetext{
${ }^{388}$ Lamentações 5,3 aponta para este relacionamento.
} 
juntos porque era de se esperar que estivessem juntos porque ambos tiveram a mesma perda o provedor.

Em segundo lugar, porém, o relacionamento entre os dois é solidário. O amparo da ’almānă ${ }^{h}$ para o yātôm (e a companhia do yātôtm para a 'almānăh̆ ) era o amparo de uma mãe para o filho que ela não teve. E para ele a 'almānă $\bar{a}^{h}$ viria a ser a "mãe" que ele precisava na hora de necessidade que ele estaria vivenciando. Os dois estão na mesma situação e se unem para enfrentar as dificuldades. Numa outra forma de ver, o solitário precisa de companhia, e um encontraria a companhia que precisava com outro e ambos buscavam sobreviver em circunstâncias difíceis.

Mas esses dois não vêm sozinhos. Eles também têm companhia do gēr. Mas quem é o gēr?

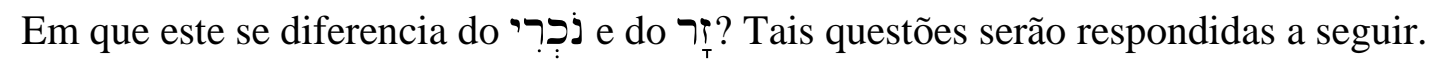

3.3. O Ente Silencioso desprovido da proteção de sua terra ou pátria: o estrangeiro [ר:̣ $\lg \bar{e} r]$

\begin{tabular}{|l|l|l|l|}
\hline Vocábulo & Deuteronômio 1-11 & Deuteronômio 12-26 & Deuteronômio 27-34 \\
\hline רạ, gēr & 1,$16 ; 5,14 ; 10,18.19$ & $\begin{array}{l}14,21.29 ; 16,11.14 ; \\
23,7 \quad(\text { Hebraico }) ; \\
24,14.17 .19 .20 .21 ; \\
26,11.12 .13\end{array}$ & $\begin{array}{l}\text { (Hebraico v. 11); } \\
31,12\end{array}$ \\
\hline
\end{tabular}

\subsubsection{Observações}

Como Ente Silencioso, o gēr é o que mais aparece dentro do livro de Deuteronômio. Segundo o quadro anterior, das noventa e duas ocorrências (HARTLEY, 1980, p. 419) dentro da BH, vinte e uma estão dentro de Deuteronômio. Pela sua natureza, o gēr poderia também participar tanto da condição de alguém desprovido da proteção de um clã quanto de alguém que goza da proteção dele. O motivo para isso é que o gēr desfrutaria do amparo de alguém por ser estrangeiro. Por outro lado, a pessoa ou clã que o acolhesse poderia explorá-lo em benefício próprio. Por isso, mesmo dentro da proteção de um clã, o gēr necessitaria de 
ordenanças que pudessem lhe dar algum tipo de proteção para que ele não viesse a ser explorado.

O gēr está presente nas três grandes unidades de literatura que compõem o livro. Isso demonstra dois aspectos. O primeiro é que a presença de estrangeiros dentro de Israel era comum. Eles poderiam vir tanto de terras próximas quanto distantes. Muitos dos escravos poderiam ser colocados dentro dessa situação por virem de outras terras. O segundo aspecto é decorrente do primeiro. As violações aos seus direitos também devem ter sido comuns. Assim, o estabelecimento de leis de relacionamento com eles se fazia necessário para que atos violentos e abusos de direitos fossem tolhidos dentro da nação. ${ }^{389}$

Para de Vaux, "o gēr é essencialmente o estrangeiro que vive de forma mais ou menos estável em meio à outra comunidade em que é aceito e usufrui de certos direitos" (2003, p. 99). Como um israelita que vive dentro de outra tribo vem a ser considerado um gēr (Juízes 19,16), então é de se considerar que os levitas também venham a ser considerados como uma espécie de estrangeiros dentro do Israel (de VAUX, 2003, p. 99).

A situação de abuso do gēr pode ter sido de tal gravidade que o redator de Deuteronômio precisa recordar do passado de Israel. Mesmo que seus ouvintes iniciais não tenham sido escravos no Egito, o redator, apelando para a solidariedade existente entre presente e passado, instrui para que os estrangeiros sejam amados porque eles também foram estrangeiros em terras egípcias. ${ }^{390}$

\subsubsection{Elementos filológicos}

\subsubsection{A etimologia}

Há dois exemplos em que esta pesquisa entende que iluminam o texto Hebraico. Os dois vêm do Ugarítico, onde a palavra pode ter dois sentidos, dependendo do contexto em que elas aparecem. O primeiro é o sentido de "alguém que habita os muros de Ugarite" e o outro é o de

\footnotetext{
${ }^{389} \mathrm{O}$ " "רִ é um homem que (sozinho ou com família) deixa vila e tribo por causa de guerra (2 Samuel 4,3; Isaías 16,4), fome (Rute 1,1), epidemia, culpa de sangue etc. e busca abrigo e residência em outro lugar, onde seu direito de propriedade, casamento e direito de participar na jurisdição, culto e guerra tem sido reduzido" (HALOT, 2001, v. 1, p. 201).

390 "E amareis o gēr, porque estrangeiros fostes na terra do Egito" (Deuteronômio 10,19 [ ${ }^{19}$ wa ${ }^{2} a$ ăhabtem 'et-

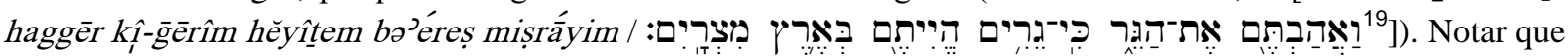
Israel também é chamado de gēr que habitou no Egito. Com base na sua experiência, Israel saberia como deveria tratar - ou melhor, amar - os estrangeiros.
} 
"alguém que habita no templo", possivelmente olhando para um que era fugitivo e estaria buscando proteção (KELLERMANN, 1975, p. 440).

O primeiro sentido aparece repetido dentro do livro de Deuteronômio para se referir aos Entes

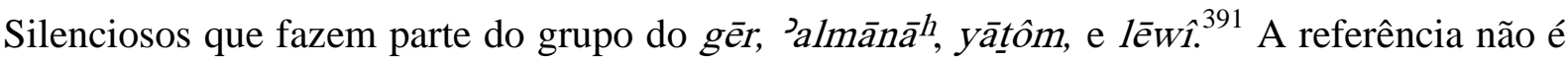

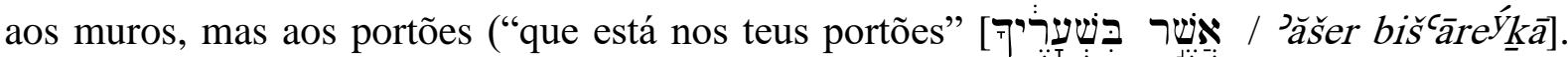
Nos Dez Mandamentos presentes em Deuteronômio 5, a menção é feita ao gēr que está nos portões daquele a quem os portões pertencem. Em um contexto do campo, os portões eram uma referência à propriedade de quem acolhia o gêr. Por outro lado, em tempos sombrios das invasões militares, as cidades fortificadas costumavam ser o lugar para onde as pessoas buscavam segurança que não encontravam nos campos, ou mesmo em cidades sem muros. Assim, "portões" é uma parte do muro da cidade ou da cerca da propriedade rural usados em lugar do todo. ${ }^{392}$

Refugiar-se no Templo Central (ou não) não parece ter sido algo que houvesse acontecido dentro do período coberto pelos escritos da $\mathrm{BH}$. Isso não quer dizer que pessoas não tenham buscado proteção do santuário segurando nos chifres do altar de sacrifício que ficava fora (1 Reis $1,50,51 ; 2.28)$. Mas a ideia de buscar a segurança do templo não parece que fosse visto com bons olhos pela comunidade, haja vista que essa alternativa fora veementemente rejeitada por Neemias (Neemias 6,9-11). Se um nativo rejeitou a entrada no Templo para buscar proteção, tal alternativa não seria uma opção oferecida para um $g \bar{e} r$.

A alternativa oferecida a alguém que precisasse poupar sua vida, porque houvesse cometido um assassinato involuntário, era aquela constituída pelo grupo de seis cidades de refúgio, distribuídas por Israel, três de um lado e três de outro lado do Rio Jordão. Elas foram estabelecidas para abrigar o homicida involuntário e poupá-lo das mãos do vingador do sangue derramado. Entre os que poderiam se abrigar numa dessas cidades por este motivo está o gēr (Números 35,11-15). Essas seis cidades estariam entre aquelas que pertenceriam aos levitas (Números 35,6). Este dado torna aquelas cidades um lugar que poderia ser acolhedor para o gēr, pois os levitas, que não podiam ter herança dentro de Israel, eram uma espécie de

\footnotetext{
${ }^{391}$ Deuteronômio 14,29 apresenta estes quatro Entes Silenciosos como quem ’ăšer biš $\bar{a} r e^{y} \underline{k} \underline{a}$. Notar ainda $16,11.14$ para outro exemplo.

${ }^{392}$ Zuck chama esta figura de linguagem de "Sinédoque... a substituição da parte pelo todo ou do todo pela parte" (1991, p. 177).
} 
gērîm, estrangeiros, dentro de seu próprio povo, e com possibilidade de entender melhor a mente de um gēr.

Assim, é possível que aquele estrangeiro que estivesse dentro dos muros de Ugarite fosse igual ao estrangeiro que estivesse "nos teus portões" no contexto da cultura tratada pelo Deuteronômio.

\subsubsection{Tradução para o Aramaico}

A tradução de gēr para o Aramaico foi feita pela palavra גיור [ $g y w r]$, "estrangeiro". Ela traz também o sentido de "prosélito", "vizinho" (KELLERMANN, 1975, p. 442). Nos outros versículos que estão no quadro acima, a palavra גיור $[g y w r]$ aparece em todos eles, exceto em Deuteronômio 14,21 e 28,43. Aqui a palavra presente é ת ת [twt $\underline{t}]$, cujo sentido é o de "residente", "estrangeiro". Em 10,8b e 23,8 a palavra usada foi דיר [dyr], cujo sentido é de

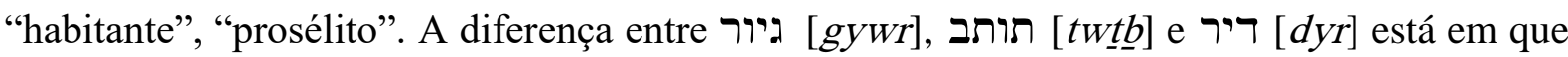
a palavra תותב [tw ] não é atrelada a ideia de "prosélito" como as outras duas (HHL-BW7).

Esta pesquisa vai mais a frente e estabelece os seguintes detalhes. A variedade de palavras empregadas para traduzir gēr para o Aramaico mostra a diferença de significados que $g \bar{e} r$ tem em diferentes contextos para os tradutores do texto Hebraico tanto para o Aramaico quanto para o Grego, como será notado abaixo. Os textos em que a palavra ג' ג $[g y w r]$ aparece como alternativa de tradução de $g \bar{e} r$ são textos em que a referência é a uma pessoa não nativa e residente dentro de Israel.

Entretanto, tem um texto em que o Aramaico faz clara distinção entre גיר e

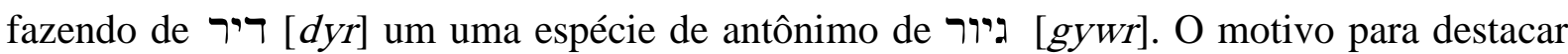
isso está em Deuteronômio 10,19 e 23,8. O texto de Deuteronômio 10,19 diz: "Portanto, amareis o estrangeiro [גיור], porque fostes estrangeiros [דיר / / dyr] no Egito" (BJ). ${ }^{393}$ Por sua vez, Deuteronômio 23,8 diz a mesma coisa, mas em forma negativa: "Não abomines o edomita, pois ele é teu irmão. Não abomines o egípcio, porque foste um estrangeiro em sua terra" (BJ). A tentativa do tradutor para o Aramaico é estabelecer uma distinção entre o Israel que habitou o Egito como gēr e os gērîm que habitavam em Israel. Para o redator do texto em

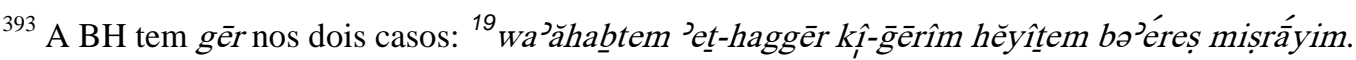


Aramaico, o Israel era apenas um morador no Egito [דיר] / $/ d y r]$, não um aderente de seus cultos, mas os estrangeiros em Israel eram moradores que eram "prosélitos" [גיור], eles haviam abraçado a fé de Israel. Para o redator do Deuteronômio, os dois são gērîm.

Assim, à palavra ריר, empregada para traduzir gēr em Deuteronômio 23,8, pode ser entendida apenas como uma pessoa que habita numa terra que não é a sua - apenas um morador. Deuteronômio 23,8 diz que Israel não deveria detestar o egípcio porque ele fora um estrangeiro residente, um habitante, na terra do Egito. Israel não era um prosélito ou aderente dos deuses dos egípcios. Desde a ida de Jacó e sua família para o Egito até o Êxodo, a BH não apresenta Israel como um aderente da religião praticada pelos egípcios. Israel era ali um habitante temporário, mesmo que ele houvesse de passar muito tempo por lá. O povo de Israel tinha a promessa que um dia sairia dali para habitar a Terra da Promessa.

Há outro detalhe a acrescentar. Em 14,21 e 28,43, a palavra תותב [twt $\underline{t}$ ] vem seguida pelo substantivo ערל [ ${ }^{C}$ I] , cujo significado é de um "macho incircunciso" (HHL-BW7), dando a entender que o estrangeiro em vista é alguém que vive no meio do povo, mas que ainda não aderiu a fé do povo do Israel. ערל explica que tipo de estrangeiro o animal morto por si mesmo deve ser dado $(14,21)$, pois um estrangeiro prosélito não comeria a carne daquele animal, pois ele estaria quebrando as leis divinas que ele abraçara ao se tornar prosélito. Em 28,43 fala de um "estrangeiro incircunciso" que, como juízo divino sobre o povo de Israel, por seu abandono do Deus de Israel, seria elevado a posição superior a de um israelita nativo. Essa seria uma forma de mostrar o desprazer divino com o povo que, em lugar de abençoar Israel, abençoaria o "estrangeiro incircunciso" que vivia no meio do povo.

Pode-se estabelecer uma distinção entre as três palavras aramaicas? Sim. Para o tradutor do texto Aramaico, גיור é um estrangeiro prosélito. Ele abraçou a fé de Israel e vive como um Israelita comum. דיר é um habitante comum, aplicado somente a Israel no Egito dentro do texto do Deuteronômio. O תותב é também estrangeiro, mas ele ainda não abraçou a fé de Israel, mesmo que habite no meio do povo de Israel. Pejorativamente ele é chamado de "macho incircunciso" [ערל]. Ele não é um prosélito.

Essa variedade de palavras para traduzir gēr também será notada nas diferentes palavras empregadas para traduzi-la para o Grego. 


\subsubsection{Tradução para a LXX}

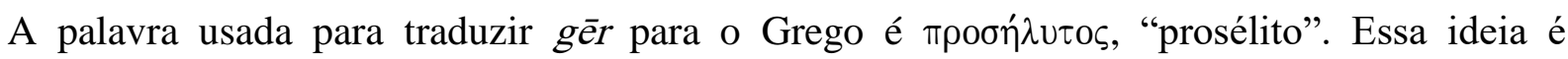
apontada por Kellermann que "sob o ponto de vista da integração religiosa, o conceito se desenvolve mais e mais na direção do prosélito, o não israelita que se torna aderente da fé em Yahweh" (1975, p. 443). Entretanto, em Deuteronômio 14,21, a palavra empregada para

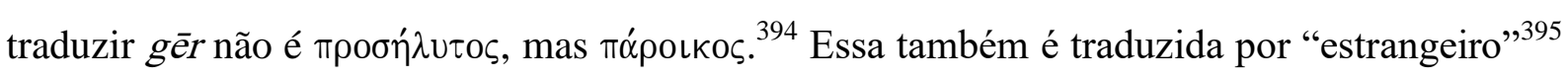
e tem um detalhe a mais - ela faz contraste com nok $r \hat{i}$ em 14,21: o animal que houvesse

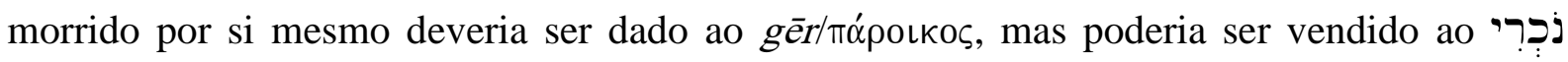

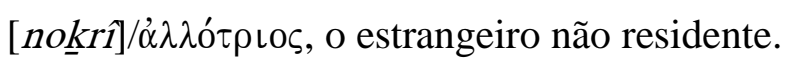

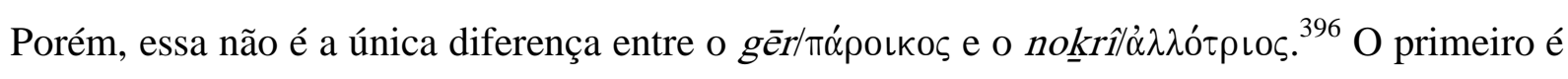
alguém "que vive em tua cidade" (BJ), deixando subentendido que o noknrîlå $\lambda \lambda$ ó $\rho \rho$ los é um estrangeiro que não "vive em tua cidade". Ele é um estrangeiro de passagem, e está ali por algum motivo, provavelmente por comércio. Ainda outra diferença o texto apresenta entre os

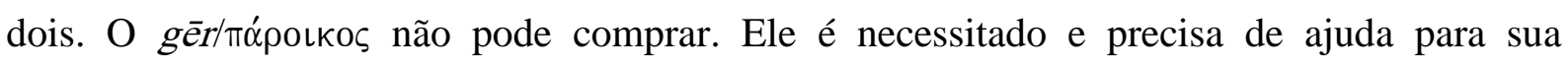

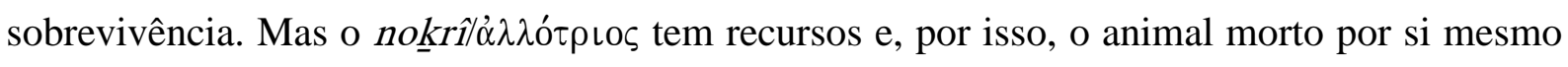
pode ser vendido para ele.

Diante do que foi colocado nos dois parágrafos acima, pode-se concluir que as duas palavras são sinônimas, haja vista que gēr foi traduzido para a Septuaginta, em Deuteronômio, tanto

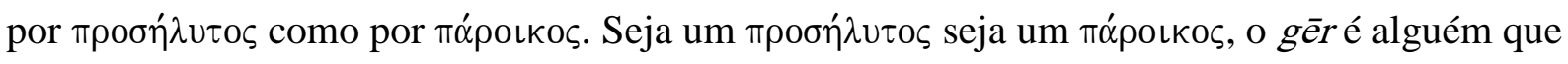
decidiu viver no meio de um povo que não é o seu de origem, e, ficará ali como um dependente daquele povo, ou, mais especificamente, daquele ou da comunidade que o acolheu.

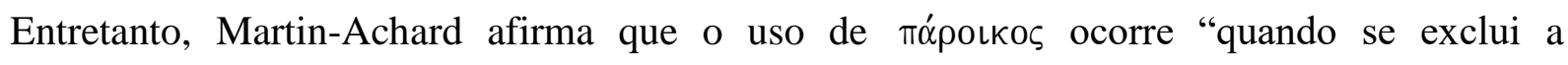
compreensão especial como prosélito" (1978, p. 586). No entanto, para esta pesquisa, os

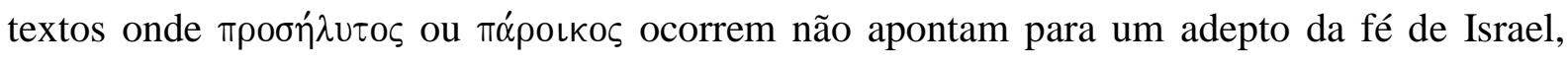

\footnotetext{
394 Rusconi traduz esta palavra por alguém "que habita como estrangeiro ou exilado: residente, hóspede,

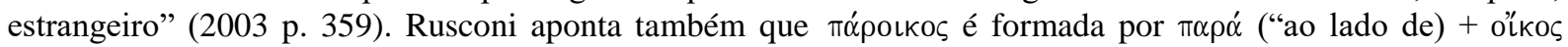
("casa").

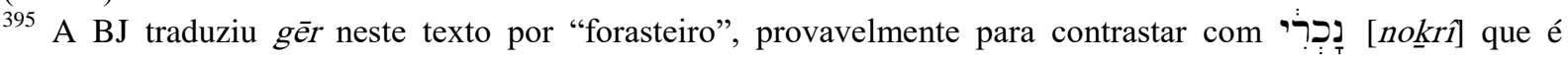
traduzido por "estrangeiro" mais adiante no versículo.

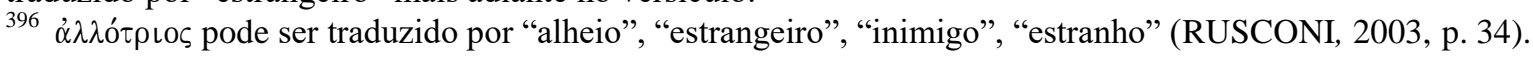




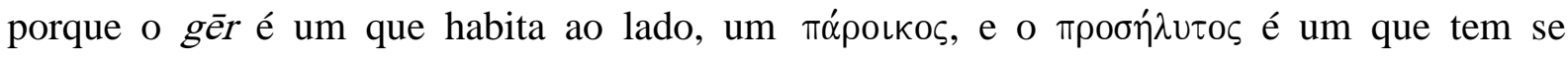
aproximado, um que está próximo - um que está próximo pode bem ser um que mora ao lado.

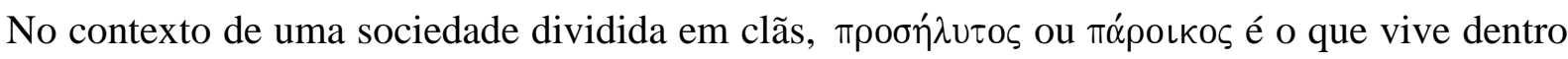
de tuas portas, ou de teus domínios. Em Deuteronômio, esse é o gēr-aquele estrangeiro que decidiu fazer das terras de Israel a sua própria terra.

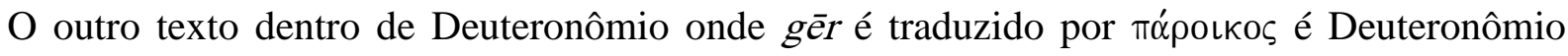

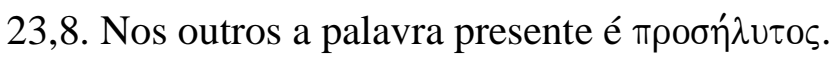

\subsubsection{O gēr dentro de Deuteronômio}

O que caracteriza o gēr dentro do livro do Deuteronômio? Ele é apresentado como um estrangeiro que é sem recursos. Mas que não é um escravo. O gēr é alguém que é integrado à sociedade e conhecido da comunidade ao seu redor. Ele é um exilado de sua terra, e que chegou a Israel sem recursos para sua sobrevivência e por isso merece atenção do povo de Deus.

Seguindo a ordem de aparição da palavra gēr dentro do livro, em primeiro lugar, o gēr era alguém caracterizado por ser tão integrado á vida do povo que podia ir ou ser levado à justiça contra ou a favor dele. Deuteronômio 1,16.17 diz que entre aqueles que poderiam se envolver num processo judicial contra o "grande" estava o gēr. A exortação para que os juízes não fossem parciais no julgamento entre o "pequeno" e o "grande" seria ainda mais forte se o caso diante dos juízes fosse entre o "grande" e o gēr.

Em segundo lugar, o gēr deveria cumprir o mandamento da guarda do sábado e não trabalhar no sétimo dia da semana (Deuteronômio 5,14). Isso implica que ele também estaria sujeito às penalidades caso ele viesse a quebrar esse mandamento. Como foi colocado acima, ele poderia fugir para uma cidade de refúgio, caso houvesse assassinado alguém involuntariamente. Porém, se ele houvesse cometido o crime voluntariamente, ele seria morto como aquele que ele matou (Números 35,15-21). Esta é uma ilustração da responsabilidade do $g \bar{e} r$ de observar as ordenanças do Deus de Israel como um nativo, pois o gēr deveria estar presente na leitura da aliança para que aprendesse a obedecer às palavras da lei de Deus (Deuteronômio 31,12). 
Em terceiro lugar, o gēr deveria ser objeto do amor do povo de Israel, assim como o gēr era objeto do amor do Deus de Israel (Deuteronômio 10,18.19). Deuteronômio 14,21.29 diz que o $g \bar{e} r$ deveria receber comida do povo, participar das festas $(16,11.14)$, as quais incluíam comida e bebida. ${ }^{397}$ Havia um tipo de dízimo que deveria ser dado ao gēr, ’almāna $\bar{a}^{h}$, yātônm, e lēwî (Deuteronômio 26,11.12.13). Em Deuteronômio 10,18 diz que o Deus de Israel seria generoso com o gerr, pois lhe daria alimento e vestimenta. E como o Deus de Israel faria isso? Por meio de seu representante - o povo de Israel. O direito dado por Deus ao gēr, 'almānā $\bar{h}$, yātôm, e $l \bar{e} W \hat{~}$ de receber o alimento não poderia ser pervertido, nem o seu direito pedido na justiça $(27,19)$. Quem pervertesse o direito deles seria amaldiçoado.

Em quarto lugar, caso Israel não fosse obediente aos mandamentos de seu Deus, em lugar de ele dominar, ele seria dominado por um $g \bar{e} r(28,43)$. Essa situação se tornaria contrastante com a condição esperada dos gērîm (Deuteronômio 29,10 [Hebraico]), que era a de prestar serviços para a comunidade de Israel, por meio de cortar madeira e retirar água - fazer o trabalho braçal. Esse último detalhe destaca a importância dos gērîm para o povo de Israel naqueles dias.

Há, porém, outros termos que são empregados dentro da BH para um estrangeiro, e que, nas traduções, não revelam distinção. Eles apontam para um contraste com o gēr.

\subsubsection{Outros termos para indicar o estrangeiro}

Duas palavras são comumente empregadas para designar um "estrangeiro" dentro da BH. São

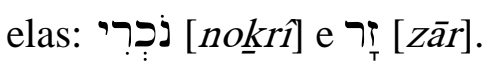

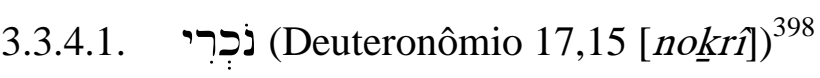

Há três tipos de estrangeiros encontrados dentro do livro de Deuteronômio. O primeiro é gēr, tratado acima. O segundo é o estrangeiro com recursos. Pode-se dizer que ele é o estrangeiro investidor. Ele é chamado de noknrî. O terceiro tipo, aparece em alguns lugares da BH como

\footnotetext{
397 Notar mais Deuteronômio 24,19-21.

398 "Estrangeiro", mas que traz embutida a ideia de "forasteiro", alguém de fora daquele lugar, que não reside junto aos nativos residentes ali. É uma palavra que funciona como um adjetivo. Ela, portanto, funciona para qualificar alguém de fora do povo, de outro povo que não Israel.
} 


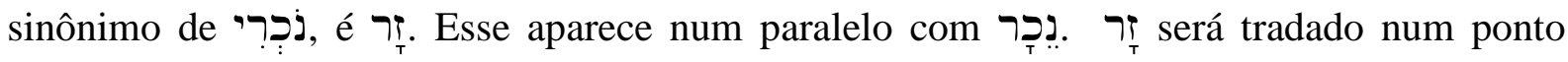
abaixo.

O nok $r i ̂$ é um forasteiro, uma pessoa não identificada com a comunidade local, e por isso ele não fazia parte da sociedade israelita. Assim, um animal morto poderia ser vendido para um nok $r i ̂$ (Deuteronômio 14,21). Esse texto mostra com clareza a diferença entre o noḱkrî e o gēr. Pois o animal morto poderia ser vendido a um, mas, em se tratando do gēr, o animal morto deveria ser doado, porque esse não teria as condições de comprá-lo enquanto que o primeiro as teria.

O nokkrî também é diferente de "teu irmão" (Deuteronômio 15,3), ${ }^{399}$ pois quando um empréstimo fosse feito ao nok $r i \hat{i}$, aquele israelita que o fez poderia pressionar o noknrî para receber o empréstimo de volta com os devidos acréscimos. Entretanto, ele não poderia fazer o mesmo com o "teu irmão", um israelita, membro da comunidade. Além disso, o noknrî nunca poderia se tornar um rei sobre o povo de Israel, em lugar de um rei que é do povo, um irmão

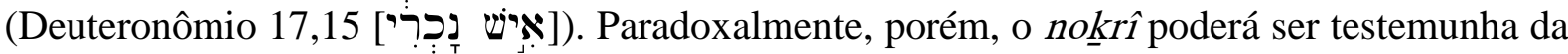
severidade do juízo com que o Deus trataria seu povo e faria sua própria lamentação diante do que verá (Deuteronômio 29,21), caso o povo siga pelo caminho da desobediência persistente contra os mandamentos de Deus.

Há dois lugares, em Deuteronômio, que, em lugar do adjetivo noknrî, é empregado o

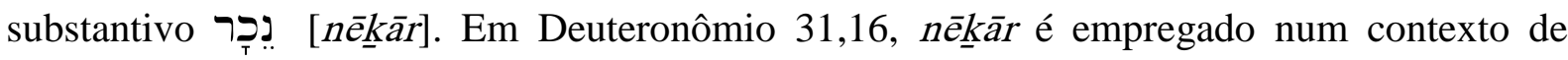
admoestação de um desvio futuro do povo para seguir "atrás dos deuses estranhos da terra"

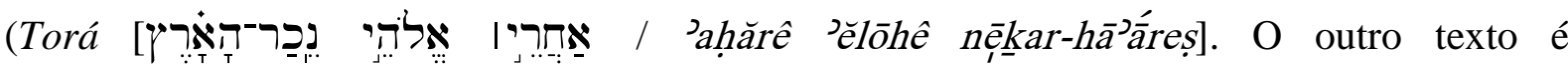
Deuteronômio 32,12. Este faz parte da canção de Moisés. Ele fala que a libertação de Israel ocorreu por intervenção do Deus de Israel unicamente, "e não havia com ele deus estranho"

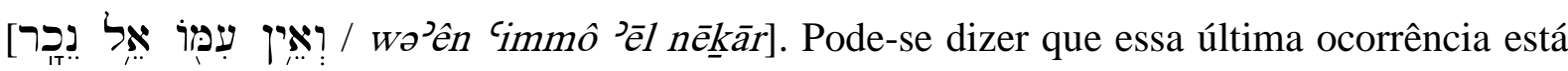
em paralelo com זָז pois mais adiante, em 32,16, "despertaram o ciúme dele com (deuses)

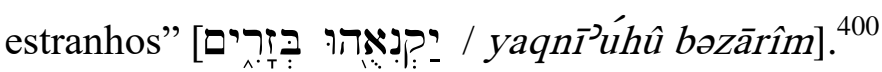

\footnotetext{
${ }^{399}$ Deuteronômio 23,21 diz que o empréstimo ao nokkrî poderia ser recebido com juros.

${ }^{400}$ O texto não tem a palavra "deuses". Porém, a palavra fica subentendida a partir de Deuteronômio 32,12, e do Salmo 78,58 que parece ser uma interpretação de Deuteronômio 32,12: "E o provocaram com os seus lugares
} 
Comparativamente, o nokrrî tem poucas ocorrências dentro do livro de Deuteronômio quando comparado com o gēr. O gēr aparece nos três grandes blocos literários do livro. A estatística apresentada anteriormente demonstra que o vocábulo gēr aparece em dezenove versículos do Deuteronômio.

O gēr era "o estrangeiro residente... (que) habitava sob a proteção da família ou tribo a qual ele não pertencia, embora não (sendo) escravo, estava obrigado a prestar serviço como recompensa pela proteção que ele recebia” (PRICE, 1908, p. 269). Por essa razão, ele é o "estrangeiro que reside em teu meio" (Deuteronômio 26,11), e deve participar da festa do camponês em sua celebração na apresentação de sua oferta do produto da terra diante de Javé. Tanto ele quanto o levita seriam participantes dessa alegria pela colheita bem sucedida e com eles a oferta do produto da terra seria repartida.

\subsubsection{2. $\mathrm{O}$ O ז $[z \bar{a} r]$}

A palavra aparece dentro do livro em apenas duas ocasiões. Uma está em Deuteronômio 25,5,

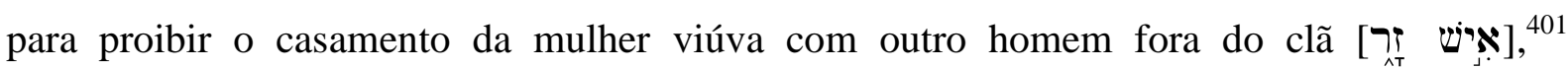
cumprindo a legislação do levirato. Mas aqui tem o sentido de fora da família, pois a mulher do morto deveria casar com o irmão para preservar o nome do morto sobre a herança. Além disso, a palavra "fora" [חיץ [זיץ como sendo um homem fora da família, mesmo que ele fosse um israelita. ${ }^{402}$

Seu sentido básico é de "estrangeiro", "estranho", e é empregada tanto como adjetivo como substantivo dentro da BH (MARTIN-ACHARD, 1978, p. 728). Nos escritos proféticos, zār carrega o "sentido étnico ou político... designam os povos estrangeiros com os quais Israel está relacionado, especialmente seus inimigos políticos" (MARTIN-ACHARD, 1978, p. 729).

nok $r \hat{i}$ e $z \bar{a} r$ aparecem em paralelo dento do livro de Provérbios para indicar de quem deveria esperar o louvor, em lugar de fazer promoção pessoal: "Seja outro [zār] quem te louve, um

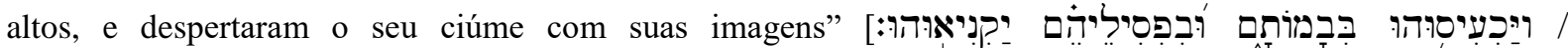

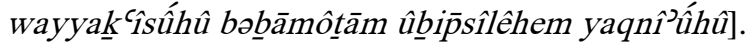

${ }^{401}$ A outra referência está em Deuteronômio 32,16, já vista no ponto anterior.

402 "O mandamento do levirato deverá ser cumprido pelo irmão maior de preferência” (Torá, 2001, p. 576). 
estranho [nokrrî], e não os teus lábios" (Provérbios 27,2, BJ). ${ }^{403}$ No livro de Provérbios as duas palavras aparecem juntas para designar uma mulher que, para os sábios de Israel, não deveria ser objeto do desejo daqueles que buscavam a sabedoria: "para livrar-te da mulher

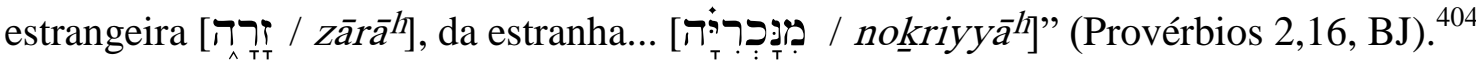

Enfim, o que mais a dizer? O gēr é o estrangeiro acolhido por Israel. Ele veio para Israel porque tinha necessidades que afetariam sua sobrevivência, caso ficasse em sua terra - ele precisava de comida, vestimenta e proteção - elementos que o Deus de Israel se propõe a suprir através de seu povo. Como gēr, ele participa das festas de Israel, e tem responsabilidades diante da lei de Deus, afinal, ele é residente e tem que se sujeitar às leis que regem aquele povo.

Como o nokkrî, o zār é um estrangeiro que está de passagem por Israel, ou que, mesmo vivendo em Israel, não tem identificação com ele e, por isso, a palavra pode ser traduzida por "estranho", distinto do nativo e do estrangeiro residente. Ele também não depende de Israel para sua sobrevivência. Ele pode comprar e, de alguma forma, não tem obrigação de vivenciar a lei a que Israel e o gēr estão sujeitos. noknrî e zār podem ser traduzidas tanto por "estranho" quanto por "estrangeiro", e quando ocorrem em paralelismo, elas são traduzidas por uma ou outra forma de tradução. Isso aponta para um intercâmbio de significados entre as duas, elas são vizinhas uma da outra (MARTIN-ACHARD, 1978, p. 728).

3.4. O Ente Silencioso desprovido de herança: o levita [לํ / lēwî]

\begin{tabular}{|c|c|c|c|}
\hline Vocábulo & Deuteronômio 1-11 & Deuteronômio 12-26 & Deuteronômio 27-34 \\
\hline , לִי? & & $\begin{array}{l}\text { 12,12.18.19; } \\
\text { 14,27.29; } 16,11.14 ; \\
\text { 18,1.6.7; } \\
26,11.12 .13\end{array}$ & $\begin{array}{l}27,9.14 ; \quad 31,9.25 ; \\
33,8\end{array}$ \\
\hline
\end{tabular}

${ }^{403}$ Dentro do livro de Salmos elas aparecem para indicar os deuses opostos ao Deus de Israel e que não deveriam

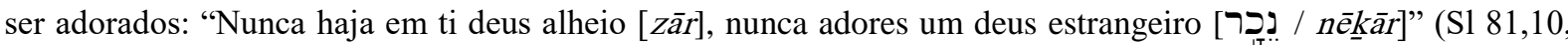
$\mathrm{BJ})$.

${ }^{404}$ As duas palavras aparecem em Provérbios 5,20; 7,5; Jeremias 5,19. Mas em Provérbios 5,10; 20,16 aparecem juntas nok $r i \hat{\mathrm{e}} z \bar{a} r$. 


\subsubsection{Observações}

Pelo quadro acima, como primeira observação, nota-se que lēwî aparece em sua maior parte no bloco literário que vai de Deuteronômio 12 a 26. Este dado aponta essencialmente para a vida do lêwî dentro de comunidades do campo ou relacionado à legislação atribuída ao Santuário Central. Pode-se dizer que o lēwî é um membro conhecido da comunidade a quem o Deuteronômio fala, e, como tal, conhecido pelo que ele é - essencialmente pela sua tribo de origem. $^{405}$

Dentro do livro de Deuteronômio, a palavra lēwîn não tem um nome próprio que lhe anteceda ou suceda, exceto quando ela vem acompanhada da palavra "sacerdotes", os chamados "levitas sacerdotes". Assim, a palavra lēwî pode funcionar tanto como um substantivo como um adjetivo - ela pode se referir ao patrono da tribo, o filho de Jacó que dera nome a ela, ou a um indivíduo que vive dentro da comunidade e descende dela.

O outro bloco literário onde a palavra $l \bar{e} w \hat{i}$ aparece trata do encerramento do livro, constando de Deuteronômio 27 a 34. O capítulo 27 é um bloco literário em que as palavras são atribuídas a Moisés; no 31 também as palavras são colocadas na boca de Moisés como as tendo falado, e no 33 é onde se apresenta a bênção atribuída a Moisés sobre as tribos de Israel, entre as quais está a tribo de $l \bar{e} w \hat{i}$.

\subsubsection{Etimologia}

A origem do nome, dentro da $\mathrm{BH}$, pode ser traçada a partir do emprego encontrado dentro da declaração de Lia, em Gênesis 29,34: "E concebeu novamente, e gerou um filho. E ela disse: 'Agora, desta vez, unir-se-á a mim meu homem, porque dei à luz para ele três filhos'. Assim, chamou-lhe Levi". ${ }^{406} \mathrm{O}$ verbo "unir" [לוה/ lā

\footnotetext{
405 A situação financeira dos levitas lhes deve ter sido favorável nos reinados de Davi e Salomão. Mas com a cisão de Israel entre Reino do Norte, denominado de Israel, e Reino do Sul, denominado de Judá, o favorecimento ao trabalho dos levitas veio a ser minimizado. O cronista narra o desprestígio que os levitas e sacerdotes desfrutaram no Reino do Norte, sob Jeroboão I, levando-os a abandonarem suas propriedades no Norte e a se mudarem para o Sul (2 Crônicas 11,11.12; 13,9), pois Jeroboão I os havia expulsado. Este deslocamento em massa provocou sobrecarga financeira em Judá que, com a divisão do reino de Salomão, não tinha mais muitos contribuintes para o Templo. Isso levou a muitos deles ao empobrecimento forçado. $\mathrm{O}$ apoio das comunidades se fazia necessário para a sobrevivência destes levitas "estrangeiros".

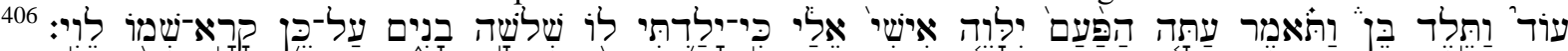

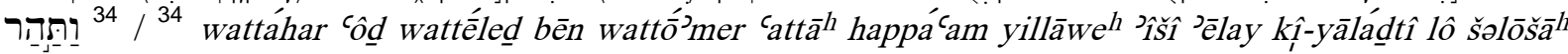
bānîm cal-kēn qārẳ’-šomô lēWî. Notar a alegria de Lia por cumprir a função que era esperada dela como mulher
} 
da declaração de Lia, dando ao nome $l \bar{e} w i ̂$ uma etimologia popular. O verbo $l \bar{a} w a \bar{a}^{h}$ aparece em Números 18,2.4 para dizer que a tribo de Levi se unirá a Arão para ajudá-lo nos serviços do Tabernáculo, e em Êxodo 32,26, no caso do bezerro de ouro, para afirmar que a tribo de Levi se une a Moisés, dando-lhe o suporte necessário em seu embate contra os demais israelitas que estavam cultuando o bezerro de ouro (KELLERMANN, 1995, p. 487). ${ }^{407}$

As notas acima não mostram o significado original do nome lēwî, mas como o nome lêwî foi interpretado e, ao observar as diversas intepretações sobre a origem deste nome, chega-se à conclusão que não se tem conhecimento sobre o significado original dele. ${ }^{408}$ Por esta dificuldade, esta pesquisa apresenta apenas o que a própria $\mathrm{BH}$ apresenta como sendo a origem da palavra lēwî.

\subsubsection{Traduções para o Aramaico e Septuaginta}

\subsubsection{Targum}

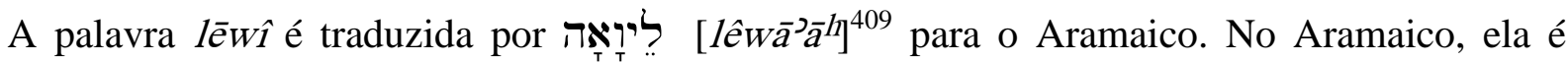
considerada um adjetivo (HHL-BW7). Portanto, ela qualifica indivíduos masculinos pertencentes à tribo de Levi. Esta palavra, lêwă $\bar{a}^{h}$, é a que aparece na maioria das ocorrências dentro de Deuteronômio. Entretanto, em Deuteronômio 21,5 e 31,9, encontra-se a construção

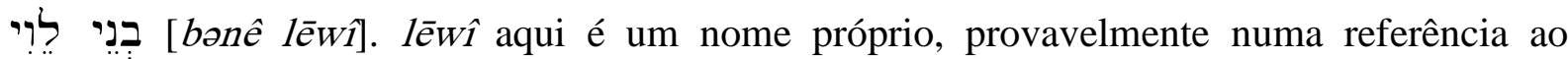
ancestral, filho de Jacó, que dera nome à tribo. Na bênção de Moisés, em Deuteronômio 33,8, a palavra lēwî aparece sozinha como nome próprio. A tribo inteira está colocada sob o nome לִ̣n nesse texto de Deuteronômio.

de Jacó. Ela gera para "o seu homem/marido, 'î̌ŝl," mostrando que a função dela dentro do clã é procriar, especialmente filhos. Ela se gaba de já ter dado a Jacó três filhos.

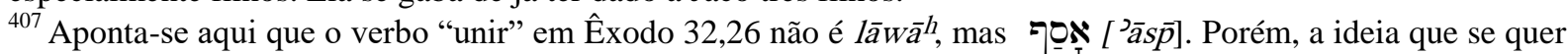
salientar é o conceito de unir repetido em relação aos levitas.

${ }^{408}$ Outras propostas quanto ao significado original do nome lēwî são apresentadas por Kellermann (1995, p. 487-490).

${ }^{409}$ Esta palavra vem de ליוי [lywy]. 


\subsubsection{Septuaginta}

A palavra $l \bar{e} w i ̂$ é traduzida para o Grego por $\Lambda \epsilon u i ́ \tau \eta \varsigma^{410}$ Ela não ocorre como adjetivo, mas como substantivo (GGL-BW7). A LXX omite a palavra lēwî em Deuteronômio 12,18. Provavelmente porque ela aparece no versículo 19 com a ênfase que o lēwî não deveria ser esquecido na generosidade do homem em sua celebração pelos frutos do campo. Em

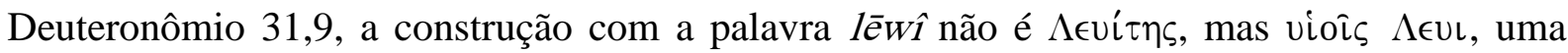
formação genitiva com a palavra $\Lambda \epsilon u$ t. $^{411}$ Como no Aramaico, $\Lambda \in$ ú é uma referência ao ancestral que doou seu nome para a formação de uma tribo de Israel.

\subsubsection{Análise textual}

Pelo quadro anterior, há no livro de Deuteronômio aproximadamente 18 versículos com aparições da palavra lēwî. Destas ocorrências, pode-se dizer que o livro apresenta quatro divisões de levitas. ${ }^{412}$ Elas são apresentadas como segue pela pesquisa abaixo. Elas não são meramente divisões internas da tribo. Elas são divisões sociais existentes na tribo levita. E o motivo para isso é que que há o lēwî que tem recursos e o que não os tem.

\subsubsection{O lēwî como Ente Silencioso específico}

O maior número de referências, no Deuteronômio, está relacionado ao grupo de levitas pertencentes ao grupo de Entes Silenciosos, de modo específico. ${ }^{413}$ Todas as ocorrências da palavra lēwî relacionadas a esse grupo estão dentro de Deuteronômio 12 a 26 (12,12.18.19; $14,27.29 ; 16,11.14 ; 26,11.12,13)$. Nessa divisão, apresentada por esta pesquisa, a primeira classe de levita era aquela que mais se adequa ao conceito de um Ente Silencioso, porque ela

\footnotetext{
${ }^{410}$ Nem todas as ocorrências da palavra aparecem com a inicial maiúscula como aqui. Ela também aparece com

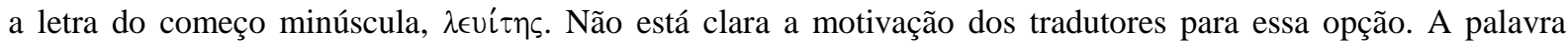
aparece na LXX com letra maiúscula em Deuteronômio 12,12.19; 14,27; 16,11.14; 18,1.6.7; 21,5; 26,11.12.13; 31,25; 27,9.14; com letra minúscula em 14,29.

${ }^{411}$ A mesma palavra ocorre em Deuteronômio 33,8, só que numa construção dativa, mas com mesma grafia.

${ }^{412}$ Kellermann, seguindo Gunneweg, diz que é possível distinguir quatro estágios no tratamento dos levitas dentro do livro de Deuteronômio: "O levita dentro dos teus portões" que era um tipo de estrangeiro; o levita “dentro dos teus portões" e que possuía os mesmos privilégios que o levita que servia no santuário central; o levita que também era sacerdote; a tribo inteira de Levi (1995, p. 496-497).

${ }^{413}$ Todos os levitas são pertencentes aos Entes Silenciosos, pois eles continuam sem falar e o que é dito sobre eles é dito por outros. Mas essa primeira divisão trata daqueles que são completamente dependentes do "tu/vós", como os demais - gēer, 'almānāa ${ }^{2}$, e yātôm. Assim, poderíamos dizer que essa divisão de levitas é a menos privilegiada dentro da tribo de $l \bar{e} w \hat{1}$.
} 
é constituída de pessoas que não possuíam qualquer propriedade dentro da comunidade em que viviam, pois isso lhe havia sido vedado (Deuteronômio 12,12.18.19).

Esse levita era aquele que necessitava ser socorrido em suas necessidades (14,27.29). O levita aqui, especificamente, era pertencente ao grupo de Entes Silenciosos presente no livro de Deuteronômio, e, como apontado, anteriormente, ele é comumente relacionado com o grupo constituído por gēr, 'almānāh, e yātôm. Isso não quer dizer que as outras divisões de levitas não pertençam ao grupo de Entes Silenciosos como essa divisão. Quer dizer que esta é a que preenche todas as características de um ser dependente, tal como o gēr, a ’almānāh, e o yātôm, com os quais esse lēwî está relacionado.

O que caracteriza esta divisão de lēwî como, essencialmente, um membro dos Entes Silenciosos? Em primeiro lugar, como notado acima, todos os textos relacionados a ela estão dentro do bloco principal de literatura que compõe o livro (12-26). É aqui onde a legislação deuteronômica se torna prática para os Entes Silenciosos, bem como para o "tu/vós" a quem o texto é dirigido.

Em segundo lugar, ele é aquele que está "nos teus portões”. Esta construção gramatical aparece relacionada ao lēwî, em Deuteronômio 12,12.18. Em Deuteronômio 14,27.29 (também 16,11.14; 26,12), o lēwî tem a companhia de outros Entes Silenciosos, gēr, ’almānāh, e yātôm. Estar dentro dos portões é uma expressão figurada para apontar que o lēwî vive dentro da propriedade do "tu/vós" e, assim, este deve conceder ao lēwî o que ele precisa para sua subsistência.

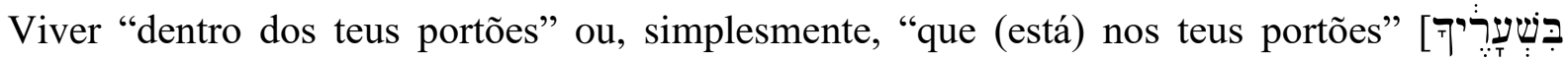

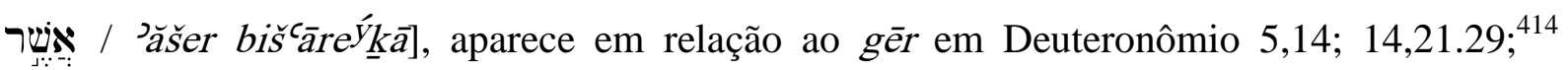
$24,14{ }^{415} 31,12$. O indivíduo a quem o redator está se referindo é especificado. É como se

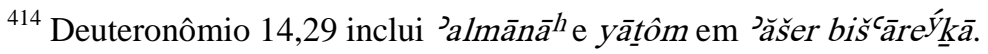

415 Este versículo acrescenta um detalhe. A construção biš $\bar{s} r e^{y} \underline{\underline{k}} \underline{a} \bar{a}$ ("na tua terra") aparece como um

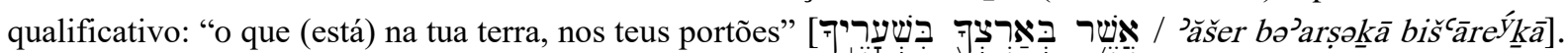
"Nos teus portões" é a especificação de "na tua terra" - estar "na tua terra" é estar dentro dos teus domínios, "nos teus portões". O que vem a ser "estar nos teus portões"? Segundo esse texto, é estar "na tua terra". a porção de terra, a herança, que pertence aquele "tu". Além disso, aqui o gêr vem acompanhado do cānî wỏebyônn. O versículo inteiro pode ser assim traduzido: "Não oprimirás o assalariado pobre e necessitado de teus irmãos ou o

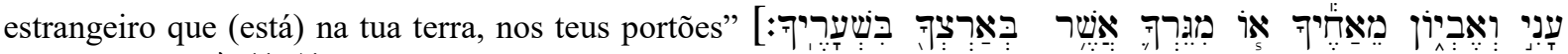

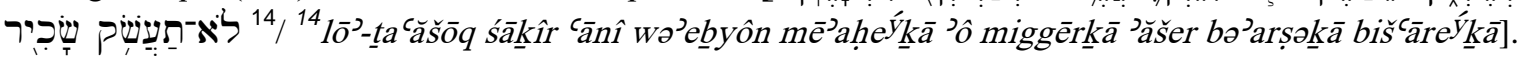


estivesse acontecendo um diálogo hipotético no texto. O redator está falando de um estrangeiro, e a audiência pergunta ao orador sobre qual estrangeiro ele estava se referindo. Então ele responde com a construção: "aquele que está nos teus portões" [ ' ’ăšer biš $\left.\bar{a} r e^{y} \underline{k} \bar{a}\right] .{ }^{416}$

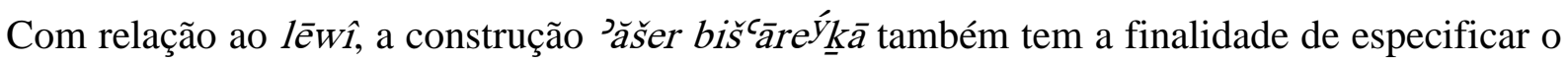
levita a quem o redator está se referindo. Com muitos levitas vivendo na Terra de Israel, qual ele tinha em mente? "Aquele que está nos teus portões". Em relação a $l \bar{e} w \hat{i}$, ela aparece em Deuteronômio 12,12.18;14,27.29; 16,11.14; 26,12.

Assim, ’ăšer biš $\bar{a} r e^{y} \underline{k} \underline{a}$ salienta a propriedade do "tu/vós" delimitada. A construção aponta para as pessoas que estão dentro daquela propriedade, desfrutando do acolhimento, temporário ou não. Sendo que o "tu/vós", a quem o texto se refere, é aquele que tem o poder de decisão - o líder do clã.

Porém, há outra formação gramatical que torna mais específica à proximidade dos Entes

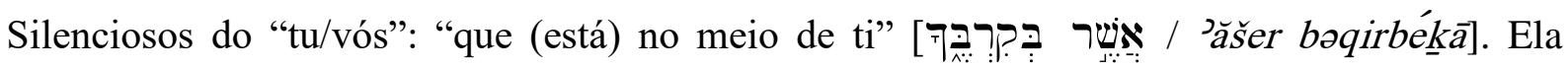
aparece em Deuteronômio 16,11, onde estão envolvidos, de modo específico, o gēr, a 'almānăh , e o yāttom; em 26,11, onde os envolvidos são apenas o lēWî e o gēr, no entanto, em 28,43 e 29,11 (hebraico v. 10) ’ăšer boqirbéḱāa aponta para o gēr, somente.

Esta construção, (1997, p. 591). Com, ב, como nesses textos em Deuteronômio, pode ter o sentido de "o lugar dentro do qual: de uma comunidade" (SHÖKEL, 1997, p. 591). ${ }^{417}$ Se se entender bəqirbékāā, "no meio de ti", como uma referência ao clã no qual o lêwî, o gēr, a 'almānāh , e o yātôm se encontravam, então se pode ver uma construção que pertença ao mesmo campo semântico de biš $\bar{a}^{-} r e^{y} \underline{k} \bar{a}$, "nos teus portões". O texto que favorece a esta interpretação é Deuteronômio 16,11, onde as duas formações aparecem: "E te alegrarás diante de yhwh teu Deus - tu, e teu

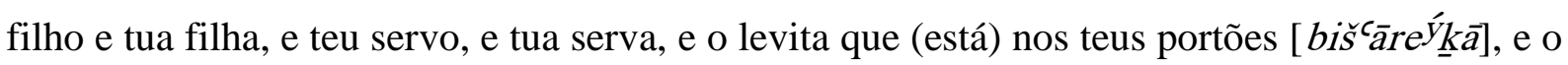

\footnotetext{
${ }^{416}$ Em um diálogo entre Jesus e um sábio judeu é desenvolvido uma definição do que vem a ser um "próximo", a partir de uma pergunta do sábio para Jesus: “Quem é o meu próximo?". Na resposta de Jesus, o próximo é aquele necessitado que precisasse de ajuda e que, tal ajuda, estava dentro da possibilidade daquele sábio ajudar e estaria perto de quem pudesse ajudar (Evangelho de Lucas 10,25-37). Aparentemente, Jesus tem seu pensamento lapidado por Deuteronômio quando conta a parábola do "bom samaritano" para aquele sábio, e tem em mente a

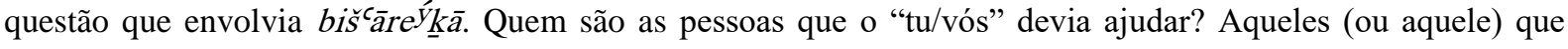
estão ao alcance dele - ele (ou eles) está (estão) nos teus portões, está na tua terra, ou está no meio de ti.

${ }^{417}$ Esse significado pode ser tanto com $\beth$ quanto com (ִ̣ (p. 591).
} 
estrangeiro, e o órfão, e a viúva que (estão) no teu meio [boqirbék̄ā], no lugar que $y h w h$ teu Deus escolher para estabelecer seu nome lá”. ${ }^{418}$

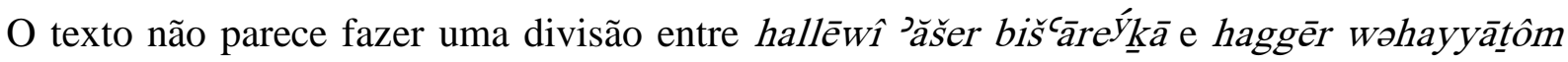

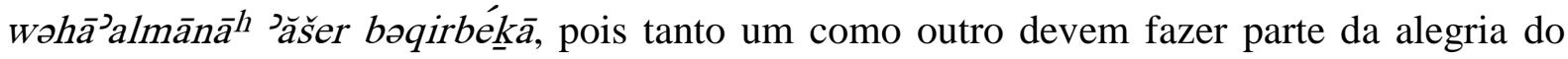
"tu” e sua família - filha e filho. Assim, estar "nos teus portões [bəqirbékeā] é estar "no meio de ti" [boqirbékāa].

Com isso, o estar dentro dos portões iguala o lēwî, de modo específico, ao gēr, a ’almānā $\bar{a}^{h}$, e ao yātôm, fazendo com que o lēwî esteja ali pelos mesmos motivos - guerra, fome, ou algum tipo de privação. Ali ele está sob a proteção daquele que o acolhe. Como o lēwî é um Ente Silencioso, o redator se dirige ao "tu/vós".

Em terceiro lugar, como membro do grupo de Entes Silenciosos, é ordenado que o lēwî jamais fosse esquecido pelo clã que o acolhe. Em Deuteronômio 12,19 é dito que: "Seja guardado $^{419}$ por ti: Não ${ }^{420}$ abandones o levita todos os teus dias sobre o teu solo". ${ }^{421}$ Dentro do contexto deste texto, de que tipo de abandono o lêwî deveria ser preservado pelo ouvinte? A resposta pode ser encontrada nos versículos 17 e 18. Nestes textos o "tu" é proibido de comer o dízimo no lugar onde vive, e que ele deve comê-lo no lugar designado. Nessa comida festiva, "perante yhwh teu Deus", participa a família, os servos, e "o levita que (está) nos teus portões". Este usufruto da comida, elemento básico para a sobrevivência do lēwî, não poderia ser esquecido. Deve-se apontar que aqui apenas o levita, além da família e dos servos, é que é indicado a participar da comida festiva.

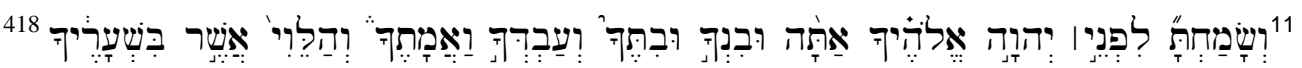

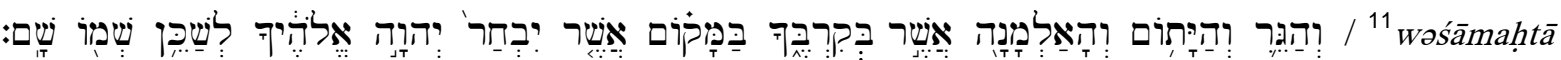

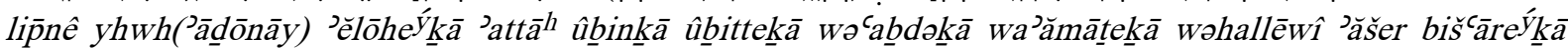

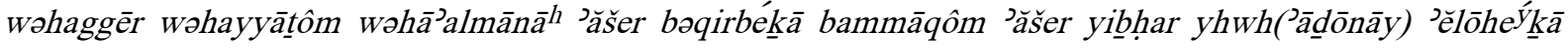
ləšakkēn šomô šăm.

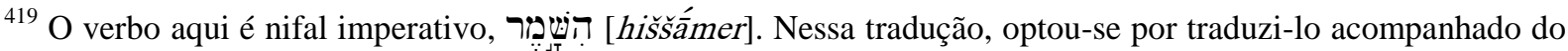
verbo ser. Assim: "Seja guardado". Mas o que deveria ser guardado pelo לְ [ [oknâ]? A observância de nunca abandonar o lēwî.

${ }^{420}$ aponta para a proibição de um evento possível por parte daquele a quem a mensagem é dirigida (BW7). O que seria possível ser esquecido pelo ouvinte? O amparo devido ao lēwî ’ăšer bəqirbéḱā (Deuteronômio 12,18). Seguido do imperfeito תַּ, pode-se sugerir que a proibição tem como propósito o impedimento do começo de uma ação.

421 hiššámer lok̄ā pện-tacăzōb 'et-hallēwî kol-

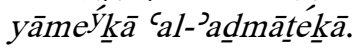


Esse tratamento especial para o lēwî aponta para ele como alguém dependente de ajuda para sua sobrevivência, ao mesmo tempo em que salienta outra qualidade dos membros deste grupo de lēwî em Deuteronômio 14,27 - "E o levita que está nos teus portões, não o abandonarás, porque para ele não há território e herança contigo". ${ }^{422}$ Esta oração explicativa volta a aparecer no versículo 29. Somente que neste versículo ela não somente qualifica o lēwî como o torna distinto dos outros Entes Silenciosos presentes no texto - o gēr, a دalmānăh , e o yātôm. A privação de uma propriedade por parte do lēwî não foi por opção pessoal tomada por ele, mas por imposição divina $(18,1)$.

Assim, a inexistência de uma propriedade havia levado este grupo de lēwî a uma situação extrema - a completa necessidade de dependência do "tu/vós".

\subsubsection{O lēwî como membro da classe sacerdotal}

A segunda divisão de levitas era aquela constituída pelos "sacerdotes levitas", onde a palavra "sacerdote" vem necessariamente qualificada pela palavra "levita". Em Deuteronômio as ocorrências são em 18,1; 21,5; 27,9 e 31,9. A forma como essa qualificação acontece segue as duas formas seguintes de formação: em Deuteronômio 18,1, a construção é: "para os

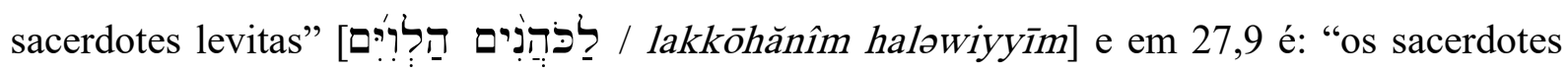

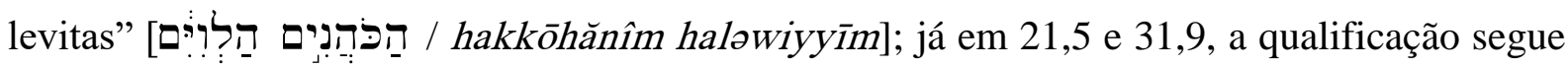

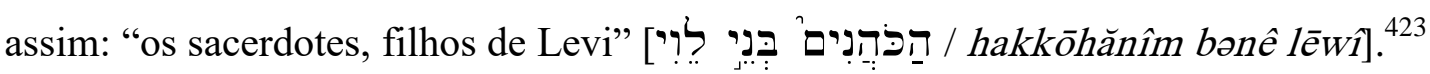

\subsection{O motivo dessa especificação}

A questão que se deve fazer é porque o livro de Deuteronômio traz, de forma específica, a definição que os sacerdotes deveriam ser "filhos de Levi” ou, simplesmente, "levitas". Em primeiro lugar, Deus definiu quem deveria ocupar o sacerdócio, posição que já havia sido disputada por outros, como mostram as narrativas do deserto. Como o sacerdócio era uma posição de grande influência, a primeira disputa para a posição aconteceu entre os próprios membros da tribo de Levi no deserto. Um grupo liderado por um homem de nome Corá

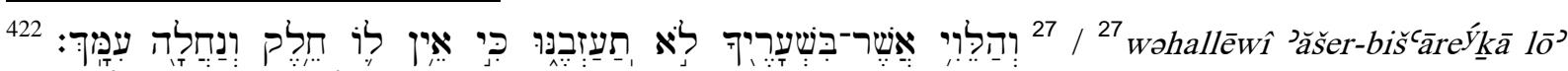

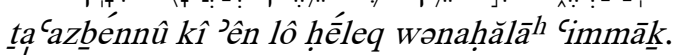

${ }^{423}$ Esta qualificação dos sacerdotes como sendo dos "filhos de Levi" fora encontrada, por esta pesquisa, somente nestes dois lugares dentro do livro de Deuteronômio, em toda a BH. As outras duas estão em 1 Reis 12,31 e Ezequiel 40,46, mas não como a construção existente dentro de Deuteronômio.
} 
questionou a posição de Arão como sacerdote (Números 16). A questão, sobre a quem pertencia o sacerdócio, fora definitivamente resolvida por escolha divina, feita mediante o milagre do florescimento da vara que levava o nome de Arão (Números 17). ${ }^{424}$

Em segundo lugar, o contexto de abrangência do livro de Deuteronômio necessita que isso seja especificado. Isso quer dizer que essa forma de salientar, que os sacerdotes deveriam ser dos filhos de Levi, vem da polêmica existente entre os redatores de Deuteronômio e os reis do norte. $^{425}$ Os reis do Norte tinham o costume de constituir seus próprios sacerdotes. A qualificação dos sacerdotes como tendo que ser dos filhos de Levi torna-se relevante para este período. ${ }^{426}$ Assim, a política de Jeroboão I, e dos reis que o sucederam no Reino do Norte, forçava o redator a especificar quem deveria ser sacerdote.

\subsection{A caracterização dos "sacerdotes levitas"}

O que caracteriza os sacerdotes levitas? Deuteronômio 18,1-5 mostra que os sacerdotes são levitas e ao mesmo tempo são distintos do restante da tribo de Levi. A eles foi dado o direito de comer das coisas sacrificadas, porém, especificamente, das ofertas que seriam queimadas ao Deus de Israel, e a motivação para isso é que a eles fora vetada a possibilidade de ter algum tipo de herança no meio de Israel. Deuteronômio 18,1 diz: "Não haverá para os sacerdotes levitas, toda a tribo de Levi, território e herança ${ }^{427}$ com Israel. (Eles) comerão as ofertas queimadas ${ }^{428}$ a $y h w h$, e (ela será) a herança/possessão dele". ${ }^{429}$

A ordenança é dirigida diretamente aos "sacerdotes levitas". "Tribo de Levi" funciona aqui como aquela que também não receberá herança no meio de Israel e o motivo de os "sacerdotes levitas" não terem qualquer tipo de herança ou propriedade no meio de Israel,

\footnotetext{
${ }^{424}$ Deus havia ordenado que cada tribo trouxesse uma vara, com o nome da tribo. A vara da tribo de Levi deveria ter o nome de Arão. Essas varas deveriam ser colocadas no Tabernáculo para passarem uma noite ali. A tribo escolhida teria a vara florescendo. Para definir a escolha divina, a vara com o nome de Arão foi a que floresceu (Números 17).

${ }^{425}$ Sánchez aponta que a origem do livro de Deuteronômio está no Reino do Norte, onde o livro sublinha a polêmica entre os seguidores de Baal e aqueles que defendiam o Deus de Israel, tendo principalmente nos oráculos de Elias, Amós e Oséias como pano de fundo (2002, p. 19).

${ }^{426} \mathrm{O}$ livro de 1 Reis 12,31 afirma que Jeroboão I constituiu seus próprios sacerdotes, os quais "não eram filhos de Levi" (BJ). Em 1 Reis 13,33 diz de Jeroboão "a quem desejasse, ele dava a investidura para se tornar sacerdote dos lugares altos" (BJ). Isto se tornou uma prática dos reis do Reino do Norte a partir de Jeroboão.

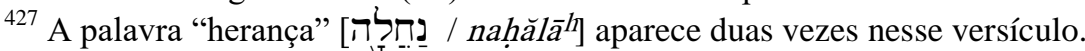

428 "Ofertas feitas ao SENHOR pelo fogo" (TENNEY, 1992, p. 119).

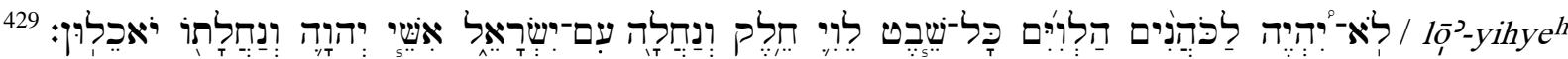

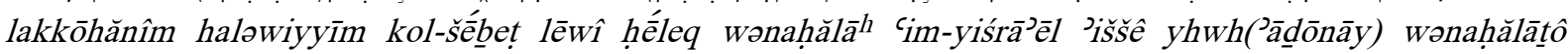
yō $\underline{\text { ke}} \bar{e}$ ûn.
} 
pois eles pertencem à Tribo de Levi. A palavra "herança" [naḥălăh], em sua primeira ocorrência nesse versículo, afirma o que os sacerdotes levitas não terão herança. Em sua segunda aparição, ela mostra o que eles terão "as ofertas queimadas a yhwh". A última frase do versículo apresenta, de forma específica, que essas ofertas devem ser dadas aos sacerdotes levitas, porque elas são uma espécie de possessão de $y h w h{ }^{430}$

Mesmo assim, os sacerdotes levitas não ficariam sem uma herança. Deuteronômio 18,2 afirma qual será a herança desses servidores do Tabernáculo: "E não haverá herança para ele no meio de seus irmãos - o próprio yhwh (será) sua herança, conforme falou para ele". ${ }^{431} \mathrm{O}$ que significa dizer que "yhwh (será) sua herança"? A construção pode ser entendida que Deus será a herança "tanto quanto possessões materiais for uma preocupação" (TENNEY, 1992, p. 318) para Israel. Assim, se havia uma preocupação com herança material para qualquer israelita comum, havia também para os membros da Tribo de Levi, e, de forma especial no texto, para os sacerdotes levitas. Para diminuir qualquer preocupação com isso, o Deus de Israel se interpõe como a sua herança, com a qual eles manterão um relacionamento especial. Outra forma de entender essa construção é do ponto de vista da perda de ganho. A Tribo de Levi perdeu em posses territoriais, mas ganhou em "posição privilegiada como intercessores entre Deus e seu povo" (MERRILL, 1994, p. 268). De modo especial os sacerdotes levitas seriam aqueles que representariam o povo de Israel diante de Deus.

A palavra nahălă $\bar{a}^{h}$ tem a ver com possessão que passa de pai para filho de forma permanente, como a herança de um clã (COPPES, 1980, p. 569). A Tribo de Levi teria a autodoação de herança, onde o próprio Deus de Israel se doa em herança a eles, como forma de compensação da perda de possessões territoriais. No caso específico dos sacerdotes levitas, como eles teriam que devotar seu tempo ao serviço no Tabernáculo, aquilo que seria dado a Deus é repassado para esses sacerdotes como forma de pagamento pelo trabalho devotado, no Tabernáculo, como demonstra Deuteronômio 18,3-5. Entretanto, toda a terra de Israel pertence ao Deus de Israel (Êxodo 19,5). Mesmo que Deus não fosse um deus para ser

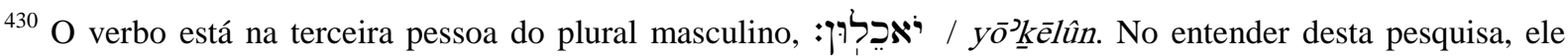

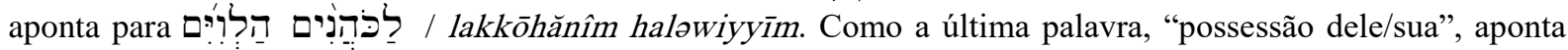
para as ofertas queimadas, então, já que as ofertas queimadas são uma porção dada ao Deus de Israel, mas ele não come, elas são dadas aos sacerdotes levitas, para a sua subsistência, pois eles comem.

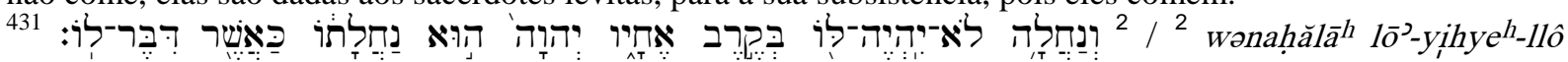
bəqéreb 'eḥāyw yhwh( āạdōnāy) hû̉ naḥălātô ka’ăšer dibber-lô. Notar que a palavra "herança" aparece duas vezes também aqui.
} 
domesticado por seus adoradores, a Tribo de Levi e, de modo especial, os sacerdotes levitas, possuiriam-no na medida em que o representassem de acordo com o que era exigido deles. Dessa forma, Deus seria a herança de Levi.

Deuteronômio 18,3-5 mostra que o redator não está falando da Tribo de Levi, mesmo que ele venha falando de "ele" no sufixo pronominal de algumas palavras. Especificamente, ele diz quais partes das ofertas devem ser dadas aos sacerdotes (v. 3), como parte de sua herança divinamente concedida - a eles cabia receber dos ofertantes partes específicas dos animais sacrificados, e também recebiam das primícias do campo e dos animais (v. 4). Com isso, mesmo que eles pertencessem à tribo de Levi, eles eram distintos dos outros também porque somente a eles foi dado o direito do sacerdócio - o fato de ser levita não dava direito ao sacerdócio, mas somente aos descendentes de Arão (v. 5).

Por último, aos sacerdotes, filhos de Levi, também competia o direito de decidir juízos, pois a Lei fora entregue por Moisés a eles - assim, os sacerdotes detinham o conhecimento, e, entre a tribo de Levi, era o grupo mais instruído $(21,5 ; 31,9)$.

Portanto, como os sacerdotes levitas também eram sem propriedade, pode-se dizer que eles pertenciam ao grupo de Entes Silenciosos, mas com ganho garantido pelas ofertas do altar, as primícias do povo, o que os distinguia dos levitas apresentados no ponto anterior, cujo sustento era dependente da comunidade que os acolhia. Assim, mesmo que os sacerdotes levitas não possuíssem herança dentro do povo de Israel, mas com sua subsistência garantida pelas ofertas do altar, eles podiam possuir vida melhor que a daquele levita que vivia dentro das comunidades rurais e cidades pequenas.

\subsubsection{O lēwî como uma tribo em Israel}

A terceira classe de levitas era aquela constituída da tribo de Levi como um todo $(18,1 ; 33,8)$. Aqui é onde a palavra lēwî designa o grupo inteiro de levitas sem se importar com o que cada um deles faz de modo específico. Porém, em Deuteronômio 18,1, como visto acima, é feita uma distinção entre a tribo de Levi como um todo e o grupo de levita denominado de "levitas sacerdotes". Nesse texto é especificada a forma de subsistência de uma parte da Tribo de Levi.

O outro texto é o que aborda a benção de Moisés às tribos de Israel, e, de forma específica, à tribo de Levi, tem algumas peculiaridades. Primeiro, as declarações iniciais são dirigidas 
diretamente à Tribo de Levi como um todo, para, logo em seguida, mostrar que a ênfase da bênção seja dirigida, não à tribo inteira, mas aos "sacerdotes levitas" e, especificamente, aquele que seria o "sumo-sacerdote" porque era a ele que caberia a responsabilidade de levar as pedras mágicas denominadas de "Urim e Tumim" $(33,8)$. Elas seriam um meio de conhecer os oráculos divinos, a vontade de Deus.

Aqui $(33,8)$ ele é chamado de "teu homem santo" - um homem separado para aquela função. Mesmo que a figura de "homem santo" se aplique ao sumo-sacerdote, neste contexto ele tem em mente Arão, e os sacerdotes que dele descendem. Como apontado no ponto acima, tal especificação mostra o destaque de quem deveria ser o sacerdote, e, novamente, entra numa polêmica com os sacerdotes constituídos no Reino do Norte, mas também coloca para os que retornam do Exílio de quem deveria ser o sacerdócio.

Essa peculiaridade coloca a primeira parte da bênção sobre apenas um grupo, a elite dos levitas, o sacerdote principal. Entretanto, a referência é a Arão, nas palavras finais do texto, onde é citado o que aconteceu em Êxodo 20, onde Moisés e Arão deveriam falar à rocha, mas a feriram, recebendo o juízo divino de não entrar na Terra da Promessa. Foi ali que o Deus de Israel contendeu com eles.

A segunda peculiaridade (Deuteronômio 33,9) é uma recordação do evento narrado em Êxodo 32, onde os levitas fizeram a opção de seguir Moisés quando do evento do bezerro de ouro. Ao dizer que nunca viu seu pai e mãe, não reconhece seus irmãos e que eles se firmaram na palavra divina, ele está apontando para aquele evento em que a lealdade dos levitas foi demonstrada por ficar ao lado de Moisés e matar todos os que estavam rebelados, por cultuarem o bezerro de ouro.

A terceira peculiaridade (Deuteronômio 33,10) é ao ensino dos levitas. Cabia a eles ministrarem o ensino das leis e juízos divinos em Israel. Juntamente com isso, também era função deles apresentarem o incenso no santuário e de oferecerem os holocaustos no altar diante do Tabernáculo e, posteriormente, do Templo Central. Com isso, apontam-se as três funções da tribo de Levi: a função oracular, com o Urim e Tumim; a função do ensino; e a função nos altares do holocausto e do incenso.

Finalmente, a benção específica vem em Deuteronômio 33,11, onde Deus é convidado a abençoar a tribo de Levi em sua força ou capacidade militar, na aceitação dos seus feitos 
(oráculo, ensino e ofertas) diante de Deus, e na derrota violenta de seus adversários. Depois da tribo de José, a bênção à tribo de Levi é a que ocupa maior espaço nas últimas palavras atribuídas a Moisés.

O que se pode ver é que a Tribo de Levi é vista, não em sua unidade somente, mas também em suas particularidades. Assim, nota-se a unidade da Tribo de Levi dentro de sua diversidade. Ela é uma tribo de Israel, mas dentro da tribo há diversidade pelas funções que ela realiza. Qualquer que seja a função, ela está relacionada ao trabalho procedente do Santuário Central - Urim e Tumim, sacrifícios e ensino.

\subsubsection{O lēwî como um cuidador da arca da aliança}

A última classe de levitas era constituída daqueles que cuidavam da arca da aliança e estavam a serviço permanente dos sacerdotes levitas, junto ao Santuário Central $(31,9.24)$. Tanto o levita que vivia no campo quanto aquele levita que era sacerdote diante do santuário central, todos pertenciam à mesma tribo, a tribo de Levi.

Quanto à questão do patrimônio, o levita que ia ao Santuário Central para prestar algum tipo de serviço, junto aos sacerdotes levitas, tinha os mesmos direitos de usufruir das ofertas ali oferecidas, durante o tempo em que estivesse a serviço do sacerdócio, e ele também poderia vender seu "patrimônio" naquele lugar $(18,6.7)$. Tanto o patrimônio dos levitas sacerdotes quanto o patrimônio referido a esse levita, que prestava serviço temporário no Santuário Central, constituía-se de bens adquiridos por sua participação no serviço junto ao Santuário, e, provavelmente, era constituído de animais e frutos do campo. Isso indica que a situação daqueles que viviam para o serviço junto ao Santuário tinham suas vantagens em relação àqueles que viviam no meio de comunidades pobres do interior.

Em suma, esta seção trata daqueles que, normalmente, aparecem juntos dentro do livro do Deuteronômio: gēr, 'almānăh , yātôm, e lēwî. Na essência, o que os caracteriza é que eles são todos como um gēr, por três motivos - eles não têm propriedade, e são dependentes dos outros para sua sobrevivência - mesmo que essa dependência fosse da generosidade da fé daqueles que faziam suas ofertas regulares, e, assim, formam um grupo social distinto dentro do Israel deuteronômico. 
Portanto, o gēr, a 'almānāh , o yātôm, e o lēwî, colocados juntos nesta unidade da pesquisa, caracterizam-se por sua completa dependência dos outros. Suas necessidades são supridas por meio de ações generosas do "tu/vós". Desse modo, como eles não têm qualquer tipo de patrimônio dentro de Israel, pode-se dizer que todos eles são um tipo especial de gēr.

Porém, como sobreviver em um mundo como peregrino? Como o Deuteronômio ajudou esse grupo de "estrangeiros" dentro do povo de Israel. A resposta está no dízimo do terceiro ano, instiuído especificamente para ajudá-los.

\subsection{O Dízimo do terceiro ano (Deuteronômio 26,12-15) (32 $^{42}$}

\subsubsection{Tradução}

12 - "Quando terminares ${ }^{433}$ de fazer a coleta do dízimo, o dízimo todo do teu produto do campo $^{434}$ naquele ano, o dízimo do terceiro ano. ${ }^{435} \mathrm{E}$ tu (o) darás ${ }^{436}$ para o levita, para

\footnotetext{
${ }^{432}$ O dízimo do terceiro ano é uma legislação específica do Deuteronômio. Ele já havia aparecido no texto de Deuteronômio 14,28-29. Nesse texto, especificamente é dito que o dízimo do terceiro ano deve ser arrecadado no fim de cada terceiro ano e colocado à disposição do levita, órfão, viúva e do estrangeiro residente. Ali o levita é qualificado como alguém que não tem patrimônio no meio de Israel: "porque para ele (o levita) não há porção e

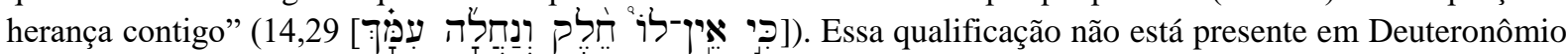
26,12-15.

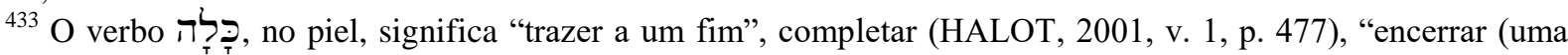
tarefa, trabalho)" (SCHÖKEL, 1997, p. 317). A ideia é que algo tem sido encerrado. Isso sugere que o redator está pressupondo que a colheita dos produtos do campo foi encerrada e que é possível quantificar o dízimo do terceiro ano. Essa quantidade separada deveria ser doada para os Entes Silenciosos. Notar que, ao ser deixado para ser retirado no fim do ano terceiro, o fazendeiro teria a noção da quatidade exata do dízimo a ser dado.

${ }^{434}$ A construção

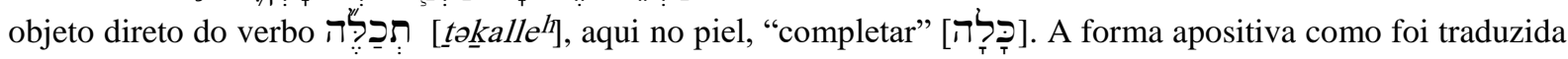

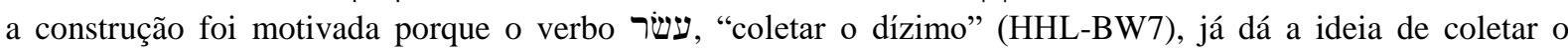

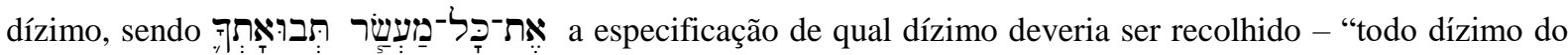
teu produto do campo". O que está apontado aqui é o balanço final das colheitas e a separação do dízimo delas. Essa parte do produto do campo é a que deveria ser concedida a esse grupo de Entes Silenciosos.

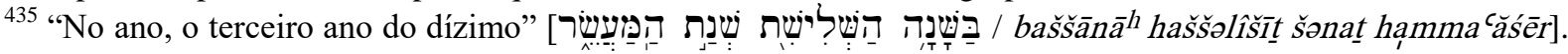
A segunda construção apositiva de Deuteronômio 26,12. "Todo teu dízimo do produto do campo no ano" precisa de uma explicação sobre qual ano o redator está pensando- a cada ano ou um ano específico? O redator, por meio de um aposto, especifica o dízimo de qual ano ele está falando. Ele está falando de "o terceiro ano do dízimo", literalmente.

${ }^{436} \mathrm{O}$ verbo "dar" [נתן] aparece quatro vezes nesta unidade textual.
} 
o estrangeiro, para o órfão e para a viúva. ${ }^{437}$ E eles comerão nos teus portões. E eles serão saciados." 438

13 - "E dirás diante de '̄ạdōnāy teu Deus: Eu removi ${ }^{439}$ o consagrado ${ }^{440}$ da casa ${ }^{441}$ e também o dei para o levita e para o estrangeiro e para o órfão e para a viúva, conforme todo o teu mandamento que tu me mandaste. Eu não transgredi ${ }^{442}$ e não me esqueci dos teus mandamentos."

14 - "Não o ${ }^{444}$ comi no meu luto ${ }^{445}$ e não o consumi em impureza, e não dei dele para o que morreu. ${ }^{446}$ Ouvi a voz de ’ādōnāy meu Deus. Fiz conforme tudo que me ordenaste $^{447},, 448$

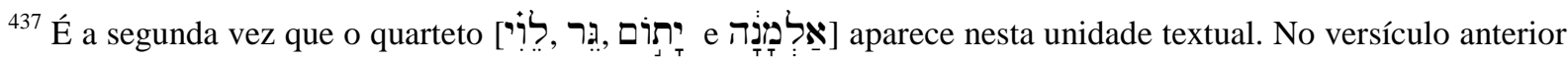
eles aparecem na boca do redator quando ele se dirige ao "tu" a quem cabe o dever de dar o dízimo do terceiro ano. Nesse versículo, os quatro aparecem na boca do "tu" confirmando a entrega do dízimo aos destinatários, segundo o mandamento recebido.
}

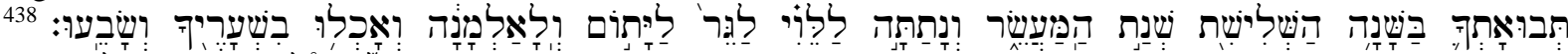

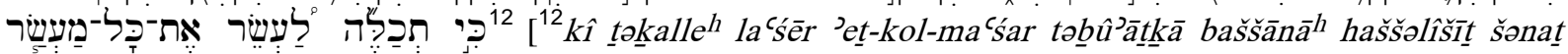

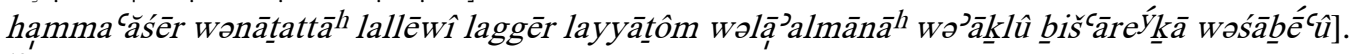

439 בפער é um verbo normalmente empregado para purificação de pecado da sociedade, mas aqui ele foi usado para indicar que a remoção do dízimo foi total e que dele nada ficou na casa do confessor (TIGAY, 1996, p. 243). Assim como a remoção do pecado deve ser completa, a do dízimo também. Ver Deuteronômio 13,6 e 2 Reis 23,24 .

${ }^{440}$ Em Deuteronômio 26,13 não aparece a palavra dízimo. Ela ocorre duas vezes no v. 12, na boca do redator. Na

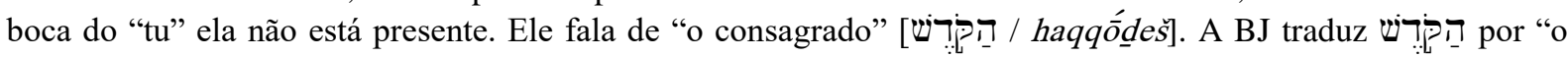
que estava consagrado". A ARA traduziu por "o que é consagrado". O "tu" entende que o dízimo é algo que

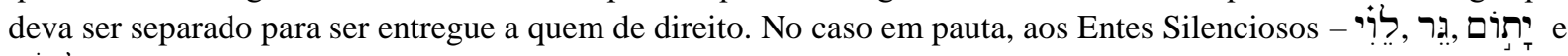
אַלְמָּנָּ . Assim, "o objeto consagrado" (SCHÖKEL, 1997, p. 572) é o dízimo do terceiro ano, cuja destinação é

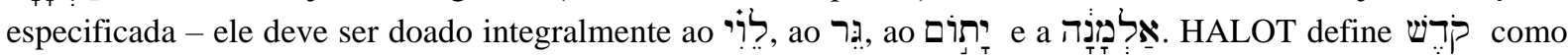
"alguma coisa com a qual a santidade é associada, que é para ser tratada cuidadosamente, alguma coisa santa; pessoa ou coisas que são santas" (2001, volume 2 , p. 1072). O conceito de algo que precisa ser tratado com cuidado está por trás da preocupação do confessor quando ele diz que não desviou o dízimo do terceiro ano para outras finalidades $(26,14)$ que não a sua entrega para os Entes Silenciosos apontados pelo redator.

${ }^{441}$ Casa aqui pode ser uma referência à casa do ofertante ou ao lugar onde se guardaria o dízimo.

${ }^{442}$ O verbo no עָבָבר, no qal, tem seu sentido básico de "atravessar, percorrer um território" (SCHÖKEL, 1997, p. 476). Aqui o verbo tem um sentido figurativo de "transgredir", e até de "quebrar" (SCHÖKEL, 1997, p. 476). O que o confessor está declarando é que ele foi até onde Deus lhe tinha ordenado. Ele não fez menos nem mais do que Deus lhe tinha mandado. Ele foi preciso na sua obediência ao que Deus lhe tinha ordenado.

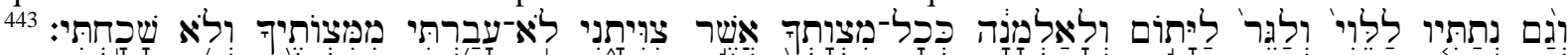

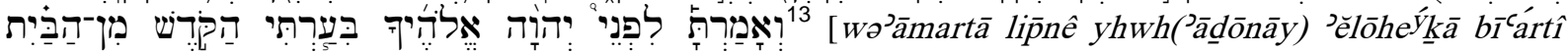

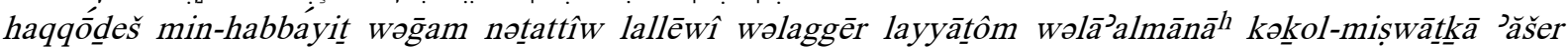

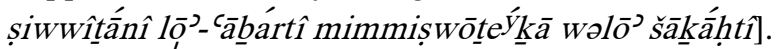

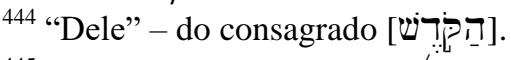

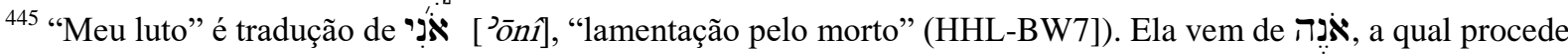
do verbo אוז I, "lamentar", "gemer" (SCHÖKEL, 1997, p. 67). Essa palavra aparece na boca de Raquel, em Gênesis 35,18 , por ocasião do nascimento de seu segundo filho e sua morte subsequente: "Filho do meu luto"

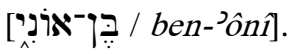


15 - "Olha ${ }^{449}$ do lugar da tua santidade, ${ }^{450}$ do céu, ${ }^{451}$ e abençoa ${ }^{452}$ o teu povo, Israel, ${ }^{453}$ e o solo $^{454}$ que deste para nós, conforme juraste para nossos pais - terra que flui ${ }^{455}$ leite $^{456}$ e mel." 457

\subsubsection{O contexto}

O contexto no qual está inserido o dízimo do terceiro ano mostra a sua importância para a memória do povo. Primeiro, em Deuteronômio 26,1-11 está a Confissão memorial que inclui a fala do confessor israelita cercada pela estrutura redacional, onde o confessor, juntamente com sua família, convida alguns Entes Silenciosos para participarem de seu banquete festivo em memória do Êxodo, como um dia festivo pela colheita dada pela bênção divina sobre o solo de sua herança.

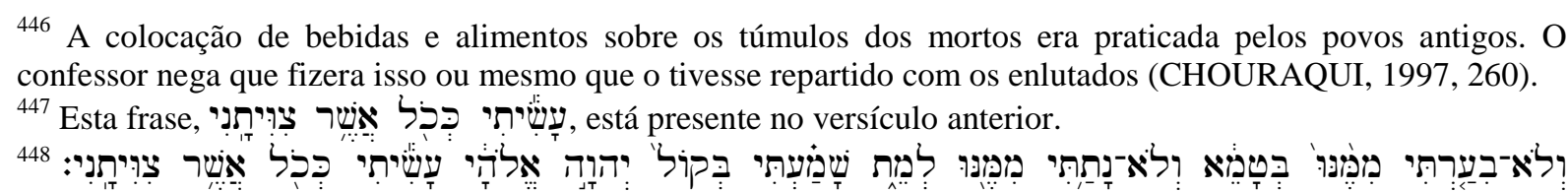

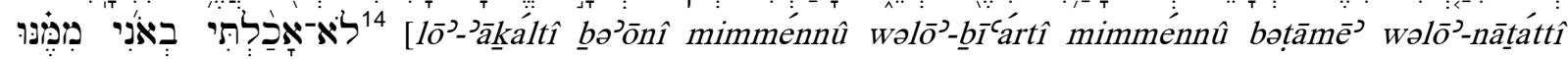

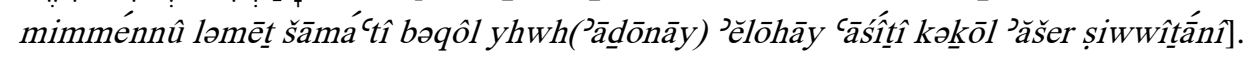

${ }^{449} \mathrm{O}$ verbo ש ש no hifil traz a ideia de "olhar para baixo" da perspectiva de quem está em baixo, enquanto que no nifal é o oposto - "olhar para baixo" da perspectiva de quem está em cima (BW7). O confessor está pedindo que Deus "se incline" para olhar para o confessor e atestar sua lealdade a ele, pois, depois de seu exame, ele atestará a lealdade do confessor e realizará o segundo imperativo. É um olhar propositivo - "olha para abençoar".

${ }^{450}$ Segunda ocorrência da palavra קדרש (Deuteronômio 26,13.15).

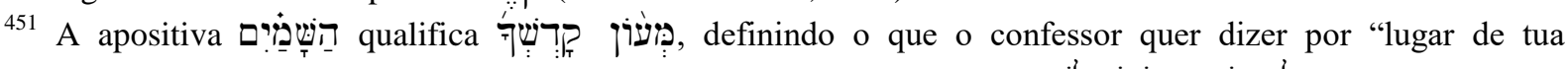

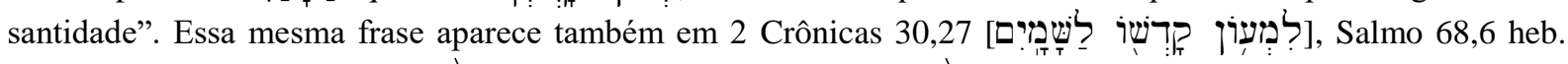

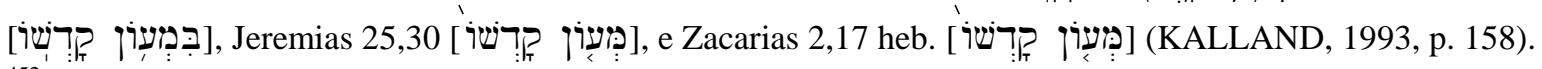

${ }_{452}$ Os verbos "olhar" e "abençoar" estão no imperativo.

${ }^{453}$ A solidariedade entre o confessor e o povo de Israel está estabelecida. Ele deseja que a resposta divina à sua lealdade tenha alcance nacional. Ele quer que seu povo, com o qual ele se identifica, seja inteiramente abençoado. Assim como o pecado de um membro do povo atinge o povo inteiro (Josué 7), a bênção também deveria ter o mesmo alcance.

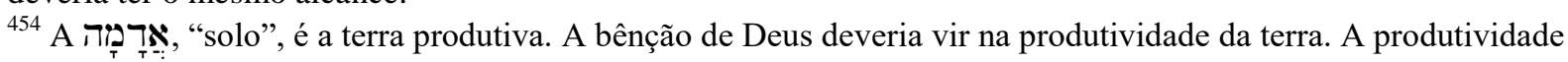
da terra seguraria o povo na sua herança, de modo que ela passaria para as gerações seguintes.

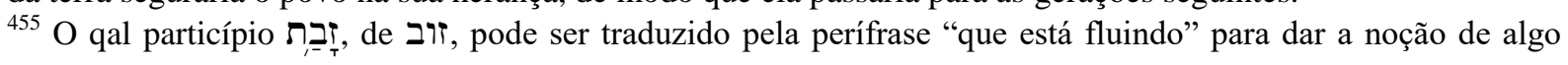
presente na vida daquele que faria o pedido a Deus, para que ele atentasse para a obediência do povo de Israel, e lhe retribuísse com bênção.

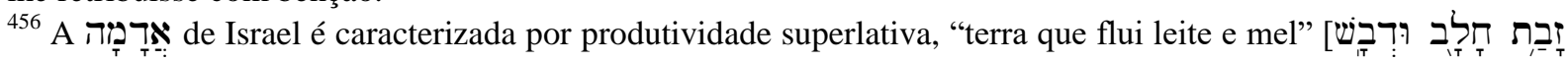
[ארץ]. A frase aparece em outros lugares no Deuteronômio $(6,3 ; 11,9 ; 26,9.15 ; 27.3)$. Em Deuteronômio 31,20

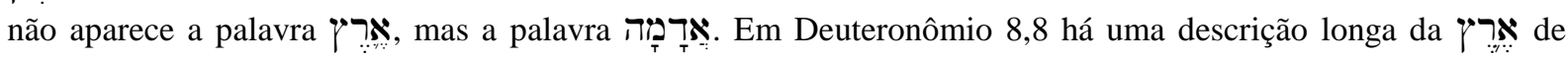
Israel. Entre suas características ela é apresentada como "terra... de mel", sem a presença do "leite".

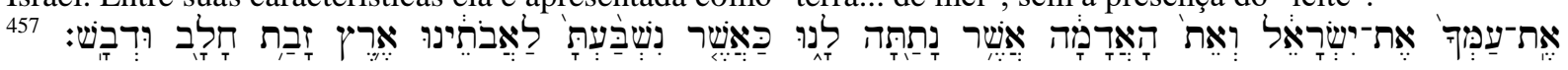

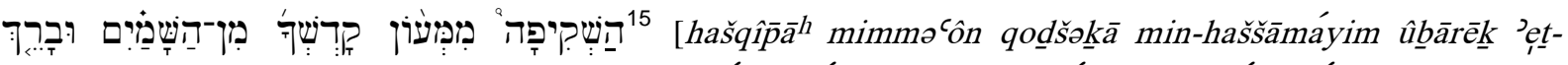

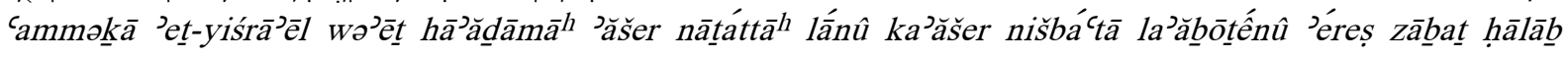
$\hat{u} \underline{d} \underline{b} \underline{b} \bar{s}]$. 
Segundo, o dízimo do terceiro ano é a última parte do bloco literário denominado de Código Deuteronômico, antes que seja feita a declaração final do redator, em 26,16-19. Isso é significante porque a última parte do Código tenderia a ser a parte melhor lembrada após sua leitura. O legislador, ao colocar no final essa legislação quis deixar marcada na mente do tu/vós que havia importância em se acudir tais Entes Silenciosos em suas necessidades. Mas, também, que os dízimos do terceiro ano não seriam para ele, sua família e convidados, como a oferta da Confissão de Deuteronômio 26,1-11. Aqui o redator diz com clareza que o dízimo do terceiro ano era para ser dado aos Entes Silenciosos considerados desenraizados, sem propriedade e sem lugar para ficar que fosse chamado de seu.

Terceiro, os últimos quatro versículos de Deuteronômio 26 encerram o Código Deuteronômico. Este começou com a ordem para que os "estatutos e preceitos" (12,1

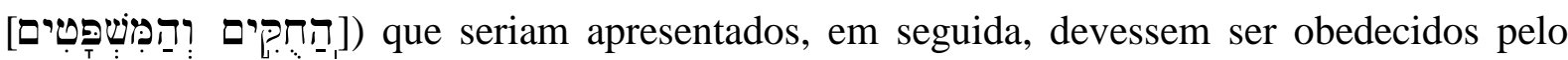
povo de Israel. Em 26,16, essas palavras surgem, formando um inclusio. Em 12,1 o redator

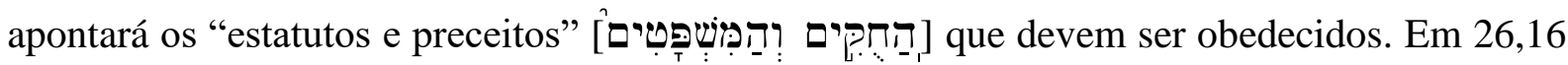
ele encerra com a ideia que "estatutos e preceitos" [את já foram apresentados entre 12,2 e 26,16.

Deuteronômio 26,16-19 contém as palavras de estabelecimento da aliança. É dito que o povo de Israel aceitou os "estatutos e preceitos" e que os obedecerá "com todo o teu coração e com toda a tua alma" $(26,16.17)$. Isso pressupõe que o povo já tenha feito essa declaração formal. Em resposta, Deus se compromente com Israel para torná-lo seu povo, com o compromisso de

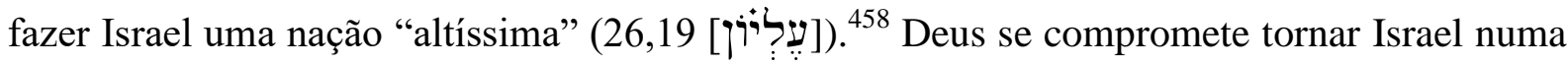
nação muito superior aos outros povos. As palavras seguintes destacam como isso será feito

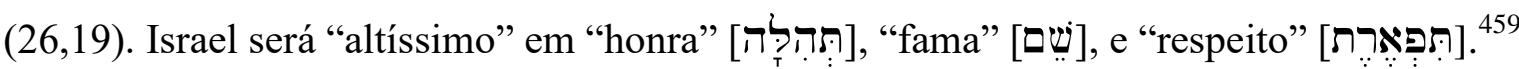

Assim, colocar o mandamento do dízimo do terceiro ano no fechamento do Código estabelecia a certeza que o povo estaria com ele na memória. A leitura e releitura desse

${ }^{458}$ Mesma palavra empregada para o título divino, "Deus Altíssimo", em Gênesis 14,18-20, onde Abraão é abençoado por Melquisedeque em nome do Deus Altíssimo. A vitória da qual retornava Abraão indicava, segundo Melquisedeque, que Deus era "superior" aos deuses dos povos derrotados. Esse conceito era recorrente entre os povos do mundo bíblico. Ao dizer que Israel viria a ser עֵלי por obedecer aos "estatutos e preceitos" de seu Deus, o redator está afirmando que Israel seria tão elevado, acima dos outros povos, quanto seu Deus seria acima dos deuses dos outros povos.

459 A BJ traduz עַלְליֹון por "superior". A ARA a traduziu por um verbo, "exaltar". O mesmo ocorre na BP,

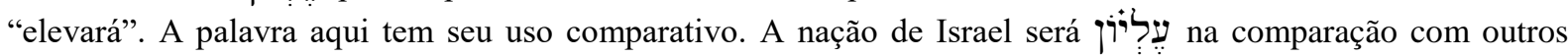

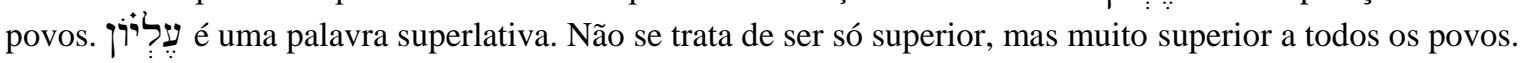


Código faria com que o povo pensasse nos resultados de sua obediência, e ficaria com disposição em obedecê-lo, ao notar que os resultados de sua obediência viriam, não somente sobre o israelita atento, mas sobre toda a nação.

Sua obediência ao Código tinha efeitos muito maiores que apenas a família individual do tu/vós abençoada, por um lado. Por outro lado, o povo de Israel, na condição de עִלְליְּן, seria o resultado da obediência de cada tu/vós espalhado pelas tribos de Israel. Atente-se para a solidariedade proposta pelo texto. A bênção divina derramada sobre o povo de Israel viria sobre cada família. Por outro lado, essa bênção dada sobre cada família resultaria no coletivo de um povo abençoado.

\subsubsection{Estrutura e análise de Deuteronômio 26,12-15}

\subsubsection{Estrutura da perícope de Deuteronômio 26,12-16}

A estutura de Deuteronômio 26,12-16, como a maior parte da legislação do Código, começa com a conjunção 'ִיִ em seu uso temporal, "quando". Ela intruduz uma estrutura simples, comum em perícopes que envolvem as falas propostas pelo redator: há a fala do redator e a fala do confessor declarando sua obediência a algum mandamento colocado na fala do redator. ${ }^{460}$ Não existe nessa unidade a fala do redator encerrando a perícope. A perícope começa com o retador e termina com o confessor.

\subsubsection{Análise: O que é o dízimo do terceiro ano?}

Como já notado, os quatro Entes Silenciosos beneficiários do dízimo do terceiro ano são caracterizados pela ausência de propriedade da terra. Entretanto, o que a legislação desse dízimo faz é levar esses Entes Silenciosos à participação dos benefícios da terra, a sua produção. A herança da terra lhes tem sido negada, não a participação na sua produção. A entrega desse dízimo deveria ser feita "no lugar dos encontros públicos e da prática do direito" (CRÜSEMANN, 2008, p. 305).

\subsection{A voz do redator}

O que o redator tem a declarar aqui? Primeiro, ele estabelece o tempo e qual dízimo deveria ser entregue para os Entes Silencisos. O dízimo deveria vir depois que toda a colheita estava

\footnotetext{
${ }^{460}$ Notar as confissões presentes em Deuteronômio 6,20-25 e 26,1-11 que começam com
} 
encerrada. Deuteronômio 14,28-29 diz que deveria ser no final do terceiro ano. O dízimo tinha que refletir a bênção divina sobre a propriedade do "tu". A contagem desse ano está relacionada ao bloco de sete. Então, no ano terceiro dos sete, o "tu" deveria separar o dízimo inteiro e consagrá-lo ao serviço social de sua comunidade.

Segundo, os destinatários desse dízimo são o grupo de pessoas, sem herança "e socialmente fracos", os quais teriam garantida uma base econômica legal e suportada pelo juramento público do produtor (CRÜSEMANN, 2008, p. 305). ${ }^{461}$ Esse "imposto social” viria suprir as necessidades daqueles que, de outro modo, não teriam como garantir sua sobrevivência. A conclusão do versículo 12 demonstra qual era a meta do dízimo - "e eles serão saciados". O dízimo vinha como um instrumento de libertação da fome daqueles que, provavelmente, eram habituados a passar por algum tipo de restrição alimentar.

Por último, o redator não deseja separar o dízimo do terceiro ano do compromisso do "tu" com Deus. Antes da entrega do dízimo, o "tu” deveria fazer uma confissão pública diante de Deus de sua completa lealdade ("E dirás diante de '̄ādōnāy teu Deus"). Essa lealdade seria atestada tanto pela quantidade precisa do dízimo quanto pela manutenção de sua sacralidade. Isso garantiria a resposta divina favorável para o próximo ano.

\subsection{A confissão de obediência do "tu"}

\subsection{O sagrado não pertence ao dono $(26,13)$}

Ao estabelecer que o dízimo é "santo", ${ }^{462}$ esse dízimo passa a não pertencer mais ao seu dono, e estará à disposição para uso daquele a quem ele foi consagrado. ${ }^{463}$ Nesse caso, ele deveria

\footnotetext{
${ }^{461}$ Leibowitz (1995, p. 276-277) levanta a questão do motivo do fazendeiro apresentar, de forma pública, o que ele fez e o que ele não fez. As respostas para isso são como segue. Primeiro, o homem tem um dom único que é sua capacidade de falar. O mandamento da confissão pública é uma forma de testemunha com os próprios lábios com o fim de que o confessor não esteja enganado com respeito às dádivas nem que elas foram ocultas (Abravanel apud LEIBOWITZ, 1995, p. 277). Segundo, seria possível que o doador tivesse hesitação em entregar o dízimo do terceiro ano para um רạ. A confissão serviria de grande incentivo para ele falar a verdade por ter dado o dízimo do terceiro ano em sua localidade, pois, ao confessar no Templo, ele teria sua generosidade publicada e sua justiça testemunhada. Ele seria honrado nos portões como se ele tivesse oferecido diante do Senhor (Abravanel apud LEIBOWITZ, 1995, p. 277-278). Portanto, a confissão funcionaria como um meio de combate à negligência do preceito e um incentivo à sua observância (LEIBOWITZ, 1995, p. 278). Por fim, como o texto declara "conforme ao mandamento que me ordenaste" e "eu não tenho transgredido nenhum dos teus mandamentos nem tenho me esquecido deles", a confissão pública seria a demonstração que o confessor estava em harmonia com o preceito divino. O alvo do preceito é que a motivação do confessor seja somente por cumprir a vontade de Deus com inteireza de coração e desempenho sincero (LEIBOWITZ, 1995, p. 278-279).

${ }^{462}$ Em Levítico 27,30 é declarado que todos os dízimos são de Deus e são santos a ele. "Talvez esse tratamento do dízimo do pobre indique que dá-lo ao pobre não é um propósito menos sagrado que trazê-lo a um santuário ou consumi-lo ali” (TIGAY, 1996, p. 243).
} 
ser entregue, em sua totalidade, para uso dos Entes Silenciosos. Esse status de santidade atribuído ao dízimo está por trás da confissão e do temor que o confessor apresenta ao declarar que ele não fez uso "ilegítimo" daquele dízimo.

O versículo 13 inteiro é uma declaração de lisura por parte do confessor. Primeiro, ele declara a Deus que nada do dízimo ficou em sua casa. Ele não tem retido nada, "seja intencionalmente nem acidentalmente" (TIGAY, 1996, p. 243). E que tudo já fora entregue ao levita, estrangeiro, órfão e viúva. Percebe-se que ele é bem específico quanto ao grupo que deve ser entregue o dízimo. Segundo, ao falar disso, ele tem em mente a demonstração de um servo completamente leal ao seu Deus. O mandamento do dízimo do terceiro ano foi obedecido em sua inteireza. Assim, o confessor estava declarando que a sua parte havia sido feita. Os versículos 13 e 14 são onde está a parte do confessor. Ele cumpriu sua parte. A expectativa é que Deus cumpra a dele.

\subsection{Os elementos de exclusão $(26,14)$}

\subsection{1. O luto}

Deuteronômio 26,14 contém a declaração do confessor dos três elementos de exclusão para os quais o confessor declara não ter desviado qualquer porção do dízimo do terceiro ano, ${ }^{464}$ por mais justificável que isso fosse. O primeiro é que ele não fez uso dele no luto. O luto no mundo bíblico durava dias. ${ }^{465}$ Assim, quando o confessor afirma que ele não comeu no seu luto, ele não está pensando em um dia, mas num período de luto. Durante os dias do luto, haveria a necessidade de alimentação tanto para si como para os que viessem passar aquele período com o enlutado, ${ }^{466}$ pois o trabalho no campo estaria suspenso. A obediência dele é

\footnotetext{
${ }^{463}$ A frase "e dirás diante de '̄âdōnāy teu Deus", normalmente, dentro de Deuteronômio, aponta para algo feito no Santuário Central. Mas aqui, o redator entende que o dízimo do terceiro ano deva ser deixado pelo confessor em sua própria cidade. Quando o redator deuteronomista entende que deva se referir especificamente ao Santuário Central, ele, usualmente, acrescenta "O lugar onde 'ād̄ōnāy teu Deus escolherá para pôr o seu nome", como em 16,1-11. "Deuteronômio é tão cuidadoso em acrescentar essa frase em passagens que se refiram à adoração que sua ausência aqui pode ser deliberada, implicando que a declaração não precisa ser feita no Templo, haja vista que o dízimo não seria depositado ali”, mas se dirige a Deus a partir de onde ele está (TIGAY, 1996, p. 243).

${ }^{464}$ Os pastores hititas faziam juramento semelhante na entrega de suas ofertas. "Os pastores responsáveis pela entrega de ofertas de gado para o templo deviam declarar, sob juramento, quando eles trouxessem o gado, que eles não tinham desviado do gado aquilo que era devido" (TIGAY, 1996, p. 243).

465 O luto por Jacó, no Egito, durou setenta dias (Gênesis 50,3); por Moisés, o luto foi de trinta dias (Deuteronômio 34,8).

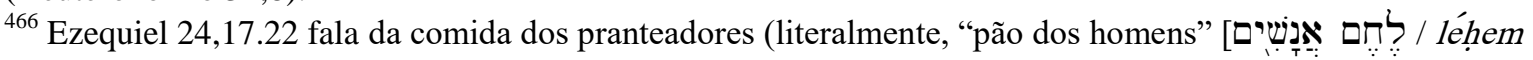
วănāšîm]).
} 
levada ao extremo - mesmo em tempo de dificuldades e, em certo sentido, em um emprego legítimo, ele se absteve de usar o dízimo do terceiro ano.

Para entendimento do que o confessor está falando, duas passagens podem ser esclarecedoras.

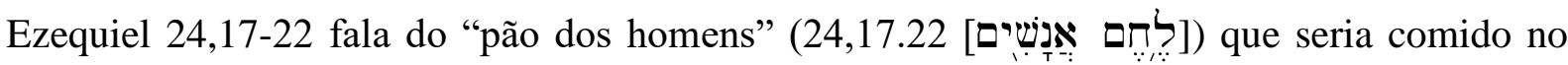
período de luto. No caso de Ezequiel, esse pão não seria comido, assim como os outros rituais do luto também não seriam cumpridos por ele pela perda de sua mulher: deixar de pôr o turbante, andar descalço, e cobrir os lábios. Ao que parece, esse pão era específico para o período de luto - era o pão de sofrimento. Oseías 9,4 fala do "pão de lamentações pelo morto" [ליְחם אוֹניםם] e, mais adiante, fala que aqueles que comessem desse pão eram imundos e que este pão não deveria ser apresentado a Deus.

Isso esclarece porque o confessor declara que não comeu do dízimo do terceiro ano no seu luto. Ao tirar desse dízimo para comer no luto, ele dessacralizaria todo o dízimo, o qual é chamado de "a coisa consagrada". O alimento feito em uma casa de luto era impuro, fazendo com que todos aqueles que participassem desse alimento também se tornassem impuros. Ao dessacralizar esse dízimo, ele não poderia mais ser entregue aos Entes Silenciosos, deixando de suprir a necessidade daqueles que mais necessitavam dele, incorrendo em grande desobediência.

A importância da confissão que ele não comeu dele no seu período de luto apontava para a sua consagração a Deus, mantendo a santidade daquilo que ele estava dedicando. O dízimo não somente estava completo (era exatamente o que o confessor devia dar) como ele estava santo (ver TIGAY, 1996, p. 243-244).

\subsection{2. A impureza}

O segundo é que ele não comeu dele estando impuro, e essa impureza está intimamente relacionada com a anterior. Deve-se considerar que o contexto no qual a palavra טָָָָ está inserida é a de impureza causada pela presença de um morto. As declarações de luto e de um morto sugerem que a impureza a que o confessor se refere tem a ver com a contaminação por morte. Como o confessor está declarando que ele não comeu do dízimo tanto no seu luto quanto que ele não deu dele para alguém que estivesse morrendo, então, pode-se afirmar que essa impureza tem a ver com a contaminação por um morto, provavelmente de um membro de sua família. 
Como apontado acima, ao dizer que ele não comeu do dízimo na sua impureza por um morto, ele estava mantendo a integridade da oferta como sendo a "coisa consagrada". Deve-se notar com isso que o período de luto era um tempo de necessidade para o "tu" da confissão. Mesmo em meio às dificuldades que o luto traria sobre aquela família, a santidade do dízimo do terceiro ano foi mantida.

\subsection{3. O morto}

E o terceiro elemento da exclusão é que ele não entregou o dízimo ao que morre. A prática de colocar comida junto com o corpo do morto no túmulo foi prática egípcia e cananeia (KALLAND, 1992, p. 156). Mas essa prática não tem sido encontrada dentro da história do Israel bíblico. O qal particípio, מִּ, pode ser traduzido por ação contínua - "aquele que está morrendo", ou "aquele que morre". Desta perspectiva, o confessor não fez um ato de misericórdia com o dízimo destinado aos Entes Silenciosos. Uma provável situação é aquela da pessoa que está prestes a morrer deseja comer algo. Se algo do desejo do moribundo se encontrasse no dízimo consagrado, ele não o tiraria de lá. O dízimo já estava santificado para propósito exclusivo.

Por outro lado, é possível encontrar outro motivo para a declaração do confessor aqui. Ele está declarando sua completa lealdade ao seu Deus, e que ele não tem dado daquilo que tem sido consagrado a Deus a nenhuma outra divindade. Merrill entende que o que está por trás da declaração do confessor deuteronomista é o "ritual cananita em que deidades, tal como Baal, que tinham sido expedidas para o mundo dos mortos, foram sustentadas por ofertas de comida até que elas pudessem reviver e retornar à sua função procriativa sobre a terra" (1994, p. 336). O confessor estava fazendo com isso sua declaração de fé. ${ }^{467}$ Ele entendia que a bênção da fertilidade da terra, da qual ele tirara o dízimo do terceiro ano, não dependida de Baal e seu panteão, mas do Deus de Israel. ${ }^{468}$

\footnotetext{
${ }^{467}$ Seguindo nessa perspedtiva religiosa, Tigay cita uma crença existente no mundo antigo, em que os antigos criam que os vivos podiam ver os espíritos dos mortos no sheol, provendo-lhes comida e bebida. Ele cita um texto mesopotâmico em que a citação do nome de uma pessoa era representativa de sua invocação com o oferecimento de comida e bebida a seu espírito. Essa talvez fosse uma das razões que morrer sem filhos era considerado uma maldição terrível (1996, p. 244, 482).

${ }^{468}$ Em Deuteronômio 14,1 é declarado que, nos rituais de luto, Israel deveria agir diferentemente dos povos ao seu redor. A razão teológica para essa diferença está em que "vós sois filhos do Senhor vosso Deus" e, por isso, Israel não deveria dilacerar-se nem abrir calva entre olhos por nenhum morto. Em 14,2 outras duas razões, derivadas da primeira, são acrescentadas. Israel é "povo santo ao Senhor teu Deus" e que "o Senhor te escolheu para lhe seres o seu próprio povo" (ARA). Portanto, Israel tem um pai e uma filiação diferentes da dos povos ao redor. Por isso ele deve agir de forma diferente da dos outros povos. "Nos textos mitológicos relacionados a Baal, há a descrição de luto de El” pela morte de Baal, onde El é descrito cortando-se (CRAIGIE, 1976, p.229).
} 
3.5.3.2.2.3. A contrapartida divina: a conclusão sem $(26,15)$

Diante de demonstração de lealdade extrema, colocadas na forma de três afirmações negativas, o confessor pede a contrapartida divina por meio de duas afirmações positivas. Deus deve cumprir sua parte abençoando o confessor e seu povo. Agora, o dízimo do terceiro ano, como o dízimo de todos os anos, já era a demonstração que Deus estava abençoando seu povo (CRAIGIE, 1976, p. 323). Assim, o pedido de bênção do confessor pressupõe seu interesse pelo próximo. Ao pedir a bênção divina, o confessor entende que sem ela, ele não poderá dar seus dízimos para os Entes Silenciosos no próximo terceiro ano.

Era de se esperar que, concluindo sua expressão de lealdade a Deus em benefício dos Entes

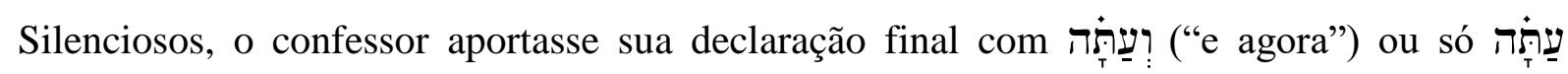
("agora"), como se o orador dissesse: "depois do que tem acontecido ou sido dito". ${ }^{469}$ A ausência dela parece demonstrar a urgência do confessor em querer abordar seu Deus pela bênção prometida. Deus não tem permissão para protelar sua parte do compromisso assumido pelos lados do acordo. O confessor tem sido um súdito leal. Por isso ele deve ser recompensado.

Dois pedidos do confessor ao Deus de Israel: "Olha do lugar da tua santidade, do céu, e abençoa o teu povo, Israel, e o solo que deste para nós, conforme juraste para nossos pais terra que flui leite e mel." O Deus transcendente não habita entre os homens, mas no céu. Mesmo assim, ele pode ouvir a oração de seu povo. Caso contrário, o confessor não suplicaria a bênção divina.

Como já apontado, o olhar divino deve ser propositivo - ele deve olhar para abençoar. Ou, de outro modo de declarar, ele deve olhar para continuar abençoando. Como citado acima, o confessor já comprovou que o solo em que ele habita "flui leite e mel", ${ }^{470}$ e isso é comprovação que o Deus de Israel tem cumprido o seu juramento feito aos ancestrais do confessor. Mas ao dizer que Deus deve abençoar Israel e o solo dado a ele, o confessor vai

\footnotetext{
$\mathrm{Na}$ "lenda de Aqht", "há uma referência a mulheres profissionais do luto que se laceram para deixar o sangue correr" e, além disso, "num texto Acadiano recuperado de Ras Shamra ('o Justo sofredor'), um homem doente, mas ainda não morto, é tratado como se já estivesse no túmulo - 'meus irmãos banham-se no sangue como uns possuídos"” (CRAIGIE, 1976, p.229-230).

${ }^{469}$ Essa forma de conclusão pode ser encontrada em Deuteronômio 2.13; 4,1; 10,12.22; 26,10; 32,39; $39,19$.

${ }^{470}$ Frase que aparece em Deuteronômio 11,$9 ; 26,9.15 ; 27,3 ; 31,20$; ela descreve "a riqueza da terra que os israelitas iriam logo possuir" (CRAIGIE, 1976, p. 168).
} 
além do cumprimento das promessas feitas aos pais. Ele quer que Deus continue a cumprir as promessas feitas a ele também, por meio de seus ancestrais, pois, afinal, ele diz "fiz conforme tudo que me ordenaste” $(26,14)$. “Aqui na Confissão do Dízimo, o indivíduo lista o que ele fez e o que ele não fez a fim de demonstrar a aceitação do jugo de Deus sobre ele mesmo, e que ele tem feito somente o que "tu tens me mandado" (LEIBOWITZ, 1995, p. 279).

A questão do dízimo do terceiro ano está entendida - ele deveria ser entregue aos Entes Silencisos do bloco dos sem herança. Mas, e o dízimo dos outros anos? O que era feito? Como ele era empregado pelo confessor?

3.5.4. O Dízimo do terceiro ano - uma antecipação a Deuteronômio 26,12-15: $14,28.29$

\subsubsection{Tradução}

"Do fim de três anos, ${ }^{471}$ tu farás $\operatorname{vir}^{472}$ o dízimo ${ }^{473}$ todo do teu trabalho naquele ano, e porás ${ }^{474}$ nos teus portões." ${ }^{475}$

"E virá o levita - porque não há, para ele, propriedade e herança contigo - e o estrangeiro e o órfão e a viúva que (estão) nos teus portões. E comerão, e serão saciados, a fim de que teu 'āâōnāy Deus te abençoe em todo feito de tua mão que tu farás." 476

\footnotetext{
${ }^{471}$ Para von Rad, "a última norma se destina a impedir o empobrecimento da região dos sacerdotes que perderam seus meios de subsistência através da centralização" (VON RAD, 1966, p. 103). Isso quer dizer que, com a escolha do Lugar Central de adoração, o pagamento dos dízimos seria encaminhado para lá, deixando os levitas e sacerdotes sem as contribuições locais. O dízimo do terceiro ano viria ser uma espécie de compensação com essa perda.

${ }^{472}$ Hifil de $\mathbf{N}$ ', "vir", traduzido aqui no sentido causativo por "fazer vir" de onde vem a ideia de "trazer".

${ }^{473}$ O dízimo é especificado como sendo do produto do campo (Deuteronômio 14,22.23), mas nada é dito no livro sobre o dízimo dos animais (cf. DRIVER, 1895, p. 166; CRAIGIE, 1976, p. 233). Mas em Levítico 27,32 os animais, "gado e rebanho", entram no dízimo.

${ }^{474}$ Usado no hifil com o sentido de "dar repouso", "por" (HHL-BW7]). O dízimo resultante do balanço anual da colheita do terceiro ano deveria ser colocado em lugar acessível aos Entes Silenciosos. É possível que ele fosse recolhido pelos fazendeiros em um depósito central para ser entregue a eles depois que o balanço da colheita estivesse completado.

475 miqoșên šāloss

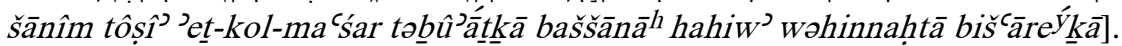

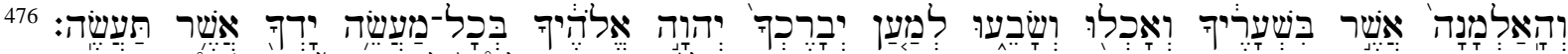

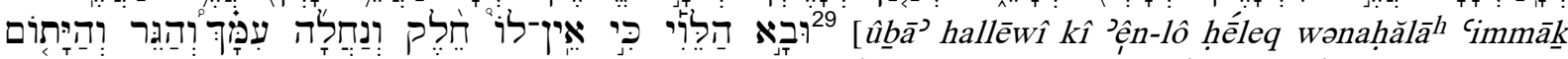

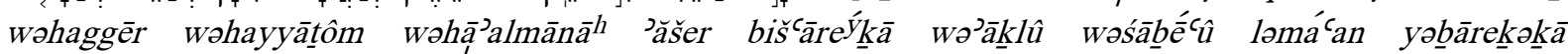

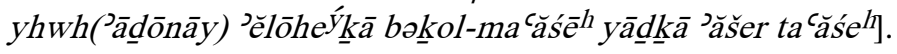




\subsubsection{O contexto}

No contexto do livro de Deuteronômio, o "dízimo" aparece pela primeira vez no primeiro capítulo do Código Deuteronômico (12,6.11). Neste capítulo, o dízimo é vinculado ao lugar de entrega, o Lugar Central sagrado que seria apontado, segundo o redator, em algum tempo no futuro. Assim como as outras ofertas apontadas nesse capítulo, o dízimo deve ser comido pelo ofertante e sua família e aqueles que a ela pertecem (o servo e a serva). E o levita deve participar desse momento familiar festivo. Em 26,12, como tratado acima, está a segunda ocorrência do dízimo do terceiro ano e sua entrega aos Entes Silenciosos.

No contexto imediato, há uma unidade (14,22-29) que trata de especificar o dízimo. Primeiro, ele deve ser entregue no Lugar Central $(14,22.23) .{ }^{477}$ A refeição deve ser com o grande Rei de Israel e seus súditos no lugar de sua residência (MERRILL, 1994, p. 240). A esse lugar, todos os dízimos devem ser levados com o fim de que o povo aprendesse a temer a seu Deus. Podese dizer que o "temer" em vista faz referência ao "reverenciar", sendo essa entrega uma forma de tributo ao Deus de Israel.

Em segundo lugar, o dízimo aqui apresenta um desenvolvimento. Caso o Lugar Central venha a ser longe demais para a entrega do dízimo, ele deve ser vendido, e o dinheiro arrecadado deve ser levado e usado para comprar aquilo que alegra o coração do ofertante, de tal forma que ele tenha uma refeição festiva diante do seu Deus (14,24-26). Dinheiro em vista fala da "prata", um metal com facilidade de câmbio (MERRILL, 1994, p. 240). Seja pelo produto em espécie, seja pela prata que será trocada por produtos equivalentes aos que foram tracados por prata antes da vigem ao Santuário Central, a comida deveria ser usufruída diante de Deus, numa demonstração que Deus é muito mais que um observador - ele é participante ativo do banquete (MERRILL, 1994, p. 241). Assim, a alegria do ofertante era, não somente na presença de Deus, como era com seu Deus. ${ }^{478}$

Em terceiro lugar, o dízimo deve ser repartido com o levita (14,27). Aqui se deve colocar um destaque. O dízimo do terceiro ano é para ser doado aos Entes Silenciosos em bloco (levita,

\footnotetext{
${ }^{477}$ Chouraqui afirma que "o dízimo é um imposto pago pelo camponês sobre o produto de sua terra, e pelo pastor sobre seu rebanho. Ele era destinado ao senhor, ao Adôn, isto é, no contexto do versículo, ao próprio Deus, e noutras circunstâncias, ao rei (1 Samuel8,15-17)" (1997, p. 172). Nelson, por sua vez, informa que é somente em Deuteronômio que os dízimos religiosos são claramente obrigatórios (2002, p. 184).

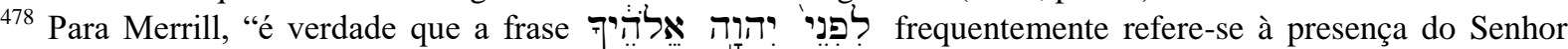
como testemunha do pacto, mas o contexto de banquete sugere, fortemente, sua participação como tal" (1994, p. 241, nota 49). Como o ofertante, sua família e seus convidados, Deus é um membro do grupo que participa do banquete festivo.
} 
estrangeiro, órfão, viúva) no lugar de vivência do fazendeiro. Entretanto, quando esse ofertante vai para o Santuário Central, o dízimo deve ser comido por ele, sua família, seus servos e o levita $(12,12.18 ; 14,27)$.

Já em Deuteronômio 26,11, as primícias devem ser repartidas com o levita e o estrangeiro. Pode-se afirmar que o dízimo em Deuteronômio, seja o dízimo para ser levado ao Santuário Central, seja o dízimo do terceiro ano, eles devem ser usufruidos pelo ofertante, sua família, seus servos, bem como pelos Entes Silenciosos em bloco.

Em quarto lugar, o dízimo e sua entrega no Santuário Central está vinculado a um momento de alegria do ofertante e daqueles que participam com ele desse momento festivo. Deuteronômio vê a festividade como o resultado natural da bênção divina sobre os bens do israelita. Por isso que ele deve vir ao Santuário Central para prestar sua celebração com seu Deus, e, com o seu Deus, "comer" o dízimo. Talvez, por isso, o levita é incluído nessa refeição festiva, como representante divino no banquete do israelita. A festividade dele e de sua família estava em ver a alegria dos carentes ao terem supridas suas necessidades de alimentação.

\subsubsection{Análise de Deuteronômio 14,28.29}

\subsection{Como identificar o dízimo para a doação aos Entes Silenciosos}

Primeiro, ele deveria ser apresentado no fim do terceiro ano. Era o período do balanço anual do fazendeiro. ${ }^{479}$ Só assim, o fazendeiro poderia, com precisão, ver se ele obteve ganho ou perda. Segundo, ele deveria ser colocado em um lugar estratégico, acessível aos Entes Silenciosos. No caso em pauta, "nos portões". Se o texto aponta diretamente para o portão de acesso à propriedade do fazendeiro, ou ao portão, ou portões, de uma cidade, de qualquer forma, ele deveria ser colocado em lugar visível e de fácil acesso a todos os que poderiam usufruir daquela dádiva. Então, Deus "abre mão" de sua oferta em favor dos Entes Silenciosos da comunidade.

Observe-se que o ofertante estava impedido, por ordem divina, de comer o dízimo dos outros anos dentro de sua propriedade (Deuteronômio 12,17). Ele deveria ser levado para o Santuário

\footnotetext{
${ }^{479}$ A exatidão de como o dízimo deveria ser medido para que não houvesse sonegação por parte do fazendeiro não é especificado. Entretanto, as afirmativas "de todo fruto da tua semente" $(14,22)$ e "todos os dízimos da tua colheita" $(14,28)$ "sugerem que deve ter havido algum grau de julgamento pessoal na determinação da quantidade" (NELSON, 2002, p. 184).
} 
Central e ali ele poderia comer. A proibição continuava também para o dízimo do terceiro ano para ofertante, mas ela não atingia os Entes Silenciosos, seus destinatários. Somente esses poderiam comer em sua cidade daquele dízimo. A razão para isso estava na própria condição econômica das pessoas desse grupo. Isso quer dizer que o levita que participava da comida festiva no Santuário Central era alguém que estava ali a serviço do Santuário, mesmo que ele vivesse dentro da comunidade do ofertante $(12,18)$.

\subsection{Os destinatários do dízimo postado "nos portões"}

O primeiro é o levita. É o único que se apresenta com uma oração apositiva com o fim de qualificá-lo ("porque não há para ele propriedade e herança contigo"). Essa oração aparece em outros lugares do Deuteronômio com o mesmo propósito - apresentar o levita como alguém desprovido de herança (Deuteronômio 12,12; 14,27.29). Todas essas ocorrências estão relacionadas ao dízimo do terceiro ano ou não. O levita é o único deste grupo de Entes Silenciosos que é beneficiado pelos dízimos do terceiro ano e os dos outros anos, e a motivação para isso é que ele não tem nenhuma propriedade como herança. Diante disso, ele deve ser apoiado pelo povo de Israel, e a apresentação do dízimo no Santuário Central ou "nos teus portões" é o momento.

Juntamente com o levita estão os demais Entes Silenciosos - gēer, yātôtom, ’almānăh ${ }^{\text {. Todos }}$ eles são os que estão "nos teus portões". Eles são da convivência do israelita que fará a entrega do dízimo do terceiro ano. Estar nos portões também indica que eles estão ali na expectativa da entrega desse dízimo especial.

O dízimo do terceiro ano tem um duplo objetivo. Em relação aos Entes Silenciosos, ele deve servir para que eles o comam até o ponto da saciedade. Pode-se propor uma tradução alternativa aqui: "e eles comerão com o fim de satisfazerem-se". Portanto, não era somente comer, era comer com o fim de ter satisfação com aquela comida. A ideia básica do verbo שֶׁבָע é “estar satisfeito por ter-se alimentado" (WALTKE, 1980, p. 869-870). Então ele pressupõe abundância na comida disponível para isso. O dízimo do terceiro ano era colocado no fim do ano à disposição dos Entes Silenciosos. ${ }^{480}$ Isso pressupõe abundância de comida dada a eles. ${ }^{481}$

\footnotetext{
${ }^{480}$ Tanto no dízimo que ia ser levado para o Santuário Central como no dízimo do terceiro ano há temas teológicos importantes relacionados: "o santuário central, a celebração alegre, a dessacralização das ofertas, a solidariedade social, e a bênção de Yahweh através da fertilidade da terra" (NELSON, 2002, p. 185). Tendo por base uma teologia da liberdade, com base no Êxodo, e uma ideologia igualitária, o Deuteronômio transformou os
} 
O outro objetivo é abençoar o israelita fiel. lomácan segue wəวāklû wəśābe échu. A benção divina virá pela plenitude de satisfação dos Entes Silenciosos com a comida recebida ali. Ela também virá pela obediência do israelita em guardar o dízimo do terceiro ano até o fim daquele ano para que ele fosse doado aos Entes Silenciosos. O texto pressupõe dupla satisfação: os Entes Silencios com a abundância de comida e o fazendeiro com a prosperidade de sua fazenda com a bênção divina - todos ganham.

3.5.4.4. O dízimo em Deuteronômio tem meta básica socorrer os Entes Silenciosos?

Primeiro, os dízimos tinham como meta primária testar a obediência do israelita. O dízimo é algo que se retira de um montante. Essa tarefa cabia ao israelita a quem pertencia o solo. Ela não era terceirizada. Segundo, os dízimos visavam, no momento da entrega, ser um momento de alegria. Era um momento de reunião do clã, incluindo servos e servos, com seu Deus, num banquete festivo. Por isso que o dízimo deveria ser levado ao Santuário Central para um momento de celebração. Por último, o dízimo do terceiro ano não perdia a característica da alegria festiva. Ele continuava sendo um momento de alegria festiva dos Entes Silenciosos com o seu Deus em um banquete, e também do fazendeiro que, no exercício da fé, dependia de Deus para que sua bênção fosse dada sobre seus bens no ano que se seguia, em resposta a sua fidelidade em dar o dízimo aos Entes Silenciosos.

Entretanto, os Entes Silenciosos também tinham outros momentos festivos de participação coletiva em Israel. Deuteronômio 16 coloca Entes Silenciosos desse bloco nos momentos festivos da nação. Eles deviam participar da Festa das Semanas (Deuteronômio 16,10.11) e da Festa dos Tabernáculos (16,13.14). A tônica dessas festas era alegria. Isso indica festividade com comida e bedida fartas. Para o Deus de Israel, eles também eram israelitas, incluindo o estrangeiro residente, e deveriam celebrar o seu Deus com a comunidade no Santuário Central.

Como síntese, deve-se mencionar que os Entes Silenciosos tratados nesse capítulo estão juntos porque, de algum modo, podem ser identificados como "estrangeiros" dentro de Israel por alguns motivos. Primeiro, por eles não terem qualquer dipo de propriedade dentro de

"dízimos que foram taxas reais ou requerimentos sacerdotais em fontes de alegria e solidariedade comunitárias" (NELSON, 2002, p. 185).

${ }^{481}$ O verbo שָׁעָ, no hifil, é usado "para mostrar que o Senhor saciou o seu povo com pão... ele satisfez os pobres com pão (Salmo 132.15)” (WALTKE, 1980, p. 869). 
Israel. Segundo, por não terem propriedade, eles não têm residência fixa. Eles vivem em Israel como heremitas em busca de algum tu/vós que lhes conceda proteção. Nesse ponto, eles são muito diferentes dos Entes Silenciosos que são denominados de "pobre". Em deuteronômio, o "pobre" tem alguma propriedade onde ele pode ser encontrado. Os Entes Silenciosos desse capítulo não. A vida era, talvez, a única coisa que possuíssem. A preservação deles era fundamental. Em terceiro lugar, por viverem como peregrinos, eles estavam mais susceptíveis à opressão e perseguição.

Por esses motivos, pode-se dizer que esse grupo de Entes Silencioso poderia ser considerado os "verdadeiros" pobres, devido a sua própria condição. Os pobres do grupo ‘ānî wə’ebyyôn tem algum tipo de propriedade, pois o credor pode chegar até à porta de sua casa (Deuteronômio 24, 10) para fazer uma cobrança - por outro lado, a casa pode pertecencer ao dono do terreno que the permitiu morar ali. Os Entes Silencisos aqui não. Eles vivem "nos portões" de outros.

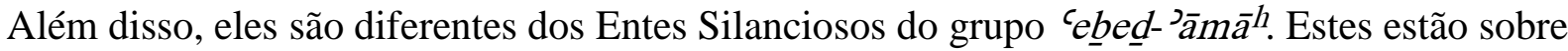
a proteção de seus "donos". E se são israelitas, no sétimo ano sairão livres e com algum bem na mão para seu recomeço na vida. Porém, os Entes Silenciosos desse capítulo estão "dentro dos teus portões" e deveriam gozar de proteção do dono daqueles portões. A legislação deuteronômica vem fazer essa proteção efetiva por meio da "voz de Deus".

Algumas considerações seguirão na forma de pergunta e resposta para que esse capítulo seja fechado. A pergunta é: porque o estrangeiro, o órfão, a viúva e às vezes o levita aparecem juntos? A resposta consiste, em primeiro lugar que esses Entes Silenciosos são considerados como uma espécie de "estrangeiros". E nessa condição eles não têm terra ou qualquer tipo de propriedade. Portanto, são sem propriedade fixa, sendo sem raiz dentro da comunidade em que vivem.

Em segundo lugar, eles não têm herança. Eles são os deserdados da comunidade em que vivem. A sobrevivência deles é resultado de um favor que a comunidade em que vivem lhes concede. Por isso que o incentivo é dado pelo redator em dizer que o Deus de Israel abençoará aquele que agir generosamente para com eles.

Em terceiro lugar, há um verbo que aparece em Deuteronômio e está relacionado à alegria das festas que deveriam envolver os Entes Silenciosos relacionados ao grupo da 'almānāh , do gēr, 
do yātôm, e do lēwî. Este verbo é o שמפח, o qual ocorre dentro do livro, especificamente dentro da seção de 12 a 26, ${ }^{482}$ para expressar "a alegria humana" (KRAMER, 2006, p. 52), mas é uma alegria humana dividida com outros (WALTKE, 1980, p. 879), na festa da colheita que era demonstração de alegria diante do Deus de Israel, para a qual os Entes Silenciosos seriam convidados para dividir com o clã aquela alegria pela colheita feita. Isso seria demonstração da generosidade do dono do campo bem sucedido no plantio. As ocorrências desse verbo estão em Deuteronômio 12,7; 14,26; 16,11; 26,11; $27,7$.

Deve-se dizer que o sentido básico do verbo שמחח é "alegrar-se", mas com o sentido de um grande regozijo por algum feito recebido ou realizado. É assim que ele é traduzido em todas as vezes que ele aparece dentro de Deuteronômio. ${ }^{483}$ A Septuaginta o traduziu pela palavra

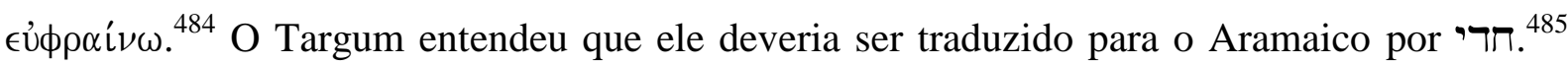

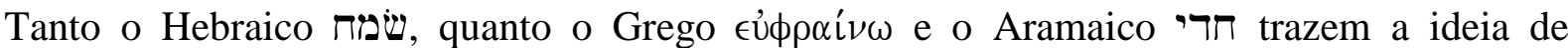
regozijo ou de uma alegria repartida, o que pode ser atestado pelo próprio contexto. Para isso vejamos (BJ): a alegria deveria ser entre "vós e vossa família" (12,7), "tu e tua família" $(14,26)$, "tu, teu filho e tua filha, teu servo e tua serva, o levita... e o estrangeiro, o órfão e a viúva" (16,11), "ti e a tua casa... o levita e o estrangeiro" $(26,11)$.

Mas de quem é a alegria - é a alegria do clã? Ou é a alegria dos Entes Silenciosos convidados para participar daquele momento? Seguindo para os contextos onde o verbo שמפח aparece, percebe-se que ele está relacionado à festa pós-colheita. A festa podia ser em algum santuário bem como dentro da própria comunidade. O convite para isso era feito pelo líder do clã aos Entes Silenciosos que estavam vivendo dentro daquela comunidade ou tinham acesso ao campo daquele clã. ${ }^{486}$ De modo específico, a alegria era do dono do campo, o líder daquele clã. Porém, por ordem divina, aquele homem é levado a compartilhar dessa alegria com aqueles que não poderiam, por seu próprio trabalho ter o mesmo sucesso. Assim, os Entes

\footnotetext{
${ }^{482}$ A exceção é Deuteronômio 27,7. Porém, aqui a ideia de sacrifício em um momento festivo para toda a família do ofertante permanece a mesma.

483 "Alegrando-vos" $(12,7)$; “e te alegrarás" (14,26); "e te alegrarás" (16,11); "alegrar-te-ás" (26,11); "alegrandote" $(27,7)$.

${ }^{484}$ Em seu sentido ativo, "alegrar/animar alguém", no passivo, "alegrar-se", "regozijar-se", "ser feliz" (RUSCONI, 2003, p. 207). "O objeto do gozo pode ser coisas ou eventos que afetam o bem-estar físico exterior, e especialmente situações que originam um modo de alegria comum” (BULTMANN, 1964, p. 772).

485 "Florescer alegria", "regozijar-se", "fazer feliz" (HHL-BW7).

${ }^{486}$ Em uma tentativa de fazer uma contextualização com o que acontecia dentro do Deuteronômio, pode-se afirmar que era uma espécie de "distribuição de renda" adaptada para aquela situação. Não se tratava de dinheiro, mas de comida - elemento essencial para a sobrevivência de qualquer um dos Entes Silenciosos, e, especial, dos membros do grupo: 'almānnă $\bar{a}^{h}$ gē $r$, yătôtm, e lēwî.
} 
Silenciosos seriam convidados daquele homem, bem-sucedido em seus negócios do campo, para participarem daquele momento festivo e comerem com ele e sua família, e até com seus escravos e escravas.

Neste aspecto, estes Entes Silenciosos - 'دalmānăh $\bar{a}^{2}$ gēr, yātôm, e $l \bar{e} w \hat{\imath}-$ eram reunidos em torno da alegria da colheita, seja na comunidade seja no santuário, para um tempo festivo, com o fim de prestar uma refeição cultual diante do Deus de Israel, como expressão de todo bem que ele tinha feito em favor de seu povo.

Uma nota deve ser colocada aqui. No Salmo 109 o cānî wə’ebyyôn (v. 22) e o yātôm e a دalmāna $\bar{a}^{h}$ (v. 9) estão colocados em polos opostos daqueles que vêm sendo tratados nesse capítulo. O Salmo 109 é um salmo imprecatório, onde o salmista suplica ao Deus de Israel a fim de que uma vingança recaia sobre a cabeça de seus inimigos. É um tipo de salmo onde é feita "uma petição de que a justiça seja feita, e o direito vindicado" (KIDNER, 1981, p. 38). Assim, entre as súplicas de vingança do salmista está "que seus filhos fiquem órfãos [yotômîm] e sua mulher se torne viúva [ 'almānā̄l]" (109,9 - BJ).

Desse modo, é pedida a condição de yātôm e 'almānāh para os filhos e a mulher de quem está maltratando injustamente o salmista. Enquanto em outros lugares da $\mathrm{BH}$ a súplica é feita para que Deus proteja o órfão e a viúva, no salmo em pauta, o salmista pede o contrário. Ele quer "que ninguém lhe mostre clemência, que ninguém tenha piedade de seus órfãos" (109,12 BJ). E entre as razões apontadas pelo salmista para tão grave pedido está o tratamento dispensado ao ‘̄anî wə’ebyôn: "Ele não se lembrou de agir com clemência: perseguiu o pobre e indigente... [ ‘ ‘̄nî wə’ebyôn]]" (109,16 - BJ), com quem o salmista se identifica no versículo

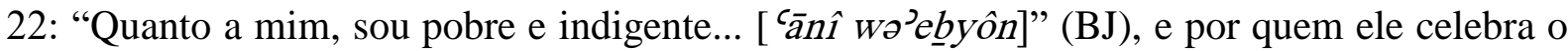
Deus de Israel como aquele que "se põe à direita do indigente... ['ebyyôn]" (109,31 - BJ), para apoiá-lo nas suas dificuldades.

Por esse exemplo, pode-se dizer que a proteção divina e da comunidade, tão requerida e ordenada dentro da comunidade do Deuteronômio, é aqui suspensa por causa das ações de deslealdade e, no final, de completa falta de fidelidade ao Deus de Israel. Assim, o surgimento do yātôm e da 'almāna $\bar{a}^{h}$ na família dos inimigos do salmista seria decorrente de seu tratamento dado ao 'ānî e 'ebyôn. O que, de certa forma, já estava previsto dentro do livro de 
Deuteronômio: "Não oprimirás um assalariado pobre, necessitado... um estrangeiro... porque ele é pobre. Deste modo ele não clamará ao Deus de Israel contra ti, e em ti não haverá pecado" (Deuteronômio 24,14-15 - BJ). 


\section{OS ENTES SILENCIOSOS COMO PROPRIEDADE}

\begin{tabular}{|c|c|c|c|c|}
\hline Vocábulos & Deuteronômio 1-11 & \multicolumn{2}{|c|}{ Deuteronômio 12-26 } & Deuteronômio 27-34 \\
\hline 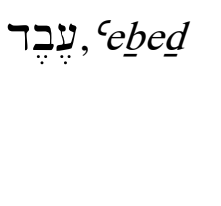 & $5,14.15 .21 ; 6,21$ & $\begin{array}{l}12,12.18 \\
16,11.14 \\
24,22\end{array}$ & $\begin{array}{l}\text { 15,15.17; } \\
23,15.16\end{array}$ & \\
\hline 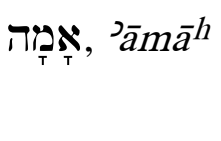 & $5,14.15 .21$ & $\begin{array}{l}12,12.18 \\
16,11.14\end{array}$ & 15,17 & \\
\hline
\end{tabular}

4.1. Algumas notas iniciais

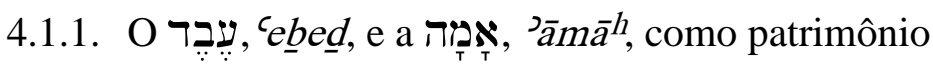

Aqui se deve fazer uma distinção entre dois tipos de escravos/escravas existentes dentro do Israel, segundo o livro de Deuteronômio. O primeiro é aquele que é escravo que vem de outros povos seja por meio de conquistas na guerra seja por meio de compras de escravos de outros povos como meio de investimento. É este tipo de servo/serva que está sendo tratado em Deuteronômio 5,51, onde há a proibição que não se cobice qualquer coisa que seja do patrimônio do "teu próximo". Entre os bens do "teu próximo" está o servo e a serva. ${ }^{487}$

Eles pertencem aos bens de herança, aqueles bens que serão passados aos herdeiros por ocasião da morte do pai. O escravo era uma forma de patrimônio do clã. A principal limitação do escravo era sua falta de liberdade. Mas como ele estava dentro do clã, ele gozava de proteção do mesmo, pois ele como, uma espécie de patrimônio, era um tipo de investimento.

Entretanto, em Deuteronômio há o segundo tipo de ${ }^{\complement} e \underline{b} e \underline{d}$ e de ${ }^{\supset} \bar{a} m \bar{a}^{h}$ que são aqueles que se tornaram escravos, mesmo sendo membros do povo de Israel. Eles entraram nessa condição voluntariamente, mesmo que forçados por suas condições de sobrevivência. Entre esses há o ${ }^{\complement} \underline{b} \underline{b} \underline{d}$ e a ${ }^{~} \bar{a} m \bar{a}^{h}$ que decidiram ficar para sempre com seus senhores. Esses passariam a fazer parte do patrimônio do clã legal e definitivamente.

\footnotetext{
${ }^{487}$ Há duas mulheres que são do "teu próximo" e que não podem ser cobiçadas, em Deuteronômio 5,21 - "a mulher do teu próximo" e a "serva" do teu próximo.
} 
Em Gênesis 30,43, "servos" e "servas" estão colocados nos mesmo nível que os animais, no sentido que eles são uma aquisição e pertecem ao patrimônio de quem os adquiriu. Isso é repetido em outros lugares dentro do livro de Gênesis. Portanto, o 'e ébed e a ' $\bar{a} m \bar{a}^{h}$ são considerados patrimônio daquele que os comprou e, a partir disso, eles passam a ser computados como bens do clã.

\subsubsection{As aparições do ${ }^{\complement} \underline{e} \underline{b} \underline{\underline{d}} \mathrm{e}$ da ${ }^{\supset} \bar{a} m \bar{a}^{h} \mathrm{em}$ Deuteronômio}

O quadro anterior apresenta os seguintes detalhes. Primeiro, o 'e $e \underline{b e} \underline{d}$ e a ${ }^{\supset} \bar{a} m \bar{a}^{h}$ não aparecem no último bloco literário de Deuteronômio, apenas o gēr, a 'almānāh, o yātônm, e o lēwî, aparecem. Segundo, como os demais Entes Silenciosos, a maior parte das referências a eles está dentro do bloco literário denominado de Código Deuteronômico (Deuteronômio 12-26). O ${ }^{c} e \underline{b} e \underline{d}$ e a ${ }^{\supset} \bar{m} m \bar{a}^{h}$ estão juntos em Deuteronômio $5,14.15 .21 ; 12.12 .18 ; 15,17 ; 16,11.14$. Mas o ‘e $\underline{b}$ ed aparece sozinho em Deuteronômio 6,21; 15.15; 23,15.16; 24,22.

\subsubsection{Outros Entes Silenciosos associados com o 'e $\underline{b} \underline{\underline{d}} \underline{\mathrm{d}}$ e a ${ }^{\mathrm{a}} \mathrm{a} m \bar{a}^{h}$}

Entre as referências do quadro estão aquelas em que o 'ebẹe e a ${ }^{2} \bar{a} m \bar{a}^{h}$ aparecem acompanhados de outros Entes Silenciosos. Em Deuteronômio 5,14, o ${ }^{\complement} e \underline{b} e \underline{d}$ e a ${ }^{\top} \bar{a} m \bar{a}^{h}$ estão juntos com o gēr. Esse texto faz parte dos Dez Mandamentos. Eles são os únicos Entes Silenciosos colocados dentro dos Dez Mandamentos, e aqui eles são apontados como aqueles que devem usufruir do descanso do sábado. Pode-se perguntar se o fato de os outros Entes Silenciosos não serem colocados nos Dez Mandamentos para descansarem no sábado, se eles não seriam alcançados pelo descanso daquele dia. A resposta do redator é que todos deveriam descansar no sábado, incluindo o ${ }^{\complement} e \underline{b} e \underline{d}$ e a ${ }^{2} \bar{a} m \bar{a}^{h}$ e o gēr, mesmo que fossem escravos adquiridos de fora de Israel.

Deuteronômio 12,12.18 apresenta o ${ }^{C} e \underline{b} e \underline{d}$ e a ${ }^{\top} \bar{a} m \bar{a}^{h}$ acompanhados do lēwî. Os textos falam de um momento festivo do clã. Neste momento, provavelmente depois da colheita, o clã se reúne para uma comemoração pelo plantio bem sucedido, e também pelo sucesso na criação de animais. Os dois textos falam de ofertas e dízimos que deveriam ser levados para o Santuário Central, onde o clã realizaria um momento festivo. O texto não é claro sobre a motivação de tal comemoração no Santuário. Provavelmente é um momento festivo devido aos lucros obtidos pelo campo - colheita e criação de animais. 
Em Deuteronômio 16,11.14, ao contrário de Deuteronômio 12, claramente o motivo é a Festa das Semanas, quando a colheita tinha sido encerrada (v. 11). Em Deuteronômio 16,14, a festa da qual esses Entes Silenciosos deveriam participar com o "tu/vós" era a Festa dos Tabernáculos. A motivação para a festividade está bem estabelecida em Deuteronômio 16,16, onde são alistadas as três festas que todo homem deveria participar no Santuário Central - a Festa dos Pães Ázimos, das Semanas, dos Tabernáculos.

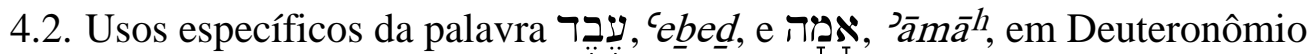

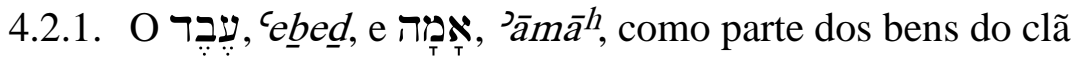

Esse é o uso mais comum das duas palavras dentro de Deuteronômio, e tem uma legislação específica para tratar deles (Deuteronômio 5,14.15.21; 23,15.16). Além das notas já apontadas em um ponto anterior, apenas dois detalhes a mais sobre estes Entes Silenciosos - o 'e $\underline{b} \underline{e}$, e a $\bar{\lambda}_{\bar{a} m \bar{a}^{h}}$. Primeiro, é significante que os Dez Mandamentos tenham se preocupado com eles para coloca-los sob o descanso no sábado, igualando à necessidade de descanso deles a de seu senhor, o "tu/vós" $(5,14)$. Era demonstração de humanidade deixá-los descansar.

Em segundo lugar, o 'e $\underline{b} e \underline{d}$, e a ${ }^{\supset} \bar{a} m \bar{a}^{h}$ são postos em outra situação dentro dos Dez Mandamentos, não mais como alvos do mandamento do descanso sabático, mas como objetos de cobiça. Como parte do patrimônio do "tu/vós", eles não poderiam ser cobiçados $(5,21)$. O mandamento tem dois verbos para cobiçar. O primeiro aparece no início da referência: "não cobiçarás a mulher de teu próximo". ${ }^{488} \mathrm{O}$ segundo verbo aparece antes dos outros elementos passíveis de cobiça: "e não cobiçarás a casa do teu próximo, seu campo, e seu servo, e sua serva, seu boi, e seu jumento, e tudo que (é) de teu próximo". 489

Qual a diferença entre eles? O primeiro fala de um desejo ardente que leva a tentativa de adquirir (HHL-BW7). Nesse caso, cobiçar a mulher do próximo implicaria na tentativa de quebrar outro mandamento - "não adulterarás", estampado em 5,18. O segundo também fala de cobiça, no sentido de "sentir um desejo", mas, normalmente, num mal sentido (HHL-

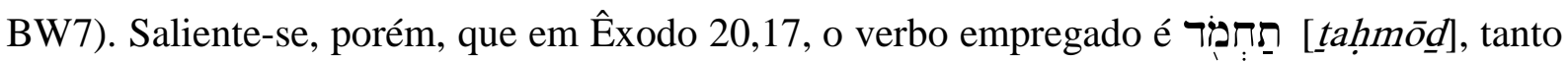
para a mulher quanto para os bens. Deuteronômio faz uma pequena e significante distinção.

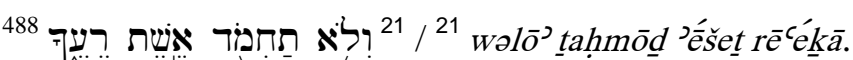

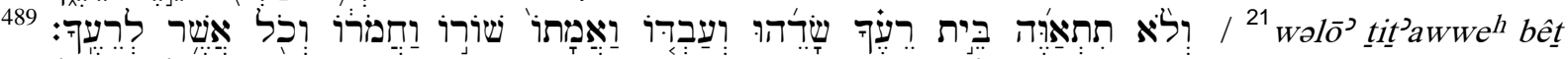

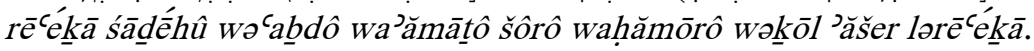




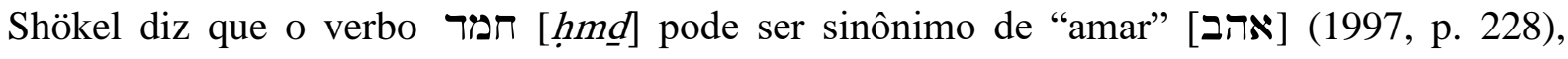
enquanto o outro verbo [אוה], no hithpael, como em Deuteronômio 5,21, tem o sentido de cobiçar, mas com a ênfase na ansiedade (1997, p. 32), fazendo da cobiça um forte desejo para ter aquilo que é do outro. Assim, para esta pesquisa, o que Deuteronômio está demonstrando é que a mulher do próximo jamais pode fazer parte do desejo amoroso do "tu/vós", pois ela tem marido que a ama. Por outro lado, o mesmo "tu/vós" não poderia vir a ser possuído de um desejo descontrolado para querer ter o patrimônio que pertence a outro - nisso incluído o 'e $\underline{b} \underline{\underline{d}} \underline{\mathrm{g}}$ e a ${ }^{2} \bar{a} m \bar{a}{ }^{h}$, pois esse desejo descontrolado poderia resultar na quebra de mais um mandamento - "não furtarás".

Finalmente, há uma referência, onde o 'e $\underline{b} e \underline{d}$ aparece sozinho, que apresenta um mandamento de ajuda humanitária para o 'e $\underline{b} \underline{e} \underline{d}$ fugitivo. Deuteronômio 23,15.16 (Hebraico v. 16 e 17) parece trazer por trás de si a questão de vida ou morte. O texto é taxativo em dizer que o ‘e $\underline{b} \underline{\underline{d}} \underline{\mathrm{d}}$ fugitivo não pode ser entregue ao seu senhor: "Não entregarás um escravo para seu senhor, aquele que escapou para ti de seus senhores". 490

O verbo traduzido nesta pesquisa por "escapar" [']

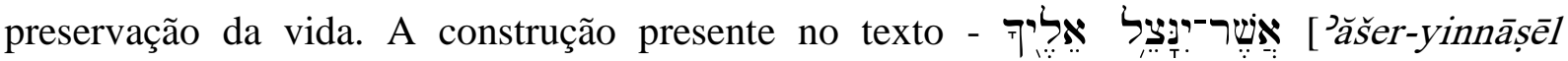

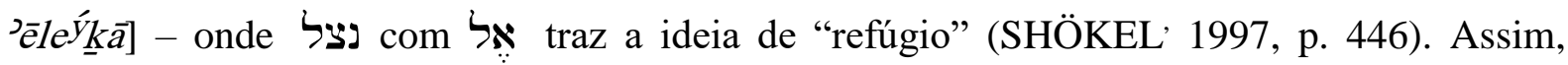
quando o "e $\underline{b} \underline{\underline{d}} \underline{\mathrm{d}}$ fugitivo procurou aquele "tu", ele o fez para buscar refúgio. Tratando-o bem, esse protetor não estará quebrando nenhum dos mandamentos dos Dez, mas os cumprindo integralmente, pois a vida está sendo preservada. Assim, o direito de propriedade do "tu" não está sendo violado pelo outro "tu" que acolhe o escravo daquele, pois o direito à vida é maior que a posse de um bem.

Por outro lado, o Código de Hamurabi estabelecia a pena de morte para quem acolhesse o escravo alheio: "Se um senhor feudal tem abrigado, em sua casa, um escravo fugitivo que pertence ao estado ou uma escrava que pertença ao estado, ou a um cidadão, e não o tem trazido na intimação da polícia, aquele chefe de família deve ser posto para morrer" (PRITCHARD, 1958, p. 141, § 16). Assim, juntamente com o aporte dado pelo senhor ao seu

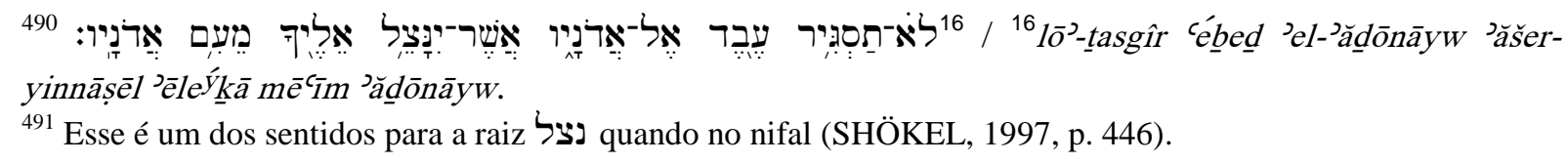

${ }^{491}$ Esse é um dos sentidos para a raiz נצל quando no nifal (SHÖKEL, 1997, p. 446). 
escravo a ser liberto, o asilo a um escravo fugitivo demonstrava avanço significativo do Código Deuteronômico em relação a legislação de Hamurabi. ${ }^{492}$

O restante do mandamento é um esclarecimento do que deve acontecer com este ce $\underline{b} e \underline{d}$ fugitivo. ${ }^{493} \mathrm{O}$ texto de Deuteronômio salienta que o direito à vida está acima dos direitos de propriedade. Mesmo que um ${ }^{\complement} e \underline{b} e \underline{d}$ e uma ${ }^{2} \bar{a} m \bar{a}^{h}$ fizessem parte do patrimônio de um clã, a vida deles estava acima de qualquer direito que um clã tivesse sobre eles. Mesmo sendo um ‘e $\underline{b} \underline{\underline{d}}$ fugitivo, ele deve ser tratado com humanidade. O final do v. 17 afirma: "Não o

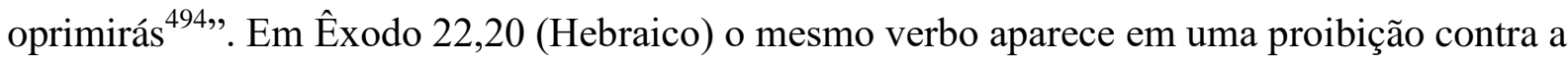
opressão de um gēr. Esse detalhe é revelador, pois o 'e $\underline{b} e \underline{d}$ fugitivo passará a viver com o "tu" como um gēr: "contigo habitará, no meio de ti, no lugar que ele escolher, em um dos teus portões, o que é bom para ti” (v. 17).

\subsubsection{O 'e $\underline{b} \underline{e} \underline{d}$ como um representante oficial}

O conceito de ${ }^{c} \underline{b} \underline{\underline{e}} \underline{d}$ dentro do livro de Deuteronômio é pouco aplicado aquele emprego de ‘e be $\underline{d}$ como título honorífico, como acontece em outros lugares dos escritos da $\mathrm{BH}$, tais como “meus servos, os profetas" (Ezequiel 38,17), onde a palavra 'e $\underline{b} \underline{\underline{d}}$ qualifica a pessoa por ela identificada como representante divino, ou como um representante de um rei (Isaías 36,9.11 e $37,5.6 .24){ }^{495}$

Em Deuteronômio, apenas quando se refere a Moisés como servo do Deus de Israel é que ocorre esse uso especializado da palavra 'e $\underline{b} e \underline{d}$. Isso ocorre em apenas dois lugares Deuteronômio 3,24 - onde Moisés é chamado de "teu servo", e 34,5 - quando Moisés é

\footnotetext{
${ }^{492}$ Nas leis de Eshnunna, § 50, há a seguinte legislação: "Se um governador militar, um governador do sistema de canal, ou qualquer pessoa na posição de autoridade apreende um escravo fugitivo, uma escrava fugitiva, um boi extraviado, ou um jumento extraviado que pertence a uma autoridade ou a um cidadão, e não o conduz a Eshnunna, mas o retém em sua casa e permite decorrer mais que um mês, o palácio deve trazer contra ele uma acusação de ladrão" (HALLO, 2003, p. 334-335). Não é clara a consequência dessa acusação, mas certamente implicaria em penalidade para quem quebrasse essa lei. Provavelmente, haveria o pagamento de certa quantia em dinheiro.

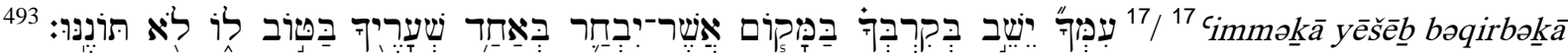

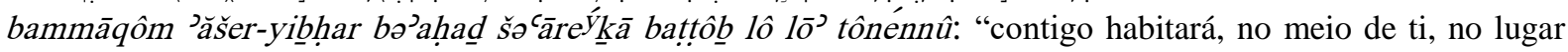
que ele escolher, em um dos teus portões, o que é bom para ti. Não oprimirás (serás violento / começarás a oprimir) a ele".

${ }^{494} \mathrm{Na}$ conjugação hifil da raiz ינה (HHL-BW7).

495 Os representantes do rei assírio Senaqueribe que invadiu Judá nos dias de Ezequias são chamados de "servos" de Senaqueribe. Eles estavam ali para representá-lo e falar com a sua autoridade.
} 
chamado de "servo de $y h w h$ ". Nos demais lugares, a palavra 'e $\underline{b} e \underline{d}$ traz o significado natural de "escravo", mesmo que haja alguma especialização salientada, como será visto abaixo.

\subsubsection{Israel como ce $\underline{b} e \underline{d}$}

As referências ao povo de Israel como um 'e $\underline{b} e \underline{d}$ aparecem em Deuteronômio 5,15; 6,21; 15,$15 ; 24,22$. O que caracteriza Israel como 'e $\underline{b} e \underline{d}$ ? A escravidão no Egito deveria fazer parte da memória permanente de Israel. A frase "E lembrarás que foste escravo na terra do Egito" ${ }^{496}$ é recorrente no trato de Deus com seu povo Israel, e está presente em Deuteronômio $(5,15 ; 15,15 ; 24,22)$ para relembrá-lo destes dias difíceis de escravidão no Egito. Com que objetivo ela é colocada para Israel?

Em primeiro lugar, essa era uma forma de incentivar Israel a agir com solidariedade. Em Deuteronômio 5,15, ela é colocada dentro do contexto dos Dez Mandamentos com o fím de dar a motivação necessária para a guarda do dia de descanso. Mas não somente o descanso do "tu", mas o descanso de todos os que são apresentados em 5,15, os quais incluem a família do "tu" e também os animais e o 'e $\underline{b} e \underline{d}$ e a $\bar{a} m \bar{a}^{h}$. Essa memória deveria ser usada como incentivo para que o "tu" usasse de atos de humanidade com aqueles que se encontravam sob seu domínio. A memória aqui serviria de incentivo à solidariedade - como Israel havia sido escravo no Egito, ele entenderia quais são as necessidades de um escravo quanto ao descanso.

Em Deuteronômio 15,15, o contexto aponta para outro tipo de escravo. O que está em vista aqui não é o 'e $\underline{b} e \underline{d}$ como patrimônio, mas aquele israelita que, por sua condição financeira, havia se deixado escravizar por outro israelita. O 'e $\underline{b} e \underline{d}$ israelita tinha um prazo para permanecer nessa condição. No prazo determinado para sua libertação, ele não deveria sair dali como entrou - sem nada. $\mathrm{O}$ "tu" israelita deveria ser generoso para com aquele que seria liberto.

Por fim, Deuteronômio 24,22, a memória deveria ser útil para que o "tu" tratasse com generosidade o gēr, a 'almānăh , e o yātôm (Deuteronômio 24,20.21). A sobrevivência deles dependia de o "tu" deixar caídos, no chão, os grãos da colheita. Esses serviriam para alimentação destes Entes Silenciosos. Lembrar-se da escravidão no Egito era lembrar-se dos momentos de necessidade que Israel passou ali.

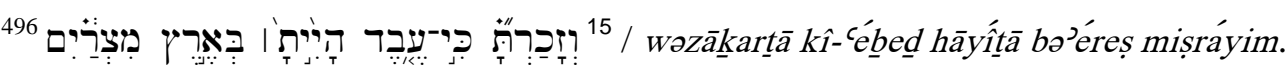


Em todas essas três referências, a memória da escravidão no Egito deveria servir para atos de solidariedade - provavelmente porque Israel não teve a empatia dos egípcios, mas a desejou. Agora, com condição diferente, Israel não deveria agir como os egípcios agiram com ele.

Em segundo lugar, essa memória deveria fazer parte da confissão de Israel como escravo liberto por seu Deus. Deuteronômio 6,21 tem uma confissão que deveria ser repassada para os filhos dos Israelitas para que eles entendessem a motivação de Israel ter que observar "testemunhos, estatutos e preceitos" (6,20). Assim, a confissão tinha um duplo propósito relembrar dos dias difíceis da escravidão no Egito, e relembrar que a saída dali foi uma saída causada pelo Deus de Israel. Observar "testemunhos, estatutos e preceitos" era guardar na memória a bondade de Deus sobre Israel. Assim, Israel é, dentro de Deuteronômio, um ${ }^{`} e \underline{b} e \underline{d}$ apenas na memória. Mas não se trata de uma memória passiva, mas ativa.

\subsubsection{O ${ }^{\complement} \underline{b} \underline{b} \underline{d}$ (ou a ${ }^{\supset} \bar{a} m \bar{a}^{h}$ ) israelita feito ${ }^{\complement} e \underline{b} e \underline{d}$ (ou a $\left.{ }^{\supset} \bar{a} m \bar{a}^{h}\right)$ para sempre}

O outro tipo de ${ }^{\complement}$ e $\underline{b} e \underline{d}$ (ou ${ }^{\supset} \bar{a} m \bar{a}^{h}$ ) é aquele que era constituído de escravos feitos dos teus irmãos (Deuteronômio 15,17). Esse era aquele escravo que foi feito escravo por sua condição financeira e ele era membro do povo de Israel - voluntariamente ele havia se vendido para algum clã com possibilidade de comprá-lo. Ele tinha oportunidade de sair livre no ano da remissão. O primeiro tipo de escravo fazia parte do patrimônio do clã e entrava na divisão da herança. O segundo tipo de escravo era um escravo temporário, a não ser que ele optasse por se tornar um escravo permanente.

O escravo israelita tinha, a seu favor, uma legislação específica para cuidar dele. Ele tinha um tempo determinado de serviço para aquele a quem ele se vendia. Por outro lado, o escravo vindo de outros povos era feito escravo compulsoriamente. Ele permaneceria escravo durante os dias de sua vida, salvo se encontrasse um dono generoso que lhe desse a sua liberdade. As demandas por mão de obra, normalmente, impediriam essa atitude por parte de um senhor de terras.

Entretanto, o 'ebe $\underline{b}$ que se fez escravo podia fazer uma escolha voluntária de ficar como escravo para sempre do clã ao qual se vendera (Deuteronômio 15,16.17). A motivação deveria ser o amor pelo seu senhor. O redator diz que deveria ser dito pelo ${ }^{\complement} e \underline{b e} \underline{d}$, ou pela ${ }^{\supset} \bar{a} m \bar{a} h$, que ele, ou ela, amava seu senhor: "E será que ele diga para ti: 'não sairei de perto de ti', porque 
ele te ama, e (ama) tua casa, porque (é) bom para ele (estar) contigo". ${ }^{497}$ Note-se: primeiro, ele deve fazer uma declaração oficial diante do tribunal da comunidade, segundo Êxodo 21,4.5. Portanto, ela é feita diante de testemunhas. Um segundo detalhe a ser observado é que aquele clã é bom para ele. Esse ambiente favorável deve ser comparado com a liberdade que ele recusa receber por direito. Isso significa que a vida de escravo naquele clã é mais favorável que a liberdade que ele estava prestes a usufruir. Diante de sua decisão oficial, ele passa a ser marcado pelas furos da servidão voluntária perpétua - as orelhas furadas (Deuteronômio 16,17).

4.3. O 'e $\underline{b} e \underline{d}$ e a ${ }^{\supset} \bar{a} m \bar{a}^{h}$ na $\check{s}$ omițt $\bar{a}^{h}$ : Liberdade ou escravidão permanente? O dilema do ${ }^{\complement} e \underline{b} e \underline{d}$ e da ${ }^{\top a} m \bar{a}^{h}$ em Deuteronômio 15,12-18

\subsubsection{Tradução}

12 - "Quando o teu irmão hebreu, ${ }^{498}$ ou (tua irmã) hebreia, ${ }^{499}$ vender-se ${ }^{500}$ a ti, seis anos servirá a ti. E no ano sétimo, tu o mandarás livre, ${ }^{501}$ de junto ${ }^{502}$ de ti’”.503

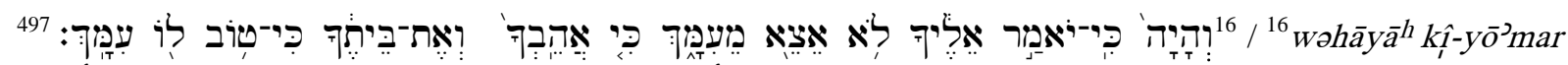

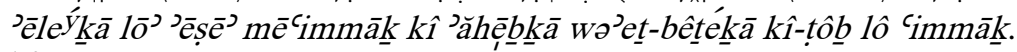

498 "Em todos os textos relativos à escravidão, distingue-se o escravo hebreu do escravo kena'ani (cananeu) que era tratado da mesma maneira que todos os escravos nas sociedades vizinhas. Quanto ao hebreu, ele permanecia 'irmão' em sua escravidão” (CHOURAQUI, 1997, p. 179).

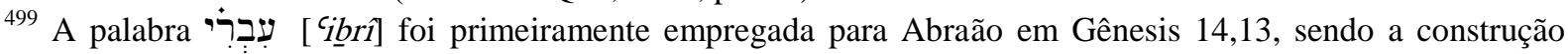

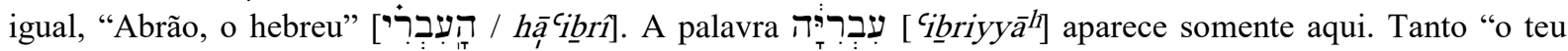

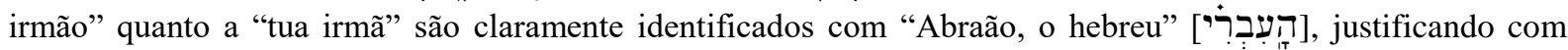
força da origem o porque de eles serem tratados diferentemente. Um descendente de Abraão não pode ser um escravo de outro descendente de Abraão nem de outro qualquer. Neemias viria a fazer todo esforço para comprar seus irmãos que haviam sido vendidos a outros povos (Neemias 5,8). Em Êxodo 21,2 a formação é com a

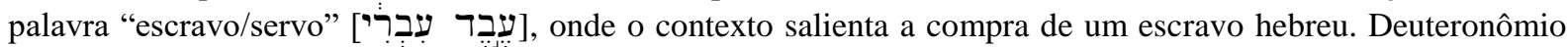
aproxima este "servo hebreu" do $b a c^{\varsigma} a l$ e diz que ele é "teu irmão hebreu". Ou, noutra forma de dizer, o $b a c^{\varsigma} a l$ e 'ébed têm a mesma origem, o "Abrão, o hebreu". "עִבְרִ " portanto, ocorre com muita frequência e usualmente na presença de (ou nos lábios de) estrangeiros (exceto Gênesis 14,13; Êxodo 21,2; Deuteronômio 15,12; Jeremias 34,9; Jonas 1,9) para indicar aspectos raciais distintivos de Israel e seus ancestrais" (HALOT, 2001, v. 1, p. 782). HALOT apresenta cinco interpretações para o emprego de עִברִר o mas aqui seguem as quatro primeiras: primeiro, indica o nome de uma nação; segundo, aponta para um grupo social e, depois, para o nome de uma nação; terceiro, mostra uma classe inferior de israelitas na comunidade preexílica; quarto, um grupo étnico que não deve ser identificado diretamente com os israelitas, mas com o grupo ao qual eles pertenceriam (2001, v. 1, p. 783). Para Cairns, עִברִ em 15,12, indica "um cidadão israelita pleno em contraste com o estrangeiro residente" (1990, p. 149). Tigay, por sua vez, acrescenta que بִבְרִ "é uma designação antiga para os israelitas que não poderiam ser chamados de 'israelitaas' antes do tempo de Israel. Ela aparece comumente nas narrativas patriarcais e de José, no Êxodo, e no período antes de Davi se tornar rei. Depois desse tempo a palavra caiu em desuso. Ela pode ser relacionada com palavra 'apiru, a qual é encontrada em textos do Antigo Oriente Próximo em referência a classe social de desenraizados, indivíduos subservientes... Entretanto, os termos 'apiru e cibrrî não são necessariamente relacionados. Há diferenças fonétics entre eles, e em outros contextos 'hebreu' claramente se refere a um grupo étnico, enquanto 'apiru refere-se a uma classe social... Aqui em Deuteronômio, 'hebreu' significa simplesmente 'israelita'” (1996, p. 148). 
13 - "E quando tu o mandares livre de ti, ${ }^{504}$ não o mandarás ${ }^{505}$ vazio ${ }^{506, .507}$

14 - "Tu certamente farás pôr, como um colar ${ }^{508}$ para ele, do teu rebanho, ${ }^{509}$ e da tua eira, e do teu lagar. Tu darás para ele (do) que ’ādōnāy teu Deus te abençoou (deu)". 510

15 - "E tu lembrarás ${ }^{511}$ que escravo foste ${ }^{512}$ na terra do Egito e ग̄âdōnāy teu Deus te regatou. ${ }^{513}$ Assim eu te ordeno esta palavra hoje". 514

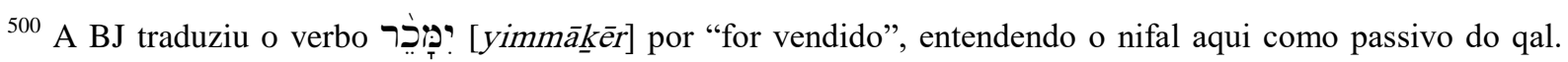
Para esta pesquisa, o nifal nesse texto pode ser traduzido como um reflexivo do qal, "vender-se". Isso é favorecido pelo contexto que salienta que o israelita, diante de sua situação social degradada, opta por se vender como escravo ao irmão israelita. Em Levítico 25,47, favorece a ideia de um reflexivo do qal aqui. Nesse texto, o

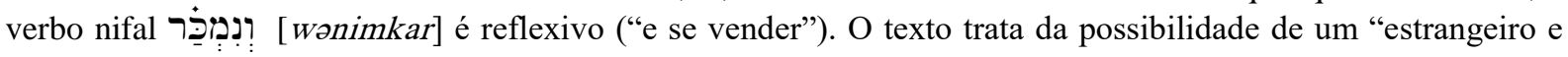

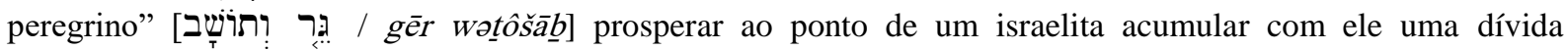
impagável, tendo como única saída sua venda para pagamento da dívida. Ele não deve ser deixado como escravo para o resto de sua vida. Ele deve ser resgatado por um parente (24,48-55). Por outro lado, Deuteronômio 15,12 pode ter por trás de si o contexto de Levítico $24,48-55$ de outra forma. O empobrecido que se vendeu para o

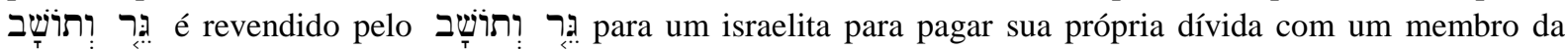
comunidade de Israel. Se for assim, a tradução "se for vendido" seria apropriada a Deuteronômio 15,12.

${ }^{501}$ Livre no sentido de libertado da escravidão a que se sujeitou, bem como de qualquer dívida que tenha motivado a sua autosservidão. Chegou a šomitța ${ }^{h}$ para ele e para ela.

502 - essa construção aparece quatro vezes nesta unidade textual $(15,12.13 .16 .18)$. Ela indica muito mais que proximidade. Ela aponta para a convivência. É alguém "de contigo". Alguém que, mesmo tendo servido como escravo, conviveu com seu senhor e da vida dele ele participou.

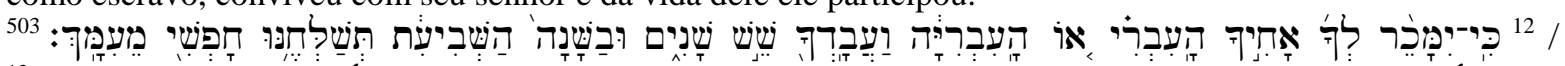

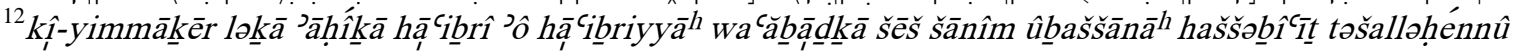
hōpšî $m \bar{e}^{c}$ immāâk.

${ }^{504}$ A primeira parte deste versículo é quase uma repetição da parte final do versículo anterior. A diferença está

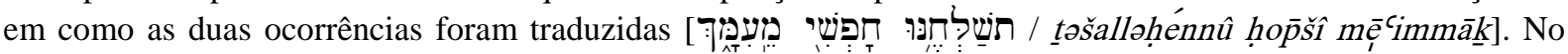
versículo anterior, o imperfectivo piel foi traduzido como uma ordem, o que se repete no final do versículo onde a mesma formação verbal aparece pela terceira vez. No versículo 13 , como um subjuntivo, no começo do versículo 13, devido a presença de 'ִ̣, traduzida por “quando". É o contexto onde estão inseridas essas formas verbais que favorece as diferenças na tradução.

${ }^{505}$ Além de o $b a{ }^{c} a l$ ter que perder a mão de obra já paga na compra do escravo, ou escrava, ele ainda teria que conceder um presente como forma de compensação por ter escravizado e usufruído dos serviços do

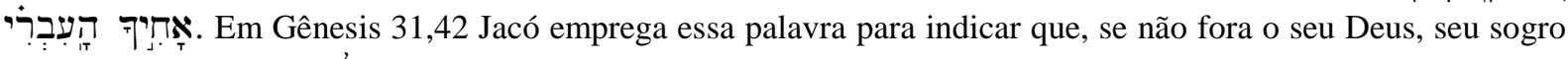

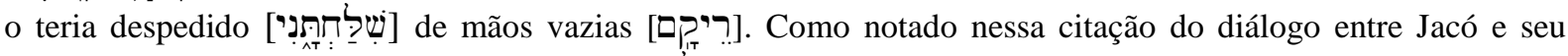
sogro, Labão, também tem presente o verbo שלח, no piel perfectivo, para indicar o ato de mandar embora

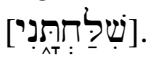

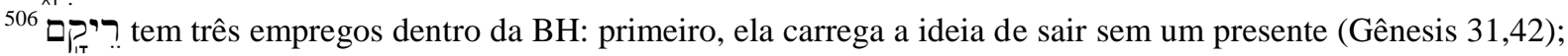
segundo, ter fracassado em algum objetivo e, por isso, não ter nada pelo que comemorar (Isaías 55,11); e, por último, ser destituídos de posses da família, como em Rute 1,21 (HALOT, 2001, v. 2, p. 1229).

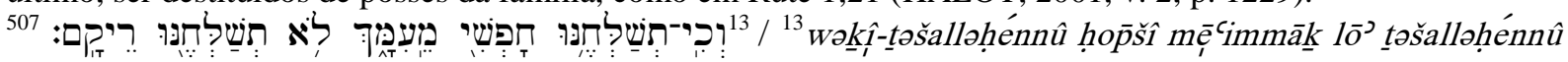
rêqām.

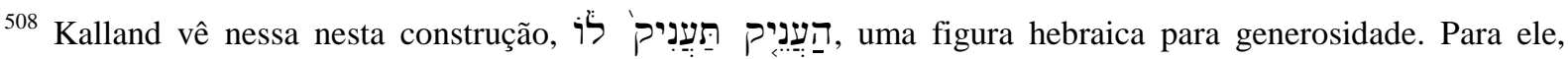
literalmente, essa construção pode ser traduzida por "tu deves fazer um rico colar", "ser liberal com os presentes" (1992, p. 107).

509 O servo liberto sairá com um animal do rebanho sobre os ombros.

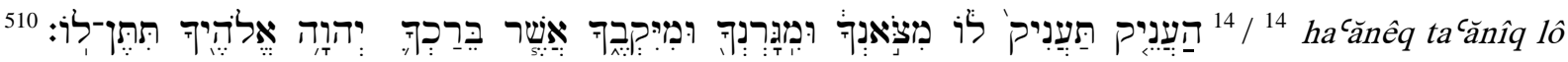

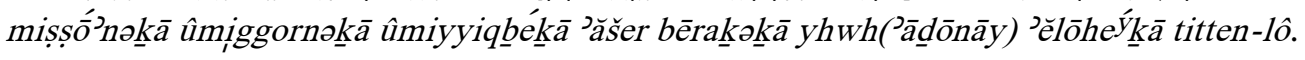


16 - "Mas, será ${ }^{515}$ que quando ${ }^{516}$ ele te disser: 'Não sairei de junto de ti'. Porque ele ama a ti e a tua casa, porque (é) bom para ele (ficar) contigo". 517

17 - "E tomarás o furador ${ }^{518}$ e meterás ${ }^{519}$ na sua orelha na porta. E ele será para ti um escravo para sempre. E também para tua serva farás assim". 520

18 - "Não será difícil nos teus olhos mandar-lhe embora, livre de ti, porque ele te serviu o dobro $^{521}$ do salário ${ }^{522}$ de um diarista ${ }^{523}$ seis anos. E ’ādōonāy teu Deus te abençoará em tudo que fizeres". 524

${ }^{511}$ O desafio da memória é para que o resultado seja diferente no trato do ba`al com o "teu irmão escravo" daquele que os egípcios deram aos israelitas.

${ }^{512}$ Lembrar que o $b a^{c} a l$ também foi um escravo no Egito invoca as lembranças do Êxodo. O Êxodo é fundamental para o tratamento misericordioso com o próximo.

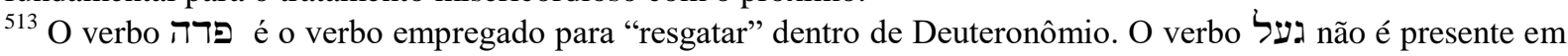

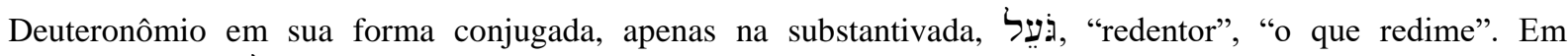

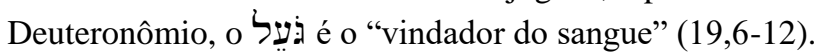

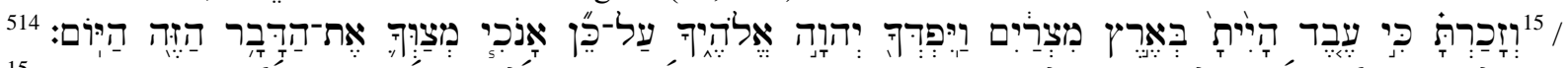

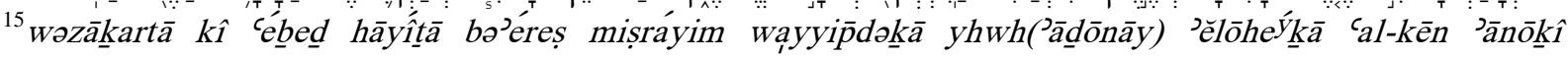
moṣawwok̄ā ’et-haddābāâr hazze hayyôm.

515 O verbo הָיז, no perfectivo com ??, é empregado para abrir locuções temporais com perspectiva futura: "E será..." (ROSS, 2001, p. 146). Aqui, com a perspectiva de uma possibilidade real futura, ele pode ser traduzido por "e acontecerá" para apontar para um evento futuro possível, quando as condições futuras forem favoráveis a sua ocorrência.

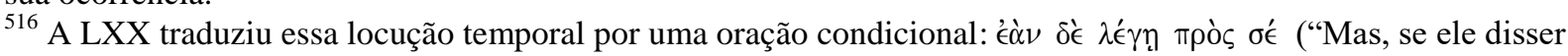
a ti"). Isso salienta que os tradutores da LXX entenderam a construção como uma condição que provavelmente poderia acontecer em um tempo futuro.

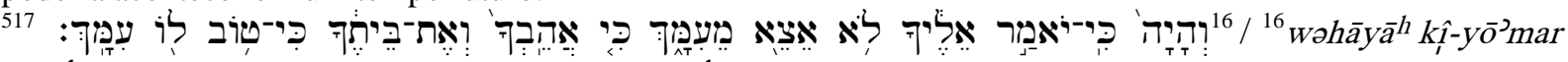

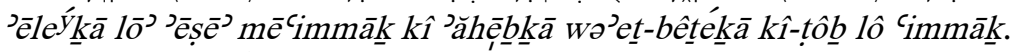

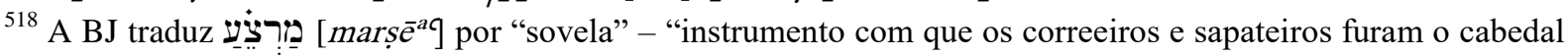
para o coser" (Michaelis, p. 1975). Na tradução apresentada nesta pesquisa, optou-se por traduzir a palavra hebraica por "furador" por ser mais fácil de o leitor entender. Essa palavra aparece em Êxodo 21,6 em contexto semelhante.

${ }^{519}$ O verbo aqui é qal de נתן, "dar”. Na tradução desse versículo se deu uma alternativa de tradução para o verbo dada por Schökel (1997, p. 458).

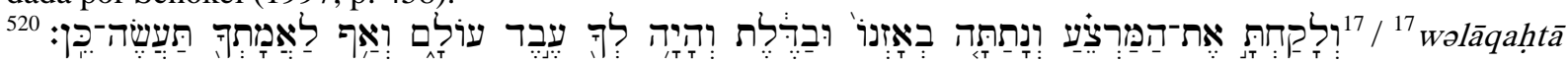

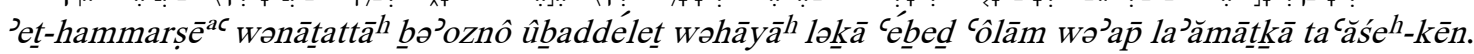

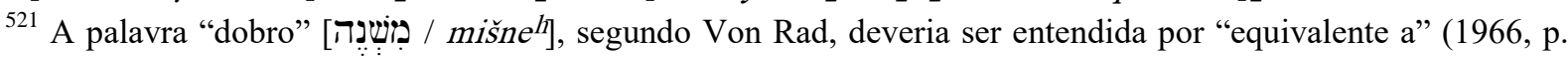
108).

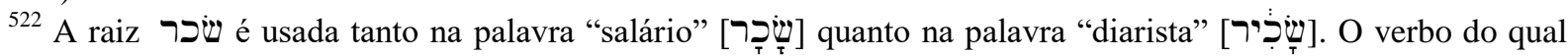
essas duas palavras procedem é שכר, traduzido como "alugar, assalariar, contratar, empregar" (DBHP, p. 643-

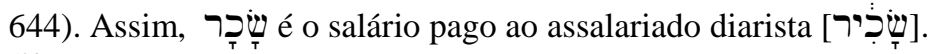

${ }^{523}$ Temos aqui uma construção que poderia salientar uma desvantagem para o $b a^{c} a l$. Entretanto, o que o redator

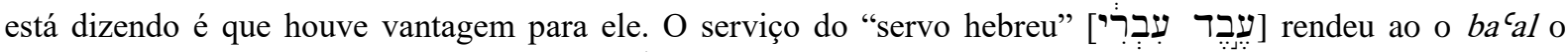

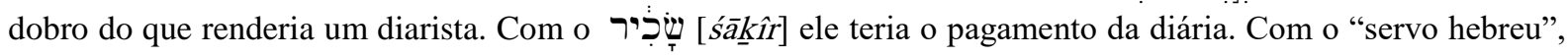

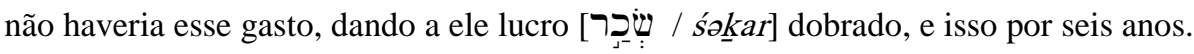




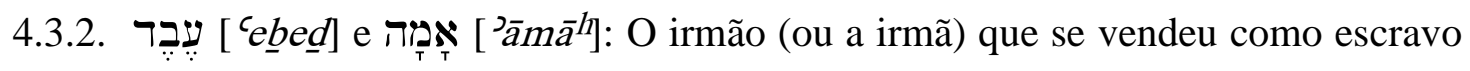
(Deuteronômio 15,12-18)

O que caracteriza a šomittta $\bar{a}^{h}$ do $e \underline{b} e \underline{d}$ e da ${ }^{\bar{a}} m \bar{a}^{h}$ ? Na essência, a šomițțăh aqui acrescenta a ideia de libertação depois de um período de seis anos de escravatura, além do cancelamento da dívida pela qual o/a israelita se vendeu ao seu irmão. Mais que isso, a šomitță é também um meio de mostrar solidariedade com o irmão que se vendeu e trabalho como escravo por um período de tempo.

\subsubsection{Venda voluntária $(15,12)^{525}$}

Ao começar com uma hipótese futura, o redator propõe a possiblidade de um israelita vir a se vender como escravo. A legislação da šomițțăh, "Quando o teu irmão... se vender a ti”, aponta para essa possibilidade futura. Mas como tratar o irmão ou irmã israelita que, diante das circunstâcias chega ao extremo de se vender a um irmão como escravo ou escrava?

Primeiro, Deuteronômio pontua que a disposição de um israelita de se sujeitar à condição de escravo deve ser voluntária. O nifal de מָָָָ, "vender-se”, aponta para essa direção. Isso está em harmonia com o contexto anterior da šomițt $\bar{a}^{h}$. O irmão empobrecido deveria receber um empréstimo e ter sua dívida concelada na šmitță $\bar{a}^{h}$ (Deuteronômio 15,1.2). Isso quer dizer que se vender para ser escravo não era compulsório, mas voluntário.

Segundo, a šomitța $\bar{a}^{h}$ estabelece um período fixo de seis anos para o israelita trabalhar como escravo para um irmão. Se esses seis anos de serviço está relacionado com o período de sete anos, sendo o sétimo o ano sabático, então o período de seis anos deve ser considerado o perído máximo para um/uma israelita servir ao seu irmão como escravo/escrava. Isso quer dizer que ele/ela poderia se vender por período menor. Mas como harmonizar esse verder-se

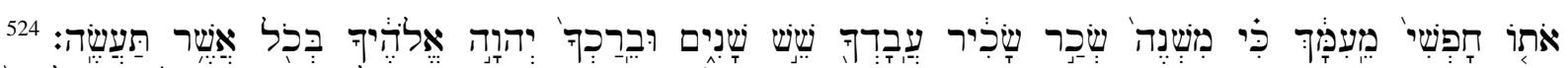

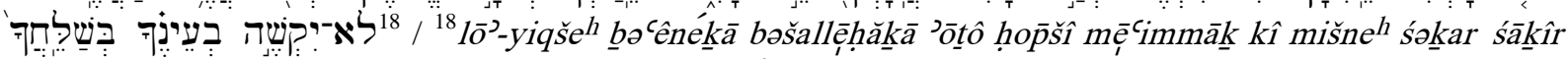

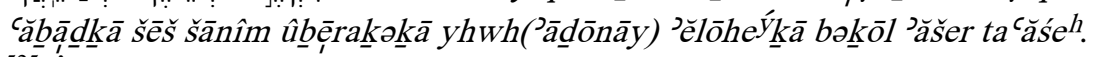

${ }^{525}$ Éxodo 21,1-11 apresenta uma legislação sobre o "escravo hebreu". Algumas diferenças podem ser anotadas entre essa legislação e a de Deuteronômio 15: o escravo hebreu deve trabalhar seis anos e sair livre no sétimo, mas se ele entrou sozinho, deve sair sozinho, se entrou com a mulher, ela deve sair com ele; se ele casou depois de se fazer escravo, a mulher e os filhos desse período ficam com quem o comprou; também um homem pode vender sua filha como escrava; porém, ela não deverá sair como escrava se caso ela tenha se casado com quem a comprou. Segundo Driver, "a verdadeira explicação para a variação é que a lei de Deuteronômio vem de um estágio mais avançado da sociedade que a lei de Êxodo; ela regula o costume para o tempo em que o poder de um pai não foi mais absoluto quanto tinha sido em tempos anteriores, e coloca os dois sexos em posição de igualdade" (1985, p. 182-183). 
como escravo com o cancelamento de dívida do irmão empobrecido na šomițțā $h$ ? O que está por trás dessa atitude extrema é a sobrevivência. O/a israelita pode chegar a um ponto onde ele/ela entende que a única forma de sobreviver é se vendendo como escravo para um irmão. Outro motivo é que um empréstimo não pago na expectativa da šomițțăh poderia levar o irmão a não fazer outro empréstimo.

Num ato de boa vontade do devedor, ele não somente se vende para pagar uma dívida anterior, mas também para não fazer outra, e ainda receber por essa venda. Deuteronômio 15, 18 diz "Não será difícil nos teus olhos o teu mandar-lhe embora livre de junto de ti, porque ele te serviu pelo dobro do salário de um diarista". O escravo/escrava israelita, aparentemente, traria um custo alto para o irmão que o/a comprou. Ele pagou pelo período de tempo que seria servido nos seis anos até a šomitțā $\bar{a}^{h}$. Esse pagamento foi o dobro do custo que ele teria com um diarista. Mas esse custo tinha a ver com a compra de um irmão israelita, e por isso ele devia ser generoso. Além disso, o/a israelita seria seu durante o período dos seis anos, e, no final, daria maior lucro que o diarista.

Terceiro, assim como a atitude do israelita que se vendia como escravo deveria ser voluntária, a do comprador também deveria ser na hora de libertá-lo: "E no ano sétimo, tu o mandarás livre de ti”. Há, por trás dessa declaração, a formalidade de um ato de libertação. A proclamação da šomitță ${ }^{h}$ para o irmão que se escravizou envolvia a declaração que ele não devia mais nada e que, a seu tempo, chegara a hora de libertá-lo.

\subsubsection{Liberalidade na saída}

\subsection{Saída com suporte $(15,13)$}

"E quando tu o mandares livre de ti, não o mandarás vazio". O ano da šomițțăh é ano de soltura. O conceito de mão que solta está colocado em Deuteronômio 15,3, a mão do $b a{ }^{c} a l$ deve ser aberta para ele soltar o que ela segura. Em 15,7.8.11, a mão do bacal é convocada a se abrir outra vez para dar ao seu irmão pobre o que ele precisa. Em 15,10, a mão que solta é a mão que recebe. Pois se o $b a^{c} a l$ liberar a mão generosa, ela receberá generosidade em tudo que ela tocar. Aqui, mesmo que 15,13 não tenha a palavra mão, mas a ideia de sair "vazio" pode ser esticada para o pensamento de "sair de mãos vazias". Sair vazio é sair sem um presente. 


\subsection{Bênção para abençoar $(15,14)$}

"Tu certamente farás pôr como um colar, para ele". Há dois detalhes sobre essa construção. Primeiro, há aqui recurso do emprego do infinitivo absoluto com um verbo finito de mesma

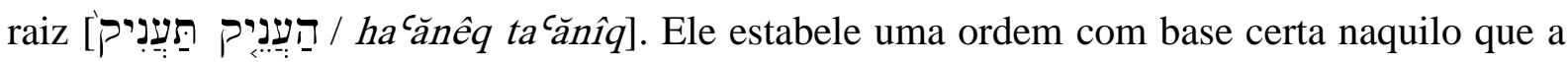
benção divina já havia concedido ao ba`al.

Segundo, o verbo no qal pode ser traduzido como "colocar como um colar" (HHL-BW7), como no Salmo 73,6. No hifil, causativo do qal, como em 15,14, "fazer colocar como um colar" (HHL-BW7). A ideia é de carregar sobre os ombros do "teu irmão escravo", recémliberto, uma ajuda, generosa, para seu recomeço. A BJ traduz essa construção por: "carregalhe o ombro com presentes". A sugestão é que o presente não seja apenas para um dia. Pode apontar para um animal que fosse carregado sobre as costas. Ele precisa recomeçar a vida de um ponto de partida melhor. A figura evocada pelo versículo é a do escravo/escrava saindo formalmente, na šmitt $\bar{a}^{h}$, com festa promovida pelo $b a^{c} a l$, na qual, como reconhecimento de ter sido abençoado por Deus, através do trabalho do servo/serva, ele abençoa o recém-liberto com provisões generosas para seu recomeço. A provisão para isso viria daquilo que Deus já o tinha dado: rebanho, eira, lagar.

\subsection{Liberdade baseada na memória $(15,15)$}

Para entender melhor Deuteronômio 15,15, deve-se recorrer a 15,12. Ali é dito que a pessoa que se venderá como escravo é "teu irmão hebreu, ou tua irmã hebreia". A palavra עִבְרִ foi foi empregada para caracterizar os israelitas feitos escravos no Egito (Êxodo 1,15-19; 3,18; 5,3; 7,16). Em 15,12, duas palavras palavras deveriam salientar a solidariedade racial entre o vendedor e comprador: "teu irmão hebreu/hebreia". Mas aqui, 15,15, o redator coloca de forma explícita - o comprador também foi um "escravo hebreu” no Egito. Então, por sua condição anterior, ele deveria tratar bem o seu irmão que se escravizou a ele.

Note o recurso da memória: "E tu lembrarás que escravo foste na terra do Egito". ${ }^{526}$ Mas isso não significaria que o $b a^{c} a l$ deveria sentir algum tipo de piedade que o levasse a ser generoso com o "teu irmão hebreu/hebreia". A implicação é que quando ba`al passou por seu tempo de escravidão, Deus o amou ao ponto de o libertar e ainda lhe trazer ampla provisão para o

\footnotetext{
${ }^{526}$ Notar a semelhança de linguagem com Deuteronômio 5,$15 ; 16,12 ; 24,18.22$. Israel foi, não somente escravo no Egito, como foi estrangeiro residente ali (Deuteronômio 10,19).
} 
recomeço na Terra da Promessa (CRAIGIE, 1976, p. 239). Portanto, não é só libertar. É libertar com presentes para seu recomeço. Não é só libertar, mas libertar com suprimento.

\subsubsection{A recusa em sair}

4.3.2.3.1. A recusa em sair tem que ser voluntária $(15,16)$

Em Êxodo 21,5.6, a recusa em sair é motivada pelo amor que o escravo hebreu tinha pela família que ele constituiu depois que ele se escravizou, bem como por seu bacal. ${ }^{527} \mathrm{Em}$ Deuteronômio 15, o motivo para ele não sair é o amor pelo seu $b a^{\complement}{ }^{c} l$ e pela sua casa e porque ele estava bem com o clã ao qual ele servira nos últimos anos. Só que essa última declaração não está na boca do declarante, mas é uma declaração do redator diante da disposição do escravo hebreu em querer ficar escravo em definitivo na casa do $b a{ }^{c} a l$ : "porque é bom para ele ficar contigo".

\subsection{A recusa tem que ser oficializada $(15,17)$}

A recusa em sair deve ser formalmente ratificada "pela cerimônia de cravar sua orelha na porta de seu senhor" (DRIVER, 1895, p. 184), sinal de completa dedicação ao seu senhor e família: "E tomarás o furador e meterás na sua orelha na porta. E ele será para ti um escravo para sempre. E também para tua serva farás assim". Em Êxodo 21,6, o escravo hebreu deve ser trazido para Deus, ${ }^{528}$ pressupondo o Santuário Central, onde teria como juízes os sacerdotes ministrantes ali.

Em Deuteronômio, o evento de formalização da escravidão por toda a vida não pressupõe ida ao Santuário Central. Ao que tudo indica, todo o procedimento formal acontece dentro da propriedade do bacal, num evento público, e, ao mesmo tempo, doméstico, pois a pessoa que está se escravizando para sempre é alguém da comunidade, e tal evento precisa ser atestado com testemunhas, para mostrar que a decisão de manter aquele escravo no patrimônio do

\footnotetext{
${ }^{527}$ A palavra traduzida por "senhor" em Exodo 21,5 é אָרוֹן. A ordem da declaração de amor é primeiramente dirigida ao seu senhor, depois à sua mulher e, finalmente, aos seus filhos. A casa do אָרָ não é citada em Êxodo 21,5, mas é implicada pela citação do próprio אָָ como objeto do amor do escravo. O tratamento recebido ali é fator decisivo para a permanência do escravo naquele clã depois do cumprimento dos seis anos. Mas também o seu amor pela sua própria família que fora formada depois de sua entrada como escravo naquele clã.

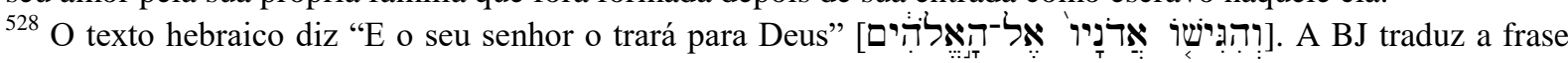
por "o seu senhor fa-lo-á aproximar-se de Deus".
} 
$b a^{c} a l$ não partiu do $b a^{c} a l$, mas do próprio escravo hebreu. Caso contrário, ele deveria sair livre. $^{529}$

\subsubsection{Obediência para a prosperidade $(15,18)$}

O versículo final trabalha com a eventual relutância do $b a^{c} a l$ em libertar seu irmão escravo. Ele pode pensar que ele teve prejuízo. Afinal, ele pode pensar que os custos com o escravo hebreu tenham sido maiores que os que ele teria se houvesse contratado um diarista. Mas o texto tem uma construção que favorece o ganho do $b a^{\complement} a l$ : "ele te serviu o dobro do salário de um diarista seis anos". O trabalho do escravo hebreu foi muito lucrativo. Ele proporcionou ganhos dobrados.

O que o texto sugere é que, segundo o redator, além de o $b a^{c} a l$ não ter que pagar um diarista, ele ainda lucrou cem por cento sobre o trabalho do escravo hebreu. Mas para não ficar apenas com esse ganho que já é muito, o redator se interpõe com uma promessa de bênção ainda maior: "E गādōnāy teu Deus te abençoará em tudo que fizeres". Isso indica que Deus o abençoará na produtividade do campo além do que ele teria se mantivesse a mão-de-obra escrava para trabalhar nos seus campos. ${ }^{530}$

\footnotetext{
${ }^{529}$ A legislação sobre a liberdade compulsória dos escravos hebreus aparece em três lugares no Pentateuco. Êxodo 21,5.6, Levítico 25,39-46 e Deuteronômio 15,16.17. A legislação de Levítico 25 estabelece que os escravos adquiridos de outros povos permaneçam no patrimônio do clã indefinidamente e, os escravos hebreus, diferentemente de Êxodo e Deuteronômio, devem sair livres no Jubileu, não após seis anos de serviço como escravo. Driver (1895, p. 185) apresenta algumas maneiras de harmonizar essa discrepância entre as legislações. A primeira é estabelecer que, se o ano do jubileu chegar primeiro que o sétimo ano, então esse será o ano de libertação do escavo hebreu. A segunda é entender que a situação de pobreza que culminou na escravidão era tal que, mesmo saindo em liberdade, ele não teria condições de se estabelecer com independência e, por isso, deveria permanecer na casa de quem o comprou como escravo. Por último, para Driver, a solução para a discrepância entre os textos está em que, em Levítico, há a suposição que a lei levítica é a provisão para a atenuação da servidão de israelitas, e sem referência a legislação anterior, e originada num tempo quando a legislação de Êxodo e Deuteronômio, a qual estabelece um limite de tempo, não poderia ser forçada. Driver nota também que a legislação de Levítico tem seu valor humanitário. Ela estabelece que o escravo israelita deva viver com seu senhor como um estrangeiro, como um diarista e, quando chegar à sua libertação, ele poderá sair com a sua mulher e filhos. Mas há outro modo de ver a libertação no ano do jubileu proposta por Levítico. Hartley indica que, tendo em vista que Êxodo 25 e Deuteronômio 15 determinam que o escravo hebreu deva sair no ano sétimo, a legislação levítica acentua que o escravo hebreu que deve sair no ano do jubileu é aquele que optou por ficar com seu senhor em definitivo. Assim, além de ele ganhar sua liberdade, ele ainda recebe o privilédio de sair com sua esposa e filhos (1992, p. 440).

530 Jeremias 34,12-16 indica que a legislação da šomițtăa $\bar{a}^{h}$ não teve aceitação generalizada pela comunidade israelita. O profeta faz crítica severa contra o povo de seu tempo por haver a escravização disseminada de irmãos e irmãs israelitas. Jeremias diz que mesmo os antepassados dos israelitas do tempo de Jeremias não foram obedientes à ordem divina de dar liberdade no sétimo ano $(34,14)$.
} 


\subsection{A אָזָ e a}

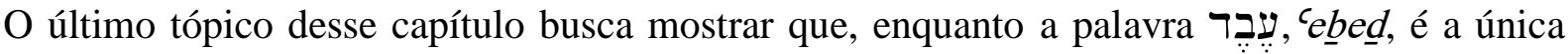
palavra para designar um homem escravo dentro da $\mathrm{BH}$, a "serva/escrava" é designado por

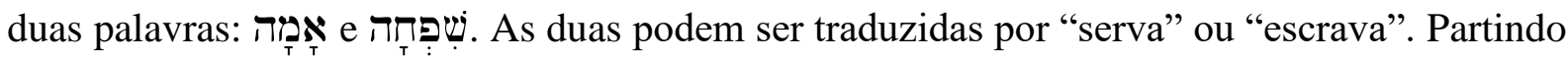
do pressuposto que Jeremias escreveu seu livro tendo uma perspectiva teológica deuteronomista, pode-se afirmar que as palavras são sinônimas. Em Jeremias 34, dentro de um contexto que faz referência a šomițtăa ${ }^{531}$ a palavra אָז , empregada em Deuteronômio

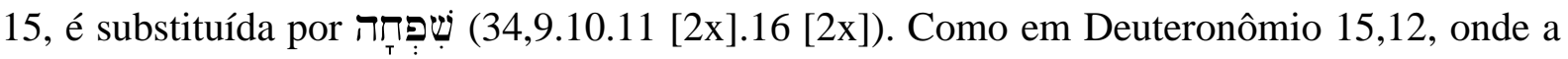

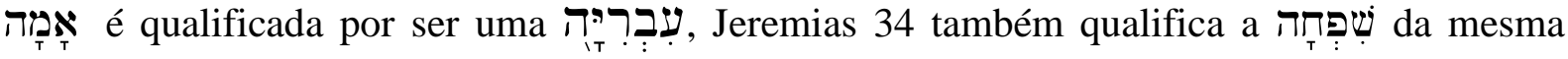
forma $(34,9)$.

Porém, enquanto que a palavra šip̣̣hāh concentra 26 de suas 60 ocorrências dentro da BH em Gênesis 12 a 35, ela é quase ausente dentro dos textos legais (REUTER, 2006, p. 406),

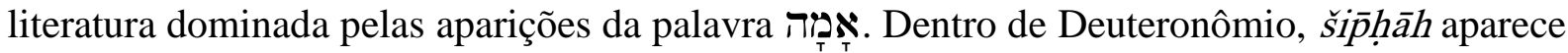
em 28,68, na companhia de ${ }^{c} e \underline{b} e \underline{d}$, dentro de um contexto de maldições que ameaçam Israel, caso ele não fosse obediente em cumprir a legislação do Deuteronômio. A única ocorrência dentro de um texto legal propriamente dito está em Levítico 19,20 (REUTER, 2006, p. 409).

Para Reuter, na literatura de Gênesis, a šip̄hāh é mencionada quando as matriarcas são sem filhos, relacionando-a a esposa do patriarca (REUTER, 2006, p. 406). Mesmo que o patriarca seja o dono dela, dentro da família ela pertence à matriarca. Desse modo, quando a filha casava, uma šipḥāh podia ser incluída como serva da noiva (REUTER, 2006, p. 407). Dessa forma, ela estaria à disposição da matriarca para ser entregue ao patriarca para lhe gerar filhos quando a matriarca estava impossibilitada, fazendo da šipḥ̂ăh, nesses casos, uma segunda esposa (REUTER, 2006, p. 407-408).

\footnotetext{
${ }^{531}$ Em Jeremias 34, o profeta faz menção ao rei Zedequias e à sua liderança que haviam tomado a decisão de libertar seus escravos e escravas israelitas. Porém, depois de alguma reflexão sobre o que fizeram, resolveram recuar e outra vez escravizar seus irmãos e irmãs, recebendo, depois disso, pesada crítica do profeta, inclusive uma acusação que a atitude deles refletia seus antepassados que, como eles, nunca foram obedientes à legislação deuteronômica da šomitț $\bar{a}^{h}(34,14)$. Em Jeremias 34,14, logo no início, mostra claro que Jeremias está se

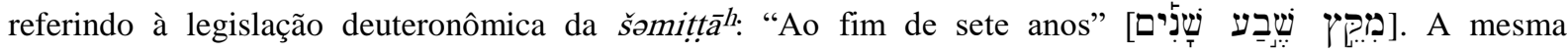
construção está em Deuteronômio 15,1.
} 
Bridge (2012, p. 1) mostra que a ' ${ }^{2} m \bar{a}^{h}$ e a ši $\bar{p} h \bar{a} h$ são usadas como sinônimos, tanto no seu emprego para demonstrar a serva em seu sentido geral (Naum 2,8; Levítico 25,44; Deuteronômio 28,68; 1 Samuel 8,16) quanto pelo emprego das duas dentro do mesmo texto e mesmo contexto (Gênesis 16,2-5; 21,10-13; 30,3.4; 31,33; 33,1.6; 1 Samuel 25,27.28).

Bridge entende que a análise das duas palavras não deve seguir pelo caminho da distinção entre elas, mas pelo padrão de uso. Segundo ele, os dois termos devem ser distinguidos pelo padrão de uso dentro da $\mathrm{BH}$, mostrando que elas podem ser usadas em seu sentido descritivo e em deferência (2012, p. 2, 3). Na primeira parte de seu artigo, Bridge critica aqueles que buscam encontrar distinção entre as duas palavras.

Os padrões de uso que Bridge (2012, p. 10-14) observa são os seguintes. Primeiro, há uma

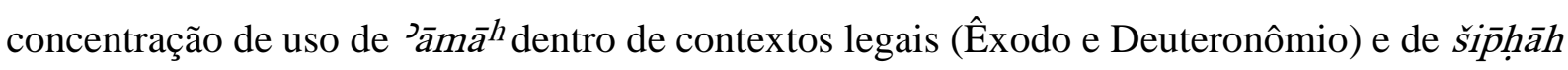
em textos narrativos, mesmo que haja exceções dentro desse padrão. Segundo, há predominância do emprego de šip̣̣hāh dentro de listas de propriedade, onde ela aparece somente duas vezes - em Êxodo 20,17 e Esdras 2,65. Terceiro, šip̣̄̂āh aparece em sua relação com sua senhora mais frequentemente (Gênesis 16,1-8; 25,12; 30,4-18; 35,25-26; Salmos 123,2; Provérbios 30,23; Isaías 24,2). Quando a relação é com o senhor, a $\bar{a} m \bar{a}^{h}$ é usualmente empregada. Por último, '̄āma $\bar{a}^{h}$ é o termo predominante em seu emprego para denotar escravas no casamento ou outras relações conjugais com o senhor ou outro membro masculino da família (Gênesis 20,17; 30,3; Êxodo 21,7-11; Juízes 9,18; 19,19).

Para esta pesquisa, basta dizer aquilo que os dados acima já declararam - que a ${ }^{\supset} \bar{a} m \bar{a}^{h}$ e a šipḥāh são termos distintos pelos seu uso em determinados contextos, mas são sinônimos pelo seu significado de "serva" ou "escrava", seja no seu sentido polido de uma referência pessoal à submissão a um superior, ou superiora, ou no sentido de caracterizar alguém em sua condição de escravidão. Como notado acima, a presença predominante de ${ }^{\supset} \bar{a} m \bar{a} \bar{a}^{h}$ em contextos legais, tanto em Êxodo como em Deuteronômio, segue o padrão de uso das duas palavras, mesmo que cada padrão ainda apresente suas exceções, mas o que se procurou notar foi o emprego predominante de cada palavra.

Basicamente há dois tipos de escravo-escrava dento de Deuteronômio: os que pertenciam ao povo de Israel e os que eram de outros povos. Por outro lado, os dois tipos eram adquiridos da mesma forma: por meio de recursos financeiros de quem os comprasse. Entretanto, os 
escravos e escravas israelitas podiam sair no sétimo ano, ano da liberdade compulsória. Os escravos e escravas de outros povos pertenciam ao patrimônio do israelita, e deveriam passar às mãos dos herdeiros. 


\section{CONSIDERAÇÕES FINAIS}

Considere-se o seguinte: os Entes Silenciosos dentro do Deuteronômio podem ser classificados em três grupos - os pobres, os "estrangeiros" e os escravos. Os pobres são homens israelitas e que podem ser considerados homens livres, mesmo que, pela sua condição econômica, venham a se tornar dependentes e até escravos de um irmão israelita; os “estrangeiros" incluem o estrangeiro residente, os demais são israelitas - o órfão, a viúva e o levita; os Entes Silenciosos do grupo dos escravos incluem os israelitas que se fizeram escravos - são homens e mulheres livres que se vendem a outro israelita com o fim de sobreviver em sua crise financeira, sendo que eles ganham sua liberdade no sétimo ano, a não ser que queiram ficar para sempre com seu senhor/senhora. Há também os escravos comprados de outras nações - para esses não há um ano de libertação. Para o Deuteronômio, essa é a estrutura da sociedade israelita, da perspectiva da pobreza.

Os Entes Silenciosos presentes no Deuteronômio são membros dos estratos sociais inferiores da sociedade israelita regida pela legislação do Deuteronômio. Tais estratos até então, pouca, ou nenhuma, atenção haviam recebido da comunidade ao seu redor com tanto detalhe como no livro de Deuteronômio. Isso não quer dizer que pessoas nunca tivessem agido em favor deles. Quer dizer que a comunidade nunca havia sido levada a pôr-lhes atenção para o

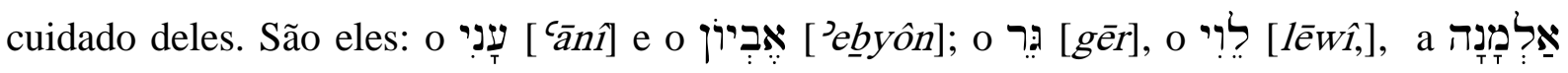

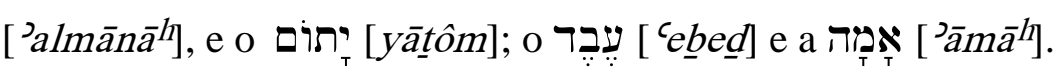

Enquanto que no Oriente Próximo a proteção aos Entes Silenciosos “era vista como uma virtude dos deuses, reis e juízes" (FENSHAM, 1962, p. 129), em Deuteronômio, a proteção é dada aos Entes Silenciosos por meio da comunidade, em obediência ao Deus de Israel, o qual, em resposta a essa obediência, abençoa o seu povo. Mesmo que a legislação venha ao povo como ordem divina do Grande Rei de Israel, seu Deus, é o povo que, no final, faz os atos de beneficência aos seus irmãos e irmãs israelitas. Porém, deve-se salientar que o cuidado dado aos Entes Silenciosos é dito como sendo a vontade de Deus (FENSHAM, 1962, p. 137).

O que o Deus de Israel fez em favor dos Entes Silenciosos foi colocar ordem em seu mundo

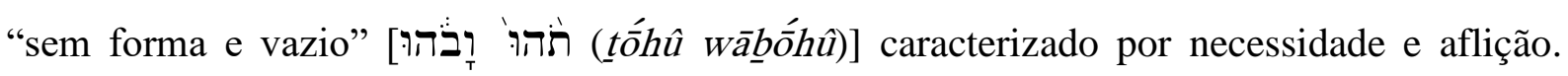
Porém, isso não foi feito unilateralmente, como as ações divinas em Gênesis 1,2. As mazelas da sociedade, prejudiciais ao próximo empobrecido, são corrigidas com a participação da 
própria comunidade, com o "tu/vós" da audiência do redator/orador. A escuridão do silêncio em que cada Ente Silencioso se encontrava - pobreza, viuvez, orfandade, estrangeirice, escravidão - recebia a luz do Deus de Israel por meio do povo obediente à sua voz. Aqui encontramos um trabalho em equipe - o divino e o humano trabalhando para o bem do próximo, o outro humano em situação de crise.

De certa forma, mesmo que o foco central de Deuteronômio não seja pôr os Entes Silenciosos no centro, o livro acaba por alcançar um alvo que talvez não fosse o seu proposto - ele chama atenção para o grupo de Entes Silenciosos. Ele mostra que eles não estão sob a maldição divina por causa de sua condição social. Há vida neles e a bênção divina repousa sobre eles por meio do "tu/vós" da audiência. Mas a benção divina também está sobre eles pela o cuidado de Deus com eles. Por outro lado, a benção de Deus só alcançará o "tu/vós" se eles contribuírem para o bem dos Entes Silenciosos de sua comunidade.

Eles estão ali para serem abençoados pela comunidade de Israel como comunidade divina no mundo e, como resultado, a comunidade, em sua obediência, viria a receber a bênção de seu Deus. Há um "ciclo da bênção": a comunidade abençoa os Entes Silenciosos, Deus abençoa o israelita obediente, e isso se repete sucessivamente. A benção seria tal que "tu/vós" seria elevado acima das nações, na medida em que eles elevasse os Entes Silenciosos por meio de seu auxílio. Assim, um grupo de esquecidos passa para a memória de Israel por meio da escrituração do Deuteronômio. Ele também entra na memória da comunidade par agir em seu auxílio.

Por último, os Entes Silenciosos em Deuteronômio não deveriam ser uma preocupação do Estado, principalmente centrado na pessoa do rei. O que é dito sobre ou para o rei em Deuteronômio 17,14-20 não traz nada sobre o cuidado que ele deveria ter com os Entes Silenciosos de sua nação. A preocupação com os Entes Silenciosos deveria ser da comunidade na qual eles estão inseridos.

Os Entes Silenciosos podem ser, portanto, definidos por sua condição financeira, por sua vulnerabilidade bem como por seu silêncio. Por sua condição financeira, pois eles não têm recursos para seu próprio sustento e também para o sustento daqueles que deles dependiam. Por sua vulnerabilidade, pois eles estavam impossibilitados de defenderem-se diante dos que detinham a força e poder dentro da comunidade e poderiam ser vítimas da vontade de um juiz fragilizado diante da pressão financeira de um clã poderoso. Por seu silêncio porque ele nada 
diz diante da legislação. A legislação não é dada em resposta a uma reivindicação sua. Ela vem porque outros veem a necessidade de proteção daqueles que não podem se proteger.

Deuteronômio tem uma questão muito importante para responder em seu escrito: Qual é a função dos Entes Silenciosos? Por que eles existem no meio do povo de Deus? Eles existem como parte do projeto divino para abençoar seu povo. Os Entes Silenciosos não são uma espécie de "mal" entre seu povo, Israel, ou algum tipo de impureza que precisa ser extirpada ou afastada do meio do povo "são". Eles são tão puros como qualquer um do grupo "tu/vós". Deus os restaura como parte do povo com um olhar divino mediado por um olhar humano de ajuda.

Mas eles são também instrumentos de poder divino entre seu povo, pois ao repartir de seus bens com eles, Deus abençoa aquele que agiu desse modo. Eles também podem clamar a Deus quando prejudicados, e seu defensor divino age para punir o agressor. Assim, a função dos Entes Silenciosos mira um projeto de povo que trabalha para o bem comum de seu próximo ao ponto de chegar o dia em que não haveria mais pobres no meio de seu povo. Esse projeto divino dependia da obediência - um povo que empresta a outros povos prosperará e ajudará seu irmão empobrecido a sair da crise de pobreza em que entrou.

Finalmente, além do que foi apresentado nos parágrafos acima, há certos pontos que unem os Entes Silencisos uns com os outros. Primeiro, por sua condição de completa dependência do Deus de Israel através de seu povo, o "tu/vós”. Segundo, com uma legislação favorável aos Entes Silenciosos, o impedimento que eles se tornassem escravos ou prostitutos cultuais se tornaria uma realidade, principalmente para as mulheres deste grupo.

Terceiro, a necessidade de proteção por parte da comunidade. Quarto, a necessidade de pertencer à comunidade na qual estão envolvidos - ao ajudar os Entes Silenciosos, o "tu/vós" demonstraria a ele a ideia de pertecimento. Eles são tao do povo de Israel como qualquer israelita com poder econômico. A proteção que a legislação de Deuteronômio apresenta não é apenas para proteção, é também para inclusão. Quinto, o estabelecimento da legislação é colocado pelo redator como algo que vem a partir da orientação divina. Com isso, o redator coloca a legislação como vontade divina que deve ser atendida pelo seu povo. Por último, a legislação é também um apelo para que o sofrimento de alguém seja amenizado, ou, se possível, eliminado. 
Em Deuteronômio, pode-se atestar o profundo senso de completa dependência do socorro dos outros, particularmente, dos homens livres apresentados no livro como "tu/vós". Esses são aqueles que lideram suas comunidades e clãs, e eles devem agir como exemplo para que seus clãs sejam generosos para com aqueles. Sem a palavra de permissão deles, nenhum membro do clã será generoso. Por outro lado, o "tu/vós" não é tão livre quanto ele poderia pensar. Se ele não fosse beneficente aos Entes Silenciosos, ele seria punido por seu Deus. Assim, o "tu/vós" livre tem uma liberdade relativa. A legislação beneficente aos Entes Silenciosos demonstra isso.

Há também o elemento de desenraizamento ${ }^{532}$ dos Entes Silenciosos. Eles pertencem aquela terra, com a exceção dos escravos estrangeiros e do ger. Porém, por outro lado, eles eram sem terra. Ou, noutra forma de dizer, a terra não pertencia mais a eles. Eles estavam à disposição da vontade daqueles que os queriam acolher. Por isso eles podiam ser considerados como um tipo de "estrangeiro", dentro de sua própria terra, porque seus deslocamentos seriam favorecidos por seu desprendimento da terra. Em um contexto onde a terra fazia parte da identidade de um povo, ser sem terra era ser sem identidade com aquele povo. Porém, Deus se identifica com eles ao ponto de ser solidário com eles por meio do redator/orador do Deuteronômio.

Aparentemente, Deuteronômio apresenta a aridez dos Entes Silenciosos. Tudo os que eles produzissem seria para os outros. Em poucas situações eles poderiam trabalhar para sua própria melhora de condição. Mas há outro elemento de aridez neles - eles não têm filhos nem família (ao menos que seja expresso no Deuteronômio). ${ }^{533}$ É como se eles estivessem mortos. Sem filhos, eles são sem continuidade e em nada contribuem para a perpetuidade de nação, nem de seu próprio nome.

Ai entra a legislação em Deuteronômio com um valor sem precedente - mesmo que ela não nomeie nenhum deles, ela os faz perpétuos por meio de seu escrito, ao lembrar o "tu/vós" que os Entes Silenciosos também são pessoas que estão na lembrança do Deus de Israel e, portanto, devem estar na lembrança do seu povo. Este aspecto se torna notório em Deuteronômio 15,11: “sempre haverá pobres na terra". Portanto, o povo deveria entender que sempre haveria a necessidade de lembrar-se dos Entes Silenciosos porque eles sempre

\footnotetext{
${ }^{532}$ Nessa última palavra sou devedor a Chwarts, por quem ela é comumente empregada em seu livro: Uma visão da esterilidade na Bíblia Hebraica (São Paulo: Associação Editorial Humanitas, 2004).

${ }^{533}$ Deuteronômio 24 fala para não entrar na casa do pobre para recolher o penhor. Isso pode indicar família. Mas nada é dito expressamente quanto a isso.
} 
existirão, e existirão ao alcance de seus olhos e de sua possibilidade de ajuda, de tal forma que nunca perdessem de vista o ideal de uma sociedade sem pobres.

Deve-se notar o elemento da singularidade dos Entes Silenciosos. O texto Hebraico de Deuteronômio não aborda os Entes Silenciosos em sua pluralidade. Eles são sempre apresentados numa condição de singularidade. Assim, o texto apresenta o pobre, órfão, viúva, estrangeiro, levita, escravo e escrava sempre no singular, nunca no plural. A implicação disso é que o texto usa um elemento particular como modelo para o conjunto. A legislação aplicada a um indivíduo deveria ser aplicada a todos os outros em igual condição.

Há um elemento a mais que deve ser mencionado quando o assunto é a ausência de família, ou clã, dos Entes Silenciosos - a sua condição não favorecia os relacionamentos familiares. Eles são aqueles que deviam ser esquecidos porque em nada ajudavam suas comunidades. Aqui entra o lado perverso do clã - eles preferiam expulsar alguém de seu meio por sua condição desfavorável que os socorrer para que voltasse a ser "alguém" dentro da comunidade. Assim, sem família que os apoiasse, eles se tornavam sujeitos vulneráveis aos aproveitadores de ocasião. Deuteronômio corrige esse aspecto também por advertir o povo de Israel que os Entes Silenciosos têm um "parente defensor", o próprio Deus do povo de Israel. Negar ajudar ao Ente Silencioso era igual a recusa em obedecer a Deus.

Há o elemento "subversivo" nos Entes Silenciosos - eles alteram a comodidade do "tu/vós" que agora tem que dar atenção a eles, tendo em vista que o Deus de Israel os incita a olhar para eles, e com as ameaças, caso isso não vier a ser feito. Em lugar da exploração habitual, a generosidade, em lugar da expulsão, uma nova oportunidade dentro da comunidade. Há poucos elementos femininos dentro do livro de Deuteronômio. Aos elementos tratados dentro dessa pesquisa, viúva e serva, soma-se a palavra "mãe"534 e o termo geral "mulher". Fora isso, todos os outros são masculinos. De qualquer modo, sem os Entes Silenciosos, não haveria boa parte da literatura do Deuteronômio. ${ }^{535}$

Os Entes Silenciosos embelezam a literatura bíblica por dar uma coloração especial aos livros em que eles estão inseridos, no sentido de acrescentar contraste e riqueza cultural a uma cultura que seria monocromática se a sua presença fosse inexistente. Assim, apesar de seu

534 घֵ., 'em, "mãe" (Deuteronômio 5,16; 13,6 [Hebraico 13,7]; 14,21 [refere-se a mãe de um animal]; $21,13.18 .19 ; 22,6.6$ [referem-se a mãe de um passarinho].15; 27,16.22; 33.9).

${ }^{535}$ Boa parte dos livros considerados proféticos não teria conteúdo, caso suas mensagens não viessem como profecia contra aqueles que pilhavam os Entres Silenciosos, e o profeta falasse em seu benefício e para sua proteção de governantes - príncipes, sacerdotes e profetas da elite. 
silêncio, eles não passam sem serem percebidos. As diversas pessoas que pertenciam ao grupo dos Entes Silenciosos demonstram a riqueza vocabular que elas trouxeram para a literatura do Deuteronômio, bem como a riqueza de uma legislação humana e com profundo interesse no seu bem estar.

O elemento religioso dentro do livro de Deuteronômio não pode deixar de ser visto, pois ele afeta não somente o "pequeno" como também o "grande". Esse elemento deve fazer uma grande mudança na forma de ver o pobre. O pobre é abençoado por Deus por meio do modo generoso como o "grande" o trata. Por outro lado, o "grande" também é abençoado mediante a resposta de Deus ao modo como o "grande" trata o "pequeno".

Para o Deuteronômio, o Ente Silencioso não é um problema social, mas uma oportunidade social. Isso quer dizer que as leis de proteção a ele foram dadas não somente para beneficiá-lo e protegê-lo, mas também para beneficiar e proteger aqueles que as aplicassem. Para o Deuteronômio, aquele que agia em benefício de um Ente Silencioso agia em benefício próprio porque o Deus de Israel lhe traria a bênção do sucesso em seus empreendimentos. $\mathrm{O}$ israelita que obedecesse aos mandamentos beneficentes aos pobres viria a ser abençoado por Deus. A pesquisa sobre Deuteronômio 15 mostrou os vários incentivos dados à obediência do israelita.

Faz-se aqui a rememoração do que é dito em Deuteronômio 15,11: "Nunca deixará de haver pobres na terra" $(\mathrm{BJ})$. O retador está estabelecendo que qualquer método para ocultar ou extinguir os Entes Silenciosos é proibido e fracassará. Talvez devesse fazer uma paráfrase desse texto: "Sempre haverá os que têm muito e os que nada ou pouco têm". Entretanto, cabe aos que têm muito repartir parte do seu muito com aqueles que pouco ou nada têm. Como disse a Chwarts: "É este caráter da Bíblia Hebraica - o de estar sempre aberta à descoberta e a novas interpretações" (2014, p. 15).

Fensham (1962, p. 139) declara:

A atitude tomada em favor da viúva, do órfão, e do pobre é para ser vista de um pano de fundo legal. Essas pessoas não tinham direito, nem personalidade legal, ou, em alguns casos, possivelmente, direitos restritos. Eles eram quase ilegais. Qualquer um poderia oprimí-los sem medo que qualquer atitude legal pudesse ir contra sua posição. Para restaurar o equilíbrio da sociedade, essas pessoas deveriam ser protegidas. Portanto, foi necessário sancionar sua proteção por mandamento direto da divindade e fazê-lo virtude dos reis.

Em Deuteronômio, a virtude para isso seria do "tu/vós". 


\section{REFERÊNCIAS}

ALLEN, Ronald B. Numbers (EBC). Grand Rapids, Michigan: Zondervan Publishing House, 1990. Volume 2: Genesis-Numbers. Frank E. Gaebelein, editor.

ARNOLD, Bill T. \& CHOI, John H. A Guide to Biblical Hebrew Syntax. New York: Cambridge University Press, 2003.

ARAÚJO, Reginaldo Gomes de. Gramática do Aramaico Bíblico. São Paulo: Targumim, 2005 .

ASHLEY, Timothy R. The book of Numbers. Grand Rapids, Michigan / Cambridge, U. K.: William B. Eerdmans Publishing Company, 1992.

AUSTEL, Hermann J. שִָָׁ shāmat IN: HARRIS, R. Laird, ARCHER JR., Gleason L., and WALTKE, Bruce K. TWOT. Chicago: The Moody Bible Institute of Chicago, 1980. Volume 2.

BARTOR, Assnat. "Reading Biblical Law as Narrative" IN: Prooftexts, Vol. 32, No. 3, 2012, p. 292-311. Publicado por: Indiana University Press. Disponível em: <http://www.jstor.org/stable/10.2979/prooftexts.32.3.292>Acesso em: 10 de nov. de 2014.

BEREZIN, Jaffa Rifka. Dicionário Hebraico-Português. São Paulo: Editora da Universidade de São Paulo, 2003.

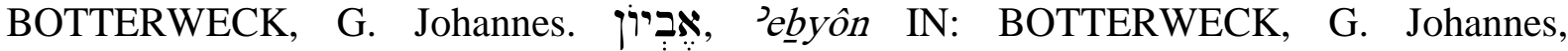
RINGGREN, Helmer, editores. TDOT. Grand Rapids, Michigan: William B. Eerdmans Publishing Company, 1974. Volume 1.

BRIDGE, Edward J. "Female slave vs Female slave: שְִָׁדָה of Hebrew Scriptures, vol. 12, 2012.

BROWN, Francis, DRIVER, S. R. \& BRIGGS, Charles A. The New Brown-Driver - Briggs - Gesenius Hebrew and English Lexicon. Peabody, Massachusetts: Hendrickson Publishers, 1979.

BUDD, Philip J. Numbers (WBC, volume 5). Nelson Reference \& Electronic, 1984.

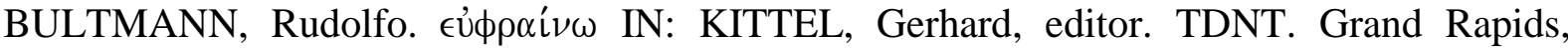
Michigan: Wm. B. Eerdmans Publishing Company, 1964. Volume 2.

BURROWS, Millar. "Levirate Marriage in Israel” IN: Journal of Biblical Literature, Vol. 59, No. 1 (Mar., 1940), pp. 23-33.

CAIRNS, Ian. Deuteronomy (ITC). Grand Rapids \& Edinburgh: Wm. B. Eerdmans Publishing $\mathrm{Co}=\mathrm{O}$. \& The Handsel Press LTD, 1992.

CHISHOLM JR., Robert B. From Exegesis to Exposition - A practical guide to using biblical Hebrew. Grand Rapids, Michigan: Baker Books, 1998. 
CHOURAQUI, André. A Bíblia: Palavras (Deuteronômio). Rio de Janeiro: Imago, 1997.

CHRISTENSEN, Duane L. Deuteronomy 21.10-34.12. Nashville: Thomas Nelson Publishers, 2002.

CHWARTS, Suzana. Uma visão da esterilidade na Bíblia Hebraica. São Paulo: Associação Editorial Humanitas, 2004.

Humanitas, 2014.

Via Maris: textos e contexto da Bíblia Hebraica. São Paulo: Editora

CLEMENTS, R. E. (org.). O mundo do Antigo Israel - perspectivas sociológicas, antropológicas e políticas. São Paulo: Paulus, 1995.

CLINES, David J. A., editor. The Dictionary of Classical Hebrew: Aleph. Sheffield, England: Sheffield Academic Press Ltd, 1993. Volume 1.

. The Dictionary of Classical Hebrew: Beh-Waw. Sheffield, England: Sheffield Academic Press Ltd, 1995. Volume 2.

The Dictionary of Classical Hebrew - volume 4: YodhLamedh. Sheffield, England: Sheffield Academic Press Ltd, 1998. Volume 4.

COLE, R. Dennis. Numbers (NAC, volume 3). Nashville, Tennessee: Broadman \& Holman Publishers, 2000.

CONRAD, J. ${ }^{\dagger} \varphi_{\uparrow}, q a \bar{t} t \bar{o} n$ IN: BOTTERWECK, G. Johannes, RINGGREN, Helmer, editores. TDOT. Grand Rapids, Michigan: William B. Eerdmans Publishing Company, 2004. Volume 13 .

CONSTABLE, Thomas L. Notes on Deuteronomy. http://www.soniclight.com/, edição 2015.

COPPES, Leonard J. אָרבה I, 'ābâ IN: HARRIS, R. Laird, ARCHER JR., Gleason L., and WALTKE, Bruce K. TWOT. Chicago: The Moody Bible Institute of Chicago, 1980. Volume 1 .

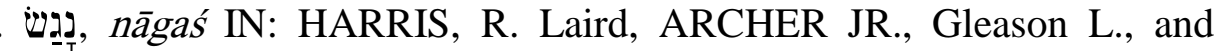
WALTKE, Bruce K. TWOT. Chicago: The Moody Bible Institute of Chicago, 1980. Volume 2.

קרוז I, qārā’ IN: HARRIS, R. Laird, ARCHER JR., Gleason L., and WALTKE, Bruce K. TWOT. Chicago: The Moody Bible Institute of Chicago, 1980. Volume 2.

נצח I, nāḥal IN: HARRIS, R. Laird, ARCHER JR., Gleason L., and WALTKE, Bruce K. TWOT. Chicago: The Moody Bible Institute of Chicago, 1980. Volume 2.

CULVER, Robert D. ריב, rîb IN: HARRIS, R. Laird, ARCHER JR., Gleason L., and WALTKE, Bruce K. TWOT. Chicago: The Moody Bible Institute of Chicago, 1980. Volume 2. 
דָרִ dālal IN: HARRIS, R. Laird, ARCHER JR., Gleason L., and WALTKE, Bruce K. TWOT. Chicago: The Moody Bible Institute of Chicago, 1980. Volume 1.

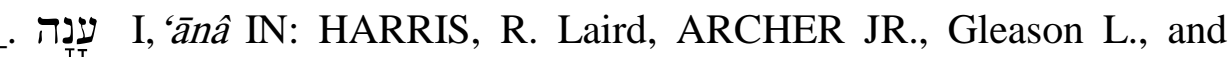
WALTKE, Bruce K. TWOT. Chicago: The Moody Bible Institute of Chicago, 1980. Volume 2.

CRAIGIE, Peter C. The Book of Deuteronomy. Grand Rapids, Michigan: William B. Eerdmans Publishing Company, 1976.

CRÜSEMANN, Frank. A Torá: teologia e história social da lei do Antigo Testamento. Petrópolis, RJ: Editora Vozes, 2008, $3^{\mathrm{a}}$ edição.

DAVIDSON, Benjamin. The Analytical Hebrew and Chaldee Lexicon. Grand Rapids, Michigan: Zondervan Publishing House, 1970.

DE VAUX, R. Instituições de Israel no Antigo Testamento. São Paulo: Editora Teológica, 2003. Tradução: Daniel de Oliveira.

DRIVER, S. R. A Critical and Exegetical Commentary on Deuteronomy. Edinburgh: T. \& T. Clark. 3a edição.

IBN EZRA, Abraham ben Meir. The commentary of Abraham ibn Ezra on the Pentateuch. Volume 5: Deuteronomy. Jersey City, NJ: KTAV Publishing House, inc., 2003.

EVEN-SHOSHAN, Abraham, editor. A New Concordance of the Old Testament. Jerusalém: Kiryat Sefer Ltd., 1989. Segunda edição.

FABRY, Heinz-Josef. רדָר, dāl IN: BOTTERWECK, G. Johannes, RINGGREN, Helmer, editores. TDOT. Grand Rapids, Michigan: William B. Eerdmans Publishing Company, 1978. Volume 3.

FENSHAM, F. Charles. "Window, orphan, and the poor in Ancient near Eastern Legal and Wisdom Literature". IN: Journal of Near Eastern Studies, vol. 21, n 2, abril de 1962, p. 129139.

FRANCISCO, Edson Faria. Manual da Bíblia Hebraica - introdução ao texto massorético, guia introdutório para a Bíblia Hebraica Stuttgartensia. São Paulo: Vida Nova, 2008. $3^{a}$ edição revisada e ampliada.

GERSTENBERGER, E. עִ עִ II 'ānâ IN: BOTTERWECK, G. Johannes, RINGGREN, Helmer, editores. TDOT. Grand Rapids, Michigan: William B. Eerdmans Publishing Company, 2001. Volume 11.

GRUNDMANN, W. $\mu$ '́ $\gamma \alpha \varsigma$ IN: KITTEL, Gerhard, editor. TDNT. Grand Rapids, Michigan: Wm. B. Eerdmans Publishing Company, 1967. Volume 4.

HALLO, William W., editor. The Context of Scripture - monumental inscriptions from the biblical world. Leiden, Holanda: Koninklojke Brill NV, 2003. Volume 2. 
HAMILTON, Victor P. שוּב, shûb IN: HARRIS, R. Laird, ARCHER JR., Gleason L., and WALTKE, Bruce K. TWOT. Chicago: The Moody Bible Institute of Chicago, 1980. Volume 2.

הָר Tădar IN: HARRIS, R. Laird, ARCHER JR., Gleason L., and WALTKE, Bruce K. TWOT. Chicago: The Moody Bible Institute of Chicago, 1980. Volume 1.

HARRIS, R. Laird, ARCHER JR., Gleason L., and WALTKE, Bruce K. TWOT. Chicago: The Moody Bible Institute of Chicago, 1980. Volumes 1 e 2.

HARRIS, R. Laird. עִבָָט, 'ābat IN: HARRIS, R. Laird, ARCHER JR., Gleason L., and WALTKE, Bruce K. TWOT. Chicago: The Moody Bible Institute of Chicago, 1980. Volume 2.

HARTLEY, Jonh E. Leviticus (WBC, volume 4). Word, Incorporated: 1992. תיז', yātôm IN: HARRIS, R. Laird, ARCHER JR., Gleason L., and WALTKE, Bruce K. TWOT. Chicago: The Moody Bible Institute of Chicago, 1980. Volume 1.

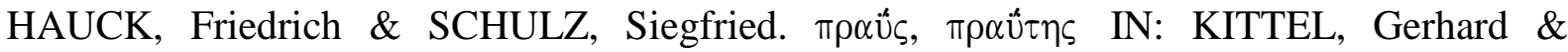
FRIEDRICH, Gerhard, editores. TDNT. Grand Rapids, Michigan: Wm. B. Eerdmans Publishing Company, 1967. Volume 6.

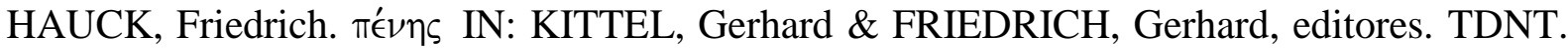
Grand Rapids, Michigan: Wm. B. Eerdmans Publishing Company, 1967. Volume 6. . $\pi \tau \omega \chi o ́ s$ IN: KITTEL, Gerhard \& FRIEDRICH, Gerhard, editores. TDNT. Grand Rapids, Michigan: Wm. B. Eerdmans Publishing Company, 1967. Volume 6.

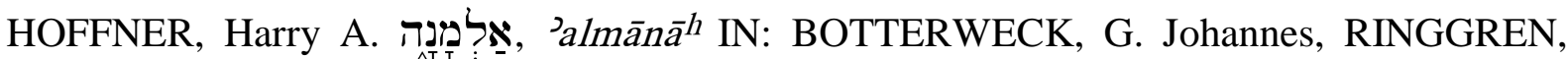
Helmer, editores. TDOT. Grand Rapids, Michigan: William B. Eerdmans Publishing Company, 1974. Volume 1.

HOUSE, Paul R. Teologia do Antigo Testamento. São Paulo: Editora Vida, 2005. Tradução: Sueli Silva Saraiva.

KALLAND, Earl S. Deuteronomy. (EBC, volume 3). Grand Rapids, Michigan: Zondervan Publishing House, 1992.

KEIL, Karl Fredreich \& DELITZSCH, Franz. Genesis to Judges 6:32 (OTC). Grand Rapids, Michigan: Associated Publishers and Authors inc. Volume 1.

KELLERMANN, Diether. גוּר gûr IN: BOTTERWECK, G. Johannes, RINGGREN, Helmer, editores. TDOT. Grand Rapids, Michigan: William B. Eerdmans Publishing Company, 1975. Volume 2. 


\section{לִיר, lēwî IN: : BOTTERWECK, G. Johannes, RINGGREN, Helmer}

e FABRY, Heinz-Josef, editores. TDOT. Grand Rapids, Michigan: William B. Eerdmans Publishing Company, 1995. Volume 7.

KELLEY, Page H. Hebraico Bíblico: Uma Gramática Introdutória. São Leopoldo, RS: Sinodal, 1998.

KIDNER, Derek. Salmos 1-72 - introdução e comentário. São Paulo: Sociedade Religiosa Edições Vida Nova e Associação Religiosa Editora Mundo Cristão, 1981. Segunda edição.

KIRST, Nelson, KILPP, Nelson, SHWANTES, Milton, RAYMANN, Acir, \& ZIMMER, Rudi. Dicionário Hebraico-Português \& Aramaico-Português. São Leopoldo, RS, e Petrópolis, RJ: Editora Sinodal e Editora Vozes, 1987. 21ª edição.

KOEHLER, Ludwig \& BAUMGARTNER, Walter. The Hebrew and Aramaic Lexicon of the Old Testament. Leiden, Holanda: Koninklijke Brill NV, 2001. Volume 2.

Old Testament. Leiden, Holanda: Koninklijke Brill NV, 2001. Volume 2.

The Hebrew and Aramaic Lexicon of the

KRAMER, Pedro. Origem e Legislação do Deuteronômio - programa de uma sociedade sem empobrecidos e excluídos. São Paulo: Paulinas, 2006.

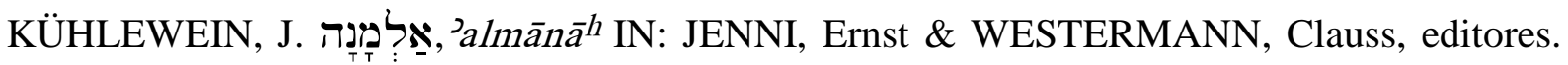
DTMAT. Madrid: Ediciones Cristiandad, 1978. Volume 1.

LAMBDIN, Thomas O. Gramática do Hebraico Bíblico. São Paulo: Paulus, 2005. $2^{\text {a }}$ edição. Tradução: Walter Eduardo Lisboa.

LEIBOWITZ, Nehama. Studies in Devarim - Deuteronomy. Jerusalém: Haomanim Press, 1995.

LEVINE, Baruch A. Numbers 1-20. New Haven \& London: Yale University Press, 1993. Leviticus (JPSTC). Philadelphia: The Jewish Publication Society, 5749 / 1989.

MARTIN-ACHARD, R. ענה II, 'nh IN: JENNI, Ernst e WESTERMANN, Claus, editores. DTMAT. Madri: Ediciones Cristiandad, 1985.

DTMAT. Madrid: Ediciones Cristiandad, 1978. Volume 1.

רז DTMAT. Madrid: Ediciones Cristiandad, 1978. Volume 1.

MAYERS, A. D. H. Deuteronomy (NCBC). Grand Rapids, Michigan: Wm. B. Eerdmans Publishing Company, 1981.

MEEK, Theophile J., tradutor. The Code of Hammurabi (ANE). Princeton, New Jersey: Princeton University Press, 1973. James B. Pritchard, editor. Volume 1. 
MERRILL, Eugene H. Teologia do Antigo Testamento. São Paulo: Shedd Publicações, 2009. Tradução: Helena Aranha, Regina Aranha.

\& Holman Publishers, 1994.

Deuteronomy (NAC, volume 4). Nashville, Tennessee: Broadman

MEYER, Rudolf. Gramática Del Hebreo Bíblico. Terrassa, España: Libros CLIE, 1989. Traducción del alemán por el Professor Ángel Sáenz-Badillos.

MILGROM, Jacob. Numbers (JPSTC). Philadelphia - New York: The Jewish Publication society, 5750 / 1990.

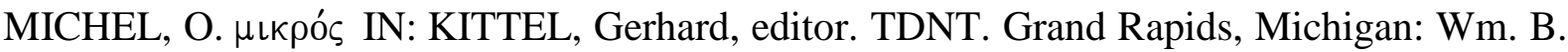
Eerdmans Publishing Company, 1967. Volume 4.

MITCHELL, H. G. "The Use of the Second Person in Deuteronomy" IN: Journal of Biblical Literature, vol. 18, No. 1/2 (1899), pp. 61-109.

MOTYER, J. A. "Maldição" IN: Novo Dicionário Bíblico. São Paulo: Edições Vida Nova, 1983, p. 987-988. Volume 2.

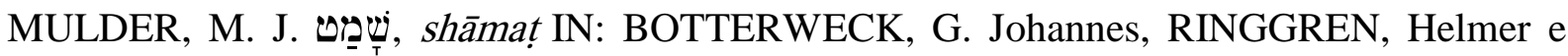
FABRY, Heinz-Josef, editores. TDOT. Grand Rapids, Michigan / Cambridge, U. K.: William B. Eerdmans Publishing Company, 2006. Volume 15.

NAKANOSE, Shigeyuki. "Para entender o livro o Deuteronômio - Uma lei a favor da vida?" IN: Revista de Interpretação Bíblica Latino-Americana/Ribla, 23, 1996, p. 176-193.

NASCIMENTO, Lucas Merlo \& SANTOS, Pedro Evaristo Conceição. Deuteronômio: Confissões de Liberdade e Fé. São Paulo: Fonte Editorial LTDA, 2014.

NELSON, Richard D. Deuteronomy, a commentary. Louisville, London: Westminster John Knox Press, 2002.

OSBORNE, Grant R. A Espiral Hermenêutica - uma nova abordagem à interpretação bíblica. São Paulo: Vida Nova, 2006.

PATTERSON, Richard D. "The window, orphan, and the poor in the Old Testament and the Extra-biblical Literature”. IN: Bibliotheca Sacra, julho de 1973, p. 223-234.

PINTO, Carlos Osvaldo Cardoso. Fundamentos para exegese do Antigo Testamento - um manual de sintaxe hebraica. São Paulo: Vida Nova, 1998.

PRICE, Orlo J. "The Biblical Teaching concerning the Hireling and the Pauper" IN: The Biblical World, Vol. 29, No. 4 (Apr., 1907), p. 269-283.

RASHI. Chumash with Rashi's Commentary: Bamidbar. Jerusalém: Feldheim Publishers Ltd, 5745 / 1934. Rabbi A. M. Silbermann, editor.

Chumash with Rashi's Commentary: Shemoth. Jerusalém: Feldheim Publishers Ltd, 5745 / 1934. Rabbi A. M. Silbermann, editor. 


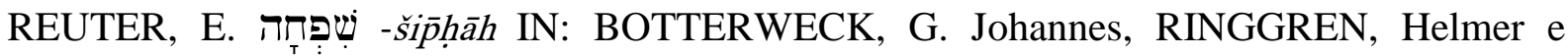
FABRY, Heinz-Josef, editores. TDOT. Grand Rapids, Michigan: William B. Eerdmans Publishing Company, 2006. Volume 15.

RINGGREN, H. יתוֹ, yātôm IN: BOTTERWECK, G. Johannes, RINGGREN, Helmer, editores. TDOT. Grand Rapids, Michigan / Cambridge, U. K.: William B. Eerdmans Publishing Company, 1990. Volume 6.

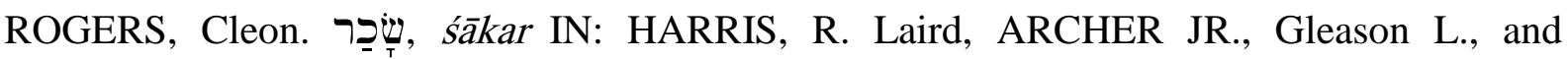
WALTKE, Bruce K. TWOT. Chicago: The Moody Bible Institute of Chicago, 1980. Volume 2 .

ROSS, Allen P. Gramática do Hebraico Bíblico para Iniciantes. São Paulo: Editora Vida, 2001. Trad. Gordon Chown.

ROTH, Martha T. “The Neo-Babylonian Widow”. IN: Journal of Cuneiform Studies, vol. 43/45 (1991 - 1993), p. 1-26. Publicado por The American Schools of Oriental Research.

RUSCONI, Carlo. Dicionário do Grego do Novo Testamento. São Paulo: Paulus, 2003. Tradução de Irineu Rabuske.

SÁNCHEZ, Edesio. Deuteronomio (CBI). Buenos Aires, Argentina: Ediciones Kairós, 2002.

SANTOS, Pedro Evaristo Conceição. A Presença de Deus em Gênesis e Êxodo. São Paulo: Faculdade Teológica Batista de São Paulo, 1997. Material não publicado.

SARNA, Nahum M. Exodus (JPSTC). Philadelphia: The Jewish Publication Society, 5751 / 1991.

SCHMIDT, Werner H. A Fé do Antigo Testamento. São Leopoldo, RS: Sinodal, 2004. Título original: "Alttestamentlicher Glaube in seiner Geschichte”. Tradução: Vilmar Schneider.

SCHNIEDEWIND, William M. Como a Bíblia tornou-se um livro - a textualização do Antigo Israel. São Paulo: Edições Loyola Jesuítas, 2011.

SCHÖKEL, Luis Alonso. Dicionário Bíblico Hebraico-Português. São Paulo: 1997.

SCHWANTES, Milton. O direito dos pobres. São Leopoldo, RS: Oikos \& São Bernardo do Campo, SP: Editeo, 2013.

Editora Oikos, 2008. História de Israel - vol. 1: Local e origens. São Leopoldo, RS:

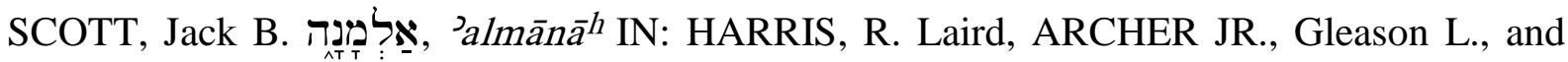
WALTKE, Bruce K. TWOT. Chicago: The Moody Bible Institute of Chicago, 1980. Volume 1.

SEESEMANN, Heinrich. o’ $\rho \alpha \nu o ́ s$ IN: KITTEL, Gerhard \& FRIEDRICH, Gerhard, editores. TDNT. Grand Rapids, Michigan: Wm. B. Eerdmans Publishing Company, 1967. Volume 5.

SILVA, Cássio Murilo Dias da. Metodologia de Exegese Bíblica. São Paulo: Paulinas, 2000. 


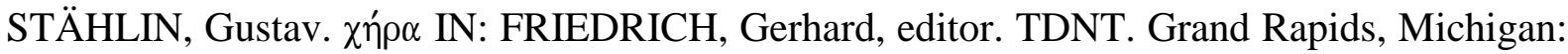
Wm. B. Eerdmans Publishing Company, 1974. Volume 9.

STENDEBACH, F. J. עִ עִ I, 'ānâ IN: BOTTERWECK, G. Johannes, RINGGREN, Helmer, editores. TDOT. Grand Rapids, Michigan: William B. Eerdmans Publishing Company, 2001. Volume 11.

STIGERS, Harold G. רוּ III, gûr IN: HARRIS, R. Laird, ARCHER JR., Gleason L., and WALTKE, Bruce K. TWOT. Chicago: The Moody Bible Institute of Chicago, 1980. Volume 1 .

TENNEY, Merrill C. Deuteronomy (EBC, volume 3). Grand Rapids, Michigan: Zondervan Publishing House, 1992. Frank E. Gaebellein, editor.

TIGAY, Jeffrey H. Deuteronomy (JPSTC). Philadelphia: The Jewish Publication Society, $5756 / 1996$.

TILESSE, Georges Minette de. "Sections 'tu' et 'vous' dans le Deuteronome" IN: Vetus Testamentum, Vol. 12, fasc. 1 (Janeiro 1962), p. 29-87.

THOMPSON, J. A. Deuteronômio, introdução e comentário. São Paulo: Sociedade Religiosa Edições Vida Nova e Associação Religiosa Editora Mundo Cristão: 1982.

VON RAD, Gerhard. Deuteronomy - A Commentary. Philadelphia: The Westminster Press, 1966. Tradução: Dorothea Barton.

Ediciones Sígueme, 1976.

Estudios sobre el Antiguo Testamento. Salamanca, España: Studies in Deuteronomy. Londres: SCM Press LTD, 1953.

WALTKE, Bruce K. e O’CONNOR, M. An Introduction to Biblical Hebrew Syntax. Winona Lake, Indiana: Eisenbrauns, 1990.

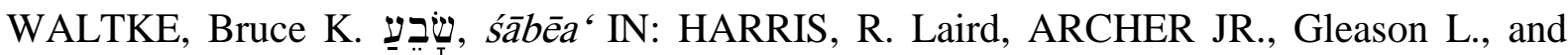
WALTKE, Bruce K. TWOT. Chicago: The Moody Bible Institute of Chicago, 1980. Volume 2.

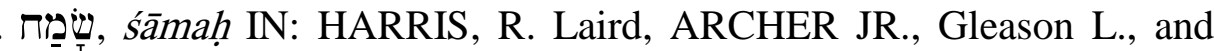
WALTKE, Bruce K. TWOT. Chicago: The Moody Bible Institute of Chicago, 1980. Volume 2.

WALTON, John H., MATTHEWS, Victor H. e CHAVALAS, Mark W. Comentario del Contexto Cultural de La Biblia - El trasfondo cultural de cada pasaje del Antiguo Testamento. El Paso, Texas: Editorial Mundo Hispano, 2006. $2^{a}$ edição.

WEINFELD, Moshe. Deuteronomy 1-11. New York: The Anchor Bible, Doubleday, 1991.

Social justice in Ancient Israel and in the Ancient Near East. Jerusalem: The Magnes Press, 1995 \& Minneapolis: Fortress Press, 1995. 
. "The Origin of the Humanism in Deuteronomy" IN: Journal of Biblical Literature, vol. 80, No. 3 (Sep., 1961), pp. 241-247.

WIESZFLOG, Walter, editor. Michaelis: moderno dicionário da língua portuguesa. São Paulo: Companhia Melhoramentos, 1998.

WILSON, Marvin R. נִכָרָ, nēkār IN: HARRIS, R. Laird, ARCHER JR., Gleason L., and WALTKE, Bruce K. TWOT. Chicago: The Moody Bible Institute of Chicago, 1980. Volume 2 .

YATES, Kyle M. The Essentials of Biblical Hebrew. New York: Harper \& Brothers, 1938.

ZUCK, Roy B., editor. A Biblical Theology of the Old Testament. Chicago: Moody Press, 1991.

YIGAY, Jeffrey H. Deuteronomy, commentary. Philadelphia: The Jewish Publication Society, 1996.

Bíblias

Antigo Testamento Poliglota - Hebraico, Grego, Português, Inglês. São Paulo: Vida Nova e Sociedade Bíblica do Brasil, 2003.

Bíblia Almeida Revista e Atualizada, $2^{\text {a }}$ edição. Barueri, SP: Sociedade Bíblica do Brasil, 1993.

Bíblia de Estudo de Genebra. São Paulo: Editora Cultura Cristã, 1999; Barueri, SP: Sociedade Bíblica do Brasil, 1999.

Bíblia Hebraica Stuttgartensia. Deutsche Bibelgesellschaft, 4a edição.

Bíblia Hebraica Quinta: Deuteronômio. Sttutgart: Deutsche Bibelgesellschaft, 2007. Preparada por Carmel McCArthy.

Bíblia de Jerusalém, nova edição - revista e ampliada. São Paulo: Paulus, 2002. 8 a impressão de 2008.

Bíblia do Peregrino. São Paulo: Paulus, 2011. 3a edição.

The Septuagint with Apocrypha: Greek and English. Peabody, MA: Hendrickson Publishers, 1986. 3a impressão de 1990.

Torá - A Lei de Moisés. Editora e Livraria Sêfer LTDA, 2001.

Sites:

“O Código de Hamurabi”. Disponível <http://www.dhnet.org.br/direitos/anthist/hamurabi.htm> Acesso em: 22 de out. de 2014.

"O Código de Hamurabi”. Disponível em: < http://www.angelfire.com/me/babiloniabrasil/hamur.html > Acesso em: 22 de out. de 2014. 